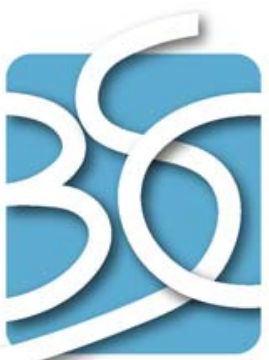

BECHTEL SAIC COMPANYLC
ANL-WIS-GS-000003 REV 00

November 2004

\title{
Qualification of Thermodynamic Data for Geochemical Modeling of Mineral-Water Interactions in Dilute Systems
}

Prepared for:

U.S. Department of Energy

Office of Civilian Radioactive Waste Management

Office of Repository Development

1551 Hillshire Drive

Las Vegas, Nevada 89134-6321

Prepared by:

Bechtel SAIC Company, LLC

1180 Town Center Drive

Las Vegas, Nevada 89144

Under Contract Number

DE-AC28-01RW12101 


\section{DISCLAIMER}

This report was prepared as an account of work sponsored by an agency of the United States Government. Neither the United States Government nor any agency thereof, nor any of their employees, nor any of their contractors, subcontractors or their employees, makes any warranty, express or implied, or assumes any legal liability or responsibility for the accuracy, completeness, or any third party's use or the results of such use of any information, apparatus, product, or process disclosed, or represents that its use would not infringe privately owned rights. Reference herein to any specific commercial product, process, or service by trade name, trademark, manufacturer, or otherwise, does not necessarily constitute or imply its endorsement, recommendation, or favoring by the United States Government or any agency thereof or its contractors or subcontractors. The views and opinions of authors expressed herein do not necessarily state or reflect those of the United States Government or any agency thereof. 
QA: QA

Qualification of Thermodynamic Data for Geochemical Modeling of Mineral-Water Interactions in Dilute Systems

ANL-WIS-GS-000003 REV 00

November 2004 


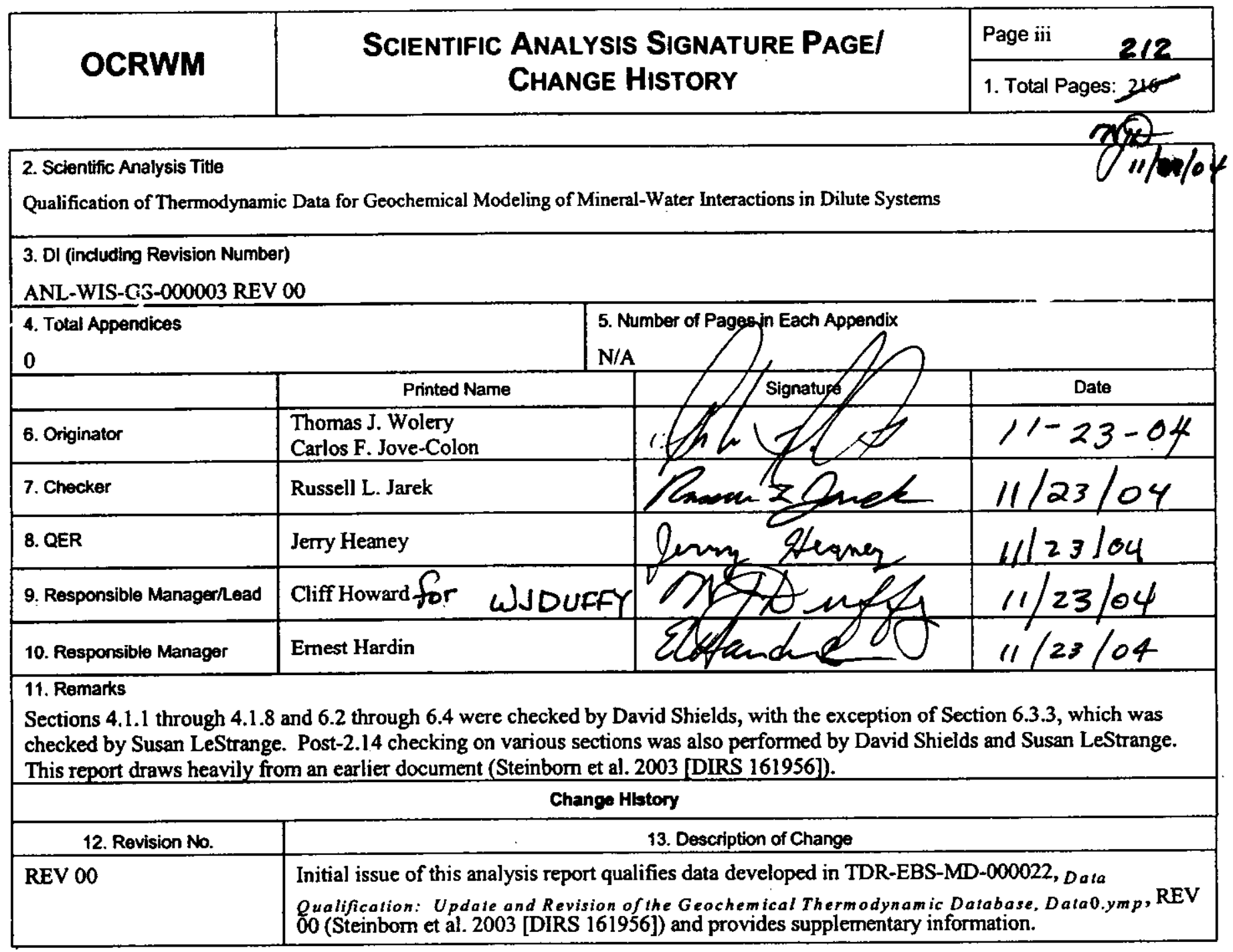




\section{INTENTIONALLY LEFT BLANK}




\section{CONTENTS}

Page

ACRONYMS AND ABBREVIATIONS xi

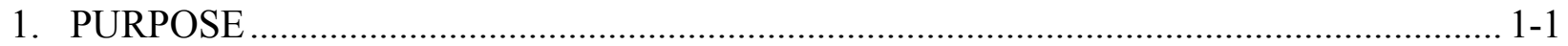

2. QUALITY ASSURANCE ................................................................................ 2-1

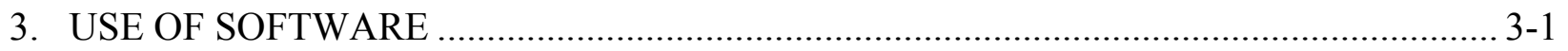

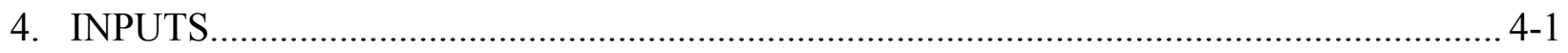

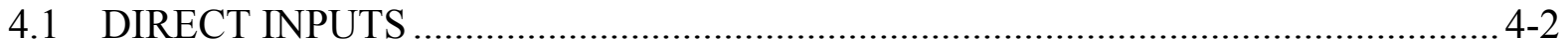

4.1.1 Compilation of Thermodynamic Data for $\mathrm{Np}$ and $\mathrm{Pu}$ Species ........................4-5

4.1.2 Compilation of Thermodynamic Data for Other Aqueous Species .................. 4-8

4.1.3 “Azero" Ion Size Parameters ........................................................................ 4-9

4.1.4 Compilation of Thermodynamic Data for Clay Minerals............................. 4-10

4.1.5 Compilation of Thermodynamic Data for Zeolites...................................... 4-13

4.1.6 Compilation of Thermodynamic Data for Cement Phases ............................ 4-14

4.1.7 Compilation of Thermodynamic Data for Additional Solid Phases ............... 4-19

4.1.8 Compilation of Thermodynamic Data for Gases and Associated Aqueous Species ......................................................................... 4-21

4.1.9 Compilation of Mineral Volume Data ..................................................... 4-30

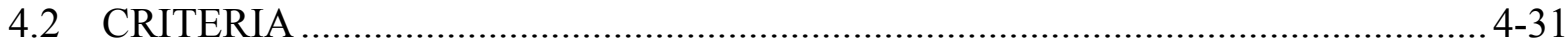

4.3 CODES, STANDARDS, AND REGULATIONS ........................................... 4-32

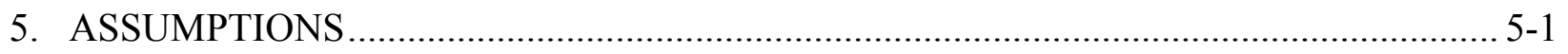

6. SCIENTIFIC ANALYSIS DISCUSSION ............................................................... $6-1$

6.1 APPROACH TO DATA REDUCTION .......................................................... $6-2$

6.1.1 The Heat Capacity of Solids as a Function of Temperature and its Relationship to Gibbs Free Energies at Higher Temperatures......................... 6-2

6.1.2 SUPCRT92 Usage and Development of Log K-Temperature Grids ............... 6-6

6.1.3 Special Function Spreadsheets................................................................ 6-7

6.1.4 Algorithms, Procedures, and Parameters Used to Obtain Input Parameters for the Temperature Extrapolation Excel Templates ..................................... 6-10

6.1.5 SUPCRT92 Silicate Mineral Revisions: Moving to the Rimstidt Paradigm ....................................................................................... 6-11

6.1.6 Clarification of the Discrepancy in $\Delta \mathrm{G}_{\mathrm{f}}{ }^{\circ}$ Data for Ca-Bearing Silicates ........ 6-16

6.2 EVALUATION AND QUALIFICATION OF THERMODYNAMIC DATA

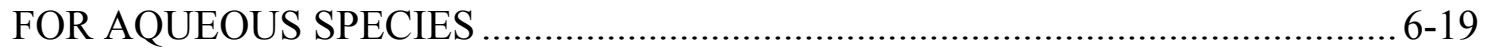

6.2.1 Evaluation and Qualification of $\mathrm{Np}$ and $\mathrm{Pu}$ Species .................................... 6-19

6.2.2 Evaluation and Qualification of Other Species........................................ 6-24

6.3 EVALUATION AND QUALIFICATION OF THERMODYNAMIC DATA

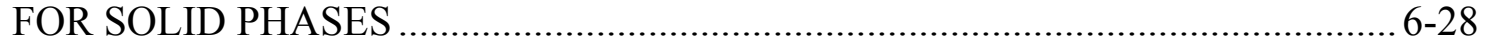

6.3.1 Evaluation and Qualification of Thermodynamic Data for Clays ................. 6-28 


\section{CONTENTS (Continued)}

Page

6.3.2 Evaluation and Qualification of Thermodynamic Data for Zeolites $6-49$

6.3.3 Evaluation and Qualification of Thermodynamic Data for Cement Phases ... 6-53

6.3.4 Evaluation and Qualification of Thermodynamic Data for Other Solids ....... 6-72

6.4 EVALUATION AND QUALIFICATION OF THERMODYNAMIC DATA FOR GASES AND ASSOCIATED AQUEOUS SPECIES ................................. 6-108

6.5 “AZERO” ION SIZE PARAMETERS ............................................................ 6-119

6.6 EVALUATION OF MINERAL MOLAR VOLUME DATA.............................. 6-121

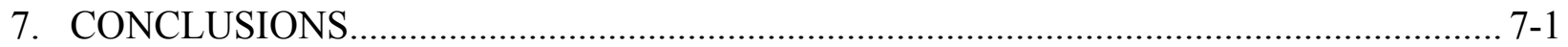

7.1 EVALUATION OF UNCERTAINTY AND RECOMMENDED USE OF THE

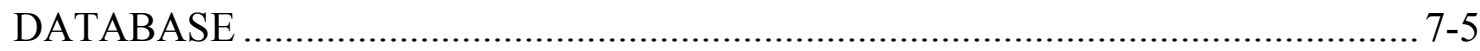

7.1.1 Uncertainty in Thermodynamic Data.................................................... 7-6

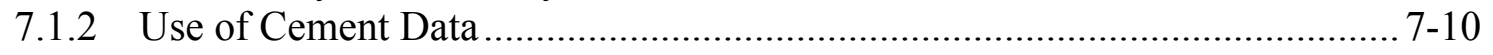

8. INPUTS AND REFERENCES .................................................................................. 8-1

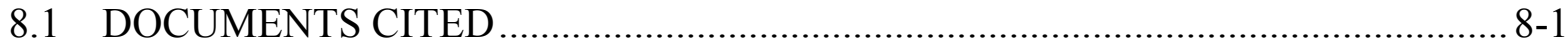

8.2 CODES, STANDARDS, REGULATIONS, AND PROCEDURES ........................ 8-15

8.3 SOURCE DATA, LISTED BY DATA TRACKING NUMBER …........................ $8-15$

8.4 OUTPUT DATA, LISTED BY DATA TRACKING NUMBER …......................... $8-16$

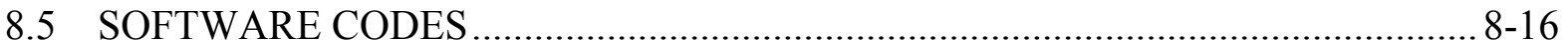




\section{TABLES}

Page

1-1. Data Evaluated in the Data Qualification Report ....................................................... 1-4

1-2. List of Approved Analysis Model Reports Using the Thermodynamic Database Data0.ymp.R2 (DTN: MO0302SPATHDYN.000 [DIRS 161756]).............................1-7

4-1. $\quad$ Direct Input Data..................................................................................................... 4-3

4-2. $\quad \mathrm{Np}$ and $\mathrm{Pu}$ Species for which Thermodynamic Data Were Added, or Existing Data Were Modified, in the Data0.ymp.R2 Database (DTN: MO0302SPATHDYN.000 [DIRS 161756])

4-3. Thermodynamic Data for Actinide Basis Species, Redox Species, Titanium, and Molybdenum Species.......................................................................................... 4-8

4-4. Suggested “Azero” Values for Various Charge Numbers ................................................ 4-9

4-5. Oxide Thermodynamic Parameters Used to Estimate Thermodynamic Properties of Clays ............................................................................................................... 4-10

4-6. $\Delta \mathrm{G}_{\mathrm{f}}{ }^{\circ}$ and $\mathrm{V}^{\circ}$ of Minerals Used to Estimate $\Delta \mathrm{G}_{\mathrm{f}}{ }^{\circ}$ and $\mathrm{V}^{\circ}$ of Silicated Components of Clay Minerals ....................................................................................................... 4-11

4-7. Thermodynamic Data for Reference Minerals Used to Estimate $\mathrm{S}^{\circ}$ and the $\mathrm{a}, \mathrm{b}$, and c Heat Capacity Parameters of the Silicated Components of Clay Minerals ...........4-12

4-8. Clay Minerals for which Molar Volumes Will Be Evaluated in this Report................. 4-13

4-9. Zeolite Minerals Included in Data0.ymp.R2 (DTN: MO0302SPATHDYN.000

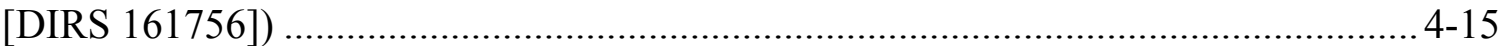

4-10. Thermodynamic Data for Zeolite Minerals .............................................................. 4-16

4-11. Thermodynamic Properties for Calcium Silicates and Aluminates ............................... 4-17

4-12. Thermodynamic Data for CSH with Ca to Si Ratio of 1.7 .......................................... 4-18

4-13. Heat Capacity Coefficient Data for Portlandite, Alpha-Quartz, and $\mathrm{H}_{2} \mathrm{O}$.................... 4-18

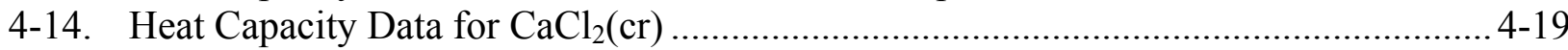

4-15. Gibbs Free Energy of Formation for Na- and Ca-Gismondine Minerals ....................... 4-19

4-16. Sources of Thermodynamic Data for Inputs for Uranium Silicate Minerals ................. 4-20

4-17. Thermodynamic Data Used as Inputs to Calculate Log K Grids for Data0.ymp.R2 (DTN: MO0302SPATHDYN.000 [DIRS 161756]) …………………………….....4-22

4-18. $\quad$ Log K Data for Dissociation of HF(aq) ………................................................ 4-29

4-19. Log K Data for the $\mathrm{HF}_{2}^{-}$Association Reaction Delineated by Eq. 4-3 ………............ 4-29

4-20. Thermodynamic Data Input for Gas Phases Updated or Added to Data0.ymp.R2 (DTN: MO0302SPATHDYN.000 [DIRS 161756]) …………………………....... 4-29

4-21. Molar Volumes of Mineral/Solid Phases from Data0.ymp.R2 ................................... 4-31

6-1. Comparison of $\Delta \mathrm{G}_{\mathrm{f}}{ }^{\circ}$ Obtained from Data0.ymp.R2 with the $\Delta \mathrm{G}_{\mathrm{f}}{ }^{\circ}$ from Gunnarsson and Arnórsson for $\mathrm{SiO}_{2}$ (aq) ..... 6-13

6-2. Calculated Log K Grids for Quartz Showing the Effect of Changing from the Fournier Paradigm to the Rimstidt Paradigm 6-15

6-3. Calculated Log K Grids for Quartz Comparing the Present Rimstidt Data (SUPCRT92 with Updated $\mathrm{SiO}_{2}(\mathrm{aq})$ ) with Rimstidt Temperature Function and with Gunnarsson and Arnórsson Temperature Function 6-16 


\section{TABLES (Continued)}

Page

6-4. Differences in $\Delta \mathrm{G}_{\mathrm{f}}{ }^{\circ}$ of Ca-Bearing Minerals Due for Updated $\mathrm{Ca}^{++}$

Thermodynamic Properties ....................................................................................... 6-18

6-5. Log K EQ3/6 Grid for Neptunium and Plutonium Aqueous Species ............................ 6-20

6-6. Log K EQ3/6 Grids for Actinide Redox Species and Titanium Species ........................ 6-26

6-7. Thermodynamic Data for Titanium-Hydroxy Species and Associated Reactions ........ 6-27

6-8. $\quad \Delta \mathrm{G}_{\mathrm{f}}{ }^{\circ}$ of Silicated Exchangeable Components Used by Wolery .................................... 6-30

6-9. Estimated Molar Volumes $\left(\mathrm{cm}^{3} / \mathrm{mol}\right)$ for the Minerals of Interest: Modified Re-Creation Versus Original Calculations.................................................................. 6-35

6-10. Estimated Standard Entropies (cal/mol-K) for the Minerals of Interest: Modified

Re-Creation Versus Original Calculations................................................................. 6-36

6-11. Comparison of Log K Grid for Margarite Between Original $\Delta \mathrm{G}_{\mathrm{f}}{ }^{\circ}$ and the

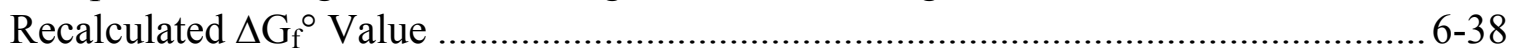

6-12. Calculated $\Delta \mathrm{G}_{\mathrm{f}}{ }^{\circ}$ Values for the Silicated Oxide Components that Are Used to Calculate the $\Delta \mathrm{G}_{\mathrm{f}}^{\circ}$ of the Clay Phases......

6-13. Calculated $\Delta \mathrm{V}_{\mathrm{f}}{ }^{\circ}$ Values for the Silicated Oxide Components that Will Be Used to Calculate the $\Delta \mathrm{G}_{\mathrm{f}}^{\circ}$ of the Clays

6-14. Estimated Gibbs Free Energies of Formation (cal $/ \mathrm{mol}$ ) for the Minerals of Interest: Original Wolery Estimates, "Re-Creation" Estimates, and Final "Reestimation" Estimates

6-15. Estimated Log K Values at $25^{\circ} \mathrm{C}$ for Dissolution Reactions of Some

Minerals: Values from Data0.ymp.R0 Versus Revised Values for Data0.ymp.R2 Based on the Current Final "Reestimation" of Gibbs Free Energies in Conjunction with the Rimstidt Paradigm for $\mathrm{SiO}_{2}$ (aq) Properties.

6-16. Summary of "Reestimated" Thermodynamic Properties of Clay Minerals.................... 6-41

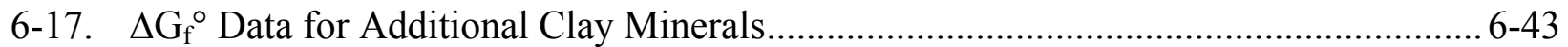

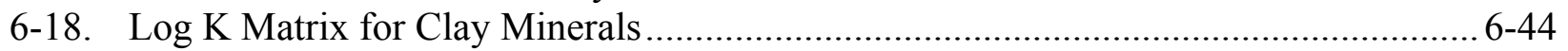

6-19. Estimated Gibbs Free Energies of Formation (cal $/ \mathrm{mol})$ for the Minerals of Interest: Original Wolery Estimates, "Re-Creation" Estimates, and Final

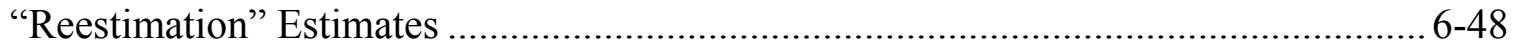

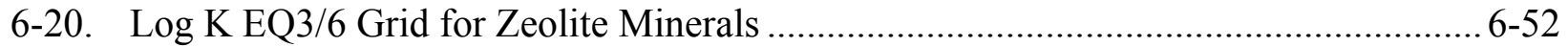

6-21. Log K EQ3/6 Grid for Corrected Zeolite Minerals ..................................................... 6-52

6-22. $\Delta \log \mathrm{K}$ (Difference Between Incorrect and Corrected Values) for Zeolite Minerals in Table 6-21 ..................................................................................... 6-53

6-23. Thermodynamic Data for Additional Zeolite Minerals Included in Data0.ymp.R2 (DTN: MO0302SPATHDYN.000 [DIRS 161756]) ……………………………..... 6-55

6-24. Minerals Commonly Associated with Cements and Grouts Along with Sources .......... 6-57

6-25. Calculated Log K Grid for Cement Mineral Phases ...................................................... 6-59

6-26. Thermodynamic Data for CSH with Ca to Si Ratio of 1.7 ….................................... 6-63

6-27. Values of Gibbs Free Energy, Enthalpy, Entropy, and Heat Capacity for Ettringite

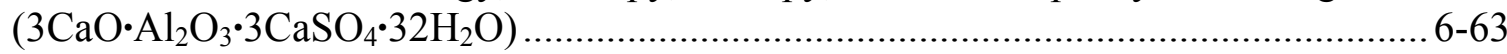

6-28. Gibbs Free Energy of Formation and Log K Values for the Dissociation Reaction Represented by Eqs. 6-24 and 6-25 for Na- and Ca-Gismondine Minerals .................. 6-65

6-29. Gibbs Free Energy of Formation and Log K Values for the Dissociation Reaction Represented by Eq. 6-26 for "Friedl Salt" in Data0.ymp.R2 Database ${ }^{\mathrm{a}}$. 


\section{TABLES (Continued)}

Page

6-30. Comparison of Gibbs Free Energy of Formation for Hydrated Gehlenite .................. 6-68

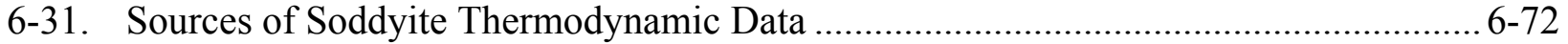

6-32. Sources of Uranophane Thermodynamic Data .................................................... 6-74

6-33. Log K EQ3/6 Grids for Solid Phases....................................................................... 6-80

6-34. Corrected Log K EQ3/6 Grids for $\mathrm{Np}$ and Pu Solid Phases ....................................... 6-88

6-35. $\Delta \log \mathrm{K}$ (Difference Between Incorrect and Corrected Values) for $\mathrm{Np}$ and $\mathrm{Pu}$

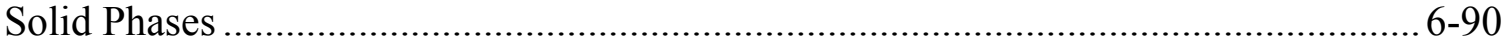

6-36. Thermodynamic Data Input for Gas Phases with the Correct Scaling of the "c" Heat Capacity Coefficient....................................................................................... 6-92

6-37. Corrected Log K EQ3/6 Grids for Affected Solid Phases ........................................ 6-95

6-38. $\Delta \log \mathrm{K}$ (Difference Between Incorrect and Corrected Values) for Solid Phases ...... 6-100

6-39. Comparison of $\Delta \mathrm{H}_{\mathrm{f}}^{\circ}$ and $\mathrm{S}^{\circ}$ Values for Solid Species from Binnewies and Milke,

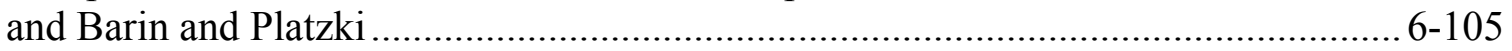

6-40. Log K EQ3/6 Grids for Hydrogen Fluoride Species .............................................. 6-109

6-41. Log K EQ3/6 Grids for Gas Species................................................................. 6-111

6-42. Thermodynamic Data Input for Gas Phases with the Correct Scaling of the "c" Heat Capacity Coefficient.......................................................................................... 6-113

6-43. Log K EQ3/6 Grid for Corrected Gas Species in Table 6-41 ................................... 6-114

6-44. $\Delta \log \mathrm{K}$ (Difference Between Incorrect and Corrected Values) for Gas Species....... 6-116

6-45. Comparison of $\Delta \mathrm{H}_{\mathrm{f}}^{\circ}$ and $\mathrm{S}^{\circ}$ Values from Binnewies and Milke, and Barin and

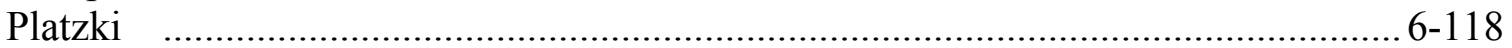

6-46. Mineral Phase Molar Volume and Density Data ................................................ 6-123

7-1. Summary of Qualification Recommendations ...................................................... 7-1

7-2. Isocoulombic Extrapolation of the Calculated Apparent Gibbs Free Energy Grids of $\mathrm{Am}^{+++}$, Comparing Extrapolations Using Various Reference Reactions

7-3. Isocoulombic Extrapolation of the Calculated Apparent Gibbs Free Energy Deviations from Mean of $\mathrm{Am}^{+++}$ 7-10 


\section{INTENTIONALLY LEFT BLANK}




\section{ACRONYMS AND ABBREVIATIONS}

(aq) aqueous

CR Condition Report

(cr) crystalline

$\mathrm{CSH} \quad$ calcium silicate hydrate

DIRS Document Input Reference System

DTN data tracking number

(g) gas

NEA Nuclear Energy Agency

OECD Organization for Economic Cooperation and Development

(s) solid

YMP Yucca Mountain Project 
INTENTIONALLY LEFT BLANK 


\section{PURPOSE}

The purpose of this analysis report is to qualify the thermochemical database data0.ymp.R2 (DTN: MO0302SPATHDYN.000 [DIRS 161756], qualified by this report) and supporting calculations (DTNs: MO0302SPATHDYN.001 [DIRS 161886], and MO0303SPASPEQ2.000 [DIRS 162278]), which were originally documented in Data Qualification: Update and Revision of the Geochemical Thermodynamic Database, Data0.ymp (Steinborn et al. 2003 [DIRS 161956]). This original document still serves as the record of development of the data0.ymp.R2 database (DTN: MO0302SPATHDYN.000 [DIRS 161756]).

The data0.ymp.R2 thermodynamic database (DTN: MO0302SPATHDYN.000 [DIRS 161756]) was developed for use with software code EQ3/6 (EQ3/6 V8.0, STN: 10813-8.0-00) (BSC 2003 [DIRS 162228]) and software code EQ6 (EQ6 V7.2bLV, STN: 10075-7.2bLV-02) (BSC 2002 [DIRS 159731]) to conduct geochemical modeling of mineral-fluid interactions involving aqueous solutions (ionic strengths of up to one molal; see Section 6.5) and temperatures of up to $300^{\circ} \mathrm{C}$ along the liquid-vapor saturation curve of pure water. The data0.ymp.R2 database (DTN: MO0302SPATHDYN.000 [DIRS 161756]) is an update of the previously qualified predecessor database data0.ymp.R0 (DTN: MO0009THRMODYN.001 [DIRS 152576]). The scope of this report is limited to qualification of the updates, as well as identification and evaluation of certain errors and discrepancies as discussed below.

This report documents the qualification of the data0.ymp.R2 database (DTN: MO0302SPATHDYN.000 [DIRS 161756]) and in so doing, also identifies and evaluates certain discrepancies between data sources and the data0.ymp.R2 database (DTN: MO0302SPATHDYN.000 [DIRS 161756]). These discrepancies are mainly the result of errors in the transcription of thermodynamic parameter data from original sources to calculation spreadsheets used to develop the data0.ymp.R2 database (DTN: MO0302SPATHDYN.000 [DIRS 161756]). The potential importance of these discrepancies for downstream applications of the data0.ymp.R2 database (DTN: MO0302SPATHDYN.000 [DIRS 161756]) is evaluated in this report, and summarized in Section 7. An updated database called data0.ymp.R4 (output DTN: SN0410T0510404.002) is generated as output from this report, to address and correct the discrepancies found. This analysis report is developed from Technical Work Plan for: Near-Field Environment and Transport In-Drift Geochemistry Analyses (BSC 2004 [DIRS 172402]).

The data0.ymp.R2 database (DTN: MO0302SPATHDYN.000 [DIRS 161756]) is used in predictive models for waste form and waste package corrosion, modeling of in-package and in-drift chemical conditions, and prediction of dissolved radionuclide concentrations. The data are also used to support criticality assessments and modeling of reactive transport of radionuclides in groundwater. This database is a principal input for geochemical code EQ3/6 and in a modified format, for PHREEQC (PHREEQC_Post V1.1, STN: 10723-1.1-00) (BSC 2002 [DIRS 157839]). Parameters from the data0.ymp.R2 database (DTN: MO0302SPATHDYN.000 [DIRS 161756]) have also been used to develop inputs for reactive transport code TOUGHREACT (TOUGHREACT V3.0, STN: 10396-3.0-00) (LBNL 2002 [DIRS 161256]; BSC 2004 [DIRS 170268]). 
Use of the data0.ymp.R2 database (DTN: MO0302SPATHDYN.000 [DIRS 161756]) has promoted consistency for the various types of thermodynamic calculations used to support licensing of the Yucca Mountain repository. The intermediate version data0.ymp.R1 of the database was generated in the course of development, but not used for calculations that support licensing. The version data0.ymp.R3 of the database (DTN: MO0312SPATDMIF.000 [DIRS 167800]) is an update of the data0.ymp.R2 database (DTN: MO0302SPATHDYN.000 [DIRS 161756]) that only incorporates a correction in the stoichiometry of the $\mathrm{Pu}$ phase $\mathrm{PuO}_{2}(\mathrm{OH})_{2}: \mathrm{H}_{2} \mathrm{O}$. This modification is also incorporated in the data0.ymp.R4 database (output DTN: SN0410T0510404.002).

The updates implemented in development of the data0.ymp.R2 database (DTN: MO0302SPATHDYN.000 [DIRS 161756]) from the predecessor database data0.ymp.R0 (DTN: MO0009THRMODYN.001 [DIRS 152576]) are documented in Data Qualification: Update and Revision of the Geochemical Thermodynamic Database, Data0.ymp (Steinborn et al. 2003 [DIRS 161956]) and summarized as follows:

1. Incorporation of newer data for $\mathrm{Np}$ and $\mathrm{Pu}$ species, published by the Organization for Economic Cooperation and Development/Nuclear Energy Agency (OECD/NEA) (Lemire 2001 [DIRS 159027]).

2. Addition of solid phases, including clays, zeolites, uranium silicate minerals, and cement phases.

3. Addition of several uranium silicate minerals.

4. Calculation of equilibrium constants $(\log \mathrm{K})$ for temperatures above $25^{\circ} \mathrm{C}$ (to at least $200^{\circ} \mathrm{C}$ whenever possible; data for many reactions extend to $300^{\circ} \mathrm{C}$ ).

5. Change in basis for silicate species using the Rimstidt (1997 [DIRS 101709]) convention.

Additional changes in the corrected data0.ymp.R4 database (output DTN: SN0410T0510404.002) consist mainly of updates and corrections to $\log \mathrm{K}$ values for dissociation reactions over the appropriate temperature ranges. Other updates and corrections are described in Section 6 and include:

- $\quad \log \mathrm{K}$ values for some zeolite phases (Section 6.3.2).

- $\quad \log \mathrm{K}$ values for $\mathrm{Np}$ and Pu solids (Section 6.3.4.5).

- Log K values for metal-bearing gases and solids (Section 6.3.4.5).

- Identification of large discrepancies in calculated $\log \mathrm{K}$ values for cement phases, such as Ca-gismondine and Friedl salt (Section 6.3.3.4). 
- Correction of the $\log \mathrm{K}$ values for the $\mathrm{HF}_{2}{ }^{-}$dissociation reaction (Section 6.4).

- Correction of the $\mathrm{Pu}$ phase $\mathrm{PuO}_{2}(\mathrm{OH})_{2}: \mathrm{H}_{2} \mathrm{O}$ stoichiometry using the formula of Lemire (2001 [DIRS 159027]; see Table 4-1 and Section 4.1.1 of this report). This correction is also made in a previous version of the database (data0.ymp.R3; DTN: MO0312SPATDMIF.000 [DIRS 167800]) and is incorporated in the output database file data0.ymp.R4 (output DTN: SN0410T0510404.002).

In addition, three condition reports (CRs) (CR-85, CR-168, and CR-304) directed against the data0.ymp.R2 database (DTN: MO0302SPATHDYN.000 [DIRS 161756]) are addressed in this report. Details of these CR items are given in Technical Work Plan for: Near-Field Environment and Transport In-Drift Geochemistry Analyses (BSC 2004 [DIRS 172402], Appendix 6). For completeness, these are also listed as follows:

1. CR-85 captures Deficiency Report BSC(O)-03-D-236 (initiated on August 14, 2003). It states that the data qualification method of technical assessment, as used originally to qualify the data0.ymp.R2 database (DTN: MO0302SPATHDYN.000 [DIRS 161756]; Steinborn et al. 2003 [DIRS 161956]) is invalid. Since the Deficiency Report was initiated, technical assessment was eliminated as a method for data qualification, then subsequently reinstated. This CR is now closed.

2. CR-168 captures Technical Error Report TER-03-0037, Data Qualification: Update and Revision of the Geochemical Thermodynamic Database, Data0.ymp. This report cited the 20 sources of data listed in Table 1-1 and describes the following deficiency: "The Data Qualification Report did not in all cases provide adequate justification for the qualification of the 20 sources for geochemical data." The error report goes on to say, "Additionally, the subject matter expert for each of the above was not identified in the Data Qualification Report. This condition was noted in BSC(O)-03-D-130."

3. CR-304 captures the previous Condition/Issue Identification and Reporting/Resolution System Issue 3867 and describes the condition as "Engineered Systems include database qualification...SA-PAP-2003-017 was conducted as a second management review of Biosphere, Waste Package, and Waste Form Analyses and Model Reports (AMR) preliminary feeds to TSPA-LA [Total System Performance Assessment for the License Application]. A major crosscutting issue observed is captured in this CIRS [Condition/Issue Identification and Reporting/Resolution System] issue. Self-Assessment Attachment 1, page 7, item 2 describes this issue. Several database issues were raised as part of the review. It was noted that the EQ3/6 and Pitzer databases (as well as an industry standard materials database used by THERMO-CALC) needed additional qualification efforts before they could be used in applications. Engineered Systems should review the schedule to ensure adequacy of database qualification and ensure that qualification is complete prior to analyses.... This may be accomplished by preparing a punchlist to help monitor the completed documents as they get approved."

An additional CR, CR-3574, which was not listed in the Technical Work Plan, identified errors in actinide and zeolite thermodynamic data in data0.ymp.R2 (DTN: MO0302SPATHDYN.000 [DIRS 161756]). This report addresses these issues and supports the closure of the CR. 
Table 1-1. Data Evaluated in the Data Qualification Report

\begin{tabular}{|c|c|c|c|c|}
\hline Description & Source & $\begin{array}{c}\text { Qualification } \\
\text { Adequate? } \\
\text { (CR-168) }\end{array}$ & $\begin{array}{l}\text { Where } \\
\text { Discussed in } \\
\text { this Report }\end{array}$ & Comments \\
\hline $\begin{array}{l}\text { Data from } \\
\text { data0.ymp.R0 }\end{array}$ & $\begin{array}{l}\text { DTN: MO0009THRMODYN. } \\
001 \text { [DIRS 152576] }\end{array}$ & Y & Throughout & $\begin{array}{l}\text { Qualified input to this } \\
\text { report. }\end{array}$ \\
\hline Handbook data & $\begin{array}{l}\text { Binnewies and Milke } 1999 \\
\text { [DIRS 158955] }\end{array}$ & Y & $\begin{array}{l}\text { 6.1.4.2, 6.3.4.5, } \\
6.4\end{array}$ & $\begin{array}{l}\text { Qualified input to this } \\
\text { report. }\end{array}$ \\
\hline Handbook data & $\begin{array}{l}\text { Barin and Platzki } 1995 \\
\text { [DIRS 157865] }\end{array}$ & $\mathrm{Y}$ & $\begin{array}{l}\text { 6, 6.1.2, 6.1.4.2 } \\
6.1 .5,6.3 .4 .5,6.4\end{array}$ & $\begin{array}{l}\text { Qualified input to this } \\
\text { report. }\end{array}$ \\
\hline $\mathrm{Np}$ and $\mathrm{Pu}$ data & Lemire 2001 [DIRS 159027] & Y & $\begin{array}{l}6,6.2 .1,6.2 .2 \\
6.3 .4 .5\end{array}$ & $\begin{array}{l}\text { Qualified input to this } \\
\text { report. }\end{array}$ \\
\hline Soddyite $\log \mathrm{K}_{\mathrm{sp}}$ & $\begin{array}{l}\text { Moll et al. 1996 } \\
\text { [DIRS 106349] }\end{array}$ & $\mathrm{N}$ & 6.3.4.1 & Corroborated. \\
\hline Uranophane $\log \mathrm{K}_{\mathrm{sp}}$ & $\begin{array}{l}\text { Perez et al. 2000 } \\
\text { [DIRS 157910] }\end{array}$ & $\mathrm{N}$ & 6.3.4.2 & Corroborated. \\
\hline Na-Weeksite log $K_{\mathrm{sp}}$ & $\begin{array}{l}\text { Nguyen et al. } 1992 \\
\text { [DIRS 100809] }\end{array}$ & $\mathrm{N}$ & 6.3.4.3 & Corroborated. \\
\hline Na-Boltwoodite log $K_{s p}$ & $\begin{array}{l}\text { Nguyen et al. } 1992 \\
\text { [DIRS 100809] }\end{array}$ & $\mathrm{N}$ & 6.3.4.3 & Corroborated. \\
\hline Zeolite data & $\begin{array}{l}\text { Chipera et al. } 1995 \\
\text { [DIRS 100025] }\end{array}$ & $\mathrm{N}$ & 6.3 .2 & Technical assessment. \\
\hline Zeolite data & $\begin{array}{l}\text { Viani and Bruton } 1992 \\
\text { [DIRS 101407] }\end{array}$ & $\mathrm{N}$ & 6.3 .2 & Technical assessment. \\
\hline $\begin{array}{l}\text { Calcium silicates, } \\
\text { aluminates, and } \\
\text { ferrites data }\end{array}$ & $\begin{array}{l}\text { Babushkin et al. } 1985 \\
\text { [DIRS 116981], App. I }\end{array}$ & Y & $\begin{array}{l}\text { 6.3.3, 6.3.3.2, } \\
6.3 .3 .4,6.3 .3 .5\end{array}$ & $\begin{array}{l}\text { Qualified, direct input to } \\
\text { this report. Note: This } \\
\text { source is used for } \\
\text { active species in } \\
\text { data0.ymp.R2, but also } \\
\text { certain inactive species. }\end{array}$ \\
\hline $\begin{array}{l}\text { Calcium silicate } \\
\text { hydrate data }\end{array}$ & $\begin{array}{l}\text { Fujii and Kondo } 1983 \\
\text { [DIRS 144876]. Note that } \\
\text { Steinborn et al. (2003 } \\
\text { [DIRS 161956]) and CR-168 } \\
\text { incorrectly cite Fujii and } \\
\text { Kondo (1981 [DIRS 158026]) } \\
\text { as the data source for } \\
\text { CSH:1.7. }\end{array}$ & $\mathrm{N}$ & 6.3.3.1 & $\begin{array}{l}\text { Used in discussion of } \\
\text { species CSH:1.7, which } \\
\text { is inactive in } \\
\text { data0.ymp.R2. }\end{array}$ \\
\hline $\mathrm{CaCl}_{2}$ data & Chase 1998 [DIRS 157874] & Y & 6.3.3.4 & $\begin{array}{l}\text { Qualified, direct input to } \\
\text { this report; used in } \\
\text { discussion of species } \\
\text { Friedl salt, which is an } \\
\text { inactive species in } \\
\text { data0.ymp.R2. }\end{array}$ \\
\hline
\end{tabular}


Table 1-1. Data Evaluated in the Data Qualification Report (Continued)

\begin{tabular}{|c|c|c|c|c|}
\hline Description & Source & $\begin{array}{c}\text { Qualification } \\
\text { Adequate? } \\
\text { (CR-168) }\end{array}$ & $\begin{array}{l}\text { Where } \\
\text { Discussed in } \\
\text { this Report }\end{array}$ & Comments \\
\hline $\begin{array}{l}\text { Gehlenite Hydrate } \\
\text { Hydrotalcite }\end{array}$ & $\begin{array}{l}\text { Gehlenite Hydrate: Atkins } \\
\text { et al. } 1992 \text { [DIRS 100700] } \\
\text { Hydrotalcite: Bennett et al. } \\
1992 \text { [DIRS 116990] }\end{array}$ & N & $\begin{array}{l}\text { Gehlenite } \\
\text { hydrate: } 6.3 .3 .5 \\
\text { Hydrotalcite: } \\
6.3 .3 .6 \\
\end{array}$ & $\begin{array}{l}\text { Gehlenite hydrate is } \\
\text { corroborated, and } \\
\text { hydrotalcite is qualified } \\
\text { by technical } \\
\text { assessment. }\end{array}$ \\
\hline $\begin{array}{l}\text { Monocarboaluminate } \\
\text { and } \\
\text { Hemicarboaluminate }\end{array}$ & $\begin{array}{l}\text { Damidot et al. } 1994 \\
\text { [DIRS 144866] }\end{array}$ & $\mathrm{N}$ & $\begin{array}{l}\text { Monocarbo- } \\
\text { aluminate: } \\
6.3 .3 .7 \\
\text { Hemicarbo- } \\
\text { aluminate: } \\
6.3 .3 .8\end{array}$ & $\begin{array}{l}\text { Qualified as input by } \\
\text { technical assessment. }\end{array}$ \\
\hline Syngenite & $\begin{array}{l}\text { DTN: MO0109THRMODYN. } \\
000 \text { [DIRS 156190] }\end{array}$ & $\mathrm{Y}$ & 6.3.3.9 & $\begin{array}{l}\text { Source shown is not } \\
\text { used as input; } \\
\text { syngenite properties } \\
\text { are redefined in this } \\
\text { report using another } \\
\text { source. }\end{array}$ \\
\hline Gismondine & $\begin{array}{l}\text { Atkins et al. } 1993 \\
\text { [DIRS 131758], Section 5.2.6 }\end{array}$ & $\mathrm{N}$ & 6.3.3.3 & $\begin{array}{l}\text { Qualified by technical } \\
\text { assessment. }\end{array}$ \\
\hline $\begin{array}{l}\text { SUPCRT92 data for } \\
\text { organic species }^{a}\end{array}$ & $\begin{array}{l}\text { DTN: MO0106MWDTDG01. } \\
\text { 035 [DIRS 161791], } \\
\text { slop98.dat }\end{array}$ & $\mathrm{Y}$ & N/A & \\
\hline $\begin{array}{l}\text { Organic metal } \\
\text { complex data }\end{array}$ & $\begin{array}{l}\text { Morel and Hering } 1993 \\
\text { [DIRS 151052] }\end{array}$ & N & $\mathrm{N} / \mathrm{A}$ & \\
\hline Organic data ${ }^{a}$ & $\begin{array}{l}\text { Krishnamurty and Harris } \\
1961 \text { [DIRS 159026] }\end{array}$ & N & $\mathrm{N} / \mathrm{A}$ & \\
\hline Organic data ${ }^{a}$ & $\begin{array}{l}\text { Martell and Smith } 1982 \\
\text { [DIRS 159196] }\end{array}$ & $\mathrm{N}$ & N/A & \\
\hline R-constant & $\begin{array}{l}\text { Weast and Astle } 1979 \\
\text { [DIRS 102865] }\end{array}$ & $\mathrm{Y}$ & Throughout & $\begin{array}{l}\text { Qualified input to this } \\
\text { report. }\end{array}$ \\
\hline $\begin{array}{l}\text { Ti-mineral data } \\
\text { (Ti-hydroxy (aq) and } \\
\text { rutile) }\end{array}$ & $\begin{array}{l}\text { Ti-hydroxy (aq): Knauss } \\
\text { et al. } 2001 \text { [DIRS 158998] } \\
\text { Rutile: Robie et al. 1979 } \\
\text { [DIRS 107109] }\end{array}$ & $\mathrm{N}$ & 6.2 .2 & $\begin{array}{l}\text { Corroboration and } \\
\text { technical assessment. }\end{array}$ \\
\hline $\mathrm{Am}^{+++}$data & $\begin{array}{l}\text { Silva et al. } 1995 \\
\text { [DIRS 102087] }\end{array}$ & $\mathrm{N}$ & 6.2 .2 & Established fact. $^{\mathrm{b}}$ \\
\hline$\beta-\mathrm{UO}_{3}$ data & $\begin{array}{l}\text { Grenthe et al. } 1992 \\
\text { [DIRS 101671] }\end{array}$ & $\mathrm{N}$ & 4.1 .7 & Established fact. $^{\mathrm{b}}$ \\
\hline $\mathrm{SiO}_{2}$ solubility & Rimstidt 1997 [DIRS 101709] & $\mathrm{N}$ & 6.3 & $\begin{array}{l}\text { This report uses } \\
\text { ANL-NBS-HS-000043 } \\
\text { Rev. 00 (BSC } 2004 \\
\text { [DIRS } 170268] \text { ) as the } \\
\text { source of these data. }\end{array}$ \\
\hline
\end{tabular}


Table 1-1. Data Evaluated in the Data Qualification Report (Continued)

\begin{tabular}{|l|l|c|l|l|}
\hline \multicolumn{1}{|c|}{ Description } & Source & $\begin{array}{c}\text { Qualification } \\
\text { Adequate? } \\
\text { (CR-168) }\end{array}$ & $\begin{array}{c}\text { Where } \\
\text { Discussed in } \\
\text { this Report }\end{array}$ & \multicolumn{1}{c|}{ Comments } \\
\hline Clay mineral data & Wolery 1978 [DIRS 151346] & $\mathrm{N}$ & 6.3 .1 & $\begin{array}{l}\text { The clay mineral data in } \\
\text { data0.ymp.R2 were } \\
\text { developed using the } \\
\text { method of Wolery (1978 } \\
\text { [DIRS 151346]) and the } \\
\text { data of Helgeson et al. } \\
\text { (1978 [DIRS 101596]). }\end{array}$ \\
\hline $\mathrm{HF}_{2}{ }^{-}$data & Clark 1966 [DIRS 153163] & $\mathrm{N}$ & 6.4 & Established fact. \\
\hline $\mathrm{HF}$ data & & $\mathrm{N}$ & 6.4 & $\begin{array}{l}\text { Corroboration and } \\
\text { technical assessment. } \\
\text { These data are used to } \\
\text { extend data from Clark } \\
\text { (1966 [DIRS 153163]), } \\
\text { which is used in this } \\
\text { report for temperatures } \\
\text { up to 200 }{ }^{\circ} \mathrm{C} .\end{array}$ \\
\hline
\end{tabular}

${ }^{a}$ These data for organic species are not included in data0.ymp.R2 (DTN: MO0302SPATHDYN.000 [DIRS 161756]) are outside the scope of this report.

b The data source(s) shown were used for data0.ymp.R0 (DTN: MO0009THRMODYN.001 [DIRS 152576]), which is qualified input to this report, but covers only the temperature range from $0^{\circ} \mathrm{C}$ to $100^{\circ} \mathrm{C}$.

Of the items listed in Table 1-1, the four associated with organic data are not addressed in this report because the organic data described in Data Qualification: Update and Revision of the Geochemical Thermodynamic Database, Data0.ymp (Steinborn et al. 2003 [DIRS 161956]) were submitted as a separate database file (total_organics.txt; DTN: MO0208THDYNORG.000 [DIRS 172399]) and are not linked to data0.ymp.R2 (DTN: MO0302SPATHDYN.000 [DIRS 161756]). Thus the qualification of the organic data is beyond the scope of this report. Log $\mathrm{K}$ data for various cement phases present in data0.ymp.R2 (DTN: MO0302SPATHDYN.000 [DIRS 161756]) and the output database data0.ymp.R4 (output DTN: SN0410T0510404.002) are inactive (they are "commented out" in the database and cannot be accessed by the EQ3/6 code), although they are evaluated and qualified in this report. These inactive data remain inactive in both the data0.ymp.R2 and the data0.ymp.R4 databases, but the thermodynamic information in the comments, and the discussion of these data in this report, are available for possible use in future applications.

Several analysis model reports that use data0.ymp.R2 (DTN: MO0302SPATHDYN.000 [DIRS 161756]) as direct input are listed in Table 1-2. 
Table 1-2. List of Approved Analysis Model Reports Using the Thermodynamic Database Data0.ymp.R2 (DTN: MO0302SPATHDYN.000 [DIRS 161756])

\begin{tabular}{|l|l|}
\hline \multicolumn{1}{|c|}{ Analysis Model Report Title } & \multicolumn{1}{|c|}{ Document Number, Revision } \\
\hline $\begin{array}{l}\text { Data Qualification for Thermodynamic Data Used to Support THC } \\
\text { Calculations }\end{array}$ & ANL-NBS-HS-000043 Rev. 00 \\
\hline $\begin{array}{l}\text { In-Drift Precipitates/Salts Model } \\
\text { Engineered Barrier System: Physical and Chemical Environment }\end{array}$ & ANL-EBS-MD-000045 Rev. 02 \\
\hline $\begin{array}{l}\text { Environment on the Surfaces of the Drip Shield and Waste } \\
\text { Package Outer Barrier }\end{array}$ & ANL-EBS-MD-000001 Rev. 01 \\
\hline Heat Capacity Analysis Report & ANL-NBS-GS-000013 Rev. 01 \\
\hline $\begin{array}{l}\text { In-Package Chemistry Abstraction } \\
\text { Dissolved Concentration Limits of Radioactive Elements }\end{array}$ & ANL-EBS-MD-000037 Rev. 03 \\
\hline $\begin{array}{l}\text { Geochemical Interactions in Failed Co-Disposal Waste Packages } \\
\text { for Shippingport PWR and TRIGA Spent Fuel and in Dual Canister } \\
\text { Packages of Three Mile Island and Fort St. Vrain Spent Fuel }\end{array}$ & ANL-EBS-PA-000008 Rev. 00 \\
\hline $\begin{array}{l}\text { Impacts of Updated Design and Rates on EQ6 Calculations for } \\
\text { Chemical Degradation of Fermi and TRIGA Codisposal Waste } \\
\text { Packages }\end{array}$ & CAL-DSD-MD-000001 Rev. 00A \\
\hline \begin{tabular}{l} 
Mass Transfer Model \\
\hline Drift-Scale THC Seepage Model
\end{tabular} & MDL-EBS-NU-000004 Rev. 01 \\
\hline \begin{tabular}{l} 
Mountain-Scale Coupled Processes (TH/THC/THM) \\
\hline
\end{tabular} & MDL-NBS-HS-000001 Rev. 03 \\
\hline
\end{tabular}




\section{INTENTIONALLY LEFT BLANK}




\section{QUALITY ASSURANCE}

The quality assurance program used for the development of this activity and document is discussed in Technical Work Plan for: Near-Field Environment and Transport In-Drift Geochemistry Analyses (BSC 2004 [DIRS 172402]). In accordance with this Technical Work Plan, this activity involves the qualification of a thermodynamic database used in the assessment of the chemical evolution and interactions of aqueous systems in the Engineered Barrier System. These interactions include those present inside the emplacement drifts and waste packages, and the exterior of the waste packages and drip shield.

The information provided by this report is used to investigate the performance of the following safety-category barriers as defined in the Q-List (BSC 2004 [DIRS 168361], Table A-2) that are important to the demonstration of compliance with the postclosure performance objectives prescribed in 10 CFR 63.113 [DIRS 156605]:

- Drip Shield

- Waste Package

- Waste Form

- Cladding

- Drift Invert (Ballast).

These barriers are classified as Safety Category with regard to importance to waste isolation as defined in AP-2.22Q, Classification Analyses and Maintenance of the Q-List. This report contributes to the analyses and modeling data used to support performance assessment; the conclusions do not directly impact the engineered features important to safety as listed above.

The methods used to control the electronic management of data, as required by AP-SV.1Q, Control of the Electronic Management of Information, are identified in Technical Work Plan for: Near-Field Environment and Transport In-Drift Geochemistry Analyses (BSC 2004 [DIRS 172402]). This document was prepared in accordance with AP-SIII.9Q, Scientific Analyses, and AP-SIII.2Q, Qualification of Unqualified Data. Software usage discussed in the next section was conducted in accordance with LP-SI.11Q-BSC, Software Management. 
INTENTIONALLY LEFT BLANK 


\section{USE OF SOFTWARE}

Only exempt software, defined in accordance with LP-SI.11Q-BSC, Software Management, were used in this data qualification analysis report. Whereas the following baseline software items are discussed in this report and included in the reference list (Section 8.5), these were either used previously to develop data that are input to this report (i.e., the data0.ymp.R2 database, DTN: MO0302SPATHDYN.000 [DIRS 161756], qualified by this report, and supporting calculations, DTNs: MO0302SPATHDYN.001 [DIRS 161886] and MO0303SPASPEQ2.000 [DIRS 162278]), or they were used in the discussion of the uses of the data0.ymp.R2 database (DTN: MO0302SPATHDYN.000 [DIRS 161756]) (see Section 1).

- PHREEQC (PHREEQC_Post V1.1, STN: 10723-1.1-00) (BSC 2002 [DIRS 157839])

- EQ3/6 (EQ3/6 V8.0, STN: 10813-8.0-00) (BSC 2003 [DIRS 162228])

- EQ6 (EQ6 V7.2bLV, STN: 10075-7.2bLV-02) (BSC 2002 [DIRS 159731])

- SUPCRT92 (SUPCRT92 V1.0, STN: 10058-1.0-00) (LBNL 1999 [DIRS 153218])

$\begin{array}{lllll}\text { - TOUGHREACT } & \text { (TOUGHREACT } & \text { V3.0, } & \text { STN: 10396-3.0-00) } & \text { (LBNL } 2002\end{array}$ [DIRS 161256]).

Microsoft Excel 2000, a commercially available spreadsheet software package, was installed and used on IBM-compatible computers using the Microsoft Windows operating system. This software, exempt in accordance with Section 2.1 of LP-SI.11Q-BSC, was used to tabulate results, visually display results, and perform standard calculations implementing algebraic equations. These algebraic equations are represented in the spreadsheets by thermodynamic formulations described in Section 6.1. The output of these calculations are presented in Section 6.2. The regression tool intrinsic to Microsoft Excel 2000 was used in many cases. No Excel macros were developed for this effort. 


\section{INTENTIONALLY LEFT BLANK}




\section{INPUTS}

Qualified and unqualified data are used as inputs in this analysis. Unqualified data are qualified in accordance with the Data Qualification Plan in Technical Work Plan for: Near-Field Environment and Transport In-Drift Geochemistry Analyses (BSC 2004 [DIRS 172402]). All source data are summarized in Table 4-1 in Section 4.1. These data are contained in a variety of reference materials that include handbook data and international scientific journal articles. They also include the qualified database data0.ymp.R0 (DTN: MO0009THRMODYN.001 [DIRS 152576]) and the associated SUPCRT92 data file slop98.dat (DTN: MO0106MWDTDG01.035 [DIRS 161791]), which were qualified in an earlier data qualification report (CRWMS M\&O 2000 [DIRS 152575]). Note that thermodynamic data from data0.ymp.R0 (DTN: MO0009THRMODYN.001 [DIRS 152576]) are only available up to $100^{\circ} \mathrm{C}$, and that $\log \mathrm{K}$ values up to temperatures of $300^{\circ} \mathrm{C}$ were developed for the data0.ymp.R2 database (DTN: MO0302SPATHDYN.000 [DIRS 161756], qualified by this report).

The qualification status of each input is documented in the Document Input Reference System (DIRS) and is summarized in Table 4-1. Inputs listed as "unqualified" in Table 4-1 are qualified in this report in accordance with AP-SIII.2Q, Qualification of Unqualified Data, using the qualification method(s) indicated in the table. These data are presented in more detail in Section 4.1 .

Potential data sources were identified by searching the on-line card catalogs of the University of New Mexico and Sandia National Laboratory technical libraries. Handbooks identified and reviewed as potential data sources began with Barin and Knacke (1973 [DIRS 160926]) and Binnewies and Milke (1999 [DIRS 158955]). The Binnewies and Milke handbook does not contain entropy data on the elements, but Barin and Platzki (1995 [DIRS 157865]) does contain those data, and was used as the source for this parameter. These handbooks also offer a comprehensive compilation of thermodynamic data and are widely accepted by geochemists in the international scientific community. The available handbook sources are reasonably comprehensive and up-to-date, so they were used to the extent possible.

In the original development of the data0.ymp.R2 database (DTN: MO0302SPATHDYN.000 [DIRS 161756]), thermodynamic data for approximately 500 solid and aqueous species and 53 elements were collected for use in calculations of in-package chemical reactions and reactions involving corrosion of materials and ambient environmental conditions relevant to the project. The species fit the following broad categories:

- A wide variety of species potentially involved in reactions among waste form, engineered components internal to the waste package, and groundwater entering the waste package

- Species potentially involved in reactions among Engineered Barrier System components and drift air and water chemistry - compounds of alloy metals with fluorides, chlorides, nitrates, carbonates, and other anions, and aqueous species. 
The thermodynamic properties compiled for the solid and aqueous species include:

$\log \mathrm{K} \quad$ Log equilibrium constant of chemical reaction (dimensionless)

$\Delta \mathrm{H}_{\mathrm{f}, 298}^{\circ}$ Standard enthalpy of formation at $298.15 \mathrm{~K}(\mathrm{~kJ} / \mathrm{mol}$ or $\mathrm{kcal} / \mathrm{mol})$

$\Delta \mathrm{G}_{\mathrm{f}, 298}^{\circ}$ Standard Gibbs free energy of formation at $298.15 \mathrm{~K}(\mathrm{~kJ} / \mathrm{mol}$ or $\mathrm{kcal} / \mathrm{mol})$

$\mathrm{S}^{\circ} \quad$ Standard entropy at $298.15 \mathrm{~K}$ (also referred to as $\left.\mathrm{S}^{\circ}{ }_{298}\right)(\mathrm{J} / \mathrm{mol}-\mathrm{K}$ or cal $/ \mathrm{mol}-\mathrm{K}$ )

$\mathrm{C}_{\mathrm{p}}{ }^{\circ} \quad$ Standard heat capacity at constant pressure, at $298.15 \mathrm{~K}(\mathrm{~J} / \mathrm{mol}-\mathrm{K}$ or cal $/ \mathrm{mol}-\mathrm{K})$

$\mathrm{a}, \mathrm{b}, \mathrm{c} \quad$ Temperature-dependent $\mathrm{C}_{\mathrm{p}}{ }^{\circ}$ coefficients (see Eq. 4-1) for use in extrapolating the database to elevated temperatures, using the Maier-Kelly equation (Eq. 4-1) as defined by Johnson et al. (1992 [DIRS 101632], p. 910) for the standard heat capacity $\mathrm{C}_{\mathrm{p}}{ }^{\circ}$, as explained in Section 6.1.1.

$$
C_{p}^{\circ}=a+b T+\frac{c}{T^{2}}
$$

where $\mathrm{T}$ is absolute temperature in Kelvin units. In some cases, log $\mathrm{K}$ data representing experimental mineral solubility based on infinite dilution solubility or a nearly-equivalent bounding condition were also extracted from the literature. Based on the thermodynamic relations explained in Section 6.1.1, $\log \mathrm{K}$ data can be used to extract standard thermodynamic data for the species of interest.

$\mathrm{S}^{\circ}$ was also compiled for the elements. This is occasionally needed to convert between $\mathrm{S}^{\circ}$ for a chemical species and the corresponding standard entropy at $298.15 \mathrm{~K}$. Corresponding heat capacity data for the elements are generally unnecessary, due to use of the apparent Gibbs free energy of formation and apparent enthalpy of formation (e.g., described by Helgeson et al. 1978 [DIRS 101596]), unless the corresponding chemical species, such as $\mathrm{O}_{2}(\mathrm{~g})$, are of direct interest.

\subsection{DIRECT INPUTS}

This section presents data collected from literature, handbooks, and other sources that are adopted as direct input and are listed in Table 4-1. These data include the direct inputs used originally to develop the data0.ymp.R2 database (DTN: MO0302SPATHDYN.000 [DIRS 161756]). Many of these direct input data required reduction and transformation for use in qualification, and in developing the corrected data0.ymp.R4 database, which is output from this report (output DTN: SN0410T0510404.002). The qualification and reduction processes are discussed in Sections 6.2 through 6.4.

The purpose of this report as stated in Section 1 is to qualify the existing data0.ymp.R2 database (DTN: MO0302SPATHDYN.000 [DIRS 161756]) and the original supporting calculations (DTN: MO0302SPATHDYN.001 [DIRS 161886], and DTN: MO0303SPASPEQ2.000 [DIRS 162278]). The qualification process focuses on changes from the previously qualified data0.ymp.R0 database (DTN: MO0009THRMODYN.001 [DIRS 152576]). Qualification frequently involves evaluation of the original sources of the information used to develop the changes. These original sources are considered direct input to this report. Certain discrepancies and errors were discovered in this process, and most of these are corrected in the data0.ymp.R4 database (output DTN: SN0410T0510404.002) and supporting calculations (DTN: SN0410T0510404.001), which are the only output from this report. 
It is noted that the SUPCRT92 database file for the original data0.ymp.R0 database (DTN: MO0009THRMODYN.001 [DIRS 152576]), was modified for the data0.ymp.R2 database (DTN: MO0302SPATHDYN.000 [DIRS 161756]) to include updates in the thermodynamic properties of quartz and $\mathrm{SiO}_{2}$ (aq) (Section 6.1.5). The modified SUPCRT92 database file is included as a direct input to this report (DTN: MO0303SPASPEQ2.000 [DIRS 162278]).

In addition to the sources of direct input data listed in Table 4-1, indirect supporting input data are presented in Section 6 where they are used for corroboration of selected direct input.

Table 4-1. Direct Input Data

\begin{tabular}{|c|c|c|c|c|}
\hline Description & \begin{tabular}{|c|} 
Source \\
\end{tabular} & $\begin{array}{l}\text { Qualification } \\
\text { Method }^{\mathrm{a}}\end{array}$ & Status & $\begin{array}{c}\text { Where } \\
\text { Discussed in } \\
\text { Section } 4.1\end{array}$ \\
\hline $\begin{array}{l}\text { Thermodynamic and volume data } \\
\text { from data0.ymp.R2 }\end{array}$ & $\begin{array}{l}\text { DTN: MO0302SPATHDYN.000 } \\
\text { [DIRS 161756] }\end{array}$ & $\mathrm{T}, \mathrm{C}$ & $\begin{array}{l}\text { Qualified by this } \\
\text { Report }\end{array}$ & All \\
\hline $\begin{array}{l}\text { Supporting calculations for } \\
\text { developing data0.ymp.R2 }\end{array}$ & $\begin{array}{l}\text { DTN: MO0302SPATHDYN.001 } \\
\text { [DIRS 161886] }\end{array}$ & $\mathrm{T}, \mathrm{C}$ & $\begin{array}{l}\text { Qualified by this } \\
\text { Report }\end{array}$ & All \\
\hline SUPCRT92 data file speq02.dat & $\begin{array}{l}\text { DTN: MO0303SPASPEQ2.000 } \\
\text { [DIRS 162278] }\end{array}$ & $\mathrm{T}, \mathrm{C}$ & $\begin{array}{l}\text { Qualified by this } \\
\text { Report }\end{array}$ & All \\
\hline $\begin{array}{l}\text { Thermodynamic and volume data } \\
\text { from data0.ymp.R0 }\end{array}$ & $\begin{array}{l}\text { DTN: MO0009THRMODYN.001 } \\
\text { [DIRS 152576] }\end{array}$ & $\mathrm{N} / \mathrm{A}$ & Qualified Data & All \\
\hline $\begin{array}{l}\text { SUPCRT92 data file, } \\
\text { slop98.dat }\end{array}$ & $\begin{array}{l}\text { DTN: MO0106MWDTDG01.035 } \\
\text { [DIRS 161791] }\end{array}$ & N/A & Qualified Data & All \\
\hline $\begin{array}{l}\text { Thermodynamic data for various } \\
\text { mineral phases }\end{array}$ & Robie et al. 1979 [DIRS 107109] & $\mathrm{N} / \mathrm{A}$ & Established Fact & 4.1.7 \\
\hline $\begin{array}{l}\text { Thermodynamic data and } \\
\text { updated stoichiometry for } \\
\mathrm{PuO}_{2}(\mathrm{OH})_{2}: \mathrm{H}_{2} \mathrm{O}\end{array}$ & Lemire 2001 [DIRS 159027] & N/A & Established Fact & 4.1.1 \\
\hline $\begin{array}{l}\text { Thermodynamic data for } \mathrm{SiO}_{2}(\mathrm{aq}) \\
\text { and quartz }\end{array}$ & $\begin{array}{l}\text { BSC 2004 [DIRS 170268], } \\
\text { Table 4-7, Section 6.3, and } \\
\text { Table 6.4-1 }\end{array}$ & $\mathrm{N} / \mathrm{A}$ & $\begin{array}{l}\text { Qualified Product } \\
\text { Output }\end{array}$ & 4.1.4 \\
\hline Handbook thermodynamic data & $\begin{array}{l}\text { Binnewies and Milke } 1999 \\
\text { [DIRS 158955] }\end{array}$ & N/A & Established Fact & $\begin{array}{l}4.1 .7 \\
4.1 .8 \\
\end{array}$ \\
\hline Handbook thermodynamic data & $\begin{array}{l}\text { Barin and Platzki } 1995 \\
\text { [DIRS 157865] }\end{array}$ & $\mathrm{N} / \mathrm{A}$ & Established Fact & $\begin{array}{l}4.1 .7 \\
4.1 .8\end{array}$ \\
\hline $\begin{array}{l}\text { Handbook solubility data (Mo } \\
\text { species) }\end{array}$ & $\begin{array}{l}\text { Martell and Smith } 1982 \\
\text { [DIRS 159196] }\end{array}$ & $\mathrm{N} / \mathrm{A}$ & Established Fact & 4.1 .2 \\
\hline Volume data for $\mathrm{CaUO}_{4}$ & $\begin{array}{l}\text { Loopstra and Rietveld } 1969 \\
\text { [DIRS 172264] }\end{array}$ & C & $\begin{array}{l}\text { Justified in this } \\
\text { Report }\end{array}$ & $4.1 .9^{b}$ \\
\hline Volume data for Cr-ferrihydrite & $\begin{array}{l}\text { Towe and Bradley } 1967 \\
\text { [DIRS 155334] }\end{array}$ & C & $\begin{array}{l}\text { Justified in this } \\
\text { Report }\end{array}$ & $4.1 .9^{b}$ \\
\hline Volume data for $\mathrm{Fe}_{2}\left(\mathrm{MoO}_{4}\right)_{3}$ & $\begin{array}{l}\text { Johnson et al. } 1992 \\
\text { [DIRS 101632] }\end{array}$ & C & $\begin{array}{l}\text { Justified in this } \\
\text { Report }\end{array}$ & $4.1 .9^{b}$ \\
\hline Volume data for $\mathrm{Ni}_{3}\left(\mathrm{PO}_{4}\right)_{2}$ & $\begin{array}{l}\text { Calvo and Faggiani } 1975 \\
\text { [DIRS 172265] }\end{array}$ & $\mathrm{T}$ & $\begin{array}{l}\text { Justified in this } \\
\text { Report }\end{array}$ & $4.1 .9^{b}$ \\
\hline Volume data for $\mathrm{Na}_{4} \mathrm{UO}_{2}\left(\mathrm{CO}_{3}\right)_{3}$ & Douglass 1956 [DIRS 172266] & C & $\begin{array}{l}\text { Justified in this } \\
\text { Report }\end{array}$ & 4.1 .9 \\
\hline $\begin{array}{l}\text { Volume data for uranophane } \\
\text { (alpha) }\end{array}$ & Hemingway 1982 [DIRS 157905] & C & $\begin{array}{l}\text { Justified in this } \\
\text { Report }\end{array}$ & 4.1 .9 \\
\hline
\end{tabular}


Table 4-1. Direct Input Data (Continued)

\begin{tabular}{|c|c|c|c|c|}
\hline Description & Source & $\begin{array}{c}\text { Qualification } \\
\text { Method }^{\mathrm{a}}\end{array}$ & Status & \begin{tabular}{|c|} 
Where \\
Discussed in \\
Section 4.1 \\
\end{tabular} \\
\hline Volume data for Na-weeksite & Hemingway 1982 [DIRS 157905] & C & $\begin{array}{l}\text { Justified in this } \\
\text { Report }\end{array}$ & 4.1 .9 \\
\hline $\mathrm{Np}$ and Pu thermodynamic data & Lemire 2001 [DIRS 159027] & $\mathrm{N} / \mathrm{A}$ & Established Fact & $\begin{array}{l}4.1 .1 \\
4.1 .2 \\
4.1 .7 \\
\end{array}$ \\
\hline Soddyite log K data & Moll et al. 1996 [DIRS 106349] & C & $\begin{array}{l}\text { Justified in this } \\
\text { Report }\end{array}$ & 4.1.7 \\
\hline Uranophane log K data & Pérez et al. 2000 [DIRS 157910] & C & $\begin{array}{l}\text { Justified in this } \\
\text { Report }\end{array}$ & 4.1.7 \\
\hline Na-Weeksite log K data & $\begin{array}{l}\text { Nguyen et al. } 1992 \\
\text { [DIRS 100809] }\end{array}$ & C & $\begin{array}{l}\text { Justified in this } \\
\text { Report }\end{array}$ & 4.1.7 \\
\hline Na-Boltwoodite log K data & $\begin{array}{l}\text { Nguyen et al. } 1992 \\
\text { [DIRS 100809] }\end{array}$ & C & $\begin{array}{l}\text { Justified in this } \\
\text { Report }\end{array}$ & 4.1.7 \\
\hline $\begin{array}{l}\text { Zeolite thermodynamic and } \\
\text { volume data }\end{array}$ & $\begin{array}{l}\text { Chipera et al. } 1995 \\
\text { [DIRS 100025], Table } 1\end{array}$ & $\mathrm{~T}, \mathrm{C}$ & $\begin{array}{l}\text { Justified in this } \\
\text { Report }\end{array}$ & $\begin{array}{l}4.1 .5 \\
4.1 .9 \\
\end{array}$ \\
\hline $\begin{array}{l}\text { Zeolite thermodynamic data } \\
\text { (above } 100^{\circ} \mathrm{C} \text { ) }\end{array}$ & $\begin{array}{l}\text { Viani and Bruton } 1992 \\
\text { [DIRS 101407] }\end{array}$ & $\mathrm{T}$ & $\begin{array}{l}\text { Justified in this } \\
\text { Report }\end{array}$ & 4.1 .5 \\
\hline $\begin{array}{l}\text { Thermodynamic data for calcium } \\
\text { silicates, aluminates, and ferrites }\end{array}$ & $\begin{array}{l}\text { Babushkin et al. } 1985 \\
\text { [DIRS 116981], Appendix } 1\end{array}$ & $\mathrm{~N} / \mathrm{A}$ & Established Fact & 4.1.6 \\
\hline Calcium silicate hydrate data & $\begin{array}{l}\text { Fujii and Kondo } 1983 \\
\text { [DIRS 144876] }\end{array}$ & $\mathrm{T}$ & $\begin{array}{l}\text { Justified in this } \\
\text { Report }\end{array}$ & 4.1 .6 \\
\hline Cr-ettringite data & $\begin{array}{l}\text { Perkins and Palmer } 2000 \\
\text { [DIRS 153349] }\end{array}$ & $\mathrm{T}$ & $\begin{array}{l}\text { Justified in this } \\
\text { Report }\end{array}$ & 4.1 .6 \\
\hline $\mathrm{CaCl}_{2}$ data & $\begin{array}{l}\text { Chase } 1998 \text { [DIRS 157874], } \\
\text { p. } 711\end{array}$ & $\mathrm{~N} / \mathrm{A}$ & Established Fact & 4.1 .6 \\
\hline Gehlenite Hydrate & Atkins et al. 1992 [DIRS 100700] & C & $\begin{array}{l}\text { Justified in this } \\
\text { Report }\end{array}$ & 4.1.6 \\
\hline Hydrotalcite & $\begin{array}{l}\text { Bennett et al. } 1992 \\
\text { [DIRS 116990] }\end{array}$ & $\mathrm{T}$ & $\begin{array}{l}\text { Justified in this } \\
\text { Report }\end{array}$ & 4.1.6 \\
\hline $\begin{array}{l}\text { Monocarboaluminate and } \\
\text { Hemicarboaluminate }\end{array}$ & $\begin{array}{l}\text { Damidot et al. } 1994 \\
\text { [DIRS 144866], Appendix } 1\end{array}$ & $\mathrm{~T}$ & $\begin{array}{l}\text { Justified in this } \\
\text { Report }\end{array}$ & 4.1 .6 \\
\hline Syngenite (updated) & $\begin{array}{l}\text { DTN: SN0302T0510102.002 } \\
\text { [DIRS 162572] }\end{array}$ & N/A & Qualified Data & 4.1 .6 \\
\hline Gismondine & Atkins et al. 1993 [DIRS 131758] & $\mathrm{T}$ & $\begin{array}{l}\text { Justified in this } \\
\text { Report }\end{array}$ & 4.1.6 \\
\hline Ti-hydroxy (aq) & $\begin{array}{l}\text { Ti-hydroxy (aq): } \\
\text { Knauss et al. 2001 } \\
\text { [DIRS 158998] } \\
\text { Rutile: Robie et al. } 1979 \\
\text { [DIRS 107109] } \\
\end{array}$ & $\mathrm{C}, \mathrm{T}$ & $\begin{array}{l}\text { Justified in this } \\
\text { Report }\end{array}$ & 4.1 .2 \\
\hline $\mathrm{Am}^{+++}$data & $\begin{array}{l}\text { Silva et al. } 1995 \text { [DIRS 102087], } \\
\text { p. } 37\end{array}$ & $\mathrm{~N} / \mathrm{A}$ & Established Fact & 4.1 .2 \\
\hline$\beta-\cup O_{3}$ data & $\begin{array}{l}\text { Grenthe et al. } 1992 \\
\text { [DIRS 101671], Tables III.1 and } \\
\text { III.3 }\end{array}$ & N/A & Established Fact & 4.1.7 \\
\hline $\begin{array}{l}\text { Mineral data used for estimation } \\
\text { of thermodynamic properties of } \\
\text { clays }\end{array}$ & $\begin{array}{l}\text { Helgeson et al. } 1978 \\
\text { [DIRS 101596] }\end{array}$ & $\mathrm{C}, \mathrm{T}$ & $\begin{array}{l}\text { Justified in this } \\
\text { Report }\end{array}$ & $\begin{array}{l}4.1 .4 \\
4.1 .6 \\
4.1 .9 \\
\end{array}$ \\
\hline $\mathrm{HF}_{2}^{-}$and $\mathrm{HF}$ data & $\begin{array}{l}\text { Clark 1966 [DIRS 153163], } \\
\text { Table 18-4 }\end{array}$ & $N / A$ & Established Fact & 4.1 .8 \\
\hline
\end{tabular}


Table 4-1. Direct Input Data (Continued)

\begin{tabular}{|l|l|c|l|c|}
\hline \multicolumn{1}{|c|}{ Description } & \multicolumn{1}{|c|}{ Source } & $\begin{array}{c}\text { Where } \\
\text { Qualification }_{\text {Method }^{\mathrm{a}}}\end{array}$ & \multicolumn{1}{c|}{ Status } & $\begin{array}{c}\text { Discussed in } \\
\text { Section 4.1 }\end{array}$ \\
\hline HF data & $\begin{array}{l}\text { Ellis and Mahon 1977 } \\
\text { [DIRS 159230], Table 8.4 }\end{array}$ & C, T & $\begin{array}{l}\text { Justified in this } \\
\text { Report }\end{array}$ & 4.1 .8 \\
\hline $\begin{array}{l}\text { R Constant value of 1.9872 } \\
\text { cal/mol-K }\end{array}$ & $\begin{array}{l}\text { Weast and Astle 1979 } \\
\text { [DIRS 102865] }\end{array}$ & N/A & Established Fact & All \\
\hline $\begin{array}{l}\text { Conversion factor: 1 calorie }= \\
\text { 4.184 Joules }\end{array}$ & $\begin{array}{l}\text { Weast and Astle 1979 } \\
\text { [DIRS 102865] }\end{array}$ & N/A & Established Fact & \multicolumn{1}{|c|}{ All } \\
\hline
\end{tabular}

a These unqualified inputs are to be qualified for intended use in Section 6 using the following qualification methods: C (corroborating data)

$\mathrm{T}$ (technical assessment)

N/A (not applicable).

$\mathrm{b}$ The source shown is the original source of molar volume data for the indicated phase, as the data appear in data0.ymp.R2 (DTN: MO0302SPATHDYN.001 [DIRS 152576]). The data are tabulated in Table 4-21 and qualified in Section 6.6.

\subsubsection{Compilation of Thermodynamic Data for Np and Pu Species}

Thermodynamic data for $\mathrm{Np}$ and $\mathrm{Pu}$ solids and aqueous species were obtained from the OECD/NEA compilation of Lemire (2001 [DIRS 159027]). This source is considered "established fact" because it was developed from a comprehensive evaluation of available thermodynamic data and published in handbook form by the NEA. The species for which data were added, or for which the data in data0.ymp.R0 (DTN: MO0009THRMODYN.001 [DIRS 152576]) were updated, are listed in Table 4-2. In many cases, data needed to calculate thermodynamic properties at elevated temperature were unavailable. For some plutonium and neptunium species, sufficient thermodynamic properties were available to estimate $\log \mathrm{K}$ values as a function of temperature using correlation algorithms, such as isocoulombic extrapolation discussed in Section 6.1.3. For most species, however, thermodynamic properties for temperatures other than $25^{\circ} \mathrm{C}$ were not available, and no extrapolation of $\log \mathrm{K}$ for other temperatures was possible. Evaluation of these data is presented in Section 6.2.1.

A modification of the $\mathrm{Pu}$ solid $\mathrm{PuO}_{2}(\mathrm{OH})_{2}: \mathrm{H}_{2} \mathrm{O}$ was made to correct an error found in data0.ymp.R2 (DTN: MO0302SPATHDYN.000 [DIRS 161756]) related to the stoichiometry of this species (the incorrect $\mathrm{PuO}_{2}(\mathrm{OH})_{2}: 2 \mathrm{H}_{2} \mathrm{O}$ was corrected to $\mathrm{PuO}_{2}(\mathrm{OH})_{2}: \mathrm{H}_{2} \mathrm{O}$ ). This correction is consistent with the usage in Lemire (2001 [DIRS 159027], Section 17.2.2.1) and was made originally in data0.ymp.R3 (DTN: MO0312SPATDMIF.000 [DIRS 167800]). This correction is carried into the new data0.ymp.R4 database (output DTN: SN0410T0510404.002). 
Table 4-2. Np and Pu Species for which Thermodynamic Data Were Added, or Existing Data Were Modified, in the Data0.ymp.R2 Database (DTN: MO0302SPATHDYN.000 [DIRS 161756])

\begin{tabular}{|c|c|c|c|c|c|}
\hline Data0 Species Designation & Change & $\begin{array}{c}\Delta \mathbf{G}_{\mathrm{f}}{ }^{\circ} \\
(\mathrm{J} / \mathrm{mol})\end{array}$ & $\begin{array}{c}\Delta \mathrm{H}_{\mathrm{f}}^{\circ} \\
(\mathrm{J} / \mathrm{mol})\end{array}$ & $\begin{array}{c}\mathrm{S}^{\circ} \\
(\mathrm{J} / \mathrm{mol}-\mathrm{K})\end{array}$ & Source \\
\hline$\left(\mathrm{NpO}_{2}\right)_{2}(\mathrm{OH})_{2}^{++}$ & new & $-2,030,400$ & - & - & 1 \\
\hline$\left(\mathrm{NpO}_{2}\right)_{2} \mathrm{CO}_{3}(\mathrm{OH})_{3}^{-}$ & new & $-2,814,900$ & - & - & 1 \\
\hline$\left(\mathrm{NpO}_{2}\right)_{3}\left(\mathrm{CO}_{3}\right)_{6}^{(-6)}$ & new & $-5,839,700$ & - & - & 1 \\
\hline$\left(\mathrm{NpO}_{2}\right)_{3}(\mathrm{OH})_{5}^{+}$ & new & $-3,475,800$ & - & - & 1 \\
\hline$\left(\mathrm{UO}_{2}\right)_{2}\left(\mathrm{NpO}_{2}\right)\left(\mathrm{CO}_{3}\right)_{6}^{(-6)}$ & new & $-6,174,300$ & - & - & 1 \\
\hline $\mathrm{Np}\left(\mathrm{CO}_{3}\right)_{3}{ }^{--}$ & new & $-2,185,900$ & - & - & 1 \\
\hline $\mathrm{Np}\left(\mathrm{CO}_{3}\right)_{4}{ }^{\cdots-\cdot}$ & updated & $-2,812,800$ & - & - & 1 \\
\hline $\mathrm{Np}\left(\mathrm{CO}_{3}\right)_{5}{ }^{(-6)}$ & updated & $-3,334,600$ & - & - & 1 \\
\hline $\mathrm{NpCl}^{+++}$ & new & $-631,550$ & - & - & 1 \\
\hline $\mathrm{NpF}^{+++}$ & updated & $-824,441$ & $-889,872$ & -263.621 & 1 \\
\hline $\mathrm{NpF}_{2}^{++}$ & updated & $-1,144,400$ & - & - & 1 \\
\hline $\mathrm{Npl}^{+++}$ & new & $-552,060$ & - & - & 1 \\
\hline $\mathrm{NpNO}_{3}{ }^{+++}$ & new & $-613,410$ & - & - & 1 \\
\hline $\mathrm{NpO}_{2}\left(\mathrm{CO}_{3}\right)_{2}{ }^{--}$ & new & $-1,946,000$ & - & - & 1 \\
\hline $\mathrm{NpO}_{2}\left(\mathrm{CO}_{3}\right)_{2}{ }^{\cdots-}$ & updated & $-2,000,900$ & - & - & 1 \\
\hline $\mathrm{NpO}_{2}\left(\mathrm{CO}_{3}\right)_{2} \mathrm{OH}^{\cdots-\cdot}$ & new & $-2,170,400$ & - & - & 1 \\
\hline $\mathrm{NpO}_{2}\left(\mathrm{CO}_{3}\right)_{3}{ }^{\cdots \cdots \cdot}$ & new & $-2,490,208$ & $-2,928,323$ & -12.070 & 1 \\
\hline $\mathrm{NpO}_{2}\left(\mathrm{CO}_{3}\right)_{3}{ }^{(-5)}$ & updated & $-2,522,859$ & $-3,017,120$ & -135.050 & 1 \\
\hline $\mathrm{NpO}_{2}\left(\mathrm{HPO}_{4}\right)_{2}{ }^{--}$ & new & $-3,042,100$ & - & - & 1 \\
\hline $\mathrm{NpO}_{2}(\mathrm{OH})_{2}^{-}$ & updated & $-1,247,336$ & $-1,431,230$ & 40.000 & 1 \\
\hline $\mathrm{NpO}_{2}(\mathrm{OH})_{2} \mathrm{CO}_{3}{ }^{-\cdots-}$ & removed & - & - & - & - \\
\hline $\mathrm{NpO}_{2} \mathrm{OH}\left(\mathrm{CO}_{3}\right)_{2}{ }^{\cdots-\cdot}$ & removed & - & - & - & - \\
\hline $\mathrm{NpO}_{2}\left(\mathrm{SO}_{4}\right)_{2}^{--}$ & new & $-2,310,775$ & $-2,653,413$ & 121.798 & 1 \\
\hline $\mathrm{NpO}_{2} \mathrm{Cl}^{+}$ & new & $-929,440$ & - & - & 1 \\
\hline $\mathrm{NpO}_{2} \mathrm{CO}_{3}^{-}$ & updated & $-1,464,000$ & - & - & 1 \\
\hline $\mathrm{NpO}_{2} \mathrm{CO}_{3}(\mathrm{aq})$ & new & $-1,377,000$ & - & - & 1 \\
\hline $\mathrm{NpO}_{2} \mathrm{~F}(\mathrm{aq})$ & updated & $-1,196,100$ & - & - & 1 \\
\hline $\mathrm{NpO}_{2} \mathrm{~F}^{+}$ & new & $-1,103,600$ & - & - & 1 \\
\hline $\mathrm{NpO}_{2} \mathrm{~F}_{2}(\mathrm{aq})$ & new & $-1,402,400$ & - & - & 1 \\
\hline $\mathrm{NpO}_{2} \mathrm{H}_{2} \mathrm{PO}_{4}^{+}$ & new & $-1,952,000$ & - & - & 1 \\
\hline $\mathrm{NpO}_{2} \mathrm{HPO}_{4}^{-}$ & new & $-2,020,600$ & - & - & 1 \\
\hline $\mathrm{NpO}_{2} \mathrm{HPO}_{4}(\mathrm{aq})$ & new & $-1,927,300$ & - & - & 1 \\
\hline $\mathrm{NpO}_{2} \mathrm{IO}_{3}(\mathrm{aq})$ & new & $-1,037,000$ & - & - & 1 \\
\hline $\mathrm{NpO}_{2} \mathrm{IO}_{3}{ }^{+}$ & new & $-929,130$ & - & - & 1 \\
\hline $\mathrm{NpO}_{2} \mathrm{OH}(\mathrm{aq})$ & updated & $-1,080,405$ & $-1,199,226$ & 25.000 & 1 \\
\hline $\mathrm{NpO}_{2} \mathrm{OH}^{+}$ & new & $-1,004,000$ & - & - & 1 \\
\hline $\mathrm{NpO}_{2} \mathrm{SO}_{4}^{-}$ & new & $-1,654,281$ & $-1,864,321$ & 58.833 & 1 \\
\hline $\mathrm{NpO}_{2} \mathrm{SO}_{4}(\mathrm{aq})$ & new & $-1,558,666$ & $-1,753,373$ & 44.920 & 1 \\
\hline $\mathrm{NpOH}^{++}$ & new & $-711,190$ & - & - & 1 \\
\hline $\mathrm{NpOH}^{+++}$ & updated & $-727,260$ & - & - & 1 \\
\hline $\mathrm{NpSO}_{4}{ }^{++}$ & new & $-1,274,887$ & $-1,435,522$ & -176.635 & 1 \\
\hline
\end{tabular}


Table 4-2. Np and Pu Species for which Thermodynamic Data Were Added, or Existing Data Were Modified, in the Data0.ymp.R2 Database (DTN: MO0302SPATHDYN.000 [DIRS 161756]) (Continued)

\begin{tabular}{|c|c|c|c|c|c|}
\hline Data0 Species Designation & Change & $\begin{array}{c}\Delta \mathrm{G}_{\mathrm{f}}^{\circ} \\
(\mathrm{J} / \mathrm{mol})\end{array}$ & $\begin{array}{c}\Delta \mathrm{H}_{\mathrm{f}}^{\circ} \\
(\mathrm{J} / \mathrm{mol})\end{array}$ & $\begin{array}{c}\mathrm{S}^{\circ} \\
(\mathrm{J} / \mathrm{mol}-\mathrm{K})\end{array}$ & Source \\
\hline $\mathrm{Np}\left(\mathrm{SO}_{4}\right)_{2}(\mathrm{aq})$ & new & $-2,042,873$ & $-2,319,322$ & 7.964 & 1 \\
\hline $\mathrm{Np}(\mathrm{SCN})^{+++}$ & new & $-416,198$ & $-486,622$ & -248.165 & 1 \\
\hline $\mathrm{Np}(\mathrm{SCN})_{2}^{++}$ & new & $-329,777$ & $-412,222$ & -248.165 & 1 \\
\hline $\mathrm{Np}(\mathrm{SCN})_{3}{ }^{+}$ & new & $-241,072$ & $-339,822$ & 54.707 & 1 \\
\hline$\left(\mathrm{PuO}_{2}\right)_{2}(\mathrm{OH})_{2}^{++}$ & updated & $-1,956,180$ & - & - & 2 \\
\hline$\left(\mathrm{PuO}_{2}\right)_{3}\left(\mathrm{CO}_{3}\right)_{6}{ }^{(-6)}$ & new & $-5,740,431$ & - & - & 2 \\
\hline$\left(\mathrm{UO}_{2}\right)_{2}\left(\mathrm{PuO}_{2}\right)\left(\mathrm{CO}_{3}\right)_{6}{ }^{(-6)}$ & new & $-6,135,670$ & - & - & 2 \\
\hline $\mathrm{Pu}\left(\mathrm{SO}_{4}\right)_{2}^{-}$ & new & $-2,099,545$ & $-2,398,590$ & 1.520 & 2 \\
\hline $\mathrm{Pu}\left(\mathrm{SO}_{4}\right)_{2}(\mathrm{aq})$ & new & $-2,029,601$ & - & - & 2 \\
\hline $\mathrm{PuBr}^{+++}$ & new & $-590,971$ & - & - & 2 \\
\hline $\mathrm{PuCl}^{++}$ & new & $-717,051$ & - & - & 2 \\
\hline $\mathrm{PuCl}^{++}$ & new & $-619,480$ & - & - & 2 \\
\hline $\mathrm{PuF}^{+++}$ & updated & $-809,970$ & $-866,145$ & -228.573 & 2 \\
\hline $\mathrm{PuF}_{2}^{++}$ & updated & $-1,130,651$ & $-1,199,595$ & -104.666 & 2 \\
\hline $\mathrm{PuH}_{3} \mathrm{PO}_{4}{ }^{++++}$ & new & $-1,641,050$ & - & - & 2 \\
\hline $\mathrm{Pul}^{++}$ & new & $-636,987$ & - & - & 2 \\
\hline $\mathrm{PuNO}_{3}{ }^{+++}$ & new & $-599,913$ & - & - & 2 \\
\hline $\mathrm{PuO}_{2}\left(\mathrm{CO}_{3}\right)_{2}{ }^{--}$ & updated & $-1,900,920$ & $-2,199,496$ & 15.796 & 2 \\
\hline $\mathrm{PuO}_{2}\left(\mathrm{CO}_{3}\right)_{2}{ }^{\cdots-}$ & removed & - & - & - & - \\
\hline $\mathrm{PuO}_{2}\left(\mathrm{CO}_{3}\right)_{3}{ }^{\cdots-\cdot}$ & updated & $-2,447,085$ & $-2,886,326$ & -11.847 & 2 \\
\hline $\mathrm{PuO}_{2}\left(\mathrm{CO}_{3}\right)_{3}{ }^{(-5)}$ & updated & $-2,465,031$ & $-2,954,927$ & -116.406 & 2 \\
\hline $\mathrm{Pu}\left(\mathrm{CO}_{3}\right)_{5}^{(-6)}$ & removed & - & - & - & - \\
\hline $\mathrm{PuO}_{2}(\mathrm{OH})_{2}(\mathrm{aq})$ & updated & $-1,161,290$ & - & - & 2 \\
\hline $\mathrm{PuO}_{2}\left(\mathrm{SO}_{4}\right)_{2}{ }^{--}$ & new & $-2,275,477$ & $-2,597,716$ & 194.214 & 2 \\
\hline $\mathrm{PuO}_{2} \mathrm{Cl}^{+}$ & new & $-897,566$ & - & - & 2 \\
\hline $\mathrm{PuO}_{2} \mathrm{Cl}_{2}(\mathrm{aq})$ & new & $-1,021,360$ & - & - & 2 \\
\hline $\mathrm{PuO}_{2} \mathrm{CO}_{3}^{-}$ & Updated & $-1,409,771$ & - & - & 2 \\
\hline $\mathrm{PuO}_{2} \mathrm{CO}_{3}(\mathrm{aq})$ & updated & $-1,356,466$ & - & - & 2 \\
\hline $\mathrm{PuO}_{2} \mathrm{~F}^{+}$ & updated & $-1,069,900$ & - & - & 2 \\
\hline $\mathrm{PuO}_{2} \mathrm{~F}_{2}(\mathrm{aq})$ & updated & $-1,366,780$ & - & - & 2 \\
\hline $\mathrm{PuO}_{2} \mathrm{OH}(\mathrm{aq})$ & updated & $-1,034,250$ & - & - & 2 \\
\hline $\mathrm{Pu}(\mathrm{OH})_{4}(\mathrm{aq})$ & removed & - & - & - & - \\
\hline $\mathrm{PuO}_{2} \mathrm{OH}^{+}$ & updated & $-968,099$ & $-1,079,866$ & -12.680 & 2 \\
\hline $\mathrm{PuO}_{2} \mathrm{SO}_{4}(\mathrm{aq})$ & new & $-1,525,650$ & $-1,715,276$ & 65.963 & 2 \\
\hline $\mathrm{PuOH}^{++}$ & updated & $-776,739$ & - & - & 2 \\
\hline $\mathrm{PuOH}^{+++}$ & updated & $-710,676$ & $-789,725$ & -238.773 & 2 \\
\hline $\mathrm{PuSCN}^{++}$ & new & $-493,704$ & - & - & 2 \\
\hline $\mathrm{PuSO}_{4}^{+}$ & new & $-1,345,315$ & $-1,483,890$ & -33.301 & 2 \\
\hline $\mathrm{PuSO}_{4}{ }^{++}$ & new & $-1,261,329$ & - & - & 2 \\
\hline
\end{tabular}

Sources: 1 Lemire 2001 [DIRS 159027], Table 3.1 pp. 41 to 46.

2 Lemire 2001 [DIRS 159027], Table 4.1, pp. 55 to 59. 


\subsubsection{Compilation of Thermodynamic Data for Other Aqueous Species}

In the development of the data0.ymp.R2 database (DTN: MO0302SPATHDYN.000 [DIRS 161756]), a variation on the isocoulombic/isoelectric spreadsheet (see Section 6.1.3 for an explanation of special function spreadsheets) was used to obtain the Gibbs free energy grids for 15 species not previously defined strictly as basis species in data0.ymp.R0 (DTN: MO0009THRMODYN.001 [DIRS 152576]). These basis species are $\mathrm{Am}^{++}, \mathrm{Am}^{++}$, $\mathrm{Am}^{+++}, \mathrm{AmO}_{2}^{+}, \mathrm{AmO}_{2}^{++}, \mathrm{Np}^{+++}, \mathrm{Np}^{+++}, \mathrm{NpO}_{2}^{+}, \mathrm{NpO}_{2}^{++}, \mathrm{Pu}^{+++}, \mathrm{Pu}^{++++}, \mathrm{PuO}_{2}^{+}, \mathrm{PuO}_{2}^{++}$, and $\mathrm{Ti}(\mathrm{OH})_{4}(\mathrm{aq})$ (Table 4-3). The major difference from the regular isocoulombic/isoelectric spreadsheet was that the final step of calculating $\log \mathrm{K}$ values for associated reactions was omitted in the case of species chosen as strict basis species (as these have no associated EQ3/6 reaction). The Am data were taken from Silva et al. (1995 [DIRS 102087]), which is a comprehensive review of the thermochemistry of Am published by the OECD/NEA. The Np and Pu data were taken from the OECD/NEA Np and Pu volume (Lemire 2001 [DIRS 159027]), while the data for the secondary basis species $\operatorname{Ti}(\mathrm{OH})_{4}(\mathrm{aq}), \mathrm{Ti}(\mathrm{OH})_{3}{ }^{+}$, and $\mathrm{Ti}(\mathrm{OH})_{5}{ }^{-}$were taken from Knauss et al. (2001 [DIRS 158998]). Data for the molybdenum aqueous species were obtained from Martell and Smith (1982 [DIRS 159196], p. 399). The OECD/NEA sources are considered "established fact" because they were developed from a comprehensive evaluation of available thermodynamic data and published in handbook form. Also, the Martell and Smith (1982 [DIRS 159196]) source is considered "established fact" because it represents a widely used comprehensive compilation of stability constants for aqueous species reactions. Evaluations of these and the $\mathrm{Ti}$ and Mo species data are given in Section 6.2.2. Standard thermodynamic data for the solid phase rutile $\left(\mathrm{TiO}_{2}\right)$ are from data0.ymp.R0 (DTN: MO0009THRMODYN.001 [DIRS 152576]), which also corresponds to the value reported by Robie et al. (1979 [DIRS 107109]), an "established fact" source.

Table 4-3. Thermodynamic Data for Actinide Basis Species, Redox Species, Titanium, and Molybdenum Species

\begin{tabular}{|c|c|c|c|c|}
\hline Species & $\begin{array}{c}\Delta \mathbf{G}_{\mathrm{f}}^{\circ} \\
(\mathrm{J} / \mathrm{mol})\end{array}$ & $\begin{array}{c}\Delta \mathrm{H}_{\mathrm{f}}^{\circ} \\
(\mathrm{J} / \mathrm{mol})\end{array}$ & $\begin{array}{c}\mathrm{S}^{\circ} \\
(\mathrm{J} / \mathrm{mol}-\mathrm{K})\end{array}$ & Source \\
\hline \multicolumn{5}{|c|}{ Basis Species } \\
\hline $\mathrm{Am}^{+++}$ & $-598,698$ & $-616,700$ & -201.000 & 1 \\
\hline $\mathrm{NpO}_{2}^{+}$ & $-907,765$ & $-978,181$ & -45.904 & 2 \\
\hline $\mathrm{PuO}_{2}^{+}$ & $-852,646$ & $-910,127$ & 1.480 & 3 \\
\hline $\mathrm{Ti}(\mathrm{OH})_{4}(\mathrm{aq})$ & $-1,322,665$ & - & 39.207 & 4 \\
\hline \multicolumn{5}{|c|}{ Secondary Basis Species (Redox) } \\
\hline $\mathrm{Am}^{++}$ & $-376,780$ & $-354,633$ & -1.000 & 1 \\
\hline $\mathrm{Am}^{++++}$ & $-346,358$ & $-406,000$ & -406.000 & 1 \\
\hline $\mathrm{AmO}_{2}^{+}$ & $-739,796$ & $-804,260$ & -21.000 & 1 \\
\hline $\mathrm{AmO}_{2}^{++}$ & $-585,801$ & $-650,760$ & -88.000 & 1 \\
\hline $\mathrm{Np}^{+++}$ & $-512,866$ & $-527,184$ & -193.584 & 2 \\
\hline $\mathrm{Np}^{++++}$ & $-491,774$ & $-556,022$ & -426.390 & 2 \\
\hline $\mathrm{NpO}_{2}^{++}$ & $-795,939$ & $-860,733$ & -92.387 & 2 \\
\hline $\mathrm{Pu}^{+++}$ & $-578,984$ & $-591,790$ & -184.510 & 3 \\
\hline $\mathrm{Pu}^{++++}$ & $-477,988$ & $-539,895$ & -414.535 & 3 \\
\hline $\mathrm{PuO}_{2}{ }^{++}$ & $-762,353$ & $-822,036$ & -71.246 & 3 \\
\hline
\end{tabular}


Table 4-3. Thermodynamic Data for Actinide Basis Species, Redox Species, Titanium, and Molybdenum Species (Continued)

\begin{tabular}{|c|c|c|c|c|}
\hline Species & $\begin{array}{l}\Delta G_{f}^{\circ} \\
(\mathrm{J} / \mathrm{mol})\end{array}$ & $\begin{array}{c}\Delta \mathrm{H}_{\mathrm{f}}^{\circ} \\
(\mathrm{J} / \mathrm{mol})\end{array}$ & $\begin{array}{c}\mathrm{S}^{\circ} \\
(\mathrm{J} / \mathrm{mol}-\mathrm{K})\end{array}$ & Source \\
\hline \multicolumn{5}{|c|}{ Titanium Species } \\
\hline $\mathrm{Ti}(\mathrm{OH})_{3}{ }^{+}$ & $-1,092,824$ & - & 55.779 & 4 \\
\hline $\mathrm{Ti}(\mathrm{OH})_{5}^{-}$ & $-1,482,898$ & - & 154.242 & 4 \\
\hline $\mathrm{TiO}_{2}$ (rutile) & $-890,700$ & - & - & 5 \\
\hline \multicolumn{5}{|c|}{ Molybdenum Species } \\
\hline Species & $\log K$ & \multicolumn{2}{|c|}{ Reaction } & Source \\
\hline $\mathrm{H}_{2} \mathrm{MoO}_{4}(\mathrm{aq})$ & 4.00 & \multicolumn{2}{|c|}{$\begin{array}{c}\mathrm{H}^{+}+\mathrm{HMoO}_{4}^{-}= \\
\mathrm{H}_{2} \mathrm{MoO}_{4}(\mathrm{aq})\end{array}$} & 6 \\
\hline $\mathrm{HMoO}_{4}^{-}$ & 4.24 & \multicolumn{2}{|c|}{$\mathrm{H}^{+}+\mathrm{MoO}_{4}^{--}=\mathrm{HMoO}_{4}^{-}$} & 6 \\
\hline
\end{tabular}

Sources: 1 Silva et al. 1995 [DIRS 102087], Table III.1, pp. 37-38.

2 Lemire 2001 [DIRS 159027], Table 3.1, p. 41.

3 Lemire 2001 [DIRS 159027], Table 4.1, p. 55.

4 Knauss et al. 2001 [DIRS 158998].

5 Data0.ymp.R0 (DTN: MO0009THRMODYN.001 [DIRS 152576]); Robie et al. 1979 [DIRS 107109].

6 Martell and Smith 1982 [DIRS 159196], p. 399.

\subsection{3 “Azero” Ion Size Parameters}

In the development of the data0.ymp.R2 database (DTN: MO0302SPATHDYN.000 [DIRS 161756]), the "azero" ion size parameters were used in the B-dot equation (Helgeson 1969 [DIRS 137246]) for estimation of activity coefficients for aqueous species (see Section 6.5). Table 4-4 shows the "azero" values within the valence-type scheme as adopted in this database. This is the scheme used in data0.ymp.R0 (DTN: MO0009THRMODYN.001 [DIRS 152576]); therefore, this input is qualified for use in data0.ymp.R2 (DTN: MO0302SPATHDYN.000 [DIRS 161756]) and data0.ymp.R4 (output DTN: SN0410T0510404.002).

Table 4-4. Suggested “Azero” Values for Various Charge Numbers

\begin{tabular}{|c|c|}
\hline Charge Number $(\mathbf{Z})$ & Ion Size $(\boldsymbol{A})$ \\
\hline$<-1$ & 4.0 \\
\hline-1 & 4.0 \\
\hline 0 & 3.0 \\
\hline+1 & 4.0 \\
\hline+2 & 4.5 \\
\hline+3 & 5.0 \\
\hline+4 & 5.5 \\
\hline$>+4$ & 6.0 \\
\hline
\end{tabular}

DTN: MO0009THRMODYN.001 [DIRS 152576] (Data0.ymp.R0). 


\subsubsection{Compilation of Thermodynamic Data for Clay Minerals}

In the development of the data0.ymp.R2 database (DTN: MO0302SPATHDYN.000 [DIRS 161756]), the data for clay minerals were recalculated using thermodynamic data developed more recently than the sources used in the data0.ymp.R0 database (DTN: MO0009THRMODYN.001 [DIRS 152576]; Wolery 1978 [DIRS 151346]). The approach of Tardy and Garrels (1974 [DIRS 159209]) was implemented for data0.ymp.R2 (DTN: MO0302SPATHDYN.000 [DIRS 161756]) using Microsoft Excel spreadsheets for reestimating these data. Its implementation is discussed in Section 6.3.1. This approach uses standard molal thermodynamic data mainly from sheet silicates and simple oxides. These data are direct inputs in the thermodynamic calculations and, with one exception (described below) were taken from Helgeson et al. (1978 [DIRS 101596]). The standard thermodynamic data include $\Delta \mathrm{G}_{\mathrm{f}}^{\circ}, \mathrm{S}^{\circ}$, and $\mathrm{V}^{\circ}$. In addition, the $\mathrm{C}_{\mathrm{p}}{ }^{\circ}$ parameters "a," "b," and "c" of the Maier-Kelly equation for extrapolation of $\mathrm{C}_{\mathrm{p}}{ }^{\circ}$ values for the solids (Eq. 4-1) are included.

The $\Delta \mathrm{G}_{\mathrm{f}}{ }^{\circ}$ data for oxides summarized in Table 4-5 were taken from Helgeson et al. (1978 [DIRS 101596], Table 8, pp. 120-121). All of the other thermodynamic data for the oxides ( $\mathrm{S}^{\circ}$, $\mathrm{V}^{\circ}$, and $\mathrm{C}_{\mathrm{p}}{ }^{\circ}$ parameters $\mathrm{a}, \mathrm{b}$, and c) were from Helgeson et al. (1978 [DIRS 101596], Table 2, p. 48). The exceptions were the $\Delta \mathrm{G}_{\mathrm{f}}{ }^{\circ}$ and $\mathrm{S}^{\circ}$ values for $\mathrm{SiO}_{2}$, which was selected for consistency with revision to the Rimstidt paradigm discussed in Section 6.1.5, as documented by BSC (2004 [DIRS 170268], Section 6.3 and Table 6.4-1). Although the values of $-204646.0 \mathrm{cal} / \mathrm{mol}$ and $9.88 \mathrm{cal} / \mathrm{mol}-\mathrm{K}$ (reported by Helgeson et al. 1978 [DIRS 101596] for $\Delta \mathrm{G}_{\mathrm{f}}{ }^{\circ}$ and $\mathrm{S}^{\circ}$, respectively) were used in comparisons with previously calculated values, the final values used to calculate the thermodynamic properties were $-204656.0 \mathrm{cal} / \mathrm{mol}$ and $9.904 \mathrm{cal} / \mathrm{mol}-\mathrm{K}$. These values are taken from Data Qualification for Thermodynamic Data Used to Support THC Calculations (BSC 2004 [DIRS 170268], Table 4-7).

Table 4-5. Oxide Thermodynamic Parameters Used to Estimate Thermodynamic Properties of Clays

\begin{tabular}{|c|c|c|c|c|c|c|}
\hline \multirow[b]{2}{*}{ Oxide Formula } & \multirow[b]{2}{*}{$\begin{array}{c}\Delta \mathbf{G}_{\mathrm{f}}^{\circ} \\
(\mathrm{cal} / \mathrm{mol})\end{array}$} & \multirow[b]{2}{*}{$\begin{array}{c}\mathrm{V}^{\circ} \\
\left(\mathrm{cm}^{3} / \mathrm{mol}\right)\end{array}$} & \multirow[b]{2}{*}{$\begin{array}{c}\mathrm{S}^{\circ} \\
\text { (cal/mol-K) }\end{array}$} & \multicolumn{3}{|c|}{ Heat Capacity Coefficients ${ }^{a}$} \\
\hline & & & & $\begin{array}{c}a \\
\text { (cal/mol-K) }\end{array}$ & $\begin{array}{c}\text { b } \times 10^{3} \\
\left(\mathrm{cal} / \mathrm{mol}^{\left.-K^{2}\right)}\right.\end{array}$ & $\begin{array}{c}\mathrm{c} \times 10^{-5} \\
(\mathrm{cal}-\mathrm{K} / \mathrm{mol})\end{array}$ \\
\hline $\mathrm{Al}_{2} \mathrm{O}_{3}$ & -374824.0 & 25.575 & 12.180 & 27.490 & 2.820 & 8.380 \\
\hline $\mathrm{CaO}$ & -144366.0 & 16.764 & 9.500 & 11.670 & 1.080 & 1.560 \\
\hline $\mathrm{Fe}_{2} \mathrm{O}_{3}$ & -178155.0 & 30.274 & 20.940 & 23.490 & 18.600 & 3.550 \\
\hline $\mathrm{FeO}$ & -60097.0 & 12.000 & 14.520 & 12.120 & 2.070 & 0.750 \\
\hline $\mathrm{K}_{2} \mathrm{O}$ & -77056.0 & 40.380 & 22.500 & 18.510 & 8.650 & 0.880 \\
\hline $\mathrm{Mg}(\mathrm{OH})_{2}$ & -199646.0 & 24.630 & $-{ }^{b}$ & $-{ }^{b}$ & $-{ }^{b}$ & $-{ }^{b}$ \\
\hline $\mathrm{MgO}$ & -136086.0 & 11.248 & 6.440 & 10.180 & 1.740 & 1.480 \\
\hline
\end{tabular}


Table 4-5. Oxide Thermodynamic Parameters Used to Estimate Thermodynamic Properties of Clays (Continued)

\begin{tabular}{|c|c|c|c|c|c|c|}
\hline \multirow[b]{2}{*}{ Oxide Formula } & \multirow[b]{2}{*}{$\begin{array}{c}\Delta \mathbf{G}_{\mathrm{f}}^{\circ} \\
(\mathrm{cal} / \mathrm{mol})\end{array}$} & \multirow[b]{2}{*}{$\begin{array}{c}V^{\circ} \\
\left(\mathrm{cm}^{3} / \mathrm{mol}\right)\end{array}$} & \multirow[b]{2}{*}{$\begin{array}{c}\mathrm{S}^{\circ} \\
(\mathrm{cal} / \mathrm{mol}-\mathrm{K})\end{array}$} & \multicolumn{3}{|c|}{ Heat Capacity Coefficients ${ }^{a}$} \\
\hline & & & & $\begin{array}{c}a \\
\text { (cal/mol-K) }\end{array}$ & $\begin{array}{c}\mathrm{b} \times 10^{3} \\
\left(\mathrm{cal} / \mathrm{mol}-\mathrm{K}^{2}\right)\end{array}$ & $\begin{array}{c}\mathrm{c} \times 10^{-5} \\
\text { (cal-K/mol) }\end{array}$ \\
\hline $\mathrm{Na}_{2} \mathrm{O}$ & -89883.0 & 25.000 & 17.935 & 18.250 & 4.890 & 2.890 \\
\hline $\mathrm{SiO}_{2}$ & $-204646.0^{\mathrm{C}}$ & 22.688 & $9.88^{\mathrm{C}}$ & 11.220 & 8.200 & 2.700 \\
\hline
\end{tabular}

Sources: $\quad \Delta G_{f}{ }^{\circ}$ from Helgeson et al. 1978 [DIRS 101596], Table 8, pp. 120-121; all other data from Helgeson et al. 1978 [DIRS 101596], Table 2, p. 48.

${ }^{\text {a }}$ Heat capacity coefficients a, b, and c defined in Eq. 4-1.

b Values not used in any calculations.

${ }^{c}$ Value of $-204656.0 \mathrm{cal} / \mathrm{mol}$ for $\Delta \mathrm{G}_{\mathrm{f}}^{\circ}$, and $9.904 \mathrm{cal} / \mathrm{mol}-\mathrm{K}$ for $\mathrm{S}^{\circ}$, from BSC (2004 [DIRS 170268], Table 4-7) were used in DTN: MO0302SPATHDYN.000 [DIRS 161756]. This is consistent with the Rimstidt paradigm for quartz solubility.

The $\Delta \mathrm{G}_{\mathrm{f}}{ }^{\circ}$ data for sheet silicates used in the estimation of free energies of the silicated oxide components by the Tardy and Garrels (1974 [DIRS 159209]) method are from Helgeson et al. (1978 [DIRS 101596], Table 8, pp. 120-125) (Table 4-6). However, there are exceptions to this source including several Ca-bearing silicate phases present in slop98.dat (DTN: MO0106MWDTDG01.035 [DIRS 161791]) and in data0.ymp.R0 (DTN: MO0009THRMODYN.001 [DIRS 152576]), that were incorporated in data0.ymp.R2 (DTN: MO0302SPATHDYN.000 [DIRS 161756]). These exceptions are discussed in Section 6.1.6.

The $\mathrm{V}^{\circ}$ values for the clays used to calculate molar volumes of other clays are from Helgeson et al. (1978 [DIRS 101596], Table 3, pp. 53-56, and Table 8, pp. 120-125) (Table 4-6). $\mathrm{S}^{\circ}$ and the $\mathrm{C}_{\mathrm{p}}{ }^{\circ}$ parameters "a," "b," and "c" for the silicated components of clay minerals were calculated from the thermodynamic data for the base silicate minerals (Table 4-7) listed. The source of these thermodynamic data is Helgeson et al. (1978 [DIRS 101596], Table 8, pp. 120-125). The list of clay phases for which mineral volumes were estimated is discussed in Section 6.3.1 and shown in Table 4-8.

Table 4-6. $\Delta \mathrm{G}_{\mathrm{f}}{ }^{\circ}$ and $\mathrm{V}^{\circ}$ of Minerals Used to Estimate $\Delta \mathrm{G}_{\mathrm{f}}^{\circ}$ and $\mathrm{V}^{\circ}$ of Silicated Components of Clay Minerals

\begin{tabular}{|l|l|c|c|}
\hline \multicolumn{1}{|c|}{ Reference Mineral } & \multicolumn{1}{|c|}{ Formula } & $\Delta \mathbf{G}_{\mathbf{f}}{ }^{\circ}(\mathbf{c a l} / \mathbf{m o l})$ & $\mathbf{V}^{\circ}\left(\mathbf{c m}^{\mathbf{3}} / \mathbf{m o l}\right)$ \\
\hline 14A-Amesite & $\mathrm{Mg}_{4} \mathrm{Al}_{4} \mathrm{Si}_{2} \mathrm{O}_{10}(\mathrm{OH})_{8}$ & $-{ }^{a}$ & 205.400 \\
\hline 14A-Clinochlore & $\mathrm{Mg}_{5} \mathrm{Al}_{2} \mathrm{Si}_{3} \mathrm{O}_{10}(\mathrm{OH})_{8}$ & -1961703 & 207.110 \\
\hline 14A-Daphnite & $\mathrm{Fe}_{5} \mathrm{Al}_{2} \mathrm{Si}_{3} \mathrm{O}_{10}(\mathrm{OH})_{8}$ & $-{ }^{a}$ & 213.420 \\
\hline 7A-Amesite & $\mathrm{Mg}_{2} \mathrm{Al}_{2} \mathrm{SiO}_{5}(\mathrm{OH})_{4}$ & $-{ }^{a}$ & 103.000 \\
\hline 7A-Chamosite & $\mathrm{Fe}_{2} \mathrm{Al}_{2} \mathrm{SiO}_{5}(\mathrm{OH})_{4}$ & $-{ }^{a}$ & 106.200 \\
\hline 7A-Clinochlore & $\mathrm{Mg}_{5} \mathrm{Al}_{2} \mathrm{Si}_{3} \mathrm{O}_{10}(\mathrm{OH})_{8}$ & -1957101 & 211.500 \\
\hline 7A-Cronstedtite & $\mathrm{Fe}^{++}{ }_{2} \mathrm{Fe}^{+++}{ }_{2} \mathrm{SiO}_{5}(\mathrm{OH})_{4}$ & $-{ }^{\mathrm{a}}$ & 110.900 \\
\hline 7A-Daphnite & $\mathrm{Fe}_{5} \mathrm{Al}_{2} \mathrm{Si}_{3} \mathrm{O}_{10}(\mathrm{OH})_{8}$ & $-{ }^{\mathrm{a}}$ & 221.200 \\
\hline Annite & $\mathrm{KFe}_{3} \mathrm{AlSi}_{3} \mathrm{O}_{10}(\mathrm{OH})_{2}$ & -1147156 & 154.320 \\
\hline Antigorite & $\mathrm{Mg}_{48} \mathrm{Si}_{34} \mathrm{O}_{85}(\mathrm{OH})_{62}$ & -15808020 & 1749.130 \\
\hline
\end{tabular}


Table 4-6. $\Delta \mathrm{G}_{\mathrm{f}}{ }^{\circ}$ and $\mathrm{V}^{\circ}$ of Minerals Used to Estimate $\Delta \mathrm{G}_{\mathrm{f}}{ }^{\circ}$ and $\mathrm{V}^{\circ}$ of Silicated Components of Clay Minerals (Continued)

\begin{tabular}{|l|l|c|c|}
\hline \multicolumn{1}{|c|}{ Reference Mineral } & \multicolumn{1}{c|}{ Formula } & $\Delta \mathbf{G}_{\mathbf{f}}^{\circ}(\mathbf{c a l} / \mathbf{m o l})$ & $\mathbf{V}^{\mathbf{0}}\left(\mathbf{c m}^{3} / \mathbf{m o l}\right)$ \\
\hline Celadonite & $\mathrm{KMgAISi}_{4} \mathrm{O}_{10}(\mathrm{OH})_{2}$ & $-^{\mathrm{a}}$ & 157.100 \\
\hline Chrysotile & $\mathrm{Mg}_{3} \mathrm{Si}_{2} \mathrm{O}_{5}(\mathrm{OH})_{4}$ & -964871 & 108.500 \\
\hline Greenalite & $\mathrm{Fe}_{3} \mathrm{Si}_{2} \mathrm{O}_{5}(\mathrm{OH})_{4}$ & $-^{\mathrm{a}}$ & 115.000 \\
\hline Hematite & $\mathrm{Fe}_{2} \mathrm{O}_{3}$ & -178155 & $-^{\mathrm{a}}$ \\
\hline Kaolinite & $\mathrm{Al}_{2} \mathrm{Si}_{2} \mathrm{O}_{5}(\mathrm{OH})_{4}$ & -905614 & 99.520 \\
\hline Margarite & $\mathrm{CaAl}_{4} \mathrm{Si}_{2} \mathrm{O}_{10}(\mathrm{OH})_{2}$ & $-1394370^{\mathrm{b}}$ & 129.400 \\
\hline Minnesotaite & $\mathrm{Fe}_{3} \mathrm{Si}_{4} \mathrm{O}_{10}(\mathrm{OH})_{2}$ & $-^{\mathrm{a}}$ & 147.860 \\
\hline Muscovite & $\mathrm{KAl}_{3} \mathrm{Si}_{3} \mathrm{O}_{10}(\mathrm{OH})_{2}$ & -1336301 & 140.710 \\
\hline Paragonite & $\mathrm{NaAl}_{3} \mathrm{Si}_{3} \mathrm{O}_{10}(\mathrm{OH})_{2}$ & -1326012 & 132.530 \\
\hline Phlogopite & $\mathrm{KAlMg}_{3} \mathrm{Si}_{3} \mathrm{O}_{10}(\mathrm{OH})_{2}$ & -1396187 & 149.660 \\
\hline Pyrophyllite & $\mathrm{Al}_{2} \mathrm{Si}_{4} \mathrm{O}_{10}(\mathrm{OH})_{2}$ & -1255997 & 126.600 \\
\hline Quartz & $\mathrm{SiO}_{2}$ & -204646 & 22.688 \\
\hline Sepiolite & $\mathrm{Mg}_{4} \mathrm{Si}_{6} \mathrm{O}_{15}(\mathrm{OH})_{2}: 6 \mathrm{H}_{2} \mathrm{O}$ & $--^{\mathrm{a}}$ & 285.600 \\
\hline Talc & $\mathrm{Mg}_{3} \mathrm{Si}_{4} \mathrm{O}_{10}(\mathrm{OH})_{2}$ & -1320188 & 136.250 \\
\hline
\end{tabular}

Sources: Column 3: Helgeson et al. 1978 [DIRS 101596], Table 8, pp. 120-125.

Column 4: Helgeson et al. 1978 [DIRS 101596], Table 3, pp. 53-56, and Table 8, pp. 120-125.

${ }^{a}$ Values are not used in any calculations.

${ }^{\mathrm{b}}$ Value of $-1394150 \mathrm{cal} / \mathrm{mol}$ used in final calculations. The change is a result of making the Gibbs free energies and enthalpies consistent with updated values of Gibbs free energies of $\mathrm{Ca}^{++}$(Shock and Helgeson 1988 [DIRS 144817]). Margarite properties are included in the SUPCRT92 data file slop98.dat (DTN: MO0106MWDTDG01.035 [DIRS 161791]).

Table 4-7. Thermodynamic Data for Reference Minerals Used to Estimate $S^{\circ}$ and the $a, b$, and $c$ Heat Capacity Parameters of the Silicated Components of Clay Minerals

\begin{tabular}{|c|c|c|c|c|c|c|}
\hline \multirow[b]{2}{*}{ Reference Mineral } & \multirow[b]{2}{*}{ Formula } & \multirow[b]{2}{*}{$\begin{array}{c}\mathrm{S}^{\circ} \\
\left(\mathrm{cm}^{3} / \mathrm{mol}-\mathrm{K}\right)\end{array}$} & \multirow[b]{2}{*}{$\begin{array}{c}\mathrm{V}^{\circ} \\
\left(\mathrm{cm}^{3} / \mathrm{mol}\right)\end{array}$} & \multicolumn{3}{|c|}{ Heat Capacity Coefficients ${ }^{a}$} \\
\hline & & & & $\begin{array}{c}a \\
\text { (cal/mol-K) }\end{array}$ & $\begin{array}{c}\mathrm{b} \times 10^{3} \\
\left(\mathrm{cal} / \mathrm{mol}^{\left.-\mathrm{K}^{2}\right)}\right.\end{array}$ & $\underset{(\mathrm{cal}-\mathrm{K} / \mathrm{mol})}{\operatorname{cc} 10^{-5}}$ \\
\hline 7A-Clinochlore & $\mathrm{Mg}_{5} \mathrm{Al}_{2} \mathrm{Si}_{3} \mathrm{O}_{10}(\mathrm{OH})_{8}$ & 106.500 & 211.500 & 162.820 & 50.620 & 40.880 \\
\hline 14A-Clinochlore & $\mathrm{Mg}_{5} \mathrm{Al}_{2} \mathrm{Si}_{3} \mathrm{O}_{10}(\mathrm{OH})_{8}$ & 111.200 & 207.110 & 166.500 & 42.100 & 37.470 \\
\hline Chrysotile & $\mathrm{Mg}_{3} \mathrm{Si}_{2} \mathrm{O}_{5}(\mathrm{OH})_{4}$ & 52.900 & 108.500 & 75.820 & 31.600 & 17.580 \\
\hline Muscovite & $\mathrm{KAl}_{3} \mathrm{Si}_{3} \mathrm{O}_{10}(\mathrm{OH})_{2}$ & $-{ }^{\mathrm{b}}$ & $-{ }^{\mathrm{b}}$ & 97.560 & 26.380 & 25.440 \\
\hline Pyrophyllite & $\mathrm{Al}_{2} \mathrm{Si}_{4} \mathrm{O}_{10}(\mathrm{OH})_{2}$ & 57.200 & 126.600 & 79.432 & 39.214 & 17.282 \\
\hline Talc & $\mathrm{Mg}_{3} \mathrm{Si}_{4} \mathrm{O}_{10}(\mathrm{OH})_{2}$ & 62.340 & 136.250 & 82.480 & 41.610 & 13.340 \\
\hline
\end{tabular}

Source: Helgeson et al. 1978 [DIRS 101596], Table 8, pp. 120-125.

${ }^{a}$ Coefficients defined in Eq. 4-1.

${ }^{\mathrm{b}}$ Values are not used in any calculations. 
Table 4-8. Clay Minerals for which Molar Volumes Will Be Evaluated in this Report

\begin{tabular}{|c|c|}
\hline Phase & Formula \\
\hline 14A-Ripidolite & $\mathrm{Mg}_{3} \mathrm{Fe}_{2} \mathrm{Al}_{2} \mathrm{Si}_{3} \mathrm{O}_{10}(\mathrm{OH})_{8}$ \\
\hline 7A-Ripidolite & $\mathrm{Mg}_{3} \mathrm{Fe}_{2} \mathrm{Al}_{2} \mathrm{Si}_{3} \mathrm{O}_{10}(\mathrm{OH})_{8}$ \\
\hline Ca-Beidellite & $\mathrm{Ca}_{0.165} \mathrm{Al}_{2.33} \mathrm{Si}_{3.67} \mathrm{O}_{10}(\mathrm{OH})_{2}$ \\
\hline Ca-Montmorillonite & $\mathrm{Ca}_{0.165} \mathrm{Mg}_{0.33} \mathrm{Al}_{1.67} \mathrm{Si}_{4} \mathrm{O}_{10}(\mathrm{OH})_{2}$ \\
\hline Ca-Nontronite & $\mathrm{Ca}_{0.165} \mathrm{Fe}_{2} \mathrm{Al}_{0.33} \mathrm{Si}_{3.67} \mathrm{O}_{10}(\mathrm{OH})_{2}$ \\
\hline Ca-Saponite & $\mathrm{Ca}_{0.165} \mathrm{Mg}_{3} \mathrm{Al}_{0.33} \mathrm{Si}_{3.67} \mathrm{O}_{10}(\mathrm{OH})_{2}$ \\
\hline Ferroaluminoceladonite & $\mathrm{KFeAISi}_{4} \mathrm{O}_{10}(\mathrm{OH})_{2}$ \\
\hline Ferroceladonite & $\mathrm{KFe}^{++} \mathrm{Fe}^{+++} \mathrm{Si}_{4} \mathrm{O}_{10}(\mathrm{OH})_{2}$ \\
\hline H-Beidellite & $\mathrm{H}_{0.33} \mathrm{Al}_{2.33} \mathrm{Si}_{3.67} \mathrm{O}_{10}(\mathrm{OH})_{2}$ \\
\hline High Fe-Mg Smectite & $\mathrm{Na}_{0.1} \mathrm{~K}_{0.2} \mathrm{Ca}_{0.025}\left(\mathrm{Mg}_{1.15} \mathrm{Fe}^{+++}{ }_{0.2} \mathrm{Fe}^{++}{ }_{0.5} \mathrm{Al}_{0.75}\right)\left(\mathrm{Al}_{0.5} \mathrm{Si}_{3.5}\right) \mathrm{O}_{10}(\mathrm{OH})_{2}$ \\
\hline H-Montmorillonite & $\mathrm{H}_{0.33} \mathrm{Mg}_{0.33} \mathrm{Al}_{1.67} \mathrm{Si}_{4} \mathrm{O}_{10}(\mathrm{OH})_{2}$ \\
\hline H-Nontronite & $\mathrm{H}_{0.33} \mathrm{Fe}_{2} \mathrm{Al}_{0.33} \mathrm{Si}_{3.67} \mathrm{O}_{10}(\mathrm{OH})_{2}$ \\
\hline H-Saponite & $\mathrm{H}_{0.33} \mathrm{Mg}_{3} \mathrm{Al}_{0.33} \mathrm{Si}_{3.67} \mathrm{O}_{10}(\mathrm{OH})_{2}$ \\
\hline Illite & $\mathrm{K}_{0.6} \mathrm{Mg}_{0.25} \mathrm{Al}_{2.3} \mathrm{Si}_{3.5} \mathrm{O}_{10}(\mathrm{OH})_{2}$ \\
\hline K-Beidellite & $\mathrm{K}_{0.33} \mathrm{Al}_{2.33} \mathrm{Si}_{3.67} \mathrm{O}_{10}(\mathrm{OH})_{2}$ \\
\hline K-Montmorillonite & $\mathrm{K}_{0.33} \mathrm{Mg}_{0.33} \mathrm{Al}_{1.67} \mathrm{Si}_{4} \mathrm{O}_{10}(\mathrm{OH})_{2}$ \\
\hline K-Nontronite & $\mathrm{K}_{0.33} \mathrm{Fe}_{2} \mathrm{Al}_{0.33} \mathrm{Si}_{3.67} \mathrm{O}_{10}(\mathrm{OH})_{2}$ \\
\hline K-Saponite & $\mathrm{K}_{0.33} \mathrm{Mg}_{3} \mathrm{Al}_{0.33} \mathrm{Si}_{3.67} \mathrm{O}_{10}(\mathrm{OH})_{2}$ \\
\hline Low Fe-Mg Smectite & $\mathrm{Na}_{0.15} \mathrm{~K}_{0.2} \mathrm{Ca}_{0.02}\left(\mathrm{Mg}_{0.9} \mathrm{Fe}^{+++}{ }_{0.16} \mathrm{Fe}^{++}{ }_{0.29} \mathrm{Al}\right)\left(\mathrm{Al}_{0.25} \mathrm{Si}_{3.75}\right) \mathrm{O}_{10}(\mathrm{OH})_{2}$ \\
\hline Mg-Beidellite & $\mathrm{Mg}_{0.165} \mathrm{Al}_{2.33} \mathrm{Si}_{3.67} \mathrm{O}_{10}(\mathrm{OH})_{2}$ \\
\hline Mg-Montmorillonite & $\mathrm{Mg}_{0.495} \mathrm{Al}_{1.67} \mathrm{Si}_{4} \mathrm{O}_{10}(\mathrm{OH})_{2}$ \\
\hline Mg-Nontronite & $\mathrm{Mg}_{0.165} \mathrm{Fe}_{2} \mathrm{Al}_{0.33} \mathrm{Si}_{3.67} \mathrm{O}_{10}(\mathrm{OH})_{2}$ \\
\hline Mg-Saponite & $\mathrm{Mg}_{0.165} \mathrm{Mg}_{3} \mathrm{Al}_{0.33} \mathrm{Si}_{3.67} \mathrm{O}_{10}(\mathrm{OH})_{2}$ \\
\hline Na-Beidellite & $\mathrm{Na}_{0.33} \mathrm{Al}_{2.33} \mathrm{Si}_{3.67} \mathrm{O}_{10}(\mathrm{OH})_{2}$ \\
\hline Na-Montmorillonite & $\mathrm{Na}_{0.33} \mathrm{Mg}_{0.33} \mathrm{Al}_{1.67} \mathrm{Si}_{4} \mathrm{O}_{10}(\mathrm{OH})_{2}$ \\
\hline Na-Nontronite & $\mathrm{Na}_{0.33} \mathrm{Fe}_{2} \mathrm{Al}_{0.33} \mathrm{Si}_{3.67} \mathrm{O}_{10}(\mathrm{OH})_{2}$ \\
\hline Na-Saponite & $\mathrm{Na}_{0.33} \mathrm{Mg}_{3} \mathrm{Al}_{0.33} \mathrm{Si}_{3.67} \mathrm{O}_{10}(\mathrm{OH})_{2}$ \\
\hline Reykjanes Smectite & $\mathrm{Na}_{0.33} \mathrm{~K}_{0.03} \mathrm{Ca}_{0.66}\left(\mathrm{Mg}_{1.29} \mathrm{Fe}^{+++}{ }_{0.35} \mathrm{Fe}^{++}{ }_{0.33} \mathrm{Mn}_{0.01} \mathrm{Al}_{0.28}\right)\left(\mathrm{Al}_{0.83} \mathrm{Si}_{3.17}\right) \mathrm{O}_{10}(\mathrm{OH})_{2}$ \\
\hline
\end{tabular}

Output DTN: SN0410T0510404.001 (Spreadsheet Volume_Q_DS_11-01-04.XIs).

\subsubsection{Compilation of Thermodynamic Data for Zeolites}

Zeolite minerals are commonly found in the rock matrix and fractures at Yucca Mountain (Vaniman and Bish 1995 [DIRS 101496]; Carlos et al. 1995 [DIRS 105213]). Therefore, consideration of these minerals is important in modeling water/rock reactions. The previous database data0.ymp.R0 (DTN: MO0009THRMODYN.001 [DIRS 152576]) contained 16 zeolite mineral phases. The data $\left(\Delta \mathrm{G}_{\mathrm{f}}{ }^{\circ}, \Delta \mathrm{H}_{\mathrm{f}}{ }^{\circ}, \mathrm{S}^{\circ}, \mathrm{V}^{\circ}\right.$, and $\left.\mathrm{C}_{\mathrm{p}}{ }^{\circ}\right)$ for these 16 minerals were originally taken from work done by Viani and Bruton (1992 [DIRS 101407], Tables 1 and 2; Appendix E, Tables 1 and 2), but were truncated at temperatures beyond $100^{\circ} \mathrm{C}$. Viani and Bruton $(1992$ [DIRS 101407]) provide heat capacity data $\left(\mathrm{C}_{\mathrm{p}}{ }^{\circ}\right)$ at elevated temperatures that would allow for extrapolation of $\Delta \mathrm{G}_{\mathrm{f}}$ data to temperatures beyond $100^{\circ} \mathrm{C}$. The requisite thermodynamic data were entered into the spreadsheets to establish the $\log \mathrm{K}$ grid beyond $100^{\circ} \mathrm{C}$. Estimated data for 
$\Delta \mathrm{G}_{\mathrm{f}}{ }^{\circ}, \Delta \mathrm{H}_{\mathrm{f}}{ }^{\circ}, \mathrm{S}^{\circ}, \mathrm{V}^{\circ}$, and $\mathrm{C}_{\mathrm{p}}{ }^{\circ}$ for an additional five zeolite minerals were taken from Table 1 of Chipera et al. (1995 [DIRS 100025]), included in a recent book on natural zeolites published by the International Committee on Natural Zeolites. A typographical error in Table 1 of Chipera et al. (1995 [DIRS 100025]) expressed the standard entropy in $\mathrm{kJ} / \mathrm{mol} \mathrm{K}$ instead of $\mathrm{J} / \mathrm{mol} \mathrm{K}$. To confirm this, standard entropy values for one of the zeolites (e.g., analcime) were checked against handbook data (Robie and Hemingway 1995 [DIRS 153683]), indicating a difference within a few $\mathrm{kJ} / \mathrm{mol}$ and not by a factor of a 1000 . The list of updated zeolite phases in the data0.ymp.R2 database (DTN: MO0302SPATHDYN.000 [DIRS 161756]) is given in Table 4-9. Thermodynamic data for these minerals are listed in Table 4-10. The analysis used to generate the computed $\log \mathrm{K}$ values (over the entire temperature range) and associated corrections using updated quartz solubility data are discussed in Section 6.3.2.

\subsubsection{Compilation of Thermodynamic Data for Cement Phases}

Previous work to derive a thermodynamic database to investigate seepage-cement interactions resulted in the creation of a cement database that was compatible with EQ3/6 (Hardin 1998 [DIRS 100350], pp. 7-28). However, this database was not developed under a qualified process and lacks cement phases common to grouts. Even though it contains many cement minerals of interest, it does not include many known minerals associated with the production of cement pastes or the dissolution of hardened concretes and grouts.

In development of the data0.ymp.R2 database (DTN: MO0302SPATHDYN.000 [DIRS 161756]), the cement data were developed using the existing qualified data0.ymp.R0 database (DTN: MO0009THRMODYN.001 [DIRS 152576]) with added data from Perkins and Palmer (2000 [DIRS 153349]) for Cr-ettringite (chromium ettringite). This source also generated a $\log \mathrm{K}$ value at $25^{\circ} \mathrm{C}(\log \mathrm{K}=-2.77)$ for the reaction $\mathrm{CaCrO}_{4}(\mathrm{aq})=\mathrm{Ca}^{++}+\mathrm{CrO}_{4}{ }^{--}$ consistent with the retrieved solubility data for $\mathrm{Cr}$-ettringite.

Numerous data sources were reviewed for thermodynamic data of cement phases but the compilation by Babushkin et al. (1985 [DIRS 116981]) was deemed sufficiently comprehensive and was selected for inclusion in the database. Certain data from Perkins and Palmer (1999 [DIRS 152703]) are used in this report to corroborate the data used from Babushkin et al. (1985 [DIRS 116981]). In addition, data from Perkins and Palmer (2000 [DIRS 153349]) for Cr-ettringite were added to the data0.ymp.R2 database (DTN: MO0302SPATHDYN.000 [DIRS 161756]) (this mineral was not included in data0.ymp.R0; DTN: MO0009THRMODYN.001 [DIRS 152576]). These data are listed in Table 4-11. Other sources such as Fujii and Kondo (1983 [DIRS 144876]), Atkins et al. (1993 [DIRS 131758]), Bennett et al. (1992 [DIRS 116990]), and Damidot et al. (1994 [DIRS 144866]) report solubility data for various cement phases which are also used as direct input. 
Table 4-9. Zeolite Minerals Included in Data0.ymp.R2 (DTN: MO0302SPATHDYN.000 [DIRS 161756])

\begin{tabular}{|c|c|c|c|}
\hline Mineral & Formula & Reaction & Source \\
\hline Analcime & $\mathrm{Na}_{0.96} \mathrm{Al}_{0.96} \mathrm{Si}_{2.04} \mathrm{O}_{6}: \mathrm{H}_{2} \mathrm{O}$ & Analcime $+3.84 \mathrm{H}^{+}=0.96 \mathrm{Al}^{+++}+0.96 \mathrm{Na}^{+}+2.04 \mathrm{SiO}_{2}+2.92 \mathrm{H}_{2} \mathrm{O}$ & 1 \\
\hline Analcime-dehy & $\mathrm{Na}_{0.96} \mathrm{Al}_{0.96} \mathrm{Si}_{2.04} \mathrm{O}_{6}$ & Analcime-dehy $+3.84 \mathrm{H}^{+}=0.96 \mathrm{Al}^{+++}+0.96 \mathrm{Na}^{+}+2.04 \mathrm{SiO}_{2}+1.92 \mathrm{H}_{2} \mathrm{O}$ & 1 \\
\hline Clinoptilolite & $\begin{array}{l}\mathrm{Na}_{0.954} \mathrm{~K}_{0.543} \mathrm{Ca}_{0.761} \mathrm{Mg}_{0.124} \mathrm{Sr}_{0.036} \mathrm{Ba}_{0.062} \\
\mathrm{Mn}_{0.002} \mathrm{Al}_{3.45} \mathrm{Fe}_{0.017} \mathrm{Si}_{14.533} \mathrm{O}_{46.922} \mathrm{H}_{21.844}\end{array}$ & $\begin{array}{l}\text { Clinoptilolite }+13.868 \mathrm{H}^{+}=0.002 \mathrm{Mn}^{++}+0.017 \mathrm{Fe}^{+++}+0.036 \mathrm{Sr}^{++}+0.062 \mathrm{Ba}^{++}+0.124 \mathrm{Mg}^{++} \\
+0.543 \mathrm{~K}^{+}+0.761 \mathrm{Ca}^{++}+0.954 \mathrm{Na}^{+}+3.45 \mathrm{Al}^{++}+14.533 \mathrm{SiO}_{2}(\mathrm{aq})+17.856 \mathrm{H}_{2} \mathrm{O}\end{array}$ & 1 \\
\hline $\begin{array}{l}\text { Clinoptilolite- } \\
\text { dehy }\end{array}$ & $\begin{array}{l}\mathrm{Na}_{0.954} \mathrm{~K}_{0.543} \mathrm{Ca}_{0.761} \mathrm{Mg}_{0.124} \mathrm{Sr}_{0.036} \mathrm{Ba}_{0.062} \\
\mathrm{Mn}_{0.002} \mathrm{Al}_{3.45} \mathrm{Fe}_{0.017} \mathrm{Si}_{14.533} \mathrm{O}_{36}\end{array}$ & $\begin{array}{l}\text { Clinoptilolite }+13.868 \mathrm{H}^{+}=0.002 \mathrm{Mn}^{++}+0.017 \mathrm{Fe}^{+++}+0.036 \mathrm{Sr}^{++}+0.062 \mathrm{Ba}^{++}+0.124 \mathrm{Mg}^{++} \\
+0.543 \mathrm{~K}^{+}+0.761 \mathrm{Ca}^{++}+0.954 \mathrm{Na}^{+}+3.45 \mathrm{Al}^{++}+14.533 \mathrm{SiO}_{2}(\mathrm{aq})+6.934 \mathrm{H}_{2} \mathrm{O}\end{array}$ & 1 \\
\hline Clinoptilolite-Ca & $\begin{array}{l}\mathrm{Ca}_{1.7335} \mathrm{Al}_{3.45} \mathrm{Fe}_{0.017} \mathrm{Si}_{14.533} \mathrm{O}_{36} \\
10.922 \mathrm{H}_{2} \mathrm{O}\end{array}$ & $\begin{array}{l}\text { Clinoptilolite-Ca }+13.868 \mathrm{H}^{+}=0.017 \mathrm{Fe}^{+++}+1.7335 \mathrm{Ca}^{++}+3.45 \mathrm{Al}^{+++}+14.533 \mathrm{SiO}_{2}(\mathrm{aq})+ \\
17.856 \mathrm{H}_{2} \mathrm{O}\end{array}$ & 1 \\
\hline Clinoptilolite-Cs & $\mathrm{Cs}_{3.467} \mathrm{Al}_{3.45} \mathrm{Fe}_{0.017} \mathrm{Si}_{14.533} \mathrm{O}_{36}: 10.922 \mathrm{H}_{2} \mathrm{O}$ & $\begin{array}{l}\text { Clinoptilolite-Cs }+13.868 \mathrm{H}^{+}=0.017 \mathrm{Fe}^{+++}+3.467 \mathrm{Cs}^{+}+3.45 \mathrm{Al}^{+++}+14.533 \mathrm{SiO}_{2}(\mathrm{aq})+ \\
17.856 \mathrm{H}_{2} \mathrm{O}\end{array}$ & 1 \\
\hline Clinoptilolite-K & $\mathrm{K}_{3.467} \mathrm{Al}_{3.45} \mathrm{Fe}_{0.017} \mathrm{Si}_{14.533} \mathrm{O}_{36}: 10.922 \mathrm{H}_{2} \mathrm{O}$ & $\begin{array}{l}\text { Clinoptilolite-K }+13.868 \mathrm{H}^{+}=0.017 \mathrm{Fe}^{+++}+3.467 \mathrm{~K}^{+}+3.45 \mathrm{Al}^{+++}+14.533 \mathrm{SiO}_{2}(\mathrm{aq})+ \\
17.856 \mathrm{H}_{2} \mathrm{O}\end{array}$ & 1 \\
\hline Clinoptilolite- $\mathrm{NH}_{4}$ & $\begin{array}{l}\left(\mathrm{NH}_{4}\right)_{3.467} \mathrm{Al}_{3.45} \mathrm{Fe}_{0.017} \mathrm{Si}_{14.533} \mathrm{O}_{36}: \\
10.922 \mathrm{H}_{2} \mathrm{O}\end{array}$ & $\begin{array}{l}\text { Clinoptilolite- } \mathrm{NH}_{4}+10.401 \mathrm{H}^{+}=0.017 \mathrm{Fe}^{+++}+3.45 \mathrm{Al}^{+++}+3.467 \mathrm{NH}_{3}(\mathrm{aq})+14.533 \mathrm{SiO}_{2}(\mathrm{aq}) \\
+17.856 \mathrm{H}_{2} \mathrm{O}\end{array}$ & 1 \\
\hline Clinoptilolite- $\mathrm{Na}$ & $\mathrm{Na}_{3.467} \mathrm{Al}_{3.45} \mathrm{Fe}_{0.017} \mathrm{Si}_{14.533} \mathrm{O}_{36}: 10.922 \mathrm{H}_{2} \mathrm{O}$ & $\begin{array}{l}\text { Clinoptilolite-Na }+13.868 \mathrm{H}^{+}=0.017 \mathrm{Fe}^{+++}+3.467 \mathrm{Na}^{+}+3.45 \mathrm{Al}^{+++}+14.533 \mathrm{SiO}_{2}(\mathrm{aq})+ \\
17.856 \mathrm{H}_{2} \mathrm{O}\end{array}$ & 1 \\
\hline Clinoptilolite-Sr & $\begin{array}{l}\mathrm{Sr}_{1.7335} \mathrm{Al}_{3.45} \mathrm{Fe}_{0.017} \mathrm{Si}_{14.533} \mathrm{O}_{36}: \\
10.922 \mathrm{H}_{2} \mathrm{O}\end{array}$ & $\begin{array}{l}\text { Clinoptilolite-Sr }+13.868 \mathrm{H}^{+}=0.017 \mathrm{Fe}^{+++}+1.7335 \mathrm{Sr}^{++}+3.45 \mathrm{Al}^{+++}+14.533 \mathrm{SiO}_{2}(\mathrm{aq})+ \\
17.856 \mathrm{H}_{2} \mathrm{O}\end{array}$ & 1 \\
\hline Heulandite & $\begin{array}{l}\mathrm{Ba}_{0.065} \mathrm{Sr}_{0.175} \mathrm{Ca}_{0.585} \mathrm{~K}_{0.132} \mathrm{Na}_{0.383} \mathrm{Al}_{2.165} \\
\mathrm{Si}_{6.835} \mathrm{O}_{18}: 6 \mathrm{H}_{2} \mathrm{O}\end{array}$ & $\begin{array}{l}\text { Heulandite }+8.66 \mathrm{H}^{+}=0.065 \mathrm{Ba}^{++}+0.132 \mathrm{~K}^{+}+0.175 \mathrm{Sr}^{++}+0.383 \mathrm{Na}^{+}+0.585 \mathrm{Ca}^{++}+ \\
2.165 \mathrm{Al}^{+++}+6.835 \mathrm{SiO}_{2}(\mathrm{aq})+10.33 \mathrm{H}_{2} \mathrm{O}\end{array}$ & 1 \\
\hline Mesolite & $\mathrm{Na}_{0.676} \mathrm{Ca}_{0.657} \mathrm{Al}_{1.99} \mathrm{Si}_{3.01} \mathrm{O}_{10}: 2.647 \mathrm{H}_{2} \mathrm{O}$ & Mesolite $+7.96 \mathrm{H}^{+}=0.657 \mathrm{Ca}^{++}+0.676 \mathrm{Na}^{+}+1.99 \mathrm{Al}^{+++}+3.01 \mathrm{SiO}_{2}(\mathrm{aq})+6.627 \mathrm{H}_{2} \mathrm{O}$ & 1 \\
\hline Mordenite & $\mathrm{Ca}_{0.2895} \mathrm{Na}_{0.361} \mathrm{Al}_{0.94} \mathrm{Si}_{5.06} \mathrm{O}_{12}: 3.468 \mathrm{H}_{2} \mathrm{O}$ & Mordenite $+3.76 \mathrm{H}^{+}=0.2895 \mathrm{Ca}^{++}+0.361 \mathrm{Na}^{+}+0.94 \mathrm{Al}^{+++}+5.06 \mathrm{SiO}_{2}(\mathrm{aq})+5.348 \mathrm{H}_{2} \mathrm{O}$ & 1 \\
\hline Natrolite & $\mathrm{Na}_{2} \mathrm{Al}_{2} \mathrm{Si}_{3} \mathrm{O}_{10}: 2 \mathrm{H}_{2} \mathrm{O}$ & Natrolite $+8 \mathrm{H}^{+}=2 \mathrm{Al}^{+++}+2 \mathrm{Na}^{+}+3 \mathrm{SiO}_{2}(\mathrm{aq})+6 \mathrm{H}_{2} \mathrm{O}$ & 1 \\
\hline Scolecite & $\mathrm{CaAl}_{2} \mathrm{Si}_{3} \mathrm{O}_{10}: 3 \mathrm{H}_{2} \mathrm{O}$ & Scolecite $+8 \mathrm{H}^{+}=\mathrm{Ca}^{++}+2 \mathrm{Al}^{+++}+3 \mathrm{SiO}_{2}(\mathrm{aq})+7 \mathrm{H}_{2} \mathrm{O}$ & 1 \\
\hline Stilbite & $\begin{array}{l}\mathrm{Ca}_{1.019} \mathrm{Na}_{0.136} \mathrm{~K}_{0.006} \mathrm{Al}_{2.18} \mathrm{Si}_{6.82} \mathrm{O}_{18} \\
7.33 \mathrm{H}_{2} \mathrm{O}\end{array}$ & $\begin{array}{l}\text { Stilbite }+8.72 \mathrm{H}^{+}=0.006 \mathrm{~K}^{+}+0.136 \mathrm{Na}^{+}+1.019 \mathrm{Ca}^{++}+2.18 \mathrm{Al}^{+++}+6.82 \mathrm{SiO}_{2}(\mathrm{aq})+ \\
11.69 \mathrm{H}_{2} \mathrm{O}\end{array}$ & 1 \\
\hline Chabazite & $\mathrm{K}_{0.6} \mathrm{Na}_{0.2} \mathrm{Ca}_{1.5} \mathrm{Al}_{3.8} \mathrm{Si}_{8.2} \mathrm{O}_{24}: 10 \mathrm{H}_{2} \mathrm{O}$ & Chabazite $+15.2 \mathrm{H}^{+}=0.6 \mathrm{~K}^{+}+0.2 \mathrm{Na}^{+}+1.5 \mathrm{Ca}^{++}+3.8 \mathrm{Al}^{++}+8.2 \mathrm{SiO}_{2}(\mathrm{aq})+17.6 \mathrm{H}_{2} \mathrm{O}$ & 2 \\
\hline Erionite & $\mathrm{K}_{1.5} \mathrm{Na}_{0.9} \mathrm{Ca}_{0.9} \mathrm{Al}_{4.2} \mathrm{Si}_{13.8} \mathrm{O}_{36}: 13.0 \mathrm{H}_{2} \mathrm{O}$ & Erionite $+16.8 \mathrm{H}^{+}=1.5 \mathrm{~K}^{+}+0.9 \mathrm{Na}^{+}+0.9 \mathrm{Ca}^{++}+4.2 \mathrm{Al}^{+++}+13.8 \mathrm{SiO}_{2}+21.4 \mathrm{H}_{2} \mathrm{O}$ & 2 \\
\hline Laumontite & $\mathrm{K}_{0.2} \mathrm{Na}_{0.2} \mathrm{Ca}_{1.8} \mathrm{Al}_{4} \mathrm{Si}_{8} \mathrm{O}_{24}: 8 \mathrm{H}_{2} \mathrm{O}$ & Laumontite $+16 \mathrm{H}^{+}=0.2 \mathrm{~K}^{+}+0.2 \mathrm{Na}^{+}+1.8 \mathrm{Ca}^{++}+4 \mathrm{Al}^{+++}+8 \mathrm{SiO}_{2}+16 \mathrm{H}_{2} \mathrm{O}$ & 2 \\
\hline Phillipsite & $\mathrm{K}_{0.7} \mathrm{Na}_{0.7} \mathrm{Ca}_{1.1} \mathrm{Al}_{3.6} \mathrm{Si}_{12.4} \mathrm{O}_{32}: 12.6 \mathrm{H}_{2} \mathrm{O}$ & Phillipsite $+14.4 \mathrm{H}^{+}=0.7 \mathrm{~K}^{+}+0.7 \mathrm{Na}^{+}+1.1 \mathrm{Ca}^{++}+3.6 \mathrm{Al}^{+++}+12.4 \mathrm{SiO}_{2}+19.8 \mathrm{H}_{2} \mathrm{O}$ & 2 \\
\hline Stellerite & $\mathrm{Ca}_{2.0} \mathrm{Al}_{4.0} \mathrm{Si}_{14} \mathrm{O}_{36}: 14 \mathrm{H}_{2} \mathrm{O}$ & Stellerite $+16 \mathrm{H}^{+}=2.0 \mathrm{Ca}^{++}+4.0 \mathrm{Al}^{+++}+14 \mathrm{SiO}_{2}+22 \mathrm{H}_{2} \mathrm{O}$ & 2 \\
\hline
\end{tabular}

Sources: 1 Viani and Bruton 1992 [DIRS 101407], Tables 1 and 2; Appendix E, Tables 1 and 2.

2 Chipera et al. 1995 [DIRS 100025], Table 1. 
Table 4-10. Thermodynamic Data for Zeolite Minerals

\begin{tabular}{|c|c|c|c|c|c|c|c|c|c|c|c|c|}
\hline \multirow[b]{2}{*}{ Phase } & \multirow[b]{2}{*}{$\begin{array}{c}\Delta \mathrm{G}_{\mathrm{f}}^{\circ} \\
(\mathrm{J} / \mathrm{mol})\end{array}$} & \multirow[b]{2}{*}{$\begin{array}{c}\Delta \mathrm{H}_{\mathrm{f}}^{\circ} \\
(\mathrm{J} / \mathrm{mol})\end{array}$} & \multirow[b]{2}{*}{$\begin{array}{c}\mathrm{S}^{\circ} \\
(\mathrm{J} / \mathrm{mol}-\mathrm{K})\end{array}$} & \multirow[b]{2}{*}{$\begin{array}{c}V^{\circ} \\
\left(\mathrm{cm}^{3} / \mathrm{mol}\right)\end{array}$} & \multicolumn{7}{|c|}{ Empirical Coefficients for the Heat Capacity Equation ${ }^{a}$} & \multirow[b]{2}{*}{ Source } \\
\hline & & & & & $\begin{array}{c}\mathrm{C}_{\mathrm{p}}{ }^{\circ} \\
(\mathrm{J} / \mathrm{mol}-\mathrm{K})\end{array}$ & $\begin{array}{c}\mathrm{T} \\
\left(\mathrm{J} / \mathrm{mol}^{2}-\mathrm{K}^{2}\right)\end{array}$ & $\begin{array}{c}\mathrm{T}^{2} \\
\left(\mathrm{~J} / \mathrm{mol}^{3}-\mathrm{K}^{3}\right)\end{array}$ & $\begin{array}{c}\mathrm{T}^{3} \\
\left(\mathrm{~J} / \mathrm{mol}^{-} \mathrm{K}^{4}\right) \\
\end{array}$ & $\begin{array}{c}\mathrm{T}^{-2} \\
\left(\mathrm{~J}-\mathrm{K}^{2} / \mathrm{mol}\right)\end{array}$ & $\begin{array}{c}\mathrm{T}^{-3} \\
\left(\mathrm{~J}-\mathrm{K}^{4} / \mathrm{mol}\right)\end{array}$ & $\begin{array}{c}\mathrm{T}^{-0.5} \\
\left(\mathrm{~J}-\mathrm{K}^{0.5} \mathrm{I}\right. \\
\mathrm{mol})\end{array}$ & \\
\hline Analcime-dehy & $-2,803,700$ & $-2,970,200$ & 171.71 & - & $1.108 \mathrm{E}+02$ & 2.717E-01 & $-1.172 \mathrm{E}-03$ & - & $-1.583 \mathrm{E}+06$ & - & - & 1 \\
\hline Clinoptilolite $^{\mathrm{b}}$ & $-19,021,200$ & $-20,587,800$ & $1,483.06$ & - & $5.016 \mathrm{E}+01$ & $6.365 \mathrm{E}+00$ & $-4.616 \mathrm{E}-03$ & - & - & - & - & 1 \\
\hline Clinoptilolite-dehy ${ }^{b}$ & $-16,227,300$ & $-17,210,200$ & 893.31 & - & $-4.781 \mathrm{E}+02$ & $6.910 \mathrm{E}+00$ & $-9.031 E-03$ & $3.902 \mathrm{E}-06$ & - & - & - & 1 \\
\hline Clinoptilolite-Cs ${ }^{\mathrm{b}}$ & $-19,115,382$ & - & $1,561.18$ & 632.050 & $5.971 \mathrm{E}+01$ & $6.398 \mathrm{E}+00$ & 4.616E-03 & - & $1.301 \mathrm{E}+06$ & - & - & 1 \\
\hline Clinoptilolite- $K^{\mathrm{b}}$ & $-19,071,429$ & - & $1,509.29$ & 632.050 & $7.951 \mathrm{E}+01$ & $6.403 E+00$ & $4.616 \mathrm{E}-03$ & - & $6.628 \mathrm{E}+05$ & - & - & 1 \\
\hline Clinoptilolite- $\mathrm{NH}_{4}{ }^{\mathrm{b}}$ & $-18,364,701$ & - & - & - & - & - & - & - & - & - & - & 1 \\
\hline Clinoptilolite- $\mathrm{Na}^{\mathrm{b}}$ & $-18,978,314$ & - & $1,507.16$ & 632.050 & $7.762 \mathrm{E}+01$ & $6.365 \mathrm{E}+00$ & $4.616 \mathrm{E}-03$ & - & - & - & - & 1 \\
\hline Clinoptilolite-Sr ${ }^{b}$ & $-19,047,857$ & - & $1,480.22$ & 632.050 & $3.476 \mathrm{E}+01$ & $6.348 \mathrm{E}+00$ & 4.616E-03 & - & $|-1.173 E+04|$ & - & - & 1 \\
\hline Heulandite & $-9,779,100$ & $-10,594,600$ & 767.18 & - & $7.456 \mathrm{E}+02$ & 6.513E-01 & - & - & $-1.411 \mathrm{E}+07$ & - & - & 1 \\
\hline Mesolite & $-5,513,200$ & $-5,947,154$ & 363.00 & - & $1.908 \mathrm{E}+02$ & 6.793E-01 & - & - & $-1.633 E+06$ & - & - & 1 \\
\hline Natrolite & $-5,316,600$ & $-5,718,600$ & 359.73 & - & $3.020 \mathrm{E}+02$ & 3.769E-01 & - & - & $-4.898 \mathrm{E}+06$ & - & - & 1 \\
\hline Scolecite & $-5,597,900$ & $-6,049,000$ & 367.42 & - & $1.352 \mathrm{E}+02$ & 8.305E-01 & - & - & - & - & - & 1 \\
\hline Stilbite & $-10,114,100$ & $-11,005,700$ & 805.54 & - & $4.430 \mathrm{E}+02$ & 6.173E-01 & 3.609E-03 & $-5.247 \mathrm{E}-06$ & - & - & - & 1 \\
\hline Chabazite & $-13,850,300$ & $-15,047,400$ & $1,194.30$ & 499.400 & $2.023 E+03$ & - & - & - & $-3.016 \mathrm{E}-03$ & 4.195E-05 & $-1.385 E+00$ & 2 \\
\hline Erionite & $-19,813,000$ & $-21,497,500$ & $1,640.50$ & 672.000 & $2.853 \mathrm{E}+03$ & - & - & - & $-4.704 \mathrm{E}-03$ & 6.723E-05 & $-1.923 E+00$ & 2 \\
\hline Laumontite & $-13,431,200$ & $-14,525,900$ & $1,011.20$ & 406.400 & $1.843 \mathrm{E}+03$ & - & - & - & $-3.012 \mathrm{E}-03$ & 4.147E-05 & $-1.227 \mathrm{E}+00$ & 2 \\
\hline Phillipsite & $-17,817,700$ & $-19,375,100$ & $1,491.90$ & 609.200 & $2.609 \mathrm{E}+03$ & - & - & - & $-4.158 \mathrm{E}-03$ & $5.918 \mathrm{E}-05$ & $-1.778 E+00$ & 2 \\
\hline Stellerite & $-19,996,800$ & $-21,751,300$ & $1,611.70$ & 665.500 & $2.887 \mathrm{E}+03$ & - & - & - & $-4.478 \mathrm{E}-03$ & $6.259 \mathrm{E}-05$ & $-1.983 E+00$ & 2 \\
\hline
\end{tabular}

Sources: 1 Viani and Bruton 1992 [DIRS 101407], Tables 1 and 2; Appendix E, Tables 1 and 2.

2 Chipera et al. 1995 [DIRS 100025], Table 1.

a Empirical coefficients based on the equation given by Viani and Bruton (1992 [DIRS 101407], p. 60, Table E.2, Footnote 1).

${ }^{b}$ Units for partial molal thermodynamic properties originally given in cal $/ \mathrm{mol}$ basis. Converted to $\mathrm{J} / \mathrm{mol}$ basis in this table. 
The following minerals associated with cement already existed in data0.ymp.R0 (DTN: MO0009THRMODYN.001 [DIRS 152576]), with $\log \mathrm{K}$ values up to $100^{\circ} \mathrm{C}$ : gypsum, wollastonite, brucite, portlandite, lime, ferrite- $\mathrm{Mg}$, ferrite-Ca, ferrite-dicalcium, sepiolite, gibbsite, anhydrite, and periclase. For data0.ymp.R2 (DTN: MO0302SPATHDYN.000 [DIRS 161756]) the $\log \mathrm{K}$ values for these minerals were calculated up to $300^{\circ} \mathrm{C}$ (except for gypsum and sepiolite) using the input thermodynamic data listed in Table 4-17. Since the sources of these data were already qualified, no further evaluation is necessary.

Data for the calcium silicate hydrate (CSH) cement phase (examined for qualification, although not active in the data0.ymp.R2 database; DTN: MO0302SPATHDYN.000 [DIRS 161756]) are from Fujii and Kondo (1983 [DIRS 144876]). Table 4-12 shows the values adopted for the analysis of $\log \mathrm{K}$ values for this phase. For evaluation of heat capacities as applied to this phase, $\mathrm{C}_{\mathrm{p}}{ }^{\circ}$ data for portlandite, alpha-quartz, and $\mathrm{H}_{2} \mathrm{O}$ (Table 4-13) were used (see Section 6.3.3.1). Also, heat capacity data for $\mathrm{CaCl}_{2}$ (cr) are listed in Table 4-14 for use in the extrapolation of $\log \mathrm{K}$ values for $\mathrm{CSH}$ and Friedl salt phases at higher temperatures. The $\log \mathrm{K}$ temperature extrapolation uses an approximation of the cement heat capacity based on a linear representation of heat capacity values of the constituent oxides, hydroxides, and salts making up the cement.

Gibbs free energy of formation data for Na-gismondine and Ca-gismondine (-1179160 and $-1187450 \mathrm{cal} / \mathrm{mol}$, respectively, Table 4-15) were obtained from Atkins et al. (1993 [DIRS 131758], Section 5.2.6). The $\log \mathrm{K}$ value (73.78) for hydrotalcite dissociation was obtained from Bennett et al. (1992 [DIRS 116990]). The log K values for monocarboaluminate $\left(3 \mathrm{CaO} \cdot \mathrm{Al}_{2} \mathrm{O}_{3} \cdot \mathrm{CaCO}_{3} \cdot 10 \mathrm{H}_{2} \mathrm{O}\right)$ and hemicarboaluminate $\left(3 \mathrm{CaO} \cdot \mathrm{Al}_{2} \mathrm{O}_{3} \cdot 0.5 \mathrm{CaCO}_{3} \cdot 0.5 \mathrm{Ca}(\mathrm{OH})_{2}\right.$ $\cdot 10.5 \mathrm{H}_{2} \mathrm{O}$ ) were obtained from Damidot et al. (1994 [DIRS 144866], Appendix 1) reporting $\log \mathrm{K}$ values of 69.99 and 85.76 , respectively.

The $\log \mathrm{K}$ value at $25 \mathrm{C}$ for the dissociation reaction of the cement phase syngenite is -7.6 as given in data0.ymp.R2 (DTN: MO0302SPATHDYN.000 [DIRS 161756]). This $\log \mathrm{K}$ value is evaluated in Section 6.3.3.9.

Table 4-11. Thermodynamic Properties for Calcium Silicates and Aluminates

\begin{tabular}{|c|c|c|c|c|c|c|c|}
\hline \multirow[b]{2}{*}{ Solid Phase } & \multirow[b]{2}{*}{ Formula } & \multirow[b]{2}{*}{$\begin{array}{c}\Delta \mathbf{G}_{\mathrm{f}}^{\circ} \\
\text { (cal } / \mathrm{mol})\end{array}$} & \multirow[b]{2}{*}{$\begin{array}{c}\Delta \mathrm{H}^{\circ}{ }_{\mathrm{f}} \\
\text { (call/mol) }\end{array}$} & \multirow[b]{2}{*}{$\begin{array}{c}\mathbf{S}_{298}^{\circ} \\
\text { (cal/mol) }\end{array}$} & \multicolumn{3}{|c|}{ Heat Capacity Coefficients ${ }^{a}$} \\
\hline & & & & & $\begin{array}{c}a \\
\text { (cal/mol-K) }\end{array}$ & $\begin{array}{c}\mathrm{b} \times 10^{3} \\
\left(\mathrm{cal} / \mathrm{mol}^{\left.-\mathrm{K}^{2}\right)}\right.\end{array}$ & $\begin{array}{c}\mathrm{c} \times 10^{-5} \\
\text { (cal-K/mol) }\end{array}$ \\
\hline Allite $\left(\mathrm{C}_{3} \mathrm{~S}\right)^{\mathrm{b}}$ & $3 \mathrm{CaO} \cdot \mathrm{SiO}_{2}$ & -665470 & -700430 & 40.3 & 49.85 & 8.62 & -10.15 \\
\hline$\left(\mathrm{C}_{12} \mathrm{~A}_{7}\right)^{\mathrm{b}}$ & $12 \mathrm{CaO} \cdot 7 \mathrm{Al}_{2} \mathrm{O}_{3}$ & -4410000 & -4640160 & 249.7 & 301.96 & 65.5 & -55.3 \\
\hline$\left(\mathrm{C}_{2} \mathrm{AH}_{8}\right)^{\mathrm{b}}$ & $2 \mathrm{CaO} \cdot \mathrm{Al}_{2} \mathrm{O}_{3} \cdot 8 \mathrm{H}_{2} \mathrm{O}$ & -1151540 & -1299200 & 106.4 & 68.38 & 153.45 & - \\
\hline$\left(C_{3} A\right)^{b}$ & $3 \mathrm{CaO} \cdot \mathrm{Al}_{2} \mathrm{O}_{3}$ & -808400 & -851000 & 49.1 & 62.28 & 4.58 & -12.1 \\
\hline$\left(\mathrm{C}_{4} \mathrm{AF}\right)^{\mathrm{b}}$ & $4 \mathrm{CaO} \cdot \mathrm{Al}_{2} \mathrm{O}_{3} \cdot \mathrm{Fe}_{2} \mathrm{O}_{3}$ & -1144000 & -1214200 & 78 & 89.49 & 17.4 & - \\
\hline$\left(\mathrm{C}_{4} \mathrm{AH}_{13}\right)^{\mathrm{b}}$ & $4 \mathrm{CaO} \cdot \mathrm{Al}_{2} \mathrm{O}_{3} \cdot 13 \mathrm{H}_{2} \mathrm{O}$ & -1756170 & -1988000 & 171.6 & 109.6 & 242.19 & - \\
\hline$\left(\mathrm{C}_{4} \mathrm{AH}_{19}\right)^{\mathrm{b}}$ & $4 \mathrm{CaO} \cdot \mathrm{Al}_{2} \mathrm{O} 3 \cdot 19 \mathrm{H}_{2} \mathrm{O}$ & -2096330 & -2411000 & 228 & 122.36 & 394 & - \\
\hline$(\mathrm{CA})^{\mathrm{b}}$ & $\mathrm{CaO} \cdot \mathrm{Al}_{2} \mathrm{O}_{3}$ & -527700 & -556180 & 27.3 & 36.01 & 9.98 & -7.96 \\
\hline$\left(\mathrm{CA}_{2}\right)^{\mathrm{b}}$ & $\mathrm{CaO} \cdot 2 \mathrm{Al}_{2} \mathrm{O}_{3}$ & -907100 & -957060 & 42.5 & 66.09 & 5.48 & -17.8 \\
\hline$\left(\mathrm{CAH}_{10}\right)^{\mathrm{b}}$ & $\mathrm{CaO} \cdot \mathrm{Al}_{2} \mathrm{O}_{3} \cdot 10 \mathrm{H}_{2} \mathrm{O}$ & -1103700 & -1271400 & 116.1 & 67.85 & 182.46 & - \\
\hline Afwillite & $\mathrm{Ca}_{3} \mathrm{Si}_{2} \mathrm{O}_{4}(\mathrm{OH})_{6}$ & -1052950 & -1143200 & 74.6 & 81.54 & 45.1 & -14.7 \\
\hline Bellite $\left(\mathrm{C}_{2} \mathrm{~S}\right)^{\mathrm{b}}$ & $2 \mathrm{CaO} \cdot \beta \mathrm{SiO}_{2}$ & -524190 & -551740 & 30.5 & 36.25 & 8.83 & -7.24 \\
\hline
\end{tabular}


Table 4-11. Thermodynamic Properties for Calcium Silicates and Aluminates (Continued)

\begin{tabular}{|c|c|c|c|c|c|c|c|}
\hline \multirow[b]{2}{*}{ Solid Phase } & \multirow[b]{2}{*}{ Formula } & \multirow[b]{2}{*}{$\begin{array}{c}\Delta \mathbf{G}_{\mathrm{f}}^{\circ} \\
\text { (cal/mol) }\end{array}$} & \multirow[b]{2}{*}{$\begin{array}{c}\Delta \mathrm{H}^{\circ}{ }_{\mathrm{f}} \\
\text { (cal } / \mathrm{mol})\end{array}$} & \multirow[b]{2}{*}{$\begin{array}{c}\mathbf{S}^{\circ}{ }_{298} \\
\text { (cal/mol) }\end{array}$} & \multicolumn{3}{|c|}{ Heat Capacity Coefficients ${ }^{a}$} \\
\hline & & & & & $\begin{array}{c}\mathrm{a} \\
\text { (cal/mol-K) }\end{array}$ & $\begin{array}{c}\mathrm{b} \times 10^{3} \\
\left(\mathrm{cal} / \mathrm{mol}^{\left.-\mathrm{K}^{2}\right)}\right)\end{array}$ & $\begin{array}{c}\mathrm{c} \times 10^{-5} \\
(\mathrm{cal}-\mathrm{K} / \mathrm{mol})\end{array}$ \\
\hline Ettringite & $3 \mathrm{CaO} \cdot \mathrm{Al}_{2} \mathrm{O}_{3} \cdot 3 \mathrm{CaSO}_{4} \cdot 32 \mathrm{H}_{2} \mathrm{O}$ & -3634260 & -4201320 & 417.6 & 208 & 740.93 & - \\
\hline Cr-ettringite & $\mathrm{Ca}_{6} \mathrm{Al}_{2}\left(\mathrm{CrO}_{4}\right)_{3}(\mathrm{OH})_{12} \cdot 26 \mathrm{H}_{2} \mathrm{O}$ & -3616395.8 & -4141969.4 & - & - & - & - \\
\hline Foshagite & $\mathrm{Ca}_{4} \mathrm{Si}_{3} \mathrm{O}_{9}(\mathrm{OH})_{2} \cdot 0.5 \mathrm{H}_{2} \mathrm{O}$ & -1347900 & -1439900 & 78.95 & 87.95 & 3.95 & -13.5 \\
\hline Friedl Salt & $\mathrm{CaCl}_{2} \cdot 3 \mathrm{CaO} \cdot 16 \mathrm{H}_{2} \mathrm{O}$ & - & -1833000 & - & - & - & - \\
\hline Gyrolite & $\mathrm{Ca}_{2} \mathrm{Si}_{3} \mathrm{O}_{7}(\mathrm{OH})_{2} \cdot 1.5 \mathrm{H}_{2} \mathrm{O}$ & -1085650 & -1175850 & 64 & 79.47 & 36.3 & -17.6 \\
\hline Hillebrandite & $\mathrm{Ca}_{2} \mathrm{SiO}_{3}(\mathrm{OH})_{2} \cdot 0.17 \mathrm{H}_{2} \mathrm{O}$ & -592900 & -637150 & 38.4 & 41.4 & 22.4 & -7.4 \\
\hline Hydrogarnet & $3 \mathrm{CaO} \cdot \mathrm{Al}_{2} \mathrm{O}_{3} \cdot 6 \mathrm{H}_{2} \mathrm{O}$ & -1198400 & -1326000 & 96.7 & 68.91 & 127.17 & - \\
\hline Monosulphate & $3 \mathrm{CaO} \cdot \mathrm{Al}_{2} \mathrm{O}_{3} \cdot \mathrm{CaSO}_{4} \cdot 12 \mathrm{H}_{2} \mathrm{O}$ & -1859140 & -2096440 & 178.6 & 113.71 & 246.84 & - \\
\hline Okenite & $\mathrm{CaSi}_{2} \mathrm{O}_{4}(\mathrm{OH})_{2} \cdot \mathrm{H}_{2} \mathrm{O}$ & -686400 & -750300 & 40.9 & 44.81 & 18.7 & -10.4 \\
\hline Plombierite & $5 \mathrm{CaO} \cdot 6 \mathrm{SiO}_{2} \cdot 10.5 \mathrm{H}_{2} \mathrm{O}$ & -2647300 & -2911250 & 193.15 & 132.2 & 270 & - \\
\hline Riversideite & $\mathrm{Ca}_{5} \mathrm{H}_{2}\left(\mathrm{SiO}_{3}\right)_{6} \cdot 2 \mathrm{H}_{2} \mathrm{O}$ & -2215000 & -2375000 & 122.65 & 143.55 & 74.7 & -20.8 \\
\hline Tobermorite & $5 \mathrm{CaO} \cdot 6 \mathrm{SiO}_{2} \cdot 5.5 \mathrm{H}_{2} \mathrm{O}$ & -2361450 & -2556300 & 146.15 & 110.6 & 189 & - \\
\hline Xonotlite & $\mathrm{Ca}_{6}\left[\mathrm{Si}_{6} \mathrm{O}_{17}\right](\mathrm{OH})_{2}$ & -2259400 & -2396700 & 121.3 & 132.25 & 65.2 & -18.4 \\
\hline
\end{tabular}

Sources: Babushkin et al. 1985 [DIRS 116981], Appendix 1.

Cr-ettringite data, which are for $25^{\circ} \mathrm{C}$, are from Perkins and Palmer 2000 [DIRS 153349].

a Heat capacity coefficients refer to those in Eq. 4-1.

${ }^{b}$ For the cement phases in parentheses, the letter "A" stands for $\mathrm{Al}_{2} \mathrm{O}_{3}$, "C" for $\mathrm{CaO}$, "S" for $\mathrm{SiO}_{2}$, and " $\mathrm{H}$ " for $\mathrm{H}_{2} \mathrm{O}$ components in the cement. This is customary notation for cement phase composition.

Table 4-12. Thermodynamic Data for CSH with Ca to Si Ratio of 1.7

\begin{tabular}{|c|c|c|}
\hline$\Delta \mathbf{H}^{\circ}$ & $\Delta \mathbf{G}^{\circ}{ }_{\boldsymbol{f}}$ & $\mathbf{S}^{\circ}$ \\
\hline$-2890 \mathrm{~kJ} / \mathrm{mol}$ & $-2630 \mathrm{~kJ} / \mathrm{mol}$ & $200 \mathrm{~J} / \mathrm{mol}-\mathrm{K}$ \\
\hline
\end{tabular}

Source: Fujii and Kondo 1983 [DIRS 144876].

Table 4-13. Heat Capacity Coefficient Data for Portlandite, Alpha-Quartz, and $\mathrm{H}_{2} \mathrm{O}$

\begin{tabular}{|c|c|c|c|c|}
\hline Phase & $\begin{array}{c}a \\
(\mathrm{cal} / \mathrm{mol}-\mathrm{K})^{\mathrm{a}}\end{array}$ & $\begin{array}{c}\mathrm{b} \times 10^{3} \\
\left(\mathrm{cal} / \mathrm{mol}-\mathrm{K}^{2}\right)^{\mathrm{a}}\end{array}$ & $\begin{array}{c}\mathrm{c} \times 10^{-5} \\
(\mathrm{cal}-\mathrm{K} / \mathrm{mol})^{\mathrm{a}}\end{array}$ & Source \\
\hline $\begin{array}{l}\text { Portlandite } \\
\left(\mathrm{Ca}[\mathrm{OH}]_{2}\right)\end{array}$ & 101.79 & $1.80 \mathrm{E}+01$ & $-1.74 \mathrm{E}+00$ & 1 \\
\hline $\begin{array}{c}\mathrm{SiO}_{2} \\
\text { (alpha-quartz) }\end{array}$ & 11.22 & $8.20 \mathrm{E}+00$ & $-2.70 \mathrm{E}+00$ & 2 \\
\hline $\mathrm{H}_{2} \mathrm{O}(\mathrm{s})$ & 7.11 & $8.24 \mathrm{E}+00$ & 0 & 2 \\
\hline $\mathrm{H}_{2} \mathrm{O}(\mathrm{zw})^{\mathrm{b}}$ & 11.4 & 0 & 0 & 2 \\
\hline
\end{tabular}

Sources: 1 Binnewies and Milke 1999 [DIRS 158955].

2 Helgeson et al. 1978 [DIRS 101596], Table 2, p. 48.

${ }^{a}$ Heat capacity coefficients refer to those in Eq. 4-1.

b $\mathrm{H}_{2} \mathrm{O}(\mathrm{zw})$ refers to "zeolitic water" after Helgeson et al. (1978 [DIRS 101596],

Table 2, p. 48). 
Table 4-14. Heat Capacity Data for $\mathrm{CaCl}_{2}(\mathrm{cr})$

\begin{tabular}{|c|c|}
\hline $\mathrm{T}(\mathrm{K})$ & $\mathrm{C}_{\mathrm{p}}{ }^{\circ}$ \\
\hline 100 & 48.812 \\
\hline 200 & 67.357 \\
\hline 298.15 & 72.856 \\
\hline 300 & 72.927 \\
\hline 400 & 75.647 \\
\hline 500 & 77.153 \\
\hline 600 & 78.199 \\
\hline 700 & 79.370 \\
\hline
\end{tabular}

Table 4-15. Gibbs Free Energy of Formation for Na- and Ca-Gismondine Minerals

\begin{tabular}{|c|c|c|c|}
\hline Mineral & Formula & $\Delta \mathbf{G}^{\circ}{ }_{\boldsymbol{~}} \mathbf{~ k c a l} / \mathbf{m o l}$ & Source \\
\hline Gismondine-Na & $\mathrm{Na}_{2} \mathrm{Al}_{2} \mathrm{Si}_{2} \mathrm{O}_{8} \bullet 4 \mathrm{H}_{2} \mathrm{O}$ & -1179.16 & $\begin{array}{c}\text { Atkins et al. 1993 } \\
\text { [DIRS 131758] }\end{array}$ \\
\hline Gismondine-Ca & $\mathrm{CaAl}_{2} \mathrm{Si}_{2} \mathrm{O}_{8} \bullet 4 \mathrm{H}_{2} \mathrm{O}$ & -1187.45 & $\begin{array}{c}\text { Atkins et al. 1993 } \\
\text { [DIRS 131758] }\end{array}$ \\
\hline
\end{tabular}

\subsubsection{Compilation of Thermodynamic Data for Additional Solid Phases}

Uranyl silicates are expected to be the major alteration products of spent nuclear fuel and high-level waste glass in the repository. Geochemical calculations require thermodynamic data for these minerals. Data for four uranyl silicates that have been observed in both laboratory spent fuel corrosion experiments and natural analog sites were included in the data0.ymp.R2 database (DTN: MO0302SPATHDYN.000 [DIRS 161756]): soddyite, uranophane, Na-weeksite, and Na-boltwoodite. The sources of $\log \mathrm{K}$ data are described in Table 4-16. Analysis of these data is discussed in Sections 6.3.4.1 through 6.3.4.4.

Data for $\beta-\mathrm{UO}_{3}$ in data0.ymp.R2 (DTN: MO0302SPATHDYN.000 [DIRS 161756]) were obtained from the qualified database data0.ymp.R0 (DTN: MO0009THRMODYN.001 [DIRS 152576]); their original source was Grenthe et al. (1992 [DIRS 101671), which is "established fact." Review of the thermodynamic data for this phase indicates that the retrieved $\log \mathrm{K}$ data are correct and since the source is qualified for Yucca Mountain Project (YMP) use, no further evaluation is necessary. 
Table 4-16. Sources of Thermodynamic Data for Inputs for Uranium Silicate Minerals

\begin{tabular}{|l|l|l|l|}
\hline \multicolumn{1}{|c|}{ Mineral } & \multicolumn{1}{|c|}{ Source } & \multicolumn{1}{c|}{ Data Extracted } & \multicolumn{1}{c|}{ Log K } \\
\hline Soddyite & Moll et al. 1996 [DIRS 106349], p. 6 & $\begin{array}{l}\text { Log K }\left(\mathrm{N}_{2} \text { atmosphere }\right. \\
\left.\text { experiments at 25 } 5^{\circ} \mathrm{C}\right)\end{array}$ & $6.03 \pm 0.45$ \\
\hline Uranophane & Pérez et al. 2000 [DIRS 157910], p. 606 & Log K $\left(25^{\circ} \mathrm{C}\right)$ & $11.7 \pm 0.6$ \\
\hline Sodium weeksite & $\begin{array}{l}\text { Nguyen et al. 1992 [DIRS 100809], } \\
\text { Table 6, p. 374 }\end{array}$ & Log K $\left(30^{\circ} \mathrm{C}\right)$ & $1.50 \pm 0.08$ \\
\hline Sodium boltwoodite & $\begin{array}{l}\text { Nguyen et al. 1992 [DIRS 100809], } \\
\text { Table 6, p. 374 }\end{array}$ & Log K $\left(30^{\circ} \mathrm{C}\right)$ & $\geq 5.82 \pm 0.16$ \\
\hline & $\begin{array}{l}\text { data0.ymp.R0 } \\
\text { (DTN: MO0009THRMODYN.001 } \\
\text { [DIRS 152576]); Grenthe et al. 1992 } \\
\text { [DIRS 101671], Tables III-1 and III-3 }\end{array}$ & $\begin{array}{l}\text { Log K values at a } \\
\text { temperature range } \\
\text { from 0.01 }\end{array}$ & $\begin{array}{l}9.6847,8.3205, \\
6.7706, \text { and } 5.3656 \\
\text { at } 0.01^{\circ} \mathrm{C}, 25^{\circ} \mathrm{C}, \\
60^{\circ} \mathrm{C}, \text { and } 100^{\circ} \mathrm{C}, \\
\text { respectively }\end{array}$ \\
\hline
\end{tabular}

Thermodynamic data for various solid phases are used for modeling of in-package chemical reactions and reactions involving degraded waste forms at relevant environmental conditions. For construction of the data0.ymp.R2 database (DTN: MO0302SPATHDYN.000 [DIRS 161756]), large data sets were obtained from well-known compilations including the OECD/NEA Database (Lemire 2001 [DIRS 159027]), Binnewies and Milke (1999 [DIRS 158955]), and Barin and Platzki (1995) [DIRS 157865]. These handbooks were chosen because they are recent, comprehensive, and accepted within the scientific community. Table 4-17 presents the thermodynamic data which were either updated or added in the data0.ymp.R2 database (DTN: MO0302SPATHDYN.000 [DIRS 161756]).

During data qualification with this report, an error was identified in the calculation of $\log \mathrm{K}$ values for $\mathrm{Np}$ and $\mathrm{Pu}$ solids. Calculation spreadsheets for neptunium and plutonium that took Maier-Kelley parameters from Tables 3.3 and 4.3 of Lemire (2001 [DIRS 159027]) were not scaled for the factor of 1000 on the "b" parameter, did not use the "c" parameter, and sometimes applied inappropriate parameters as Maier-Kelly parameters. Therefore, the temperature extrapolations of $\log \mathrm{K}$ for solids calculated in data0.ymp.R2 (DTN: MO0302SPATHDYN.000 [DIRS 161756]) using thermodynamic data from these two tables in Lemire (2001 [DIRS 159027]) are incorrect. The $\log \mathrm{K}$ values at $25^{\circ} \mathrm{C}$ are correct, and in many cases the maximum deviations in the $\log \mathrm{K}$ values are relatively small, generally less than $0.2 \log \mathrm{K}$ units at $300^{\circ} \mathrm{C}$. In general, these deviations increase with increasing temperature. The affected $\log \mathrm{K}$ values are corrected in the data0.ymp.R4 database (output DTN: SN0410T0510404.002) and an evaluation is given in Section 6.3.4. Transcription errors were identified for solid species in the scaling of the "c" coefficient for heat capacity from Binnewies and Milke (1999 [DIRS 158955]) into the calculation spreadsheet for the species listed in Table 4-17 using this source. This error is further discussed in Section 6.3.4.5. 


\subsubsection{Compilation of Thermodynamic Data for Gases and Associated Aqueous Species}

Additional gas data and their associated aqueous species were added to the data0.ymp.R2 database (DTN: MO0302SPATHDYN.000 [DIRS 161756]). The values included in the data0.ymp.R2 database (DTN: MO0302SPATHDYN.000 [DIRS 161756]) are those developed using the same SUPCRT92 approach with the template spreadsheets as was used for other species extrapolated to temperatures above $25^{\circ} \mathrm{C}$ as will be discussed in Section 6.1.2 of this report.

Data for the dissociation of HF (aq) (Eq. 4-2) from ionic species were taken from two sources. The values selected from Ellis and Mahon (1977 [DIRS 159230], Table 8.4, p. 288) are for the $\mathrm{pK}_{\mathrm{a}}$ (referring to the association constant) of $\mathrm{HF}$ between steam and water at various temperatures $\left(250\right.$ to $300^{\circ} \mathrm{C}$ ) (Table 4-18). This source is an excellent compilation of data collected from geothermal wells in New Zealand. In addition to this, data from Clark (1966 [DIRS 153163], Table 18-4, p. 407) for a temperature range of 15 to $200^{\circ} \mathrm{C}$ were also used to complement the data from Ellis and Mahon (1977 [DIRS 159230]).

$$
\mathrm{HF}(\mathrm{aq})=\mathrm{H}^{+}+\mathrm{F}^{-}
$$




\begin{tabular}{|c|c|c|c|c|c|c|c|c|}
\hline & & & & & $\mathrm{He}$ & apacity Coe & $e^{e n t s}{ }^{a}$ & \\
\hline Phase & $\begin{array}{r}\Delta \mathbf{G}^{\circ}{ }_{\mathrm{f}} \\
(\mathrm{J} / \mathrm{mol})\end{array}$ & $\begin{array}{c}\Delta H^{\circ}{ }_{f} \\
(\mathrm{~J} / \mathrm{mol})\end{array}$ & $\begin{array}{c}\mathrm{S}^{\circ} \\
(\mathrm{J} / \mathrm{mol}-\mathrm{K})\end{array}$ & $\begin{array}{c}\mathrm{V}^{\circ} \\
\left(\mathrm{cm}^{3} / \mathrm{mol}\right)\end{array}$ & $\begin{array}{c}a \\
(\mathrm{~J} / \mathrm{mol}-\mathrm{K})\end{array}$ & $\begin{array}{c}\mathrm{b} \times 10^{3} \\
\left(\mathrm{~J} / \mathrm{mol}^{\left.-\mathrm{K}^{2}\right)}\right.\end{array}$ & $\begin{array}{c}\mathrm{c} \times 10^{-5} \\
(\mathrm{~J}-\mathrm{K} / \mathrm{mol})^{\mathrm{b}}\end{array}$ & Source \\
\hline$\left(\mathrm{NH}_{4}\right)_{4} \mathrm{NpO}_{2}\left(\mathrm{CO}_{3}\right)_{3}$ & $-2,850,284$ & - & - & - & - & - & - & 1 \\
\hline Portlandite $\mathrm{Ca}(\mathrm{OH})_{2}$ & $-898,470$ & $-986,100$ & 83.40 & 33.06 & 101.790 & 18.0000 & -1.740 & 2,3 \\
\hline $\begin{array}{l}\text { Ferrite-Dicalcium } \\
\mathrm{Ca}_{2} \mathrm{Fe}_{2} \mathrm{O}_{5}\end{array}$ & $-2,001,686$ & $-2,133,700$ & 188.70 & 67.18 & 248.610 & -4.8900 & 0.000 & 2,3 \\
\hline Brucite & $-835,319$ & $-926,296$ & 63.14 & 24.63 & 101.031 & 16.786 & -25.564 & 4 \\
\hline $\mathrm{CaO}$ (lime) & $-604,027$ & $-635,089$ & 39.75 & 16.764 & 48.827 & 4.519 & -6.527 & 4 \\
\hline Periclase & -569384 & -601659 & 26.94 & 11.25 & 42.593 & 7.280 & -6.192 & 4 \\
\hline Ferrite-Mg & $-1,317,429$ & $-1,440,100$ & 123.8 & 44.57 & 167.19 & 14.23 & -2.99 & 2,3 \\
\hline Gypsum $\left(\mathrm{CaSO}_{4} \cdot 2 \mathrm{H}_{2} \mathrm{O}\right)$ & $-1,797,197$ & $-2,022,628$ & 194.14 & 74.69 & 5.220 & 0.3180 & - & 6 \\
\hline Anhydrite & $-1,321,830$ & $-1,434,108$ & 106.69 & 45.94 & 70.208 & 98.742 & 0.000 & 4 \\
\hline Gibbsite & $-1,155,487$ & $-1,293,128$ & 70.08 & 31.96 & 36.192 & 190.790 & 0.000 & 4 \\
\hline Sepiolite & $-9,251,627$ & $-10,116,912$ & 613.37 & 285.6 & - & - & - & 4 \\
\hline $\mathrm{Ca}_{3} \mathrm{Al}_{2} \mathrm{O}_{6}$ & $-3,411,786$ & $-3,587,800$ & 205.90 & 88.94 & 260.580 & 19.1600 & -5.030 & 2,3 \\
\hline $\mathrm{CaAl}_{2} \mathrm{O}_{4}$ & $-2,208,820$ & $-2,326,300$ & 114.20 & 53.02 & 150.620 & 24.9400 & -3.330 & 2,3 \\
\hline Wollastonite & $-1,544,837$ & $-1,630,045$ & 82.0 & 39.93 & 111.462 & 15.062 & 27.280 & 2 \\
\hline $\begin{array}{l}\text { Pseudo wollastonite } \\
\mathrm{CaSiO}_{3}\end{array}$ & $-1,544,739$ & $-1,628,400$ & 87.40 & 40.08 & 108.160 & 16.4800 & -2.360 & 2,3 \\
\hline 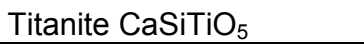 & $-2,461,780$ & $-2,603,300$ & 129.20 & 55.65 & 177.360 & 23.1800 & -4.030 & 2,3 \\
\hline Perovskite $\mathrm{CaTiO}_{3}$ & $-1,575,247$ & $-1,659,000$ & 93.70 & 33.63 & $127.490^{\circ}$ & 5.6900 & -2.800 & 2,3 \\
\hline $\mathrm{Co}(\mathrm{OH})_{2}$ & $-454,168$ & $-541,300$ & 93.30 & 24.74 & 82.840 & 47.7000 & 0.000 & 2,3 \\
\hline Spinel-Co $\mathrm{Co}_{3} \mathrm{O}_{4}$ & $-794,901$ & $-918,700$ & 109.30 & - & 131.650 & 66.0200 & -2.480 & 2,3 \\
\hline $\mathrm{CoCl}_{2}$ & $-269,650$ & $-312,500$ & 109.30 & 38.69 & 81.580 & 7.4100 & -0.470 & 2,3 \\
\hline $\mathrm{CoF}_{3}$ & $-718,899$ & $-790,400$ & 94.60 & 29.88 & 100.280 & 4.8800 & -0.880 & 2,3 \\
\hline Sphaerocobaltite $\mathrm{CoCO}_{3}$ & $-636,782$ & $-713,000$ & 87.90 & 28.80 & 88.280 & 38.9100 & -1.800 & 2,3 \\
\hline $\mathrm{CoCr}_{2} \mathrm{O}_{4}$ & $-1,329,788$ & $-1,438,300$ & 126.80 & - & 167.650 & 17.7400 & -1.400 & 2,3 \\
\hline $\mathrm{CoF}_{2}$ & $-626,562$ & $-672,400$ & 82.00 & 21.73 & 80.910 & 6.1500 & -1.240 & 2,3 \\
\hline $\mathrm{CoFe}_{2} \mathrm{O}_{4}$ & $-980,455$ & $-1,088,700$ & 142.70 & - & 173.220 & 54.3900 & -3.280 & 2,3 \\
\hline $\mathrm{CoO}$ & $-241,198$ & $-237,700$ & 53.00 & - & 45.260 & 10.6900 & 0.600 & 2,3 \\
\hline
\end{tabular}


Table 4-17. Thermodynamic Data Used as Inputs to Calculate Log K Grids for Data0.ymp.R2 (DTN: MO0302SPATHDYN.000 [DIRS 161756]) (Continued)

\begin{tabular}{|c|c|c|c|c|c|c|c|c|}
\hline & & & & & $\mathrm{He}$ & apacity Coc & $n_{t s}{ }^{a}$ & \\
\hline Phase & $\begin{array}{r}\Delta \mathbf{G}_{\mathrm{f}}^{\circ} \\
(\mathrm{J} / \mathrm{mol}) \\
\end{array}$ & $\begin{array}{c}\Delta \mathrm{H}_{\mathrm{f}}^{\circ} \\
(\mathrm{J} / \mathrm{mol})\end{array}$ & $\begin{array}{c}\mathrm{S}^{\circ} \\
(\mathrm{J} / \mathrm{mol}-\mathrm{K})\end{array}$ & $\begin{array}{c}V^{\circ} \\
\left(\mathrm{cm}^{3} / \mathrm{mol}\right)\end{array}$ & $\begin{array}{c}a \\
(\mathrm{~J} / \mathrm{mol}-\mathrm{K})\end{array}$ & $\begin{array}{c}\mathrm{b} \times 10^{3} \\
\left(\mathrm{~J} / \mathrm{mol}-\mathrm{K}^{2}\right)\end{array}$ & $\begin{array}{c}\mathrm{c} \times 10^{-5} \\
(\mathrm{~J}-\mathrm{K} / \mathrm{mol})^{\mathrm{b}}\end{array}$ & Source \\
\hline $\mathrm{CoTiO}_{3}$ & $-1,129,498$ & $-1,207,400$ & 96.90 & - & 123.470 & 9.7100 & -1.650 & 2,3 \\
\hline $\mathrm{CoWO}_{4}$ & $-1,035,813$ & $-1,142,700$ & 126.40 & - & 115.480 & 48.4900 & 0.000 & 2,3 \\
\hline Eskolaite $\mathrm{Cr}_{2} \mathrm{O}_{3}$ & $-1,058,067$ & $-1,140,600$ & 81.20 & 29.09 & 109.650 & 15.4600 & 0.000 & 2,3 \\
\hline $\mathrm{CrCl}_{3}$ & $-486,316$ & $-556,500$ & 123.00 & 57.38 & 98.830 & 13.9800 & -1.000 & 2,3 \\
\hline $\mathrm{CrF}_{3}$ & $-1,103,441$ & $-1,173,200$ & 93.90 & 28.68 & 93.970 & 10.2500 & -1.620 & 2,3 \\
\hline $\mathrm{Crl}_{3}$ & $-205,530$ & $-205,000$ & 199.60 & 88.04 & 105.440 & 20.9200 & 0.000 & 2,3 \\
\hline $\mathrm{CrO}_{3}$ & $-512,562$ & $-587,000$ & 73.20 & 35.14 & 71.760 & 87.8700 & -1.670 & 2,3 \\
\hline $\mathrm{Cs}_{2} \mathrm{NaPuCl}_{6}$ & $-2,143,496$ & $-2,294,200$ & 440.00 & - & - & - & - & 1 \\
\hline $\mathrm{Cs}_{2} \mathrm{NpBr}_{6}$ & $-1,620,121$ & $-1,682,300$ & 469.00 & - & - & - & - & 1 \\
\hline $\mathrm{Cs}_{2} \mathrm{NpCl}_{6}$ & $-1,833,039$ & $-1,976,200$ & 410.00 & - & - & - & - & 1 \\
\hline $\mathrm{Cs}_{2} \mathrm{PuBr}_{6}$ & $-1,634,326$ & $-1,697,400$ & 470.00 & - & - & - & - & 1 \\
\hline $\mathrm{Cs}_{2} \mathrm{PuCl}_{6}$ & $-1,838,243$ & $-1,982,000$ & 412.00 & - & - & - & - & 1 \\
\hline $\mathrm{Cs}_{3} \mathrm{PuCl}_{6}$ & $-2,208,045$ & $-2,364,415$ & 454.92 & - & 256.600 & 34.60 & -7.40 & 1 \\
\hline $\mathrm{CsPu}_{2} \mathrm{Cl}_{7}$ & $-2,235,119$ & $-2,399,380$ & 424.00 & - & 237.800 & 51.50 & 1.55 & 1 \\
\hline Ferrite-Cu CuFe ${ }_{2} \mathrm{O}_{4}$ & $-863,240$ & $-1,025,100$ & 177.70 & 44.53 & 200.080 & 20.2500 & -3.360 & 2,3 \\
\hline Iron Fe & 0 & 0 & 27.30 & 7.09 & 14.950 & 28.0800 & 0.160 & 2,3 \\
\hline $\mathrm{Fe}(\mathrm{OH})_{2}$ & $-486,975$ & $-574,000$ & 87.90 & 26.43 & 116.060 & 8.6500 & -2.870 & 2,3 \\
\hline $\mathrm{Fe}(\mathrm{OH})_{3}$ & $-696,486$ & $-832,600$ & 104.60 & 34.36 & 127.610 & 41.6400 & -4.220 & 2,3 \\
\hline $\mathrm{Fe}_{2}\left(\mathrm{SO}_{4}\right)_{3}$ & $-2,262,753$ & $-2,583,000$ & 307.50 & 130.77 & 361.300 & 54.7600 & -10.640 & 2,3 \\
\hline Hercynite $\mathrm{FeAl}_{2} \mathrm{O}_{4}$ & $-1,879,669$ & $-1,969,500$ & 106.30 & 40.75 & 155.310 & 26.1500 & -3.520 & 2,3 \\
\hline Lawrencite $\mathrm{FeCl}_{2}$ & $-302,343$ & $-341,600$ & 117.90 & - & 78.260 & 9.9500 & -0.420 & 2,3 \\
\hline Molysite $\mathrm{FeCl}_{3}$ & $-333,926$ & $-399,200$ & 147.80 & - & 74.590 & 78.2700 & -0.090 & 2,3 \\
\hline Chromite $\mathrm{FeCr}_{2} \mathrm{O}_{4}$ & $-1,355,891$ & $-1,458,600$ & 146.90 & 44.01 & 163.010 & 22.3400 & -3.190 & 2,3 \\
\hline $\mathrm{FeF}_{2}$ & $-633,179$ & $-705,800$ & 87.00 & 22.94 & 73.080 & 9.6100 & -0.700 & 2,3 \\
\hline $\mathrm{FeF}_{3}$ & $-972,303$ & $-1,039,300$ & 98.30 & 32.06 & 90.750 & 11.3100 & -0.220 & 2,3 \\
\hline Goethite FeOOH & $-488,550$ & $-558,100$ & 60.40 & 20.82 & 49.370 & 83.6800 & 0.000 & 5 \\
\hline Ferrite-Ca & $-1,412,731$ & $-1,479,400$ & 145.20 & 44.98 & 164.930 & 19.9200 & -1.530 & 2,3 \\
\hline Ferrite-Ni & $-972,893$ & $-1,084,500$ & 125.90 & - & 152.670 & 77.8200 & -1.490 & 2,3 \\
\hline
\end{tabular}


Table 4-17. Thermodynamic Data Used as Inputs to Calculate Log K Grids for Data0.ymp.R2 (DTN: MO0302SPATHDYN.000 [DIRS 161756]) (Continued)

\begin{tabular}{|c|c|c|c|c|c|c|c|c|}
\hline \multirow[b]{2}{*}{ Phase } & \multirow[b]{2}{*}{$\begin{array}{r}\Delta \mathbf{G}^{\circ}{ }_{\mathrm{f}} \\
(\mathrm{J} / \mathrm{mol})\end{array}$} & \multirow[b]{2}{*}{$\begin{array}{c}\Delta{H^{\circ}}^{\circ} \\
(\mathrm{J} / \mathrm{mol})\end{array}$} & \multirow[b]{2}{*}{$\begin{array}{c}\mathrm{S}^{\circ} \\
(\mathrm{J} / \mathrm{mol}-\mathrm{K})\end{array}$} & \multirow[b]{2}{*}{$\begin{array}{c}V^{\circ} \\
\left(\mathrm{cm}^{3} / \mathrm{mol}\right)\end{array}$} & \multicolumn{3}{|c|}{ Heat Capacity Coefficients ${ }^{a}$} & \multirow[b]{2}{*}{ Source } \\
\hline & & & & & $\begin{array}{c}a \\
(\mathrm{~J} / \mathrm{mol}-\mathrm{K})\end{array}$ & $\begin{array}{c}\mathrm{b} \times 10^{3} \\
\left(\mathrm{~J} / \mathrm{mol}-\mathrm{K}^{2}\right)\end{array}$ & $\begin{array}{c}\mathrm{c} \times 10^{-5} \\
(\mathrm{~J}-\mathrm{K} / \mathrm{mol})^{b}\end{array}$ & \\
\hline $\mathrm{FeSO}_{4}$ & $-824,892$ & $-928,900$ & 121.00 & 41.58 & 122.000 & 37.8200 & -2.930 & 2,3 \\
\hline Ilmenite $\mathrm{FeTiO}_{3}$ & $-1,158,045$ & $-1,239,200$ & 105.90 & - & 116.610 & 18.2400 & -2.000 & 2,3 \\
\hline $\mathrm{K}_{4} \mathrm{NpO}_{2}\left(\mathrm{CO}_{3}\right)_{3}$ & $-3,660,395$ & - & - & - & - & - & - & 1 \\
\hline $\mathrm{MgBr}_{2}$ & $-504,060$ & $-524,300$ & 117.20 & 49.49 & 70.510 & 18.0700 & -0.110 & 2,3 \\
\hline Chloro magnesite $\mathrm{MgCl}_{2}$ & $-592,074$ & $-644,200$ & 89.50 & - & 76.400 & 9.2500 & -0.700 & 2,3 \\
\hline $\mathrm{MgSO}_{4}$ & $-1,170,579$ & $-1,261,800$ & 91.40 & 45.25 & 106.440 & 46.2800 & -2.190 & 2,3 \\
\hline Bixbyite $\mathrm{Mn}_{2} \mathrm{O}_{3}$ & $-881,114$ & $-959,000$ & 110.50 & - & 102.800 & 35.6700 & -1.280 & 2,3 \\
\hline Tephroite $\mathrm{Mn}_{2} \mathrm{SiO}_{4}$ & $-1,632,130$ & $-1,725,300$ & 142.20 & - & 159.080 & 19.5000 & -3.110 & 2,3 \\
\hline Scacchite $\mathrm{MnCl}_{2}$ & $-440,478$ & $-481,300$ & 118.20 & - & 73.800 & 15.2300 & -0.470 & 2,3 \\
\hline $\mathrm{MnSO}_{4}$ & $-957,243$ & $-1,065,300$ & 112.10 & - & 122.420 & 37.3200 & -2.950 & 2,3 \\
\hline $\mathrm{MoO}_{2} \mathrm{Cl}_{2}$ & $-623,302$ & $-725,800$ & 120.50 & - & 127.400 & 7.0300 & -1.940 & 2,3 \\
\hline $\mathrm{Na}_{2} \mathrm{CO}_{3}$ & $-1,048,005$ & $-1,130,800$ & 138.80 & 41.86 & 11.000 & 244.0500 & 2.450 & 2,3 \\
\hline $\mathrm{Na}_{2} \mathrm{CrO}_{4}$ & $-1,234,795$ & $-1,334,300$ & 176.60 & 59.48 & 101.040 & 140.0000 & 0.000 & 2,3 \\
\hline $\mathrm{Na}_{3} \mathrm{NpF}_{8}$ & $-3,521,239$ & $-3,714,000$ & 369.00 & - & 270.000 & 56.60 & -13.00 & 1 \\
\hline $\mathrm{Na}_{3} \mathrm{NpO}_{2}\left(\mathrm{CO}_{3}\right)_{2}$ & $-2,833,333$ & - & - & - & - & - & - & 1 \\
\hline Nahcolite $\mathrm{NaHCO}_{3}$ & $-852,851$ & $-936,300$ & 101.20 & 38.62 & 45.310 & 143.1000 & 0.000 & 2,3 \\
\hline $\mathrm{NaNpO}_{2} \mathrm{CO}_{3}$ & $-1,764,157$ & - & - & - & - & - & - & 1 \\
\hline $\mathrm{NaNpO}_{2} \mathrm{CO}_{3} \cdot 3.5 \mathrm{H}_{2} \mathrm{O}$ & $-2,591,287$ & - & - & - & - & - & - & 1 \\
\hline Heazlewoodite $\mathrm{Ni}_{3} \mathrm{~S}_{2}$ & $-2,591,287$ & $-210,396$ & 133.90 & 40.95 & 110.790 & 51.6700 & -0.750 & 2,3 \\
\hline $\mathrm{NiCl}_{2}$ & $-259,139$ & $-305,300$ & 98.00 & 36.70 & 73.190 & 13.1200 & -0.480 & 2,3 \\
\hline $\mathrm{NiCO}_{3}$ & $-617,876$ & $-696,300$ & 86.20 & 27.05 & 88.700 & 38.9100 & -1.230 & 2,3 \\
\hline $\mathrm{NiCr}_{2} \mathrm{O}_{4}$ & $-1,271,777$ & $-1,392,400$ & 129.70 & - & 167.150 & 17.8700 & -2.110 & 2,3 \\
\hline $\mathrm{NiF}_{2}$ & $-610,298$ & $-657,700$ & 73.60 & 20.88 & 66.600 & 13.9400 & -0.590 & 2,3 \\
\hline Trevorite $\mathrm{NiFe}_{2} \mathrm{O}_{4}$ & $-972,893$ & $-1,084,500$ & 125.90 & 45.38 & 152.670 & 77.8200 & -1.490 & 2,3 \\
\hline $\mathrm{NiSO}_{4}$ & $-759,545$ & $-873,200$ & 101.30 & 42.05 & 125.940 & 27.8200 & -3.260 & 2,3 \\
\hline $\mathrm{NiTiO}_{3}$ & $-1,118,188$ & $-1,201,400$ & 82.60 & - & 115.100 & 15.9800 & -1.830 & 2,3 \\
\hline $\mathrm{NiWO}_{4}$ & $-1,023,620$ & $-1,127,800$ & 118.00 & - & 110.630 & 53.3900 & -0.440 & 2,3 \\
\hline $\mathrm{Np}$ & 0 & 0 & 50.460 & - & -4.054 & 82.555 & 8.0571 & 1 \\
\hline
\end{tabular}


Table 4-17. Thermodynamic Data Used as Inputs to Calculate Log K Grids for Data0.ymp.R2 (DTN: MO0302SPATHDYN.000 [DIRS 161756]) (Continued)

\begin{tabular}{|c|c|c|c|c|c|c|c|c|}
\hline \multirow[b]{2}{*}{ Phase } & \multirow[b]{2}{*}{$\begin{array}{r}\Delta \mathbf{G}^{\circ}{ }_{\mathrm{f}} \\
(\mathrm{J} / \mathrm{mol})\end{array}$} & \multirow[b]{2}{*}{$\begin{array}{c}\Delta{H^{\circ}}^{\circ} \\
(\mathrm{J} / \mathrm{mol})\end{array}$} & \multirow[b]{2}{*}{$\begin{array}{c}\mathrm{S}^{\circ} \\
(\mathrm{J} / \mathrm{mol}-\mathrm{K})\end{array}$} & \multirow[b]{2}{*}{$\begin{array}{c}V^{\circ} \\
\left(\mathrm{cm}^{3} / \mathrm{mol}\right)\end{array}$} & \multicolumn{3}{|c|}{ Heat Capacity Coefficients ${ }^{a}$} & \multirow[b]{2}{*}{ Source } \\
\hline & & & & & $\begin{array}{c}a \\
(\mathrm{~J} / \mathrm{mol}-\mathrm{K})\end{array}$ & $\begin{array}{c}b \times 10^{3} \\
\left(\mathrm{~J} / \mathrm{mol}^{\left.-\mathrm{K}^{2}\right)}\right.\end{array}$ & $\begin{array}{c}\mathrm{c} \times 10^{-5} \\
(\mathrm{~J}-\mathrm{K} / \mathrm{mol})^{b}\end{array}$ & \\
\hline $\mathrm{Np}_{2} \mathrm{C}_{3}$ & $-192,427$ & $-187,400$ & 135.00 & - & - & - & - & 1 \\
\hline $\mathrm{Np}_{2} \mathrm{O}_{5}$ & $-2,031,574$ & $-2,162,700$ & 174.00 & - & 99.200 & 98.60 & - & 1 \\
\hline $\mathrm{NpBr}_{3}$ & $-705,521$ & $-730,200$ & 196.00 & - & 101.230 & 20.68 & -3.20 & 1 \\
\hline $\mathrm{NpBr}_{4}$ & $-737,843$ & $-771,200$ & 243.00 & - & 119.000 & 30.00 & - & 1 \\
\hline $\mathrm{NpC}_{0.91}$ & $-76,024$ & $-71,100$ & 72.20 & - & $-{ }^{\mathrm{c}}$ & - & - & 1 \\
\hline $\mathrm{NpCl}_{3}$ & $-829,811$ & $-896,800$ & 160.40 & - & 89.600 & 27.50 & 3.60 & 1 \\
\hline $\mathrm{NpCl}_{4}$ & $-895,562$ & $-984,000$ & 200.00 & - & 112.500 & 36.00 & -1.10 & 1 \\
\hline $\mathrm{NpF}_{3}$ & $-1,460,501$ & $-1,529,000$ & 124.90 & - & 105.200 & 0.812 & -10.00 & 1 \\
\hline $\mathrm{NpF}_{4}$ & $-1,783,797$ & $1,874,000$ & 153.50 & - & 122.635 & 9.684 & -8.365 & 1 \\
\hline $\mathrm{NpF}_{5}$ & $-1,834,430$ & $-1,941,000$ & 200.00 & - & 126.000 & 30.00 & -1.90 & 1 \\
\hline $\mathrm{NpF}_{6}$ & $-1,841,872$ & $-1,970,000$ & 229.09 & - & 62.333 & 352.55 & - & 1 \\
\hline $\mathrm{Npl}_{3}$ & $-512,498$ & $-512,400$ & 225.00 & - & 104.000 & 20.00 & - & 1 \\
\hline $\mathrm{NpN}$ & $-270,043$ & $-294,600$ & 63.90 & - & 47.670 & 13.174 & -2.576 & 1 \\
\hline $\mathrm{NpO}_{2}$ & $-1,021,371$ & $-1,074,000$ & 80.30 & 24.22 & 67.511 & 26.60 & -8.19 & 1 \\
\hline $\mathrm{NpO}_{2}$ (hyd, aged) & $-957,321$ & - & - & - & - & - & - & 1 \\
\hline $\mathrm{NpO}_{2}\left(\mathrm{NO}_{3}\right)_{2} \cdot 6 \mathrm{H}_{2} \mathrm{O}$ & $-2,428,069$ & $-3,008,241$ & 516.31 & - & - & - & - & 1 \\
\hline $\mathrm{NpO}_{2} \mathrm{CO}_{3}$ & $-1,407$ & - & - & - & - & - & - & 1 \\
\hline $\mathrm{NpO}_{2} \mathrm{OH}(\mathrm{am})$ & $-1,118,078$ & $-1,222,900$ & 71.95 & - & - & - & - & 1 \\
\hline $\mathrm{NpO}_{2} \mathrm{OH}(\mathrm{am}$, aged $)$ & $-1,114,652$ & $-1,222,900$ & 60.46 & - & - & - & - & 1 \\
\hline $\mathrm{NpO}_{3} \cdot \mathrm{H}_{2} \mathrm{O}$ & $-1,238,997$ & - & - & - & - & - & - & 1 \\
\hline $\mathrm{NpOBr}_{2}$ & $-906,933$ & $-950,000$ & 160.80 & - & 111.000 & 13.70 & -15.00 & 1 \\
\hline $\mathrm{NpOCl}_{2}$ & $-960,645$ & $-1,030,000$ & 143.50 & - & 98.800 & 22.00 & -9.20 & 1 \\
\hline $\mathrm{Pu}$ & 0 & 0 & 54.46 & - & 18.126 & 44.82 & - & 1 \\
\hline $\mathrm{Pu}\left(\mathrm{HPO}_{4}\right)_{2}(\mathrm{am}, \mathrm{hyd})$ & $-2,843,768$ & - & - & - & - & - & - & 1 \\
\hline $\mathrm{Pu}(\mathrm{OH})_{3}$ & $-1,200,218$ & - & - & - & - & - & - & 1 \\
\hline $\mathrm{Pu}_{2} \mathrm{C}_{3}$ & $-156,614$ & $-149,400$ & 150.00 & - & $-^{c}$ & - & - & 1 \\
\hline $\mathrm{Pu}_{2} \mathrm{O}_{3}$ & $-1,580,375$ & $-1,656,000$ & 163.00 & - & 169.446 & -79.98 & -25.459 & 1 \\
\hline $\mathrm{Pu}_{3} \mathrm{C}_{2}$ & $-123,477$ & $-113,000$ & 210.00 & - & 120.670 & 46.86 & 1.9456 & 1 \\
\hline
\end{tabular}


Table 4-17. Thermodynamic Data Used as Inputs to Calculate Log K Grids for Data0.ymp.R2 (DTN: MO0302SPATHDYN.000 [DIRS 161756]) (Continued)

\begin{tabular}{|c|c|c|c|c|c|c|c|c|}
\hline \multirow[b]{2}{*}{ Phase } & \multirow[b]{2}{*}{$\begin{array}{r}\Delta \mathbf{G}^{\circ}{ }_{\mathrm{f}} \\
(\mathrm{J} / \mathrm{mol})\end{array}$} & \multirow[b]{2}{*}{$\begin{array}{c}\Delta \mathrm{H}^{\circ}{ }_{\mathrm{f}} \\
(\mathrm{J} / \mathrm{mol})\end{array}$} & \multirow[b]{2}{*}{$\begin{array}{c}\mathrm{S}^{\circ} \\
(\mathrm{J} / \mathrm{mol}-\mathrm{K})\end{array}$} & \multirow[b]{2}{*}{$\begin{array}{c}V^{\circ} \\
\left(\mathrm{cm}^{3} / \mathrm{mol}\right)\end{array}$} & \multicolumn{3}{|c|}{ Heat Capacity Coefficients ${ }^{a}$} & \multirow[b]{2}{*}{ Source } \\
\hline & & & & & $\begin{array}{c}a \\
(\mathrm{~J} / \mathrm{mol}-\mathrm{K})\end{array}$ & $\begin{array}{c}b \times 10^{3} \\
\left(\mathrm{~J} / \mathrm{mol}^{\left.-\mathrm{K}^{2}\right)}\right.\end{array}$ & $\begin{array}{c}\mathrm{c} \times 10^{-5} \\
(\mathrm{~J}-\mathrm{K} / \mathrm{mol})^{b}\end{array}$ & \\
\hline PuAs & $-241,413$ & $-240,000$ & 94.30 & - & - & - & - & 1 \\
\hline $\mathrm{PuBi}$ & $-119,624$ & $-117,000$ & 120.00 & - & - & - & - & 1 \\
\hline $\mathrm{PuBi}_{2}$ & $-124,527$ & $-126,000$ & 163.00 & - & - & - & - & 1 \\
\hline $\mathrm{PuBr}_{3}$ & $-767,324$ & $-792,600$ & 198.00 & - & 104.5 & 15.00 & -6.38 & 1 \\
\hline $\mathrm{PuC}_{0.84}$ & $-49,827$ & $-45,200$ & 74.80 & - & $-{ }^{c}$ & - & - & 1 \\
\hline $\mathrm{PuCl}_{3}$ & $-891,806$ & $-959,600$ & 161.70 & - & 91.350 & 24.00 & 2.40 & 1 \\
\hline $\mathrm{PuCl}_{3} \cdot 6 \mathrm{H}_{2} \mathrm{O}$ & $-2,365,347$ & $-2,773,400$ & 420.00 & - & - & - & - & 1 \\
\hline $\mathrm{PuCl}_{4}$ & $-879,368$ & $-968,700$ & 201.00 & - & - & - & - & 1 \\
\hline $\mathrm{PuF}_{3}$ & $-1,517,369$ & $-1,586,700$ & 126.11 & - & 104.078 & 0.707 & -10.355 & 1 \\
\hline $\mathrm{PuF}_{6}$ & $-1,729,856$ & $1,861,350$ & 221.80 & - & 72.348 & 32.13 & - & 1 \\
\hline $\mathrm{Pul}_{3}$ & $-579,000$ & $-579,200$ & 228.00 & - & 104.000 & 20.00 & - & 1 \\
\hline PuN & $-273,719$ & $-299,200$ & 64.80 & - & - & - & - & 1 \\
\hline $\mathrm{PuO}_{1.61}$ & $-834,771$ & $-875,500$ & 83.00 & - & 65.910 & 13.85 & -8.757 & 1 \\
\hline $\mathrm{PuO}_{2}$ & $-998,113$ & $-1,055,800$ & 66.13 & 23.83 & $-^{\mathrm{c}}$ & - & - & 1 \\
\hline $\mathrm{PuO}_{2}$ (hyd, aged) & $-963,654$ & - & - & - & - & - & - & 1 \\
\hline $\mathrm{PuO}_{2}\left(\mathrm{NO}_{3}\right)_{2} \cdot 6 \mathrm{H}_{2} \mathrm{O}$ & $-2,393,300$ & - & - & - & - & - & - & 1 \\
\hline $\mathrm{PuO}_{2}(\mathrm{OH})_{2} \cdot 2 \mathrm{H}_{2} \mathrm{O}^{\mathrm{d}}$ & - & - & - & - & - & - & - & d \\
\hline $\mathrm{PuO}_{2}(\mathrm{OH})_{2} \cdot \mathrm{H}_{2} \mathrm{O}$ & $-1,442,379$ & $-1,632,808$ & 190.00 & - & - & - & - & 1 \\
\hline $\mathrm{PuO}_{2} \mathrm{CO}_{3}$ & $-1,371,307$ & - & - & - & - & - & - & 1 \\
\hline $\mathrm{PuO}_{2} \mathrm{OH}(\mathrm{am})$ & $-1,061,246$ & $-1,159,793$ & 97.00 & - & - & - & - & 1 \\
\hline $\mathrm{PuOBr}$ & $-838,354$ & $-870,000$ & 127.00 & - & 73.700 & 17.00 & -5.15 & 1 \\
\hline $\mathrm{PuOCI}$ & $-882,409$ & $-931,000$ & 105.60 & - & 73.030 & 17.10 & -5.83 & 1 \\
\hline PuOF & $-1,091,571$ & $-1,140,000$ & 96.00 & - & $-{ }^{\mathrm{C}}$ & - & - & 1 \\
\hline $\mathrm{PuOI}$ & $-776,626$ & $-802,000$ & 130.00 & - & $-^{c}$ & - & - & 1 \\
\hline PuP & $-313,757$ & $-318,000$ & 81.32 & - & - & - & - & 1 \\
\hline $\mathrm{PuPO}_{4}(\mathrm{~s}$, hyd $)$ & $-1,744,893$ & - & - & - & - & - & - & 1 \\
\hline PuSb & $-152,063$ & $-150,000$ & 106.90 & - & - & - & - & 1 \\
\hline $\mathrm{Ti}_{2} \mathrm{O}_{3}$ & $-1,433,824$ & $-1,520,900$ & 77.30 & - & 53.070 & 163.4400 & - & 2,3 \\
\hline
\end{tabular}


Table 4-17. Thermodynamic Data Used as Inputs to Calculate Log K Grids for Data0.ymp.R2 (DTN: MO0302SPATHDYN.000 [DIRS 161756]) (Continued)

\begin{tabular}{|c|c|c|c|c|c|c|c|c|}
\hline \multirow[b]{2}{*}{ Phase } & \multirow[b]{2}{*}{$\begin{array}{r}\Delta \mathbf{G}^{\circ}{ }_{f} \\
(\mathrm{~J} / \mathrm{mol})\end{array}$} & \multirow[b]{2}{*}{$\begin{array}{c}\Delta \mathrm{H}^{\circ}{ }_{\mathrm{f}} \\
(\mathrm{J} / \mathrm{mol})\end{array}$} & \multirow[b]{2}{*}{$\begin{array}{c}\mathrm{S}^{\circ} \\
(\mathrm{J} / \mathrm{mol}-\mathrm{K})\end{array}$} & \multirow[b]{2}{*}{$\begin{array}{c}V^{\circ} \\
\left(\mathrm{cm}^{3} / \mathrm{mol}\right)\end{array}$} & \multicolumn{3}{|c|}{ Heat Capacity Coefficients ${ }^{a}$} & \multirow[b]{2}{*}{ Source } \\
\hline & & & & & $\begin{array}{c}a \\
(\mathrm{~J} / \mathrm{mol}-K)\end{array}$ & $\begin{array}{c}\mathrm{b} \times 10^{3} \\
\left(\mathrm{~J} / \mathrm{mol}-\mathrm{K}^{2}\right)\end{array}$ & $\begin{array}{c}\mathrm{C} \times 10^{-5} \\
(\mathrm{~J}-\mathrm{K} / \mathrm{mol})^{b}\end{array}$ & \\
\hline $\mathrm{Ti}_{3} \mathrm{O}_{5}$ & $-2,317,294$ & $-2,459,100$ & 129.40 & - & 231.040 & -24.7700 & -6.130 & 2,3 \\
\hline $\mathrm{TiB}_{2}$ & $-319,648$ & $-315,900$ & 28.50 & - & 56.380 & 25.8600 & -1.750 & 2,3 \\
\hline $\mathrm{TiBr}_{3}$ & $-525,596$ & $-551,900$ & 176.60 & - & 73.070 & 87.2500 & 0.080 & 2,3 \\
\hline $\mathrm{TiBr}_{4}$ & $-590,646$ & $-619,700$ & 243.50 & - & 80.930 & 169.6200 & - & 2,3 \\
\hline $\mathrm{TiCl}_{2}$ & $-465,823$ & $-5,155$ & 87.30 & - & 68.370 & 18.0300 & -0.350 & 2,3 \\
\hline $\mathrm{TiCl}_{3}$ & $-654,451$ & $-721,700$ & 139.80 & - & 95.810 & 11.0600 & -0.180 & 2,3 \\
\hline $\mathrm{TiF}_{3}$ & $-1,361,861$ & $-1,435,500$ & 87.90 & - & 79.080 & 29.2900 & 0.340 & 2,3 \\
\hline $\mathrm{TiF}_{4}(\mathrm{am})$ & $-1,559,179$ & $-1,649,300$ & 134.00 & - & 123.310 & 36.2400 & -1.770 & 2,3 \\
\hline $\mathrm{Til}_{4}$ & $-370,647$ & $-375,700$ & 246.20 & - & 71.420 & 181.8700 & - & 2,3 \\
\hline $\mathrm{TiO}$ & $-513,278$ & $-542,700$ & 34.80 & - & 44.220 & 15.0600 & -0.780 & 2,3 \\
\hline Uranium U & 0 & 0 & 50.30 & - & 27.590 & -4.0400 & -0.110 & 2,3 \\
\hline $\mathrm{U}\left(\mathrm{SO}_{4}\right)_{2}$ & $-2,087,195$ & $-2,318,000$ & 164.00 & - & 104.600 & 230.9600 & - & 2,3 \\
\hline $\mathrm{U}_{2} \mathrm{~S}_{3}$ & $-854,730$ & $-854,000$ & 199.20 & - & 140.830 & 16.1100 & -0.380 & 2,3 \\
\hline $\mathrm{UBr}_{3}$ & $-673,463$ & $-699,100$ & 192.50 & - & 100.000 & 29.2900 & - & 2,3 \\
\hline $\mathrm{UBr}_{4}$ & $-767,852$ & $-802,500$ & 238.50 & - & 134.730 & 20.5000 & -1.130 & 2,3 \\
\hline $\mathrm{UCl}_{3}$ & $-794,530$ & 861,900 & 159.00 & - & 87.780 & 31.1300 & 0.490 & 2,3 \\
\hline $\mathrm{UCl}_{4}$ & $-929,927$ & $-1,018,800$ & 197.20 & - & 113.810 & 35.8600 & -0.0330 & 2,3 \\
\hline $\mathrm{UCl}_{5}$ & $-950,061$ & $-1,041,500$ & 246.90 & - & 140.040 & 35.4400 & -0.540 & 2,3 \\
\hline $\mathrm{UCl}_{6}$ & $-962,649$ & $-1,068,200$ & 285.80 & - & 173.400 & 35.0600 & -0.740 & 2,3 \\
\hline $\mathrm{UF}_{3}$ & $-1,439,861$ & $1,502,100$ & 123.40 & - & 85.980 & 30.5400 & - & 2,3 \\
\hline $\mathrm{UF}_{4}$ & $-1,830,173$ & $1,914,200$ & 151.70 & 46.88 & 123.560 & 9.6200 & -0.930 & 2,3 \\
\hline $\mathrm{UF}_{5}$ (beta) & $-1,970,577$ & $-2,083,200$ & 179.50 & - & 125.520 & 30.2100 & -0.200 & 2,3 \\
\hline $\mathrm{UF}_{6}$ & $-2,068,477$ & $-2,197,000$ & 227.60 & - & 52.720 & 384.9300 & - & 2,3 \\
\hline $\mathrm{UI}_{3}$ & $-459,962$ & $-460,700$ & 222.00 & - & 102.970 & 30.5400 & - & 2,3 \\
\hline $\mathrm{UI}_{4}$ & $-506,462$ & $-512,100$ & 263.60 & - & 149.370 & 9.9600 & -1.590 & 2,3 \\
\hline $\mathrm{UO}_{2} \mathrm{Br}_{2}$ & $-1,066,612$ & $-1,137,600$ & 169.50 & - & 117.950 & 17.5300 & -1.070 & 2,3 \\
\hline $\mathrm{UO}_{2} \mathrm{Cl}_{2}$ & $-1,146,105$ & $-1,243,500$ & 150.60 & - & 115.230 & 18.2000 & -1.140 & 2,3 \\
\hline $\mathrm{UO}_{2} \mathrm{~F}_{2}$ & $-1,551,873$ & $-1,651,400$ & 135.60 & - & 122.880 & 8.6200 & -1.990 & 2,3 \\
\hline
\end{tabular}


Table 4-17. Thermodynamic Data Used as Inputs to Calculate Log K Grids for Data0.ymp.R2 (DTN: MO0302SPATHDYN.000 [DIRS 161756]) (Continued)

\begin{tabular}{|c|c|c|c|c|c|c|c|c|}
\hline & & & & & $\mathrm{He}$ & apacity Coef & $\mathrm{nts}^{\mathrm{a}}$ & \\
\hline Phase & $\begin{array}{r}\Delta \mathbf{G}^{\circ}{ }_{\mathrm{f}} \\
(\mathrm{J} / \mathrm{mol})\end{array}$ & $\begin{array}{c}\Delta \mathrm{H}_{\mathrm{f}}^{\circ} \\
(\mathrm{J} / \mathrm{mol})\end{array}$ & $\begin{array}{c}\mathrm{S}^{\circ} \\
(\mathrm{J} / \mathrm{mol}-\mathrm{K})\end{array}$ & $\begin{array}{c}V^{\circ} \\
\left(\mathrm{cm}^{3} / \mathrm{mol}\right)\end{array}$ & $\begin{array}{c}a \\
(\mathrm{~J} / \mathrm{mol}-\mathrm{K}) \\
\end{array}$ & $\begin{array}{c}b \times 10^{3} \\
\left(\mathrm{~J} / \mathrm{mol}-\mathrm{K}^{2}\right)\end{array}$ & $\begin{array}{c}\mathrm{c} \times 10^{-5} \\
(\mathrm{~J}-\mathrm{K} / \mathrm{mol})^{b}\end{array}$ & Source \\
\hline $\mathrm{UO}_{2} \mathrm{SO}_{4}$ & $-1,683,212$ & $-1,845,100$ & 154.80 & - & 112.470 & 108.7800 & - & 2,3 \\
\hline $\mathrm{UO}_{3}($ gamma $)$ & $-1,144,896$ & $-1,226,500$ & 98.80 & - & 90.370 & 11.0500 & -1.110 & 2,3 \\
\hline $\mathrm{UOBr}_{2}$ & $-929,638$ & $-973,600$ & 157.60 & - & 110.580 & 13.6800 & -1.490 & 2,3 \\
\hline $\mathrm{UOBr}_{3}$ & $-901,429$ & $-954,000$ & 205.00 & - & 130.540 & 20.5000 & -1.380 & 2,3 \\
\hline UOCI & $-899,108$ & $-833,900$ & 102.50 & - & 75.810 & 14.3500 & -0.830 & 2,3 \\
\hline $\mathrm{UOCl}_{2}$ & $-996,062$ & $-1,067,500$ & 138.30 & - & 98.950 & 14.6400 & -0.740 & 2,3 \\
\hline $\mathrm{UOCl}_{3}$ & $-1,068,773$ & $-1,151,600$ & 170.70 & - & 122.590 & 20.9200 & -1.190 & 2,3 \\
\hline $\mathrm{WCl}_{2}(\mathrm{~s})$ & $-219,977$ & $-260,300$ & 130.50 & - & 71.280 & 21.9000 & - & 2,3 \\
\hline $\mathrm{WCl}_{4}(\mathrm{~s})$ & $-359,433$ & $-443,100$ & 198.30 & - & 113.450 & 54.6000 & - & 2,3 \\
\hline $\mathrm{WCl}_{5}(\mathrm{~s})$ & $-401,783$ & $-513,000$ & 217.60 & - & 124.450 & 109.9200 & -0.140 & 2,3 \\
\hline $\mathrm{WCl}_{6}(\mathrm{~s})$ & $-455,511$ & $-593,700$ & 238.50 & - & 125.560 & 167.2300 & - & 2,3 \\
\hline $\mathrm{WO}_{2} \mathrm{Cl}_{2}(\mathrm{~s})$ & $-702,770$ & $-780,300$ & 200.80 & - & 79.510 & 94.1100 & -0.290 & 2,3 \\
\hline $\mathrm{WOCl}_{4}(\mathrm{~s})$ & $-549,270$ & $-671,100$ & 172.80 & - & 115.000 & 104.6900 & - & 2,3 \\
\hline $\mathrm{WOF}_{4}(\mathrm{~s})$ & $-1,285,507$ & $1,406,900$ & 175.70 & - & 83.650 & 167.4200 & - & 2,3 \\
\hline
\end{tabular}

Sources: 1 Lemire 2001 [DIRS 159027]

2 Barin and Platzki 1995 [DIRS 157865].

3 Binnewies and Milke 1999 [DIRS 158955].

4 slop98.dat (DTN: MO0106MWDTDG01.035 [DIRS 161791]).

5 Robie et al. 1979 [DIRS 107109].

6 data0.ymp.RO (DTN: MO0009THRMODYN.001 [DIRS 152576]).

a Heat capacity coefficients a, b, and c defined in Eq. 4-1.

b The coefficient $c$ for heat capacity obtained from Binnewies and Milke (1999 [DIRS 158955]) is incorrectly scaled as given in this table. This item is corrected to the proper scaling factor given in the source as discussed in Section 6.3.4.5.

c Lemire (2001 [DIRS 159027]) Tables 3.3 and 4.3 do not give Maier-Kelley parameters for this species.

d Phase $\mathrm{PuO}_{2}(\mathrm{OH})_{2} \cdot 2 \mathrm{H}_{2} \mathrm{O}$ was an incorrect representation of $\mathrm{PuO}_{2}(\mathrm{OH})_{2} \cdot \mathrm{H}_{2} \mathrm{O}$ in data0.ymp.R2. The data reported in data0.ymp.R2 are shown in this table for the correct phase $\mathrm{PuO}_{2}(\mathrm{OH})_{2} \cdot \mathrm{H}_{2} \mathrm{O}$, consistent with Lemire (2001 [DIRS 159027]). 
Table 4-18. Log K Data for Dissociation of HF(aq)

\begin{tabular}{|c|c|c|c|c|c|c|c|c|c|c|c|c|}
\hline $\mathrm{T}\left({ }^{\circ} \mathrm{C}\right)$ & $15^{a}$ & $25^{a}$ & $35^{\mathrm{a}}$ & $50^{a}$ & $75^{a}$ & $100^{a}$ & $125^{a}$ & $150^{a}$ & $175^{a}$ & $200^{a}$ & $250^{b}$ & $300^{b}$ \\
\hline $\log K$ & -3.1 & -3.18 & -3.25 & -3.40 & -3.64 & -3.85 & -4.09 & -4.34 & -4.59 & -4.89 & -5.8 & -6.8 \\
\hline
\end{tabular}

Data for the $\mathrm{HF}_{2}^{-}$association reaction were taken from data in Clark (1966 [DIRS 153163], Table 18-4, p. 407) (Table 4-19).

$$
\mathrm{HF}(\mathrm{aq})+\mathrm{F}^{-}=\mathrm{HF}_{2}^{-}
$$

Table 4-19. Log K Data for the $\mathrm{HF}_{2}^{-}$Association Reaction Delineated by Eq. 4-3

\begin{tabular}{|c|c|c|c|c|c|c|c|c|}
\hline $\mathbf{T}\left({ }^{\circ} \mathbf{C}\right)$ & $\mathbf{2 5}$ & $\mathbf{5 0}$ & $\mathbf{7 5}$ & $\mathbf{1 0 0}$ & $\mathbf{1 2 5}$ & $\mathbf{1 5 0}$ & $\mathbf{1 7 5}$ & $\mathbf{2 0 0}$ \\
\hline Log $\mathrm{K}$ & 3.4 & 4 & 4.7 & 4.8 & 4.9 & 5.7 & 5.8 & 8 \\
\hline
\end{tabular}

Source: Clark 1966 [DIRS 153163], p.407, Table 18-4.

The values listed in Table 4-19 are for the reaction represented by Eq. 4-3 and not the reaction listed in the data0.ymp.R2 database (DTN: MO0302SPATHDYN.000 [DIRS 161756]), which is $\mathrm{HF}_{2}^{-}=\mathrm{H}^{+}+2 \mathrm{~F}^{-}$. Therefore, these values were reassessed in the source spreadsheets and compared to those in data0.ymp.R0 (DTN: MO0009THRMODYN.001 [DIRS 152576]). Also, an "established fact" source (Wagman et al. 1982 [DIRS 159216]) was used for comparison. The analysis of these gas species is given in Section 6.4.

Additional gas-phase thermodynamic data were obtained from handbook compilations of Barin and Platzki (1995 [DIRS 157865]) and Binnewies and Milke (1999 [DIRS 158955]) and are listed in Table 4-20. Transcription errors were identified for gas species in the scaling of the "c" heat capacity coefficient from Binnewies and Milke (1999 [DIRS 158955]) into the calculation spreadsheet for the species listed in Table 4-20 using this source. This error is further discussed in Section 6.4.

Table 4-20. Thermodynamic Data Input for Gas Phases Updated or Added to Data0.ymp.R2 (DTN: MO0302SPATHDYN.000 [DIRS 161756])

\begin{tabular}{|c|c|c|c|c|c|c|c|}
\hline \multirow[b]{2}{*}{ Gas Species } & \multirow[b]{2}{*}{$\begin{array}{c}\Delta \mathbf{G}_{\mathrm{f}}^{\circ} \\
(\mathrm{J} / \mathrm{mol})\end{array}$} & \multirow[b]{2}{*}{$\begin{array}{c}\Delta \mathrm{H}_{\mathrm{f}}^{\circ} \\
(\mathrm{J} / \mathrm{mol}) \\
\end{array}$} & \multirow[b]{2}{*}{$\begin{array}{c}\mathrm{S}^{\circ} \\
(\mathrm{J} / \mathrm{mol}-\mathrm{K})\end{array}$} & \multicolumn{3}{|c|}{ Heat Capacity Coefficients ${ }^{a}$} & \multirow[b]{2}{*}{ Source } \\
\hline & & & & $\begin{array}{c}a \\
(\mathrm{~J} / \mathrm{mol}-\mathrm{K})\end{array}$ & $\begin{array}{c}\mathrm{b} \times 10^{3} \\
\left(\mathrm{~J} / \mathrm{mol}-\mathrm{K}^{2}\right)\end{array}$ & $\begin{array}{c}\mathrm{c} \times 10^{-5} \\
(\mathrm{~J}-\mathrm{K} / \mathrm{mol})^{b}\end{array}$ & \\
\hline $\mathrm{CoCl}_{2}(\mathrm{~g})$ & $-107,220$ & $-93,700$ & 298.50 & 60.730 & 2.820 & -0.170 & 1,2 \\
\hline $\mathrm{CoF}_{2}(\mathrm{~g})$ & $-369,947$ & $-356,500$ & 278.00 & 55.410 & 2.680 & -0.440 & 1,2 \\
\hline $\mathrm{CoCl}_{3}(\mathrm{~g})$ & $-154,434$ & $-163,600$ & 334.20 & 87.610 & -2.000 & -0.960 & 1,2 \\
\hline $\mathrm{CrCl}_{4}(\mathrm{~g})$ & $-395,322$ & $-426,800$ & 364.4 & 106.43 & 1.31 & -0.95 & 1,2 \\
\hline $\mathrm{FeCl}_{2}(\mathrm{~g})$ & $-155,571$ & $-141,000$ & 299.30 & 59.950 & 2.920 & -0.290 & 1,2 \\
\hline $\mathrm{FeCl}_{3}(\mathrm{~g})$ & $-247,843$ & $-253,100$ & 344.20 & 82.880 & 0.160 & -0.460 & 1,2 \\
\hline $\mathrm{FeF}_{2}(\mathrm{~g})$ & $-400,055$ & $-389,500$ & 265.20 & 70.540 & -3.320 & -1.230 & 1,2 \\
\hline $\mathrm{FeF}_{3}(\mathrm{~g})$ & $-812,795$ & $-820,900$ & 304.20 & 78.590 & 2.800 & -1.230 & 1,2 \\
\hline $\mathrm{H}_{2} \mathrm{O}(\mathrm{g})$ & $-228,620$ & $-241,826$ & 188.959 & 28.590 & 12.343 & 1.173 & 1 \\
\hline $\mathrm{HNO}_{3}(\mathrm{~g})$ & $-73,964$ & $-134,306$ & 266.475 & 42.278 & 61.932 & -6.524 & 1 \\
\hline
\end{tabular}


Table 4-20. Thermodynamic Data Input for Gas Phases Updated or Added to Data0.ymp.R2 (DTN: MO0302SPATHDYN.000 [DIRS 161756]) (Continued)

\begin{tabular}{|c|c|c|c|c|c|c|c|}
\hline & \multirow{2}{*}{\multicolumn{3}{|c|}{ Heat Capacity Coefficients ${ }^{a}$}} & \multirow[b]{3}{*}{ Source } \\
\hline & & & & & & & \\
\hline Gas Species & $\begin{array}{c}\Delta \mathbf{G}_{\mathrm{f}}^{\circ} \\
(\mathrm{J} / \mathrm{mol})\end{array}$ & $\begin{array}{c}\Delta \mathrm{H}_{\mathrm{f}}^{\circ} \\
(\mathrm{J} / \mathrm{mol})\end{array}$ & $\begin{array}{c}\mathrm{S}^{\circ} \\
(\mathrm{J} / \mathrm{mol}-\mathrm{K})\end{array}$ & $\begin{array}{c}\mathrm{a} \\
(\mathrm{J} / \mathrm{mol}-\mathrm{K})\end{array}$ & $\begin{array}{c}\mathrm{b} \times 10^{3} \\
\left(\mathrm{~J} / \mathrm{mol}-\mathrm{K}^{2}\right)\end{array}$ & $\begin{array}{c}\mathrm{c} \times 10^{-5} \\
(\mathrm{~J}-\mathrm{K} / \mathrm{mol})^{b}\end{array}$ & \\
\hline $\mathrm{N}_{2} \mathrm{O}(\mathrm{g})$ & 104,172 & 82,048 & 219.979 & 27.371 & 35.896 & 0.629 & 1 \\
\hline $\mathrm{N}_{2} \mathrm{O}_{3}(\mathrm{~g})$ & 139,486 & 82,843 & 309.349 & 49.369 & 58.009 & -0.755 & 1 \\
\hline $\mathrm{N}_{2} \mathrm{O}_{4}(\mathrm{~g})$ & 97,788 & 9,079 & 304.37 & 58.598 & 79.906 & -4.402 & 1 \\
\hline $\mathrm{N}_{2} \mathrm{O}_{5}(\mathrm{~g})$ & 118,014 & 11,297 & 346.545 & 98.612 & 58.437 & -17.578 & 1 \\
\hline $\mathrm{NiCl}_{2}(\mathrm{~g})$ & $-83,779$ & $-70,200$ & 298.20 & 68.290 & -0.970 & -0.660 & 1,2 \\
\hline $\mathrm{NiF}_{2}(\mathrm{~g})$ & $-347,601$ & $-335,600$ & 273.10 & 64.310 & 1.040 & -1.080 & 1,2 \\
\hline $\mathrm{NO}(\mathrm{g})$ & 86,599 & 90,291 & 210.761 & 25.034 & 9.523 & 1.754 & 1 \\
\hline $\mathrm{NO}_{2}(\mathrm{~g})$ & 51,262 & 33,095 & 240.02 & 38.108 & 15.389 & -5.366 & 1 \\
\hline $\mathrm{NO}_{3}(\mathrm{~g})$ & 116,060 & 71,128 & 252.823 & 58.598 & 79.906 & -4.402 & 1 \\
\hline $\mathrm{TiCl}(\mathrm{g})$ & 122,516 & 154,400 & 249.20 & 43.940 & 0.250 & -0.610 & 1,2 \\
\hline $\mathrm{TiCl}_{2}(\mathrm{~g})$ & $-244,529$ & $-237,200$ & 278.30 & 60.120 & 2.220 & -0.280 & 1,2 \\
\hline $\mathrm{TiCl}_{3}(\mathrm{~g})$ & $-524,829$ & $-539,300$ & 316.90 & 87.260 & -0.710 & -1.290 & 1,2 \\
\hline $\mathrm{TiCl}_{4}(\mathrm{~g})$ & $-726,764$ & $-763,200$ & 354.90 & 107.170 & 0.490 & -1.050 & 1,2 \\
\hline $\mathrm{TiF}(\mathrm{g})$ & $-98,305$ & $-66,900$ & 237.30 & 43.480 & 0.340 & -0.760 & 1,2 \\
\hline $\mathrm{TiF}_{2}(\mathrm{~g})$ & $-694,886$ & $-688,300$ & 255.70 & 59.470 & 2.560 & -0.650 & 1,2 \\
\hline $\mathrm{TiF}_{3}(\mathrm{~g})$ & $-1,175,664$ & $-1,188,200$ & 291.20 & 86.280 & -0.260 & -2.070 & 1,2 \\
\hline $\mathrm{TiF}_{4}(\mathrm{~g})$ & $-1,515,221$ & $-1,551,400$ & 314.90 & 104.250 & 1.980 & -1.800 & 1,2 \\
\hline $\mathrm{TiO}(\mathrm{g})$ & 24,534 & 54,400 & 233.50 & 37.040 & 0.970 & -0.490 & 1,2 \\
\hline $\mathrm{WCl}_{2}(\mathrm{~g})$ & $-28,637$ & $-12,600$ & 309.40 & 58.170 & 4.510 & -0.100 & 1,2 \\
\hline $\mathrm{WCl}_{4}(\mathrm{~g})$ & $-306,245$ & $-336,000$ & 379.30 & 107.400 & 0.460 & -0.780 & 1,2 \\
\hline $\mathrm{WCl}_{6}(\mathrm{~g})$ & $-409,436$ & $-493,700$ & 419.20 & 157.540 & 0.190 & -1.230 & 1,2 \\
\hline $\mathrm{WF}(\mathrm{g})$ & 351,397 & 386,200 & 251.10 & 37.810 & 2.900 & -0.520 & 1,2 \\
\hline $\mathrm{WF}_{6}(\mathrm{~g})$ & $-1,632,294$ & $-1,721,700$ & 341.10 & 152.650 & 2.750 & -3.140 & 1,2 \\
\hline $\mathrm{WO}_{2} \mathrm{Cl}_{2}(\mathrm{~g})$ & \begin{tabular}{|l|}
$-639,675$ \\
\end{tabular} & $-671,500$ & 353.90 & 103.580 & 2.300 & -1.570 & 1,2 \\
\hline $\mathrm{WOCl}_{4}(\mathrm{~g})$ & $-512,272$ & $-573,500$ & 377.10 & 128.840 & 1.850 & -2.230 & 1,2 \\
\hline $\mathrm{WOF}_{4}(\mathrm{~g})$ & $-1,275,166$ & $-1,336,600$ & 334.70 & 125.690 & 4.140 & -2.770 & 1,2 \\
\hline
\end{tabular}

Sources: 1 Barin and Platzki 1995 [DIRS 157865].

2 Binnewies and Milke 1999 [DIRS 158955].

a Heat capacity coefficients a, b, and c defined in Eq. 4-1.

${ }^{b}$ The coefficient c for heat capacity is incorrectly scaled as given in this table. These data were corrected to the proper scaling factor given in the source as discussed in Section 6.4.

\subsubsection{Compilation of Mineral Volume Data}

Molar volume data for mineral phases excluding those used to estimate volume data for clay phases (discussed in Section 4.1.4) are given in Table 4-21. Mineral volume data from data0.ymp.R0 (DTN: MO0009THRMODYN.001 [DIRS 152576]) are already qualified and are not considered for qualification in this report. Also, volume data from "established fact" sources, which are rather extensive, are not considered for qualification. That is, only the data listed in Table 4-21 are qualified in this report. The qualification of the data given in the table below and those developed for clay phases is evaluated in Section 6.6. It is noted that cement 
phases CSH:1.7, Friedl salt, and hydrogarnet are inactive in the data0.ymp.R2 database (DTN: MO0302SPATHDYN.000 [DIRS 161756]), and the molar volume data for these species are not considered for qualification of molar volume data in Section 6.6.

Table 4-21. Molar Volumes of Mineral/Solid Phases from Data0.ymp.R2

\begin{tabular}{|c|c|c|}
\hline Reference Mineral & Chemical Formula & $\begin{array}{c}V^{\circ} \\
\left(\mathrm{cm}^{3} / \mathrm{mol}\right)\end{array}$ \\
\hline 7A-Amesite & $\mathrm{Mg}_{2} \mathrm{Al}_{2} \mathrm{SiO}_{5}(\mathrm{OH})_{4}$ & 103 \\
\hline $\mathrm{CaUO}_{4}$ & $\mathrm{CaUO}_{4}$ & 45.926 \\
\hline Chabazite & $\mathrm{K}_{0.6} \mathrm{Na}_{0.2} \mathrm{Ca}_{1.55} \mathrm{Al}_{3.8} \mathrm{Si}_{8.2} \mathrm{O}_{24} \cdot 10.0 \mathrm{H}_{2} \mathrm{O}$ & 499.4 \\
\hline Cr-ferrihydrite & $\mathrm{Fe}_{4}\left(\mathrm{CrO}_{4}\right)(\mathrm{OH})_{10}$ & 129 \\
\hline 7A-Cronstedtite & $\mathrm{Fe}_{2} \mathrm{Fe}_{2} \mathrm{SiO}_{5}(\mathrm{OH})_{4}$ & 110.9 \\
\hline Erionite & $\mathrm{K}_{1.5} \mathrm{Na}_{0.9} \mathrm{Ca}_{0.9} \mathrm{Al}_{4.2} \mathrm{Si}_{13.8} \mathrm{O}_{36} \cdot 13.0 \mathrm{H}_{2} \mathrm{O}$ & 672 \\
\hline $\mathrm{Fe}_{2}\left(\mathrm{MoO}_{4}\right)_{3}$ & $\mathrm{Fe}_{2}\left(\mathrm{MoO}_{4}\right)_{3}$ & 131.85 \\
\hline Laumontite & $\mathrm{K}_{0.2} \mathrm{Na}_{0.2} \mathrm{Ca}_{1.8} \mathrm{Al}_{4} \mathrm{Si}_{8.0} \mathrm{O}_{24} \cdot 8.0 \mathrm{H}_{2} \mathrm{O}$ & 406.40 \\
\hline $\mathrm{Ni}_{3}\left(\mathrm{PO}_{4}\right)_{2}$ & $\mathrm{Ni}_{3}\left(\mathrm{PO}_{4}\right)_{2}$ & 83.36 \\
\hline $\mathrm{Na}_{4} \mathrm{UO}_{2}\left(\mathrm{CO}_{3}\right)_{3}$ & $\mathrm{Na}_{4} \mathrm{UO}_{2}\left(\mathrm{CO}_{3}\right)_{3}$ & 149.31 \\
\hline Phillipsite & $\mathrm{K}_{0.7} \mathrm{Na}_{0.7} \mathrm{Ca}_{1.1} \mathrm{Al}_{3.6} \mathrm{Si}_{12.4} \mathrm{O}_{32} \cdot 12.6 \mathrm{H}_{2} \mathrm{O}$ & 609.20 \\
\hline Stellerite & $\mathrm{Ca}_{2.0} \mathrm{Al}_{4.0} \mathrm{Si}_{14.0} \mathrm{O}_{36} \cdot 14.0 \mathrm{H}_{2} \mathrm{O}$ & 665.50 \\
\hline Uranophane (alpha) & $\mathrm{Ca}\left(\mathrm{UO}_{2} \mathrm{SiO}_{3} \mathrm{OH}\right)_{2} \cdot 5 \mathrm{H}_{2} \mathrm{O}$ & 251.34 \\
\hline Weeksite-Na & $\mathrm{Na}_{2}\left(\mathrm{UO}_{2}\right)_{2} \mathrm{Si}_{5} \mathrm{O}_{13} \cdot 3 \mathrm{H}_{2} \mathrm{O}$ & 246.04 \\
\hline
\end{tabular}

DTN: $\quad$ MO0302SPATHDYN.000 [DIRS 161756] (data0.ymp.R2). Included in output DTN: SN0410T0510404.001 (Spreadsheet Volume_Q_DS_11-01-04.xIs).

\subsection{CRITERIA}

The criteria for the development and qualification of the data0.ymp.R2 database (DTN: MO0302SPATHDYN.000 [DIRS 161756]) are specified in the Data Qualification Plan of Technical Work Plan for: Near-Field Environment and Transport In-Drift Geochemistry Analyses (BSC 2004 [DIRS 172402], Appendix A). These criteria were selected to incorporate the qualification methods and applicable qualification process attributes defined in AP-SIII.2Q, Qualification of Unqualified Data. The source data considered for qualification for YMP use are those that are directly used in the final database or are the bases for calculated data that are included in the final database. Corroborating data are not directly used in the final database and therefore do not require qualification.

The AP-SIII.2Q qualification methods specified in the Data Qualification Plan are:

Method 2. Corroborating Data. This method can be used when independently measured data can be used to substantiate or confirm parameter values. This method requires that data be available for comparison to the unqualified data sets, and that inferences drawn to corroborate the unqualified data be clearly identified, justified, and documented.

Method 5. Technical Assessment. This method is used when it is determined that independent assessment of the data, by a subject matter expert, is needed to raise the confidence of the data to the proper level for intended use. Technical assessments may be required if the confidence in the data is in question because data collection procedures are unavailable for review, or the procedures 
are not adequate, or if documentation or proof of proper data acquisition is unavailable for review. The technical assessment must include one or more of the following: 1) determination that the employed methodology is acceptable; 2) determination that confidence in the data acquisition or developmental results in warranted; or 3) confirmation that the data have been used in similar applications (e.g., by the U.S. Nuclear Regulatory Commission or the State Department of Environmental Protection, by nationally/internationally recognized organizations, or by the scientific community including publications, peer reviews, etc.).

Data qualifications for the data listed in Table 4-1 were performed using Method 2 or 5, or a combination of these. These qualifications are documented in Section 6. It was not required (nor possible) to assess all of the attributes/criteria to qualify these data for their intended use. Data sufficiency and acceptability were assessed using those attributes that could be evaluated. Corroborative data in the form of independently derived parameter values or of thermodynamic data for chemical analogs were used where available. It was not necessary to use Method 4 (Peer Review) to qualify the data0.ymp.R2 database (DTN: MO0302SPATHDYN.000 [DIRS 161756]) and its supporting calculations (DTNs: MO0302SPATHDYN.001 [DIRS 161886], and MO0303SPASPEQ2.000 [DIRS 162278]).

There was considerable overlap in the attributes that were considered in the qualification process. For instance, Technical Assessment involved both an evaluation of data collection procedures and comparisons with corroborating data. Conversely, use of corroborating data generally involved an evaluation, or assessment, of the methodology used in collecting both the data set of interest and the corroborating data. Each attribute was considered, to the degree possible, when assessing the data quality.

\subsection{CODES, STANDARDS, AND REGULATIONS}

This analysis was developed to support a demonstration of compliance with 10 CFR 63 [DIRS 156605]. No codes or standards are applicable to this analysis. 


\section{ASSUMPTIONS}

Assumption 1: For purposes of qualifying the data0.ymp.R2 database (DTN: MO0302SPATHDYN.000 [DIRS 161756], qualified by this report) and developing the new data0.ymp.R4 database (output DTN: SN0410T0510404.002), it is assumed that systems modeled with the data0.ymp.R2 (DTN: MO0302SPATHDYN.000 [DIRS 161756]) or data0.ymp.R4 databases (output DTN: SN0410T0510404.002) at temperatures above the boiling point of water will have the pressure controlled so that aqueous solutions are stable. For example, if a dilute solution is modeled at temperatures above the boiling point, this assumption implies that pressure conditions are controlled (i.e., pressure is increased) to maintain the solution in liquid form. As another example, for the study of deliquescence the dryout temperature of an evaporatively concentrated solution is defined with respect to the estimated total pressure in the repository, which is limited to approximately $1 \mathrm{bar}$. This assumption is consistent with anticipated repository conditions.

In accordance with this assumption the temperature grid selected for calculations of log $\mathrm{K}$ values as used in the EQ3/6 calculations is computed along the liquid-vapor saturation curve of pure water given the required physical state of the solvent, and application to repository conditions above the boiling point of water is limited using a realistic total pressure limit. No confirmation or additional investigation of this assumption is needed because it is a realistic depiction of temperature and pressure conditions in the repository and the adjacent host rock. This assumption is used throughout Section 6 in the data qualification discussion. 


\section{INTENTIONALLY LEFT BLANK}




\section{SCIENTIFIC ANALYSIS DISCUSSION}

The primary source of data making up the data0.ymp.R2 database (DTN: MO0302SPATHDYN.000 [DIRS 161756], qualified by this report) is the previously existing database, data0.ymp.R0 (DTN: MO0009THRMODYN.001 [DIRS 152576]). In support of the changes made in developing data0.ymp.R2 (DTN: MO0302SPATHDYN.000 [DIRS 161756]), a wide variety of published sources (listed in Section 4) was evaluated. In the following sections the sources are assessed for applicability and defensibility, and justified for use where appropriate.

Large data sets were obtained from well known compilations including the OECD/NEA Database (Lemire 2001 [DIRS 159027]) and the compilations in Babushkin et al. (1985 [DIRS 116981]), Binnewies and Milke (1999 [DIRS 158955]), Barin and Platzki (1995 [DIRS 157865]), and Chase (1998 [DIRS 157874]). Binnewies and Milke (1999 [DIRS 158955]) is a recent comprehensive compilation of thermodynamic data that draws on six references, four of which are pertinent to this effort. The six references each draw on many published and unpublished thermodynamic data, although those references are not listed in Binnewies and Milke (1999 [DIRS 158955]). Barin and Platzki (1995 [DIRS 157865]) and Babushkin et al. (1985 [DIRS 116981]) are likewise comprehensive compilations of thermodynamic data that include extensive lists of references. The handbooks (Lemire 2001 [DIRS 159027]; Babushkin et al. 1985 [DIRS 116981]; Barin and Platzki 1995 [DIRS 157865]; Chase 1998 [DIRS 157874]; Binnewies and Milke 1999 [DIRS 158955]) were chosen because they are recent, comprehensive, and generally accepted within the scientific community. Their data sources were reviewed and assessed (to varying degrees) with regard to data quality prior to publication.

The body of this section consists of two parts. The first part (Section 6.1) describes the approach used to convert the data into the forms and parameters used in the data0.ymp.R2 database (DTN: MO0302SPATHDYN.000 [DIRS 161756]). In the second part (Sections 6.2 through 6.4), the data as collected from the sources, are evaluated and qualified for use using the approaches described in Section 4.2. In this manner, the data0.ymp.R2 database (DTN: MO0302SPATHDYN.000 [DIRS 161756]) is qualified. Data reduction consists of converting fundamental thermodynamic properties into temperature-dependent equilibrium constants for the species of interest, and is largely performed in Excel spreadsheets.

Qualified data from two sources were used: data0.ymp.R0 (DTN: MO0009THRMODYN.001 [DIRS 152576]), which was the existing project database used for geochemistry calculations, and slop98.dat (DTN: MO0106MWDTDG01.035 [DIRS 161791]), a SUPCRT92 database that supports the data0.ymp.R0 database (DTN: MO0009THRMODYN.001 [DIRS 152576]) and contains organic data. The slop98.dat database (DTN: MO0106MWDTDG01.035 [DIRS 161791]) was qualified along with the data0.ymp.R0 database (DTN: MO0009THRMODYN.001 [DIRS 152576]) but was posted under a separate Data Tracking Number (DTN).

It should be noted that most of the available thermodynamic data originate in external university and international government laboratories. The data are therefore available only in published reports sponsored by government agencies and in international refereed technical journals. 
This section includes discussion of the data sources considered and the calculation methods used in developing the data0.ymp.R2 database (DTN: MO0302SPATHDYN.000 [DIRS 161756]). The data sources are identified, and justification for using data from those sources is presented. In addition, the conversions used to produce appropriate parameter values are discussed. All of the Excel spreadsheets used in performing the calculations to develop the data0.ymp.R2 database (DTN: MO0302SPATHDYN.000 [DIRS 161756]) are contained on a supplemental compact disk-read-only memory (CD-ROM) (DTN: MO0302SPATHDYN.001 [DIRS 161886]).

\subsection{APPROACH TO DATA REDUCTION}

While the basic thermodynamic data used in the development of the data0.ymp.R2 database (DTN: MO0302SPATHDYN.000 [DIRS 161756]) were obtained from published sources, most of the values actually included in the database were derived using various calculational techniques which are conventionally used in the retrieval and manipulation of thermodynamic data for solids, aqueous species, and gases. These methods generally calculate equilibrium constants from Gibbs free energy data and extrapolate those equilibrium constants to higher temperatures. The approaches adopted in this report for retrieval and extrapolation of thermodynamic data follow those adopted in the previous report Data Qualification Report for Thermodynamic Data File, Data0.ympR0 for Geochemical Code, EQ3/6 (CRWMS M\&O 2000 [DIRS 152575]). Therefore consistency is maintained between the various methods used in the extraction and extrapolation of data considered for the data0.ymp.R2 database (DTN: MO0302SPATHDYN.000 [DIRS 161756]). The calculations are discussed in detail below.

\subsubsection{The Heat Capacity of Solids as a Function of Temperature and its Relationship to Gibbs Free Energies at Higher Temperatures}

The Maier-Kelley heat capacity equation (Maier and Kelley 1932 [DIRS 101691]) is used in the software code SUPCRT92 (e.g., Johnson et al. 1992 [DIRS 101632]) to represent the temperature dependence of the standard molal heat capacities $\left(\mathrm{C}_{\mathrm{p}}{ }^{\circ}\right)$ of minerals and gases. As it is generally used, this empirical equation applies to conditions of 1 bar pressure. It can be written as (see Helgeson et al. 1978 [DIRS 101596], p. 29):

$$
C_{p}^{o}=a+b T-\frac{C}{T^{2}}
$$

where $\mathrm{T}$ is the absolute temperature $(\mathrm{K})$. There is no generally accepted convention about the sign of the third term and hence the "c" coefficient. The above formulation was embedded in the original version of the SUPCRT software used in Helgeson et al. (1978 [DIRS 101596]). However, Johnson et al. (1992 [DIRS 101632], p. 910) writes the equation as:

$$
C_{p}^{o}=a+b T+\frac{c}{T^{2}}
$$

with a positive sign for the "c" coefficient. This convention is embedded in the more recent version of SUPCRT92 (Johnson et al. 1992 [DIRS 101632]) and is the form that is followed in 
qualification of the data0.ymp.R2 database (DTN: MO0302SPATHDYN.000 [DIRS 161756]), except as noted in the following discussion.

Usually some temperature range is associated with any set of values. If a solid undergoes a phase transition at some temperature, one set of coefficients applies below that temperature and another applies above it. In addition, transitions involve changes in enthalpy and entropy (and volume) but not Gibbs free energy. In the temperature range of interest to YMP applications, generally less than $300^{\circ} \mathrm{C}$ (BSC 2004 [DIRS 169565], Section 6.3), only a small fraction of solids exhibits such transitions.

Values of Maier-Kelley heat capacity coefficients along with corresponding temperature ranges are given for many common rock-forming minerals by Helgeson et al. (1978 [DIRS 101596], Table 2, p. 48, Table 5, p. 61, and Table 7, pp. 68-73) (in all instances the old sign convention for "c" is employed as in Eq. 6-4). Some of these data have since been revised (apart from changing the sign of "c"); therefore, one should consult a recent copy of the SUPCRT92 database (e.g., slop98.dat; DTN: MO0106MWDTDG01.035 [DIRS 161791]) if values are desired as input for new calculations. These updated data also include a broader range of solids and gases. In both Helgeson et al. (1978 [DIRS 101596]) and in SUPCRT92 data files, the coefficients are treated such that the heat capacity is yielded in units of $\mathrm{cal} / \mathrm{mol}-\mathrm{K}(1 \mathrm{cal}=4.184$ joules $)$. Also in both places the tabulated values are actually expressed as $\mathrm{a}, \mathrm{b} \times 10^{3}$, and $\mathrm{c} \times 10^{-5}$. Thus, from Helgeson et al. (1978 [DIRS 101596], Table 2) (going back to the old convention for "c"), the coefficients for $\alpha$-quartz are $\mathrm{a}=11.22, \mathrm{~b} \times 10^{3}=8.20$, and $\mathrm{c} \times 10^{-5}=-2.70$, meaning $\mathrm{a}=11.22$, $\mathrm{b}=8.20 \times 10^{-3}$, and $\mathrm{c}=-2.70 \times 10^{5}$.

Heat capacity temperature functions such as the Maier-Kelley equation are important because they are needed to calculate thermodynamic properties such as the Gibbs free energy as a function of temperature. In relation to EQ3/6, their role is to provide the Gibbs free energies of solids and gases, thus the Gibbs free energy change for reactions involving these species, and finally the corresponding equilibrium constants (log $\mathrm{K}$ values) on the EQ3/6 temperature grid. The "classic" grid of relevance to the data0.ymp.R2 database (DTN: MO0302SPATHDYN.000 [DIRS 161756]) consists of values for $0^{\circ} \mathrm{C}, 25^{\circ} \mathrm{C}, 60^{\circ} \mathrm{C}, 100^{\circ} \mathrm{C}, 150^{\circ} \mathrm{C}, 200^{\circ} \mathrm{C}, 250^{\circ} \mathrm{C}$, and $300^{\circ} \mathrm{C}$; corresponding pressures are $1 \mathrm{~atm}(1.013 \mathrm{bar})$ for temperatures between $0^{\circ} \mathrm{C}$ and $100^{\circ} \mathrm{C}$ and the steam/liquid water pressure for temperatures between $100^{\circ} \mathrm{C}$ and $300^{\circ} \mathrm{C}$.

The mechanics of using heat capacity temperature functions to calculate apparent standard partial molar Gibbs free energies is discussed in both Helgeson et al. (1978 [DIRS 101596], pp. 28-30) and Johnson et al. (1992 [DIRS 101632], pp. 909-911). The equations as given in Johnson et al. (1992 [DIRS 101632]) are for the special case of Gibbs free energy of reactions among minerals. To obtain the equations for the Gibbs free energy for a single mineral, one is better served by referring to Helgeson et al. (1978 [DIRS 101596]) and where necessary, accounting for the change in the sign of "c." 
The general retrieval equation for the apparent standard partial molar Gibbs free energy of a solid as a function of temperature $\mathrm{T}$ and pressure $\mathrm{P}$ is in Helgeson et al. (1978 [DIRS 101596], p. 28):

$$
\Delta G_{f, T, P}^{o(a p p)}=\Delta G_{f, T_{r}, P_{r}}^{o}-S_{T_{r}, P_{r}}^{o}\left(T-T_{r}\right)+\int_{T r}^{T} C_{P_{r}}^{o} d T-T \int_{T r}^{T} C_{P_{r}}^{o} d \ln T+\int_{\operatorname{Pr}}^{P} V_{T}^{o} d P
$$

where $T_{r}$ is the reference temperature of $298.15 \mathrm{~K}\left(25^{\circ} \mathrm{C}\right), P_{r}$ is the reference pressure of $1 \mathrm{bar}$, $\Delta G_{f, T_{r}, P_{r}}^{o}$ is the actual standard partial molar Gibbs free energy of formation from the elements at the reference temperature and pressure, $S_{T_{r}, P_{r}}^{o}$ is the corresponding standard molar entropy, $V_{T}^{o}$ is the corresponding standard partial molar volume at temperature $\mathrm{T}$ (for many solids, this is closely approximated by $V_{T_{r}, P_{r}}^{o}$, thus simplifying the final integral in this equation), and $C_{P_{r}}^{o}$ is the standard partial molar heat capacity at the reference pressure. Similar retrieval equations exist for the apparent standard partial molar enthalpy, the standard partial molar entropy, and so forth. However, only the Gibbs free energy relation is immediately pertinent here and therefore Eq. 6-3 was used to retrieve $\log \mathrm{K}$ data for the data0.ymp.R2 database (DTN: MO0302SPATHDYN.000 [DIRS 161756]).

In the case of the Maier-Kelley formulation, the two heat capacity integrals appearing in the above equation are in Helgeson et al. (1978 [DIRS 101596], p. 29, corrected with regard to "c"):

$$
\int_{T r}^{T} C_{P_{r}}^{o} d T=a\left(T-T_{r}\right)+\frac{b\left(T^{2}-T_{r}^{2}\right)}{2}-c\left(\frac{1}{T}-\frac{1}{T_{r}}\right)
$$

and

$$
\int_{T r}^{T} C_{P_{r}}^{o} d \ln T=a \ln \left(T / T_{r}\right)+b\left(T-T_{r}\right)-\frac{c}{2}\left(\frac{1}{T^{2}}-\frac{1}{T_{r}^{2}}\right)
$$

For purposes of qualifying the database (i.e., $\log \mathrm{K}$ values for $0^{\circ} \mathrm{C}<\mathrm{T}<300^{\circ} \mathrm{C}$ ), the Maier-Kelley equation is more than sufficient. However, heat capacity coefficients reported and tabulated in the literature often extend this equation by adding one or more additional terms. The purpose of this is to facilitate accurate representation of the heat capacity over a wider temperature range than that considered here. An example is the equation proposed in Haas and Fisher (1976 [DIRS 158983]):

$$
C_{P_{r}}^{o}=a+2 b T+\frac{c}{T^{2}}+f T^{2}+\frac{g}{\sqrt{T}}
$$

(Note that $b$ and $c$ are subtly redefined here.)

Given the data in such extended forms, one must use all the coefficients in the integrations necessary to obtain the Gibbs free energy as a function of temperature. Alternatively, if one uses 
the retrieval equations for the Gibbs free energy given previously assuming the Maier-Kelley format, one must refit the given data to the Maier-Kelley equation. One may not simply take "a," "b," and "c" from a larger set of coefficients and plug these into these retrieval equations, with or without corrections for the subtle redefinitions. In some cases, the coefficients obtained by fitting of heat capacity data using equations resembling that of Eq. 6-7 can be used in the Maier-Kelley equation if the coefficient for the terms are zero (i.e., Eq. 6-7 simplifies to the Maier-Kelley equation).

There are numerous examples of such extended Maier-Kelley equations. The following very general form is used in the database of the NEA-Thermodynamic Data Base project (Puigdomenech et al. 1997 [DIRS 159204], Chapter X, Eq. 8, p. 430):

$$
C_{P_{r}}^{o}=a+b T+c T^{2}+j T^{3}+\frac{d}{T}+\frac{e}{T^{2}}+\frac{k}{T^{3}}+f \ln T+g T \ln T+h \sqrt{T}+\frac{i}{\sqrt{T}}
$$

Although the right hand side of this equation contains 11 terms, each with its corresponding coefficient, typically no more than about five would actually be used in any given instance. This equation is merely intended to be all-inclusive in form, combining all the kinds of terms that one might expect to have to deal with in constructing a large database from numerous and varied sources. Frequently only the a, b, and e terms are actually used, which corresponds to the use of the Maier-Kelley equation (here "e" is the Maier-Kelley "c"), or those plus one other. Note that in a global sense, one cannot count on the letter used to represent a coefficient to match any given power in $\mathrm{T}$.

Eq. 6-7 may also be written as:

$$
C_{P_{r}}^{o}=a+b T+c T^{2}+d T^{3}+\frac{e}{T}+\frac{f}{T^{2}}+\frac{g}{T^{3}}+h \sqrt{T}+\frac{i}{\sqrt{T}}+j \ln T+k T \ln T
$$

This group relates terms more closely together and emphasizes the fact that formulations containing terms in $\ln T$ and $T \ln T$ are less commonly employed than terms in actual powers. Therefore,

$$
\begin{aligned}
& \int_{T_{r}}^{T} C_{P_{r}}^{o} d T=a\left(T-T_{r}\right)+\frac{b\left(T^{2}-T_{r}^{2}\right)}{2}+\frac{c\left(T^{3}-T_{r}^{3}\right)}{3}+\frac{d\left(T^{4}-T_{r}^{4}\right)}{4}+e \ln \left(T / T_{r}\right) \\
& -f\left(\frac{1}{T}-\frac{1}{T_{r}}\right)-\frac{g}{2}\left(\frac{1}{T^{2}}-\frac{1}{T_{r}^{2}}\right)+\frac{2 h}{3}\left(T^{3 / 2}-T_{r}^{3 / 2}\right)+2 i\left(\sqrt{T}-\sqrt{T_{r}}\right) \\
& +j\left[T(\ln T-1)-T_{r}\left(\ln T_{r}-1\right)\right]+\frac{k}{2}\left[T^{2}\left(\ln T-\frac{1}{2}\right)-T_{r}^{2}\left(\ln T_{r}-\frac{1}{2}\right)\right]
\end{aligned}
$$


and

$$
\begin{aligned}
& \int_{T_{r}}^{T} C_{P_{r}}^{o} d \ln T=a \ln \left(T / T_{r}\right)+b\left(T-T_{r}\right)+\frac{c\left(T^{2}-T_{r}^{2}\right)}{2}+\frac{d\left(T^{3}-T_{r}^{3}\right)}{3}-e\left(\frac{1}{T}-\frac{1}{T_{r}}\right) \\
& -\frac{f}{2}\left(\frac{1}{T^{2}}-\frac{1}{T_{r}^{2}}\right)-\frac{g}{3}\left(\frac{1}{T^{3}}-\frac{1}{T_{r}^{3}}\right)+2 h\left(\sqrt{T}-\sqrt{T_{r}}\right)-2 i\left(\frac{1}{\sqrt{T}}-\frac{1}{\sqrt{T_{r}}}\right) \\
& +\frac{j}{2}\left(\ln T \ln T-\ln T_{r} \ln T_{r}\right)+k\left[T(\ln T-1)-T_{r}\left(\ln T_{r}-1\right)\right]
\end{aligned}
$$

Substitution of these results into the generalized retrieval equation then yields the apparent standard molar Gibbs free energy for solids whose heat capacities are described using extensions of the Maier-Kelley formalism.

\subsubsection{SUPCRT92 Usage and Development of Log K-Temperature Grids}

SUPCRT92 was used primarily in two ways to develop the data0.ymp.R2 database (DTN: MO0302SPATHDYN.000 [DIRS 161756]) (i.e., to develop changes from the previous data0.ymp.R0 database; DTN: MO0009THRMODYN.001 [DIRS 152576]). One application was to update the preexisting $\log \mathrm{K}$ data for silicate mineral dissolution for consistency with the Rimstidt paradigm of quartz solubility, which differs from the older Fournier paradigm. The Rimstidt paradigm is characterized by a higher solubility of quartz at $25^{\circ} \mathrm{C}$ with the effect principally associated with a greater thermodynamic stability of the species $\operatorname{SiO}_{2}(\mathrm{aq})$. The rationale behind this change is discussed elsewhere in this report (see Section 6.1.5). The second application of SUPCRT92 was to provide "library" worksheets of thermodynamic data for basis and analog species for use in the specialized spreadsheets discussed below.

The basis species data consisted of the apparent Gibbs free energy of formation on the standard EQ3/6 temperature grid $\left(0^{\circ} \mathrm{C}-25^{\circ} \mathrm{C}-60^{\circ} \mathrm{C}-100^{\circ} \mathrm{C}-150^{\circ} \mathrm{C}-200^{\circ} \mathrm{C}-250^{\circ} \mathrm{C}-300^{\circ} \mathrm{C}\right)$. These data were used to compute reaction properties for species whose individual thermodynamic properties are developed entirely in the spreadsheets. Analog species data are needed to facilitate temperature extrapolations using the isocoulombic/isoelectric method described below. The requisite data for analog species (which include many if not most basis species) are the standard Gibbs free energy of formation and standard entropy, both at $298.15 \mathrm{~K}$ and 1 bar pressure.

SUPCRT92 produces various kinds of output files. All data were taken from the "plot" files, which have filename extensions of the form .?xy (e.g., Gibbs free energies on the .gxy file, entropies on the .sxy file, $\log \mathrm{K}$ values on the .kxy file). The precision used in these files better matches that employed in EQ3/6 data files than that found on the SUPCRT92 "output" file. For example, the "output" file gives $\log \mathrm{K}$ values to only three decimal places, whereas the .kxy file and the EQ3/6 data0 file use four decimal places. The plot files are also much more convenient as a source of data because the desired data are isolated in a special, smaller file, rather than mixed up with other data in the larger "output" file. Fairly modest editing of a plot file permits working it into the form of a *.csv (comma separated value) file, which can be opened by Excel. 
Many of the data in data0.ymp.R0 (DTN: MO0009THRMODYN.001 [DIRS 152576]) were originally generated using SUPCRT92 in conjunction with an associated data file known as slop98.dat (DTN: MO0106MWDTDG01.035 [DIRS 161791]). The sources of data in this file were described in CRWMS M\&O (2000 [DIRS 152575]). A problem with earlier SUPCRT92 data files is that they used a different set of conventions from EQ3/6 in handling species names. For example, these files have " $\mathrm{Ca}+2$ " instead of the EQ3/6 " $\mathrm{Ca}++$," "FORMATE,AQ" in place of "Formate," "QUARTZ" instead of "Quartz," and "H2,g" in place of "H2(g)". To avoid lengthy and repeated exercises changing or matching species names, a new SUPCRT92 data file, speq02.dat (DTN: MO0303SPASPEQ2.000 [DIRS 162278]), was set up to use the EQ3/6 names. As noted elsewhere in the discussion of the Rimstidt vs. Fournier paradigms, the data were changed for quartz (very minor change) and $\mathrm{SiO}_{2}$ (aq) (significant change). Both data files are included in DTN: MO0302SPATHDYN.001 [DIRS 161886], which is input to, and qualified by, this report.

The thermodynamic data for steam $\left(\mathrm{H}_{2} \mathrm{O}(\mathrm{g})\right)$ in all SUPCRT92 data files were known to be erroneous at the start of this qualification. They appear to have been constructed to match up with the gas phase properties calculable (in principle at least) from the equation of state model for $\mathrm{H}_{2} \mathrm{O}$ that is built into SUPCRT92. Due to technical details in the implementation of the equation of state model in the software, that model can not be used to directly obtain the $\mathrm{H}_{2} \mathrm{O}(\mathrm{g})$ properties and a data file species is required. However, the match in the current instance is calibrated for a temperature/pressure range that is outside that of interest to the YMP, and it does not extrapolate accurately into the needed range. This problem was not fixed in speq02.dat (DTN: MO0303SPASPEQ2.000 [DIRS 162278]). Rather, corrected data were obtained using the spreadsheet approach and incorporated into data0.ymp.R2 (DTN: MO0302SPATHDYN.001 [DIRS 161886]). That is, the properties for $\mathrm{H}_{2} \mathrm{O}(\mathrm{g})$ were obtained from Barin and Platzki (1995 [DIRS 157865]) and the calculation is given in Spreadsheet Gases_j_TJW_2.xls (DTN: MO0302SPATHDYN.001 [DIRS 161886]).

\subsubsection{Special Function Spreadsheets}

Three types of special function spreadsheets were developed to facilitate the other calculations needed to develop the $\log \mathrm{K}$ grids for the data0.ymp.R2 database (DTN: MO0302SPATHDYN.000 [DIRS 161756]). The term "generic" spreadsheet is used to describe the type, with the understanding that this actually is the template or general form that is applied to a particular type of calculation, without regard to the specific set of data treated. There are many specific applications of such "generic" spreadsheets (representing the work of various contributors). These spreadsheets use no macros, just formulas and built-in functions. All the spreadsheets used in developing the data0.ymp.R2 database (DTN: MO0302SPATHDYN.000 [DIRS 161756]) are included in DTN: MO0302SPATHDYN.001 ([DIRS 161886]).

Some generic spreadsheets use calorie units, some joule units. The latter are more prominent today (the SI standard); however, it was thought expedient to allow some calculations in calorie units. SUPCRT92 still uses calorie units.

Most spreadsheets have a "Cover" worksheet of some type, a "Directions" worksheet, an "Example" worksheet (with a real example), and a "Template" worksheet, which can be copied 
as needed. In general, the data for one species or reaction is worked up on a single worksheet, and multiple worksheets then appear for workups of multiple species or reactions. Many spreadsheets also have a "Results Summary" worksheet. This worksheet can be exported under Excel as a *.csv (comma separated value) file, which facilitates getting the data into EQ3/6 data blocks. Some spreadsheets also have "library" worksheets of data for basis and analog species to be copied and pasted as needed onto the worksheets for specific species or reactions.

One type of spreadsheet was used to reduce tabulated heat capacity values (heat capacities vs. temperature) to Maier-Kelley heat capacity coefficients (which are then used in another type of spreadsheet described below). The heat capacity-fitting spreadsheets exist in two generic forms, here termed Cp_Solids_cal.xls (uses calorie units) and Cp_Solids_j.xls (uses joule units). Specific instances of usage of these are represented by spreadsheets with more complex names, usually indicating the user and at least one other distinguishing characteristic. An earlier version of these spreadsheets allowed work in mixed calorie/joule units, and specific instances of that were also used in developing data0.ymp.R2 (DTN: MO0302SPATHDYN.000 [DIRS 161756]). The heat capacity coefficient regression spreadsheets utilize Excel's built-in regression tool. Directions for activating and using it are included in the spreadsheets themselves (in the generic templates, hence in every specific instance of usage). Regression to fit other types of heat capacity temperature functions (such as those described in Section 6.1.1) was not necessary and no generic spreadsheet development to support this was done.

The second type of spreadsheet was developed to compute $\log \mathrm{K}$ values on the EQ3/6 temperature grid for mineral dissolution reactions (it is also applicable to, and was used in the case of gas species dissolution reactions). The four generic forms are here termed Minerals_cal.xls, Minerals_j.xls, Solids_cal.xls, and Solids_j.xls. The "Minerals" spreadsheets presume the Maier-Kelley formalism for the description of heat capacities, whereas the "Solids" spreadsheets allow a very generalized formalism for heat capacities. The "_cal" spreadsheets use calorie units, while the " $\mathrm{j}$ " ones use joule units.

These spreadsheets operate by inputting the standard Gibbs free energy and standard entropy of a species at $298.15 \mathrm{~K}$ and 1 bar pressure along with the heat capacity coefficients. The apparent Gibbs free energy (the same Gibbs free energy used in SUPCRT92) is then calculated on the EQ3 $/ 6$ temperature grid $\left(0^{\circ} \mathrm{C}-25^{\circ} \mathrm{C}-60^{\circ} \mathrm{C}-100^{\circ} \mathrm{C}-150^{\circ} \mathrm{C}-200^{\circ} \mathrm{C}-250^{\circ} \mathrm{C}-300^{\circ} \mathrm{C}\right)$. The retrieval equation for this is given in the heat capacity discussion (Section 6.1.1, Eq. 6-6). This Gibbs free energy grid was carried forward on the worksheet into an area in which the associated reaction properties were then calculated. The user must supply the reaction coefficients, negative for reactants, positive for products (the coefficient is always -1 for the associated species). The user must copy the parallel Gibbs free energy grids for the other species in the reaction (which must all be basis species) from "Basis Species" library worksheets. Standard thermodynamic relations are then used to compute the Gibbs free energy of reaction on the temperature grid and then the $\log \mathrm{K}$. The $\log \mathrm{K}$ grids are the desired output and may be copied onto the "Results Summary" worksheet.

With very few exceptions (noted below), the "library" data for basis species were obtained from SUPCRT92 and slop98.dat (DTN: MO0106MWDTDG01.035 [DIRS 161791]). This set of library data grew during the update as additional needs were identified. The final collection, summarized in BasisSpeciesLib_j_TJW_1p3.xls in DTN: MO0302SPATHDYN.001 
[DIRS 161886], contained data for 139 species (124 from SUPCRT92, 15 worked up in other spreadsheets described below) distributed over four worksheets. Not all specific instances of the "Mineral/Solid" log K spreadsheets contain the full set of final basis species data. In the course of work, data for two basis species, $\mathrm{SiO}_{2}(\mathrm{aq})$ and $\mathrm{Ti}(\mathrm{OH})_{4}(\mathrm{aq})$, were revised. Users were notified of the changes and directed to use the replacement worksheets provided. To avoid any possible confusion, the deprecated data were retained on the revised library worksheets along with the revised data. The deprecated data were marked as such, and a different background color was used to highlight them.

The third type of spreadsheet uses the isocoulombic/isoelectric method (Lindsay 1980 [DIRS 159038]; Murray and Cobble 1980 [DIRS 159200]; see also Fernandez-Prini et al. 1992 [DIRS 161651], Section 3-7, pp. 124-127; Puigdomenech et al. 1999 [DIRS 159205], p. 65) to obtain the apparent Gibbs free energy of a species (aqueous or mineral) on the temperature grid. The method is not exact but appears to give accurate results to $275^{\circ} \mathrm{C}$ to $300^{\circ} \mathrm{C}$. It replaces the Criss-Cobble method and the "const-H" method that were both found unsuitable in CRWMS M\&O (2000 [DIRS 152575], pp. 13-17). Comments on the Criss-Cobble method are provided by Puigdomenech et al. (1999 [DIRS 159205], pp. 64-65). The isocoulombic/isoelectric method also replaces the "DQUANT" method in Helgeson (1969 [DIRS 137246]) that was previously used in the case of neutral aqueous species but is only generally valid to about $150^{\circ} \mathrm{C}$.

The isocoulombic/isoelectric method, like those it replaces, is a temperature extrapolation algorithm that requires for its primary input only the standard Gibbs free energy and standard entropy at $298.15 \mathrm{~K}$ and 1 bar for the species in question as well as for other species (basis or analog) that appear in a chosen isocoulombic/isoelectric reaction. An isocoulombic reaction (the better of the two) is characterized by equal numbers of ions of a given charge type on both sides of the reaction (as an example, see Spreadsheet BasisSpecies_j_TJW_4.xls in DTN: MO0302SPATHDYN.001 [DIRS 161886]). Neutral species are commonly ignored. An example is:

$$
\mathrm{PuO}_{2} \mathrm{SO}_{4}(\mathrm{aq})+\mathrm{UO}_{2}^{++}=\mathrm{UO}_{2} \mathrm{SO}_{4}(\mathrm{aq})+\mathrm{PuO}_{2}^{++}
$$

As suggested by this example, most of the best isocoulombic reactions are exchange reactions. Here the properties of $\mathrm{PuO}_{2} \mathrm{SO}_{4}$ (aq) could be extrapolated if sufficient data (entropies at 298.15K and full Gibbs free energy grids) were available for $\mathrm{UO}_{2} \mathrm{SO}_{4}(\mathrm{aq})$ (an "analog" species) and two basis species, $\mathrm{UO}_{2}{ }^{++}$and $\mathrm{PuO}_{2}{ }^{++}$. An isoelectric reaction only requires that the sums of charge types (positive and negative) be the same on both sides of the equation. An example is:

$$
\mathrm{HSO}_{4}{ }^{-}+\mathrm{OH}^{-}=\mathrm{SO}_{4}{ }^{--}+\mathrm{H}_{2} \mathrm{O}
$$

Normally an isoelectric reaction is required to deal with very highly charged species for which there are few usable analogs. Note also that most EQ3/6 reactions are not isocoulombic/isoelectric (for example: $\mathrm{CdSO}_{4}(\mathrm{aq})=\mathrm{SO}_{4}{ }^{--}+\mathrm{Cd}^{++}$). Normally a distinct reaction is required to use the method.

The user must choose the reaction and provide the requisite data for the other species, normally from another set of "library" pages. In essence, the spreadsheet uses the input data to calculate the Gibbs free energy of reaction and entropy of reaction at $298.15 \mathrm{~K}$ and 1 bar for the 
isocoulombic or isoelectric reaction. The Gibbs free energy of reaction is then normally extrapolated up-temperature using the van't Hoff relation of thermodynamics along with the assumption of a zero heat capacity of reaction over the entire temperature range. The method allows the assumption of a constant non-zero heat capacity of reaction, but the usage of this is rare. The apparent Gibbs free energy grid for the species in question is then extracted from the Gibbs free energy of reaction grid in a calculation that resembles but partially inverts the process of calculating a Gibbs free energy of reaction grid from the Gibbs free energy grids for the species in the reaction. This requires copying Gibbs free energy grids for basis and analog species from library pages. The log $\mathrm{K}$ grid for the desired EQ3/6 reaction (which is normally different from the isocoulombic/isoelectric reaction) is then obtained using the same kind of operations as in the "Minerals/Solids" log K worksheets.

\subsubsection{Algorithms, Procedures, and Parameters Used to Obtain Input Parameters for the Temperature Extrapolation Excel Templates}

\subsubsection{Estimation of the Coefficients of the Maier-Kelley Equation}

The Spreadsheet Minerals_cal.xls (DTN: MO0302SPATHDYN.001 [DIRS 161886]) was used to extrapolate Gibbs free energies of solids at different temperatures, using the Maier-Kelley equation to represent the standard molal heat capacity of solids. The Maier-Kelley equation implemented in the spreadsheets is:

$$
C_{p}^{0}=a+b T+c / T^{2}
$$

If the heat capacity data were not available for a mineral, an estimation method given in Helgeson et al. (1978 [DIRS 101596]) was used to obtain them. The method assumes that the standard molal heat capacity equals the summation of the heat capacity of its constituent oxides. If the Maier-Kelley coefficients (Eq. 6-13) of the constituent oxides of a solid were known, the Maier-Kelley coefficients $\left(a_{i}, b_{i}\right.$, and $\left.c_{i}\right)$ of the standard molal heat capacity of the solid were developed using the following formulas:

$$
\begin{aligned}
a_{i} & =\sum_{j} v_{j, i} a_{j} \\
b_{i} & =\sum_{j} v_{j, i} b_{j} \\
c_{i} & =\sum_{j} v_{j, i} c_{j}
\end{aligned}
$$

where $v_{j, i}$ is the number of moles of the $\mathrm{j}^{\text {th }}$ oxide formula unit in one mole of the $\mathrm{i}^{\text {th }}$ solid.

The Maier-Kelley coefficients of most oxides given in Table 2 in Helgeson et al. (1978 [DIRS 101596]) were used in the estimation. Note that the Maier-Kelley equation in Helgeson et al. (1978 [DIRS 101596]) differs from Eq. 4-1 in the sign for the third term. Thus, the sign for $c_{j}$ in this discussion is opposite from Helgeson et al. (1978 [DIRS 101596]). 


\subsubsection{Estimation of Entropies}

Eqs. 55, 56, and 57 in Helgeson et al. (1978 [DIRS 101596]) were used to estimate the standard molal entropies of solids. The molal entropy and volume data of oxides are also from Table 2 in Helgeson et al. (1978 [DIRS 101596]). The molal entropy of radionuclide solids were obtained from Grenthe et al. (1992 [DIRS 101671]), Barin and Platzki (1995 [DIRS 157865]) and Binnewies and Milke (1999 [DIRS 158955]). The molal volumes, when available, were from these sources plus those obtained from peer-reviewed journals, and data0.ymp.R0 (DTN: MO0009THRMODYN.001 [DIRS 152576]).

\subsubsection{Obtaining Gibbs Free Energies of Formation at $25^{\circ} \mathrm{C}$ from Measurements at Other Temperatures}

To obtain $\Delta G_{f}^{o}(T=298.15 K)$ of a solid from solubility measurements at temperatures other than $25^{\circ} \mathrm{C}$ (say $30^{\circ} \mathrm{C}$ ), $\Delta G_{f}^{o}(T=303.15 K)$ has to be obtained first. This requires the $\Delta G_{f}^{o}(T=303.15 K)$ data for involved species. Those $\Delta G_{f}^{o}(T=303.15 K)$ data were obtained by running SUPCRT92 with the slop98.dat (DTN: MO0106MWDTDG01.035 [DIRS 161791]) or its modified version speq02.dat (DTN: MO0303SPASPEQ2.000 [DIRS 162278]).

The next step was to derive $\Delta G_{f}^{o}(T=298.15 K)$ from $\Delta G_{f}^{o}(T=303.15 K)$. The temperature extrapolation spreadsheet (Minerals_cal.xls) was used for this purpose. In order to do that, $\Delta G_{f}^{o}(T=298.15 K)$ was adjusted iteratively until the $\Delta G_{f}^{o}(T=303.15 K)$ value extrapolated using the spreadsheet was equal to the measured value. The final value of $\Delta G_{f}^{o}(T=298.15 K)$ was the answer.

\subsubsection{SUPCRT92 Silicate Mineral Revisions: Moving to the Rimstidt Paradigm}

The original treatment of silicate mineral thermodynamics in SUPCRT92 (Helgeson et al. 1978 [DIRS 101596]) has long been a core part of EQ3/6 data files. The equilibrium constants for the dissolution reactions of the minerals in data0.ymp.R2 (DTN: MO0302SPATHDYN.000 [DIRS 161756]) were calculated from a combination of the thermodynamic properties of the minerals themselves and those of the aqueous species participating in the reactions. In the vast majority of cases, the mineral properties described in Helgeson et al. (1978 [DIRS 101596]) were obtained directly from calorimetric ("third law") measurements, high-temperature (non-aqueous) phase equilibrium data in conjunction with calorimetric measurements for other minerals, or the use of predictive correlations. The equilibrium constants for the silicate mineral dissolution reactions are therefore "synthetic" in the sense that they are not based on measurements of aqueous solubility. In particular for the silicate minerals, such results depend on the assumed thermodynamic properties of aqueous silica $\left[\mathrm{SiO}_{2}(\mathrm{aq})\right]$. These properties have long been somewhat controversial, particularly at temperatures near $25^{\circ} \mathrm{C}$ (Walther and Helgeson 1977 [DIRS 133240], pp. 1324-1328).

In general, the properties of $\mathrm{SiO}_{2}(\mathrm{aq})$ (or the alternative species $\mathrm{H}_{4} \mathrm{SiO}_{4}(\mathrm{aq})$ ) are derived from measurements of the aqueous solubilities of quartz or other silica polymorphs, combined with calorimetric measurements of the thermodynamic properties of these minerals. Helgeson et al. 
(1978 [DIRS 101596]) followed the earlier analysis in Walther and Helgeson (1977 [DIRS 133240]). They in turn had recognized the disparity of reported measurements of the solubility of quartz especially at the lower temperatures, noting that sluggish reaction rates impede the attainment of equilibrium in experiments under these conditions. They chose the low-temperature solubility measurements in Morey et al. (1962 [DIRS 159198]) as a cornerstone of their analysis. These data, which are on the low end of the spectrum, are consistent with a $25^{\circ} \mathrm{C}$ solubility of $6 \mathrm{ppm} \mathrm{SiO}_{2}$ or very nearly $1.00 \times 10^{-4}$ molal. The higher reported measurements were ascribed to disequilibrium effects, such as abnormally high surface energies of mineral particle surfaces, due to grinding. To simplify further discussion, this interpretation of aqueous silica thermodynamics will be referred to as the Fournier paradigm, after the second author of Morey et al. (1962 [DIRS 159198]), who later reiterated this picture (Fournier and Potter 1982 [DIRS 160956]).

The issue was reopened by Rimstidt (1997 [DIRS 101709]) who performed a new set of quartz solubility experiments in the range of $21^{\circ} \mathrm{C}$ to $96^{\circ} \mathrm{C}$. His results indicated a $25^{\circ} \mathrm{C}$ solubility of $11.0 \pm 1.1 \mathrm{ppm} \mathrm{SiO} 2$ (about $1.83 \times 10^{-4} \mathrm{molal}$ ). As support for these higher results, he cites both a problem with Morey et al. (1962 [DIRS 159198]) data in relation to the solubility of amorphous silica and also the fact that the higher results seem in better accord with the dissolved silica concentrations in ancient groundwaters.

Rimstidt (1997 [DIRS 101709]) did not claim to have delivered a definitive case. However, his analysis gained increasing favor (e.g., Gunnarsson and Arnórsson 2000 [DIRS 160465]; Stefánsson 2001 [DIRS 159208]). The principal reason is that it provides an equilibrium model for silicate mineral/water interactions that better fits real groundwaters, including geothermal waters. This is true for silicate minerals in general, not just for $\mathrm{SiO}_{2}$ phases.

Most research areas of the YMP (e.g., the waste form degradation) had used the previously qualified data file (data0.ymp.R0; DTN: MO0009THRMODYN.001 [DIRS 152576]) or its unqualified predecessors. These were all based on the Fournier paradigm. However, thermal-hydrologic-chemical reactive transport calculations using a modified database were among activities that were based on the Rimstidt paradigm. A key goal of the data0.ymp.R2 (DTN: MO0302SPATHDYN.000 [DIRS 161756]) development was to fold everything together so that all modeling activities within the YMP could use the same database.

The decision was made to move to the Rimstidt paradigm for data0.ymp.R2 (DTN: MO0302SPATHDYN.000 [DIRS 161756]). One expectation of doing this was that it would reduce the number of mineral suppressions needed in reaction-path and reactive transport calculations.

It was decided to adopt the SUPCRT92 data for $\mathrm{SiO}_{2}$ (aq) and quartz, as documented in the report Data Qualification for Thermodynamic Data Used to Support THC Calculations (BSC 2004 [DIRS 170268], Section 6.3 and Table 6.4-1). These data are consistent with the Rimstidt paradigm and represent a substantial revision due to the shift in the updated silica thermodynamic properties. The changes in the data for quartz itself are in fact quite small, and only reflect a newer "best fit" to more recent thermodynamic data. The new data are consistent with, but not really reflective of, the change in silica solubility paradigm. Similar refinements 
were calculated for the thermodynamic data for other silicate minerals, but not included in the data0.ymp.R2 database (DTN: MO0302SPATHDYN.000 [DIRS 161756]) as discussed below.

In implementing the Rimstidt paradigm in data0.ymp.R2 (DTN: MO0302SPATHDYN.000 [DIRS 161756]), the following actions were taken. Updated thermodynamic data for $\mathrm{SiO}_{2}(\mathrm{aq})$ and quartz were put in the SUPCRT92 data file speq02.dat (DTN: MO0303SPASPEQ2.000 [DIRS 162278]). Gibbs free energy grids (values of the Gibbs free energies on the standard EQ3/6 temperature grid) were calculated using SUPCRT92 and placed in the library worksheets of the spreadsheets used for non-SUPCRT92 calculations. In both speq02.dat and the library worksheets, the updated data were labeled Rimstidt and the previous data were retained and marked "Fournier." The Fournier data on the library worksheets were also marked as "deprecated" and highlighted in a different color (gray instead of yellow). The Gibbs free energy grid as a function of temperature calculated for $\mathrm{SiO}_{2}(\mathrm{aq})$ in SUPCRT92 is very similar to the grid calculated from the data from Gunnarsson and Arnórsson (2000 [DIRS 160465], Table 3) with a maximum difference of $125 \mathrm{cal} / \mathrm{mol}$ at $200^{\circ} \mathrm{C}$ (Table 6-1). Such relatively small differences provide corroboration of the thermodynamic data used in data0.ymp.R0 (DTN: MO0009THRMODYN.001 [DIRS 152576]). Next, the log K grids for all SUPCRT92 minerals were recalculated using the Rimstidt data. This was done by extracting all the relevant minerals and reactions from data0.ymp.R0 (DTN: MO0009THRMODYN.001 [DIRS 152576]) onto a set of SUPCRT92 input (.rxn) files and running these through SUPCRT92 in conjunction with a modified SUPCRT92 data file (speq02.dat; DTN: MO0303SPASPEQ2.000 [DIRS 162278]). The log K values from the relevant SUPCRT92 "plot" (.kxy) files were then pasted into the relevant mineral data blocks for data0.ymp.R2 (DTN: MO0302SPATHDYN.000 [DIRS 161756]).

Table 6-1. Comparison of $\Delta G_{f}^{\circ}$ Obtained from Data0.ymp.R2 with the $\Delta G_{f}^{\circ}$ from Gunnarsson and Arnórsson for $\mathrm{SiO}_{2}(\mathrm{aq})$

\begin{tabular}{|l|c|c|c|c|c|c|c|c|}
\hline \multicolumn{1}{|c|}{$\mathbf{T}\left({ }^{\circ} \mathbf{C}\right)$} & $\mathbf{0 . 0 1}$ & $\mathbf{2 5}$ & $\mathbf{6 0}$ & $\mathbf{1 0 0}$ & $\mathbf{1 5 0}$ & $\mathbf{2 0 0}$ & $\mathbf{2 5 0}$ & \multicolumn{1}{c|}{$\mathbf{3 0 0}$} \\
\hline bars & 1.0133 & 1.0133 & 1.0133 & 1.0133 & 4.7572 & 15.5366 & 39.7366 & 85.8379 \\
\hline $\mathrm{K}$ & 273.16 & 298.15 & 333.15 & 373.15 & 423.15 & 473.15 & 523.15 & 573.15 \\
\hline \multicolumn{7}{|c|}{ Source } & \multicolumn{7}{|c|}{$\Delta \mathbf{G}_{\mathbf{f}}{ }^{\circ}(\mathbf{c a l} / \mathbf{m o l})$} \\
\hline 1 & -199219.4 & -199540.0 & -199909.5 & -200352.1 & -200994.3 & -201739.0 & -202555.6 & -203362.2 \\
\hline 2 & -199337.7 & -199546.4 & -199912.5 & -200411.4 & -201115.1 & -201864.1 & -202617.1 & -203337.1 \\
\hline Difference & 118.3 & 6.4 & 3.0 & 59.3 & 120.8 & 125.1 & 61.5 & -25.1 \\
\hline
\end{tabular}

Sources: 1 Data0.ymp.R2 (DTN: MO0302SPATHDYN.000 [DIRS 161756]).

2 Gunnarsson and Arnórsson 2000 [DIRS 160465].

In doing this SUPCRT92 silicate update, the $\log \mathrm{K}$ grids for silica reactions involving only aqueous species (e.g., $\mathrm{HSiO}_{3}{ }^{-}+\mathrm{H}^{+}=\mathrm{SiO}_{2}(\mathrm{aq})+\mathrm{H}_{2} \mathrm{O}$ ) were not updated, as the original constraining data were $\log \mathrm{K}$ values. In theory, the SUPCRT92 data file properties for species like $\mathrm{HSiO}_{3}^{-}$should have been reevaluated to produce the old $\log \mathrm{K}$ values. For the data0.ymp.R2 database (DTN: MO0302SPATHDYN.000 [DIRS 161756]), that was not carried out as it was not strictly necessary considering that the predominance of this particular silica species $\left(\mathrm{HSiO}_{3}{ }^{-}\right)$is restricted to alkaline $\mathrm{pH}$ values greater than 9 to 10 . The lack of such corrections has no significant impact on qualification of data0.ymp.R2 (DTN: MO0302SPATHDYN.000 [DIRS 161756]) because the predicted pH values for waters 
of interest to YMP are lower (BSC 2004 [DIRS 169860]). Calculation of the appropriate log K values with the current SUPCRT92 data file (speq02.dat; DTN: MO0303SPASPEQ2.000 [DIRS 162278]) can be performed by specifying the "SiO2(aq)(Fournier)" species in the relevant reaction.

The revision as carried out for the silicate minerals assumed a calorimetric or equivalent origin of the constraining data. Thus the $\log \mathrm{K}$ values were synthetic and somewhat different than those previously obtained using the Fournier data. However, the data for two minerals in the SUPCRT92 data set were derived in Helgeson et al. (1978 [DIRS 101596]) from low-temperature solubility $(\log \mathrm{K})$ data. These were amorphous silica (Helgeson et al. 1978 [DIRS 101596], p. 86; see also Walther and Helgeson 1977 [DIRS 133240], p. 1321 and pp. 1326-1328) and sepiolite (Helgeson et al. 1978 [DIRS 101596], p. 98 and Figure 34, p. 99). Therefore, the $\log \mathrm{K}$ grids for these minerals were left consistent with previous results (as were those for aqueous species like $\mathrm{HSiO}_{3}{ }^{-}$). The appropriate $\log \mathrm{K}$ values can be calculated using the speq02.dat data file (DTN: MO0303SPASPEQ2.000 [DIRS 162278]) by specifying the "SiO2(aq) (Fournier)" species in the relevant reactions.

The status of a few other silicate minerals was questioned in the development of data0.ymp.R2 (DTN: MO0302SPATHDYN.000 [DIRS 161756]), but the necessity of further corrections in moving to the Rimstidt paradigm was not clear. This was in part due to uncertainty as to exactly how the constraining data were used in Helgeson et al. (1978 [DIRS 101596]) to obtain the reported values for the standard Gibbs free energies of formation (and by implication those for the standard enthalpies of formation). No further corrections were made. However, the cases are discussed here for possible future reference.

Solubility measurements appear to have been used in whole or in part in Helgeson et al. (1978 [DIRS 101596]) to determine the standard Gibbs free energies of formation of forsterite, chrysotile, and antigorite. In the case of forsterite, the solubility data in question were at temperatures in excess of $500^{\circ} \mathrm{C}$ (Helgeson et al. 1978 [DIRS 101596], p. 89 and p. 93, Figure 27), which are required for this phase to be stable. In the case of antigorite (Helgeson et al. 1978 [DIRS 101596], p. 89 and p. 94, Figure 28), solubility data at and above $300^{\circ} \mathrm{C}$ were employed. If the apparent Gibbs free energies of these minerals were obtained from the solubility data at high temperature (where the difference in paradigms is small) and then extrapolated down using the standard entropy and heat capacity data for each mineral, any further necessary correction would be rather small. If on the other hand the solubility data were extrapolated down to $298.15 \mathrm{~K}$ and the Gibbs free energies of formation then extracted, a significant further correction would be necessary. However, the exact calculational path was not given in Helgeson et al. (1978 [DIRS 101596]). There may be a more definite problem with chrysotile (Helgeson et al. 1978 [DIRS 101596], p. 89 and p. 93, Figure 27) as some solubility data shown extend down to $100^{\circ} \mathrm{C}$. Note that none of these minerals appears to have much if any relevance to YMP investigations.

The Gibbs free energy of formation of kaolinite was partially constrained by assuming equilibrium with some low-temperature groundwaters of known composition (Helgeson et al. 1978 [DIRS 101596], pp. 112-114 and p. 125, Footnote). No attempt was made to correct for this. The methodology used in Helgeson et al. (1978 [DIRS 101596]) was not fully compelling, and corrections also involving aluminum could be in order. More telling, the original Gibbs free 
energy of formation $(-905.614 \mathrm{kcal} / \mathrm{mol}$ or $-3789.089 \mathrm{~kJ} / \mathrm{mol})$ was in line with expectations based on data for related minerals. This was shown by a very small residual of $-0.009 \mathrm{kcal} / \mathrm{mol}$ in the final Gibbs free energy regression for sheet silicate minerals discussed in the "clay minerals" section of this report. Furthermore, this value is in reasonable accord with more recent calorimetric determinations of $-3799.4 \pm 6.4 \mathrm{~kJ} / \mathrm{mol}$ (de Ligny and Navrotsky 1999 [DIRS 158973]) and $-3793.9 \pm 4.1 \mathrm{~kJ} / \mathrm{mol}$ (Fialips et al. 2001 [DIRS 158975]), falling in the uncertainty band of the latter and slightly above that of the former. Barin and Platzki (1995 [DIRS 157865], p. 61) give a value of $-3799.444 \mathrm{~kJ} / \mathrm{mol}$. This is probably based on calorimetric measurement, but the ultimate source could not be determined. The compilation of Wagman et al. (1982 [DIRS 159216]) was cited as the source, and they in turn do not identify sources.

The data for pyrophyllite appear to be partly tied to those of kaolinite (Helgeson et al. 1978 [DIRS 101596], p. 113, reaction 138 and p. 114, Figure 47). However, the mutual solubility data that may have been employed only extended down to $200^{\circ} \mathrm{C}$. There may be similar concerns in the case of analcime (Helgeson et al. 1978 [DIRS 101596], pp. 149-150 and p. 150, Figure 72), as some relevant solubility data appear to extend down to about $150^{\circ} \mathrm{C}$.

No other cases were found in which possible further corrections were a potential issue.

The effect of the move from the Fournier paradigm to the Rimstidt paradigm is illustrated by its effect on the $\log \mathrm{K}$ grid for quartz as shown in Table 6-2. The Rimstidt data are taken from data0.ymp.R2 (DTN: MO0302SPATHDYN.000 [DIRS 161756]) and the Fournier data from data0.ymp.R0 (DTN: MO0009THRMODYN.001 [DIRS 152576]). The differences are largest at lower temperatures. A very small part of the differences shown is due to changes in the thermodynamic data for quartz itself. A much larger part is due to changes in the data for $\mathrm{SiO}_{2}(\mathrm{aq})$. Therefore, multiplying these differences by the number of $\mathrm{SiO}_{2}$ units in the mineral formula of another silicate closely approximates the changes in the $\log \mathrm{K}$ data for that silicate.

Table 6-2. Calculated Log K Grids for Quartz Showing the Effect of Changing from the Fournier Paradigm to the Rimstidt Paradigm

\begin{tabular}{|c|l|l|l|}
\hline Temperature $\left({ }^{\circ} \mathbf{C}\right)$ & Fournier & Rimstidt & Difference \\
\hline 0 & -4.6319 & -4.1605 & 0.4714 \\
\hline 25 & -3.9993 & -3.7501 & 0.2492 \\
\hline 60 & -3.4734 & -3.3553 & 0.1181 \\
\hline 100 & -3.0782 & -3.0132 & 0.0650 \\
\hline 150 & -2.7191 & -2.6679 & 0.0512 \\
\hline 200 & -2.4378 & -2.3823 & 0.0555 \\
\hline 250 & -2.2058 & -2.1490 & 0.0568 \\
\hline 300 & -2.0171 & -1.9822 & 0.0349 \\
\hline
\end{tabular}

NOTE: See Spreadsheet silica.xIs (DTN: MO0302SPATHDYN.001 [DIRS 161886]). 
A check of the modified SUPCRT92 data was made by comparing the present Rimstidt results for the $\log \mathrm{K}$ for quartz with those obtained by evaluating a temperature function given in Rimstidt (1997 [DIRS 101709]). The comparison, on the EQ3/6 temperature grid, is shown in Table 6-3. Also shown for comparison are results obtained by evaluating a similar temperature function given in Gunnarsson and Arnórsson (2000 [DIRS 160465]), which also follows the Rimstidt paradigm (these temperature function evaluations were done in spreadsheet Rimstidt_Silica_TJW.xls as shown in DTN: MO0302SPATHDYN.001 [DIRS 161886]).

Table 6-3. Calculated Log K Grids for Quartz Comparing the Present Rimstidt Data (SUPCRT92 with Updated $\mathrm{SiO}_{2}(\mathrm{aq})$ ) with Rimstidt Temperature Function and with Gunnarsson and Arnórsson Temperature Function

\begin{tabular}{|c|c|c|c|}
\hline $\begin{array}{c}\text { Temperature } \\
\left({ }^{\circ} \mathbf{C}\right)\end{array}$ & $\begin{array}{c}\text { Rimstidt } \\
\text { (SUPCRT92 } \\
\text { Calculation) }\end{array}$ & $\begin{array}{c}\text { Rimstidt } \\
\text { Temperature } \\
\text { Function }\end{array}$ & $\begin{array}{c}\text { Gunnarsson and } \\
\text { Arnórsson } \\
\text { Temperature Function }\end{array}$ \\
\hline 0 & -4.1605 & -4.0786 & -4.0679 \\
\hline 25 & -3.7501 & -3.7387 & -3.7463 \\
\hline 60 & -3.3553 & -3.3486 & -3.3549 \\
\hline 100 & -3.0132 & -2.9924 & -2.9808 \\
\hline 150 & -2.6679 & -2.6418 & -2.6076 \\
\hline 200 & -2.3823 & -2.3653 & -2.3252 \\
\hline 250 & -2.1490 & -2.1417 & -2.1223 \\
\hline 300 & -1.9822 & -1.9570 & -1.9905 \\
\hline
\end{tabular}

Sources: Rimstidt 1997 [DIRS 101709]; Gunnarsson and Arnórsson 2000 [DIRS 160465]. DTNs: MO0303SPASPEQ2.000 ([DIRS 162278], SUPCRT92 data file speq02.dat); MO0302SPATHDYN.001 ([DIRS 161886], spreadsheet calculation given in the Worksheet Rimstidt_Silica_TJW.xIs).

Approximately 100 silicate solids were not corrected to the Rimstidt paradigm in data0.ymp.R2 (DTN: MO0302SPATHDYN.000 [DIRS 161756]). These species generally do not occur in natural geologic systems but may be encountered in interactions with engineered materials. The resulting difference in $\log \mathrm{K}$ is generally less than about one $\log$ unit, usually less than 0.5 units. The basic thermodynamic data are contained in the revised data0.ymp.R2 database (DTN: MO0302SPATHDYN.000 [DIRS 161756]) for most of the species, so the Rimstidt calculation could be made for these species using the template spreadsheets included in the supplemental CD-ROM. A note to this effect was added in the Comments section of the data0.ymp.R2 database (DTN: MO0302SPATHDYN.000 [DIRS 161756]). At the present time, the affected silicates can only be identified by comparing $\log \mathrm{K}$ values for silicates in the data0.ymp.R2 database (DTN: MO0302SPATHDYN.000 [DIRS 161756]) with those in the data0.ymp.R0 database (DTN: MO0009THRMODYN.001 [DIRS 152576]).

\subsubsection{Clarification of the Discrepancy in $\Delta \mathrm{G}_{\mathrm{f}}{ }^{\circ}$ Data for Ca-Bearing Silicates}

In comparing thermodynamic parameters such as $\Delta \mathrm{G}_{\mathrm{f}}{ }^{\circ}$ for Ca-bearing silicates against their given source in the database (i.e., Helgeson et al. 1978 [DIRS 101596], Table 8, pp. 120-125), a discrepancy was found between these values and those listed in the former source. The $\Delta \mathrm{G}_{\mathrm{f}}{ }^{\circ}$ values are correct in the databases slop98.dat (DTN: MO0106MWDTDG01.035 [DIRS 161791]), speq02.dat (DTN: MO0303SPASPEQ2.000 [DIRS 162278]), and accordingly in data0.ymp.R2 (DTN: MO0302SPATHDYN.000 [DIRS 161756]). Moreover, these $\Delta \mathrm{G}_{\mathrm{f}}{ }^{\circ}$ values for Ca-bearing silicates are also internally consistent with other species. It is not clear 
why the values given by the source Helgeson et al. (1978 [DIRS 101596]) differ from those in the database and the goal of this section is to precisely clarify this discrepancy.

The Gibbs free energy of formation data for most of the minerals in the SUPCRT92 database (e.g., slop98.dat, DTN: MO0106MWDTDG01.035 [DIRS 161791]) and speq02.dat (DTN: MO0303SPASPEQ2.000 [DIRS 162278]) were regressed from high-temperature phase equilibrium experiments reported in the literature preceding the publication of Helgeson et al. (1978 [DIRS 101596]). These experiments represent the thermodynamic stabilities of assemblages of one or more minerals relative to other such assemblages. In order to utilize this approach, one must first establish a set of values for the Gibbs free energies of formation (i.e., $\Delta \mathrm{G}_{\mathrm{f}}{ }^{\circ}$ ) of some "basis" set of minerals, commonly the simple oxides. The values for these minerals are determined purely from other kinds of data, principally calorimetric. Other calorimetric data (for all the minerals delineating the phase equilibrium reaction in the experiments) are used to make temperature and pressure corrections to the apparent Gibbs free energies of formation of the minerals, such that only the values at $298.15 \mathrm{~K}$ and 1 bar pressure of certain minerals remain to be regressed from the experimental data. By this logic, one would use lime $(\mathrm{CaO})$ as the "basis" mineral for $\mathrm{Ca}$ in regressing phase equilibrium data for other $\mathrm{Ca}$ minerals. However, the available phase equilibrium data did not permit this linkage, so calcite $\left(\mathrm{CaCO}_{3}\right.$, the stable form at $298.15 \mathrm{~K}$ and 1 bar pressure $)$ was used instead. The Gibbs free energy of formation at $298.15 \mathrm{~K}$ and 1 bar pressure for calcite was itself regressed by Helgeson et al. (1978 [DIRS 101596], p. 87-88) from a solubility experiment. This required the assumption of values for the Gibbs free energies of formation of the $\mathrm{Ca}^{++}$and $\mathrm{CO}_{3}{ }^{--}$ions at $298.15 \mathrm{~K}$ and 1 bar pressure as detailed in Helgeson et al. (1978 [DIRS 101596]). Aragonite (a less stable form of $\mathrm{CaCO}_{3}$ at ambient conditions) was treated in a similar manner, using solubility data from the same sources. The data for lime $(\mathrm{CaO})$ and monticellite $\left(\mathrm{CaMgSiO}_{4}\right)$ were established purely from calorimetric data. The data for all remaining Ca minerals, however, were linked to the data for calcite. Sometime in the late 1980s, notification was received from an EQ3/6 user (to the code developer, Dr. T. J. Wolery) that saturation indices for calcite as computed from EQ3/6 and a largely SUPCRT92-derived database differed noticeably from values calculated using another code. This was initially puzzling, as the ultimate data source for calcite solubility in both cases was listed as the same given in Helgeson et al. (1978 [DIRS 101596]). The matter was referred to Professor H.C. Helgeson at the University of California, Berkeley. The problem, which has not heretofore been documented except for an informal written communication distributed thereafter by Professor Helgeson to known users of the SUPCRT92 database, was that changes in the Gibbs free energies of formation of the ions (including $\mathrm{Ca}^{++}$and $\mathrm{CO}_{3}{ }^{--}$) had occurred. In order to obtain the original equilibrium constant for calcite dissolution (and hence a consistent set of saturation indices), the Gibbs free energy of formation of calcite at $298.15 \mathrm{~K}$ and 1 bar pressure needed to be recalculated. The corresponding Gibbs free energy of formation of every mineral linked to calcite (directly or indirectly) therefore also needed to be relcalculated (all $\mathrm{Ca}$ minerals except calcite itself, aragonite, lime, and monticellite). The Worksheet Ca Mineral Data Comparison in the Spreadsheet SUPCRT92 Ca Minerals Analysis.xls (output DTN: SN0410T0510404.001) shows that the Gibbs free energy of formation of calcite at $298.15 \mathrm{~K}$ and 1 bar pressure was increased by $220 \mathrm{cal} / \mathrm{mol}$. Then, that of each of the affected minerals was increased by $220 \mathrm{cal} / \mathrm{mol}$ for each calcium appearing in the molecular formula of the linked mineral. This correction precisely preserves the phase equilibrium relations in the original paper by Helgeson et al. (1978 [DIRS 101596]). The Worksheet Calcite Data 
Correction in the Spreadsheet SUPCRT92 Ca Minerals Analysis.xls (output DTN: SN0410T0510404.001) shows the derivation of the $220 \mathrm{cal} / \mathrm{mol}$ per Ca correction. In this derivation, two factors must be kept in mind. First, the Gibbs free energies of formation of the ions at $298.15 \mathrm{~K}$ and 1 bar pressure changed from the set of values adopted by Helgeson et al. (1978 [DIRS 101596]) to a set that is now documented by Shock et al. (1997 [DIRS 127953]). Second, the revised solubility data for calcite and aragonite are based on a later paper (Plummer and Busenberg, 1982 [DIRS 151737]). These newer solubility data account for the fact that the correction to the Gibbs free energy of formation of aragonite is $192 \mathrm{cal} / \mathrm{mol}$, not $220 \mathrm{cal} / \mathrm{mol}$. The affected Ca-bearing silicates along with the corrected Gibbs free energy values are listed in Table 6-4. Since these values are correct in the input data used to develop data0.ymp.R2 (DTN: MO0302SPATHDYN.000 [DIRS 161756]), no further qualification is necessary except to specify that Helgeson et al. (1978 [DIRS 101596]) is not the root source for the thermodynamic data of Ca silicates listed in Table 6-4.

Table 6-4. Differences in $\Delta \mathrm{G}_{\mathrm{f}}{ }^{\circ}$ of Ca-Bearing Minerals Due for Updated $\mathrm{Ca}^{++}$Thermodynamic Properties

\begin{tabular}{|c|c|c|c|c|c|}
\hline Mineral & Formula & $\Delta \mathbf{G}_{\mathrm{f}}^{\circ}(\mathrm{cal} / \mathrm{mol})$ & $\Delta \mathbf{G}_{\mathrm{f}}^{\circ}(\mathrm{cal} / \mathrm{mol})$ & $\begin{array}{c}\text { Difference per } \\
\text { Ca in Formula } \\
\text { (cal/mol) }\end{array}$ & Comment \\
\hline Lime & $\mathrm{CaO}$ & -144366 & -144366 & 0 & NL \\
\hline Calcite & $\mathrm{CaCO}_{3}$ & -270100 & -269880 & 220 & $\mathrm{~L}$ \\
\hline Aragonite & $\mathrm{CaCO}_{3}$ & -269875 & -269683 & 192 & NS \\
\hline Ordered Dolomite & $\mathrm{CaMg}\left(\mathrm{CO}_{3}\right)_{2}$ & -517980 & -517760 & 220 & $\mathrm{~L}$ \\
\hline Disordered Dolomite & $\mathrm{CaMg}\left(\mathrm{CO}_{3}\right)_{2}$ & -515873 & -515653 & 220 & $\mathrm{~L}$ \\
\hline Dolomite & $\mathrm{CaMg}\left(\mathrm{CO}_{3}\right)_{2}$ & -517980 & -517760 & 220 & L \\
\hline Gehlenite & $\mathrm{Ca}_{2} \mathrm{Al}_{2} \mathrm{SiO}_{7}$ & -903588 & -903148 & 220 & $\mathrm{~L}$ \\
\hline Grossular & $\mathrm{Ca}_{3} \mathrm{Al}_{2} \mathrm{Si}_{3} \mathrm{O}_{12}$ & -1496967 & -1496307 & 220 & $\mathrm{~L}$ \\
\hline Andradite & $\mathrm{Ca}_{3} \mathrm{Fe}_{2} \mathrm{Si}_{3} \mathrm{O}_{12}$ & -1297479 & -1296819 & 220 & $\mathrm{~L}$ \\
\hline Monticellite & $\mathrm{CaMgSiO}_{4}$ & -512829 & -512829 & 0 & $\mathrm{NL}$ \\
\hline Merwinite & $\mathrm{Ca}_{3} \mathrm{Mg}\left(\mathrm{SiO}_{4}\right)_{2}$ & -1037186 & -1036526 & 220 & $\mathrm{~L}$ \\
\hline Akermanite & $\mathrm{Ca}_{2} \mathrm{MgSi}_{2} \mathrm{O}_{7}$ & -879802 & -879362 & 220 & $\mathrm{~L}$ \\
\hline Clinozoisite & $\mathrm{Ca}_{2} \mathrm{Al}_{3} \mathrm{Si}_{3} \mathrm{O}_{12}(\mathrm{OH})$ & -1549680 & -1549240 & 220 & $\mathrm{~L}$ \\
\hline Zoisite & $\mathrm{Ca}_{2} \mathrm{Al}_{3} \mathrm{Si}_{3} \mathrm{O}_{12}(\mathrm{OH})$ & -1549619 & -1549179 & 220 & $\mathrm{~L}$ \\
\hline Ordered Epidote & $\mathrm{Ca}_{2} \mathrm{FeAl}_{2} \mathrm{Si}_{3} \mathrm{O}_{12}(\mathrm{OH})$ & -1451346 & -1450906 & 220 & $\mathrm{~L}$ \\
\hline Epidote & $\mathrm{Ca}_{2} \mathrm{FeAl}_{2} \mathrm{Si}_{3} \mathrm{O}_{12}(\mathrm{OH})$ & -1451346 & -1450906 & 220 & $\mathrm{~L}$ \\
\hline Lawsonite & $\mathrm{CaAl}_{2} \mathrm{Si}_{2} \mathrm{O}_{7}(\mathrm{OH})_{2} \cdot \mathrm{H}_{2} \mathrm{O}$ & -1073628 & -1073408 & 220 & $\mathrm{~L}$ \\
\hline Wollastonite & $\mathrm{CaSiO}_{3}$ & -369445 & -369225 & 220 & L \\
\hline Ca-Al Pyroxene & $\mathrm{CaAl}_{2} \mathrm{SiO}_{6}$ & -742287 & -742067 & 220 & $\mathrm{~L}$ \\
\hline Diopside & $\mathrm{CaMg}\left(\mathrm{SiO}_{3}\right)_{2}$ & -724000 & -723780 & 220 & $\mathrm{~L}$ \\
\hline Tremolite & $\mathrm{Ca}_{2} \mathrm{Mg}_{5} \mathrm{Si}_{8} \mathrm{O}_{22}(\mathrm{OH})_{2}$ & -2770685 & -2770245 & 220 & $\mathrm{~L}$ \\
\hline Pargasite & $\mathrm{NaCa}_{2} \mathrm{Mg}_{4} \mathrm{Al}\left(\mathrm{Al}_{2} \mathrm{Si}_{6} \mathrm{O}_{22}\right)(\mathrm{OH})_{2}$ & -2847168 & -2846728 & 220 & $\mathrm{~L}$ \\
\hline Anorthite & $\mathrm{CaAl}_{2} \mathrm{Si}_{2} \mathrm{O}_{8}$ & -954298 & -954078 & 220 & $\mathrm{~L}$ \\
\hline Wairakite & $\mathrm{CaAl}_{2} \mathrm{Si}_{4} \mathrm{O}_{12} \cdot 2 \mathrm{H}_{2} \mathrm{O}$ & -1477652 & -1477432 & 220 & $\mathrm{~L}$ \\
\hline
\end{tabular}


Table 6-4. Differences in $\Delta \mathrm{G}_{\mathrm{f}}^{\circ}$ of Ca-Bearing Minerals Due for Updated $\mathrm{Ca}^{++}$Thermodynamic Properties (Continued)

\begin{tabular}{|c|c|c|c|c|c|}
\hline Mineral & Formula & $\Delta G_{\mathrm{f}}{ }^{\circ}(\mathrm{cal} / \mathrm{mol})$ & $\Delta \mathrm{G}_{\mathrm{f}}{ }^{\circ}(\mathrm{cal} / \mathrm{mol})$ & $\begin{array}{c}\text { Difference per } \\
\text { Ca in Formula } \\
\text { (cal/mol) }\end{array}$ & Comment \\
\hline Laumontite & $\mathrm{CaAl}_{2} \mathrm{Si}_{4} \mathrm{O}_{12} \cdot 4 \mathrm{H}_{2} \mathrm{O}$ & -1597043 & -1596823 & 220 & $\mathrm{~L}$ \\
\hline Prehnite & $\mathrm{Ca}_{2} \mathrm{Al}\left(\mathrm{AlSi}_{3} \mathrm{O}_{10}\right)(\mathrm{OH})_{2}$ & -1390537 & -1390097 & 220 & $\mathrm{~L}$ \\
\hline Margarite & $\mathrm{CaAl}_{2}\left(\mathrm{Al}_{2} \mathrm{Si}_{2} \mathrm{O}_{10}\right)(\mathrm{OH})_{2}$ & -1394370 & -1394150 & 220 & $\mathrm{~L}$ \\
\hline
\end{tabular}

Sources: Column 3: Helgeson et al. 1978 [DIRS 101596], Table 8, pp. 120-125.

Column 4: slop98.dat (DTN: MO0106MWDTDG01.035 [DIRS 161791]); data0.ymp.R0

(DTN: MO0009THRMODYN.001 [DIRS 152576]).

$\mathrm{NL}=$ Not linked to the calcite correction; $\mathrm{L}=$ Linked to the calcite correction; NS = Value based on newer solubility data.

\subsection{EVALUATION AND QUALIFICATION OF THERMODYNAMIC DATA FOR AQUEOUS SPECIES}

In this section, qualified $\log \mathrm{K}$ grids are presented for temperatures of $0.01^{\circ} \mathrm{C}, 25^{\circ} \mathrm{C}, 60^{\circ} \mathrm{C}$, $100^{\circ} \mathrm{C}, 150^{\circ} \mathrm{C}, 200^{\circ} \mathrm{C}, 250^{\circ} \mathrm{C}$, and $300^{\circ} \mathrm{C}$ as incorporated into the data0.ymp. $\mathrm{R} 2$ database (DTN: MO0302SPATHDYN.000 [DIRS 161756]) to model geochemical reactions for the YMP. These $\log \mathrm{K}$ grids were derived from thermodynamic data gathered from the literature and presented in Section 4 using data reduction methods presented in Section 6.1.2.

\subsubsection{Evaluation and Qualification of Np and Pu Species}

The OECD/NEA recently published the results of an extensive peer review of thermodynamic data for neptunium and plutonium (Lemire 2001 [DIRS 159027]). This panel gathered a wide range of peer review publications, government publications, and previous compilations of data. Using the techniques of corroborating data, peer review, and technical assessment, details of which are documented in the published book, the panel of internationally recognized scientists reached consensus on the best available thermodynamic data for neptunium and plutonium. The data in this publication are accepted by the scientific community as "established fact" and therefore do not require further qualification per AP-SIII.2Q.

The thermodynamic data published in Lemire (2001 [DIRS 159027]) were then processed using the methods discussed in Section 6.1 to develop EQ3/6 $\log \mathrm{K}$ grids. When possible, $\log \mathrm{K}$ values were derived for the temperature range from $0.01^{\circ} \mathrm{C}$ to $300^{\circ} \mathrm{C}(273.16 \mathrm{~K}$ to $573.15 \mathrm{~K})$ (the value of $0.01^{\circ} \mathrm{C}$ is used to represent $0^{\circ} \mathrm{C}$, avoiding singularity in the Maier-Kelly heat capacity equation). In many instances, data were only available for $25^{\circ} \mathrm{C}$, and temperature extrapolation was not possible. The resulting $\log \mathrm{K}$ grids for neptunium and plutonium aqueous species are shown in Table 6-5. 
Table 6-5. Log K EQ3/6 Grid for Neptunium and Plutonium Aqueous Species

\begin{tabular}{|c|c|c|c|c|c|c|c|c|c|}
\hline Data0 Species Designation & Reaction & $\begin{array}{r}\log \mathrm{K} \\
0.01^{\circ} \mathrm{C} \\
\end{array}$ & $\begin{array}{l}\log K \\
25^{\circ} \mathrm{C} \\
\end{array}$ & $\begin{array}{l}\log \mathrm{K} \\
60^{\circ} \mathrm{C} \\
\end{array}$ & $\begin{array}{l}\log \mathrm{K} \\
100^{\circ} \mathrm{C} \\
\end{array}$ & $\begin{array}{l}\log K \\
150^{\circ} \mathrm{C} \\
\end{array}$ & $\begin{array}{l}\log \mathrm{K} \\
200^{\circ} \mathrm{C} \\
\end{array}$ & $\begin{array}{l}\log K \\
250^{\circ} \mathrm{C} \\
\end{array}$ & $\begin{array}{l}\log \mathrm{K} \\
300^{\circ} \mathrm{C}\end{array}$ \\
\hline$\left(\mathrm{NpO}_{2}\right)_{2}(\mathrm{OH})_{2}^{++}$ & $\left(\mathrm{NpO}_{2}\right)_{2}(\mathrm{OH})_{2}^{++}+2 \mathrm{H}^{+}=2 \mathrm{NpO}_{2}^{++}+2 \mathrm{H}_{2} \mathrm{O}$ & - & 6.2700 & - & - & - & - & - & - \\
\hline$\left(\mathrm{NpO}_{2}\right)_{2} \mathrm{CO}_{3}(\mathrm{OH})_{3}^{-}$ & $\begin{array}{l}\left(\mathrm{NpO}_{2}\right)_{2} \mathrm{CO}_{3}(\mathrm{OH})_{3}^{-}+4 \mathrm{H}^{+}=2 \mathrm{NpO}_{2}^{++}+ \\
\mathrm{HCO}_{3}^{-}+3 \mathrm{H}_{2} \mathrm{O}\end{array}$ & - & 13.2180 & - & - & - & - & - & - \\
\hline$\left(\mathrm{NpO}_{2}\right)_{3}\left(\mathrm{CO}_{3}\right)_{6}^{(-6)}$ & $\begin{array}{l}\left(\mathrm{NpO}_{2}\right)_{3}\left(\mathrm{CO}_{3}\right)_{6}^{(-6)}+6 \mathrm{H}^{+}=3 \mathrm{NpO}_{2}^{++}+ \\
6 \mathrm{HCO}_{3}^{-}\end{array}$ & - & 12.2193 & - & - & - & - & - & - \\
\hline$\left(\mathrm{NpO}_{2}\right)_{3}(\mathrm{OH})_{5}^{+}$ & $\left(\mathrm{NpO}_{2}\right)_{3}(\mathrm{OH})_{5}^{+}+5 \mathrm{H}^{+}=3 \mathrm{NpO}_{2}^{++}+5 \mathrm{H}_{2} \mathrm{O}$ & - & 17.1200 & - & - & - & - & - & - \\
\hline$\left(\mathrm{UO}_{2}\right)_{2}\left(\mathrm{NpO}_{2}\right)\left(\mathrm{CO}_{3}\right)_{6}^{(-6)}$ & $\begin{array}{l}\left(\mathrm{UO}_{2}\right)_{2}\left(\mathrm{NpO}_{2}\right)\left(\mathrm{CO}_{3}\right)_{6}^{(-6)}+6 \mathrm{H}^{+}=2 \mathrm{UO}_{2}^{++}+ \\
\mathrm{NpO}_{2}^{++}+6 \mathrm{HCO}_{3}^{-}\end{array}$ & - & 8.4965 & - & - & - & - & - & - \\
\hline $\mathrm{Np}\left(\mathrm{CO}_{3}\right)_{3}{ }^{\cdots-}$ & $\mathrm{Np}\left(\mathrm{CO}_{3}\right)_{3}{ }^{\cdots-}+3 \mathrm{H}^{+}=\mathrm{Np}^{+++}+3 \mathrm{HCO}_{3}^{-}$ & - & 15.3709 & - & - & - & - & - & - \\
\hline $\mathrm{Np}\left(\mathrm{CO}_{3}\right)_{4}{ }^{\cdots \cdot-}$ & $\mathrm{Np}\left(\mathrm{CO}_{3}\right)_{4}^{\cdots+-}+4 \mathrm{H}^{+}=\mathrm{Np}^{++++}+4 \mathrm{HCO}_{3}^{-}$ & - & 4.6879 & - & - & - & - & - & - \\
\hline $\mathrm{Np}\left(\mathrm{CO}_{3}\right)_{5}^{(-6)}$ & $\mathrm{Np}\left(\mathrm{CO}_{3}\right)_{5}^{(-6)}+5 \mathrm{H}^{+}=\mathrm{Np}^{++++}+5 \mathrm{HCO}_{3}^{-}$ & - & 16.1014 & - & - & - & - & - & - \\
\hline $\mathrm{NpCl}^{+++}$ & $\mathrm{NpCl}^{+++}=\mathrm{Np}^{++++}+\mathrm{Cl}^{-}$ & - & -1.5000 & - & - & - & - & - & - \\
\hline $\mathrm{NpF}^{+++}$ & $\mathrm{NpF}^{+++}=\mathrm{Np}^{++++}+\mathrm{F}^{-}$ & -8.9464 & -8.9202 & -9.0057 & -9.1891 & -9.5059 & -9.9165 & -10.4436 & -11.1428 \\
\hline $\mathrm{NpF}_{2}^{++}$ & $\mathrm{NpF}_{2}^{++}=\mathrm{Np}^{++++}+2 \mathrm{~F}^{-}$ & - & -15.7000 & - & - & - & - & - & - \\
\hline $\mathrm{Npl}^{+++}$ & $\mathrm{Npl}^{+++}=\mathrm{Np}^{++++}+\mathrm{I}^{-}$ & - & -1.5000 & - & - & - & - & - & - \\
\hline $\mathrm{NpNO}_{3}{ }^{+++}$ & $\mathrm{NpNO}_{3}{ }^{+++}=\mathrm{Np}^{++++}+\mathrm{NO}_{3}^{-}$ & - & -1.9000 & - & - & - & - & - & - \\
\hline $\mathrm{NpO}_{2}\left(\mathrm{CO}_{3}\right)_{2}{ }^{--}$ & $\mathrm{NpO}_{2}\left(\mathrm{CO}_{3}\right)_{2}^{--}+2 \mathrm{H}^{+}=\mathrm{NpO}_{2}^{++}+2 \mathrm{HCO}_{3}^{-}$ & - & 4.1703 & - & - & - & - & - & - \\
\hline $\mathrm{NpO}_{2}\left(\mathrm{CO}_{3}\right)_{2}{ }^{\cdots-\cdot}$ & $\mathrm{NpO}_{2}\left(\mathrm{CO}_{3}\right)_{2}^{-\cdots}+2 \mathrm{H}^{+}=\mathrm{NpO}_{2}^{+}+2 \mathrm{HCO}_{3}^{-}$ & - & 14.1528 & - & - & - & - & - & - \\
\hline $\mathrm{NpO}_{2}\left(\mathrm{CO}_{3}\right)_{2} \mathrm{OH}^{\cdots \cdot \cdot}$ & $\begin{array}{l}\mathrm{NpO}_{2}\left(\mathrm{CO}_{3}\right)_{2} \mathrm{OH}^{-\cdots}+3 \mathrm{H}^{+}=\mathrm{NpO}_{2}^{++}+ \\
2 \mathrm{HCO}_{3}^{-}+\mathrm{H}_{2} \mathrm{O}\end{array}$ & - & 26.0003 & - & - & - & - & - & - \\
\hline $\mathrm{NpO}_{2}\left(\mathrm{CO}_{3}\right)_{3} \cdots$ & $\begin{array}{l}\mathrm{NpO}_{2}\left(\mathrm{CO}_{3}\right)_{3}{ }^{-\cdots}+3 \mathrm{H}^{+}=\mathrm{NpO}_{2}^{++}+ \\
3 \mathrm{HCO}_{3}^{-}\end{array}$ & 11.7234 & 11.6593 & 11.6647 & 11.7893 & 12.0773 & 12.4781 & 12.9816 & 13.6214 \\
\hline $\mathrm{NpO}_{2}\left(\mathrm{CO}_{3}\right)_{3}{ }^{(-5)}$ & $\mathrm{NpO}_{2}\left(\mathrm{CO}_{3}\right)_{3}{ }^{(-5)}+3 \mathrm{H}^{+}=\mathrm{NpO}_{2}^{+}+3 \mathrm{HCO}_{3}^{-}$ & 26.1033 & 25.5302 & 25.0683 & 24.8778 & 24.9913 & 25.3997 & 26.0739 & 27.0833 \\
\hline
\end{tabular}


Table 6-5. Log K EQ3/6 Grid for Neptunium and Plutonium Aqueous Species (Continued)

\begin{tabular}{|c|c|c|c|c|c|c|c|c|c|}
\hline Data0 Species Designation & Reaction & $\begin{array}{l}\log K \\
0.01^{\circ} \mathrm{C}\end{array}$ & $\begin{array}{l}\log K \\
25^{\circ} \mathrm{C}\end{array}$ & $\begin{array}{l}\log K \\
60^{\circ} \mathrm{C}\end{array}$ & $\begin{array}{l}\log K \\
100^{\circ} \mathrm{C}\end{array}$ & $\begin{array}{l}\log K \\
150^{\circ} \mathrm{C}\end{array}$ & $\begin{array}{l}\log K \\
200^{\circ} \mathrm{C}\end{array}$ & $\begin{array}{l}\log K \\
250^{\circ} \mathrm{C}\end{array}$ & $\begin{array}{l}\log K \\
300^{\circ} \mathrm{C}\end{array}$ \\
\hline $\mathrm{NpO}_{2}\left(\mathrm{HPO}_{4}\right)_{2}{ }^{--}$ & $\mathrm{NpO}_{2}\left(\mathrm{HPO}_{4}\right)_{2}{ }^{--}=\mathrm{NpO}_{2}^{++}+2 \mathrm{HPO}_{4}{ }^{--}$ & - & -9.5000 & - & - & - & - & - & - \\
\hline $\mathrm{NpO}_{2}(\mathrm{OH})_{2}^{-}$ & $\mathrm{NpO}_{2}(\mathrm{OH})_{2}^{-}+2 \mathrm{H}^{+}=\mathrm{NpO}_{2}^{+}+2 \mathrm{H}_{2} \mathrm{O}$ & 25.5045 & 23.6147 & 21.4199 & 19.4099 & 17.4475 & 15.9411 & 14.7957 & 13.9864 \\
\hline $\mathrm{NpO}_{2}\left(\mathrm{SO}_{4}\right)_{2}{ }^{--}$ & $\mathrm{NpO}_{2}\left(\mathrm{SO}_{4}\right)_{2}{ }^{--}=\mathrm{NpO}_{2}^{++}+2 \mathrm{SO}_{4}^{--}$ & -4.2153 & -4.5406 & -5.1435 & -5.8895 & -6.8628 & -7.9061 & -9.0919 & -10.5738 \\
\hline $\mathrm{NpO}_{2} \mathrm{Cl}^{+}$ & $\mathrm{NpO}_{2} \mathrm{Cl}^{+}=\mathrm{NpO}^{++}+\mathrm{Cl}^{-}$ & - & -0.4000 & - & - & - & - & \begin{tabular}{|c|}
- \\
\end{tabular} & - \\
\hline $\mathrm{NpO}_{2} \mathrm{CO}_{3}^{-}$ & $\mathrm{NpO}_{2} \mathrm{CO}_{3}{ }^{-}+\mathrm{H}^{+}=\mathrm{NpO}_{2}^{+}+\mathrm{HCO}_{3}^{-}$ & - & 5.3814 & - & - & - & - & - & - \\
\hline $\mathrm{NpO}_{2} \mathrm{CO}_{3}(\mathrm{aq})$ & $\mathrm{NpO}_{2} \mathrm{CO}_{3}(\mathrm{aq})+\mathrm{H}^{+}=\mathrm{NpO}_{2}{ }^{++}+\mathrm{HCO}_{3}^{-}$ & - & 1.0229 & - & - & - & - & - & - \\
\hline $\mathrm{NpO}_{2} \mathrm{~F}(\mathrm{aq})$ & $\mathrm{NpO}_{2} \mathrm{~F}(\mathrm{aq})=\mathrm{NpO}_{2}^{+}+\mathrm{F}^{-}$ & - & -1.2000 & - & - & - & - & - & - \\
\hline $\mathrm{NpO}_{2} \mathrm{~F}^{+}$ & $\mathrm{NpO}_{2} \mathrm{~F}^{+}=\mathrm{NpO}_{2}^{++}+\mathrm{F}^{-}$ & - & -4.5700 & - & - & - & - & - & - \\
\hline $\mathrm{NpO}_{2} \mathrm{~F}_{2}(\mathrm{aq})$ & $\mathrm{NpO}_{2} \mathrm{~F}_{2}(\mathrm{aq})=\mathrm{NpO}_{2}^{++}+2 \mathrm{~F}^{-}$ & - & -7.6000 & - & - & - & - & - & - \\
\hline $\mathrm{NpO}_{2} \mathrm{H}_{2} \mathrm{PO}_{4}^{+}$ & $\mathrm{NpO}_{2} \mathrm{H}_{2} \mathrm{PO}_{4}^{+}=\mathrm{NpO}_{2}^{++}+\mathrm{H}^{+}+\mathrm{HPO}_{4}^{--}$ & - & -11.7320 & - & - & - & - & - & - \\
\hline $\mathrm{NpO}_{2} \mathrm{HPO}_{4}^{-}$ & $\mathrm{NpO}_{2} \mathrm{HPO}_{4}^{-}=\mathrm{NpO}_{2}^{+}+\mathrm{HPO}_{4}^{--}$ & - & -2.9500 & - & - & - & - & - & - \\
\hline $\mathrm{NpO}_{2} \mathrm{HPO}_{4}(\mathrm{aq})$ & $\mathrm{NpO}_{2} \mathrm{HPO}_{4}(\mathrm{aq})=\mathrm{NpO}_{2}^{++}+\mathrm{HPO}_{4}^{--}$ & - & -6.2000 & - & - & - & - & - & - \\
\hline $\mathrm{NpO}_{2} \mathrm{IO}_{3}(\mathrm{aq})$ & $\mathrm{NpO}_{2} \mathrm{IO}_{3}(\mathrm{aq})=\mathrm{NpO}_{2}^{+}+\mathrm{IO}_{3}^{-}$ & - & -0.5000 & - & - & - & - & - & - \\
\hline $\mathrm{NpO}_{2} \mathrm{IO}_{3}^{+}$ & $\mathrm{NpO}_{2} \mathrm{IO}_{3}^{+}=\mathrm{NpO}_{2}^{++}+\mathrm{IO}_{3}^{-}$ & - & -1.2000 & - & - & - & - & - & - \\
\hline $\mathrm{NpO}_{2} \mathrm{OH}(\mathrm{aq})$ & $\mathrm{NpO}_{2} \mathrm{OH}(\mathrm{aq})+\mathrm{H}^{+}=\mathrm{NpO}_{2}^{+}+\mathrm{H}_{2} \mathrm{O}$ & 12.3159 & 11.3072 & 10.0823 & 8.9121 & 7.7057 & 6.7012 & 5.8331 & 5.0502 \\
\hline $\mathrm{NpO}_{2} \mathrm{OH}^{+}$ & $\mathrm{NpO}_{2} \mathrm{OH}^{+}+\mathrm{H}^{+}=\mathrm{NpO}_{2}^{++}+\mathrm{H}_{2} \mathrm{O}$ & - & 5.1000 & - & - & - & - & - & - \\
\hline $\mathrm{NpO}_{2} \mathrm{SO}_{4}^{-}$ & $\mathrm{NpO}_{2} \mathrm{SO}_{4}^{-}=\mathrm{NpO}_{2}^{+}+\mathrm{SO}_{4}^{--}$ & -0.0950 & -0.3604 & -0.9237 & -1.6673 & -2.6546 & -3.6824 & -4.7698 & -5.9887 \\
\hline $\mathrm{NpO}_{2} \mathrm{SO}_{4}(\mathrm{aq})$ & $\mathrm{NpO}_{2} \mathrm{SO}_{4}(\mathrm{aq})=\mathrm{NpO}_{2}^{++}+\mathrm{SO}_{4}^{--}$ & -3.0004 & -3.2004 & -3.6011 & -4.1338 & -4.8842 & -5.7501 & -6.7969 & -8.1732 \\
\hline $\mathrm{Np}\left(\mathrm{SO}_{4}\right)_{2}(\mathrm{aq})$ & $\mathrm{Np}\left(\mathrm{SO}_{4}\right)_{2}(\mathrm{aq})=\mathrm{Np}^{++++}+2 \mathrm{SO}_{4}^{--}$ & -10.1808 & -10.8937 & -12.1427 & -13.6900 & -15.7423 & -17.9799 & -20.5442 & -23.7254 \\
\hline $\mathrm{Np}(\mathrm{SCN})^{+++}$ & $\mathrm{Np}(\mathrm{SCN})^{+++}=\mathrm{Np}^{++++}+\mathrm{SCN}^{-}$ & -3.1668 & -3.0031 & -2.9306 & -2.9697 & -3.1445 & -3.4432 & -3.8796 & -4.5041 \\
\hline $\mathrm{Np}(\mathrm{SCN})_{2}^{++}$ & $\mathrm{Np}(\mathrm{SCN})_{2}^{++}=\mathrm{Np}^{++++}+2 \mathrm{SCN}^{-}$ & -4.3131 & -4.1062 & -4.0096 & -4.0596 & -4.3086 & -4.7634 & -5.4699 & -6.5496 \\
\hline $\mathrm{Np}(\mathrm{SCN})_{3}{ }^{+}$ & $\mathrm{Np}(\mathrm{SCN})_{3}{ }^{+}=\mathrm{Np}^{++++}+3 \mathrm{SCN}^{-}$ & -5.1615 & -4.8091 & -4.7234 & -4.9336 & -5.5376 & -6.5209 & -7.9941 & -10.2561 \\
\hline $\mathrm{NpOH}^{++}$ & $\mathrm{NpOH}^{++}+\mathrm{H}^{+}=\mathrm{Np}^{+++}+\mathrm{H}_{2} \mathrm{O}$ & - & 6.8000 & - & - & - & - & - & - \\
\hline $\mathrm{NpOH}^{+++}$ & $\mathrm{NpOH}^{+++}+\mathrm{H}^{+}=\mathrm{Np}^{++++}+\mathrm{H}_{2} \mathrm{O}$ & - & 0.2900 & - & - & - & - & - & - \\
\hline $\mathrm{NpSO}_{4}^{++}$ & $\mathrm{NpSO}_{4}^{++}=\mathrm{Np}^{++++}+\mathrm{SO}_{4}^{--}$ & -6.3493 & -6.7719 & -7.3983 & -8.1085 & -9.0072 & -9.9744 & -11.0953 & -12.5171 \\
\hline$\left(\mathrm{PuO}_{2}\right)_{2}(\mathrm{OH})_{2}^{++}$ & $\left(\mathrm{PuO}_{2}\right)_{2}(\mathrm{OH})_{2}^{++}+2 \mathrm{H}^{+}=2 \mathrm{PuO}_{2}^{++}+2 \mathrm{H}_{2} \mathrm{O}$ & - & 7.5000 & - & - & - & - & - & - \\
\hline$\left(\mathrm{PuO}_{2}\right)_{3}\left(\mathrm{CO}_{3}\right)_{6}^{(-6)}$ & $\begin{array}{l}\left(\mathrm{PuO}_{2}\right)_{3}\left(\mathrm{CO}_{3}\right)_{6}^{(-6)}+6 \mathrm{H}^{+}=3 \mathrm{PuO}_{2}^{++}+ \\
6 \mathrm{HCO}_{3}^{-}\end{array}$ & - & 11.9600 & - & - & - & - & - & - \\
\hline
\end{tabular}


Table 6-5. Log K EQ3/6 Grid for Neptunium and Plutonium Aqueous Species (Continued)

\begin{tabular}{|c|c|c|c|c|c|c|c|c|c|}
\hline Data0 Species Designation & Reaction & $\begin{array}{r}\log \mathrm{K} \\
0.01^{\circ} \mathrm{C} \\
\end{array}$ & $\begin{array}{l}\log K \\
25^{\circ} \mathrm{C} \\
\end{array}$ & $\begin{array}{l}\log \mathrm{K} \\
60^{\circ} \mathrm{C}\end{array}$ & $\begin{array}{l}\log K \\
100^{\circ} \mathrm{C}\end{array}$ & $\begin{array}{l}\log K \\
150^{\circ} \mathrm{C}\end{array}$ & $\begin{array}{l}\log K \\
200^{\circ} \mathrm{C}\end{array}$ & $\begin{array}{l}\log K \\
250^{\circ} \mathrm{C} \\
\end{array}$ & $\begin{array}{l}\log \mathrm{K} \\
300^{\circ} \mathrm{C}\end{array}$ \\
\hline$\left(\mathrm{UO}_{2}\right)_{2}\left(\mathrm{PuO}_{2}\right)\left(\mathrm{CO}_{3}\right)_{6}^{(-6)}$ & $\begin{array}{l}\left(\mathrm{UO}_{2}\right)_{2}\left(\mathrm{PuO}_{2}\right)\left(\mathrm{CO}_{3}\right)_{6}^{(-6)}+6 \mathrm{H}^{+}=2 \mathrm{UO}_{2}{ }^{++}+ \\
\mathrm{PuO}_{2}^{++}+6 \mathrm{HCO}_{3}^{-}\end{array}$ & 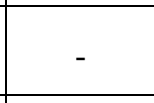 & 9.3821 & - & - & - & - & - & - \\
\hline $\mathrm{Pu}\left(\mathrm{SO}_{4}\right)_{2}^{-}$ & $\mathrm{Pu}\left(\mathrm{SO}_{4}\right)_{2}^{-}=\mathrm{Pu}^{+++}+2 \mathrm{SO}_{4}^{--}$ & -5.4444 & -5.5436 & -5.8876 & -6.4087 & -7.2038 & -8.1883 & -9.4577 & -11.2236 \\
\hline $\mathrm{Pu}\left(\mathrm{SO}_{4}\right)_{2}(\mathrm{aq})$ & $\mathrm{Pu}\left(\mathrm{SO}_{4}\right)_{2}(\mathrm{aq})=\mathrm{Pu}^{++++}+2 \mathrm{SO}_{4}{ }^{--}$ & - & -10.9837 & - & - & - & - & - & - \\
\hline $\mathrm{PuBr}^{+++}$ & $\mathrm{PuBr}^{+++}=\mathrm{Pu}^{++++}+\mathrm{Br}^{-}$ & - & -1.6000 & - & - & - & - & - & - \\
\hline $\mathrm{PuCl}^{++}$ & $\mathrm{PuCl}^{++}=\mathrm{Pu}^{+++}+\mathrm{Cl}^{-}$ & - & -1.2000 & - & - & - & - & - & - \\
\hline $\mathrm{PuCl}^{++}$ & $\mathrm{PuCl}^{+++}=\mathrm{Pu}^{++++}+\mathrm{Cl}^{-}$ & - & -1.8000 & - & - & - & - & - & - \\
\hline $\mathrm{PuF}^{+++}$ & $\mathrm{PuF}^{+++}=\mathrm{Pu}^{++++}+\mathrm{F}^{-}$ & -8.7046 & -8.8002 & -9.0256 & -9.3367 & -9.7792 & -10.2890 & -10.8962 & -11.6616 \\
\hline $\mathrm{PuF}_{2}^{++}$ & $\mathrm{PuF}_{2}^{++}=\mathrm{Pu}^{++++}+2 \mathrm{~F}^{-}$ & -15.5043 & -15.6206 & -15.8952 & -16.2842 & -16.8667 & -17.5846 & -18.5039 & -19.7593 \\
\hline $\mathrm{PuH}_{3} \mathrm{PO}_{4}^{++++}$ & $\mathrm{PuH}_{3} \mathrm{PO}_{4}^{++++}=\mathrm{Pu}^{++++}+\mathrm{HPO}_{4}^{--}+2 \mathrm{H}^{+}$ & - & -12.9512 & - & - & - & - & - & - \\
\hline $\mathrm{Pul}^{++}$ & $\mathrm{Pul}^{++}=\mathrm{Pu}^{+++}+\mathrm{I}^{-}$ & - & -1.1000 & - & - & - & - & - & - \\
\hline $\mathrm{PuNO}_{3}{ }^{+++}$ & $\mathrm{PuNO}_{3}{ }^{+++}=\mathrm{Pu}^{++++}+\mathrm{NO}_{3}^{-}$ & - & -1.9500 & - & - & - & - & - & - \\
\hline $\mathrm{PuO}_{2}\left(\mathrm{CO}_{3}\right)_{2}^{--}$ & $\mathrm{PuO}_{2}\left(\mathrm{CO}_{3}\right)_{2}{ }^{--}+2 \mathrm{H}^{+}=\mathrm{PuO}_{2}^{++}+2 \mathrm{HCO}_{3}^{-}$ & 6.2444 & 6.1866 & 6.1725 & 6.2329 & 6.3787 & 6.5629 & 6.7540 & 6.9248 \\
\hline $\left.\mathrm{PuO}_{2}\left(\mathrm{CO}_{3}\right)_{3}\right)^{\cdots-}$ & $\begin{array}{l}\mathrm{PuO}_{2}\left(\mathrm{CO}_{3}\right)_{3} \cdots+\cdot 3 \mathrm{H}^{+}=\mathrm{PuO}_{2}^{+++}+ \\
3 \mathrm{HCO}_{3}^{-}\end{array}$ & 13.4332 & 13.3301 & 13.2568 & 13.2671 & 13.3616 & 13.4842 & 13.5686 & 13.5195 \\
\hline $\mathrm{PuO}_{2}\left(\mathrm{CO}_{3}\right)_{3}{ }^{(-5)}$ & $\mathrm{PuO}_{2}\left(\mathrm{CO}_{3}\right)_{3}{ }^{(-5)}+3 \mathrm{H}^{+}=\mathrm{PuO}_{2}^{+}+3 \mathrm{HCO}_{3}{ }^{-}$ & 26.4092 & 26.0048 & 25.5405 & 25.1164 & 24.6992 & 24.3701 & 24.1039 & 23.8841 \\
\hline $\mathrm{PuO}_{2}(\mathrm{OH})_{2}(\mathrm{aq})$ & $\mathrm{PuO}_{2}(\mathrm{OH})_{2}(\mathrm{aq})+2 \mathrm{H}^{+}=\mathrm{PuO}_{2}^{++}+2 \mathrm{H}_{2} \mathrm{O}$ & - & 13.2000 & - & - & - & - & - & - \\
\hline $\mathrm{PuO}_{2}\left(\mathrm{SO}_{4}\right)_{2}{ }^{--}$ & $\mathrm{PuO}_{2}\left(\mathrm{SO}_{4}\right)_{2}{ }^{--}=\mathrm{PuO}_{2}^{++}+2 \mathrm{SO}_{4}{ }^{--}$ & -3.6429 & -4.2407 & -5.1565 & -6.1882 & -7.4427 & -8.7078 & -10.0728 & -11.7028 \\
\hline $\mathrm{PuO}_{2} \mathrm{Cl}^{+}$ & $\mathrm{PuO}_{2} \mathrm{Cl}^{+}=\mathrm{PuO}_{2}^{++}+\mathrm{Cl}^{-}$ & - & -0.7000 & \begin{tabular}{|l|}
- \\
\end{tabular} & - & - & - & - & - \\
\hline $\mathrm{PuO}_{2} \mathrm{Cl}_{2}(\mathrm{aq})$ & $\mathrm{PuO}_{2} \mathrm{Cl}_{2}(\mathrm{aq})=\mathrm{PuO}_{2}^{++}+2 \mathrm{Cl}^{-}$ & - & 0.6000 & - & - & - & - & - & - \\
\hline $\mathrm{PuO}_{2} \mathrm{CO}_{3}^{-}$ & $\mathrm{PuO}_{2} \mathrm{CO}_{3}^{-}+\mathrm{H}^{+}=\mathrm{PuO}_{2}^{+}+\mathrm{HCO}_{3}^{-}$ & - & 5.2234 & - & - & - & - & - & - \\
\hline $\mathrm{PuO}_{2} \mathrm{CO}_{3}(\mathrm{aq})$ & $\mathrm{PuO}_{2} \mathrm{CO}_{3}(\mathrm{aq})+\mathrm{H}^{+}=\mathrm{PuO}_{2}^{++}+\mathrm{HCO}_{3}^{-}$ & - & -1.2567 & - & - & - & - & - & - \\
\hline $\mathrm{PuO}_{2} \mathrm{~F}^{+}$ & $\mathrm{PuO}_{2} \mathrm{~F}^{+}=\mathrm{PuO}_{2}^{++}+\mathrm{F}^{-}$ & - & -4.5600 & - & - & - & - & - & - \\
\hline $\mathrm{PuO}_{2} \mathrm{~F}_{2}(\mathrm{aq})$ & $\mathrm{PuO}_{2} \mathrm{~F}_{2}(\mathrm{aq})=\mathrm{PuO}_{2}^{++}+2 \mathrm{~F}^{-}$ & - & -7.2500 & - & - & - & - & - & - \\
\hline $\mathrm{PuO}_{2} \mathrm{OH}(\mathrm{aq})$ & $\mathrm{PuO}_{2} \mathrm{OH}(\mathrm{aq})+\mathrm{H}^{+}=\mathrm{PuO}_{2}^{+}+\mathrm{H}_{2} \mathrm{O}$ & - & 9.7300 & - & - & - & - & - & - \\
\hline $\mathrm{PuO}_{2} \mathrm{OH}^{+}$ & $\mathrm{PuO}_{2} \mathrm{OH}^{+}+\mathrm{H}^{+}=\mathrm{PuO}_{2}^{++}+\mathrm{H}_{2} \mathrm{O}$ & 5.9780 & 5.5073 & 5.0185 & 4.6203 & 4.2718 & 4.0208 & 3.8200 & 3.6358 \\
\hline $\mathrm{PuO}_{2} \mathrm{SO}_{4}(\mathrm{aq})$ & $\mathrm{PuO}_{2} \mathrm{SO}_{4}(\mathrm{aq})=\mathrm{PuO}_{2}^{++}+\mathrm{SO}_{4}^{--}$ & -3.0878 & -3.3003 & -3.6596 & -4.0955 & -4.6821 & -5.3562 & -6.1948 & -7.3529 \\
\hline
\end{tabular}


Table 6-5. Log K EQ3/6 Grid for Neptunium and Plutonium Species (Continued)

\begin{tabular}{|c|c|c|c|c|c|c|c|c|c|}
\hline Data0 Species Designation & Reaction & $\begin{array}{c}\log \mathrm{K} \\
0.01^{\circ} \mathrm{C}\end{array}$ & $\begin{array}{l}\log \mathrm{K} \\
25^{\circ} \mathrm{C}\end{array}$ & $\begin{array}{l}\log \mathrm{K} \\
60^{\circ} \mathrm{C}\end{array}$ & $\begin{array}{l}\log \mathrm{K} \\
100^{\circ} \mathrm{C} \\
\end{array}$ & $\begin{array}{l}\log \mathrm{K} \\
150^{\circ} \mathrm{C} \\
\end{array}$ & $\begin{array}{l}\log \mathrm{K} \\
200^{\circ} \mathrm{C} \\
\end{array}$ & $\begin{array}{l}\log \mathrm{K} \\
250^{\circ} \mathrm{C} \\
\end{array}$ & $\begin{array}{l}\log \mathrm{K} \\
300^{\circ} \mathrm{C}\end{array}$ \\
\hline $\mathrm{PuOH}^{++}$ & $\mathrm{PuOH}^{++}+\mathrm{H}^{+}=\mathrm{Pu}^{+++}+\mathrm{H}_{2} \mathrm{O}$ & - & 6.9000 & - & - & - & - & - & - \\
\hline $\mathrm{PuOH}^{+++}$ & $\mathrm{PuOH}^{+++}+\mathrm{H}^{+}=\mathrm{Pu}^{++++}+\mathrm{H}_{2} \mathrm{O}$ & 1.3638 & 0.7872 & 0.1266 & -0.4703 & -1.0585 & -1.5380 & -1.9561 & -2.3367 \\
\hline $\mathrm{PuSCN}^{++}$ & $\mathrm{PuSCN}^{++}=\mathrm{Pu}^{+++}+\mathrm{SCN}^{-}$ & - & -1.3000 & - & - & - & - & - & - \\
\hline $\mathrm{PuSO}_{4}{ }^{+}$ & $\mathrm{PuSO}_{4}^{+}=\mathrm{Pu}^{+++}+\mathrm{SO}_{4}{ }^{--}$ & -3.6010 & -3.8318 & -4.2121 & -4.6676 & -5.2743 & -5.9659 & -6.8203 & -7.9921 \\
\hline $\mathrm{PuSO}_{4}^{++}$ & $\mathrm{PuSO}_{4}^{++}=\mathrm{Pu}^{++++}+\mathrm{SO}_{4}{ }^{--}$ & - & -6.8119 & - & - & - & - & - & - \\
\hline
\end{tabular}

DTN: MO0302SPATHDYN.001 ([DIRS 161886], Spreadsheets Np_25C_aquSpeRXN.xls, AqueousSpecies_j_TJW_1.xIs, Pu_25C_aquSpeRXN.xIs, and AqueousSpecies_j_YC_Pu.XIs).

NOTE: For information about specific spreadsheets used to generate these calculations, see the data0.ymp.R2 database (DTN: MO0302SPATHDYN.000 [DIRS 161756]). 


\subsubsection{Evaluation and Qualification of Other Species}

Based on isocoulombic/isoelectric spreadsheet calculations, the $\log \mathrm{K}$ grid for EQ3/6 input for secondary (redox) species for actinides was calculated (Table 6-5). The Am data were taken from Silva et al. (1995 [DIRS 102087]) and the Np and Pu data were taken from the OECD/NEA $\mathrm{Np}$ and $\mathrm{Pu}$ volume (Lemire 2001 [DIRS 159027]). Log K grids were also calculated for titanium hydrolysis species using data taken from Knauss et al. (2001 [DIRS 158998]). The results summarized in Knauss et al. (2001 [DIRS 158998]) for $\mathrm{Ti}(\mathrm{OH})_{3}{ }^{+}$and $\mathrm{Ti}(\mathrm{OH})_{5}{ }^{-}$were not all mutually consistent, thus these species were treated as follows. The primary results were $\log \mathrm{K}$ values for $\mathrm{TiO}_{2}$ (rutile) solubility (in three $\mathrm{pH}$ ranges corresponding to dominance by each of the three aqueous species) at $100^{\circ} \mathrm{C}, 150^{\circ} \mathrm{C}, 200^{\circ} \mathrm{C}, 250^{\circ} \mathrm{C}$, and $300^{\circ} \mathrm{C}$. Also provided were three-parameter temperature functions for the $\log \mathrm{Ks}$ and two-parameter or constant enthalpy extrapolations of reaction properties at $298.15 \mathrm{~K}$. The authors warned that the three-parameter temperature functions were over-fits (fitting function detail not fully supported by the discrete values). The approach taken for data0.ymp.R2 (DTN: MO0302SPATHDYN.000 [DIRS 161756]) was to use the grid of $\log \mathrm{K}$ values for each species, create a solubility reaction that was isocoulombic/isoelectric, and use the Excel Regression Tool to fit the requisite 298.15K reaction properties (Gibbs free energy of reaction, entropy of reaction) to fit that $\log \mathrm{K}$ grid. The desired species properties at $298.15 \mathrm{~K}$ were then extracted and used in a normal isocoulombic/isoelectric temperature extrapolation to obtain the needed apparent Gibbs free energy grid for the species. Then, the $\log \mathrm{K}$ grid (Table 6-6) for the EQ3/6 reaction is obtained as described in Section 6.1.1.

Knauss et al. (2001 [DIRS 158998]) also provided calculation of reference state thermodynamic data at $25^{\circ} \mathrm{C}$ of several reactions representing the equilibria between Ti-hydroxy complexes and rutile solubility. These values are based on thermodynamic data developed from experimental studies and from other rutile solubility investigations (e.g., Ziemniak et al. 1993 [DIRS 172325]). Stefánsson (2001 [DIRS 159208]) evaluated thermodynamic data for Ti-hydroxy complexes from hydrolysis constants given by Baes and Mesmer (1976 [DIRS 157860]) in combination with thermodynamic properties of rutile given by Robie and Hemingway (1995 [DIRS 153683]) and thermodynamic data for $\mathrm{H}_{2} \mathrm{O}$ equivalent to that present in speq02.dat (DTN: MO0303SPASPEQ2.000 [DIRS 162278]) or data0.ymp.R2 (DTN: MO0302SPATHDYN.000 [DIRS 161756]). All these data comparisons at reference state for given reactions are given in Table 6-7.

Notice that the differences in the estimates for the $\log \mathrm{K}$ of reaction $\mathrm{Ti}(\mathrm{OH})_{3}{ }^{+}+\mathrm{H}_{2} \mathrm{O}=$ $\mathrm{Ti}(\mathrm{OH})_{4}(\mathrm{aq})+\mathrm{H}^{+}$at $25^{\circ} \mathrm{C}$ are in good agreement with values obtained using thermodynamic data from other sources (e.g., Ziemniak et al. 1993 [DIRS 172325]); Stefánsson 2001 [DIRS 159208]) establishing confidence in the adopted source Knauss et al. (2001 [DIRS 158998]) through data corroboration. The extrapolation to $298.15 \mathrm{~K}\left(25^{\circ} \mathrm{C}\right)$ for this reaction as described above generates a $\log \mathrm{K}$ value of -1.2859 (Table 6-6) which is larger than those listed in Table 6-7. The range of estimated Gibbs free energies of formation for these complexes reported by various sources (see discussion by Stefánsson 2001 [DIRS 159208], p. 235) can produce differences in $\log \mathrm{K}$ values of approximately 0.6 to $1.1 \log \mathrm{K}$ units.

Therefore, the extrapolation obtained using the isocoulombic/isoelectric method can be considered within the overall uncertainty bounds of the data. The experimental data of Knauss 
et al. (2001 [DIRS 158998]) were produced by workers recognized in the field of experimental geochemistry using laboratory techniques (analytical and experimental) that are considered highly appropriate for the retrieval of accurate solubility data at high temperatures and pressures.

Rutile $\left(\mathrm{TiO}_{2}\right)$ thermodynamic data were also updated in data0.ymp.R2 (DTN: MO0302SPATHDYN.000 [DIRS 161756]) to be consistent with thermodynamic properties of the Ti aqueous species used in this report. The calculations for the $\log \mathrm{K}$ grid of the rutile solubility reaction $\left(\mathrm{TiO}_{2}(\mathrm{~s})+2 \mathrm{H}_{2} \mathrm{O}=\mathrm{Ti}(\mathrm{OH})_{4}(\mathrm{aq})\right)$ (see Table 6-6) were computed in the Spreadsheet Minerals_j_ERP_rutile.xls (DTN: MO0302SPATHDYN.001 [DIRS 161886]). The thermodynamic properties of this phase are consistent with those reported by Robie and Hemingway (1995 [DIRS 153683], p. 222) and those adopted by Stefánsson (2001 [DIRS 159208], p. 235), therefore qualifying the data for use in the YMP. However, the $\log \mathrm{K}$ values for the same rutile solubility reaction present in data0.ymp.R0 (DTN: MO0009THRMODYN.001 [DIRS 152576]) are different from those in data0.ymp.R2 (DTN: MO0302SPATHDYN.000 [DIRS 161756]). A possible reason for this discrepancy is the thermodynamic property values for $\mathrm{Ti}(\mathrm{OH})_{4}(\mathrm{aq})$ that were adopted in data0.ymp.R0 (DTN: MO0009THRMODYN.001 [DIRS 152576]). 
Table 6-6. Log K EQ3/6 Grids for Actinide Redox Species and Titanium Species

\begin{tabular}{|c|c|c|c|c|c|c|c|c|c|}
\hline \multirow[b]{2}{*}{ Species } & \multirow[b]{2}{*}{ Reaction } & \multicolumn{8}{|c|}{ Temperature $\left({ }^{\circ} \mathrm{C}\right)$} \\
\hline & & 0.01 & 25 & 60 & 100 & 150 & 200 & 250 & 300 \\
\hline \multicolumn{10}{|c|}{ Secondary Basis Species (Redox) } \\
\hline $\mathrm{Am}^{++} \quad \mathrm{a}$ & $\mathrm{Am}^{++}+\mathrm{H}^{+}+0.25 \mathrm{O}_{2}(\mathrm{~g})=\mathrm{Am}^{+++}+0.5 \mathrm{H}_{2} \mathrm{O}$ & 66.1230 & 59.6550 & 52.1783 & 45.3165 & 38.5253 & 33.1271 & 28.7110 & 25.0128 \\
\hline $\mathrm{Am}^{+++} \quad \mathrm{a}$ & $\begin{array}{l}\mathrm{Am}^{++++}+0.5 \mathrm{H}_{2} \mathrm{O}=\mathrm{Am}^{+++}+\mathrm{H}^{+}+ \\
0.25 \mathrm{O}_{2}(\mathrm{~g})\end{array}$ & 24.4899 & 23.4320 & 22.1496 & 20.9176 & 19.6484 & 18.6122 & 17.7614 & 17.0643 \\
\hline $\mathrm{AmO}_{2}^{+} \quad \mathrm{a}$ & $\mathrm{AmO}_{2}^{+}+2 \mathrm{H}^{+}=\mathrm{Am}^{+++}+0.5 \mathrm{O}_{2}(\mathrm{~g})+\mathrm{H}_{2} \mathrm{O}$ & 18.4277 & 16.8332 & 15.0507 & 13.4700 & 11.9471 & 10.7457 & 9.7386 & 8.8443 \\
\hline $\mathrm{AmO}_{2}^{++} \mathrm{a}$ & $\begin{array}{l}\mathrm{AmO}_{2}^{++}+\mathrm{H}^{+}=\mathrm{Am}^{+++}+0.75 \mathrm{O}_{2}(\mathrm{~g})+ \\
0.5 \mathrm{H}_{2} \mathrm{O}\end{array}$ & 24.7620 & 23.0358 & 21.0145 & 19.1413 & 17.2626 & 15.7368 & 14.4484 & 13.3263 \\
\hline $\mathrm{Np}^{+++} \quad \mathrm{b}$ & $\mathrm{Np}^{+++}+\mathrm{H}_{2} \mathrm{O}+0.5 \mathrm{O}_{2}(\mathrm{~g})=\mathrm{NpO}_{2}^{+}+2 \mathrm{H}^{+}$ & 30.2579 & 27.6311 & 24.5634 & 21.7116 & 18.8682 & 16.6225 & 14.8388 & 13.4272 \\
\hline $\mathrm{Np}^{++++} \quad \mathrm{b}$ & $\begin{array}{l}\mathrm{Np}^{++++}+1.5 \mathrm{H}_{2} \mathrm{O}+0.25 \mathrm{O}_{2}(\mathrm{~g})=\mathrm{NpO}_{2}^{+}+ \\
3 \mathrm{H}^{+}\end{array}$ & 10.3964 & 10.5500 & 10.6102 & 10.5572 & 10.4156 & 10.2690 & 10.1733 & 10.1622 \\
\hline $\mathrm{NpO}_{2}^{++} \mathrm{b}$ & $\begin{array}{l}\mathrm{NpO}_{2}^{++}+0.5 \mathrm{H}_{2} \mathrm{O}=\mathrm{NpO}_{2}^{+}+\mathrm{H}^{+}+ \\
0.25 \mathrm{O}_{2}(\mathrm{~g})\end{array}$ & -1.6314 & -1.1851 & -0.7603 & -0.4470 & -0.2064 & -0.0606 & 0.0386 & 0.1247 \\
\hline $\mathrm{Pu}^{+++} \quad{ }^{\mathrm{c}}$ & $\mathrm{Pu}^{+++}+\mathrm{H}_{2} \mathrm{O}+0.5 \mathrm{O}_{2}(\mathrm{~g})=\mathrm{PuO}_{2}^{+}+2 \mathrm{H}^{+}$ & 6.8918 & 6.3912 & 5.7651 & 5.1429 & 4.4937 & 3.9785 & 3.5945 & 3.3384 \\
\hline $\mathrm{Pu}^{++++} \quad \mathrm{c}$ & $\begin{array}{l}\mathrm{Pu}^{++++}+1.5 \mathrm{H}_{2} \mathrm{O}+0.25 \mathrm{O}_{2}(\mathrm{~g})=\mathrm{PuO}_{2}^{+}+ \\
3 \mathrm{H}^{+}\end{array}$ & 2.3229 & 3.3087 & 4.3247 & 5.1444 & 5.8616 & 6.3924 & 6.8445 & 7.2858 \\
\hline $\mathrm{PuO}_{2}^{++} \mathrm{c}$ & $\begin{array}{l}\mathrm{PuO}_{2}^{++}+0.5 \mathrm{H}_{2} \mathrm{O}=\mathrm{PuO}_{2}^{+}+\mathrm{H}^{+}+ \\
0.25 \mathrm{O}_{2}(\mathrm{~g})\end{array}$ & -5.8743 & -4.9576 & -3.9924 & -3.1857 & -2.4595 & -1.9308 & -1.5218 & -1.1800 \\
\hline \multicolumn{10}{|c|}{ Titanium Species } \\
\hline $\mathrm{Ti}(\mathrm{OH})_{3}^{+d}$ & $\mathrm{Ti}(\mathrm{OH})_{3}{ }^{+}+\mathrm{H}_{2} \mathrm{O}=\mathrm{Ti}(\mathrm{OH})_{4}(\mathrm{aq})+\mathrm{H}^{+}$ & -1.0332 & -1.2859 & -1.6528 & -2.0061 & -2.3452 & -2.5995 & -2.8028 & -2.9964 \\
\hline $\mathrm{Ti}(\mathrm{OH})_{5}^{-\mathrm{d}}$ & $\mathrm{Ti}(\mathrm{OH})_{5}{ }^{-}+\mathrm{H}^{+}=\mathrm{Ti}(\mathrm{OH})_{4}(\mathrm{aq})+\mathrm{H}_{2} \mathrm{O}$ & 14.9337 & 13.4810 & 11.8506 & 10.4623 & 9.2533 & 8.4703 & 8.0123 & 7.8416 \\
\hline $\begin{array}{l}\mathrm{TiO}_{2}(\mathrm{~s}) \\
\text { (rutile) e }\end{array}$ & $\mathrm{TiO}_{2}(\mathrm{~s})+2 \mathrm{H}_{2} \mathrm{O}=\mathrm{Ti}(\mathrm{OH})_{4}(\mathrm{aq})$ & -7.4295 & -7.4282 & -7.5034 & -7.5904 & -7.6674 & -7.7149 & -7.7510 & -7.8065 \\
\hline \multicolumn{10}{|c|}{ Molybdenum Species } \\
\hline $\mathrm{H}_{2} \mathrm{MoO}_{4}(\mathrm{aq})^{\mathrm{f}}$ & $\mathrm{H}_{2} \mathrm{MoO}_{4}(\mathrm{aq})=2 \mathrm{H}^{+}+\mathrm{MoO}_{4}^{--}$ & -8.9145 & -8.2400 & -7.8007 & -7.7233 & -8.0273 & -8.6485 & -9.5498 & -10.8062 \\
\hline $\mathrm{HMoO}_{4}^{-f}$ & $\mathrm{HMoO}_{4}^{-}=\mathrm{H}^{+}+\mathrm{MoO}_{4}{ }^{--}$ & -4.0079 & -4.2400 & -4.6473 & -5.1536 & -5.8146 & -6.5084 & -7.2615 & -8.1413 \\
\hline
\end{tabular}

DTN: MO0302SPATHDYN.001 [DIRS 161886].

${ }^{a}$ Spreadsheet: BasisSpecies_j_TJW_2_Rev1.xIs.

b Spreadsheet: BasisSpecies _ _TJW_3.xls.

' Spreadsheet: BasisSpecies_j_TJW_4.XIs.

d Spreadsheet: AqueousSpecies_j_TJW_2.xIs.

e Spreadsheet: Minerals j ERP rutile.xIs.

f Spreadsheet: AqueousReactions_j_TJW_MoW1.xIs. 
Table 6-7. Thermodynamic Data for Titanium-Hydroxy Species and Associated Reactions

\begin{tabular}{|c|c|c|c|}
\hline Reaction & $\begin{array}{l}\Delta \mathbf{G}_{\mathrm{r}}^{\circ}\left(25^{\circ} \mathrm{C}\right) \\
(\mathrm{kJ} / \mathrm{mol})\end{array}$ & $\begin{array}{l}\log K \\
\left(25^{\circ} \mathrm{C}\right)\end{array}$ & Source \\
\hline $\mathrm{Ti}(\mathrm{OH})_{3}{ }^{+}+\mathrm{H}_{2} \mathrm{O}=\mathrm{Ti}(\mathrm{OH})_{4}(\mathrm{aq})+\mathrm{H}^{+}$ & 10.4 & -1.8220 & Knauss et al. 2001 [DIRS 158998], Table 5 \\
\hline $\mathrm{Ti}(\mathrm{OH})_{3}{ }^{+}+\mathrm{H}_{2} \mathrm{O}=\mathrm{Ti}(\mathrm{OH})_{4}(\mathrm{aq})+\mathrm{H}^{+}$ & 11.3 & -1.9797 & $\begin{array}{l}\text { Knauss et al. } 2001 \text { [DIRS 158998], Table 5; based } \\
\text { on data from Vasil'ev et al. (1974 [DIRS 150836]) }\end{array}$ \\
\hline $\mathrm{Ti}(\mathrm{OH})_{3}{ }^{+}+\mathrm{H}_{2} \mathrm{O}=\mathrm{Ti}(\mathrm{OH})_{4}(\mathrm{aq})+\mathrm{H}^{+}$ & 10.9 & -1.9096 & $\begin{array}{l}\text { Knauss et al. } 2001 \text { [DIRS 158998], Table 5; based } \\
\text { on data from Ziemniak et al. (1993 [DIRS 172325]) }\end{array}$ \\
\hline $\mathrm{Ti}(\mathrm{OH})_{3}{ }^{+}+\mathrm{H}_{2} \mathrm{O}=\mathrm{Ti}(\mathrm{OH})_{4}(\mathrm{aq})+\mathrm{H}^{+}$ & 11.421 & -2.0010 & $\begin{array}{l}\text { Calculated with data given in Stefánsson (2001 } \\
\text { [DIRS 159208]); Spreadsheet } \\
\text { AqueousSpecies_j_TJW_2_CFJC.xIs (output } \\
\text { DTN: SN0410T0510404.001) }\end{array}$ \\
\hline $\mathrm{Ti}(\mathrm{OH})_{5}{ }^{-}+\mathrm{H}^{+}=\mathrm{Ti}(\mathrm{OH})_{4}(\mathrm{aq})+\mathrm{H}_{2} \mathrm{O}$ & -68.4 & 11.9832 & Knauss et al. 2001 [DIRS 158998], Table 5 \\
\hline $\mathrm{Ti}(\mathrm{OH})_{4}(\mathrm{aq})+\mathrm{H}_{2} \mathrm{O}=\mathrm{Ti}(\mathrm{OH})_{5}{ }^{-}+\mathrm{H}^{+}$ & -70.46 & 12.3336 & $\begin{array}{l}\text { Ziemniak et al. } 1993 \text { [DIRS 172325]; also in Knauss } \\
\text { et al. (2001 [DIRS 158998], Table 5) but for inverted } \\
\text { reaction }\end{array}$ \\
\hline $\mathrm{Ti}(\mathrm{OH})_{5}{ }^{-}+\mathrm{H}^{+}=\mathrm{Ti}(\mathrm{OH})_{4}(\mathrm{aq})+\mathrm{H}_{2} \mathrm{O}$ & -70.441 & 12.3409 & $\begin{array}{l}\text { Calculated with data given in Stefánsson (2001 } \\
\text { [DIRS 159208]); Spreadsheet } \\
\text { AqueousSpecies_j_TJW_2_CFJC.xIs (output } \\
\text { DTN: SN0410T0510404.001) }\end{array}$ \\
\hline $\mathrm{H}_{2} \mathrm{O}=\mathrm{H}^{+}+\mathrm{OH}^{-}$ & - & -13.9951 & $\begin{array}{l}\text { data0.ymp.R0 (DTN: MO0009THRMODYN.001 } \\
\text { [DIRS 152576]) }\end{array}$ \\
\hline Species & $\begin{array}{l}\Delta \mathrm{G}_{\mathrm{f}}^{\circ}\left(25^{\circ} \mathrm{C}\right) \\
(\mathrm{kJJ} / \mathrm{mol})\end{array}$ & & Source \\
\hline $\mathrm{Ti}(\mathrm{OH})_{3}{ }^{+}$ & -1086.7 & \multicolumn{2}{|c|}{ Stefánsson 2001 [DIRS 159208], p. 235} \\
\hline $\mathrm{Ti}(\mathrm{OH})_{3}^{+}$ & -1086.21 & \multicolumn{2}{|c|}{ Ziemniak et al. 1993 [DIRS 172325], Table V, p. 617} \\
\hline $\mathrm{Ti}(\mathrm{OH})_{4}(\mathrm{aq})^{\mathrm{a}}$ & -1312.48 & \multicolumn{2}{|c|}{ Stefánsson 2001 [DIRS 159208], Table 3, p. 229} \\
\hline $\mathrm{Ti}(\mathrm{OH})_{4}(\mathrm{aq})^{\mathrm{b}}$ & -1309.0 & \multicolumn{2}{|c|}{ Stefánsson 2001 [DIRS 159208], p. 235} \\
\hline $\mathrm{Ti}(\mathrm{OH})_{4}(\mathrm{aq})$ & -1322.7 & \multicolumn{2}{|c|}{$\begin{array}{l}\text { Spreadsheet AqueousSpecies_j_TJW_2.xls } \\
\text { (DTN: MO0302SPATHDYN.001 [DIRS 161886]) }\end{array}$} \\
\hline $\mathrm{Ti}(\mathrm{OH})_{5}^{-\mathrm{a}}$ & -1479.2 & \multicolumn{2}{|c|}{ Stefánsson 2001 [DIRS 159208], p. 235} \\
\hline $\mathrm{Ti}(\mathrm{OH})_{5}^{-}$ & -1482.9 & \multicolumn{2}{|c|}{$\begin{array}{l}\text { Spreadsheet AqueousSpecies_j_TJW_2.x/s } \\
\text { (DTN: MO0302SPATHDYN.001 [DIRS 161886]) }\end{array}$} \\
\hline $\mathrm{TiO}_{2}$ (rutile) & -890.7 & \multicolumn{2}{|c|}{$\begin{array}{l}\text { Robie et al. } 1979 \text { [DIRS 107109]; Spreadsheet } \\
\text { Minerals_j_ERP_rutile.xls (DTN: MO0302SPATHDYN.001 } \\
\text { [DIRS 161886]) }\end{array}$} \\
\hline $\mathrm{TiO}_{2}$ (rutile) & -888.8 & \multicolumn{2}{|c|}{ Robie and Hemingway 1995 [DIRS 153683], p. 222} \\
\hline $\mathrm{H}_{2} \mathrm{O}$ & -237.181 & \multicolumn{2}{|c|}{$\begin{array}{l}\text { Spreadsheet AqueousSpecies_j_TJW_2_CFJC.xls (output } \\
\text { DTN: SN0410T0510404.001) }\end{array}$} \\
\hline $\mathrm{H}^{+}$ & 0.0 & \multicolumn{2}{|c|}{$\begin{array}{l}\text { Spreadsheet AqueousSpecies_j_TJW_2_CFJC.xIs (output } \\
\text { DTN: SN0410T0510404.001) }\end{array}$} \\
\hline
\end{tabular}

Output DTN: SN0410T0510404.001 (Log K values calculated in Spreadsheet AqueousSpecies_j_TJW_2_CFJC.xIs).

a Original data reported in Ziemniak et al. (1993 [DIRS 172325]). For Ti(OH) $4(\mathrm{aq})$, Ziemniak et al. (1993 [DIRS 172325], Table V, p. 617) reports a value of $-1312.48 \mathrm{~kJ} / \mathrm{mol}$.

${ }^{b}$ Calculated from hydrolysis constants given in Baes and Mesmer (1976 [DIRS 157860]), rutile $\Delta G_{\mathrm{f}}{ }^{\circ}$ from Robie and Hemingway (1995 [DIRS 153683]), and $\Delta \mathrm{G}_{\mathrm{f}}^{\circ}$ for $\mathrm{H}_{2} \mathrm{O}$ equivalent to that in speq02.dat (DTN: MO0303SPASPEQ2.000 [DIRS 162278]). 


\subsection{EVALUATION AND QUALIFICATION OF THERMODYNAMIC DATA FOR SOLID PHASES}

\subsubsection{Evaluation and Qualification of Thermodynamic Data for Clays}

Wolery (1978 [DIRS 151346], pp. 230-251, Appendix A) provided estimates of the thermodynamic data for a number of sheet silicates, including various important clay minerals. These data were intended to supplement the data provided in Helgeson et al. (1978 [DIRS 101596]). In some cases, these estimates were needed to fill out the data sets for sheet silicates treated at least in part in Helgeson et al. (1978 [DIRS 101596]). The missing data in such cases consisted of the Gibbs free energy of formation and the enthalpy of formation, both at $298.15 \mathrm{~K}$ and 1 bar pressure. In other cases, the minerals were ignored in Helgeson et al. (1978 [DIRS 101596]) and all requisite thermodynamic functions had to be estimated. These minerals were chosen because of their general relevance to geochemical processes or specific relevance to hydrothermal alteration of oceanic crust at mid-ocean ridges, the principal topic addressed by Wolery (1978 [DIRS 151346]).

The following terms and groupings are used to provide some context for the aspects of the data0.ymp.R2 (DTN: MO0302SPATHDYN.000 [DIRS 161756]) development related to clays. There is no intent to provide a formal classification of such minerals, which may exhibit greater breadth than described here. The sheet silicates as are comprised of two main groups, the "micas" (including chlorites and "brittle" micas) and the clays. Both groups include examples of nearly constant stoichiometry (e.g., micas: muscovite; clays: kaolinite) and highly variable composition (e.g., micas: chlorites; clays: smectites). The clays of variable composition consist of two main groups: illites and smectites. These are distinguished for the present purposes by their ion exchange properties. Smectites (and the similar mineral group, the vermiculites) contain a significant proportion of readily exchangeable mono and divalent cations, whereas illites (and the similar mineral group, the celadonites) do not.

The smectites can be further divided into various characteristic groups. Montmorillonites and beidellites can be thought of as derivatives of the stoichiometric clay mineral pyrophyllite $\left(\mathrm{Al}_{2} \mathrm{Si}_{4} \mathrm{O}_{10}(\mathrm{OH})_{2}\right)$. In pyrophyllite, the aluminum is octahedrally coordinated in a layer sandwiched between layers of tetrahedrally coordinated silicon. An idealized montmorillonite (e.g., $\left.\mathrm{Na}_{0.33} \mathrm{Mg}_{0.33} \mathrm{Al}_{1.67} \mathrm{Si}_{4} \mathrm{O}_{10}(\mathrm{OH})_{2}\right)$ can be obtained by replacing some of the octahedral aluminum with $\mathrm{Mg}$ and balancing the missing electrical charge by putting exchangeable cations (here $\mathrm{Na}^{+}$) in a new, adjacent exchange layer. Changing the exchangeable cation can create other idealized montmorillonites. An idealized beidellite (e.g., $\mathrm{Na}_{0.33} \mathrm{Al}_{2} \mathrm{Al}_{0.33} \mathrm{Si}_{3.67} \mathrm{O}_{10}(\mathrm{OH})_{2}$ ) is created by bringing in more aluminum and substituting it for some of the tetrahedral silicon. This creates charge imbalance that is countered by the addition of exchangeable cations. Natural smectite compositions usually contain a mix of exchangeable cations, including $\mathrm{Na}^{+}, \mathrm{K}^{+}, \mathrm{Ca}^{++}$, and $\mathrm{Mg}^{++}$.

Two other smectite groups are important. The saponites are related to talc $\left(\mathrm{Mg}_{3} \mathrm{Si}_{4} \mathrm{O}_{10}(\mathrm{OH})_{2}\right)$ in somewhat the same way that the beidellites are related to pyrophyllite. An idealized saponite $\left(\mathrm{Na}_{0.33} \mathrm{Mg}_{3} \mathrm{Al}_{0.33} \mathrm{Si}_{3.67} \mathrm{O}_{10}(\mathrm{OH})_{2}\right)$ is created by substituting aluminum for tetrahedral silicon and balancing the resulting charge by adding exchangeable cation. The nontronites are similar to the beidellites, except that ferric iron replaces the octahedral aluminum. This suggests a parent 
mineral of composition $\mathrm{Fe}_{2} \mathrm{Si}_{4} \mathrm{O}_{10}(\mathrm{OH})_{2}$ analogous to pyrophyllite; however, no such phase is known to exist.

Wolery (1978 [DIRS 151346]) estimated thermodynamic data for some chlorite compositions and all illite and smectite compositions of interest. The actual compositions for which data were estimated were in most instances idealized as indicated in the preceding paragraphs. These included beidellites, saponites, and nontronites (montmorillonites as defined here were not addressed). In addition, some actual reported compositions were treated (e.g., "Reykjanes" smectite, "low Fe-Mg" smectite, and "high $\mathrm{Fe}-\mathrm{Mg}$ " smectite).

Several empirical methods have been proposed to estimate the thermodynamic properties of minerals including sheet silicates. Although a general review of such methods is tempting, this has been eschewed because it is doubtful that any methods would produce inarguably superior results. Nevertheless, some alternative approaches and results therefrom are discussed at the end of this section.

Wolery (1978 [DIRS 151346], Appendix A) estimated the Gibbs free energy of formation $\left(\Delta G_{f}^{o}\right.$ ) at $298.15 \mathrm{~K}$ and 1 bar pressure using an algorithm proposed in Tardy and Garrels (1974 [DIRS 159209]). This is a linear approach that assumes that the Gibbs free energy of a sheet silicate is the sum of the product of the Gibbs free energies of "silicated" oxide and hydroxide components and the stoichiometric coefficient in the clay. Tardy and Garrels (1974 [DIRS 159209]) analyzed the (Gibbs) free energy of silication (in sheet silicates), defined by them as the difference between the Gibbs energy of a "silicated" oxide component (as determined in their regression) and the Gibbs energy of the corresponding stable oxide phase. They found that the Gibbs energy of silicated $\mathrm{SiO}_{2}$ was identical to that of quartz. This result was dependent on their usage of data for a sepiolite of composition $\mathrm{Mg}_{2} \mathrm{Si}_{3} \mathrm{O}_{6}(\mathrm{OH})_{4}$ in conjunction with data for talc and chrysotile to regress the Gibbs free energies of silicated $\mathrm{Mg}(\mathrm{OH})_{2}, \mathrm{MgO}$, and $\mathrm{SiO}_{2}$. The present regressions use data from Helgeson et al. (1978 [DIRS 101596]). They included data (p. 124) for a sepiolite of composition " $\mathrm{Mg}_{4} \mathrm{Si}_{6} \mathrm{O}_{15}(\mathrm{OH})_{2} \cdot 6 \mathrm{H}_{2} \mathrm{O}$." Because of the presence of water of hydration in this formulation, data for this sepiolite could not be used in the regression for data0.ymp.R2 (DTN: MO0302SPATHDYN.000 [DIRS 161756]). Absent the inclusion of sepiolite, the linear system in the regression is nearly singular. Quartz was included in the regression to stabilize it. This can be justified by the zero Gibbs energy of silication found by Tardy and Garrels. Because the Gibbs energies of formation for both chrysotile and talc are identical to the precision presented in both the Tardy and Garrels and Helgeson et al. data sets, this usage of quartz is equivalent to using the Tardy-Garrels sepiolite in the regression.

Insufficient data were available to regress values for any form of silicated $\mathrm{Fe}_{2} \mathrm{O}_{3}$ for the data0.ymp.R2 database (DTN: MO0302SPATHDYN.000 [DIRS 161756]). The Tardy-Garrels analysis yielded a bilinear relationship between the Gibbs energy of silication and the electronegativity of the cation in the silicated oxide components. From this, Tardy and Garrels deduced that silicated $\mathrm{Fe}_{2} \mathrm{O}_{3}$ should have a Gibbs free energy very close to that of hematite. Hematite was used for the data0.ymp.R2 (DTN: MO0302SPATHDYN.000 [DIRS 161756]) development to fix the Gibbs free energies of both octahedral and tetrahedral silicated $\mathrm{Fe}_{2} \mathrm{O}_{3}$. Tardy and Garrels did not distinguish between octahedral and tetrahedral $\mathrm{Al}_{2} \mathrm{O}_{3}$. An attempt to distinguish the latter pair obtained a difference of only $608 \mathrm{cal} / \mathrm{mol}$. In the estimations for 
data0.ymp.R2 (DTN: MO0302SPATHDYN.000 [DIRS 161756]), the distinction between octahedral and tetrahedral forms of both $\mathrm{Al}_{2} \mathrm{O}_{3}$ and $\mathrm{Fe}_{2} \mathrm{O}_{3}$ was ignored. Nothing in this work addressed the Gibbs energies of silication of $\mathrm{SiO}_{2}$ and $\mathrm{Fe}_{2} \mathrm{O}_{3}$ in other kinds of silicates. Silicated $\mathrm{Mg}(\mathrm{OH})_{2}$ is the only hydroxide component, and any $\mathrm{OH}$ in a mineral was first assigned to it. Any remaining $\mathrm{OH}$ was assigned to silicated $\mathrm{H}_{2} \mathrm{O}$. The Gibbs free energies of these silicated components were derived from a regression of known Gibbs free energy of formation for relevant (related) minerals (including pyrophyllite, talc, muscovite, phlogopite, and the $7 \AA$ and $14 \AA$ clinochlores) against their known stoichiometries. Wolery (1978 [DIRS 151346]) took all such data in his regression from Helgeson et al. (1978 [DIRS 101596]) with the aim of maintaining consistency with the associated SUPCRT92 data set.

The regression did not give values for the exchangeable cation oxide components. Such components (e.g., $\mathrm{CaO}(\mathrm{ex})$ vs. $\mathrm{CaO}$ ) are required to deal with readily exchangeable cations from the "exchange" layers of smectites and vermiculites. No data for examples of such phases were available to include in the regressions. The necessary data were extracted (Tardy and Garrels 1974 [DIRS 159209]) from reported exchange equilibrium measurements. The data were initially for reactions exemplified by:

$$
\mathrm{CaO}(\mathrm{ex})+2 \mathrm{Na}^{+}=\mathrm{Na}_{2} \mathrm{O}(\mathrm{ex})+\mathrm{Ca}^{++}
$$

They were then adjusted as recommended in Tardy and Garrels (1974 [DIRS 159209]) so that the silicated $\mathrm{K}_{2} \mathrm{O}(\mathrm{ex})$ had the same Gibbs free energy as silicated $\mathrm{K}_{2} \mathrm{O}$ (Wolery 1978 [DIRS 151346], pp. 236-237).

The method of Tardy and Garrels (1974 [DIRS 159209]) does not directly give values for exchangeable cation oxide components. Such components (e.g., $\mathrm{CaO}(\mathrm{ex})$ vs. $\mathrm{CaO}$ ) are required to deal with readily exchangeable cations from the exchange layers of smectites and vermiculites. The original $\Delta \mathrm{G}_{\mathrm{f}}{ }^{\circ}$ for these exchangeable oxide components (Table 6-8) was calculated by Wolery (1978 [DIRS 151346], Table 3b, p. 236). These data were corrected for data0.ymp.R2 (DTN: MO0302SPATHDYN.000 [DIRS 161756]) by calculating $\Delta \mathrm{G}_{\mathrm{f}}{ }^{\circ}\left(\mathrm{K}_{2} \mathrm{O}(\mathrm{ex})\right)-\Delta \mathrm{G}_{\mathrm{f}}{ }^{\circ}\left(\mathrm{K}_{2} \mathrm{O}\right)$ and adding this difference to each of the original $\Delta \mathrm{G}_{\mathrm{f}}{ }^{\circ}$ values in Table 4-5 (see Spreadsheet Clays_TJW_1_Rev1b.xls, Worksheet G matrix; DTN: MO0302SPATHDYN.001 [DIRS 161886]).

Table 6-8. $\Delta \mathrm{G}_{\mathrm{f}}{ }^{\circ}$ of Silicated Exchangeable Components Used by Wolery

\begin{tabular}{|c|c|c|}
\hline \multirow{2}{*}{$\begin{array}{c}\text { Silicated } \\
\text { Component }\end{array}$} & Original & Corrected $^{\boldsymbol{*}}$ \\
\cline { 2 - 3 } & $\begin{array}{c}\Delta \mathbf{G}_{\mathbf{f}}{ }^{\circ} \\
\text { (cal/mol) }\end{array}$ & $\begin{array}{c}\Delta \mathbf{G}_{\mathbf{f}}{ }^{\circ} \\
\text { (cal/mol) }\end{array}$ \\
\hline $\mathrm{CaO}(\mathrm{ex})$ & -180200 & -180062.7 \\
\hline $\mathrm{H}_{2} \mathrm{O}(\mathrm{ex})$ & -56000 & -55862.7 \\
\hline $\mathrm{K}_{2} \mathrm{O}(\mathrm{ex})$ & -185440 & -185302.7 \\
\hline $\mathrm{Li}_{2} \mathrm{O}(\mathrm{ex})$ & -188000 & -187862.7 \\
\hline $\mathrm{MgO}(\mathrm{ex})$ & -156900 & -156762.7 \\
\hline $\mathrm{Na}_{2} \mathrm{O}(\mathrm{ex})$ & -172800 & -172662.7 \\
\hline
\end{tabular}

Sources: Column 2: Wolery 1978 [DIRS 151346], Table 3b, p. 236.

Column 3: DTN: MO0302SPATHDYN.001 ([DIRS 161886], the computation of corrected values is given in Spreadsheet Clays_TJW_1_Rev1b.xIs, Worksheet G Calc A).

* See p. 237 and Footnote e of Table $3 b$ to make the Gibbs free energy of formation the same for the $\mathrm{K}_{2} \mathrm{O}$ and $\mathrm{K}_{2} \mathrm{O}(\mathrm{ex})$ components consistent with the original assumptions of Wolery (1978 [DIRS 151346]). 
Wolery (1978 [DIRS 151346], Appendix B) used an analogous method (with more minerals in the regression set) to estimate molar volumes. However, a separate set of silicated exchangeable cation oxide components was not employed. This was equivalent to assuming that the molar volume of a silicated exchangeable oxide component was the same as that of the corresponding "regular" silicated oxide component.

The entropy at $298.15 \mathrm{~K}$ and 1 bar pressure was obtained using a method described by Helgeson et al. (1978 [DIRS 101596], pp. 43-52). First, a molar volume (V) was calculated from the silicated oxide components of the clay (e.g., Worksheet $V$ Calc in Spreadsheet Clays_TJW_1_Rev1b.xls; DTN: MO0302SPATHDYN.001 [DIRS 161886]). Next, for a reference reaction involving a similar mineral (Eq. 6-18), the changes in the entropy $\left(\Delta \mathrm{S}_{\mathrm{s}}{ }^{\circ}\right)$ and molar volume $\left(\Delta \mathrm{V}_{\mathrm{s}}{ }^{\circ}\right)$ were calculated assuming that the entropies and molar volumes for the reaction are zero (e.g., Worksheets Delta Ss Calc and Delta Vs Calc, respectively, in the Spreadsheet Clays_TJW_1_Rev1b.xls; DTN: MO0302SPATHDYN.001 [DIRS 161886]). The entropy for the clay $\left(\mathrm{S}^{\circ}\right)$ was then calculated by:

$$
S^{\circ}=\Delta S_{s}\left(\Delta V_{S}^{\circ}+V^{\circ}\right) / \Delta V_{S}^{\circ}-2 v_{F e(I I I)}
$$

where $v_{\mathrm{Fe}(\mathrm{III})}$ is the stoichiometric coefficient of ferric iron in the chemical formula for the clay. The heat capacity coefficients were obtained by a simple linear method (Helgeson et al. 1978 [DIRS 101596], pp. 52-66) that used mostly real oxide components. In both the entropy and heat capacity coefficient estimation schemes, a "structural $\mathrm{H}_{2} \mathrm{O}$ " component was used in addition to the real oxide components. Helgeson et al. (1978 [DIRS 101596]) also employed a "zeolitic" $\mathrm{H}_{2} \mathrm{O}$ component, though this has no relevance to sheet silicates.

The enthalpy of formation at $298.15 \mathrm{~K}$ and 1 bar pressure $\left(\Delta H_{f}^{o}\right)$ was calculated from the corresponding Gibbs free energy and entropy. First, the entropy of formation $\left(\Delta S_{f}^{o}\right)$ was calculated from the entropy and the entropies of the elements in their standard reference states. Then the following standard thermodynamic relation was applied:

$$
\Delta H_{f}^{o}=\Delta G_{f}^{o}+T \Delta S_{f}^{o}
$$

The data estimated by Wolery (1978 [DIRS 151346], Appendix A) have long been a staple of EQ3/6 thermodynamic data files. The estimation was revisited for the data0.ymp.R2 database (DTN: MO0302SPATHDYN.000 [DIRS 161756]) because the SUPCRT92 data for some of the minerals in the original Gibbs free energy regression set had changed over the years, and there was concern that some of the data for other thermodynamic functions might have changed as well. There was also an intent to take better account of mixing effects (e.g., regressing on Gibbs free energies with any mixing effects taken out, then when estimating Gibbs free energies for other minerals, adding any such effects back in at the end of the process). But mixing corrections were not implemented in the reestimation for data0.ymp.R2 (DTN: MO0302SPATHDYN.000 [DIRS 161756]) for several reasons. First, the choice of mixing entities is not always straightforward. Second, such corrections appear to be comparable 
or of lesser magnitude than differences due to structural effects. The Gibbs free energy of mixing (assumed ideal in the site mixing sense and that enthalpic mixing terms are negligible) on the $j$-th site is given by:

$$
\Delta G_{j}^{\text {mixing }}=n_{j} R T \sum_{i} x_{i} \ln x_{i}
$$

where $n_{j}$ is the stoichiometric number of the site in the mineral's chemical formula, $R$ is the gas constant, $T$ is the absolute temperature, and $x_{i}$ is the mole fraction of the $i$-th entity on the $j$-th site. Consider the case of muscovite $\left[\mathrm{KAl}_{2} \mathrm{AlSi}_{3} \mathrm{O}_{10}(\mathrm{OH})_{2}\right]$ in which an aluminum substitutes for one of what would be four tetrahedral silicons. Assuming that the mixing entities are just $\mathrm{Al}^{+++}$ and $\mathrm{Si}^{+++}$(ignoring vacancies and any potential pairing/ordering effects), the Gibbs free energies of mixing on the tetrahedral site would be:

$$
\Delta G_{j}^{\text {mixing }}=4 R T\left[\frac{1}{4} \ln \left(\frac{1}{4}\right)+\frac{3}{4} \ln \left(\frac{3}{4}\right)\right]
$$

Taking $R$ to be $1.9872 \mathrm{cal} / \mathrm{mol}-\mathrm{K}$ (Weast and Astle 1979 [DIRS 102865], p. F-108) and T to be $298.15 \mathrm{~K}$, this Gibbs free energy of mixing evaluates to $-1,333 \mathrm{cal} / \mathrm{mol}(-5,577 \mathrm{joule} / \mathrm{mol})$. In contrast, the difference in Gibbs free energies of $7 \AA$ and $14 \AA$ clinochlores as given in Helgeson et al. (1978 [DIRS 101596], p. 124) is 4,602 cal/mol (19,255 joule/mol). This illustrates that a subtle structural difference can be more significant than mixing. Furthermore, the magnitude of mixing corrections will be matched or exceeded by the uncertainties in the Gibbs free energies of the minerals used in the regression. Uncertainties in calorimetric determinations of the Gibbs free energies of formation of kaolinite and dickite, for example, are on the order of 4,000 to 7,000 joule/mol (roughly 960 to $1,670 \mathrm{cal} / \mathrm{mol}$ ) (de Ligny and Navrotsky 1999 [DIRS 158973]; Fialips et al. 2001 [DIRS 158975]). From such considerations, it must be concluded that there is little likelihood of reducing the error in the regression by introducing mixing corrections. (Note that dickite is not included in this version of the database.)

The first step in the reestimation was to prepare a spreadsheet (Clays_TJW_0_Rev1b.xls; DTN: MO0302SPATHDYN.001 [DIRS 161886]) to re-create the original calculations. The purpose of this spreadsheet was to confirm the original calculations and to provide a template for the updated calculations; no data from this were carried forward into the database update. This re-creation included the modification by Wolery (1978 [DIRS 151346]) of the Tardy-Garrels method in which the silicated $\mathrm{Al}_{2} \mathrm{O}_{3}$ component was split into separate octahedral and tetrahedral forms. The values obtained in Wolery (1978 [DIRS 151346], p. 236, Table 3b) for these two components were almost identical: $-380.08 \mathrm{kcal} / \mathrm{mol}$ for $\mathrm{Al}_{2} \mathrm{O}_{3 \mathrm{tetr}},-380.69 \mathrm{kcal} / \mathrm{mol}$ for $\mathrm{Al}_{2} \mathrm{O}_{3 \text { oct }}$ ). Another modification from the original Tardy-Garrels method had been the use of quartz and hematite in the regression suite, though these are not sheet silicates. That was justified by arguments given in Tardy and Garrels (1974 [DIRS 159209]) that the Gibbs free energies of silication of these oxides should be negligible (see previous discussion in p. 6-29). The use of quartz in the regression was found in Wolery (1978 [DIRS 151346]) to be necessary to stabilize the regression. In the original Tardy-Garrels work, the inclusion of a sepiolite in the regression had apparently played a stabilizing role. However, Helgeson et al. (1978 
[DIRS 101596]) used a sepiolite of a different composition, and Wolery (1978 [DIRS 151346]) reported that this failed to have the necessary stabilizing effect.

Excel's Regression Tool (part of the Analysis Tool Pak) was used for data0.ymp.R2 (DTN: MO0302SPATHDYN.000 [DIRS 161756]) development, to perform multiple linear regression of the known $\Delta \mathrm{G}_{\mathrm{f}}{ }^{\circ}$ for a suite of minerals against the stoichiometric coefficients of the component oxides. The fitted parameters were the $\Delta \mathrm{G}_{\mathrm{f}}{ }^{\circ}$ for the silicated oxided components. As there was no guarantee that the fitting criteria would be identical to those employed in the original calculations (which were unknown at the start of the work), there was a possibility that the results might differ. However, the re-created Gibbs free energy regression (Worksheet $G$ matrix 0 in Spreadsheet Clays_TJW_0_Rev1b.xls; DTN: MO0302SPATHDYN.001 [DIRS 161886]) exactly duplicated that reported in Wolery (1978 [DIRS 151346], p. 235, Table $3 \mathrm{a}$ ) to the precision reported in the original work.

The molar volume calculations were done in analogous manner with a larger suite of minerals in the regression set. The original regression (Wolery 1978 [DIRS 151346], p. 247, Table 5a) could not be duplicated (the attempt is documented in Worksheet $V$ matrix 0, Spreadsheet Clays_TJW_0_Rev1b.xls; DTN: MO0302SPATHDYN.001 [DIRS 161886]). The calculated molar volumes for the minerals used in the regression and hence the regression errors were identical in the original work and the attempted re-creation; only the values for the components differed. The standard errors of the component values in the Excel output in Worksheet Vmatrix 0, Spreadsheet Clays_TJW_0_Rev1b.xls; (DTN: MO0302SPATHDYN.001 [DIRS 161886]) were large and only one of the 11 fitted parameters was significantly different from zero. Therefore, the nature of the problem was that the regression matrix was insufficient to produce a unique set of values for the component volumes. In order to resolve this problem and provide a usable template, it was necessary to modify the original volume calculations.

Three possibilities for extending the suite of minerals in the regression matrix were evaluated in the data0.ymp.R2 (DTN: MO0302SPATHDYN.000 [DIRS 161756]) development. The first involved adding two sheet silicates (antigorite and sepiolite) for which SUPCRT92 data were readily available but which, for unknown reasons, were not used in the original regression. It was found that including these minerals (Spreadsheet Clays_TJW_0_Rev1b.xls, Worksheet V matrix 1; DTN: MO0302SPATHDYN.001 [DIRS 161886]) yielded parameters with reasonably small standard errors, and that were significantly different from zero. These results for the component volumes were notably different from either the original results in Wolery (1978 [DIRS 151346]) or the first attempted re-creation described above. A second attempt (Spreadsheet Clays_TJW_0_Rev1b.xls, Worksheet V matrix 2; DTN: MO0302SPATHDYN.001 [DIRS 161886]) adding instead quartz and hematite (which are not sheet silicates, but which were included in the Gibbs free energy regression) also gave regression parameters significantly different from zero with results for the components that were very close to those obtained by adding antigorite and sepiolite. Consequently, it was decided to do yet another regression (Worksheet V matrix 3, Spreadsheet Clays_TJW_0_Rev1b.xls; DTN: MO0302SPATHDYN.001 [DIRS 161886]) that included all four additional minerals.

The old molar volume regression (Wolery 1978 [DIRS 151346], p. 247, Table 5b) had yielded a large difference in the molar volumes of silicated octahedral and tetrahedral $\mathrm{Al}_{2} \mathrm{O}_{3}$ components $\left(37.629 \mathrm{~cm}^{3} / \mathrm{mol}\right.$ for $\mathrm{Al}_{2} \mathrm{O}_{3 \text { tetr }}, 4.099 \mathrm{~cm}^{3} / \mathrm{mol}$ for $\left.\mathrm{Al}_{2} \mathrm{O}_{3 \text { oct }}\right)$. This result had been used to justify a 
proportionally large difference for analogous $\mathrm{Fe}_{2} \mathrm{O}_{3}$ components (only a value for a "mean" $\mathrm{Fe}_{2} \mathrm{O}_{3}$ component could be obtained from the regression itself). In the first attempt to re-create the original regression (Worksheet $V$ matrix 0, Spreadsheet Clays_TJW_0_Rev1b.xls; DTN: MO0302SPATHDYN.001 [DIRS 161886])), an even larger difference between the values for the two $\mathrm{Al}_{2} \mathrm{O}_{3}$ components was obtained; however, as noted above, the results of this regression in general failed to match those reported by Wolery (1978 [DIRS 151346]). Adding antigorite and sepiolite (Worksheet $V$ matrix 1, Spreadsheet Clays_TJW_0_Rev1b.xls; DTN: MO0302SPATHDYN.001 [DIRS 161886])) as previously discussed resulted in notably different results. In particular, the values obtained for the two $\mathrm{Al}_{2} \mathrm{O}_{3}$ components were very close $\left(26.461 \pm 4.443 \mathrm{~cm}^{3} / \mathrm{mol}\right.$ for $\mathrm{Al}_{2} \mathrm{O}_{3 \text { tetr, }} 25.030 \pm 2.802 \mathrm{~cm}^{3} / \mathrm{mol}$ for $\mathrm{Al}_{2} \mathrm{O}_{3 \text { oct }}$ ), where the uncertainty is the standard error of the fitted volume. Very similar results were obtained by adding instead quartz and hematite (Worksheet $V$ matrix 2) and by using all four additional minerals together (Worksheet V matrix 3).

The re-creation of the entropy and heat capacity coefficient calculations proceeded in a more straightforward manner. The entropy calculations (Spreadsheet Clays_TJW_0_Rev1b.xls, Worksheets Delta Ss Calc, Delta Vs Calc, and S calc; DTN: MO0302SPATHDYN.001 [DIRS 161886]) were changed somewhat in that the algorithm for obtaining them depended on the corresponding molar volumes. Since the volumes were estimated in many instances, and the values so obtained were not identical to those previously described, somewhat modified results for the corresponding entropies were obtained as well. No such complication was encountered in dealing with the heat capacity coefficients (Spreadsheet Clays_TJW_0_Rev1b.xls, Worksheets Cp a Calc, Cp b Calc, and Cp c Calc; DTN: MO0302SPATHDYN.001 [DIRS 161886]).

Instead of using a straightforward summation of the contributions of the components, in many instances a difference calculation (based on a reference reaction involving a similar or related mineral with a known thermodynamic function) was employed for data0.ymp.R2 (DTN: MO0302SPATHDYN.000 [DIRS 161756]) development, in an attempt to reduce relative errors (Helgeson et al. 1978 [DIRS 101596]). Such a reference reaction is exemplified by that for Na-beidellite:

$$
\begin{gathered}
\mathrm{Na}_{0.33} \mathrm{Al}_{2.33} \mathrm{Si}_{3.67} \mathrm{O}_{10}(\mathrm{OH})_{2}+0.33 \mathrm{SiO}_{2}= \\
\mathrm{Al}_{2} \mathrm{Si}_{4} \mathrm{O}_{10}(\mathrm{OH})_{2}+0.165 \mathrm{Na}_{2} \mathrm{O}(\mathrm{ex})+0.165 \mathrm{Al}_{2} \mathrm{O}_{3}
\end{gathered}
$$

This reaction emphasizes the role of pyrophyllite as a conceptual "parent" mineral. Such reference reactions were employed to estimate the entropies (linear portion of the algorithm) and the heat capacity coefficients of all minerals for which estimates are made. They were also employed to estimate the Gibbs free energies of the beidellites, the saponites, greenalite, minnesotaite, and all the chlorite minerals for which such estimations were necessary. A few errors were discovered in the original documented set of reference reactions, none of which appeared to have affected the actual calculations. The reference reactions used for data0.ymp.R2 (DTN: MO0302SPATHDYN.000 [DIRS 161756]) are documented on the appropriate worksheets (where these reactions are used) in the spreadsheet.

In general, the re-creation of Wolery's (1978 [DIRS 151346], Appendix A) estimates of the free energy of formation of the clays, in the development of data0.ymp.R2 (DTN: MO0302SPATHDYN.000 [DIRS 161756]), did not produce very different results from 
the original ones. The elimination of distinct octahedral and tetrahedral forms of the $\mathrm{Al}_{2} \mathrm{O}_{3}$ component in the Gibbs free energy had almost no effect, as expected, as the values for those two components were nearly identical. The approach used for volume estimation produced more significant changes (the elimination of distinct octahedral and tetrahedral forms of the $\mathrm{Al}_{2} \mathrm{O}_{3}$ and $\mathrm{Fe}_{2} \mathrm{O}_{3}$ components, and significant changes to the regressed values for the volumes of the components). However, the molar volume estimates for various minerals were not significantly impacted as indicated in Table 6-9. Changes for the beidellites, illite, and high Fe-Mg smectite were basically insignificant. Changes for saponites were larger but still small. Only the changes for the nontronites were potentially significant. These changes were associated with the removal of distinct octahedral and tetrahedral $\mathrm{Fe}_{2} \mathrm{O}_{3}$ components. In the original estimates, there was a large difference between the values for the nontronite minerals.

Table 6-9. Estimated Molar Volumes $\left(\mathrm{cm}^{3} / \mathrm{mol}\right)$ for the Minerals of Interest: Modified Re-Creation Versus Original Calculations

\begin{tabular}{|l|c|c|c|}
\hline \multicolumn{1}{|c|}{ Mineral } & Original & $\begin{array}{c}\text { Modified } \\
\text { Re-Creation: Worksheet } \\
\text { V Calc }\end{array}$ & Change \\
\hline Na-beidellite & 130.54 & 130.73 & 0.19 \\
\hline Ca-beidellite & 129.53 & 129.77 & 0.24 \\
\hline K-beidellite & 133.70 & 134.15 & 0.45 \\
\hline Mg-beidellite & 128.19 & 128.73 & 0.54 \\
\hline Na-saponite & 136.69 & 135.32 & -1.37 \\
\hline Ca-saponite & 135.68 & 134.36 & -1.32 \\
\hline Na-nontronite & 132.11 & 136.81 & 4.70 \\
\hline Ca-nontronite & 131.10 & 135.85 & 4.75 \\
\hline Illite & 138.94 & 139.35 & 0.41 \\
\hline High Fe-Mg smectite & 139.07 & 139.51 & 0.44 \\
\hline
\end{tabular}

Sources: Column 2: Wolery 1978 [DIRS 151346], p. 231, Table 1.

Column 3: DTN: MO0302SPATHDYN.001 ([DIRS 161886], Spreadsheet Clays_TJW_1_Rev1b.xls, Worksheet $V$ Calc).

Because the entropy estimation algorithm depends on molar volumes, the changes in estimated volumes for some minerals caused a corresponding change in the estimated entropies. However, as the volume changes were small, so were the entropy changes. For comparison, however, some cases are shown in Table 6-10. Only the changes for the nontronites were significant, but they are still relatively small. To give some perspective, the effect of a $1 \mathrm{cal} / \mathrm{mol}-\mathrm{K}$ change on the entropy changes the apparent molal Gibbs free energy at $300^{\circ} \mathrm{C}$ by only $275 \mathrm{cal} / \mathrm{mol}$ $(1,151$ joule $/ \mathrm{mol})$, which in turn would change a $\log \mathrm{K}$ value by 0.241 unit. At $200^{\circ} \mathrm{C}$ those changes would be $175 \mathrm{cal} / \mathrm{mol}$ (732 joule/mol) in the Gibbs free energy and 0.186 in the $\log \mathrm{K}$ value. For minerals with large chemical formulas such as these, such changes are relatively small. They are overwhelmed by larger uncertainties in experimental determinations (solubility or calorimetric). 
Table 6-10. Estimated Standard Entropies (cal/mol-K) for the Minerals of Interest: Modified Re-Creation Versus Original Calculations

\begin{tabular}{|l|c|c|c|}
\hline \multicolumn{1}{|c|}{ Mineral } & Original & Modified Re-Creation & Change \\
\hline Na-beidellite & 59.62 & 59.664 & 0.04 \\
\hline Ca-beidellite & 58.30 & 58.353 & 0.05 \\
\hline Na-saponite & 63.95 & 63.631 & -0.32 \\
\hline Ca-saponite & 62.64 & 62.336 & -0.30 \\
\hline Na-nontronite & 67.64 & 68.860 & 1.20 \\
\hline Ca-nontronite & 66.35 & 67.557 & 1.21 \\
\hline Illite & 63.59 & 63.688 & 0.10 \\
\hline High Fe-Mg smectite & 68.30 & 68.408 & 0.11 \\
\hline
\end{tabular}

Sources: Column 2: Wolery 1978 [DIRS 151346], p. 231, Table 1.

Column 3: DTN: MO0302SPATHDYN.001 ([DIRS 161886], Spreadsheet

Clays_TJW_1_Rev1b.xls, Worksheet S Calc).

Wolery (1978 [DIRS 151346]) had noted that the estimated Gibbs free energies for $7 \AA$ and $14 \AA$ ripidolites were greater than the corresponding physical mixtures of clinochlores and daphnites, a condition that seemed unreasonable. He adjusted the Gibbs free energies of the ripidolites to the physical mixture values and then applied a correction for the ideal Gibbs free energy of mixing. In the re-creation, the situation was identical, and the same strategy was employed. However, the mixing correction applied by Wolery (1978 [DIRS 151346]) did not account for a site stoichiometry factor of five. This was accounted for in the re-creation, resulting in a mixing correction with a magnitude larger by this factor.

The entropies of the ripidolites were treated in a similar manner to ensure that the Gibbs free energy of mixing relation given previously holds at all temperatures, another consideration not included in Wolery (1978 [DIRS 151346]). The appropriate mixing correction is given by:

$$
\Delta S_{j}^{\text {mixing }}=-n_{j} R \sum_{i} x_{i} \ln x_{i}
$$

For a ripidolite (formed by mixing $3 / 5$ clinochlore and $2 / 5$ daphnite), this correction is 6.687 $\mathrm{cal} / \mathrm{mol}-\mathrm{K}$. At $300^{\circ} \mathrm{C}$, the entropy correction results in a change of $-1,839 \mathrm{cal} / \mathrm{mol}$ in the apparent molar Gibbs free energy of a ripidolite. This is close to the Gibbs free energy of mixing at $25^{\circ} \mathrm{C}(-1,994 \mathrm{cal} / \mathrm{mol})$. From another perspective, the entropy correction would decrease the $\log \mathrm{K}$ by 1.615 units at $300^{\circ} \mathrm{C}$, and by 1.245 unit at $200^{\circ} \mathrm{C}$.

In theory, the molar volumes and heat capacity coefficients are unaffected by mixing corrections. Thus, there are no issues to resolve here with regard to those properties.

The results of the modified "re-creation" of the calculations in Wolery (1978 [DIRS 151346]) are summarized on the Worksheet Results Summary of the Spreadsheet Clays_TJW_0_Rev1b.xls (DTN: MO0302SPATHDYN.001 [DIRS 161886]). As has been discussed, the re-created molar volume regression does not match the original reported one, and is thereby improved. Furthermore, distinctions among octahedral vs. tetrahedral silicated oxide components $\left(\mathrm{Al}_{2} \mathrm{O}_{3}\right.$ in the Gibbs free energy regression, $\mathrm{Al}_{2} \mathrm{O}_{3}$ and $\mathrm{Fe}_{2} \mathrm{O}_{3}$ in the molar volume regression) were found 
to be statistically unsupported and were removed from the final regressions. This resulted in no sensible change in the Gibbs free energy method, as the Gibbs free energies for the two distinct $\mathrm{Al}_{2} \mathrm{O}_{3}$ components in the original method were virtually identical. Despite the reevaluation of the molar volume regression, the estimated values in most cases matched quite well with those reported in the original work. The principal exception concerned the nontronite clays, which exhibited molar volumes larger by roughly 3-4 percent. Although the changes in estimated molar volumes were carried through to those in the corresponding entropy estimates, the differences were increasingly insignificant. It was found that some of the reference reactions documented in Wolery (1978 [DIRS 151346]) were in error; however, it appeared that these errors were only in the documentation, not the actual calculations. In making some final adjustments for ripidolite chlorites, it was discovered that the entropy of mixing correction should have been larger than in the work in Wolery (1978 [DIRS 151346]) to accommodate a non-unit site stoichiometric factor. Also, the entropy itself should have received a mixing correction.

The "re-creation" of the calculations in Wolery (1978 [DIRS 151346]) in Spreadsheet Clays_TJW_0_Rev1b.xls, DTN: MO0302SPATHDYN.001 [DIRS 161886]) was then used as the basis for a second set of calculations. These are given in Spreadsheet Clays_TJW_1_Rev1b.xls, in DTN: MO0302SPATHDYN.001 [DIRS 161886]). Here the effects of updates to the SUPCRT92 data used in the regressions were taken into account. This second spreadsheet does not contain the extra worksheets with alternate regressions for the Gibbs free energies and molar volumes, as in the first spreadsheet. Thus, there is only a $G$ matrix worksheet corresponding to the G matrix 1 worksheet in the first spreadsheet, and a V matrix corresponding to the $V$ matrix 4 . There is again a similar regression on enthalpies on an $H$ matrix worksheet, but again this was not used to make any actual enthalpy estimates.

The final "reestimation" calculations conducted for data0.ymp.R2 (DTN: MO0302SPATHDYN.000 [DIRS 161756]) differed from the "re-creation" calculations described above, in that a few of the thermodynamic data used to calibrate the method were changed from those originally reported in Helgeson et al. (1978 [DIRS 101596]). These included the Gibbs free energy, enthalpy, and entropy for quartz and the Gibbs free energy and enthalpy for margarite. These changes were the only ones found by comparing the data from the SUPCRT92 data speq02.dat (DTN: MO0303SPASPEQ2.000 [DIRS 162278]) with the data given in Helgeson et al. (1978 [DIRS 101596], pp. 120-125, Table 8). The changes for quartz are discussed elsewhere in this report and are related to the change to the Rimstidt paradigm in which quartz is more soluble at low temperature than in the Walther and Helgeson (1977 [DIRS 133240]) method adopted in Helgeson et al. (1978 [DIRS 101596]). (Note: this increase in solubility is due more to changes in the stability of $\mathrm{SiO}_{2}(\mathrm{aq})$ than of quartz itself.) The changes for margarite were part of an overall correction for calcium-bearing minerals that was required in response to a change in aqueous species properties in SUPCRT92 that occurred several years after the publication of Helgeson et al. (1978 [DIRS 101596]). This change in the Gibbs free energy of margarite resulted in changes in the log K grid for margarite (Table 6-11). More details on the Ca correction for Ca-bearing silicated are provided in Section 6.1.6. 
Table 6-11. Comparison of Log K Grid for Margarite Between Original $\Delta \mathrm{G}_{f}^{\circ}$ and the Recalculated $\Delta \mathrm{G}_{\mathrm{f}}^{\circ}$ Value

\begin{tabular}{|c|c|c|c|c|c|c|c|c|c|c|}
\hline & \multirow[b]{2}{*}{$\begin{array}{c}\Delta \mathbf{G}_{\mathrm{f}}^{\circ} \\
(\mathrm{cal} / \mathrm{mol})\end{array}$} & \multirow[b]{2}{*}{ Source } & \multicolumn{8}{|c|}{ Temperature $\left({ }^{\circ} \mathrm{C}\right)$} \\
\hline & & & 0.01 & 25 & 60 & 100 & 150 & 200 & 250 & 300 \\
\hline Original & -1394370 & $\begin{array}{l}\text { Helgeson et al. } \\
1978 \\
\text { [DIRS 101596], } \\
\text { Table 8, p. 124 }\end{array}$ & 46.7189 & 38.6793 & 29.1917 & 20.4123 & 11.6081 & 4.3707 & -1.9478 & -7.8367 \\
\hline Recalculated & -1394150 & Recalculated & 46.895 & 38.840 & 29.336 & 20.541 & 11.722 & 4.472 & -1.856 & -7.753 \\
\hline Difference & & & -0.176 & -0.161 & -0.144 & -0.129 & -0.114 & -0.101 & -0.092 & -0.084 \\
\hline
\end{tabular}

DTN: MO0302SPATHDYN.001 ([DIRS 161886], Recalculated log K values in SUPCRT92 output file supmins2.out).

Using these new data, the $\Delta \mathrm{G}_{\mathrm{f}}{ }^{\circ}$ values for the silicated oxide components were recalculated in the Excel worksheet $G$ matrix in Clays_TJW_1_Rev1b.xls (DTN: MO0302SPATHDYN.001 [DIRS 161886]). These $\Delta \mathrm{G}_{\mathrm{f}}^{\circ}$ values were similar to those originally calculated by Tardy and Garrels (1974 [DIRS 159209]) with the largest difference (4124.4 cal/mol) being between the $\mathrm{Na}_{2} \mathrm{O}$ values (see Table 6-12). The $\Delta \mathrm{V}_{\mathrm{f}}{ }^{\circ}$ of the silicated oxide components were recalculated in the Excel worksheet $V$ matrix in Clays_TJW_1_Rev1b.xls (DTN: MO0302SPATHDYN.001 [DIRS 161886]). The calculated values (Table 6-13) were all significantly greater than zero as indicated by the very small probability values.

Table 6-12. Calculated $\Delta \mathrm{G}_{\mathrm{f}}{ }^{\circ}$ Values for the Silicated Oxide Components that Are Used to Calculate the $\Delta \mathrm{G}_{\mathrm{f}}^{\circ}$ of the Clay Phases

\begin{tabular}{|l|c|c|c|}
\hline Oxide & $\begin{array}{c}\text { Calculated } \\
\text { Silicated } \Delta \mathbf{G}_{\mathbf{f}}{ }^{\circ} \\
(\mathbf{c a l} / \mathbf{m o l})\end{array}$ & $\begin{array}{c}\text { Reported } \\
\text { Silicated } \Delta \mathbf{G}_{\mathbf{f}}{ }^{\circ} \\
\text { (cal/mol) }\end{array}$ & $\begin{array}{c}\text { Difference } \\
\text { (cal/mol) }\end{array}$ \\
\hline $\mathrm{Al}_{2} \mathrm{O}_{3}$ & -380339.5 & -382400 & 2060.5 \\
\hline $\mathrm{CaO}$ & -166129.9 & - & - \\
\hline $\mathrm{Fe}_{2} \mathrm{O}_{3}$ & -178155.0 & -177700 & 1.9 \\
\hline $\mathrm{FeO}$ & -64098.1 & -64100 & 1257.9 \\
\hline $\mathrm{H}_{2} \mathrm{O}$ & -57942.1 & -59200 & 2697.3 \\
\hline $\mathrm{K}_{2} \mathrm{O}$ & -185302.7 & -188000 & -924.2 \\
\hline $\mathrm{Mg}(\mathrm{OH})_{2}$ & -204224.2 & -203300 & 1128.4 \\
\hline $\mathrm{MgO}$ & -148071.6 & -149200 & -4124.4 \\
\hline $\mathrm{Na}_{2} \mathrm{O}$ & -166924.4 & -162800 & -99.4 \\
\hline $\mathrm{SiO}_{2}$ & -204699.4 & -204600 & \\
\hline
\end{tabular}

Sources: Column 2: DTN: MO0302SPATHDYN.001 ([DIRS 161886], Spreadsheet Clays_TJW_1_Rev1b.xIs, Worksheet $G$ matrix).

Column 3: Tardy and Garrels 1974 [DIRS 159209], Table 2, p. 1105. 
Table 6-13. Calculated $\Delta \mathrm{V}_{f}{ }^{\circ}$ Values for the Silicated Oxide Components that Will Be Used to Calculate the $\Delta \mathrm{G}_{\mathrm{f}}{ }^{\circ}$ of the Clays

\begin{tabular}{|l|c|}
\hline \multicolumn{1}{|c|}{ Oxide } & Calculated Silicated $\Delta \mathbf{V}^{\mathbf{0}}\left(\mathbf{c m}^{\mathbf{3}} / \mathbf{m o l}\right)$ \\
\hline $\mathrm{Al}_{2} \mathrm{O}_{3}$ & 25.483 \\
\hline $\mathrm{CaO}$ & 19.228 \\
\hline $\mathrm{Fe}_{2} \mathrm{O}_{3}$ & 31.567 \\
\hline $\mathrm{FeO}$ & 13.677 \\
\hline $\mathrm{H}_{2} \mathrm{O}$ & 14.056 \\
\hline $\mathrm{K}_{2} \mathrm{O}$ & 45.809 \\
\hline $\mathrm{Mg}(\mathrm{OH})_{2}$ & 26.975 \\
\hline $\mathrm{MgO}$ & 8.578 \\
\hline $\mathrm{Na}_{2} \mathrm{O}$ & 25.050 \\
\hline $\mathrm{SiO}_{2}$ & 22.575 \\
\hline
\end{tabular}

DTN: MO0302SPATHDYN.001 ([DIRS 161886],

Spreadsheet Clays_TJW_1_Rev1b.xls, Worksheet $\checkmark$ matrix).

The changes in the affected quartz properties, in the development of data0.ymp.R2 (DTN: MO0302SPATHDYN.000 [DIRS 161756]), were quite small. Also, the inclusion of margarite in the regression basically served only to constrain the Gibbs free energy of a non-exchangeable $\mathrm{CaO}$ component that was not actually used in any of the further estimations. The effect of these changes with respect to the "re-creation" calculations was therefore virtually negligible with regard to Gibbs free energies of formation and associated thermodynamic properties. Changes in the Gibbs free energy are shown for representative cases in Table 6-14. These are on the order of several calories at most, far less than any associated uncertainties. However, in moving to the Rimstidt paradigm, the significant changes to the thermodynamic properties of $\mathrm{SiO}_{2}(\mathrm{aq})$ introduced more significant changes to the $\log \mathrm{K}$ values for the associated reactions. Comparison of final calculated values with corresponding values from data0.ymp.R0 (DTN: MO0009THRMODYN.001 [DIRS 152576]) (Table 6-15) show a typical change of about one $\log \mathrm{K}$ unit.

Table 6-14. Estimated Gibbs Free Energies of Formation (cal/mol) for the Minerals of Interest: Original Wolery Estimates, "Re-Creation" Estimates, and Final "Reestimation" Estimates

\begin{tabular}{|l|c|c|c|}
\hline \multicolumn{1}{|c|}{ Mineral } & $\begin{array}{c}\text { Original: Wolery 1978 [DIRS 151346], } \\
\text { Table 1, p. 231 }\end{array}$ & "Re-Creation" & $\begin{array}{c}\text { Final } \\
\text { "Reestimation" }\end{array}$ \\
\hline Na-beidellite & -1279688 & -1279691.9 & -1279691.6 \\
\hline Ca-beidellite & -1280909 & -1280912.9 & -1280912.6 \\
\hline K-beidellite & -1281773 & -1281777.5 & -1281777.2 \\
\hline Mg-beidellite & -1277064 & -1277068.4 & -1277068.1 \\
\hline Na-saponite & -1343879 & -1343882.9 & -1343882.6 \\
\hline Ca-saponite & -1345100 & -1345103.9 & -1345103.6 \\
\hline Na-nontronite & -1078271 & -1078585.1 & -1078589.5 \\
\hline Ca-nontronite & -1079492 & -1079806.1 & -1079810.5 \\
\hline Illite & -1303971 & -1303939.6 & -1303942.0 \\
\hline High Fe-Mg smectite & -1262121 & -1262121.7 & -1262124.8 \\
\hline
\end{tabular}

DTN: MO0302SPATHDYN.001 ([DIRS 161886]; Column 3 is from Spreadsheet Clays_TJW_0_Rev1b.xls; Column 4 is from Spreadsheet Clays_TJW_1_Rev1b.xls). 
Table 6-15. Estimated Log $\mathrm{K}$ Values at $25^{\circ} \mathrm{C}$ for Dissolution Reactions of Some Minerals: Values from Data0.ymp.R0 Versus Revised Values for Data0.ymp.R2 Based on the Current Final "Reestimation" of Gibbs Free Energies in Conjunction with the Rimstidt Paradigm for $\mathrm{SiO}_{2}(\mathrm{aq})$ Properties

\begin{tabular}{|l|c|c|}
\hline \multicolumn{1}{|c|}{ Mineral } & Old: Data0.ymp.R0 & New: Data0.ymp.R2 \\
\hline Na-beidellite & 4.0521 & 4.9911 \\
\hline Ca-beidellite & 3.9962 & 4.9352 \\
\hline K-beidellite & 3.7136 & 4.6522 \\
\hline Mg-beidellite & 3.9585 & 4.8971 \\
\hline Na-saponite & 26.1200 & 27.0591 \\
\hline Ca-saponite & 26.0641 & 27.0032 \\
\hline Na-nontronite & -11.7523 & -11.0442 \\
\hline Ca-nontronite & -11.8082 & -11.1001 \\
\hline Illite & 7.4514 & 8.3706 \\
\hline High Fe-Mg smectite & 16.5642 & 17.4595 \\
\hline
\end{tabular}

Sources: Column 2: DTN: MO0009THRMODYN.001 [DIRS 152576].

Column 3: DTN: MO0302SPATHDYN.001 [DIRS 161886].

In making these estimations, some additional minerals were added to data0.ymp.R2 (DTN: MO0302SPATHDYN.000 [DIRS 161756]). A set of idealized montmorillonites was added to complement the other groups of idealized smectites (beidellites, saponites, and nontronites). The montmorillonites had been included on some earlier EQ3/6 data files, but owing to uncertainty over the origin of the corresponding data, they were excluded from data0.ymp.R0 (DTN: MO0009THRMODYN.001 [DIRS 152576]). Two additional minerals from the celadonite group were also added, ferroceladonite $\left(\mathrm{K}_{2} \mathrm{Fe}^{++}{ }_{2} \mathrm{Fe}^{+++}{ }_{2} \mathrm{Si}_{8} \mathrm{O}_{20}(\mathrm{OH})_{4}\right)$ and ferroaluminoceladonite $\left(\mathrm{K}_{2} \mathrm{Fe}^{++}{ }_{2} \mathrm{Al}_{2} \mathrm{Si}_{8} \mathrm{O}_{20}(\mathrm{OH})_{4}\right)$. These minerals were recently described by $\mathrm{Li}$ et al. (1997 [DIRS 159034]). The authors described the archetypal celadonite by the formula $\mathrm{K}_{2} \mathrm{Mg}_{2} \mathrm{Al}_{2} \mathrm{Si}_{8} \mathrm{O}_{20}(\mathrm{OH})_{4}$.

The "reestimated" thermodynamic properties $\left(\Delta \mathrm{G}_{\mathrm{f}}{ }^{\circ}, \mathrm{S}^{\circ}, \Delta \mathrm{V}_{\mathrm{f}}{ }^{\circ}\right.$, and the heat capacity coefficients "a," "b," and "c") were summarized in the Worksheet Results Summary of the Spreadsheet Clays_TJW_1_Rev1b.xls (DTN: MO0302SPATHDYN.001 [DIRS 161886]), and are presented in Table 6-16. The "reestimated" $\Delta \mathrm{G}_{\mathrm{f}}{ }^{\circ}$ for several additional clay minerals are shown in Table 6-17. The requisite entropies and heat capacity coefficients for these clays are those in the SUPCRT92 database are from Helgeson et al. (1978 [DIRS 101596]) and were included in the qualified slop98.dat database (DTN: MO0106MWDTDG01.035 [DIRS 161791]). These thermodynamic data were used in the Spreadsheet Minerals_cal_sea_clays1a.xls (DTN: MO0302SPATHDYN.001 [DIRS 161886]) to calculate the log K for each reaction for the EQ3/6 temperature grid from 0.01 up to $300^{\circ} \mathrm{C}$. These results are summarized in Table 6-18. 


\begin{tabular}{|c|c|c|c|c|c|c|c|}
\hline & & & & & Heat $C_{a}$ & apacity Coeff & icients* \\
\hline Phase & Formula & $\begin{array}{c}\Delta \mathbf{G}_{\mathrm{f}}^{\circ} \\
(\mathrm{cal} / \mathrm{mol})\end{array}$ & $\begin{array}{c}\mathrm{S}^{\circ} \\
\text { (cal/mol-K) }\end{array}$ & $\begin{array}{c}V^{\circ} \\
\left(\mathrm{cm}^{3} / \mathrm{mol}\right)\end{array}$ & $\begin{array}{c}\mathrm{a} \\
(\mathrm{cal} / \mathrm{mol}-\mathrm{K}) \\
\end{array}$ & $\begin{array}{c}\mathrm{b} \times 10^{3} \\
\left(\mathrm{cal} / \mathrm{mol}-\mathrm{K}^{2}\right) \\
\end{array}$ & $\begin{array}{c}\mathrm{c} \times 10^{-5} \\
(\mathrm{cal}-\mathrm{K} / \mathrm{mol})\end{array}$ \\
\hline 14A-Ripidolite & $\mathrm{Mg}_{3} \mathrm{Fe}_{2} \mathrm{Al}_{2} \mathrm{Si}_{3} \mathrm{O}_{10}(\mathrm{OH})_{8}$ & -1798613.01 & 130.407 & 209.634 & 170.38 & \begin{tabular}{|l|}
42.76 \\
\end{tabular} & 36.01 \\
\hline 7A-Ripidolite & $\mathrm{Mg}_{3} \mathrm{Fe}_{2} \mathrm{Al}_{2} \mathrm{Si}_{3} \mathrm{O}_{10}(\mathrm{OH})_{8}$ & -1794011.01 & 126.147 & 215.380 & 166.7 & 51.28 & 39.42 \\
\hline Ca-Beidellite & $\mathrm{Ca}_{0.165} \mathrm{Al}_{2.33} \mathrm{Si}_{3.67} \mathrm{O}_{10}(\mathrm{OH})_{2}$ & -1280912.557 & 58.345 & 129.766 & 82.1908 & 37.1515 & 18.0311 \\
\hline Ca-Montmorillonite & $\mathrm{Ca}_{0.165} \mathrm{Mg}_{0.33} \mathrm{Al}_{1.67} \mathrm{Si}_{4} \mathrm{O}_{10}(\mathrm{OH})_{2}$ & -1272306.883 & 59.845 & 133.070 & 80.1811 & 39.5011 & 16.6451 \\
\hline Ca-Nontronite & $\mathrm{Ca}_{0.165} \mathrm{Fe}_{2} \mathrm{Al}_{0.33} \mathrm{Si}_{3.67} \mathrm{O}_{10}(\mathrm{OH})_{2}$ & -1079810.475 & 67.549 & 135.850 & 78.1908 & 52.9315 & 13.2011 \\
\hline Ca-Saponite & $\mathrm{Ca}_{0.165} \mathrm{Mg}_{3} \mathrm{Al}_{0.33} \mathrm{Si}_{3.67} \mathrm{O}_{10}(\mathrm{OH})_{2}$ & -1345103.557 & 62.328 & 134.359 & 85.2388 & 39.5475 & 14.0891 \\
\hline Ferroaluminoceladonite & $\mathrm{KFeAISi}_{4} \mathrm{O}_{10}(\mathrm{OH})_{2}$ & -1223659.186 & 76.901 & 153.678 & 87.062 & 44.199 & 14.282 \\
\hline Ferroceladonite & $\mathrm{KFeFeSi}_{4} \mathrm{O}_{10}(\mathrm{OH})_{2}$ & -1122566.912 & 81.552 & 156.720 & 85.062 & 52.089 & 11.867 \\
\hline $\mathrm{H}$-Beidellite & $\mathrm{H}_{0.33} \mathrm{Al}_{2.33} \mathrm{Si}_{3.67} \mathrm{O}_{10}(\mathrm{OH})_{2}$ & -1260419.557 & 58.286 & 128.913 & 81.4384 & 38.3329 & 17.7737 \\
\hline High Fe-Mg Smectite & $\begin{array}{l}\mathrm{Na}_{0.1} \mathrm{~K}_{0.2} \mathrm{Ca}_{0.025}\left(\mathrm{Mg}_{1.15} \mathrm{Fe}^{+++}{ }_{0.2} \mathrm{Fe}^{++}{ }_{0.5} \mathrm{Al}_{0.75}\right) \\
\quad\left(\mathrm{Al}_{0.5} \mathrm{Si}_{3.5}\right) \mathrm{O}_{10}(\mathrm{OH})_{2}\end{array}$ & -1262124.787 & 68.395 & 139.510 & 86.6845 & 40.089 & 15.493 \\
\hline H-Montmorillonite & $\mathrm{H}_{0.33} \mathrm{Mg}_{0.33} \mathrm{Al}_{1.67} \mathrm{Si}_{4} \mathrm{O}_{10}(\mathrm{OH})_{2}$ & -1251813.883 & 59.786 & 132.216 & 79.4287 & 40.6825 & 16.3877 \\
\hline H-Nontronite & $\mathrm{H}_{0.33} \mathrm{Fe}_{2} \mathrm{Al}_{0.33} \mathrm{Si}_{3.67} \mathrm{O}_{10}(\mathrm{OH})_{2}$ & -1059317.475 & 67.482 & 134.996 & 77.4384 & 54.1129 & 12.9437 \\
\hline H-Saponite & $\mathrm{H}_{0.33} \mathrm{Mg}_{3} \mathrm{Al}_{0.33} \mathrm{Si}_{3.67} \mathrm{O}_{10}(\mathrm{OH})_{2}$ & -1324610.557 & 62.263 & 133.506 & 84.4864 & 40.7289 & 13.8317 \\
\hline Illite & $\mathrm{K}_{0.6} \mathrm{Mg}_{0.25} \mathrm{Al}_{2.3} \mathrm{Si}_{3.5} \mathrm{O}_{10}(\mathrm{OH})_{2}$ & -1303942.016 & 63.676 & 139.346 & 86.0435 & 38.567 & 17.823 \\
\hline K-Beidellite & $\mathrm{K}_{0.33} \mathrm{Al}_{2.33} \mathrm{Si}_{3.67} \mathrm{O}_{10}(\mathrm{OH})_{2}$ & -1281777.157 & 60.608 & 134.152 & 83.3194 & 38.40055 & 17.9189 \\
\hline K-Montmorillonite & $\mathrm{K}_{0.33} \mathrm{Mg}_{0.33} \mathrm{Al}_{1.67} \mathrm{Si}_{4} \mathrm{O}_{10}(\mathrm{OH})_{2}$ & -1273171.483 & 62.108 & 137.455 & 81.3097 & 40.75015 & 16.5329 \\
\hline K-Nontronite & $\mathrm{K}_{0.33} \mathrm{Fe}_{2} \mathrm{Al}_{0.33} \mathrm{Si}_{3.67} \mathrm{O}_{10}(\mathrm{OH})_{2}$ & -1080675.075 & 69.821 & 140.235 & 79.3194 & 54.18055 & 13.0889 \\
\hline K-Saponite & $\mathrm{K}_{0.33} \mathrm{Mg}_{3} \mathrm{Al}_{0.33} \mathrm{Si}_{3.67} \mathrm{O}_{10}(\mathrm{OH})_{2}$ & -1345968.157 & 64.585 & 138.745 & 86.3674 & 40.79655 & 13.9769 \\
\hline Low Fe-Mg Smectite & $\begin{array}{l}\mathrm{Na} a_{0.15} \mathrm{~K}_{0.2} \mathrm{Ca}_{0.02}\left(\mathrm{Mg}_{0.9} \mathrm{Fe}^{+++}{ }_{0.16} \mathrm{Fe}^{++}{ }_{0.29} \mathrm{Al}\right) \\
\left(\mathrm{Al}_{0.25} \mathrm{Si}_{3.75}\right) \mathrm{O}_{10}(\mathrm{OH})_{2}\end{array}$ & -1262853.251 & 66.515 & 139.602 & 84.3274 & 41.01415 & 15.63395 \\
\hline Mg-Beidellite & $\mathrm{Mg}_{0.165} \mathrm{Al}_{2.33} \mathrm{Si}_{3.67} \mathrm{O}_{10}(\mathrm{OH})_{2}$ & -1277068.057 & 57.809 & 128.725 & 81.94495 & 37.2604 & 18.0179 \\
\hline Mg-Montmorillonite & $\mathrm{Mg}_{0.495} \mathrm{Al}_{1.67} \mathrm{Si}_{4} \mathrm{O}_{10}(\mathrm{OH})_{2}$ & -1268462.383 & 59.309 & 132.029 & 79.93525 & 39.61 & 16.6319 \\
\hline Mg-Nontronite & $\mathrm{Mg}_{0.165} \mathrm{Fe}_{2} \mathrm{Al}_{0.33} \mathrm{Si}_{3.67} \mathrm{O}_{10}(\mathrm{OH})_{2}$ & -1075965.975 & 67.010 & 134.809 & 77.94495 & 53.0404 & 13.1879 \\
\hline Mg-Saponite & $\mathrm{Mg}_{3.165} \mathrm{Al}_{0.33} \mathrm{Si}_{3.67} \mathrm{O}_{10}(\mathrm{OH})_{2}$ & -1341259.057 & 61.629 & 132.602 & 84.99295 & 39.6564 & 14.0759 \\
\hline Na-Beidellite & $\mathrm{Na}_{0.33} \mathrm{Al}_{2.33} \mathrm{Si}_{3.67} \mathrm{O}_{10}(\mathrm{OH})_{2}$ & -1279691.557 & 59.656 & 130.727 & 83.2765 & 37.78015 & 18.25055 \\
\hline
\end{tabular}


Table 6-16. Summary of "Reestimated" Thermodynamic Properties of Clay Minerals (Continued)

\begin{tabular}{|c|c|c|c|c|c|c|c|}
\hline & & & & & Heat $\mathrm{Ca}$ & pacity Coeffi & cients ${ }^{*}$ \\
\hline Name & Formula & $\begin{array}{c}\Delta \mathbf{G}_{\mathrm{f}}^{\circ} \\
(\mathrm{cal} / \mathrm{mol})\end{array}$ & $\begin{array}{c}\mathrm{S}^{\circ} \\
(\mathrm{cal} / \mathrm{mol}-\mathrm{K})\end{array}$ & $\begin{array}{c}V^{\circ} \\
\left(\mathrm{cm}^{3} / \mathrm{mol}\right)\end{array}$ & $\begin{array}{c}\mathrm{a} \\
\text { (cal/mol-K) }\end{array}$ & $\begin{array}{c}\mathrm{b} \times 10^{3} \\
\left(\mathrm{cal} / \mathrm{mol}^{\left.-\mathrm{K}^{2}\right)}\right. \\
\end{array}$ & $\begin{array}{c}\mathrm{c} \times 10^{-5} \\
\text { (cal-K/mol) }\end{array}$ \\
\hline Na-Montmorillonite & $\mathrm{Na}_{0.33} \mathrm{Mg}_{0.33} \mathrm{Al}_{1.67} \mathrm{Si}_{4} \mathrm{O}_{10}(\mathrm{OH})_{2}$ & -1271085.883 & 61.157 & 134.030 & 81.2668 & 40.12975 & 16.86455 \\
\hline Na-Nontronite & $\mathrm{Na}_{0.33} \mathrm{Fe}_{2} \mathrm{Al}_{0.33} \mathrm{Si}_{3.67} \mathrm{O}_{10}(\mathrm{OH})_{2}$ & -1078589.475 & 68.852 & 136.810 & 79.2765 & 53.56015 & 13.42055 \\
\hline Na-Saponite & $\mathrm{Na}_{0.33} \mathrm{Mg}_{3} \mathrm{Al}_{0.33} \mathrm{Si}_{3.67} \mathrm{O}_{10}(\mathrm{OH})_{2}$ & -1343882.557 & 63.623 & 135.320 & 86.3245 & 40.17615 & 14.30855 \\
\hline Reykjanes Smectite & $\begin{array}{l}\mathrm{Na}_{0.33} \mathrm{~K}_{0.03} \mathrm{Ca}_{0.66}\left(\mathrm{Mg}_{1.22} \mathrm{Fe}^{+++}{ }_{0.35} \mathrm{Fe}^{++}{ }_{0.33} \mathrm{Mn}_{0.01}\right. \\
\left.\quad \mathrm{Al}_{0.28}\right)\left(\mathrm{Al}_{0.83} \mathrm{Si}_{3.17}\right) \mathrm{O}_{10}(\mathrm{OH})_{2}\end{array}$ & -1310547.875 & 71.115 & 142.853 & 90.2311 & 39.0046 & 15.6183 \\
\hline
\end{tabular}

DTN: MO0302SPATHDYN.001 ([DIRS 161886], Spreadsheet Clays_TJW_1_Rev1b.xIs, Worksheet Results Summary).

* Coefficients defined in Eq. 4-1. 
Table 6-17. $\Delta \mathrm{G}_{\mathrm{f}}^{\circ}$ Data for Additional Clay Minerals

\begin{tabular}{|l|c|c|}
\hline \multicolumn{1}{|c|}{ Phase } & Formula & $\Delta \mathbf{G}_{\mathbf{f}}{ }^{\circ}(\mathbf{c a l} / \mathbf{m o l})$ \\
\hline 14A-Amesite & $\mathrm{Mg}_{4} \mathrm{Al}_{4} \mathrm{Si}_{2} \mathrm{O}_{10}(\mathrm{OH})_{8}$ & -1991568.2 \\
\hline 14A-Daphnite & $\mathrm{Fe}_{5} \mathrm{Al}_{2} \mathrm{Si}_{3} \mathrm{O}_{10}(\mathrm{OH})_{8}$ & -1548993.7 \\
\hline 7A-Amesite & $\mathrm{Mg}_{2} \mathrm{Al}_{2} \mathrm{SiO}_{5}(\mathrm{OH})_{4}$ & -991182.1 \\
\hline 7A-Chamosite & $\mathrm{Fe}_{2} \mathrm{Al}_{2} \mathrm{SiO}_{5}(\mathrm{OH})_{4}$ & -826814.2 \\
\hline 7A-Cronstedtite & $\mathrm{Fe}_{2} \mathrm{Fe}_{2} \mathrm{SiO}_{5}(\mathrm{OH})_{4}$ & -624629.6 \\
\hline 7A-Daphnite & $\mathrm{Fe}_{5} \mathrm{Al}_{2} \mathrm{Si}_{3} \mathrm{O}_{10}(\mathrm{OH})_{8}$ & -1544391.7 \\
\hline Celadonite & $\mathrm{KMgAlSi}_{4} \mathrm{O}_{10}(\mathrm{OH})_{2}$ & -1305843.2 \\
\hline Greenalite & $\mathrm{Fe}_{3} \mathrm{Si}_{2} \mathrm{O}_{5}(\mathrm{OH})_{4}$ & -716529.6 \\
\hline Minnesotaite & $\mathrm{Fe}_{3} \mathrm{Si}_{4} \mathrm{O}_{10}(\mathrm{OH})_{2}$ & -1070057.2 \\
\hline
\end{tabular}

DTN: MO0302SPATHDYN.001 ([DIRS 161886], Spreadsheet Clays_TJW_1_Rev1b.xls, Worksheet Results Summary).

NOTE: The requisite entropies and heat capacity coefficients in the SUPCRT92 database speq02.dat (DTN: MO0303SPASPEQ2.000 [DIRS 162278]) are from Helgeson et al. (1978 [DIRS 101596]) and were included in the qualified slop98.dat database (DTN: MO0106MWDTDG01.035 [DIRS 161791]).

Some additional comments are appropriate concerning the accuracy of the estimated values presented here. These are primarily directed toward values for Gibbs free energy and molar volume, for which regressions were made. The Excel regression tool computes standard errors for regressed parameters. It might be tempting to use these to estimate uncertainties in estimated properties for minerals outside the regression set. However, these standard errors tend to be strongly correlated, so using them in this way would tend to overestimate uncertainties. That was clearly shown in the attempt to re-create the original molar volume regression discussed above.

The regression errors themselves largely underestimate the likely uncertainties in estimated parameter values for minerals outside the regression set. The number of minerals used in the regressions is not large compared to the number of regression components. Thus in the Gibbs free energy regression, the regression error in the case of margarite is zero. That is because only margarite contains the $\mathrm{CaO}$ component. Clearly, the uncertainty in the Gibbs free energy of margarite itself is not zero.

A minimum measure of uncertainty in estimated Gibbs free energies is suggested by the general level of uncertainty in experimental determinations. This would be best represented by the uncertainty in calorimetric measurements as this avoids problems of error correlation associated with phase equilibrium or solubility measurements. It was mentioned earlier that such uncertainties for the Gibbs free energies of formation of kaolinite and dickite are roughly 960 to $1,670 \mathrm{cal} / \mathrm{mol}$ (de Ligny and Navrotsky 1999 [DIRS 158973]; Fialips et al. 2001 [DIRS 158975]). To extrapolate such results, it is necessary to use some kind of normalization to account for the size of the molecular formula. For sheet silicates, a reasonable normalizing factor is the number of cations $\left(\mathrm{Si}^{++++}, \mathrm{Al}^{+++}\right)$in the tetrahedral layers. For kaolinite and dickite that factor would be 2. So a minimal uncertainty for sheet silicates is in the range of 500 to $800 \mathrm{cal} / \mathrm{mol}$ per tetrahedral cation. The number of tetrahedral cations for most of the compositions for which Gibbs free energies were estimated is four. The minimum uncertainty in such a "typical" case is about 2,000 to $3,200 \mathrm{cal} / \mathrm{mol}$. 
Table 6-18. Log K Matrix for Clay Minerals

\begin{tabular}{|c|c|c|c|c|c|c|c|c|c|}
\hline \multirow[b]{2}{*}{ Mineral } & \multirow[b]{2}{*}{ Reaction } & \multicolumn{8}{|c|}{ Temperature $\left({ }^{\circ} \mathrm{C}\right)$} \\
\hline & & 0.01 & 25 & 60 & 100 & 150 & 200 & 250 & 300 \\
\hline Celadonite & $\begin{array}{l}\text { Celadonite }+6 \mathrm{H}^{+}= \\
\mathrm{K}^{+}+\mathrm{Al}^{+++}+4 \mathrm{H}_{2} \mathrm{O}+\mathrm{Mg}^{++}+4 \mathrm{SiO}_{2}(\mathrm{aq})\end{array}$ & 9.3867 & 7.8372 & 5.7794 & 3.8829 & 2.0909 & 0.7097 & -0.4913 & -1.7540 \\
\hline 7A-Chamosite & $\begin{array}{l}7 \mathrm{~A}-\text { Chamosite }+10 \mathrm{H}^{+}= \\
2 \mathrm{Al}^{+++}+7 \mathrm{H}_{2} \mathrm{O}+2 \mathrm{Fe}^{++}+\mathrm{SiO}_{2}(\mathrm{aq})\end{array}$ & 38.3852 & 32.6174 & 25.8845 & 19.7095 & 13.5709 & 8.5699 & 4.2401 & 0.2323 \\
\hline 7A-Cronstedtite & $\begin{array}{l}\text { 7A-Cronstedtite }+10 \mathrm{H}^{+}= \\
2 \mathrm{Fe}^{+++}+7 \mathrm{H}_{2} \mathrm{O}+2 \mathrm{Fe}^{++}+\mathrm{SiO}_{2}(\mathrm{aq})\end{array}$ & 21.4814 & 17.3756 & 12.5812 & 8.2074 & 3.8785 & 0.3407 & -2.7751 & -5.7609 \\
\hline 7A-Amesite & $\begin{array}{l}7 \mathrm{~A}-\mathrm{Amesite}+10 \mathrm{H}^{+}= \\
2 \mathrm{Al}^{++}+7 \mathrm{H}_{2} \mathrm{O}+2 \mathrm{Mg}^{++}+\mathrm{SiO}_{2}(\mathrm{aq})\end{array}$ & 45.5694 & 39.1427 & 31.6777 & 24.8682 & 18.1455 & 12.7178 & 8.0675 & 3.8149 \\
\hline 14A-Amesite & $\begin{array}{l}14 \mathrm{~A}-\mathrm{Amesite}+2 \mathrm{OH}^{+}= \\
4 \mathrm{Al}^{+++}+14 \mathrm{H}_{2} \mathrm{O}+4 \mathrm{Mg}^{++}+2 \mathrm{SiO}_{2}(\mathrm{aq})\end{array}$ & 83.8687 & 71.5387 & 57.1989 & 44.1066 & 31.1666 & 20.6994 & 11.7058 & 3.4494 \\
\hline H-Beidellite & $\begin{array}{l}\mathrm{H} \text {-Beidellite }+6.99 \mathrm{H}^{+}= \\
2.33 \mathrm{Al}^{+++}+4.66 \mathrm{H}_{2} \mathrm{O}+3.67 \mathrm{SiO}_{2}(\mathrm{aq})\end{array}$ & 6.5291 & 3.9773 & 0.6217 & -2.6329 & -5.9722 & -8.7737 & -11.3044 & -13.8242 \\
\hline Na-Beidellite & $\begin{array}{l}\text { Na-Beidellite }+7.32 \mathrm{H}^{+}= \\
0.33 \mathrm{Na}^{+}+2.33 \mathrm{Al}^{+++}+4.66 \mathrm{H}_{2} \mathrm{O}+3.67 \mathrm{SiO}_{2}(\mathrm{aq})\end{array}$ & 7.5710 & 4.9911 & 1.6049 & -1.6729 & -5.0287 & -7.8389 & -10.3752 & -12.9025 \\
\hline K-Beidellite & $\begin{array}{l}\text { K-Beidellite }+7.32 \mathrm{H}^{+}= \\
0.33 \mathrm{~K}^{+}+2.33 \mathrm{Al}^{+++}+4.66 \mathrm{H}_{2} \mathrm{O}+3.67 \mathrm{SiO}_{2}(\mathrm{aq})\end{array}$ & 7.1513 & 4.6522 & 1.3538 & -1.8507 & -5.1429 & -7.9101 & -10.4166 & -12.9220 \\
\hline Ca-Beidellite & $\begin{array}{l}\text { Ca-Beidellite }+7.32 \mathrm{H}^{+}= \\
0.165 \mathrm{Ca}^{++}+2.33 \mathrm{Al}^{++}+4.66 \mathrm{H}_{2} \mathrm{O}+3.67 \mathrm{SiO}_{2}(\mathrm{aq})\end{array}$ & 7.6185 & 4.9352 & 1.4241 & -1.9769 & -5.4668 & -8.3955 & -11.0397 & -13.6677 \\
\hline Mg-Beidellite & $\begin{array}{l}\text { Mg-Beidellite }+7.32 \mathrm{H}^{+}= \\
0.165 \mathrm{Mg}^{++}+2.33 \mathrm{Al}^{+++}+4.66 \mathrm{H}_{2} \mathrm{O}+3.67 \mathrm{SiO}_{2}(\mathrm{aq})\end{array}$ & 7.6307 & 4.8971 & 1.3296 & -2.1202 & -5.6543 & -8.6151 & -11.2835 & -13.9303 \\
\hline 7A-Daphnite & $\begin{array}{l}\text { 7A-Daphnite }+16 \mathrm{H}^{+}= \\
2 \mathrm{Al}^{+++}+12 \mathrm{H}_{2} \mathrm{O}+5 \mathrm{Fe}^{++}+3 \mathrm{SiO}_{2}(\mathrm{aq})\end{array}$ & 63.6316 & 55.0117 & 44.8770 & 35.6047 & 26.4563 & 19.0674 & 12.6966 & 6.7515 \\
\hline 14A-Daphnite & $\begin{array}{l}\text { 14A-Daphnite }+16 \mathrm{H}^{+}= \\
2 \mathrm{Al}^{+++}+12 \mathrm{H}_{2} \mathrm{O}+5 \mathrm{Fe}^{++}+3 \mathrm{SiO}_{2}(\mathrm{aq})\end{array}$ & 60.0171 & 51.6383 & 41.7694 & 32.7295 & 23.8005 & 16.5785 & 10.3389 & 4.4998 \\
\hline $\begin{array}{l}\text { Ferroalumino- } \\
\text { celadonite }\end{array}$ & $\begin{array}{l}\text { Ferroaluminoceladonite }+6 \mathrm{H}^{+}= \\
\mathrm{K}^{+}+\mathrm{Al}^{+++}+4 \mathrm{H}_{2} \mathrm{O}+\mathrm{Fe}^{++}+4 \mathrm{SiO}_{2}(\mathrm{aq})\end{array}$ & 5.6657 & 4.5745 & 2.9253 & 1.2797 & -0.3933 & -1.7825 & -3.0649 & -4.4541 \\
\hline Ferroceladonite & $\begin{array}{l}\text { Ferroceladonite }+6 \mathrm{H}^{+}= \\
\mathrm{K}^{+}+\mathrm{Fe}^{+++}+4 \mathrm{H}_{2} \mathrm{O}+\mathrm{Fe}^{++}+4 \mathrm{SiO}_{2}(\mathrm{aq})\end{array}$ & -2.7737 & -3.0464 & -3.7219 & -4.4443 & -5.1715 & -5.7824 & -6.4098 & -7.2406 \\
\hline
\end{tabular}


Table 6-18. Log K Matrix for Clay Minerals (Continued)

\begin{tabular}{|c|c|c|c|c|c|c|c|c|c|}
\hline \multirow[b]{2}{*}{ Mineral } & \multirow[b]{2}{*}{ Reaction } & \multicolumn{8}{|c|}{ Temperature $\left({ }^{\circ} \mathrm{C}\right)$} \\
\hline & & 0.01 & 25 & 60 & 100 & 150 & 200 & 250 & 300 \\
\hline Greenalite & $\begin{array}{l}\text { Greenalite }+6 \mathrm{H}^{+}= \\
5 \mathrm{H}_{2} \mathrm{O}+3 \mathrm{Fe}^{++}+2 \mathrm{SiO}_{2}(\mathrm{aq})\end{array}$ & 26.0534 & 23.1624 & 19.7179 & 16.5850 & 13.5453 & 11.1388 & 9.0868 & 7.1439 \\
\hline Illite & $\begin{array}{l}\text { Illite }+8 \mathrm{H}^{+}= \\
2.3 \mathrm{Al}^{+++}+0.25 \mathrm{Mg}^{++}+5 \mathrm{H}_{2} \mathrm{O}+0.6 \mathrm{~K}^{+}+3.5 \mathrm{SiO}_{2}(\mathrm{aq})\end{array}$ & 11.1913 & 8.3706 & 4.7199 & 1.2042 & -2.3885 & -5.3930 & -8.0973 & -10.7757 \\
\hline Minnesotaite & $\begin{array}{l}\text { Minnesotaite }+6 \mathrm{H}^{+}= \\
4 \mathrm{H}_{2} \mathrm{O}+3 \mathrm{Fe}^{++}+4 \mathrm{SiO}_{2}(\mathrm{aq})\end{array}$ & 17.1553 & 15.0002 & 12.2222 & 9.6380 & 7.1347 & 5.1629 & 3.4582 & 1.7440 \\
\hline $\begin{array}{l}\text { H-Montmo- } \\
\text { rillonite }\end{array}$ & $\begin{array}{l}\text { H-Montmorillonite }+5.67 \mathrm{H}^{+}= \\
0.33 \mathrm{Mg}^{++}+1.67 \mathrm{Al}^{+++}+4 \mathrm{H}_{2} \mathrm{O}+4 \mathrm{SiO}_{2}(\mathrm{aq})\end{array}$ & 3.1333 & 1.4445 & -0.9146 & -3.2347 & -5.6069 & -7.5864 & -9.3859 & -11.2358 \\
\hline $\begin{array}{l}\text { Na-Montmo- } \\
\text { rillonite }\end{array}$ & $\begin{array}{l}\text { Na-Montmorillonite }+6 \mathrm{H}^{+}= \\
0.33 \mathrm{Na}^{+}+0.33 \mathrm{Mg}^{++}+1.67 \mathrm{Al}^{+++}+4 \mathrm{H}_{2} \mathrm{O}+4 \mathrm{SiO}_{2}(\mathrm{aq})\end{array}$ & 4.1752 & 2.4583 & 0.0686 & -2.2746 & -4.6636 & -6.6516 & -8.4568 & -10.3142 \\
\hline $\begin{array}{l}\text { K-Montmo- } \\
\text { rillonite }\end{array}$ & $\begin{array}{l}\text { K-Montmorillonite }+6 \mathrm{H}^{+}= \\
0.33 \mathrm{~K}^{+}+0.33 \mathrm{Mg}^{++}+1.67 \mathrm{Al}^{+++}+4 \mathrm{H}_{2} \mathrm{O}+4 \mathrm{SiO}_{2}(\mathrm{aq})\end{array}$ & 3.7554 & 2.1194 & -0.1824 & -2.4524 & -4.7777 & -6.7228 & -8.4982 & -10.3337 \\
\hline $\begin{array}{l}\text { Ca-Montmo- } \\
\text { rillonite }\end{array}$ & $\begin{array}{l}\text { Ca-Montmorillonite }+6 \mathrm{H}^{+}= \\
0.165 \mathrm{Ca}^{++}+0.33 \mathrm{Mg}^{++}+1.67 \mathrm{Al}^{+++}+4 \mathrm{H}_{2} \mathrm{O}+ \\
4 \mathrm{SiO}_{2}(\mathrm{aq})\end{array}$ & 4.2226 & 2.4024 & -0.1121 & -2.5786 & -5.1015 & -7.2081 & -9.1212 & -11.0793 \\
\hline $\begin{array}{l}\text { Mg-Montmo- } \\
\text { rillonite }\end{array}$ & $\begin{array}{l}\text { Mg-Montmorillonite }+6 \mathrm{H}^{+}= \\
0.495 \mathrm{Mg}^{++}+1.67 \mathrm{Al}^{+++}+4 \mathrm{H}_{2} \mathrm{O}+4 \mathrm{SiO}_{2}(\mathrm{aq})\end{array}$ & 4.2348 & 2.3643 & -0.2067 & -2.7218 & -5.2890 & -7.4277 & -9.3650 & -11.3418 \\
\hline H-Nontronite & $\begin{array}{l}\mathrm{H}-\text { Nontronite }+6.99 \mathrm{H}^{+}= \\
2 \mathrm{Fe}^{+++}+0.33 \mathrm{Al}^{+++}+4.66 \mathrm{H}_{2} \mathrm{O}+3.67 \mathrm{SiO}_{2}(\mathrm{aq})\end{array}$ & -11.2178 & -12.0580 & -13.3804 & -14.7103 & -16.0807 & -17.2650 & -18.4365 & -19.7989 \\
\hline Na-Nontronite & $\begin{array}{l}\text { Na-Nontronite }+7.32 \mathrm{H}^{+}= \\
0.33 \mathrm{Na}^{+}+2 \mathrm{Fe}^{+++}+0.33 \mathrm{Al}^{+++}+4.66 \mathrm{H}_{2} \mathrm{O}+ \\
3.67 \mathrm{SiO}_{2}(\mathrm{aq})\end{array}$ & -10.1759 & -11.0442 & -12.3972 & -13.7502 & -15.1373 & -16.3301 & -17.5073 & -18.8772 \\
\hline K-Nontronite & $\begin{array}{l}\mathrm{K}-N o n t r o n i t e+7.32 \mathrm{H}^{+}= \\
0.33 \mathrm{~K}^{+}+2 \mathrm{Fe}^{+++}+0.33 \mathrm{Al}^{+++}+4.66 \mathrm{H}_{2} \mathrm{O}+ \\
3.67 \mathrm{SiO}_{2}(\mathrm{aq})\end{array}$ & -10.5953 & -11.3831 & -12.6486 & -13.9288 & -15.2526 & -16.4027 & -17.5503 & -18.8986 \\
\hline Ca-Nontronite & $\begin{array}{l}\text { Ca-Nontronite }+7.32 \mathrm{H}^{+}= \\
0.165 \mathrm{Ca}^{++}+2 \mathrm{Fe}^{+++}+0.33 \mathrm{Al}^{+++}+4.66 \mathrm{H}_{2} \mathrm{O}+ \\
3.67 \mathrm{SiO}_{2}(\mathrm{aq})\end{array}$ & -10.1283 & -11.1001 & -12.5781 & -14.0546 & -15.5758 & -16.8873 & -18.1725 & -19.6432 \\
\hline
\end{tabular}


Table 6-18. Log K Matrix for Clay Minerals (Continued)

\begin{tabular}{|c|c|c|c|c|c|c|c|c|c|}
\hline \multirow[b]{2}{*}{ Mineral } & \multirow[b]{2}{*}{ Reaction } & \multicolumn{8}{|c|}{ Temperature $\left({ }^{\circ} \mathrm{C}\right)$} \\
\hline & & 0.01 & 25 & 60 & 100 & \begin{tabular}{|l|}
150 \\
\end{tabular} & 200 & 250 & 300 \\
\hline Mg-Nontronite & $\begin{array}{l}\mathrm{Mg}-\mathrm{Nontronite}^{+}+7.32 \mathrm{H}^{+}= \\
0.165 \mathrm{Mg}^{++}+2 \mathrm{Fe}^{+++}+0.33 \mathrm{Al}^{+++}+4.66 \mathrm{H}_{2} \mathrm{O}+ \\
3.67 \mathrm{SiO}_{2}(\mathrm{aq})\end{array}$ & -10.1162 & -11.1382 & -12.6726 & -14.1977 & -15.7631 & -17.1067 & -18.4161 & -19.9055 \\
\hline Ripidolite-7A & $\begin{array}{l}\text { Ripidolite- } 7 \mathrm{~A}+16 \mathrm{H}^{+}= \\
2 \mathrm{Al}^{+++}+3 \mathrm{Mg}^{++}+12 \mathrm{H}_{2} \mathrm{O}+2 \mathrm{Fe}^{++}+3 \mathrm{SiO}_{2}(\mathrm{aq})\end{array}$ & 71.9986 & 62.5511 & 51.3031 & 40.8781 & 30.4819 & 22.0378 & 14.7716 & 8.0641 \\
\hline Ripidolite-14A & $\begin{array}{l}\text { Ripidolite- } 14 \mathrm{~A}+16 \mathrm{H}^{+}= \\
2 \mathrm{Al}^{+++}+3 \mathrm{Mg}^{++}+12 \mathrm{H}_{2} \mathrm{O}+2 \mathrm{Fe}^{++}+3 \mathrm{SiO}_{2}(\mathrm{aq})\end{array}$ & 68.4043 & 59.1778 & 48.1896 & 38.0078 & 27.8567 & 19.6105 & 12.5078 & 5.9378 \\
\hline H-Saponite & $\begin{array}{l}\mathrm{H} \text {-Saponite }+6.99 \mathrm{H}^{+}= \\
3 \mathrm{Mg}^{++}+0.33 \mathrm{Al}^{+++}+4.66 \mathrm{H}_{2} \mathrm{O}+3.67 \mathrm{SiO}_{2}(\mathrm{aq})\end{array}$ & 29.6074 & 26.0453 & 21.6364 & 17.5487 & 13.5495 & 10.3777 & 7.6756 & 5.1115 \\
\hline Na-Saponite & $\begin{array}{l}\mathrm{Na}-\text { Saponite }+7.32 \mathrm{H}^{+}= \\
0.33 \mathrm{Na}^{+}+3 \mathrm{Mg}^{++}+0.33 \mathrm{Al}^{+++}+4.66 \mathrm{H}_{2} \mathrm{O}+ \\
3.67 \mathrm{SiO}_{2} \text { (aq) }\end{array}$ & 30.6491 & 27.0591 & 22.6199 & 18.5093 & 14.4935 & 11.3133 & 8.6058 & 6.0343 \\
\hline K-Saponite & $\begin{array}{l}\mathrm{K}-\text { Saponite }+7.32 \mathrm{H}^{+}= \\
0.33 \mathrm{~K}^{+}+3 \mathrm{Mg}^{++}+0.33 \mathrm{Al}^{+++}+4.66 \mathrm{H}_{2} \mathrm{O}+ \\
3.67 \mathrm{SiO}_{2}(\mathrm{aq})\end{array}$ & 30.2295 & 26.7202 & 22.3686 & 18.3310 & 14.3787 & 11.2413 & 8.5634 & 6.0136 \\
\hline Ca-Saponite & $\begin{array}{l}\text { Ca-Saponite }+7.32 \mathrm{H}^{+}= \\
0.165 \mathrm{Ca}^{++}+3 \mathrm{Mg}^{++}+0.33 \mathrm{Al}^{+++}+4.66 \mathrm{H}_{2} \mathrm{O}+ \\
3.67 \mathrm{SiO}_{2}(\mathrm{aq})\end{array}$ & 30.6968 & 27.0032 & 22.4387 & 18.2045 & 14.0545 & 10.7554 & 7.9397 & 5.2674 \\
\hline Mg-Saponite & $\begin{array}{l}\text { Mg-Saponite }+7.32 \mathrm{H}^{+}= \\
3.165 \mathrm{Mg}^{++}+0.33 \mathrm{Al}^{+++}+4.66 \mathrm{H}_{2} \mathrm{O}+3.67 \mathrm{SiO}_{2}(\mathrm{aq})\end{array}$ & 30.7058 & 26.9651 & 22.3479 & 18.0685 & 13.8775 & 10.5490 & 7.7110 & 5.0214 \\
\hline $\begin{array}{l}\text { Low Fe-Mg } \\
\text { Smectite }\end{array}$ & $\begin{array}{l}\text { Low Fe-Mg Smectite }+7 \mathrm{H}^{+}= \\
0.15 \mathrm{Na}^{+}+0.2 \mathrm{~K}^{+}+0.02 \mathrm{Ca}^{++}+0.9 \mathrm{Mg}^{++}+0.16 \mathrm{Fe}^{+++}+ \\
0.29 \mathrm{Fe}^{++}+1.25 \mathrm{Al}^{++}+4.5 \mathrm{H}_{2} \mathrm{O}+3.75 \mathrm{SiO}_{2}(\mathrm{aq})\end{array}$ & 13.7198 & 11.1541 & 7.8261 & 4.6537 & 1.4698 & -1.1361 & -3.4437 & -5.7296 \\
\hline $\begin{array}{l}\text { High Fe-Mg } \\
\text { Smectite }\end{array}$ & $\begin{array}{l}\text { High Fe-Mg Smectite }+8 \mathrm{H}^{+}= \\
0.1 \mathrm{Na}^{+}+0.2 \mathrm{~K}^{+}+0.025 \mathrm{Ca}^{++}+1.15 \mathrm{Mg}^{++}+0.2 \mathrm{Fe}^{+++}+ \\
0.5 \mathrm{Fe}^{++}+1.25 \mathrm{Al}^{++}+5 \mathrm{H}_{2} \mathrm{O}+3.5 \mathrm{SiO}_{2}(\mathrm{aq})\end{array}$ & 20.8773 & 17.4595 & 13.1723 & 9.1326 & 5.0925 & 1.7976 & -1.0908 & -3.8865 \\
\hline $\begin{array}{l}\text { Reykjanes } \\
\text { Smectite }\end{array}$ & \begin{tabular}{|l|} 
Reykjanes Smectite $+9.32 \mathrm{H}^{+}=$ \\
$0.33 \mathrm{Na}^{+}+0.03 \mathrm{~K}^{+}+0.66 \mathrm{Ca}^{++}+1.29 \mathrm{Mg}^{++}+0.35 \mathrm{Fe}^{+++}$ \\
$+0.33 \mathrm{Fe}^{++}+0.01 \mathrm{Mn}^{++}+1.11 \mathrm{Al}^{+++}+5.66 \mathrm{H}_{2} \mathrm{O}+$ \\
$3.17 \mathrm{SiO}_{2}(\mathrm{aq})$
\end{tabular} & 26.1136 & 22.1615 & 17.2950 & 12.7445 & 8.2070 & 4.5112 & 1.2779 & -1.8342 \\
\hline
\end{tabular}


Actual uncertainties in estimated Gibbs free energy values for minerals not in the regression set are difficult to quantify due to correlated errors and other factors (some of which are noted below). It is likely that they are about 2 to 3 times greater than the minimal values suggested by uncertainties in calorimetric measurements. Thus in "typical" cases with four tetrahedral cations in the molecular formula, the uncertainties are approximately 4,000 to $9,600 \mathrm{cal} / \mathrm{mol}$.

In the case of the molar volume regression, more minerals were included and the regression error ( 2 to $4 \mathrm{~cm}^{3} / \mathrm{mol}$ for formulas with four tetrahedral cations, or 1 to 2.5 percent) probably gives a fair estimation of the actual uncertainty in estimating molar volumes for minerals not in the regression matrix. Uncertainties of this magnitude are acceptable for two reasons. First, molar volume values do not significantly affect $\log \mathrm{K}$ values in the temperature-pressure range of interest to the YMP. Second, with regard to pure volumetric calculations (e.g., in calculating gain or loss of permeability), uncertainties at this level tend to be insignificant in relation to natural variation in real minerals.

With regard to errors in estimating entropies and heat capacity coefficients, refer to Helgeson et al. (1978 [DIRS 101596], pp. 43-52 for entropies, pp. 52-66 for heat capacity coefficients). Unlike molar volumes, these properties are basically of interest only when they affect Gibbs free energies or $\log \mathrm{K}$ values at elevated temperature. Generally the uncertainty in the Gibbs free energy at $25^{\circ} \mathrm{C}$ is a significantly larger factor in the $25^{\circ} \mathrm{C}$ to $200^{\circ} \mathrm{C}$ range of principal interest to the YMP.

The estimation methods used here have some uncertainties that should be discussed. First, the mineral compositions tend to be idealized. Even when formulas are comprised on the basis of detailed chemical analyses, the true amount of interlayer water in smectites and some other clay minerals is not represented. This is in part due to a lack of reliable means of determining the amount of interlayer water in real clays. Second, the temperature dependence of the Gibbs free energies of the exchangeable oxide components is approximate. It is assumed that the entropy and heat capacity coefficients of, say, exchangeable $\mathrm{CaO}(\mathrm{ex})$ are identical to those of non-exchangeable $\mathrm{CaO}$. It would be better to assume that this is true only for $\mathrm{K}_{2} \mathrm{O}(\mathrm{ex})$ and non-exchangeable $\mathrm{K}_{2} \mathrm{O}$, following the assumption of equality of Gibbs free energies for these components at $25^{\circ} \mathrm{C}$. This problem is due to a paucity of exchange data at elevated temperature.

An issue unique to the Gibbs free energy and molar volume regressions concerns the use of a silicated $\mathrm{Mg}(\mathrm{OH})_{2}$ component in addition to silicated $\mathrm{MgO}$ and $\mathrm{H}_{2} \mathrm{O}$ components. The justification for this should be reconsidered on a statistical basis. The use of this component in a sense "de-linearizes" the method (because of the arbitrary rule of assigning $\mathrm{Mg}$ to this component first as the amount of $\mathrm{OH}$ permits). This applies to the situation in which ripidolites are found to be less stable than the equivalent mixtures of corresponding clinochlores and daphnites.

Vieillard (1994 [DIRS 159213], 1994 [DIRS 159214]) has developed more complex techniques for estimating the enthalpies of formation of silicates, including sheet silicates. These appear not to have been applied to smectite but rather only to some micas, some chlorites, an illite of different composition $\left[\left(\mathrm{K}_{0.65} \mathrm{Na}_{0.03}\right)\left(\mathrm{Al}_{1.83} \mathrm{Fe}_{0.03}{ }^{+++} \mathrm{Fe}_{0.04}{ }^{++} \mathrm{Mg}_{0.1} \mathrm{Mn}\right)\left(\mathrm{Si}_{3.59} \mathrm{Al}_{0.41}\right) \mathrm{O}_{10}(\mathrm{OH})_{1.8} \mathrm{~F}_{0.07}\right]$ than the one used here, and a few other sheet silicates. Although Vieillard (1994 [DIRS 159214], Table A14) gives simplified compositions for all the considered phases in this 
work, the author makes it clear that the calculated enthalpies mostly pertain to more detailed actual compositions such as that given for the specified illite composition in his study. A comparison between the final reestimated values and the calculated and predicted values given in Vieillard (2000 [DIRS 171586]) (Table 6-19) show only small differences than these values and provides corroboration that the computed values are reasonable.

Ransom and Helgeson (1994 [DIRS 159207]) discussed estimation of heat capacities, entropies, and volumes of the 2:1 (Si:Al) clay minerals (which include smectites, illites, and vermiculites). As they did not estimate Gibbs free energies (or enthalpies), quantitative comparisons are not possible. The methods of estimation were largely similar if not identical to those used here. They discussed the problem of variable interlayer water content in clay minerals, and suggested ways in which the estimation method used for data0.ymp.R2 (DTN: MO0302SPATHDYN.000 [DIRS 161756]) might be improved by accounting for additional water.

Table 6-19. Estimated Gibbs Free Energies of Formation (cal/mol) for the Minerals of Interest: Original Wolery Estimates, "Re-Creation" Estimates, and Final "Reestimation" Estimates

\begin{tabular}{|l|c|c|c|c|c|}
\hline \multicolumn{1}{|c|}{ Mineral } & Original & Re-Creation & $\begin{array}{c}\text { Final } \\
\text { “Reestimation" }\end{array}$ & $\begin{array}{c}\text { Calculated } \\
\text { (cal/mol) }\end{array}$ & $\begin{array}{c}\text { Predicted } \\
\text { (cal/mol) }\end{array}$ \\
\hline Na-beidellite & $-1,279,688$ & $-1,279,692$ & $-1,279,692$ & $-1,278,601$ & $-1,279,177$ \\
\hline Ca-beidellite & $-1,280,909$ & $-1,280,913$ & $-1,280,913$ & $-1,279,827$ & $-1,280,420$ \\
\hline K-beidellite & $-1,281,773$ & $-1,281,778$ & $-1,281,777$ & $-1,280,675$ & $-1,281,134$ \\
\hline Mg-beidellite & $-1,277,064$ & $-1,277,068$ & $-1,277,068$ & $-1,275,955$ & $-1,277,346$ \\
\hline Na-saponite & $-1,343,879$ & $-1,343,883$ & $-1,343,883$ & $-1,343,056$ & $-1,335,182$ \\
\hline Ca-saponite & $-1,345,100$ & $-1,345,104$ & $-1,345,104$ & $-1,341,553$ & $-1,336,424$ \\
\hline Na-nontronite & $-1,078,271$ & $-1,078,585$ & $-1,078,590$ & $-1,077,664$ & $-1,077,439$ \\
\hline Ca-nontronite & $-1,079,492$ & $-1,079,806$ & $-1,079,811$ & $-1,078,888$ & $-1,078,682$ \\
\hline Illite & $-1,303,971$ & $-1,303,940$ & $-1,303,942$ & $-{ }^{*}$ & $-{ }^{*}$ \\
\hline High Fe-Mg smectite & $-1,262,121$ & $-1,262,122$ & $-1,262,125$ & $-1,263,411$ & $-1,263,344$ \\
\hline
\end{tabular}

Sources: Column 2: $\quad$ Wolery 1978 [DIRS 151346], p. 231, Table 1.

Column 3: $\quad$ DTN: MO0302SPATHDYN.001 ([DIRS 161886], Spreadsheet

Clays_TJW_O_Rev1b.xls, Worksheet Results Summary).

Column 4: $\quad$ DTN: MO0302SPATHDYN.001 ([DIRS 161886], Spreadsheet

Clays_TJW_1_Rev1b.xls, Worksheet Results Summary).

Columns 5 and 6: Vieillard 2000 [DIRS 171586], Table 5, p. 462-463.

* No equivalent mineral in Vieillard (2000 [DIRS 171586]).

Other estimation schemes for the Gibbs free energies of sheet silicates can be found in older literature dating back around the time of Tardy and Garrels (1974 [DIRS 159209]). These include methods proposed in Mattigod and Sposito (1978 [DIRS 159197]) and Kashik et al. (1979 [DIRS 158992]). Other more recent methods such as that used in Vieillard (2000 [DIRS 171586]) are based mainly on that of Tardy and Garrels (1974 [DIRS 159209]) but with further refinements. When the likely uncertainties are considered, these other methods produce results that are basically similar to the ones presented here. This is shown by the reasonable similarities between the values predicted by Vieillard (2000 [DIRS 171586]; see previous discussion in this section) and those determined for data0.ymp.R2 (DTN: MO0302SPATHDYN.000 [DIRS 161756]). This comparison of corroborative 
information demonstrates confidence in the data0.ymp.R2 (DTN: MO0302SPATHDYN.000 [DIRS 161756]) estimates of thermodynamic quantities for clay phases even when some differences exist between the various methods.

\subsubsection{Evaluation and Qualification of Thermodynamic Data for Zeolites}

The previous data0.ymp.R0 database (DTN: MO0009THRMODYN.001 [DIRS 152576]) contained 16 zeolite mineral phases with thermodynamic data taken from work reported by Viani and Bruton (1992 [DIRS 101407], Tables 1 and 2; Appendix E, Tables 1 and 2). Log K values were not calculated beyond $100^{\circ} \mathrm{C}$. The requisite thermodynamic data for extending this temperature range are available in Viani and Bruton (1992 [DIRS 101407]), and these data were entered into spreadsheets to establish the $\log \mathrm{K}$ grid beyond $100^{\circ} \mathrm{C}$.

The heat capacity data given by Viani and Bruton (1992 [DIRS 101407]) allow for extrapolation of Gibbs energies to temperatures beyond $100^{\circ} \mathrm{C}$ in most cases. For the clinoptilolite phases, the maximum temperature limit given for heat capacity as a function of temperature is $500 \mathrm{~K}$ $\left(226.85^{\circ} \mathrm{C}\right)$. Only Cs-clinoptilolite has a lower temperature limit for heat capacity of $350 \mathrm{~K}$ $\left(76.85^{\circ} \mathrm{C}\right)$. For the other zeolites described by this source the upper temperature limits for heat capacity data range from $470 \mathrm{~K}$ to $1,000 \mathrm{~K}\left(196.85^{\circ} \mathrm{C}\right.$ to $\left.726.85^{\circ} \mathrm{C}\right)$ depending on the zeolite phase. The report Data Qualification Report for Thermodynamic Data File, Data0.ympR0 for Geochemical Code, EQ3/6 (CRWMS M\&O 2000 [DIRS 152575]) that qualified data0.ymp.R0 (DTN: MO0009THRMODYN.001 [DIRS 152576]) also qualified the Viani and Bruton (1992 [DIRS 101407]) data up to $100^{\circ} \mathrm{C}$. However, this temperature cutoff was imposed on the entire data0.ymp.R0 database (DTN: MO0009THRMODYN.001 [DIRS 152576]) on the basis of what was considered relevant for the YMP repository environment at that time.

The basic methodology utilized in the retrieval of zeolite thermodynamic data by Viani and Bruton (1992 [DIRS 101407]) was qualified (CRWMS M\&O 2000 [DIRS 152575]), and is applicable to higher temperatures (greater than $100^{\circ} \mathrm{C}$ ) in aqueous systems. The original source (Viani and Bruton 1992 [DIRS 101407]) provides experimental and analytical results for temperatures greater than $100^{\circ} \mathrm{C}$. Accordingly, defensible zeolite thermodynamic data can be estimated for temperatures greater than $100^{\circ} \mathrm{C}$, and this was performed for the data0.ymp.R2 database (DTN: MO0302SPATHDYN.000 [DIRS 161756]). Given the intended use of these data in the YMP and the adequacy of the methodology in providing a temperature extrapolation of thermodynamic parameters (e.g., $\Delta \mathrm{G}_{f}^{\circ}$ ) for the zeolites, the extrapolated $\Delta \mathrm{G}_{f}^{\circ}$ values above $100^{\circ} \mathrm{C}$ are qualified up to the upper temperature limits given by the authors Viani and Bruton (1992 [DIRS 101407]). Any extrapolation beyond these temperature limits should be further justified. Since nearly all the heat capacity data for the zeolites considered by Viani and Bruton (1992 [DIRS 101407]) are based on experimental calorimetric work, the temperature bounds given by the authors provide realistic stability limits for these zeolite phases.

Thermodynamic data for an additional five zeolite minerals were taken from Table 1 of Chipera et al. (1995 [DIRS 100025]), included in a recent book on natural zeolites published by the International Committee on Natural Zeolites. The thermodynamic data presented in the study by Chipera et al. (1995 [DIRS 100025]) were estimated using a methodology similar to that used for determination of thermodynamic properties of clays in data0.ymp.R2 
(DTN: MO0302SPATHDYN.000 [DIRS 161756]) (see Section 6.3.1). In general, these methods use an additive approach to represent the thermodynamic contributions of framework components of the mineral phase. The accuracy of these methods has been discussed in the geochemistry literature, and the most common way of validating the methods is by comparison with experimental data. More important for the data0.ymp.R2 database (DTN: MO0302SPATHDYN.000 [DIRS 161756]), is that the thermodynamic data retrieved using these methods are consistent with the basic conventions defining thermodynamic parameters. The estimation methods used in the work of Chipera et al. (1995 [DIRS 100025]) are consistent with these conventions and have been applied to the retrieval of reference-state thermodynamic data for various rock-forming minerals. These are combined with extrapolation to elevated temperatures to assess the description of mineral phase equilibria in various geologic environments.

Modeling results using these data (BSC 2004 [DIRS 170031]) suggest that the data represent the behavior of known zeolite phases at Yucca Mountain. The data were entered into Excel spreadsheets (Zeolite Solids_j.xls, Zeolite \#2 Solids_cal.xls, and Zeolite \#3 Solids_j.xls; DTN: MO0302SPATHDYN.001 [DIRS 161886]), and the log K grid was developed using the updated quartz solubility data as discussed in Section 6.1.5. Qualified log K values are shown in Table 6-20. It should be pointed-out that the Maier-Kelley coefficients from the source were incorrectly implemented in the calculation spreadsheets for the phases analcime, laumontite, philipsite, Na-clinoptilolite, chabazite, erionite, and stellerite. These errors are documented in the Spreadsheets Zeolite_Solids_j_CFJC_fix.xls, Zeolite_2_Solids_cal_CFJC_fix.xls, and Zeolite_3_Solids_j_CFJC_fix.xls (output DTN: SN0410T0510404.001). An insignificant error was found for mesolite that did not change the computed log $\mathrm{K}$ values, and the corrected values are the same as in Table 6-20 (DTN: SN0410T0510404.001; Spreadsheet Zeolite_Solids_j_CFJC_fix.xls). The log K values for the dissociation reactions that need to be corrected for the temperature extrapolations are given in Table 6-20. The $\log \mathrm{K}$ values at $25^{\circ} \mathrm{C}$ for these phases in Table 6-20 are correct as is. All the above-mentioned corrections in extrapolated $\log \mathrm{K}$ values are updated into data0.ymp.R4 (output DTN: SN0410T0510404.002). Therefore, only the corrected $\log \mathrm{K}$ values (see Table 6-21) at temperatures other than $25^{\circ} \mathrm{C}$ and present in data0.ymp.R4 (output DTN: SN0410T0510404.002) are qualified for use at extrapolated temperatures. Given the large discrepancies produced by this transcription error in the heat capacity coefficients (see Table 6-22), only the affected zeolite data for temperatures below $100^{\circ} \mathrm{C}$ in data0.ymp.R2 (DTN: MO0302SPATHDYN.000 [DIRS 161756]) should be considered for use in the YMP. Since the differences in $\log \mathrm{K}$ (i.e., $\Delta \log \mathrm{K}$ ) increase markedly with temperature above $100^{\circ} \mathrm{C}$ (see Table 6-22), the user should use data0.ymp.R4 (output DTN: SN0410T0510404.002) to perform qualified calculations.

Qualification of thermodynamic data listed in Table 6-23 is mainly done through data comparisons with experimental data and/or tabulated data in handbook sources. Overall, the differences in Gibbs free energies of formation at the reference state of $25^{\circ} \mathrm{C}$ extracted from calorimetric or solubility experiments are considered reasonable given the uncertainties involved in the experimental determinations coupled with those related to the extraction of data used to generate reference-state thermodynamic data and associated parameter extrapolations as a function of pressure and temperature. Because the compositions for many of the zeolites reported by Chipera et al. (1995 [DIRS 100025]) do not generally resemble those of end-members, their reported thermodynamic values are in most cases different from those 
reported in the literature. These differences in composition, even if they appear to be negligible, could contribute to the aforementioned discrepancies in the values for standard thermodynamic data. For the zeolites listed in Table 6-23, the largest discrepancies for which data comparisons were conducted are observed for Na-clinoptilolite and stellerite. These discrepancies ranged from approximately $72 \mathrm{~kJ} / \mathrm{mol}$ for stellerite to $175 \mathrm{~kJ} / \mathrm{mol}$ for Na-clinoptilolite. When the corroborative data for Na-clinoptilolite from Wilkin and Barnes (1998 [DIRS 172351]) are corrected for the amount of water of hydration (see Footnote $\mathrm{g}$ of Table 6-23), the difference is reduced from approximately 175 to $74.5 \mathrm{~kJ} / \mathrm{mol}$. Even with this simplistic correction that doesn't account for Gibbs energies of hydration attached to "zeolitic" $\mathrm{H}_{2} \mathrm{O}$ in the mineral structure, the overall differences in estimated and measured Gibbs free energies due to thermodynamic contributions for a given zeolite composition are within the general uncertainty of the experimental measurements and the methodology, and are therefore reasonable.

There are few experimental data assessing the thermodynamic properties of erionite and phillipsite for the compositions adopted in data0.ymp.R2 (DTN: MO0302SPATHDYN.000 [DIRS 161756]). Therefore, no comparison with other data sources was attempted for this report. These data are qualified on the basis that the authors used an estimation approach that generally provides values of standard thermodynamic data (e.g., $\Delta \mathrm{G}_{\mathrm{f}}{ }^{\circ}$ and $\Delta \mathrm{H}_{\mathrm{f}}{ }^{\circ}$ ) for various zeolite phases that are reasonably close to those obtained using experimental methods. This is shown in Figure 2 of Chipera and Apps (2001 [DIRS 171017], Figure 2, p. 124), which depicts the percent difference between estimated and experimental values for a suite of zeolites all within approximately $0.4 \%(2 \sigma)$ for Gibbs free energies and enthalpies of formation. Given this reasonable difference in the predictive capability of the model, this establishes confidence in the thermodynamic values retrieved from their work and for the intended use by the YMP. Pages 121 through 124 of Chipera and Apps (2001 [DIRS 171017], pp. 121-124) provide further discussion of the model comparisons with reported thermodynamic data on zeolites. For stellerite, a comparison was done with data retrieved from Fridriksson et al. (2001 [DIRS 160460]), Table 4, p. 4002) and from Kiseleva et al. (2001 [DIRS 172352], Table 5, p. 174). The difference in Gibbs free energies between the values given by Chipera et al. (1995 [DIRS 100025]) and those given in these two studies are approximately $44 \mathrm{~kJ} / \mathrm{mol}$ and $72 \mathrm{~kJ} / \mathrm{mol}$, for Kiseleva et al. (2001 [DIRS 172352]) and Fridriksson et al. (2001 [DIRS 160460]), respectively. These differences can be considered within the overall uncertainty of the model prediction of Chipera et al. (1995 [DIRS 100025]) and that of Fridriksson et al. (2001 [DIRS 160460]) for the estimates of Gibbs free energies. Therefore, as with other zeolites, these differences are deemed reasonable for use by the YMP. 
Table 6-20. Log K EQ3/6 Grid for Zeolite Minerals

\begin{tabular}{|l|c|c|c|c|c|c|c|c|}
\hline \multicolumn{1}{|c|}{ Mineral } & $\begin{array}{c}\log \mathbf{K} \\
\mathbf{0 . 0 1} \mathbf{C}\end{array}$ & $\begin{array}{c}\log \mathbf{K} \\
\mathbf{2 5} \mathbf{5}^{\circ} \mathbf{C}\end{array}$ & $\begin{array}{c}\log \mathbf{K} \\
\mathbf{6 0} \mathbf{0}^{\circ} \mathbf{C}\end{array}$ & $\begin{array}{c}\log \mathbf{K} \\
\mathbf{1 0 0} \mathbf{C}\end{array}$ & $\begin{array}{c}\log \mathbf{K} \\
\mathbf{1 5 0 ^ { \circ } \mathbf { C }}\end{array}$ & $\begin{array}{c}\log \mathbf{K} \\
\mathbf{2 0 0} \mathbf{C}\end{array}$ & $\begin{array}{c}\log \mathbf{K} \\
\mathbf{2 5 0 ^ { \circ } \mathbf { C }}\end{array}$ & $\begin{array}{c}\log \mathbf{~} \\
\mathbf{3 0 0}^{\circ} \mathbf{C}\end{array}$ \\
\hline Analcime & 7.5960 & 6.0057 & 4.7307 & 4.4496 & 5.3841 & 7.2915 & 9.8175 & 12.6819 \\
\hline Analcime-dehy & 14.3700 & 12.3685 & 9.9558 & 7.7943 & 5.7799 & 4.2869 & 3.1077 & 2.0570 \\
\hline Clinoptilolite & -6.7954 & -8.4187 & -11.3963 & -14.3663 & -17.2881 & -19.7134 & -22.1498 & -25.2382 \\
\hline $\begin{array}{l}\text { Clinoptilolite- } \\
\text { dehy }\end{array}$ & 32.8947 & 27.2165 & 19.4921 & 12.1056 & 4.7793 & -1.1392 & -6.3869 & -11.7610 \\
\hline Clinoptilolite-Ca & -3.3234 & -5.6428 & -9.8999 & -14.7214 & -20.4488 & -26.1649 & -32.3164 & -39.4939 \\
\hline Clinoptilolite-Cs & -12.1520 & -11.6912 & -12.8071 & -14.7666 & -17.6478 & -21.0608 & -25.2702 & -30.7396 \\
\hline Clinoptilolite-K & -9.5409 & -9.5819 & -11.2158 & -13.6232 & -16.9382 & -20.6995 & -25.2043 & -30.9401 \\
\hline Clinoptilolite-NH 4 & - & -41.1127 & - & - & - & - & - & - \\
\hline Clinoptilolite-Na & -4.6606 & -5.7696 & -8.5627 & -11.9415 & -16.1074 & -20.4506 & -25.3610 & -31.3903 \\
\hline Clinoptilolite-Sr & -3.6061 & -5.7825 & -9.8870 & -14.5695 & -20.1523 & -25.7427 & -31.7793 & -38.8489 \\
\hline Heulandite & 5.7184 & 3.6220 & 0.6905 & -2.0963 & -4.8363 & -7.0706 & -9.1445 & -11.4378 \\
\hline Mesolite & 16.0131 & 13.0290 & 9.3709 & 5.9953 & 2.6630 & -0.0574 & -2.4907 & -4.9270 \\
\hline Mordenite & -4.3249 & -4.5423 & -5.1668 & -5.8036 & -6.3837 & -6.8167 & -7.2523 & -7.8972 \\
\hline Natrolite & 21.0240 & 17.9209 & 14.1477 & 10.7013 & 7.3511 & 4.6742 & 2.3348 & 0.0358 \\
\hline Scolecite & 18.6599 & 15.2772 & 11.1522 & 7.3339 & 3.5403 & 0.4265 & -2.3557 & -5.1117 \\
\hline Stilbite & 3.1884 & 1.3118 & -1.3340 & -3.8211 & -6.2218 & -8.1485 & -9.9375 & -11.9568 \\
\hline Chabazite & 14.7333 & 10.3714 & 4.2602 & -1.9440 & -8.5835 & -14.3739 & -19.7583 & -25.2283 \\
\hline Erionite & -2.7178 & -4.8296 & -8.9463 & -13.5913 & -18.8201 & -23.5713 & -28.2226 & -33.3381 \\
\hline Laumontite & 19.2830 & 14.2657 & 7.4233 & 0.5631 & -6.7243 & -13.0442 & -18.8908 & -24.7894 \\
\hline Phillipsite & -5.0381 & -6.7617 & -10.2599 & -14.2541 & -18.7801 & -22.9139 & -26.9789 & -31.4706 \\
\hline Stellerite & -6.4688 & -8.7844 & -13.1698 & -18.0986 & -23.6535 & -28.7068 & -33.6443 & -39.0401 \\
\hline
\end{tabular}

DTN: MO0302SPATHDYN.001 ([DIRS 161886], Spreadsheets Zeolite Solids_j.xls, Zeolite \#2 Solids_cal.xls, and Zeolite \#3 Solids_j.xIs).

Table 6-21. Log K EQ3/6 Grid for Corrected Zeolite Minerals

\begin{tabular}{|c|c|c|c|c|c|c|c|c|}
\hline Mineral & $\begin{array}{l}\log K \\
0.01^{\circ} \mathrm{C}\end{array}$ & $\begin{array}{l}\log K \\
25^{\circ} \mathrm{C}\end{array}$ & $\begin{array}{l}\log K \\
60^{\circ} \mathrm{C}\end{array}$ & $\begin{array}{l}\log K \\
100^{\circ} \mathrm{C}\end{array}$ & $\begin{array}{l}\log \mathrm{K} \\
150^{\circ} \mathrm{C}\end{array}$ & $\begin{array}{l}\log K \\
200^{\circ} \mathrm{C}\end{array}$ & $\begin{array}{l}\log K \\
250^{\circ} \mathrm{C}\end{array}$ & $\begin{array}{l}\log K \\
300^{\circ} \mathrm{C}\end{array}$ \\
\hline Analcime & 7.3411 & 6.0057 & 4.3207 & 2.7687 & 1.2666 & 0.0739 & -0.9734 & -2.0317 \\
\hline Clinoptilolite-Na & -4.6593 & -5.7696 & -8.5612 & -11.9362 & -16.0971 & -20.4363 & -25.3442 & -31.3726 \\
\hline Chabazite & 14.9395 & 10.3714 & 4.5581 & -0.7982 & -5.9745 & -10.0955 & -13.7420 & -17.4773 \\
\hline Erionite & -2.4264 & -4.8296 & -8.5254 & -11.9726 & -15.1353 & -17.5303 & -19.7298 & -22.3994 \\
\hline Laumontite & 19.4704 & 14.2657 & 7.6939 & 1.6028 & -4.3587 & -9.1673 & -13.4421 & -17.7733 \\
\hline Phillipsite & -4.7708 & -6.7617 & -9.8737 & -12.7688 & -15.3984 & -17.3689 & -19.1824 & -21.4273 \\
\hline Stellerite & -6.1718 & -8.7844 & -12.7407 & -16.4486 & -19.8970 & -22.5474 & -24.9839 & -27.8839 \\
\hline
\end{tabular}

Output DTN: SN0410T0510404.001 (Spreadsheets Zeolite_Solids_j_CFJC_fix.xIs, Zeolite_2_Solids_cal_CFJC_fix.xIs, and Zeolite_3_Solids_j_CFJC_fix.xIs). 
Table 6-22. $\quad \Delta$ Log K (Difference Between Incorrect and Corrected Values) for Zeolite Minerals in Table 6-21

\begin{tabular}{|c|c|c|c|c|c|c|c|c|}
\hline Mineral & $\begin{array}{c}\Delta \log K \\
0.01^{\circ} \mathrm{C}\end{array}$ & $\begin{array}{c}\Delta \log K \\
25^{\circ} \mathrm{C}\end{array}$ & $\begin{array}{c}\Delta \log \mathrm{K} \\
60^{\circ} \mathrm{C}\end{array}$ & $\begin{array}{c}\Delta \log K \\
100^{\circ} \mathrm{C}\end{array}$ & $\begin{array}{c}\Delta \log K \\
150^{\circ} \mathrm{C}\end{array}$ & $\begin{array}{l}\Delta \log K \\
200^{\circ} \mathrm{C}\end{array}$ & $\begin{array}{c}\Delta \log K \\
250^{\circ} \mathrm{C}\end{array}$ & $\begin{array}{c}\Delta \log K \\
300^{\circ} \mathrm{C}\end{array}$ \\
\hline Analcime & -0.2549 & 0.0000 & -0.4100 & -1.6809 & -4.1175 & -7.2176 & -10.7909 & -14.7136 \\
\hline Clinoptilolite-Na & 0.0013 & 0.0000 & 0.0016 & 0.0053 & 0.0103 & 0.0143 & 0.0168 & 0.0177 \\
\hline Chabazite & 0.2062 & 0.0000 & 0.2980 & 1.1458 & 2.6090 & 4.2784 & 6.0163 & 7.7509 \\
\hline Erionite & 0.2914 & 0.0000 & 0.4210 & 1.6187 & 3.6848 & 6.0411 & 8.4928 & 10.9387 \\
\hline Laumontite & 0.1874 & 0.0000 & 0.2705 & 1.0397 & 2.3657 & 3.8769 & 5.4487 & 7.0162 \\
\hline Phillipsite & 0.2673 & 0.0000 & 0.3862 & 1.4853 & 3.3817 & 5.5450 & 7.7966 & 10.0433 \\
\hline Stellerite & 0.2970 & 0.0000 & 0.4291 & 1.6500 & 3.7565 & 6.1594 & 8.6604 & 11.1563 \\
\hline
\end{tabular}

Output DTN: SN0410T0510404.001 (Spreadsheets Zeolite_Solids_j_CFJC_fix.xIs, Zeolite_2_Solids_cal_CFJC_fix.xIs, and Zeolite_3_Solids_j_CFJC_fix.xIs).

\subsubsection{Evaluation and Qualification of Thermodynamic Data for Cement Phases}

For the data0.ymp.R2 database (DTN: MO0302SPATHDYN.000 [DIRS 161756]), a review of the literature on geochemical modeling of cement was conducted to support possible investigation of the effects from cement grouts on the Engineered Barrier System chemical environment. Thermodynamic modeling based on chemical equilibria has been advanced as a useful tool for modeling cement-water interactions (Gartner and Jennings 1987 [DIRS 144879]; Reardon 1990 [DIRS 100821]).

Given the compositional complexity of common cement phases, the compilation of data was restricted to cement phases for which solubility and/or thermodynamic data were well-constrained. For example, thermodynamic data for some cement phases are represented by their pure end-member compositions. Nevertheless, these data are useful in establishing a modeling framework even with all inherent limitations on data availability, uncertainties, and compositional variability of cement. The minerals shown in bold-italics in Table 6-24 were added to the data0.ymp.R2 database (DTN: MO0302SPATHDYN.000 [DIRS 161756]) for this reason.

The data selected for use are qualified for inclusion in the database by technical assessment. A number of sources were reviewed (Taylor 1990 [DIRS 120495]; Reardon 1992 [DIRS 100822]; Bruton et al. 1993 [DIRS 100710]; Atkins et al. 1992 [DIRS 100700]; Neall 1996 [DIRS 144784]; Batchelor and Wu 1993 [DIRS 156182]; Sarkar et al. 1982 [DIRS 119581]; Atkins et al. 1993 [DIRS 131758]; Shaw et al. 2000 [DIRS 158028]; Glasser et al. 1987 [DIRS 118111]; Damidot et al. 1994 [DIRS 144866]; Bennett et al. 1992 [DIRS 116990]; Babushkin et al. 1985 [DIRS 116981]; Greenberg and Chang 1965 [DIRS 144989]; Fujii and Kondo 1983 [DIRS 144876]; Harvie et al. 1984 [DIRS 118163]; MacPhee et al. 1989 [DIRS 145004]; Berner 1987 [DIRS 116991], 1990 [DIRS 100707]; Greenberg and Moller 1989 DIRS 152684]; and Perkins and Palmer 1999 [DIRS 152703]) to develop a list of applicable mineral phases (Table 6-24). These sources include not only the discussion from Taylor (1990 [DIRS 120495]), but also previous modeling studies from U.S. and international nuclear waste management projects. The minerals listed formed the basis for an additional literature search for the pertinent data required for generating the data0.ymp.R2 database 
(DTN: MO0302SPATHDYN.000 [DIRS 161756]). The minerals listed are those that are common to the hydration of Portland cements and are generally limited to the $\mathrm{Ca}-\mathrm{Al}-\mathrm{Si}-\mathrm{S}-\mathrm{Mg}-\mathrm{H}_{2} \mathrm{O}$ system. When available the common mineral names are used. However, some cement chemical nomenclature is used (see Taylor 1990 [DIRS 120495], Section 1.1.3, for a description of this nomenclature).

Thermodynamic data for cement phases were evaluated based on the data obtained in the thermodynamic compilation of Babushkin et al. (1985 [DIRS 116981]). Data extracted from this source are included in Table 4-11. As a cross-check on the quality of thermodynamic data, the data for several cement minerals that were previously included in the data0.ymp.R0 database file (DTN: MO0009THRMODYN.001 [DIRS 152576]) were found to be the same. The data in Table 4-11 were entered into Spreadsheet Minerals_cal_DJ_Cement.xls (DTN: MO0302SPATHDYN.001 [DIRS 161886]) for the temperature dependent derivation of the formation constants and direct inclusion into the data0.ymp.R2 database (DTN: MO0302SPATHDYN.000 [DIRS 161756]).

Sarkar et al. (1982 [DIRS 119581]) provides a compilation of thermodynamic data from various sources in the literature. They evaluated and selected the best values for heats, entropies, and free energies of formation for calcium silicates, aluminates, and ferrites. They also presented data for other cement phases including CSH gel and Friedl salt. Sarkar et al. (1982 [DIRS 119581]) indicate that the best data source for most of the minerals of interest is a 1972 edition of a volume translated from Russian entitled Thermodynamics of Silicates. This book was revised and published in English in 1985 and is the current edition of Babushkin et al. (1985 [DIRS 116981]). Heat capacity data for most of the cement phases were extracted from Babushkin et al. (1985 [DIRS 116981]). However, heat capacity data did not exist for CSH, therefore, these values needed to be estimated. They were processed in the same manner as the values found in Section 6.3.1 using a simple linear model (Helgeson et al. 1978 [DIRS 101596], pp. 52-66). For more details, see Sections 6.3.3.1 and 6.3.3.4. The $\log \mathrm{K}$ grid generated for the cement mineral phases and included in the data0.ymp.R2 database (DTN: MO0302SPATHDYN.000 [DIRS 161756]) is summarized in Table 6-25.

It is noted that cement phases CSH:1.7, Friedl salt, and hydrogarnet are inactive in the data0.ymp.R2 database (DTN: MO0302SPATHDYN.000 [DIRS 161756]). These phases remain inactive in the data0.ymp.R4 database (output DTN: SN0410T0510404.002). However, these phases are discussed in detail and qualified in this report as possible additions to future calculations. 
Table 6-23. Thermodynamic Data for Additional Zeolite Minerals Included in Data0.ymp.R2 (DTN: MO0302SPATHDYN.000 [DIRS 161756])

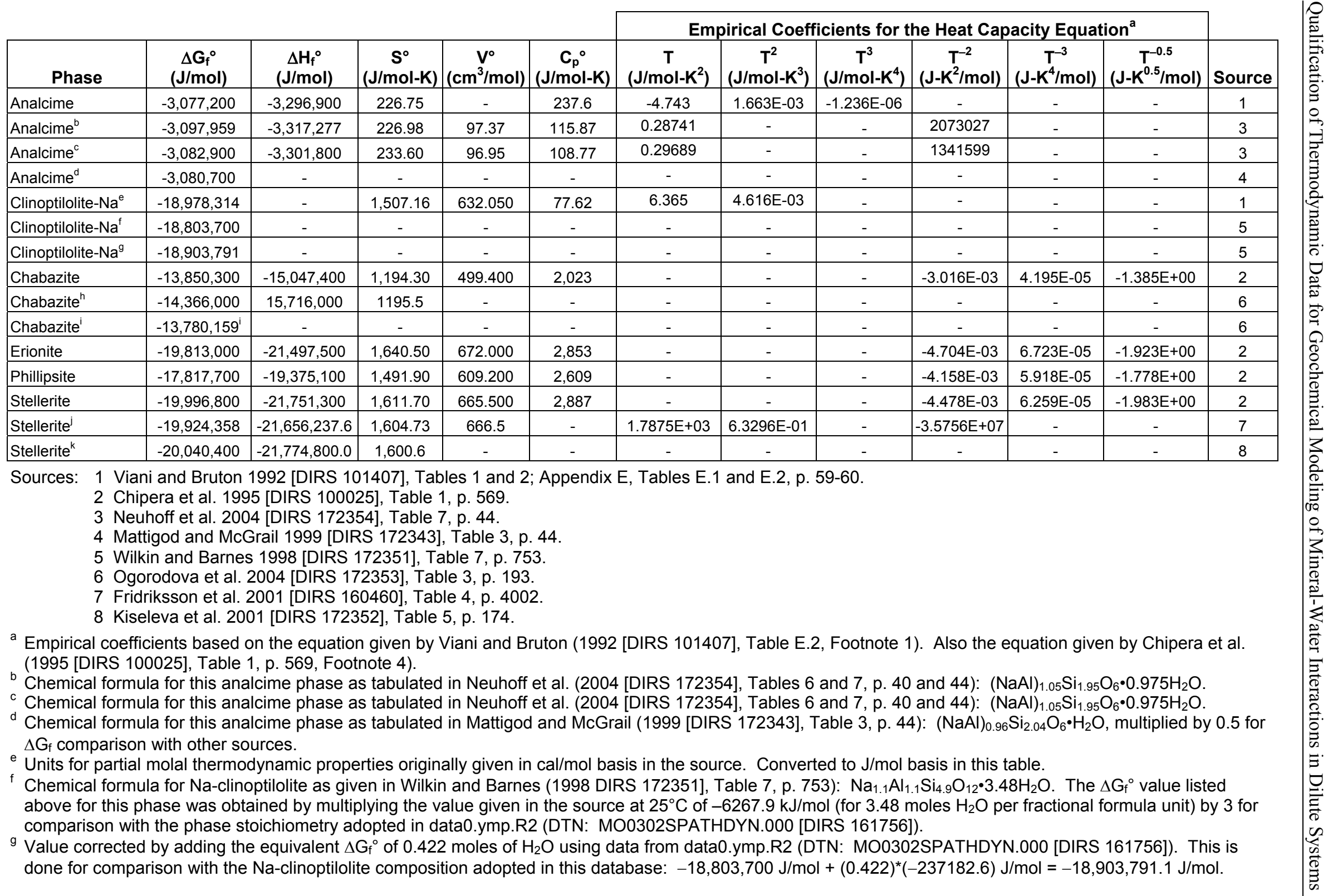


Table 6-23. Thermodynamic Data for Additional Zeolite Minerals Included in Data0.ymp.R2 (DTN: MO0302SPATHDYN.000 [DIRS 161756]) (Continued)

${ }^{h}$ Thermodynamic data for the chemical formula of chabazite as given in Ogorodova et al. (2004 [DIRS 172353], Table 3, p. 193): $\left(\mathrm{Ca}_{1.65} \mathrm{Na}_{0.24} \mathrm{~K}_{0.10}\right)\left[\mathrm{Al}_{3.79} \mathrm{Si}_{8.25} \mathrm{O}_{24}\right]^{\cdot}$ $12.47 \mathrm{H}_{2} \mathrm{O}$

' Value corrected by substracting the equivalent $\Delta \mathrm{G}_{\mathrm{f}}^{\circ}$ of 2.47 moles of $\mathrm{H}_{2} \mathrm{O}$ using data from data0.ymp.R2 (DTN: MO0302SPATHDYN.000 [DIRS 161756]). This is done for comparison with the chabazite composition adopted in this database: $-14,366,000 \mathrm{~J} / \mathrm{mol}-(2.47)^{*}(-237182.6 \mathrm{~J} / \mathrm{mol})=-13,780,159 \mathrm{~J} / \mathrm{mol}$.

i Thermodynamic data for the chemical formula of stellerite as given in Fridriksson et al. (2001 [DIRS 160460], Table 4, p. 4002 ): $\mathrm{Ca}_{2} \mathrm{Al}_{4} \mathrm{Si}_{14} \mathrm{O}_{36} \cdot 14 \mathrm{H}_{2} \mathrm{O}$. Values in the source given in cal/mol units and converted in $\mathrm{J} / \mathrm{mol}$ in this table.

${ }^{k}$ Thermodynamic data for the chemical formula of stellerite as given in Kiseleva et al. (2001 [DIRS 172352], Table 5, p. 174): $\mathrm{Ca}_{2} \mathrm{Al}_{4} \mathrm{Si}_{14} \mathrm{O}_{36} \cdot 14 \mathrm{H}_{2} \mathrm{O}$. In the source, the stoichiometry of the chemical formula is half of that presented in this table. Therefore, the thermodynamic values were multiplied by two so it can be compared to the stellerite composition adopted in data0.ymp.R2 (DTN: MO0302SPATHDYN.000 [DIRS 161756]). 
Table 6-24. Minerals Commonly Associated with Cements and Grouts Along with Sources

\begin{tabular}{|c|c|c|c|c|c|c|c|c|c|c|c|}
\hline Mineral & 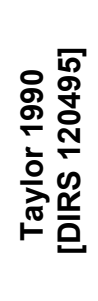 & 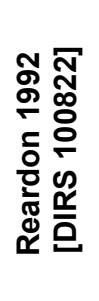 & 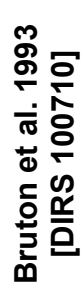 & 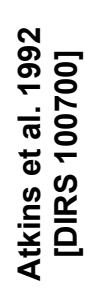 & 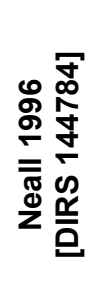 & 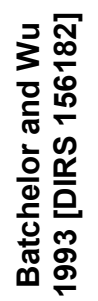 & 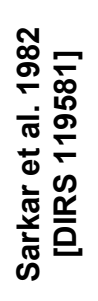 & 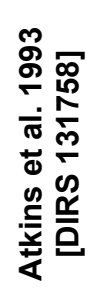 & 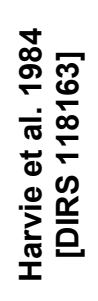 & 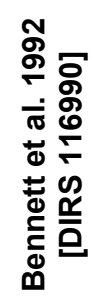 & 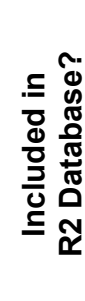 \\
\hline Afwillite & $\mathrm{x}$ & & $x$ & & & & $\mathrm{x}$ & $\mathrm{x}$ & & & $y$ \\
\hline Allite $\left(\mathrm{C}_{3} \mathrm{~S}\right)$ & $x$ & $x$ & & & & & $x$ & & & & $y$ \\
\hline Anhydrite & $x$ & $\mathrm{x}$ & & & & & & & $\mathrm{x}$ & & $y$ \\
\hline Bellite $\left(\mathrm{C}_{2} \mathrm{~S}\right)$ & $\mathrm{x}$ & $\mathrm{x}$ & & & & & $\mathrm{x}$ & & & & $y$ \\
\hline Brucite & $x$ & $x$ & & $x$ & & & & & $x$ & & $y$ \\
\hline $\mathrm{C}_{12} \mathrm{~A}_{7}$ & $x$ & & & & & & $x$ & & & & $\mathrm{y}$ \\
\hline $\mathrm{C}_{2} \mathrm{AH}_{8}$ & $x$ & & & & & $x$ & $x$ & & & & $\mathrm{y}$ \\
\hline $\mathrm{C}_{3} \mathrm{~A}$ & $x$ & $\mathrm{x}$ & & & & & $x$ & & & & $y$ \\
\hline $\mathrm{C}_{4} \mathrm{AF}$ & $x$ & $x$ & & & & & & & & & $y$ \\
\hline $\mathrm{C}_{4} \mathrm{AH}_{13}$ & $x$ & $x$ & & $x$ & & $x$ & $x$ & $x$ & & & $y$ \\
\hline $\mathrm{C}_{4} \mathrm{AH}_{19}$ & $x$ & & & & & & $x$ & & & & $y$ \\
\hline CA & $x$ & & & & & & $x$ & & & & $\mathrm{y}$ \\
\hline $\mathrm{CA}_{2}$ & $x$ & & & & & & $x$ & & & & $y$ \\
\hline $\mathrm{CAH}_{10}$ & $x$ & & & & & & $x$ & & & & $y$ \\
\hline $\mathrm{CSH}^{a}$ & $x$ & $x$ & & $x$ & $x$ & $x$ & $x$ & $x$ & & $x$ & $\mathrm{y}$ \\
\hline Ettringite & $\mathrm{x}$ & $x$ & & $x$ & $x$ & $x$ & $x$ & $x$ & & & $\mathrm{y}$ \\
\hline Ferrite-Ca & $x$ & & & & & & $x$ & & & & $\mathrm{y}$ \\
\hline Ferrite-Dicalcium & $x$ & & & & & & $x$ & & & & $\mathrm{y}$ \\
\hline Foshagite & & & $x$ & & & & $x$ & & & & $y$ \\
\hline Friedl Salt ${ }^{\mathrm{b}}$ & $x$ & & & & & $x$ & $x$ & $x$ & & & $\mathrm{y}$ \\
\hline Gehlenite Hydrate $^{c}$ & $\mathrm{x}$ & & & $\mathrm{x}$ & & & & $x$ & & $x$ & $25^{d}$ \\
\hline Gibbsite & $x$ & $\mathrm{x}$ & & $x$ & & & & & & & $\mathrm{y}$ \\
\hline Gismondine-Na & & & & & & & & $x$ & & & $25^{d}$ \\
\hline Gismondine-Ca & & & & & & & & $\mathrm{x}$ & & & $25^{d}$ \\
\hline Gypsum & $x$ & & & $x$ & & & & & $x$ & & $\mathrm{y}$ \\
\hline Gyrolite & $x$ & & $\mathrm{x}$ & & & & $x$ & & & & $\mathrm{y}$ \\
\hline Hillebrandite & $x$ & & $x$ & & & & $x$ & & & & $\mathrm{y}$ \\
\hline Hydrogarnet & $x$ & $x$ & & $x$ & $x$ & & $x$ & $x$ & & $x$ & $y$ \\
\hline Hydrotalcite ${ }^{\mathrm{e}}$ & $x$ & $\mathrm{x}$ & & $x$ & $x$ & & & $x$ & & $x$ & $25^{\mathrm{d}}$ \\
\hline Jennite & $x$ & & & & & & & $x$ & & & \\
\hline Monocarboaluminate & & $\mathrm{x}$ & & & & $\mathrm{x}$ & & $\mathrm{x}$ & & & $25^{d}$ \\
\hline
\end{tabular}


Table 6-24. Minerals Commonly Associated with Cements and Grouts Along with Sources (Continued)

\begin{tabular}{|c|c|c|c|c|c|c|c|c|c|c|c|}
\hline Mineral & 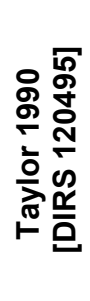 & 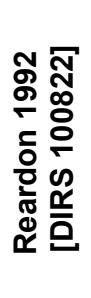 & 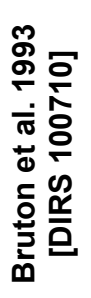 & 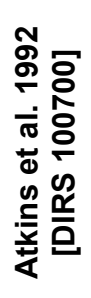 & 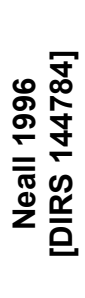 & 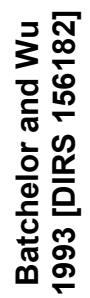 & 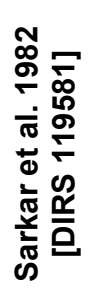 & 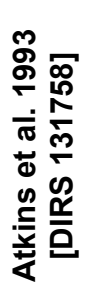 & 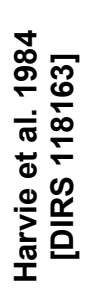 & 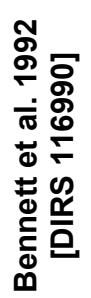 & 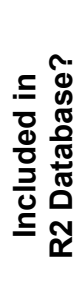 \\
\hline Monosulphate & $x$ & $x$ & & $x$ & & $x$ & $x$ & $x$ & & & $y$ \\
\hline Nekoite & & & $x$ & & & & & & & & \\
\hline Okenite & & & $x$ & & & & $x$ & & & & $y$ \\
\hline Periclase & $x$ & $x$ & & & & & & & & & $\mathrm{y}$ \\
\hline Plombierite $^{f}$ & $x$ & & $x$ & & & & $x$ & & & & $\mathrm{y}$ \\
\hline Portlandite & $x$ & $x$ & & $\mathrm{x}$ & $x$ & & & & $\mathrm{x}$ & & $\mathrm{y}$ \\
\hline Reyerite & & & $\mathrm{x}$ & & & & & & & & \\
\hline Riversideite $^{\mathrm{g}}$ & & & $x$ & & & & $x$ & & & & $\mathrm{y}$ \\
\hline Syngenite & $x$ & $x$ & & & & $x$ & & & $x$ & & $25^{d}$ \\
\hline Thaumasite & $\mathrm{x}$ & & & & & & & & & & \\
\hline Tobermorite-11A $A^{\mathrm{h}}$ & $x$ & & $x$ & $x$ & & & $x$ & $x$ & & & $\mathrm{y}$ \\
\hline Truscottite & $x$ & & $x$ & & & & & & & & \\
\hline Xonotlite & $x$ & & $x$ & & & & $x$ & & & & $\mathrm{y}$ \\
\hline $\mathrm{CaSO}_{4} \cdot 0.5 \mathrm{H}_{2} \mathrm{O}$ (beta) & & & & & & & & & & & $\mathrm{y}$ \\
\hline Hemicarboaluminate & & & & & & & & & & & $25^{d}$ \\
\hline Tricarboaluminate $^{i}$ & & & & & & & & & & & \\
\hline
\end{tabular}

${ }^{a}$ CSH can be a solid solution. Note that Glasser et al. (1987 [DIRS 118111], p. 338) indicates that Portland cement generally hydrates to give a $\mathrm{CSH}$ with a $\mathrm{Ca} / \mathrm{Si}$ ratio close to 1.7 .

b Often listed as $\mathrm{C}_{3} \mathrm{AlCaCl}_{2} \cdot 10 \mathrm{H}_{2} \mathrm{O}$ or called calcium chloroaluminate hydrate (Taylor 1990 [DIRS 120495]). The reported name for this phase in the cement literature is "Friedel's salt," not "Friedl Salt."

${ }^{c}$ Also known as stratlingite (Taylor 1990 [DIRS 120495]).

"The annotation " 25 " indicates $25^{\circ} \mathrm{C}$ data only.

${ }^{\mathrm{e}}$ Hydrotalcite referred to here is the formulation of Bennett et al. (1992 [DIRS 116990]), not the natural hydrotalcite mineral with a formula of $\left.\left(\mathrm{Mg}_{0.75} \mathrm{Al}_{0.25}[\mathrm{OH}]_{2}\right)\right]\left(\mathrm{CO}_{3}\right)_{0.125}\left(\mathrm{H}_{2} \mathrm{O}\right)_{0.5}$.

f 1.4A Tobermorite is also known as Plombierite (Shaw et al. 2000 [DIRS 158028], p. 143).

g 9A Tobermorite is known as Riversideite (Shaw et al. 2000 [DIRS 158028], p. 143).

h This is "normal" Tobermorite.

' Never reported to occur in cement pastes submitted to intensive carbonation (Damidot et al. 1994 [DIRS 144866], p. 563).

NOTE: Listing includes minerals used in modeling studies. Also shown are YMP databases that contain cement phase minerals. Bold italics signify species added to the data0.ymp.R2 database (DTN: MO0302SPATHDYN.000 [DIRS 161756]) (see text). 


\begin{tabular}{|c|c|c|c|c|c|c|c|c|c|}
\hline Mineral & Reaction & 0.01 & 25 & 60 & 100 & 150 & 200 & 250 & 300 \\
\hline$\left(\mathrm{C}_{12} \mathrm{~A}_{7}\right)^{\mathrm{a}}$ & $\begin{array}{c}\left(\mathrm{C}_{12} \mathrm{~A}_{7}\right)+66 \mathrm{H}^{+}= \\
12 \mathrm{Ca}^{++}+33 \mathrm{H}_{2} \mathrm{O}+14 \mathrm{Al}^{+++}\end{array}$ & 550.4886 & 487.2030 & 414.0713 & 346.9265 & 280.0183 & 225.8021 & 179.8050 & 138.9111 \\
\hline$\left(\mathrm{C}_{2} \mathrm{AH}_{8}\right)^{\mathrm{a}}$ & $\begin{array}{c}\left(\mathrm{C}_{2} \mathrm{AH}_{8}\right)+10 \mathrm{H}^{+}= \\
2 \mathrm{Ca}^{++}+2 \mathrm{Al}^{+++}+13 \mathrm{H}_{2} \mathrm{O} \\
\end{array}$ & 66.1489 & 59.2699 & 51.4645 & 44.4608 & 37.6368 & 32.1948 & 27.5826 & 23.4125 \\
\hline$\left(C_{3} A\right)^{a}$ & $\begin{array}{c}\left(\mathrm{C}_{3} \mathrm{~A}\right)+12 \mathrm{H}^{+}= \\
3 \mathrm{Ca}^{++}+6 \mathrm{H}_{2} \mathrm{O}+2 \mathrm{Al}^{+++}\end{array}$ & 130.3127 & 116.7717 & 101.1568 & 86.8476 & 72.6344 & 61.1837 & 51.5545 & 43.0912 \\
\hline$\left(\mathrm{C}_{4} \mathrm{AF}\right)^{\mathrm{a}}$ & $\begin{array}{c}\left(\mathrm{C}_{4} \mathrm{AF}\right)+2 \mathrm{OH}^{+}= \\
4 \mathrm{Ca}^{++}+2 \mathrm{Al}^{+++}+10 \mathrm{H}_{2} \mathrm{O}+2 \mathrm{Fe}^{+++}\end{array}$ & 157.6612 & 139.8695 & 119.3314 & 100.5049 & 81.7809 & 66.6349 & 53.7907 & 42.3452 \\
\hline$\left(\mathrm{C}_{4} \mathrm{AH}_{13}\right)^{\mathrm{a}}$ & $\begin{array}{c}\left(\mathrm{C}_{4} \mathrm{AH}_{13}\right)+14 \mathrm{H}^{+}= \\
4 \mathrm{Ca}^{++}+2 \mathrm{Al}^{+++}+2 \mathrm{H}_{2} \mathrm{O}\end{array}$ & 110.8317 & 100.6293 & 89.1050 & 78.8149 & 68.8522 & 60.9746 & 54.3629 & 48.4368 \\
\hline$\left(\mathrm{C}_{4} \mathrm{AH}_{19}\right)^{\mathrm{a}}$ & $\begin{array}{c}\left(\mathrm{C}_{4} \mathrm{AH}_{19}\right)+14 \mathrm{H}^{+}= \\
4 \mathrm{Ca}^{++}+2 \mathrm{Al}^{+++}+26 \mathrm{H}_{2} \mathrm{O}\end{array}$ & 109.9718 & 100.6045 & 90.1529 & 80.9597 & 72.1928 & 65.3429 & 59.6128 & 54.4408 \\
\hline$(C A)^{a}$ & $\begin{array}{c}(\mathrm{CA})+8 \mathrm{H}^{+}= \\
\mathrm{Ca}^{++}+4 \mathrm{H}_{2} \mathrm{O}+2 \mathrm{Al}^{+++}\end{array}$ & 52.4679 & 45.7317 & 37.9299 & 30.7511 & 23.5715 & 17.7179 & 12.7075 & 8.2047 \\
\hline$\left(\mathrm{CA}_{2}\right)^{\mathrm{a}}$ & $\begin{array}{c}\left(\mathrm{CA}_{2}\right)+14 \mathrm{H}^{+}= \\
\mathrm{Ca}^{++}+7 \mathrm{H}_{2} \mathrm{O}+4 \mathrm{Al}^{+++}\end{array}$ & 72.3522 & 61.7708 & 49.4921 & 38.1739 & 26.8205 & 17.5151 & 9.4887 & 2.2092 \\
\hline$\left(\mathrm{CAH}_{10}\right)^{\mathrm{a}}$ & $\begin{array}{c}\left(\mathrm{CAH}_{10}\right)+8 \mathrm{H}^{+}= \\
\mathrm{Ca}^{++}+2 \mathrm{Al}^{+++}+14 \mathrm{H}_{2} \mathrm{O}\end{array}$ & 43.6796 & 39.0445 & 33.8558 & 29.2831 & 24.9053 & 21.4541 & 18.5237 & 15.8339 \\
\hline Afwillite & $\begin{array}{c}\text { Afwillite }+6 \mathrm{H}^{+}= \\
3 \mathrm{Ca}^{++}+2 \mathrm{SiO}_{2}(\mathrm{aq})+6 \mathrm{H}_{2} \mathrm{O}\end{array}$ & 65.8852 & 60.5586 & 54.3512 & 48.7177 & 43.2335 & 38.9119 & 35.3174 & 32.0963 \\
\hline Allite $\left(\mathrm{C}_{3} \mathrm{~S}\right)$ & $\begin{array}{c}\text { Allite }+6 \mathrm{H}^{+}= \\
\mathrm{SiO}_{2}(\mathrm{aq})+3 \mathrm{Ca}^{++}+3 \mathrm{H}_{2} \mathrm{O}\end{array}$ & 80.7463 & 73.6625 & 65.4520 & 57.9399 & 50.5253 & 44.6084 & 39.6786 & 35.3514 \\
\hline Bellite $\left(C_{2} S\right)^{a}$ & $\begin{array}{c}\text { Bellite }+4 \mathrm{H}+= \\
2 \mathrm{Ca}+++2 \mathrm{H}_{2} \mathrm{O}+\mathrm{SiO}_{2}(\mathrm{aq}) \\
\end{array}$ & 42.5902 & 38.8242 & 34.4238 & 30.3903 & 26.4097 & 23.2289 & 20.5608 & 18.1770 \\
\hline $\mathrm{CSH}: 1.7^{1, a}$ & $\begin{array}{c}\mathrm{CSH}+3.4 \mathrm{H}^{+}= \\
1.7 \mathrm{Ca}^{++}+\mathrm{SiO}_{2}(\mathrm{aq})+4.317 \mathrm{H}_{2} \mathrm{O}\end{array}$ & 31.9548 & 29.5255 & 26.7220 & 24.2206 & 21.8439 & 20.0241 & 18.5492 & 17.2455 \\
\hline Ettringite & $\begin{array}{c}\text { Ettringite }(\mathrm{B})+12 \mathrm{H}^{+}= \\
6 \mathrm{Ca}^{++}+2 \mathrm{Al}^{+++}+38 \mathrm{H}_{2} \mathrm{O}+3 \mathrm{SO}_{4}^{--}\end{array}$ & 62.1144 & 56.8823 & 50.7600 & 45.1311 & 39.3132 & 34.0737 & 28.7003 & 22.3823 \\
\hline Cr-ettringite & $\begin{array}{c}\text { Cr-ettringite }+12 \mathrm{H}^{+}= \\
6 \mathrm{Ca}^{++}+2 \mathrm{Al}^{++}+3 \mathrm{CrO}_{4}^{2-}+38 \mathrm{H}_{2} \mathrm{O}\end{array}$ & $-b$ & 59.0000 & $-b$ & $-b$ & $-b$ & $-b$ & $-b$ & $-b$ \\
\hline Foshagite & $\begin{array}{c}\text { Foshagite }+8 \mathrm{H}^{+}= \\
4 \mathrm{Ca}^{++}+3 \mathrm{SiO}_{2}(\mathrm{aq})+5.5 \mathrm{H}_{2} \mathrm{O}\end{array}$ & 72.8341 & 66.6910 & 59.4664 & 52.8906 & 46.4921 & 41.4558 & 37.2600 & 33.4631 \\
\hline
\end{tabular}




\begin{tabular}{|c|c|c|c|c|c|c|c|c|c|}
\hline \multirow[b]{2}{*}{ Mineral } & \multirow[b]{2}{*}{ Reaction } & \multicolumn{8}{|c|}{ Temperature $\left({ }^{\circ} \mathrm{C}\right)$} \\
\hline & & 0.01 & 25 & 60 & 100 & 150 & 200 & 250 & 300 \\
\hline Friedl Salt $^{\mathrm{a}}$ & $\begin{array}{c}\text { Friedl Salt }+6 \mathrm{H}^{+}= \\
4 \mathrm{Ca}^{++}+2 \mathrm{Cl}^{-}+19 \mathrm{H}_{2} \mathrm{O}\end{array}$ & -178.8322 & -160.3061 & -138.9735 & -119.3986 & -100.0899 & -84.9403 & -72.9462 & -63.5893 \\
\hline $\begin{array}{l}\text { Gehlenite } \\
\text { Hydrate }^{2}\end{array}$ & $\begin{array}{c}\mathrm{Ca}_{2} \mathrm{Al}_{2} \mathrm{SiO}_{7} \cdot 8 \mathrm{H}_{2} \mathrm{O}+10 \mathrm{H}^{+}= \\
2 \mathrm{Ca}^{++}+2 \mathrm{Al}^{+++}+\mathrm{SiO}_{2}+13 \mathrm{H}_{2} \mathrm{O}\end{array}$ & $-\mathrm{b}$ & 49.2204 & $-\mathrm{b}$ & $-\mathrm{b}$ & $-\mathrm{b}$ & $-\mathrm{b}$ & $-\mathrm{b}$ & $-\mathrm{b}$ \\
\hline Gismondine-Ca & $\begin{array}{c}\mathrm{CaAl}_{2} \mathrm{Si}_{2} \mathrm{O}_{8} 4 \mathrm{H}_{2} \mathrm{O}+8 \mathrm{H}^{+}= \\
\mathrm{Ca}^{++}+2 \mathrm{Al}^{+++}+2 \mathrm{SiO}_{2}+8 \mathrm{H}_{2} \mathrm{O}\end{array}$ & $-\mathrm{b}$ & 20.8686 & $-\mathrm{b}$ & $-\mathrm{b}$ & $-b$ & $-\mathrm{b}$ & $-\mathrm{b}$ & $-b$ \\
\hline Gismondine-Na & $\begin{array}{c}\mathrm{Na}_{2} \mathrm{Al}_{2} \mathrm{Si}_{2} \mathrm{O}_{8} 4 \mathrm{H}_{2} \mathrm{O}+8 \mathrm{H}^{+}= \\
2 \mathrm{Na}^{+}+2 \mathrm{Al}^{+++}+2 \mathrm{SiO}_{2}+8 \mathrm{H}_{2} \mathrm{O}\end{array}$ & $-b$ & 21.8596 & $-\mathrm{b}$ & $-b$ & $-b$ & $-b$ & $-b$ & $-\mathrm{b}$ \\
\hline Gyrolite & $\begin{array}{c}\text { Gyrolite }+4 \mathrm{H}+= \\
2 \mathrm{Ca}^{++}+3 \mathrm{SiO}_{2}(\mathrm{aq})+4.5 \mathrm{H}_{2} \mathrm{O}\end{array}$ & 25.3869 & 23.6797 & 21.5505 & 19.6199 & 17.7964 & 16.4002 & 15.2205 & 14.0407 \\
\hline $\begin{array}{l}\text { Hemicarbo- } \\
\text { aluminate }^{3}\end{array}$ & $\begin{array}{c}\text { Hemicarboaluminate }+13.5 \mathrm{H}^{+}= \\
4 \mathrm{Ca}^{++}+2 \mathrm{Al}^{+++}+0.5 \mathrm{HCO}_{3}^{-}+17.5 \mathrm{H}_{2} \mathrm{O}\end{array}$ & $-\mathrm{b}$ & 88.3235 & $-\mathrm{b}$ & $-\mathrm{b}$ & $-b$ & $-\mathrm{b}$ & $-\mathrm{b}$ & $-\mathrm{b}$ \\
\hline Hillebrandite & $\begin{array}{c}\text { Hillebrandite }+4 \mathrm{H}^{+}= \\
2 \mathrm{Ca}^{++}+\mathrm{SiO}_{2}(\mathrm{aq})+3.17 \mathrm{H}_{2} \mathrm{O}\end{array}$ & 40.4592 & 37.0757 & 33.1420 & 29.5650 & 26.0671 & 23.2950 & 20.9782 & 18.9002 \\
\hline Hydrogarnet $^{a}$ & $\begin{array}{l}\text { Hydrogarnet }+12 \mathrm{H}^{+}= \\
3 \mathrm{Ca}^{++}+2 \mathrm{Al}^{+++}+6 \mathrm{H}_{2} \mathrm{O}\end{array}$ & -180.8116 & -169.1024 & -155.8511 & -143.9549 & -132.5681 & -124.0078 & -117.6057 & -112.9719 \\
\hline Hydrotalcite $^{4}$ & $\begin{array}{c}4 \mathrm{MgO} \cdot \mathrm{Al}_{2} \mathrm{O}_{3} \cdot 10 \mathrm{H}_{2} \mathrm{O}+14 \mathrm{H}^{+}= \\
4 \mathrm{Mg}^{++}+2 \mathrm{Al}^{+++}+17 \mathrm{H}_{2} \mathrm{O}\end{array}$ & $-\mathrm{b}$ & 73.7800 & $-b$ & $-\mathrm{b}$ & $-b$ & $-b$ & $-\mathrm{b}$ & $-\mathrm{b}$ \\
\hline $\begin{array}{l}\text { Monocarbo- } \\
\text { aluminate }^{3}\end{array}$ & $\begin{array}{c}3 \mathrm{CaO} \cdot \mathrm{Al}_{2} \mathrm{O}_{3} \cdot \mathrm{CaCO}_{3} \cdot 10 \mathrm{H}_{2} \mathrm{O}+13 \mathrm{H}^{+}= \\
4 \mathrm{Ca}^{++}+2 \mathrm{Al}^{+++}+\mathrm{HCO}_{3}^{-}+16 \mathrm{H}_{2} \mathrm{O}\end{array}$ & $-b$ & 77.3538 & $-\mathrm{b}$ & $-b$ & $-b$ & $-b$ & $-b$ & $-b$ \\
\hline Monosulphate & $\begin{array}{c}\text { Monosulphate }+12 \mathrm{H}^{+}= \\
4 \mathrm{Ca}^{++}+2 \mathrm{Al}^{+++}+18 \mathrm{H}_{2} \mathrm{O}+\mathrm{SO}_{4}^{--}\end{array}$ & 80.7137 & 72.4704 & 62.9530 & 54.2551 & 45.5660 & 38.3842 & 31.9936 & 25.7834 \\
\hline Okenite & $\begin{array}{c}\text { Okenite }+2 \mathrm{H}^{+}= \\
\mathrm{Ca}^{++}+2 \mathrm{SiO}_{2}(\mathrm{aq})+3 \mathrm{H}_{2} \mathrm{O}\end{array}$ & 11.4698 & 10.8948 & 10.1470 & 9.5024 & 8.9579 & 8.5978 & 8.3158 & 7.9937 \\
\hline Plombierite & $\begin{array}{c}\text { Plombierite }+10 \mathrm{H}^{+}= \\
5 \mathrm{Ca}^{++}+6 \mathrm{SiO}_{2}(\mathrm{aq})+15.5 \mathrm{H}_{2} \mathrm{O}\end{array}$ & 69.8789 & 65.3842 & 59.9716 & 55.1602 & 50.6830 & 47.3017 & 44.4797 & 41.6996 \\
\hline Riversideite & $\begin{array}{c}\text { Riversideite }+10 \mathrm{H}^{+}= \\
5 \mathrm{Ca}^{++}+6 \mathrm{SiO}_{2}(\mathrm{aq})+8 \mathrm{H}_{2} \mathrm{O}\end{array}$ & 76.6335 & 70.6194 & 63.3144 & 56.6105 & 50.0934 & 44.9615 & 40.6267 & 36.5343 \\
\hline Syngenite $^{5}$ & $\begin{array}{c}\mathrm{K}_{2} \mathrm{Ca}\left(\mathrm{SO}_{4}\right)_{2} \cdot \mathrm{H}_{2} \mathrm{O}= \\
\mathrm{Ca}^{++}+2 \mathrm{~K}^{+}+2 \mathrm{SO}_{4}^{--}+\mathrm{H}_{2} \mathrm{O}\end{array}$ & $-\mathrm{b}$ & $-7.6001^{c}$ & $-\mathrm{b}$ & $-\mathrm{b}$ & $-\mathrm{b}$ & $-\mathrm{b}$ & $-\mathrm{b}$ & $--^{b}$ \\
\hline
\end{tabular}




\begin{tabular}{|c|c|c|c|c|c|c|c|c|c|}
\hline \multirow[b]{2}{*}{ Mineral } & \multirow[b]{2}{*}{ Reaction } & \multicolumn{8}{|c|}{ Temperature $\left({ }^{\circ} \mathrm{C}\right)$} \\
\hline & & 0.01 & 25 & 60 & 100 & 150 & 200 & 250 & 300 \\
\hline Syngenite $^{d}$ & $\begin{array}{c}\mathrm{K}_{2} \mathrm{Ca}\left(\mathrm{SO}_{4}\right)_{2} \cdot \mathrm{H}_{2} \mathrm{O}= \\
\mathrm{Ca}^{++}+2 \mathrm{~K}^{+}+2 \mathrm{SO}_{4}^{--}+\mathrm{H}_{2} \mathrm{O}\end{array}$ & -7.5463 & -7.2618 & -7.1520 & -7.2929 & -7.7579 & -8.6663 & -10.6136 & $-{ }^{b}$ \\
\hline Tobermorite & $\begin{array}{c}\text { Tobermorite }+10 \mathrm{H}^{+}= \\
5 \mathrm{Ca}^{++}+6 \mathrm{SiO}_{2}(\mathrm{aq})+10.5 \mathrm{H}_{2} \mathrm{O}\end{array}$ & 72.5004 & 67.1518 & 60.6578 & 54.7498 & 49.0777 & 44.6609 & 40.9360 & 37.3654 \\
\hline Xonotlite & $\begin{array}{c}\text { Xonotlite }+12 \mathrm{H}^{+}= \\
6 \mathrm{Ca}^{++}+6 \mathrm{SiO}_{2}(\mathrm{aq})+7 \mathrm{H}_{2} \mathrm{O}\end{array}$ & 102.0247 & 93.3664 & 82.9922 & 73.4523 & 64.0988 & 56.6744 & 50.4171 & 44.6471 \\
\hline
\end{tabular}

Sources: DTN: MO0302SPATHDYN.001 ([DIRS 161886], Spreadsheet Minerals_cal_DJ_Cement.xls), except as noted.

1 DTN: MO0302SPATHDYN.001 ([DIRS 161886], Spreadsheet Minerals_j_DJ_CSH.xls).

2 DTN: MO0302SPATHDYN.001 ([DIRS 161886], Spreadsheet Solids_j_DJ_Cement.xls).

3 Damidot et al. 1994 [DIRS 144866], Appendix 1.

4 Bennett et al. 1992 [DIRS 116990].

5 Harvie et al. 1984 [DIRS 118163].

a Phases with commented (inactive) data blocks in data0.ymp.R2 (DTN: MO0302SPATHDYN.000 [DIRS 161756]).

${ }^{b}$ Data insufficient to estimate log $\mathrm{K}$ at temperatures other than $298.15 \mathrm{~K}$.

${ }^{c}$ The $\log \mathrm{K}$ value of 7.6001 appears to be in error. The recalculated $\log \mathrm{K}$ value at $25^{\circ} \mathrm{C}$ from the same source is -7.4484 .

${ }^{d}$ These values for syngenite are from the Pitzer database (DTN: SN0302T0510102.002 [DIRS 162572]). 


\subsubsection{Calcium Silicate Hydrate}

The data blocks for this phase are inactive in data0.ymp.R2 (DTN: MO0302SPATHDYN.000 [DIRS 161756]). The following discussion is provided for qualification, for possible future application of thermodynamic data for this species.

$\mathrm{CSH}$ gels are the principle bonding material in Portland cements. This mineral phase has been the subject of much investigation into its solubility product and other thermodynamic properties. Studies done in MacPhee et al. (1989 [DIRS 145004]), Bennett et al. (1992 [DIRS 116990]), Berner (1987 [DIRS 116991], 1990 [DIRS 100707]), Atkins et al. (1992 [DIRS 100700], 1993 [DIRS 131758]), Greenberg and Chang (1965 [DIRS 144989]), Glasser et al. (1987 [DIRS 118111]), Fujii and Kondo (1983 [DIRS 144876]), Gartner and Jennings (1987 [DIRS 144879]), and Reardon (1990 [DIRS 100821]) all suggest the difficulty in determining thermodynamic properties for $\mathrm{CSH}$. The general consensus is that $\mathrm{CSH}$ dissolves incongruently and behaves as a solid solution. The solubility of $\mathrm{CSH}$ is thought to be a function of the calcium to silica ratio ranging between approximately $0.85<\mathrm{Ca} / \mathrm{Si}$ (mole ratio) $<1.70$. This range could lead to the inclusion in the database of several $\mathrm{CSH}$ phases each with its own specific set of thermodynamic data. This is a reasonable approach, but it leads to difficulty in modeling the different phases. Each phase has to be suppressed or not allowed to form, to test the sensitivity to the solid solution. This approach can be evaluated in a different manner where one might model a specific $\mathrm{CSH}$ phase and then modify the $\log \mathrm{K}$ as an input parameter. Both approaches work equally well in determining the effects of the possible solid solution behavior. But because Portland cement generally hydrates to give a $\mathrm{CSH}$ with a $\mathrm{Ca} / \mathrm{Si}$ ratio close to 1.70 (Glasser et al. 1987 [DIRS 118111]), this specific ratio should be the most likely to form. Therefore, only selecting the values that are associated with a $\mathrm{Ca} / \mathrm{Si}$ ratio of 1.70 will simplify data selection, and this is the basis for the CSH:1.7 species.

Based on this criterion, the data selection is simplified. Data for $\Delta \mathrm{H}^{\circ}, \Delta \mathrm{G}^{\circ}$, and $\mathrm{S}^{\circ}$ from Fujii and Kondo (1983 [DIRS 144876]) for $\mathrm{CSH}$ at a $\mathrm{Ca} / \mathrm{Si}$ ratio $=1.7$ exist (Table 6-26), and the method for their derivation is technically reasonable. The source data used for the basis of these data (Fujii and Kondo 1983 [DIRS 144876]) along with data from Greenberg and Chang (1965 [DIRS 144989]) are also used in Glasser et al. (1987 [DIRS 118111]) as a basis for a solid solution solubility model for CSH. These same source data (Greenberg and Chang 1965 [DIRS 144989]) were also used in Berner (1987 [DIRS 116991]) for his solid solution solubility model. The source data are accepted by others in the scientific community, and a review of Fujii and Kondo (1981 [DIRS 158026]) indicates that the method for the derivation of the data in Table 6-26 is reasonable. Calculation of the $\log \mathrm{K}$ grid was done in the Excel Spreadsheet Minerals_j_DJ_CSH.xls in DTN: MO0302SPATHDYN.001 ([DIRS 161886]). The estimation of heat capacity values for the temperature extrapolation using the data and method of Helgeson et al. 1978 [DIRS 101596]) are documented in the Spreadsheet DJ Cp and Vm Calculations.xls (DTN: MO0302SPATHDYN.001 [DIRS 161886]). 
Table 6-26. Thermodynamic Data for CSH with Ca to Si Ratio of 1.7

\begin{tabular}{|c|c|c|c|c|c|c|}
\hline \multirow[b]{2}{*}{$\Delta \mathrm{H}^{\circ}{ }_{f}(\mathrm{~kJ} / \mathrm{mol})$} & \multirow[b]{2}{*}{$\Delta \mathbf{G}_{f}^{\circ}(\mathrm{kJ} / \mathrm{mol})$} & \multirow[b]{2}{*}{$\mathrm{V}^{\circ}\left(\mathrm{cm}^{3} / \mathrm{mol}\right)$} & \multirow[b]{2}{*}{$\mathrm{S}^{\circ}(\mathrm{J} / \mathrm{mol}-\mathrm{K})$} & \multicolumn{3}{|c|}{ Heat Capacity Coefficients } \\
\hline & & & & $\begin{array}{c}a \\
(\mathrm{~J} / \mathrm{mol}-K)\end{array}$ & $\begin{array}{c}b \times 10^{3} \\
\left(\mathrm{~J} / \mathrm{mol}-K^{2}\right)\end{array}$ & $\begin{array}{c}\mathrm{c} \times 10^{-5} \\
(\mathrm{~J}-\mathrm{K} / \mathrm{mol})\end{array}$ \\
\hline-2890 & -2630 & 86.22 & 200 & 194.72 & 38.80 & -5.66 \\
\hline
\end{tabular}

Sources: Fujii and Kondo 1983 [DIRS 144876].

DTN: MO0302SPATHDYN.001 ([DIRS 161886], Spreadsheets Minerals_j_DJ_CSH.xIs and DJ Cp and Vm Calculations.xIs).

\subsubsection{Ettringite}

Two data sources exist for ettringite (Table 6-27). The $\log \mathrm{K}$ value (57.0804) at $25^{\circ} \mathrm{C}$ from Perkins and Palmer (1999 [DIRS 152703]) and the $\log \mathrm{K}$ value (56.8823) calculated in Spreadsheet Minerals_cal_DJ_Cement.xls in DTN: MO0302SPATHDYN.001 [DIRS 161886] with data from Babushkin et al. (1985 [DIRS 116981]) are both within $2 \sigma$ variance of the Ion Activity Product for ettringite reported in Perkins and Palmer (1999 [DIRS 152703]) $( \pm 0.81 \log$ units). Since the data are within the experimental error, either the Perkins and Palmer or Babushkin data set could be used with confidence. To maintain consistency with previously selected data for other cement phases, the values from Babushkin et al. (1985 [DIRS 116981]) were included in the data0.ymp.R2 database (DTN: MO0302SPATHDYN.000 [DIRS 161756]) and the Perkins and Palmer (1999 [DIRS 152703]) data are used in this report for corroboration. Calculation of the $\log \mathrm{K}$ grid was originally done in the Excel Spreadsheet Minerals_cal_DJ_Cement.xls (DTN: MO0302SPATHDYN.001 [DIRS 161886]).

Cr-ettringite data are obtained from the solubility study of Perkins and Palmer (2000 [DIRS 153349]). The study is a detailed investigation of the dissolution and precipitation of this phase at various solution compositions of combined with the accurate characterization of run products. The authors generated solubility data for ettringite, which is closely related to Cr-ettringite, in a previous study (Perkins and Palmer 1999 [DIRS 152703]), in which the thermodynamic parameters reported for ettringite were in good agreement with an established fact source (Babushkin et al. 1985 [DIRS 116981]). Accordingly, confidence in the log K value for Cr-ettringite in data0.ymp.R2 (DTN: MO0302SPATHDYN.000 [DIRS 161756]) is justified given the expertise of the authors and the similarity of the thermodynamic parameters for ettringite and $\mathrm{Cr}$-ettringite as shown in Table 4-11. This study also generates a $\log \mathrm{K}$ value at $25^{\circ} \mathrm{C}(\log \mathrm{K}=-2.77)$ for the reaction $\mathrm{CaCrO}_{4}(\mathrm{aq})=\mathrm{Ca}^{++}+\mathrm{CrO}_{4}{ }^{--}$consistent with the solubility data for Cr-ettringite.

Table 6-27. Values of Gibbs Free Energy, Enthalpy, Entropy, and Heat Capacity for Ettringite $\left(3 \mathrm{CaO} \cdot \mathrm{Al}_{2} \mathrm{O}_{3} \cdot 3 \mathrm{CaSO}_{4} \cdot 32 \mathrm{H}_{2} \mathrm{O}\right)$

\begin{tabular}{|l|l|c|c|c|c|c|}
\hline \multicolumn{1}{|c|}{ Source } & $\Delta \mathbf{G}^{\circ}{ }_{f}(\mathbf{c a l} / \mathbf{m o l})$ & $\begin{array}{c}\Delta \mathbf{H}^{\circ}{ }_{f} \\
(\mathbf{c a l} / \mathbf{m o l})\end{array}$ & $\begin{array}{c}\mathbf{S}^{\circ} \\
(\mathbf{c a l} / \mathbf{m o l})\end{array}$ & $\begin{array}{c}\mathbf{C}_{\mathbf{p}}{ }^{\circ} \mathbf{a} \\
(\mathbf{c a l} / \mathbf{m o l}-\mathbf{K})\end{array}$ & $\begin{array}{c}\mathbf{b} \times \mathbf{1 0}^{3}(\mathbf{c a l} / \\
\left.\mathbf{m o l}^{2} \mathbf{K}^{2}\right)\end{array}$ & $\begin{array}{c}\mathbf{c} \times \mathbf{1 0}^{-5} \\
(\mathbf{c a l}-\mathbf{K} / \mathbf{m o l})\end{array}$ \\
\hline Babushkin et al. & -3634260 & -4201320 & 417.6 & 208 & 740.93 & - \\
\hline $\begin{array}{l}\text { Perkins and } \\
\text { Palmer }\end{array}$ & -3635516 & -4194550 & 444.93 & 141 & - & - \\
\hline
\end{tabular}

Sources: Babushkin et al. 1985 [DIRS 116981], Appendix 1; Perkins and Palmer 1999 [DIRS 152703]. 


\subsubsection{Gismondine}

The $\mathrm{Na}$ and Ca-gismondine species are active in data0.ymp.R2 (DTN: MO0302SPATHDYN.000 [DIRS 161756]). The following discussion is provided for qualification of the $\log \mathrm{K}$ values, and results in a conclusion that the data are questionable. Atkins et al. (1993 [DIRS 131758], Section 5.2.6) reported $\Delta \mathrm{G}_{f}^{\circ}$ values for $\mathrm{Na}-$ and Ca-gismondine (shown in Table 4-14). For development of the data0.ymp.R2 database (DTN: MO0302SPATHDYN.000 [DIRS 161756]), these values were entered into a spreadsheet (Cement_phases_Gismon_fixed_CFJC.xls; DTN: MO0302SPATHDYN.001 [DIRS 161886]) to determine the $\log \mathrm{K}$ values at $25^{\circ} \mathrm{C}$ based on the following reactions:

$$
\begin{gathered}
\mathrm{Na}_{2} \mathrm{Al}_{2} \mathrm{Si}_{2} \mathrm{O}_{8} \bullet 4 \mathrm{H}_{2} \mathrm{O}+8 \mathrm{H}^{+}=2 \mathrm{Na}^{+}+2 \mathrm{Al}^{+++}+2 \mathrm{SiO}_{2}(\mathrm{aq})+8 \mathrm{H}_{2} \mathrm{O} \\
\mathrm{CaAl}_{2} \mathrm{Si}_{2} \mathrm{O}_{8} \bullet 4 \mathrm{H}_{2} \mathrm{O}+8 \mathrm{H}+=\mathrm{Ca}^{++}+2 \mathrm{Al}^{+++}+2 \mathrm{SiO}_{2}(\mathrm{aq})+8 \mathrm{H}_{2} \mathrm{O}
\end{gathered}
$$

Calculation of the $\log \mathrm{K}$ grid was done in the Excel Spreadsheet Cement_phases_Gismon_fixed_CFJC.xls (output DTN: SN0410T0510404.001) and the results are shown in Table 6-28.

Thermodynamic data for Ca-gismondine are reported by Ogorodova et al. (2003 [DIRS 172005]). So far, these are the only thermodynamic data available to conduct a corroborative comparison with the values reported by Atkins et al. (1993 [DIRS 131758]. Unlike the work of Atkins et al. (1993 [DIRS 131758], the recent study by Ogorodova et al. (2003 [DIRS 172005]) reports a detailed calorimetric study on natural samples and also retrieves thermodynamic data for an ideal end-member composition of Ca-gismondine close to the one adopted in this report. The only difference is that the Ca-Gismondine composition $\left(\mathrm{CaAl}_{2} \mathrm{Si}_{2} \mathrm{O}_{8} \cdot 4.5 \mathrm{H}_{2} \mathrm{O}\right)$ reported by Ogorodova et al. (2003 [DIRS 172005]) has 4.5 instead of 4 moles of $\mathrm{H}_{2} \mathrm{O}$ relative to that reported by Atkins et al. (1993 [DIRS 131758]). To correct for this difference, it was assumed that $\mathrm{H}_{2} \mathrm{O}$ is loosely bound to the zeolite structure (not treated as zeolitic $\mathrm{H}_{2} \mathrm{O}$ ) so this difference is substracted (see Spreadsheet Cement_phases_Gismon_fixed_CFJC.xls; output DTN: SN0410T0510404.001) from the $\Delta \mathrm{G}_{f}^{\circ}$ value listed by Ogorodova et al. (2003 [DIRS 172005]). The resulting value given in Table 6-28 is $-1236.32 \mathrm{kcal} / \mathrm{mol}$. This value is about $49 \mathrm{kcal} / \mathrm{mol}$ different from the one reported by Atkins et al. (1993 [DIRS 131758]). This difference in $\Delta \mathrm{G}_{f}^{\circ}$ is substantial and generates a $\log \mathrm{K}$ value (see Table 6-28) that is also very different from that computed using Atkins et al. (1993 [DIRS 131758]) data, therefore rendering the latter data questionable. One of the coauthors (Irina Kiseleva) of the work by Ogorodova et al. (2003 [DIRS 172005]) has published several articles on zeolite thermochemistry in peer-reviewed journals along with leading investigators in the field, thus establishing confidence in their calorimetric results and data analysis. A study by Vieillard (1995 [DIRS 172320]) on the estimation of enthalpies of formation at $25^{\circ} \mathrm{C}$ for various zeolite phases reports $\Delta \mathrm{H}_{f}^{\circ}$ data for Ca-gismondine $\left(\mathrm{CaAl}_{2} \mathrm{Si}_{2} \mathrm{O}_{8} \cdot 4.5 \mathrm{H}_{2} \mathrm{O}\right)$ having the same compositions as that reported by Ogorodova et al. (2003 [DIRS 172005]). The $\Delta \mathrm{H}_{f}^{\circ}$ value reported by Vieillard (1995 [DIRS 172320], Table 4, p. 210) is $-5613.35 \mathrm{~kJ} / \mathrm{mol}$. The value reported by Ogorodova et al. (2003 [DIRS 172005]) is $-5631 \mathrm{~kJ} / \mathrm{mol}$ and differs by approximately $18 \mathrm{~kJ} / \mathrm{mol}$ relative to that reported by Vieillard (1995 [DIRS 172320]). This difference is within the overall uncertainty bounds given by both authors for their reported $\Delta \mathrm{H}_{f}^{\circ}$ values. This data corroboration between model and experimental measurements confirms that 
the value given by Atkins et al. (1993 [DIRS 131758] is incorrect. Moreover, given the relatively close values for $\Delta \mathrm{G}_{f}^{\circ}$ obtained from Atkins et al. (1993 [DIRS 131758]) data between $\mathrm{Na}$-gismondine and $\mathrm{Ca}$-gismondine, their data for $\mathrm{Na}$-gismondine are also questionable.

Table 6-28. Gibbs Free Energy of Formation and Log K Values for the Dissociation Reaction Represented by Eqs. 6-24 and 6-25 for Na- and Ca-Gismondine Minerals

\begin{tabular}{|c|c|c|c|c|}
\hline Mineral & Formula & $\Delta \mathbf{G}^{\circ}{ }_{\mathbf{f}} \mathbf{( \mathbf { k c a l } / \mathbf { m o l } )}$ & $\begin{array}{c}\text { Log K } \\
\left.\mathbf{( 2 5}{ }^{\circ} \mathbf{C}\right)\end{array}$ & Source \\
\hline Gismondine- $\mathrm{Na}$ & $\mathrm{Na}_{2} \mathrm{Al}_{2} \mathrm{Si}_{2} \mathrm{O}_{8} \bullet 4 \mathrm{H}_{2} \mathrm{O}$ & -1179.16 & 21.8596 & Atkins et al. 1993 [DIRS 131758] \\
\hline Gismondine-Ca & $\mathrm{CaAl}_{2} \mathrm{Si}_{2} \mathrm{O}_{8} \bullet 4 \mathrm{H}_{2} \mathrm{O}$ & -1187.45 & 20.8686 & Atkins et al. 1993 [DIRS 131758] \\
\hline Gismondine-Ca & $\mathrm{CaAl}_{2} \mathrm{Si}_{2} \mathrm{O}_{8} \bullet 4.5 \mathrm{H}_{2} \mathrm{O}$ & -1234.70 & - & $\begin{array}{c}\text { Ogorodova et al. 2003 } \\
\text { [DIRS 172005], Table 3, p.1545 }\end{array}$ \\
\hline Gismondine-Ca* & $\mathrm{CaAl}_{2} \mathrm{Si}_{2} \mathrm{O}_{8} \bullet 4 \mathrm{H}_{2} \mathrm{O}$ & -1236.32 & -14.9557 & $\begin{array}{c}\text { Ogorodova et al. 2003 } \\
\text { [DIRS 172005], Table 3, p.1545 }\end{array}$ \\
\hline
\end{tabular}

${ }^{*} \Delta \mathrm{G}^{\circ}$ estimated by substracting half of the $\Delta \mathrm{G}^{\circ}$ associated with one $\mathrm{H}_{2} \mathrm{O}$, assuming it is loosely bound to the zeolite structure (see Spreadsheet Cement_phases_Gismon_fixed_CFJC.xIs, output DTN: SN0410T0510404.001).

\subsubsection{Friedl Salt}

The data block for this phase is inactive in data0.ymp.R2 (DTN: MO0302SPATHDYN.000 [DIRS 161756]). The following discussion is relevant to possible future application of thermodynamic data for these species.

The composition given for this phase in data0.ymp.R2 (DTN: MO0302SPATHDYN.000 [DIRS 161756]) is not that of Friedel's salt (as known in the cement literature; see Taylor 1990 [DIRS 120495]) but that of the cement phase calcium oxychloride hydrate. In the following discussion, the terms Friedl salt and Ca-oxychloride hydrate are used interchangeably.

The estimation of $\log \mathrm{K}$ values for this phase extrapolated to temperatures other than $25^{\circ} \mathrm{C}$ was assessed for development of data0.ymp.R2 (DTN: MO0302SPATHDYN.000 [DIRS 161756]), using an approximation based on the non-oxide component $\mathrm{CaCl}_{2}$. The needed heat capacity values were taken from Chase (1998 [DIRS 157874]) and calculated in the Spreadsheet Heat Capacity Regression for CaCl2 solid.xls (DTN: MO0302SPATHDYN.001 [DIRS 161886]). These values were added to the remaining oxides to determine elemental heat capacity. The calculations were conducted in Spreadsheet $D J C p$ and $\mathrm{Vm}$ calculations.xls (DTN: MO0302SPATHDYN.001 [DIRS 161886]). Calculation of the log K grid was done in the Excel Spreadsheet Minerals_cal_DJ_Cement.xls (DTN: MO0302SPATHDYN.001 [DIRS 161886]). The resulting $\log \mathrm{K}$ values for the reaction in Eq. 6-26, shown as inactive data in the data0.ymp.R2 database (DTN: MO0302SPATHDYN.000 [DIRS 161756]), are relevant to cement calculations only and the low solubilities cause extreme precipitation if activated and not suppressed in an EQ3/6 run.

$$
\mathrm{CaCl}_{2}(\mathrm{CaO})_{3}: 16 \mathrm{H}_{2} \mathrm{O}+6 \mathrm{H}^{+}=4 \mathrm{Ca}^{++}+2 \mathrm{Cl}^{-}+19 \mathrm{H}_{2} \mathrm{O}
$$

Subsequent revisiting of thermodynamic data for this Ca-oxychloride hydrate cement phase indicate that the Gibbs free energy of formation and standard entropy values given in the 
Spreadsheet Minerals_cal_DJ_Cement.xls (DTN: MO0302SPATHDYN.001 [DIRS 161886]) could not be found in the source Babushkin et al. (1985 [DIRS 116981], Appendix I). Only enthalpy of formation data are given by this source. A literature search on this phase revealed another source of data for a similar composition given by Harvie et al. (1984 [DIRS 118163]) and adopted by Reardon (1990 [DIRS 100821]) in his model of cement-water interactions. The phase is designated "calcium oxychloride $\mathrm{A}$ " $\left(\mathrm{CaCl}_{2}(\mathrm{CaO})_{3} \cdot 13 \mathrm{H}_{2} \mathrm{O}\right)$ and the only difference from the Ca-oxychloride hydrate phase discussed here are the three waters. Harvie et al. (1984 [DIRS 118163]) conducted a comprehensive review of salt solubility data of the system $\mathrm{Ca}(\mathrm{OH})_{2}-\mathrm{CaCl}_{2}-\mathrm{H}_{2} \mathrm{O}$ and advanced a predictive model using the Pitzer approach. They obtained values for standard chemical potentials that can be converted to Gibbs free energies of formation (see Spreadsheet Minerals_cal_DJ_Cement_CFJC_fix.xls; DTN: SN0410T0510404.001). Assuming $\Delta \mathrm{H}^{\circ}{ }_{r}=0$ for a reaction that adds three extra waters to the phase described by Harvie et al. (1984 [DIRS 118163]) or that water is loosely bound to the mineral structure, the recalculated Gibbs free energy of formation is $-1745.14 \mathrm{kcal} / \mathrm{mol}$. The difference in Gibbs free energy of formation between the input values and newly estimated values is significant (Table 6-29). Consequently, the estimated $\log \mathrm{K}$ values for the dissociation reaction are also very different (Table 6-29). For this reason, the datablock for "Friedl Salt" in data0.ymp.R2 (DTN: MO0302SPATHDYN.000 [DIRS 161756]) was commented out (i.e., inactivated) and is not considered for qualification in this report.

The analysis by Harvie et al. (1984 [DIRS 118163]) is considered comprehensive and the agreement between their model and solubility data is good (see Harvie et al. 1984 [DIRS 118163], Figure 11a, p. 738). The authors of this work have published numerous peer-reviewed studies in the evaluation of thermodynamic data for saline systems and proposed a robust thermodynamic model to explain the chemical equilibria between concentrated electrolytes and synthetic/natural phases. Thus, all these factors establish confidence in their retrieval of the standard chemical potential data for this phase. Moreover the model of Reardon (1990 [DIRS 100821] for evaluating cement-water interactions using the Pitzer approach adopts the standard chemical potential value given by Harvie et al. (1984 [DIRS 118163]).

\subsubsection{Gehlenite Hydrate $\left(\mathrm{Ca}_{2} \mathrm{Al}_{2} \mathrm{SiO}_{7} \bullet 8 \mathrm{H}_{2} \mathrm{O}\right)$}

Bennett et al. (1992 [DIRS 116990]) reported an average log $\mathrm{K}$ value of 49.16 for gehlenite hydrate $\left(\mathrm{Ca}_{2} \mathrm{Al}_{2} \mathrm{SiO}_{7} \cdot 8 \mathrm{H}_{2} \mathrm{O}\right)$ based on the following reaction:

$$
\mathrm{Ca}_{2} \mathrm{Al}_{2} \mathrm{SiO}_{7} \cdot 8 \mathrm{H}_{2} \mathrm{O}+10 \mathrm{H}^{+}=2 \mathrm{Ca}^{++}+2 \mathrm{Al}^{+++}+\mathrm{H}_{4} \mathrm{SiO}_{4}+11 \mathrm{H}_{2} \mathrm{O}
$$


Table 6-29. Gibbs Free Energy of Formation and Log K Values for the Dissociation Reaction Represented by Eq. 6-26 for "Friedl Salt" in Data0.ymp.R2 Database

\begin{tabular}{|l|c|c|c|l|}
\hline \multicolumn{1}{|c|}{ Mineral } & Formula & $\begin{array}{c}\Delta \mathbf{G}^{\circ} \\
(\mathbf{k c a l} / \mathbf{m o l})\end{array}$ & \multicolumn{1}{c|}{ Log K $^{\mathbf{b}}$} & \multicolumn{1}{c|}{ Source } \\
\hline $\begin{array}{l}\text { Ca-oxychloride } \\
\text { Hydrate (R2) }\end{array}$ & $\mathrm{CaCl}_{2} \cdot 3 \mathrm{CaO} \cdot 16 \mathrm{H}_{2} \mathrm{O}$ & -1887 & -160.3061 & $\begin{array}{l}\text { Spreadsheet } \\
\text { Minerals_cal_DJ_Cement_CFJC_fix.xls } \\
\text { (output DTN: SN0410T0510404.001) }\end{array}$ \\
\hline $\begin{array}{l}\text { Ca-oxychloride } \\
\text { Hydrate (New) }\end{array}$ & $\mathrm{CaCl}_{2} \cdot 3 \mathrm{CaO} \cdot 16 \mathrm{H}_{2} \mathrm{O}$ & -1745.14 & -56.3238 & Harvie et al. 1984 [DIRS 118163] \\
\hline
\end{tabular}

Sources: Spreadsheet Minerals_cal_DJ_Cement_CFJC_fix.xIs (output DTN: SN0410T0510404.001). Babushkin et al. (1985 [DIRS 116981], Appendix I, p. 403) only reports $\Delta \mathrm{K}^{\circ}$ of this phase.

Harvie et al. 1984 [DIRS 118163], Table 4, p.728.

a Phase incorrectly named "Friedl Salt" in data0.ymp.R2 (DTN: MO0302SPATHDYN.000 [DIRS 161756]). The composition of this phase as given in the database file is for calcium oxychloride hydrate.

b See Spreadsheet Minerals_cal_DJ_Cement_CFJC_fix.xIs (output DTN: SN0410T0510404.001) for details of the $\log \mathrm{K}$ calculations.

Bennett et al. (1992 [DIRS 116990]) corroborated their data point using a $\Delta \mathrm{G}_{\mathrm{f}}{ }^{\circ}$ data point of $-5710.281 \mathrm{~kJ} / \mathrm{mol}$ at $25^{\circ} \mathrm{C}$ as reported in Atkins et al. (1992 [DIRS 100700], p. 73). For the data0.ymp.R2 database (DTN: MO0302SPATHDYN.000 [DIRS 161756]), using this value within the Spreadsheet Solids_j_DJ_Cement.xls (DTN: MO0302SPATHDYN.001 [DIRS 161886]) and calculating log $\mathrm{K}$ gave a result of 49.22 based on the following reaction:

$$
\mathrm{Ca}_{2} \mathrm{Al}_{2} \mathrm{SiO}_{7} \cdot 8 \mathrm{H}_{2} \mathrm{O}+10 \mathrm{H}^{+}=2 \mathrm{Ca}^{++}+2 \mathrm{Al}^{+++}+\mathrm{SiO}_{2}(\mathrm{aq})+13 \mathrm{H}_{2} \mathrm{O}
$$

This value (49.22) also compares well with the values reported in Bennett et al. (1992 [DIRS 116990]) and is used in data0.ymp.R2 (DTN: MO0302SPATHDYN.000 [DIRS 161756]).

An alternate way of corroborating these data is to take the Gibbs free energy of formation values for anhydrous gehlenite $\left(\mathrm{Ca}_{2} \mathrm{Al}_{2} \mathrm{SiO}_{7}\right)$ given by Babushkin et al. (1985 [DIRS 116981], Appendix I, p. 403) and Robie and Hemingway (1995 [DIRS 153683], p. 314) and approximate that of the hydrated phase by adding the equivalent Gibbs free energy of formation of eight moles of $\mathrm{H}_{2} \mathrm{O}$ to the value for the anhydrous phase. This of course represents an approximation and implicitly assumes that $\mathrm{H}_{2} \mathrm{O}$ is weakly attached to the mineral structure (i.e., no "structural" $\mathrm{H}_{2} \mathrm{O}$ ). The resulting values are given in Table 6-30. Vieillard and Rassineux (1992 [DIRS 120508], Table 2, p. 130) also provide a Gibbs free energy of formation value for this phase which is larger than all others reported by the above-mentioned sources.

Notice that the difference between the values obtained from various sources and that given by Atkins et al. (1992 [DIRS 100700], p. 73) is approximately within the range of 7 and $37 \mathrm{~kJ} / \mathrm{mol}$. These differences are relatively minor considering the overall uncertainty in thermochemical determinations, use of data from different sources, and the assumptions considered in this comparison. Accordingly, the comparison between the adopted value of Atkins et al. (1992 [DIRS 100700]) and handbook data ("established fact") sources provide justification for use in modeling cement-water interactions. 
Table 6-30. Comparison of Gibbs Free Energy of Formation for Hydrated Gehlenite

\begin{tabular}{|l|l|l|l|}
\hline \multicolumn{1}{|c|}{ Mineral } & \multicolumn{1}{|c|}{ Formula } & \multicolumn{1}{|c|}{$\Delta \mathbf{G}^{\circ}{ }_{\boldsymbol{f}} \mathbf{( k J / m o l )}$} & \multicolumn{1}{c|}{ Source } \\
\hline Gehlenite Hydrate & $\mathrm{Ca}_{2} \mathrm{Al}_{2} \mathrm{SiO}_{7} \cdot 8 \mathrm{H}_{2} \mathrm{O}^{\mathrm{a}}$ & -5703.22 & $\begin{array}{l}\text { Babushkin et al. 1985 } \\
\text { [DIRS 116981] }\end{array}$ \\
\hline Gehlenite Hydrate & $\mathrm{Ca}_{2} \mathrm{Al}_{2} \mathrm{SiO}_{7} \cdot 8 \mathrm{H}_{2} \mathrm{O}$ & -5673.5 & $\begin{array}{l}\text { Vieillard and Rassineux } \\
1992 \text { [DIRS 120508] }\end{array}$ \\
\hline Gehlenite Hydrate & $\mathrm{Ca}_{2} \mathrm{Al}_{2} \mathrm{SiO}_{7} \cdot 8 \mathrm{H}_{2} \mathrm{O}^{\mathrm{a}}$ & -5682.95 & $\begin{array}{l}\text { Robie and Hemingway 1995 } \\
\text { [DIRS 153683] }\end{array}$ \\
\hline Gehlenite Hydrate & $\mathrm{Ca}_{2} \mathrm{Al}_{2} \mathrm{SiO}_{7} \cdot 8 \mathrm{H}_{2} \mathrm{O}^{\mathrm{b}}$ & $-5710.28^{\mathrm{b}}$ & $\begin{array}{l}\text { Atkins et al. 1992 } \\
\text { [DIRS 100700] }\end{array}$ \\
\hline
\end{tabular}

Sources: Robie and Hemingway 1995 [DIRS 153683], p. 314.

Babushkin et al. 1985 [DIRS 116981], Appendix I, p. 403.

Atkins et al. 1992 [DIRS 100700], p. 73.

Vieillard and Rassineux 1992 [DIRS 120508], Table 2, p. 130.

a Estimated from the anhydrous gehlenite phase. See text and Spreadsheet Solids_j_DJ_Cement CFJC fix.xIs (output DTN: SN0410T0510404.001).

${ }^{b}$ Value adopted in this study.

\subsubsection{Hydrotalcite $\left(4 \mathrm{MgO} \cdot \mathrm{Al}_{2} \mathrm{O}_{3} \cdot 10 \mathrm{H}_{2} \mathrm{O}\right)$}

Bennett et al. (1992 [DIRS 116990]) report an average log K value for hydrotalcite of 73.78 based on the following reaction:

$$
4 \mathrm{MgO} \cdot \mathrm{Al}_{2} \mathrm{O}_{3} \cdot 10 \mathrm{H}_{2} \mathrm{O}+14 \mathrm{H}^{+}=4 \mathrm{Mg}^{++}+2 \mathrm{Al}^{+++}+17 \mathrm{H}_{2} \mathrm{O}
$$

The $\log \mathrm{K}$ value for the above reaction was obtained from various solubility runs assuming congruent dissolution of the hydrotalcite phase. The distinct composition of this phase differs from hydrotalcites reported elsewhere. For this reason, obtaining corroborative thermodynamic data with the exact same composition is not possible at this point. Nevertheless, the solubility experiments of Bennett et al. (1992 [DIRS 116990]) were done on different runs and the solubility product obtained from solution composition yielded $\mathrm{K}$ (or $\mathrm{K}_{\mathrm{sp}}$ as identified in the source) values of 73.68 and 73.87. An average value of 73.78 was then selected for data0.ymp.R2 (DTN: MO0302SPATHDYN.000 [DIRS 161756]). The authors have published numerous articles (Glasser et al. 1987 [DIRS 118111]; Atkins et al. 1991 [DIRS 116979]; Atkins et al. 1992 [DIRS 100700]; Atkins et al. 1993 [DIRS 131758]; Damidot et al. 1994 [DIRS 144866]) on the thermodynamic properties of several cement phases and this establishes confidence in the results obtained in this study. Moreover, similar $\mathrm{K}_{\mathrm{sp}}$ values were obtained from duplicate runs in their study strengthening the confidence in the experimental results.

\subsubsection{Monocarboaluminate $\left(3 \mathrm{CaO} \cdot \mathrm{Al}_{2} \mathrm{O}_{3} \cdot \mathrm{CaCO}_{3} \cdot 10 \mathrm{H}_{2} \mathrm{O}\right)$}

Damidot et al. (1994 [DIRS 144866], Appendix 1) report a log K value of 69.99 for monocarboaluminate that was derived from solubility data using PHRQPITZ (a Pitzer equation version of PHREEQC). This $\log \mathrm{K}$ was then recalculated for the following reaction:

$$
3 \mathrm{CaO} \cdot \mathrm{Al}_{2} \mathrm{O}_{3} \cdot \mathrm{CaCO}_{3} \cdot 10 \mathrm{H}_{2} \mathrm{O}+13 \mathrm{H}^{+}=4 \mathrm{Ca}^{++}+2 \mathrm{Al}^{+++}+\mathrm{HCO}_{3}^{-}+16 \mathrm{H}_{2} \mathrm{O}
$$


The recalculated $\log \mathrm{K}$ value (see final carboaluminate solubility_TJW_mod.xls in DTN: MO0302SPATHDYN.001 [DIRS 161886]) based on the solubility data using the Davies equation (Stumm and Morgan 1981 [DIRS 100829], Table 3.3) and approximating ionic strength using Eq. 2.69 in Garrels and Christ (1990 [DIRS 144877]) agrees within approximately two orders of magnitude with the value from Damidot et al. (1994 [DIRS 144866]). This value was then corrected for a basis species switch from $\mathrm{CO}_{3}{ }^{--}$to $\mathrm{HCO}_{3}{ }^{-}$to give the value of 77.3538 before being entered into its data block in data0.ymp.R2 (DTN: MO0302SPATHDYN.000 [DIRS 161756]).

No alternate solubility data for this phase has been found for corroborative purposes. However, Vieillard and Rassineux (1992 [DIRS 120508], Table 2, p. 130) report an estimated value of $\Delta \mathrm{G}_{f}^{\circ}$ at $25^{\circ} \mathrm{C}$ for the $\mathrm{Ca}$-carboaluminate phase with the stoichiometry $3 \mathrm{CaO} \cdot \mathrm{Al}_{2} \mathrm{O}_{3} \cdot \mathrm{CaCO}_{3} \cdot 12 \mathrm{H}_{2} \mathrm{O}$. This value of $\Delta \mathrm{G}_{f}^{\circ}$ is $-7598.1 \mathrm{~kJ} / \mathrm{mol}$. This stoichiometry has two additional waters relative to that of Damidot et al. (1994 [DIRS 144866]) given in Eq. 6-30. Assuming an enthalpy of reaction equal to zero (i.e., $\Delta \mathrm{H}^{\circ}{ }_{r}=0$ ) and substracting the $\Delta \mathrm{G}^{\circ}{ }_{f}$ for two moles of $\mathrm{H}_{2} \mathrm{O}$ (i.e., $-474.363 \mathrm{~kJ} / \mathrm{mol}$ ) from the $\Delta \mathrm{G}_{f}^{\circ}$ given by Vieillard and Rassineux (1992 [DIRS 120508]) yields a value of $-7123.737 \mathrm{~kJ} / \mathrm{mol}$. The $\Delta \mathrm{G}_{f}^{\circ}$ value for the monocarboaluminate phase of Damidot et al. (1994 [DIRS 144866]) obtained from the recalculated $\log \mathrm{K}$ of reaction (77.3538) of Eq. 6-30 and $\Delta \mathrm{G}_{f}^{\circ}$ data for the aqueous species and $\mathrm{H}_{2} \mathrm{O}$ from data0.ymp.R0 (DTN: MO0009THRMODYN.001 [DIRS 152576]) is $-7118.885 \mathrm{~kJ} / \mathrm{mol}$. The difference between the two values is approximately $4.85 \mathrm{~kJ} / \mathrm{mol}$, which is well within the uncertainty of the experiments of Damidot et al. (1994 [DIRS 144866]) and the thermodynamic estimations of Vieillard and Rassineux (1992 [DIRS 120508]). Even though the experimental solubility data is unique, the results of the above data corroboration with all the considered assumptions qualifies the data for use in YMP. Also, the numerous contributions made by the authors in the field of experimental cement solubility further establish confidence in the data. As with other cement phases, these data are subject to large uncertainties due to limitations in the attainment of equilibrium and plausible co-existence with other cement phases (not present in the equilibrium reaction above) during the experiments.

\subsubsection{Hemicarboaluminate $\left(3 \mathrm{CaO} \bullet \mathrm{Al}_{2} \mathrm{O}_{3} \bullet 0.5 \mathrm{CaCO}_{3} \bullet 0.5 \mathrm{Ca}(\mathrm{OH})_{2} \bullet 10.5 \mathrm{H}_{2} \mathrm{O}\right)$}

Damidot et al. (1994 [DIRS 144866], Appendix 1) report a $\log \mathrm{K}$ value of 85.738 for hemicarboaluminate that was derived from solubility data using PHRQPITZ. This $\log \mathrm{K}$ is then corrected for the following reaction:

$$
\begin{gathered}
3 \mathrm{CaO} \cdot \mathrm{Al}_{2} \mathrm{O}_{3} \bullet 0.5 \mathrm{CaCO}_{3} \bullet 0.5 \mathrm{Ca}(\mathrm{OH})_{2} \bullet 10.5 \mathrm{H}_{2} \mathrm{O}+13.5 \mathrm{H}^{+}= \\
4 \mathrm{Ca}^{++}+2 \mathrm{Al}^{+++}+0.5 \mathrm{HCO}_{3}{ }^{-}+17.5 \mathrm{H}_{2} \mathrm{O}
\end{gathered}
$$

The recalculated $\log \mathrm{K}$ value (see final carboaluminate solubility.xls in DTN: MO0302SPATHDYN.001 [DIRS 161886]) based on the solubility data using the Davies equation (Stumm and Morgan 1981 [DIRS 100829], Table 3.3) and approximating ionic strength using equation 2.69 in Garrels and Christ (1990 [DIRS 144877]) agrees within approximately two orders of magnitude with the value from Damidot et al. (1994 [DIRS 144866]). This value was then corrected for a basis species switch from $\mathrm{CO}_{3}{ }^{--}$to $\mathrm{HCO}_{3}{ }^{-}$to give the value of 88.3235 before being entered into its data block in data0.ymp.R2 (DTN: MO0302SPATHDYN.000 [DIRS 161756]). 
No alternate solubility data for this phase has been found for corroborative purposes. However, Vieillard and Rassineux (1992 [DIRS 120508], Table 2, p. 130) report an estimate if $\Delta \mathrm{G}_{f}^{\circ}$ for Ca-carboaluminate phase with the stoichiometry $3 \mathrm{CaO} \cdot \mathrm{Al}_{2} \mathrm{O}_{3} \cdot \mathrm{CaCO}_{3} \cdot 12 \mathrm{H}_{2} \mathrm{O}$ with a value of $\Delta \mathrm{G}^{\circ}$ is $-7598.1 \mathrm{~kJ} / \mathrm{mol}$. Assuming an enthalpy of reaction equal to zero (i.e., $\Delta \mathrm{H}^{\circ}{ }_{r}=0$ ), the $\Delta \mathrm{G}_{f}^{\circ}$ of the hemicarboaluminate phase can be approximated by the following reaction:

$3 \mathrm{CaO} \cdot \mathrm{Al}_{2} \mathrm{O}_{3} \cdot 0.5 \mathrm{CaCO}_{3} \cdot 0.5 \mathrm{Ca}(\mathrm{OH})_{2} \cdot 10.5 \mathrm{H}_{2} \mathrm{O}=$

$$
3 \mathrm{CaO} \cdot \mathrm{Al}_{2} \mathrm{O}_{3} \cdot \mathrm{CaCO}_{3} \cdot 12 \mathrm{H}_{2} \mathrm{O}+0.5 \mathrm{Ca}(\mathrm{OH})_{2}-0.5 \mathrm{CaCO}_{3}-1.5 \mathrm{H}_{2} \mathrm{O}
$$

Using the $\Delta \mathrm{G}_{f}^{\circ}$ data reported by Vieillard and Rassineux (1992 [DIRS 120508], Table 2, p. 130) for $3 \mathrm{CaO} \cdot \mathrm{Al}_{2} \mathrm{O}_{3} \cdot \mathrm{CaCO}_{3} \cdot 12 \mathrm{H}_{2} \mathrm{O}(-7598.1 \mathrm{~kJ} / \mathrm{mol}), \mathrm{Ca}(\mathrm{OH})_{2}(-898.49 \mathrm{~kJ} / \mathrm{mol})$, and $\mathrm{CaCO}_{3}$ $(-1128.76 \mathrm{~kJ} / \mathrm{mol})$ plus that of $\mathrm{H}_{2} \mathrm{O} \quad(-237.181 \mathrm{~kJ} / \mathrm{mol})$ from data0.ymp.R0 (DTN: MO0009THRMODYN.001 [DIRS 152576]), the resulting $\Delta \mathrm{G}_{f}^{\circ}$ at $25^{\circ} \mathrm{C}$ of the hemicarboaluminate phase obtained using the relation given by Eq. 6-32 yields a value of $-7127.193 \mathrm{~kJ} / \mathrm{mol}$. The values for the phases $\mathrm{CaCO}_{3}$ (calcite) and $\mathrm{Ca}(\mathrm{OH})_{2}$ (portlandite) are almost identical to those in data0.ymp.R0 (DTN: MO0009THRMODYN.001 [DIRS 152576]). The $\Delta \mathrm{G}_{f}^{\circ}$ obtained from the data by Damidot et al. (1994 [DIRS 144866]) using the recalculated $\log \mathrm{K}$ value (88.3235) given above and $\Delta \mathrm{G}^{\circ}$ data for the aqueous species and $\mathrm{H}_{2} \mathrm{O}$ from data0.ymp.R0 (DTN: MO0009THRMODYN.001 [DIRS 152576]) is $-7152.82 \mathrm{~kJ} / \mathrm{mol}$. The difference between the two estimated $\Delta \mathrm{G}^{\circ}{ }_{f}$ values is approximately $26 \mathrm{~kJ} / \mathrm{mol}$, which is within the uncertainty of the experiments of Damidot et al. (1994 [DIRS 144866]) and the thermodynamic estimations of Vieillard and Rassineux (1992 [DIRS 120508]) plus all the assumptions considered in this analysis. Even though the solubility data of Damidot et al. (1994 [DIRS 144866]) is unique, the results obtained using the above relation and data corroboration qualifies the data for use in YMP. Also, the numerous contributions made by the authors in the field of experimental cement solubility further establish confidence in the data. As with other cement phases, these data are subject to large uncertainties due to limitations in the attainment of equilibrium and plausible co-existence with other cement phases (not present in the equilibrium reaction above) during the experiments.

\subsubsection{Syngenite $\left(\mathrm{K}_{2} \mathrm{Ca}\left(\mathrm{SO}_{4}\right)_{2} \cdot \mathrm{H}_{2} \mathrm{O}\right)$}

A $\log \mathrm{K}$ value of -7.6 for the dissolution of syngenite for the following reaction in data0.ymp.R2 (DTN: MO0302SPATHDYN.000 [DIRS 161756]) was obtained from Harvie et al. (1984 [DIRS 118163]).

$$
\mathrm{K}_{2} \mathrm{Ca}(\mathrm{SO} 4)_{2} \cdot \mathrm{H}_{2} \mathrm{O}=\mathrm{Ca}^{++}+2 \mathrm{~K}^{+}+2 \mathrm{SO}_{4}{ }^{--}+\mathrm{H}_{2} \mathrm{O}
$$

However, the $\log \mathrm{K}$ value given above cannot be duplicated using the available data given in Harvie et al. (1984 [DIRS 118163]) and no documentation on how it was estimated is available. The recalculated value using the data of Harvie et al. (1984 [DIRS 118163]) yields a log K at $25^{\circ} \mathrm{C}$ of -7.45 ; different from the one present in data0.ymp.R2 (DTN: MO0302SPATHDYN.000 [DIRS 161756]) (see Table 6-25). It was decided to update this value with a more recent set of data up to elevated temperatures given by Greenberg and Moller (1989 [DIRS 152684]) from the qualified Pitzer thermodynamic database data0.ypf (DTN: SN0302T0510102.002 [DIRS 162572]). The updated value of -7.4484 will replace the 
current one in the updated output database data0.ymp.R4 (output DTN: SN0410T0510404.002). The difference in $\log \mathrm{K}$ at $25^{\circ} \mathrm{C}$ between both values is relatively small (approximately $0.15 \log$ units), therefore the resulting impact of this difference is expected to be minimal considering that syngenite is a fairly soluble phase.

\subsubsection{Uncertainty in Data for Cement Mineral Phases}

The uncertainty evaluations in this section are not intended to be an exhaustive representation of all data reported. However, the data presented below represent the types of errors reported in the literature. Various reasons exist for the variation in data. They include charge imbalance in reported compositions of aqueous solutions, incongruency of dissolution, lack of complete data sets, minimal data points, and temperature dependency of dissolution to name a few. The following sections discuss two of the major sources of uncertainty inherent in geochemical modeling (experimental or analytical uncertainty and differences in results reported by different investigators).

\subsection{Uncertainty in CSH Values}

For uncertainty evaluations based on the solid solution behavior or incongruent dissolution of CSH, the information in Glasser et al. (1987 [DIRS 118111], Table I) can be used. The range in $\log \mathrm{K}$ data reported in Glasser et al. (1987 [DIRS 118111], Table I) for the Fujii and Kondo (1981 [DIRS 158026]) data is from -16.09 to -26.17 , (10.08 log units) and for the Greenberg and Chang (1965 [DIRS 144989]) data, from -15.01 to -24.34 (9.33 log units) across $\mathrm{Ca} / \mathrm{Si}$ ratios of 0.76 to 1.83 .

For uncertainty based on experimental and literature error, an evaluation was done using Table I in Glasser et al. (1987 [DIRS 118111]). The log K data in Glasser et al. (1987 [DIRS 118111]) was converted to $\log$ units. For the data with the Ca/Si ratio of 1.2 (labeled "Suzuki et al. [27]" in that table), the uncertainty in $\log \mathrm{K}$ varies from -18.82 to -21.42 or about $2.61 \log$ units. This would represent an approximate experimental error (95 percent confidence interval) in $\log \mathrm{K}$ of $\pm 1.31 \log$ units. The differences in $\log \mathrm{K}$ from alternative literature sources from Table $\mathrm{I}$ in Glasser et al. (1987 [DIRS 118111]) for all the data at or near a Ca/Si ratio of 1.2 (three separate data sets with $\mathrm{Ca} / \mathrm{Si}$ ratios ranging from 1.17 to 1.25 ) gives the same range in variability in $\log \mathrm{K}$ as for the single data set of $\mathrm{Ca} / \mathrm{Si}$ ratio of 1.2 .

\subsection{Uncertainty in Ettringite Values}

Perkins and Palmer (1999 [DIRS 152703], Table 1) provide an excellent compilation of literature sources for $\log \mathrm{K}$ data at $25^{\circ} \mathrm{C}$ as well as the ranges in experimental error reported in several of the sources. The tabulated literature sources identify a 10-unit range in reported values for the $\log \mathrm{K}$ for ettringite. The maximum experimental error reported by the sources is much smaller. For studies with charge balance errors $<10 \%$, the uncertainty is about $\pm 0.6 \log$ units (one standard deviation). Using two standard deviations or $\pm 1.2 \log$ units would represent an approximate 95 percent confidence interval. 


\subsection{Uncertainty in Hydrogarnet Values}

Neall (1994 [DIRS 100807], Table C-3) evaluated both experimental and literature uncertainty for hydrogarnet $\log \mathrm{K}$ values from six different studies. The minimum and maximum values reported in the literature are -86.6 and -89.8 , respectively. These values give an uncertainty range of $3.2 \log$ units.

The experimental or analytical error $(2 \sigma)$ on the mean of the six unbalanced $\log \mathrm{K}$ values reported in Table C-2 of Neall (1994 [DIRS 100807]) is \pm 1.85 log units.

\subsubsection{Evaluation and Qualification of Thermodynamic Data for Other Solids}

As described in Section 4.1.7, the uranyl phases to be evaluated in data0.ymp.R2 (DTN: MO0302SPATHDYN.000 [DIRS 161756]) are soddyite, uranophane, Na-weeksite, and Na-boltwoodite. The $\log \mathrm{K}$ values given by the sources (some adjusted for changes in the mineral formulae) were used to calculate the $\Delta \mathrm{G}_{\mathrm{r}}^{\circ}$ (standard Gibbs free energy of reaction), which was then used to calculate the $\Delta \mathrm{G}_{\mathrm{f}}^{\circ}$ (standard Gibbs free energy of formation). The $\Delta \mathrm{G}_{\mathrm{f}}^{\circ}$ was then used to calculate the temperature dependent $\log \mathrm{K}$ values used in the database (calculations in Spreadsheet Usilicates_yc_tls_ch.xls; DTN: MO0302SPATHDYN.001 [DIRS 161886]). Extrapolation of $\Delta \mathrm{G}^{0}$ and thus $\log \mathrm{K}$ values to temperatures other than $25^{\circ} \mathrm{C}$ was done using the heat capacity estimation method used by Helgeson et al. (1978 [DIRS 101596]) and Section 6.1.4.1.

\subsubsection{Soddyite $\left(\left(\mathrm{UO}_{2}\right)_{2} \mathrm{SiO}_{4} \cdot 2 \mathrm{H}_{2} \mathrm{O}\right)$}

There have been several soddyite solubility studies. The Gibbs free energy of formation of soddyite was reported for a study by Nguyen et al. (1992 [DIRS 100809]) in which synthesized soddyite was used to measure solubilities at $30^{\circ} \mathrm{C}$. Since equilibrium was approached from undersaturation, the value reported in Nguyen et al. (1992 [DIRS 100809]) for soddyite should be considered as its lower solubility limit (Murphy and Pabalan 1995 [DIRS 144449]) (Table 6-31).

Table 6-31. Sources of Soddyite Thermodynamic Data

\begin{tabular}{|l|l|l|l|}
\hline \multicolumn{1}{|c|}{ Source } & \multicolumn{1}{|c|}{ Data Extracted } & \multicolumn{1}{c|}{ Value } & \multicolumn{1}{c|}{ Use } \\
\hline $\begin{array}{l}\text { Nguyen et al. 1992 } \\
\text { [DIRS 100809] }\end{array}$ & $\log \mathrm{K}\left(25^{\circ} \mathrm{C}\right)$ & $5.74 \pm 0.21$ & Corroborative data \\
\hline Moll et al. 1996 [DIRS 106349] & $\begin{array}{l}\log \mathrm{K}\left(\mathrm{N}_{2} \text { atmosphere }\right. \\
\text { experiments at 25 } \mathrm{C})\end{array}$ & $6.03 \pm 0.45$ & $\begin{array}{l}\text { Inclusion in data0.ymp.R2 } \\
\text { (DTN: MO0302SPATHDYN. } \\
\text { 000 [DIRS 161756]) }\end{array}$ \\
\hline Moll et al. 1996 [DIRS 106349] & $\Delta \mathrm{G}^{\circ}$ & $-3654.41 \mathrm{~kJ} / \mathrm{mol}$ & $\begin{array}{l}\text { Inclusion in data0.ymp.R2 } \\
\text { (DTN: MO0302SPATHDYN. } \\
\text { 000 [DIRS 161756]) }\end{array}$ \\
\hline $\begin{array}{l}\text { Chen et al. 1999 [DIRS 123270], } \\
\text { Table 9, p. 658 }\end{array}$ & $\Delta \mathrm{G}^{\circ}{ }_{f}$ (predicted) & $-3653.0 \mathrm{~kJ} / \mathrm{mol}$ & Corroborative data \\
\hline $\begin{array}{l}\text { Chen et al. 1999 [DIRS 123270], } \\
\text { Table 5, p. 657 }\end{array}$ & $\Delta \mathrm{G}^{\circ}{ }_{f}$ (measured) & $-3652.8 \mathrm{~kJ} / \mathrm{mol}$ & Corroborative data \\
\hline
\end{tabular}


Table 6-31. Sources of Soddyite Thermodynamic Data (Continued)

\begin{tabular}{|l|l|l|l|}
\hline $\begin{array}{l}\text { Finch 1997 [DIRS 106347], } \\
\text { Table II, p. 1187; Nguyen et al. } \\
1992 \text { [DIRS 100809] }\end{array}$ & $\Delta \mathrm{G}^{\circ}{ }_{f}$ & $-3658.0 \mathrm{~kJ} / \mathrm{mol}$ & Corroborative data \\
\hline $\begin{array}{l}\text { McKenzie et al. 2001 } \\
\text { [DIRS 172346], Table 1, p. } 303\end{array}$ & $\Delta \mathrm{G}^{\circ}{ }_{f}$ & $-3671 \mathrm{~kJ} / \mathrm{mol}$ & Corroborative data \\
\hline
\end{tabular}

* As calculated in Spreadsheet Usilicates_yc_tls_ch.xIs (DTN: MO0302SPATHDYN.001 [DIRS 161886]), with unit conversion from cal $/ \mathrm{mol}$.

Casas et al. (1994 [DIRS 100714]) reported their experimental study on the kinetics and thermodynamics of several uranium minerals. The solids used in their experiments are naturally occurring minerals, and chemical purity was not assured because of the existence of microscopic inclusions. The authors believe that soddyite formed as a secondary mineral during the process of uranophane dissolution and that soddyite was the $U$ solubility-controlling phase. A solubility product constant for soddyite was given based on this experiment. However, this result is considered to be unreliable for several reasons as pointed out in Murphy and Pabalan (1995 [DIRS 144449]). The main reason is that the mineral of interest, soddyite, was a secondary phase of uranophane dissolution. Thus, this experiment was not a solubility experiment for soddyite per se, but rather, the solubility of soddyite was estimated from an experiment controlled by uranophane dissolution.

Moll et al. (1996 [DIRS 106349]) reported results from experiments at $25^{\circ} \mathrm{C}$ using synthesized soddyite. The $\mathrm{pH}$ in these experiments ranged from 3 to 9 . Equilibrium was approached from undersaturation. The experiments were conducted in both ambient laboratory air conditions and under controlled $\mathrm{N}_{2}$ atmosphere. The derived $\log \mathrm{K}$ values at infinite dilution are $6.15 \pm 0.53$ and $6.03 \pm 0.45$, respectively. Those results are relatively close to the value $(5.74 \pm 0.21)$ reported in Nguyen et al. (1992 [DIRS 100809]). The value obtained from $\mathrm{N}_{2}$ atmosphere experiments was selected for data0.ymp.R2 (DTN: MO0302SPATHDYN.000 [DIRS 161756]), as it seems the $\mathrm{N}_{2}$ atmosphere experiments might be better controlled (as shown in Figure 2 of Moll et al. 1996 [DIRS 106349]: the results in the $\mathrm{N}_{2}$ atmosphere have far less irregularities than those obtained in air). The two values agree within the uncertainty range, and thus the difference between them is insignificant. To further establish confidence in this value, comparison of Gibbs free energy estimates from the empirical method used by Chen et al. (1999 [DIRS 123270], Tables 2, 5, and 9, pp. 654, 657, and 658, respectively) were compared to that extracted in this report. The value extracted using the $\log \mathrm{K}(6.03 \pm 0.45)$ given above is $-873425.6 \mathrm{cal} / \mathrm{mol}$ or $-3654.41 \mathrm{~kJ} / \mathrm{mol}$. The predicted value tabulated by Chen et al. (1999 [DIRS 123270], Table 9, p. 658) is $-3653.0 \mathrm{~kJ} / \mathrm{mol}$. The "measured" value tabulated by Chen et al. (1999 [DIRS 123270], Table 5, p. 657) is $-3652.8 \mathrm{~kJ} / \mathrm{mol}$. These values given by Chen et al. (1999 [DIRS 123270]) are in strong agreement with that estimated using the log K value of Moll et al. (1996 [DIRS 106349]). This value is also in good agreement with that reported by Finch (1997) [DIRS 106347]) and Nguyen et al. (1992 [DIRS 100809]) of $-3658.0 \mathrm{~kJ} / \mathrm{mol}$. Furthermore, an intermediate value (within a range of proposed $\Delta \mathrm{G}^{\circ}{ }_{f}$ values) of $-3671 \mathrm{~kJ} / \mathrm{mol}$ was estimated by the thermodynamic analysis for uranyl silicates. For these reasons, the Moll et al. (1996 [DIRS 106349]) data (Table 6-31) selected for use in this section are qualified for inclusion in the database by technical assessment and corroborative data. 
There is a consistent discrepancy between data0.ymp.R2 (DTN: MO0302SPATHDYN.000 [DIRS 161756]) and the source Spreadsheet Minerals_cal_YC_Usilicates.xls (DTN: MO0302SPATHDYN.001 [DIRS 161886]) for extrapolation of all $\log$ K values for soddyite to temperatures other than $25^{\circ} \mathrm{C}$. The heat capacity coefficient data are estimated using the method of Helgeson et al. (1978 [DIRS 101596]) described in Section 6.1.4.1. These heat capacity data along with $S^{\circ}$ values are computed in Spreadsheet Usilicates_yc_tls_ch.xls (DTN: MO0302SPATHDYN.001 [DIRS 161886]). This latter spreadsheet feeds data to Spreadsheet Minerals_cal_YC_Usilicates.xls to calculate the extrapolated $\log \mathrm{K}$ values. A transcription error in the $\mathrm{S}^{\circ}$ value for soddyite was identified in Spreadsheet Minerals_cal_YC_Usilicates.xls by comparison to the other source Spreadsheet Usilicates_yc_tls_ch.xls. Once the correct $\mathrm{S}^{\circ}$ given by this spreadsheet is used, the $\log \mathrm{K}$ values computed in the spreadsheet match those in data0.ymp.R2. Therefore the values in R2 are correct and are consistent with the heat capacity and standard entropy values given in Spreadsheet Usilicates_yc_tls_ch.xls.

\subsubsection{Uranophane $\left(\mathrm{Ca}\left(\mathrm{UO}_{2}\right)_{2}\left(\mathrm{SiO}_{3} \mathrm{OH}\right)_{2} \cdot 5 \mathrm{H}_{2} \mathrm{O}\right)$}

Table 6-32 lists the source of the uranophane thermodynamic data used for data0.ymp.R2 (DTN: MO0302SPATHDYN.000 [DIRS 161756]), and also other solubility studies, the results of which will be used as corroborative data.

Table 6-32. Sources of Uranophane Thermodynamic Data

\begin{tabular}{|l|l|l|l|}
\hline \multicolumn{1}{|c|}{ Source } & \multicolumn{1}{c|}{ Data Extracted } & \multicolumn{1}{c|}{ Value } & \multicolumn{1}{c|}{ Use } \\
\hline $\begin{array}{l}\text { Pérez et al. 2000 [DIRS 157910], } \\
\text { p. 606 }\end{array}$ & Log $\mathrm{K}\left(25^{\circ} \mathrm{C}\right)$ & $11.7 \pm 0.6$ & $\begin{array}{l}\text { Inclusion in data0.ymp.R2 } \\
\text { (DTN: MO0302SPATHDYN.000 } \\
\text { [DIRS 161756]) }\end{array}$ \\
\hline $\begin{array}{l}\text { Pérez et al. 2000 [DIRS 157910], } \\
\text { p. 606 }\end{array}$ & $\Delta \mathrm{G}^{\circ}$ & $-6195.6 \mathrm{~kJ} / \mathrm{mol}^{*}$ & $\begin{array}{l}\text { Inclusion in data0.ymp.R2 } \\
\text { (DTN: MO0302SPATHDYN.000 } \\
\text { [DIRS 161756]) }\end{array}$ \\
\hline $\begin{array}{l}\text { Chen et al. 1999 [DIRS 123270], } \\
\text { Table 5, p. 657 }\end{array}$ & $\Delta \mathrm{G}^{\circ}{ }_{f}$ (measured) & $-6192.3 \mathrm{~kJ} / \mathrm{mol}$ & Corroborative data \\
\hline $\begin{array}{l}\text { Chen et al. 1999 [DIRS 123270], } \\
\text { Table 5, p. 657 }\end{array}$ & $\Delta \mathrm{G}^{\circ}{ }_{f}$ (predicted) & $-6189.2 \mathrm{~kJ} / \mathrm{mol}$ & Corroborative data \\
\hline $\begin{array}{l}\text { Finch 1997 [DIRS 106347], Table II, } \\
\text { p. 1187; Nguyen et al. 1992 } \\
\text { [DIRS 100809] }\end{array}$ & $\Delta \mathrm{G}^{\circ}{ }_{f}$ & $-6210.6 \mathrm{~kJ} / \mathrm{mol}$ & Corroborative data \\
\hline $\begin{array}{l}\text { McKenzie et al. 2001 [DIRS 172346], } \\
\text { Table 1, p. 303 }\end{array}$ & $\Delta \mathrm{G}^{\circ}{ }_{f}$ & $-6213 \mathrm{~kJ} / \mathrm{mol}$ & Corroborative data \\
\hline
\end{tabular}

* Value shown is calculated using input from Perez et al. (2000 [DIRS 157910]), in Spreadsheet Usilicates_yc_tls_ch.xIs (DTN: MO0302SPATHDYN.000 [DIRS 161886]), with unit conversion from cal/mol.

There have been several solubility studies conducted for uranophane. The Gibbs free energy of formation of uranophane has been reported in Nguyen et al. (1992 [DIRS 100809]) in which synthesized uranophane was used to conduct a solubility study at $30^{\circ} \mathrm{C}$. A $\log \mathrm{K}$ of $9.42( \pm 0.48)$ was derived from experimental measurements. Since equilibrium was approached from undersaturation, the data reported in Nguyen et al. (1992 [DIRS 100809]) for uranophane should be considered as the lower solubility limit (Murphy and Pabalan 1995 [DIRS 144449]). 
Moreover, it was suspected that a secondary silica phase (e.g., amorphous silica) precipitated during the experiments (Murphy and Pabalan 1995 [DIRS 144449]).

Casas et al. (1994 [DIRS 100714]) reported their experimental study on the kinetics and thermodynamics of several uranium minerals, including uranophane. The solids used in their experiments are naturally occurring minerals, and chemical purity was not assured because of the existence of microscopic inclusions. Moreover, soddyite precipitation was observed in their uranophane solubility experiments. These observations can exert limitations in the use of their data to extract thermodynamic parameters for the single phase of interest.

Pérez et al. (2000 [DIRS 157910]) published their experimental study on uranophane dissolution thermodynamics and kinetics in bicarbonate solution in the respected peer-reviewed journal Geochimica et Cosmochimica Acta, though the results had been reported previously in a technical report (Casas et al. 1997 [DIRS 102432]). The starting material for this study at $25^{\circ} \mathrm{C}$ is synthesized uranophane. Their average measured $\log \mathrm{K}$ value at infinite dilution is 11.7 ( \pm 0.6$)$. Pérez et al. (2000 [DIRS 157910]) also compared the Gibbs free energies of formation $\left(\Delta \mathrm{G}_{f}^{\circ}\right)$ calculated from their estimated solubility constant (log $\left.\mathrm{K}=11.7\right)$ obtaining a value of $-6192.3 \mathrm{~kJ} / \mathrm{mol}$ ). The recalculated value for Gibbs free energy based on input from Perez et al. (2000 [DIRS 157910]), and thermodynamic data from data0.ymp.R2, is $-6195.6 \mathrm{~kJ} / \mathrm{mol}$ (DTN: MO0302SPATHDYN.000 [DIRS 161886], Spreadsheet Usilicates_yc_tls_ch.xls). These values are in very good agreement with that "predicted" by Chen et al. (1999 [DIRS 123270], Table 9, p. 658) of $-6189.2 \mathrm{~kJ} / \mathrm{mol}$ and the "measured" value of $-6192.3 \mathrm{~kJ} / \mathrm{mol}$ in the same source (Chen et al. 1999 [DIRS 123270], Table 5, p. 657). The Gibbs free energy of formation value obtained from Pérez et al. (2000 [DIRS 157910]) in this study is also in overall agreement with that of Nguyen et al. (1992 [DIRS 100809]) (and reported later by Finch (1997 [DIRS 106347]) of $-6210.6 \mathrm{~kJ} / \mathrm{mol}$ even with some of the limitations in the thermodynamic estimations using Nguyen et al. (1992 [DIRS 100809]) data. The thermodynamic evaluation of McKenzie et al. (2001 [DIRS 172346]) recommended a $\Delta \mathrm{G}_{f}^{\circ}$ value of $-6213 \mathrm{~kJ} / \mathrm{mol}$, which is also in overall agreement with that adopted in this study. Based on all these data comparisons, the Perez et al. (2000 [DIRS 157910]) data selected for use in this section are qualified for inclusion in the database by data corroboration.

There is a consistent discrepancy between data0.ymp.R2 (DTN: MO0302SPATHDYN.000 [DIRS 161756]) and the source Spreadsheet Minerals_cal_YC_Usilicates.xls (DTN: MO0302SPATHDYN.001 [DIRS 161886]) for extrapolation of all $\log \mathrm{K}$ values for uranophane to temperatures other than $25^{\circ} \mathrm{C}$. The heat capacity coefficient data are estimated using the method of Helgeson et al. (1978 [DIRS 101596]) described in Section 6.1.4.1. These heat capacity coefficient data along with $\mathrm{S}^{\circ}$ values are computed in the Spreadsheet Usilicates_yc_tls_ch.xls (MO0302SPATHDYN.001 [DIRS 161886]). This latter spreadsheet feeds data to Spreadsheet Minerals_cal_YC_Usilicates.xls to calculate the extrapolated $\log \mathrm{K}$ values. A transcription error for the $S^{\circ}$ value for uranophane was identified in Spreadsheet Minerals_cal_YC_Usilicates.xls by comparison to the other source Spreadsheet Usilicates_yc_tls_ch.xls. When the correct $\mathrm{S}^{\circ}$ value given by this spreadsheet is used, the $\log \mathrm{K}$ values computed in the spreadsheet match those in data0.ymp.R2. Therefore the values in R2 are correct and are consistent with the heat capacity and standard entropy values given in Spreadsheet Usilicates_yc_tls_ch.xls. 


\subsubsection{Sodium Weeksite $\left(\mathrm{Na}_{2}\left(\mathrm{UO}_{2}\right)_{2}\left(\mathrm{Si}_{5} \mathrm{O}_{13}\right) \cdot 3 \mathrm{H}_{2} \mathrm{O}\right)$}

The reported $\log \mathrm{K}$ at $30^{\circ} \mathrm{C}$ by Nguyen et al. (1992 [DIRS 100809]) is $1.50 \pm 0.08$ for a formula of $\mathrm{Na}_{2}\left(\mathrm{UO}_{2}\right)_{2}\left(\mathrm{Si}_{2} \mathrm{O}_{5}\right)_{3} \cdot 4 \mathrm{H}_{2} \mathrm{O}$. Chen et al. (1999 [DIRS 106346]) suggest that a different formula $\left(\mathrm{Na}_{2}\left(\mathrm{UO}_{2}\right)_{2}\left(\mathrm{Si}_{5} \mathrm{O}_{13}\right) \cdot 3 \mathrm{H}_{2} \mathrm{O}\right)$ be used for sodium weeksite (see Appendix 1 in Chen et al. (1999 [DIRS 106346], p. 66). With this formula, the $\log \mathrm{K}$ value was rederived from the original experimental data reported in Nguyen et al. (1992 [DIRS 100809]), as 3.97 (at $30^{\circ} \mathrm{C}$ ) (see Spreadsheet Minerals_cal_YC_Usilicates.xls; DTN: MO0302SPATHDYN.001 [DIRS 161886]). The extracted Gibbs free energy of formation at $25^{\circ} \mathrm{C}$ from this $\log \mathrm{K}$ value given in this spreadsheet is $-1912843.6 \mathrm{cal} / \mathrm{mol}$ or $-8003.34 \mathrm{~kJ} / \mathrm{mol}$. The latter value is in strong agreement with that predicted by Chen et al. (1999 [DIRS 123270], Table 5, p. 657) of $-8001.8 \mathrm{~kJ} / \mathrm{mol}$. The relatively small difference in the Gibbs free energies of formation between these two, which is much smaller than the Gibbs free energy of formation of one mole of $\mathrm{H}_{2} \mathrm{O}$, justifies the use of the stoichiometry proposed by Chen et al. (1999 [DIRS 123270]). Therefore, the $\log \mathrm{K}$ value is used in data0.ymp.R2 (DTN: MO0302SPATHDYN.000 [DIRS 161756]). The data selected for use in this section are qualified for inclusion in the database by data corroboration.

There is a discrepancy between data0.ymp.R2 (DTN: MO0302SPATHDYN.000 [DIRS 161756]) and the source Spreadsheet Minerals_cal_YC_Usilicates.xls (DTN: MO0302SPATHDYN.001 [DIRS 161886]) for $\log \mathrm{K}$ values for Na-weeksite. A transcription error in the $\mathrm{S}^{\circ}$ value, similar to that identified for soddyite and uranophane, was identified for this phase as well. However, after correcting this value the discrepancy in the calculated $\log \mathrm{K}$ values still remains. The maximum difference between the corrected values and those in data0.ymp.R2 (DTN: MO0302SPATHDYN.000 [DIRS 161756]) is insignificant (approximately $0.003 \log \mathrm{K}$ units) and within the uncertainty in the $\log \mathrm{K}$ at $25^{\circ} \mathrm{C}$ given by the source $( \pm 0.08)$. Hence the values used in data0.ymp.R2 for Na-weeksite are qualified although the cause of the discrepancy cannot be determined (it may be related to extrapolation of $\log \mathrm{K}$ from $30^{\circ} \mathrm{C}$ to $25^{\circ} \mathrm{C}$ ).

\subsubsection{Sodium Boltwoodite $\left(\mathrm{Na}\left(\mathrm{UO}_{2}\right)\left(\mathrm{SiO}_{3}\right)(\mathrm{OH}) \cdot 1.5 \mathrm{H}_{2} \mathrm{O}\right)$}

The reported $\log \mathrm{K}$ value for this phase at $30^{\circ} \mathrm{C}$ by Nguyen et al. (1992 [DIRS 100809]) is $\geq 5.82 \pm 0.16$ for a formula of $\mathrm{Na}\left(\mathrm{H}_{3} \mathrm{O}\right)\left(\mathrm{UO}_{2}\right)\left(\mathrm{SiO}_{4}\right) \cdot \mathrm{H}_{2} \mathrm{O}$. Since soddyite was observed in this solubility experiment, the $\log \mathrm{K}$ value should be considered to be a minimum value. In a recent comprehensive study of boltwoodite, Burns (1998 [DIRS 127210]) recommended that a different formula $\left(\mathrm{Na}\left(\mathrm{UO}_{2}\right)\left(\mathrm{SiO}_{3}\right)(\mathrm{OH}) \cdot 1.5 \mathrm{H}_{2} \mathrm{O}\right)$ be adopted. With this formula, the $\log \mathrm{K}$ value was rederived from the original experimental data reported in Nguyen et al. (1992 [DIRS 100809]), extrapolated to infinite dilution, as $\geq 5.97$ at $25^{\circ} \mathrm{C}$ (no significant change in log $\mathrm{K}$ because of the different formula) (DTN: MO0302SPATHDYN.001 [DIRS 161886], Spreadsheet: Minerals_cal_YC_Usilicates.xls, Worksheet: Na-boltwoodite 30Cto25C). The extracted Gibbs free energy of formation based on this $\log \mathrm{K}$ value is $-2845.42 \mathrm{~kJ} / \mathrm{mol}$ (at $25^{\circ} \mathrm{C}$ ). The predicted value for Gibbs free energy of formation given by the empirical thermodynamic estimation of Chen et al. (1999 [DIRS 123270], Table 5, p. 657) is $-2838.9 \mathrm{~kJ} / \mathrm{mol}$ which is in strong agreement with that extracted from Nguyen et al. (1992 [DIRS 100809]) data and the analysis explained above. Moreover, McKenzie et al. (2001 [DIRS 172346]) recommended a 
value of $-2839 \mathrm{~kJ} / \mathrm{mol}$ based on their analysis of thermodynamic properties of uranyl silicates. The "measured" value of $-2844.8 \mathrm{~kJ} / \mathrm{mol}$ given by Chen et al. (1999 [DIRS 123270], Table 5, p. 657) (see also Appendix 1 in Chen et al. (1999 [DIRS 106346], p. 66)) is even closer to that determined from Nguyen et al. (1992 [DIRS 100809]) data. Therefore, this log $\mathrm{K}$ value is recommended for inclusion in the database. The data selected for use in this section are qualified for inclusion in the database by data corroboration.

There is a discrepancy between data0.ymp.R2 (DTN: MO0302SPATHDYN.000 [DIRS 161756]) and the source Spreadsheet Minerals_cal_YC_Usilicates.xls (DTN: MO0302SPATHDYN.001 [DIRS 161886]) for $\log \mathrm{K}$ values for Na-boltwoodite. A transcription error in the $\mathrm{S}^{\circ}$ value, similar to that identified for soddyite and uranophane, was identified for this phase as well. However, after correcting this value the discrepancy in the calculated $\log \mathrm{K}$ values still remains. The maximum difference between the corrected values and those in data0.ymp.R2 (DTN: MO0302SPATHDYN.000 [DIRS 161756]) is insignificant (approximately $0.007 \log \mathrm{K}$ units) and within the uncertainty in the $\log \mathrm{K}$ at $25^{\circ} \mathrm{C}$ given by the source $( \pm 0.16)$. Hence the values used in data0.ymp.R2 for Na-boltwoodite are qualified although the cause of the discrepancy cannot be determined (it may be related to extrapolation of $\log \mathrm{K}$ from $30^{\circ} \mathrm{C}$ to $25^{\circ} \mathrm{C}$ ).

\subsubsection{Qualified Equilibrium Constant Grids for Other Solid Phases from Compilations and Handbooks}

Large data sets were obtained from well known compilations that include the OECD/NEA Database (Lemire 2001 [DIRS 159027]) and the compilations in Binnewies and Milke (1999 [DIRS 158955]) and Barin and Platzki (1995 [DIRS 157865]). Binnewies and Milke (1999 [DIRS 158955]) is a recent comprehensive compilation of thermodynamic data that draws on six references, four of which are relevant to this effort. The six references draw on a large set of published and unpublished thermodynamic data, although those references are not listed in Binnewies and Milke (1999 [DIRS 158955]). Barin and Platzki (1995 [DIRS 157865]) is also a comprehensive compilation of thermodynamic data that includes extensive lists of references. The OECD/NEA has recently published the results of an extensive peer review of thermodynamic data for neptunium and plutonium (Lemire 2001 [DIRS 159027]). This panel gathered a wide range of peer review publications, government publications, and previous compilations of data. Using corroborating data, peer review, and technical assessment, details of which are documented in the published book, the panel of internationally recognized scientists reached consensus on the best available thermodynamic data for neptunium and plutonium. These handbooks were chosen because they are recent, comprehensive, unique, and generally accepted within the scientific community. Their data sources were reviewed and assessed (to varying degrees) with regard to data quality prior to publication. The data selected for inclusion in the data0.ymp.R2 database (DTN: MO0302SPATHDYN.000 [DIRS 161756]) were derived from these sources using the methods discussed in Section 6.1. Results are shown in Table 6-33.

In the current qualification stage of this database, transcription errors in the heat capacity coefficients were found for $\mathrm{Np}$ and $\mathrm{Pu}$ solids as obtained from Lemire (2001 [DIRS 159027]). Also, other transcription errors related to the "c" heat capacity coefficient for several solids species from Binnewies and Milke (1999 [DIRS 158955]) were found in the calculation spreadsheets. For all these solids, the problem stems from the incorrect scaling of heat capacity 
coefficients when implemented in the spreadsheets used in the development of the data0.ymp.R2 database (DTN: MO0302SPATHDYN.000 [DIRS 161756]). $\mathrm{Np}$ and $\mathrm{Pu}$ heat capacity coefficients were extracted from Tables 3.3 and 4.3 of Lemire (2001 [DIRS 159027]) to correspond with the parameters a, b, and $\mathrm{c}$ of the Maier-Kelly equation (Eq. 4-1). The problems with this approach are: 1) a difference by a factor of 1000 on the "b" parameter, 2) the "c" parameter was ignored in many cases, and 3) in a few cases the adopted coefficients were inappropriately applied as Maier-Kelly parameters. For the last case, the heat capacity equation used by Lemire (2001 [DIRS 159027]) contains the same terms as the Maier-Kelley equation but also has additional terms that are entirely different. Taking into account that if the only fitting terms used by Lemire (2001 [DIRS 159027]) match those of the Maier-Kelly equation (assuming the other terms are zero), then these are readily transferable to Eq. 4-1. Conversely, if more terms are used by Lemire (2001 [DIRS 159027]) that do not correspond to the Maier-Kelly equation, then a complete refitting of the data must be done since there is a break in correspondence between the usage of the two formulations.

In this case of inappropriate implementation of Maier-Kelley parameters (Item 3 above), only one $\mathrm{Np}$ and several $\mathrm{Pu}$ species were affected: $\mathrm{NpC}_{0.91}(\mathrm{cr}), \mathrm{Pu}_{2} \mathrm{C}_{3}(\mathrm{cr}), \mathrm{PuC}_{0.84}(\mathrm{cr}), \mathrm{PuOI}(\mathrm{cr})$, $\mathrm{PuOF}(\mathrm{cr})$, and $\mathrm{PuO}_{2}$ (cr). The effect of this error on these species is not quantitatively evaluated in this report, and the corrected $\log \mathrm{K}$ values listed in Table 6-34 are based on the assumption of a negligible effect on the computed heat capacity as a function of temperature. Accordingly, a reevaluation of these $\log \mathrm{K}$ values using the proper heat capacity function is recommended if $\log$ $\mathrm{K}$ values for temperatures other than $25^{\circ} \mathrm{C}$ are to be used.

For all these reasons, the $\log \mathrm{K}$ values extrapolated to temperatures other than $25^{\circ} \mathrm{C}$ are incorrect. In many cases, except for two exceptions, the maximum deviations in the $\log \mathrm{K}$ values are relatively small, generally less than $0.2 \log \mathrm{K}$ at $300^{\circ} \mathrm{C}$. There are two cases $\left(\mathrm{NpF}_{6}\right.$ and $\left.\mathrm{PuF}_{6}\right)$ in which the difference can be as large as $1 \log \mathrm{K}$ unit. These deviations increase with increasing temperature. Table 6-34 shows the affected $\mathrm{Np}$ and $\mathrm{Pu}$ solid phases with the corrected $\log \mathrm{K}$ values. Table 6-35 shows the difference in $\log \mathrm{K}$ as a function of temperature. Notice that in general, the maximum differences do not exceed a $\Delta \log \mathrm{K}$ of approximately 0.3 in the worst case. The corrected values can be located in the source Spreadsheets Minerals_j_PVB_Pu_CFJC_fix.xls and Minerals_j_PVB_Np_CFJC_fix.xls (output DTN: SN0410T0510404.001) and have been incorporated in data0.ymp.R4 (output DTN: SN0410T0510404.002).

Log K values for other solid species computed using thermodynamic data from Barin and Platzki (1995 [DIRS 157865]) and Binnewies and Milke (1999 [DIRS 158955]) are listed in Table 6-33. In revising the heat capacity coefficient data in Table 4-14, an error was identified corresponding to the correct scaling of the "c" coefficient for the solid species shown in Table 6-36. The scaling difference between source and adopted values in this work is by a factor of 10 . The corrected $\log \mathrm{K}$ values upon correction of this heat capacity term in the source spreadsheets are given in Table 6-37. The $\Delta \log \mathrm{K}$ (difference between incorrect and corrected values) values are given in Table 6-38. Notice in this table that the maximum difference is on the order of 0.1 to $0.6 \log \mathrm{K}$ units at $300^{\circ} \mathrm{C}$ which is considered insignificant given the inherent uncertainties in the source data. 
The combined use of different sets of thermodynamic could generate discrepancy between the retrieved thermodynamic parameters generated to this study (e.g., $\Delta \mathrm{G}_{\mathrm{f}}{ }^{\circ}$ and $\log \mathrm{K}$ ). In this report, two types of thermodynamic data $\left(\Delta \mathrm{G}_{\mathrm{f}}^{\circ}\right.$ and $\Delta \mathrm{H}_{\mathrm{f}}{ }^{\circ} ; \mathrm{S}^{\circ}$ and $\left.\mathrm{Cp}^{\circ}\right)$ from two different sources (Barin and Platzki 1995 [DIRS 157865], and Binnewies and Milke 1999 [DIRS 158955], respectively) were combined in the source spreadsheets. To anyone knowledgeable in the manipulation of thermodynamic parameters such mixing of data could translate into some level of inconsistency that could affect the resulting $\log \mathrm{K}$ value adopted in this report. That is, the retrieved $\log \mathrm{K}$ value as obtained using reference-state thermodynamic data from two different sources can have some level of discrepancy due to differences in the standard-state thermodynamic data adopted by each source. In the case of the affected solid species given in Table 6-39, the $\Delta \mathrm{G}_{\mathrm{f}}{ }^{\circ}$ values were obtained from Barin and Platzki (1995 [DIRS 157865]) and the heat capacity data $\left(\mathrm{Cp}^{\circ}\right)$ used to extrapolate the apparent Gibbs free energy of formation to temperatures other than $25^{\circ} \mathrm{C}$ were obtained from Binnewies and Milke (1999 [DIRS 158955]). This combination of data can be justified if the source thermodynamic data used to derived values of $\Delta \mathrm{G}_{\mathrm{f}}{ }^{\circ}$ (i.e., $\Delta \mathrm{H}_{\mathrm{f}}{ }^{\circ}$ and $\mathrm{S}^{\circ}$ ) are identical or at least very close within the uncertainty reported in each source. Table 6-39 show a comparison of $\Delta \mathrm{H}_{\mathrm{f}}{ }^{\circ}$ and $\mathrm{S}^{\circ}$ values given by Barin and Platzki (1995 [DIRS 157865]) and Binnewies and Milke (1999 [DIRS 158955]) for the affected solid species, respectively. As can be seen in Table 6-39, in general the maximum difference in $\Delta \mathrm{H}_{\mathrm{f}}{ }^{\circ}$ is approximately $41 \mathrm{~kJ} / \mathrm{mol}$ (the case for Ferrite-Ca). The majority of the differences in $\Delta \mathrm{H}_{\mathrm{f}}^{\circ}$ values between the two sources range from less than $5 \mathrm{~kJ} / \mathrm{mol}$ to approximately $15 \mathrm{~kJ} / \mathrm{mol}$. For the most part, even when these differences can have non-negligible effects on the estimated $\log \mathrm{K}$ of reaction, the average percentage difference evaluated for the whole $\Delta \mathrm{H}_{\mathrm{f}}{ }^{\mathrm{O}}$ data set in Table 6-39 does not exceed approximately $0.5 \%$. Of course, in some cases, the difference can be larger but this needs to be evaluated separately for specific cases.

The difference in $\mathrm{S}^{\circ}$ values between the two sources does not exceed $7 \mathrm{~kJ} / \mathrm{mol}$ in most cases. These differences are deemed small given the observed range of values observed for this thermodynamic parameter. If all the differences in the data were evaluated as a whole, the average difference would be on the order of $0.2 \mathrm{~J} / \mathrm{mol}-\mathrm{K}$ or approximately $1.2 \%$. In general, given the observed bulk differences, it is not expected that the combined use of these data should generate large inconsistencies that could significantly affect the extrapolation of $\log \mathrm{K}$ values at various temperatures. However, in cases where substantial inconsistencies exist and/or data is deemed suspect, further evaluation of the thermodynamic parameter is required. 
Table 6-33. Log K EQ3/6 Grids for Solid Phases

\begin{tabular}{|c|c|c|c|c|c|c|c|c|c|}
\hline $\begin{array}{c}\text { Data0.ymp.R2 } \\
\text { Species Name }^{\mathrm{a}} \\
\end{array}$ & Reaction & $\begin{array}{l}\log \mathrm{K} \\
0.01^{\circ} \mathrm{C}\end{array}$ & $\begin{array}{l}\log \mathrm{K} \\
25^{\circ} \mathrm{C}\end{array}$ & $\begin{array}{l}\log K \\
60^{\circ} \mathrm{C}\end{array}$ & $\begin{array}{l}\log K \\
100^{\circ} \mathrm{C}\end{array}$ & $\begin{array}{l}\log K \\
150^{\circ} \mathrm{C}\end{array}$ & $\begin{array}{l}\log K \\
200^{\circ} \mathrm{C}\end{array}$ & $\begin{array}{l}\log K \\
250^{\circ} \mathrm{C}\end{array}$ & $\begin{array}{l}\log K \\
300^{\circ} \mathrm{C}\end{array}$ \\
\hline$\left(\mathrm{NH}_{4}\right)_{4} \mathrm{NpO}_{2}\left(\mathrm{CO}_{3}\right)_{3}$ & $\begin{array}{l}\left(\mathrm{NH}_{4}\right)_{4} \mathrm{NpO}_{2}\left(\mathrm{CO}_{3}\right)_{3}=\mathrm{NpO}_{2}^{++}+\mathrm{H}^{+}+ \\
4 \mathrm{NH}_{3}(\mathrm{aq})+3 \mathrm{HCO}_{3}^{-}\end{array}$ & - & -32.7086 & - & - & - & - & - & - \\
\hline Portlandite & $\mathrm{Ca}(\mathrm{OH})_{2}+2 \mathrm{H}^{+}=\mathrm{Ca}^{++}+2 \mathrm{H}_{2} \mathrm{O}$ & 24.6086 & 22.5444 & 20.1812 & 18.0331 & 15.9215 & 14.2416 & 12.8472 & 11.6332 \\
\hline Ferrite-Dicalcium & $\begin{array}{l}\mathrm{Ca}_{2} \mathrm{Fe}_{2} \mathrm{O}_{5}+10 \mathrm{H}^{+}=2 \mathrm{Ca}^{++}+2 \mathrm{Fe}^{+++}+ \\
5 \mathrm{H}_{2} \mathrm{O}\end{array}$ & 64.4019 & 56.8114 & 48.0430 & 40.0003 & 31.9910 & 25.4933 & 19.9542 & 14.9759 \\
\hline $\mathrm{Ca}_{3} \mathrm{Al}_{2} \mathrm{O}_{6}$ & $\begin{array}{l}\mathrm{Ca}_{3} \mathrm{Al}_{2} \mathrm{O}_{6}+12 \mathrm{H}^{+}=3 \mathrm{Ca}^{++}+2 \mathrm{Al}^{+++}+ \\
6 \mathrm{H}_{2} \mathrm{O}\end{array}$ & 124.6741 & 111.6139 & 96.5236 & 82.6676 & 68.8804 & 57.7558 & 48.3914 & 40.1572 \\
\hline $\mathrm{CaAl}_{2} \mathrm{O}_{4}$ & $\mathrm{CaAl}_{2} \mathrm{O}_{4}+8 \mathrm{H}^{+}=\mathrm{Ca}^{++}+2 \mathrm{Al}^{+++}+4 \mathrm{H}_{2} \mathrm{O}$ & 52.2849 & 45.5699 & 37.7772 & 30.5932 & 23.3999 & 17.5331 & 12.5163 & 8.0178 \\
\hline Pseudowollastonite & $\mathrm{CaSiO}_{3}+2 \mathrm{H}^{+}=\mathrm{Ca}^{++}+\mathrm{SiO}_{2}(\mathrm{aq})+\mathrm{H}_{2} \mathrm{O}$ & 15.4002 & 14.0344 & 12.3769 & 10.8345 & 9.3058 & 8.0809 & 7.0433 & 6.0865 \\
\hline Titanite & $\begin{array}{l}\mathrm{CaSiTiO}_{5}+2 \mathrm{H}^{+}+\mathrm{H}_{2} \mathrm{O}=\mathrm{Ti}(\mathrm{OH})_{4}+ \\
\mathrm{Ca}^{++}+\mathrm{SiO}_{2}(\mathrm{aq})\end{array}$ & 2.8906 & 1.9918 & 0.7864 & -0.3694 & -1.5167 & -2.4339 & -3.2249 & -4.0075 \\
\hline Perovskite & $\mathrm{CaTiO}_{3}+2 \mathrm{H}^{+}+\mathrm{H}_{2} \mathrm{O}=\mathrm{Ti}(\mathrm{OH})_{4}+\mathrm{Ca}^{++}$ & 12.8665 & 11.0419 & 8.8548 & 6.8252 & 4.8119 & 3.1997 & 1.8439 & 0.6201 \\
\hline $\mathrm{Co}(\mathrm{OH})_{2}$ & $\mathrm{Co}(\mathrm{OH})_{2}+2 \mathrm{H}^{+}=\mathrm{Co}^{++}+2 \mathrm{H}_{2} \mathrm{O}$ & 14.5818 & 13.0671 & 11.3386 & 9.7790 & 8.2566 & 7.0476 & 6.0355 & 5.1363 \\
\hline Spinel-Co & $\mathrm{Co}_{3} \mathrm{O}_{4}+8 \mathrm{H}^{+}=\mathrm{Co}^{++}+2 \mathrm{Co}^{+++}+4 \mathrm{H}_{2} \mathrm{O}$ & -8.7738 & -10.4344 & -12.3917 & -14.2060 & -16.0687 & -17.6943 & -19.2575 & -20.8940 \\
\hline $\mathrm{CoCl}_{2}$ & $\mathrm{CoCl}_{2}(\mathrm{~s})=\mathrm{Co}^{++}+2 \mathrm{Cl}^{-}$ & 9.4850 & 8.2904 & 6.7186 & 5.0820 & 3.2084 & 1.4315 & -0.3634 & -2.3549 \\
\hline $\mathrm{CoF}_{3}{ }^{\mathrm{b}}$ & $\mathrm{CoF}_{3}=\mathrm{Co}^{+++}+3 \mathrm{~F}^{-}$ & 0.5298 & -1.3201 & -3.7465 & -6.2538 & -9.1083 & -11.8169 & -14.5685 & -17.6326 \\
\hline Sphaerocobaltite & $\mathrm{CoCO}_{3}(\mathrm{~s})+\mathrm{H}^{+}=\mathrm{Co}^{++}+\mathrm{HCO}_{3}^{-}$ & 1.3201 & 0.7971 & 0.1047 & -0.6184 & -1.4547 & -2.2664 & -3.1146 & -4.0936 \\
\hline $\mathrm{CoCr}_{2} \mathrm{O}_{4}$ & $\mathrm{CoCr}_{2} \mathrm{O}_{4}+8 \mathrm{H}^{+}=\mathrm{Co}^{++}+2 \mathrm{Cr}^{+++}+4 \mathrm{H}_{2} \mathrm{O}$ & 19.2781 & 15.0442 & 10.1278 & 5.6052 & 1.0693 & -2.6715 & -5.9511 & -9.0071 \\
\hline $\mathrm{CoF}_{2}$ & $\mathrm{CoF}_{2}=\mathrm{Co}^{++}+2 \mathrm{~F}^{-}$ & -0.6816 & -1.5187 & -2.6692 & -3.9012 & -5.3543 & -6.7866 & -8.3009 & -10.0662 \\
\hline $\mathrm{CoFe}_{2} \mathrm{O}_{4}$ & $\mathrm{CoFe}_{2} \mathrm{O}_{4}+8 \mathrm{H}^{+}=\mathrm{Co}^{++}+2 \mathrm{Fe}^{+++}+4 \mathrm{H}_{2} \mathrm{O}$ & 13.4374 & 10.0104 & 6.0324 & 2.3757 & -1.2984 & -4.3496 & -7.0622 & -9.6472 \\
\hline $\mathrm{CoO}$ & $\mathrm{CoO}+2 \mathrm{H}^{+}=\mathrm{Co}^{++}+\mathrm{H}_{2} \mathrm{O}$ & 15.2509 & 13.5557 & 11.6049 & 9.8261 & 8.0691 & 6.6585 & 5.4696 & 4.4118 \\
\hline $\mathrm{CoTiO}_{3}$ & $\begin{array}{l}\mathrm{CoTiO}_{3}+2 \mathrm{H}^{+}+\mathrm{H}_{2} \mathrm{O}=\mathrm{Co}^{++}+ \\
\mathrm{Ti}(\mathrm{OH})_{4}(\mathrm{aq})\end{array}$ & 18.2260 & 17.0136 & 15.5294 & 14.1469 & 12.7758 & 11.6719 & 10.7238 & 9.8303 \\
\hline $\mathrm{CoWO}_{4}$ & $\mathrm{CoWO}_{4}=\mathrm{Co}^{++}+\mathrm{WO}_{4}^{--}$ & -11.9847 & -11.7760 & -11.7291 & -11.8788 & -12.2822 & -12.8981 & -13.7588 & -14.9905 \\
\hline
\end{tabular}


Table 6-33. Log K EQ3/6 Grids for Solid Phases (Continued)

\begin{tabular}{|c|c|c|c|c|c|c|c|c|c|}
\hline $\begin{array}{l}\text { Data0.ymp.R2 } \\
\text { Species Name }^{\text {a }}\end{array}$ & Reaction & $\begin{array}{l}\log \mathrm{K} \\
0.01^{\circ} \mathrm{C}\end{array}$ & $\begin{array}{l}\log \mathrm{K} \\
25^{\circ} \mathrm{C}\end{array}$ & $\begin{array}{l}\log K \\
60^{\circ} \mathrm{C}\end{array}$ & $\begin{array}{l}\log K \\
100^{\circ} \mathrm{C}\end{array}$ & $\begin{array}{l}\log K \\
150^{\circ} \mathrm{C}\end{array}$ & $\begin{array}{l}\log K \\
200^{\circ} \mathrm{C}\end{array}$ & $\begin{array}{l}\log K \\
250^{\circ} \mathrm{C}\end{array}$ & $\begin{array}{l}\log K \\
300^{\circ} \mathrm{C}\end{array}$ \\
\hline Eskolaite & $\begin{array}{l}\mathrm{Cr}_{2} \mathrm{O}_{3}+2 \mathrm{H}_{2} \mathrm{O}+1.5 \mathrm{O}_{2}(\mathrm{~g})=2 \mathrm{CrO}_{4}{ }^{--}+ \\
4 \mathrm{H}^{+}\end{array}$ & -11.5436 & -12.2116 & -13.4372 & -15.0171 & -17.1381 & -19.4062 & -21.9006 & -24.8658 \\
\hline $\mathrm{CrCl}_{3}$ & $\mathrm{CrCl}_{3}(\mathrm{~s})=\mathrm{Cr}^{+++}+3 \mathrm{Cl}^{-}$ & 22.9486 & 19.9413 & 16.1747 & 12.4178 & 8.3039 & 4.5844 & 1.0134 & -2.7177 \\
\hline $\mathrm{CrF}_{3}$ & $\mathrm{CrF}_{3}(\mathrm{~s})=\mathrm{Cr}^{+++}+3 \mathrm{~F}^{-}$ & -7.8776 & -9.0957 & -10.7894 & -12.6210 & -14.8039 & -16.9783 & -19.2950 & -21.9974 \\
\hline $\mathrm{Crl}_{3}$ & $\mathrm{Crl}_{3}=\mathrm{Cr}^{+++}+3 \mathrm{I}^{-}$ & 30.7636 & 27.4198 & 23.2699 & 19.1619 & 14.7015 & 10.7132 & 6.9359 & 3.0557 \\
\hline $\mathrm{CrO}_{3}$ & $\mathrm{CrO}_{3}+\mathrm{H}_{2} \mathrm{O}=\mathrm{CrO}_{4}{ }^{--}+2 \mathrm{H}^{+}$ & -3.2049 & -3.2201 & -3.4762 & -3.9529 & -4.7213 & -5.6408 & -6.7279 & -8.0893 \\
\hline $\mathrm{Cs}_{2} \mathrm{NaPuCl}_{6}$ & $\begin{array}{l}\mathrm{Cs}_{2} \mathrm{NaPuCl}_{6}=\mathrm{Pu}^{+++}+\mathrm{Na}^{+}+2 \mathrm{Cs}^{+}+ \\
6 \mathrm{Cl}^{-}\end{array}$ & 12.6910 & 11.9903 & 10.7216 & 9.1448 & 7.0406 & 4.7083 & 1.9462 & -1.6789 \\
\hline $\mathrm{Cs}_{2} \mathrm{NpBr}_{6}$ & $\mathrm{Cs}_{2} \mathrm{NpBr}_{6}=\mathrm{Np}^{++++}+2 \mathrm{Cs}^{+}+6 \mathrm{Br}^{-}$ & - & 13.8968 & - & - & - & - & - & - \\
\hline $\mathrm{Cs}_{2} \mathrm{NpCl}_{6}$ & $\mathrm{Cs}_{2} \mathrm{NpCl}_{6}=\mathrm{Np}^{++++}+2 \mathrm{Cs}^{+}+6 \mathrm{Cl}^{-}$ & - & 5.2219 & - & - & - & - & - & - \\
\hline $\mathrm{Cs}_{2} \mathrm{PuBr}_{6}$ & $\mathrm{Cs}_{2} \mathrm{PuBr}_{6}=\mathrm{Pu}^{++++}+2 \mathrm{Cs}^{+}+6 \mathrm{Br}^{-}$ & - & 8.9929 & - & - & - & - & - & - \\
\hline $\mathrm{Cs}_{2} \mathrm{PuCl}_{6}$ & $\mathrm{Cs}_{2} \mathrm{PuCl}_{6}=\mathrm{Pu}^{++++}+2 \mathrm{Cs}^{+}+6 \mathrm{Cl}^{-}$ & - & 1.8950 & - & - & - & - & - & - \\
\hline $\mathrm{Cs}_{3} \mathrm{PuCl}_{6}$ & $\mathrm{Cs}_{3} \mathrm{PuCl}_{6}=\mathrm{Pu}^{+++}+3 \mathrm{Cs}^{+}+6 \mathrm{Cl}^{-}$ & 76.2003 & 70.6870 & 63.7161 & 56.7397 & 49.1001 & 42.2114 & 35.6138 & 28.7057 \\
\hline $\mathrm{CsPu}_{2} \mathrm{Cl}_{7}$ & $\mathrm{CsPu}_{2} \mathrm{Cl}_{7}=2 \mathrm{Pu}^{+++}+\mathrm{Cs}^{+}+7 \mathrm{Cl}^{-}$ & 31.8161 & 28.1392 & 23.2011 & 17.9835 & 11.9216 & 6.0813 & 0.0880 & -6.6516 \\
\hline Ferrite-Cu & $\mathrm{CuFe}_{2} \mathrm{O}_{4}+8 \mathrm{H}^{+}=\mathrm{Cu}^{++}+2 \mathrm{Fe}^{+++}+4 \mathrm{H}_{2} \mathrm{O}$ & 13.0021 & 9.5266 & 5.4967 & 1.7969 & -1.9118 & -4.9806 & -7.6956 & -10.2679 \\
\hline Iron & $\mathrm{Fe}+2 \mathrm{H}^{+}+0.5 \mathrm{O}_{2}(\mathrm{~g})=\mathrm{Fe}^{++}+\mathrm{H}_{2} \mathrm{O}$ & 63.6422 & 57.5836 & 50.6277 & 44.2848 & 38.0433 & 33.1025 & 29.0637 & 25.6580 \\
\hline $\mathrm{Fe}(\mathrm{OH})_{2}$ & $\mathrm{Fe}(\mathrm{OH})_{2}(\mathrm{~s})+2 \mathrm{H}^{+}=\mathrm{Fe}^{++}+2 \mathrm{H}_{2} \mathrm{O}$ & 15.3413 & 13.8214 & 12.0765 & 10.4910 & 8.9312 & 7.6838 & 6.6348 & 5.7012 \\
\hline $\mathrm{Fe}(\mathrm{OH})_{3}$ & $\mathrm{Fe}(\mathrm{OH})_{3}(\mathrm{~s})+3 \mathrm{H}^{+}=\mathrm{Fe}^{+++}+3 \mathrm{H}_{2} \mathrm{O}$ & 6.9977 & 5.6581 & 4.1257 & 2.7413 & 1.3775 & 0.2679 & -0.7022 & -1.6141 \\
\hline $\mathrm{Fe}_{2}\left(\mathrm{SO}_{4}\right)_{3}$ & $\mathrm{Fe}_{2}\left(\mathrm{SO}_{4}\right)_{3}(\mathrm{~s})=\mathrm{Fe}^{+++}+3 \mathrm{SO}_{4}^{--}$ & 4.5147 & 0.8936 & -3.9957 & -9.1664 & -15.1498 & -20.8688 & -26.6630 & -33.0596 \\
\hline hercynite & $\mathrm{FeAl}_{2} \mathrm{O}_{4}+8 \mathrm{H}^{+}=\mathrm{Fe}^{++}+2 \mathrm{Al}^{+++}+4 \mathrm{H}_{2} \mathrm{O}$ & 27.2135 & 22.4207 & 16.8317 & 11.6611 & 6.4509 & 2.1479 & -1.6071 & -5.0680 \\
\hline lawrencite & $\mathrm{FeCl}_{2}=\mathrm{Fe}^{++}+2 \mathrm{Cl}^{-}$ & 10.3376 & 9.0646 & 7.4040 & 5.6877 & 3.7361 & 1.8968 & 0.0484 & -1.9931 \\
\hline molysite & $\mathrm{FeCl}_{3}(\mathrm{~s})=\mathrm{Fe}^{+++}+3 \mathrm{Cl}^{-}$ & 15.8514 & 13.5217 & 10.5451 & 7.5206 & 4.1357 & 0.9961 & -2.1068 & -5.4602 \\
\hline chromite & $\mathrm{FeCr}_{2} \mathrm{O}_{4}+8 \mathrm{H}^{+}=\mathrm{Fe}^{++}+2 \mathrm{Cr}^{+++}+4 \mathrm{H}_{2} \mathrm{O}$ & 21.4464 & 16.9730 & 11.7841 & 7.0157 & 2.2433 & -1.6773 & -5.0937 & -8.2518 \\
\hline $\mathrm{FeF}_{2}$ & $\mathrm{FeF}_{2}(\mathrm{~s})=\mathrm{Fe}^{++}+2 \mathrm{~F}^{-}$ & -0.5959 & -1.4320 & -2.5782 & -3.8024 & -5.2429 & -6.6604 & -8.1584 & -9.9065 \\
\hline $\mathrm{FeF}_{3}$ & $\mathrm{FeF}_{3}(\mathrm{~s})=\mathrm{Fe}^{+++}+3 \mathrm{~F}^{-}$ & -19.1368 & -19.2386 & -19.6397 & -20.2803 & -21.2782 & -22.5050 & -24.0432 & -26.0946 \\
\hline Goethite & $\mathrm{FeOOH}(\mathrm{s})+3 \mathrm{H}^{+}=\mathrm{Fe}^{+++}+2 \mathrm{H}_{2} \mathrm{O}$ & 1.5251 & 0.5347 & -0.6066 & -1.6494 & -2.7014 & -3.5942 & -4.4184 & -5.2402 \\
\hline Ferrite-Ca & $\mathrm{CaFe}_{2} \mathrm{O}_{4}+8 \mathrm{H}^{+}=2 \mathrm{Fe}^{+++}+\mathrm{Ca}^{++}+4 \mathrm{H}_{2} \mathrm{O}$ & 25.8281 & 21.5945 & 16.7003 & 12.2140 & 7.7348 & 4.0632 & 0.8671 & -2.0967 \\
\hline Ferrite-Ni & $\mathrm{NiFe}_{2} \mathrm{O}_{4}+8 \mathrm{H}^{+}=2 \mathrm{Fe}^{+++}+\mathrm{Ni}^{++}+4 \mathrm{H}_{2} \mathrm{O}$ & 13.1975 & 9.7959 & 5.8444 & 2.2106 & -1.4416 & -4.4763 & -7.1766 & -9.7520 \\
\hline
\end{tabular}


Table 6-33. Log K EQ3/6 Grids for Solid Phases (Continued)

\begin{tabular}{|c|c|c|c|c|c|c|c|c|c|}
\hline $\begin{array}{l}\text { Data0.ymp.R2 } \\
\text { Species Name }^{\mathrm{a}}\end{array}$ & Reaction & $\begin{array}{r}\log K \\
0.01^{\circ} \mathrm{C}\end{array}$ & $\begin{array}{l}\log K \\
25^{\circ} \mathrm{C}\end{array}$ & $\begin{array}{l}\log \mathrm{K} \\
60^{\circ} \mathrm{C}\end{array}$ & $\begin{array}{l}\log \mathrm{K} \\
100^{\circ} \mathrm{C}\end{array}$ & $\begin{array}{l}\log \mathrm{K} \\
150^{\circ} \mathrm{C}\end{array}$ & $\begin{array}{l}\log \mathrm{K} \\
200^{\circ} \mathrm{C}\end{array}$ & $\begin{array}{l}\log \mathrm{K} \\
250^{\circ} \mathrm{C}\end{array}$ & $\begin{array}{l}\log K \\
300^{\circ} \mathrm{C}\end{array}$ \\
\hline $\mathrm{FeSO}_{4}$ & $\mathrm{FeSO}_{4}(\mathrm{~s})=\mathrm{Fe}^{++}+\mathrm{SO}_{4}{ }^{--}$ & 3.0095 & 1.9396 & 0.4732 & -1.0933 & -2.9213 & -4.6831 & -6.4843 & -8.4996 \\
\hline IImenite & $\mathrm{FeTiO}_{3}+2 \mathrm{H}^{+}+\mathrm{H}_{2} \mathrm{O}=\mathrm{Ti}(\mathrm{OH})_{4}+\mathrm{Fe}^{++}$ & 4.7306 & 3.3187 & 1.6078 & 0.0209 & -1.5482 & -2.8051 & -3.8743 & -4.8659 \\
\hline $\mathrm{K}_{4} \mathrm{NpO}_{2}\left(\mathrm{CO}_{3}\right)_{3}$ & $\begin{array}{l}\mathrm{K}_{4} \mathrm{NpO}_{2}\left(\mathrm{CO}_{3}\right)_{3}+3 \mathrm{H}^{+}=\mathrm{NpO}_{2}^{++}+4 \mathrm{~K}^{+}+ \\
3 \mathrm{HCO}_{3}{ }^{-}\end{array}$ & - & 4.5920 & - & - & - & - & - & - \\
\hline $\mathrm{MgBr}_{2}$ & $\mathrm{MgBr}_{2}=\mathrm{Mg}^{++}+2 \mathrm{Br}^{-}$ & 30.5643 & 27.6871 & 24.1881 & 20.8077 & 17.2423 & 14.1551 & 11.3222 & 8.4951 \\
\hline Chloromagnesite & $\mathrm{MgCl}_{2}=\mathrm{Mg}^{++}+2 \mathrm{Cl}^{-}$ & 24.2691 & 21.8099 & 18.7942 & 15.8518 & 12.7075 & 9.9394 & 7.3482 & 4.7003 \\
\hline $\mathrm{MgSO}_{4}$ & $\mathrm{MgSO}_{4}=\mathrm{Mg}^{++}+\mathrm{SO}_{4}^{--}$ & 6.2374 & 4.8818 & 3.0998 & 1.2626 & -0.8107 & -2.7478 & -4.6772 & -6.7870 \\
\hline Bixbyite & $\mathrm{Mn}_{2} \mathrm{O}_{3}+6 \mathrm{H}^{+}=2 \mathrm{Mn}^{+++}+3 \mathrm{H}_{2} \mathrm{O}$ & 2.5123 & 0.0527 & -2.8289 & -5.5008 & -8.2129 & -10.4932 & -12.5452 & -14.5141 \\
\hline Tephroite & $\begin{array}{l}\mathrm{Mn}_{2} \mathrm{SiO}_{4}+4 \mathrm{H}^{+}=2 \mathrm{Mn}^{++}+\mathrm{SiO}_{2}(\mathrm{aq}) \\
+2 \mathrm{H}_{2} \mathrm{O}\end{array}$ & 26.8129 & 24.2091 & 21.1411 & 18.3322 & 15.5705 & 13.3635 & 11.4914 & 9.7712 \\
\hline Scacchite & $\mathrm{MnCl}_{2}=\mathrm{Mn}^{++}+2 \mathrm{Cl}^{-}$ & 10.3334 & 9.2222 & 7.7576 & 6.2301 & 4.4744 & 2.7984 & 1.0891 & -0.8326 \\
\hline $\mathrm{MnSO}_{4}$ & $\mathrm{MnSO}_{4}=\mathrm{Mn}^{++}+\mathrm{SO}_{4}^{--}$ & 4.0667 & 3.1105 & 1.7833 & 0.3516 & -1.3374 & -2.9856 & -4.6947 & -6.6381 \\
\hline $\mathrm{MoO}_{2} \mathrm{Cl}_{2}$ & $\mathrm{MoO}_{2} \mathrm{Cl}_{2}+2 \mathrm{H}_{2} \mathrm{O}=\mathrm{MoO}_{4}^{--}+2 \mathrm{Cl}^{-}+4 \mathrm{H}^{+}$ & 1.0071 & 0.5936 & -0.2793 & -1.4889 & -3.2010 & -5.1125 & -7.2954 & -9.9885 \\
\hline $\mathrm{Na}_{2} \mathrm{CO}_{3}$ & $\mathrm{Na}_{2} \mathrm{CO}_{3}+\mathrm{H}^{+}=2 \mathrm{Na}^{+}+\mathrm{HCO}_{3}^{-}$ & 11.6083 & 10.9840 & 10.2407 & 9.5499 & 8.8427 & 8.2248 & 7.6155 & 6.9083 \\
\hline $\mathrm{Na}_{2} \mathrm{CrO}_{4}$ & $\mathrm{Na}_{2} \mathrm{CrO}_{4}=2 \mathrm{Na}^{+}+\mathrm{CrO}_{4}^{--}$ & 3.8172 & 3.5616 & 3.0862 & 2.4882 & 1.6936 & 0.8277 & -0.1710 & -1.4480 \\
\hline $\mathrm{Na}_{3} \mathrm{NpF}_{8}$ & $\begin{array}{l}\mathrm{Na}_{3} \mathrm{NpF}_{8}+2 \mathrm{H}_{2} \mathrm{O}=\mathrm{NpO}_{2}{ }^{+}+3 \mathrm{Na}^{+}+4 \mathrm{H}^{+} \\
+8 \mathrm{~F}^{-}\end{array}$ & -7.2108 & -8.4426 & -10.5799 & -13.2060 & -16.6535 & -20.3726 & -24.6157 & -29.9430 \\
\hline $\mathrm{Na}_{3} \mathrm{NpO}_{2}\left(\mathrm{CO}_{3}\right)_{2}$ & $\begin{array}{l}\mathrm{Na}_{3} \mathrm{NpO}_{2}\left(\mathrm{CO}_{3}\right)_{2}+2 \mathrm{H}^{+}=\mathrm{NpO}_{2}^{+}+3 \mathrm{Na}^{+} \\
+2 \mathrm{HCO}_{3}^{-}\end{array}$ & - & 5.9485 & - & - & - & - & - & - \\
\hline Nahcolite & $\mathrm{NaHCO}_{3}=\mathrm{Na}^{+}+\mathrm{HCO}_{3}^{-}$ & -1.0584 & -0.7061 & -0.3492 & -0.0651 & 0.1539 & 0.2439 & 0.1989 & -0.0343 \\
\hline $\mathrm{NaNpO}_{2} \mathrm{CO}_{3}$ & $\begin{array}{l}\mathrm{NaNpO}_{2} \mathrm{CO}_{3}+\mathrm{H}^{+}=\mathrm{NpO}_{2}^{+}+\mathrm{Na}^{+}+ \\
\mathrm{HCO}_{3}^{-}\end{array}$ & - & -1.3265 & - & - & - & - & - & - \\
\hline $\mathrm{NaNpO}_{2} \mathrm{CO}_{3} \cdot 3.5 \mathrm{H}_{2} \mathrm{O}$ & $\begin{array}{l}\mathrm{NaNpO}_{2} \mathrm{CO}_{3} \cdot 3.5 \mathrm{H}_{2} \mathrm{O}+\mathrm{H}^{+}=\mathrm{NpO}_{2}^{+}+ \\
\mathrm{Na}^{+}+\mathrm{HCO}_{3}^{-}+3.5 \mathrm{H}_{2} \mathrm{O}\end{array}$ & - & -0.8000 & - & - & - & - & - & - \\
\hline Heazlewoodite & $\begin{array}{l}\mathrm{Ni}_{3} \mathrm{~S}_{2}+4 \mathrm{H}^{+}+0.5 \mathrm{O}_{2}(\mathrm{~g})=3 \mathrm{Ni}^{++}+2 \mathrm{HS}^{-} \\
+\mathrm{H}_{2} \mathrm{O}\end{array}$ & 28.6004 & 24.4693 & 19.5027 & 14.7638 & 9.8201 & 5.5688 & 1.6743 & -2.2027 \\
\hline $\mathrm{NiCl}_{2}$ & $\mathrm{NiCl}_{2}(\mathrm{~s})=\mathrm{Ni}^{++}+2 \mathrm{Cl}^{-}$ & 9.8343 & 8.5926 & 6.9613 & 5.2662 & 3.3313 & 1.5025 & -0.3371 & -2.3675 \\
\hline $\mathrm{NiCO}_{3}$ & $\mathrm{NiCO}_{3}+\mathrm{H}^{+}=\mathrm{Ni}^{++}+\mathrm{HCO}_{3}^{-}$ & 3.3189 & 2.5700 & 1.6085 & 0.6310 & -0.4648 & -1.4889 & -2.5152 & -3.6457 \\
\hline $\mathrm{NiCr}_{2} \mathrm{O}_{4}$ & $\mathrm{NiCr}_{2} \mathrm{O}_{4}+8 \mathrm{H}^{+}=\mathrm{Ni}^{++}+2 \mathrm{Cr}^{+++}+4 \mathrm{H}_{2} \mathrm{O}$ & 28.7772 & 23.6681 & 17.7383 & 12.2829 & 6.8212 & 2.3437 & -1.5369 & -5.0928 \\
\hline
\end{tabular}


Table 6-33. Log K EQ3/6 Grids for Solid Phases (Continued)

\begin{tabular}{|c|c|c|c|c|c|c|c|c|c|}
\hline $\begin{array}{l}\text { Data0.ymp.R2 } \\
\text { Species Name }^{\mathrm{a}}\end{array}$ & Reaction & $\begin{array}{r}\log K \\
0.01^{\circ} \mathrm{C}\end{array}$ & $\begin{array}{l}\log K \\
25^{\circ} \mathrm{C}\end{array}$ & $\begin{array}{l}\log K \\
60^{\circ} \mathrm{C}\end{array}$ & $\begin{array}{l}\log K \\
100^{\circ} \mathrm{C}\end{array}$ & $\begin{array}{l}\log K \\
150^{\circ} \mathrm{C}\end{array}$ & $\begin{array}{l}\log K \\
200^{\circ} \mathrm{C}\end{array}$ & $\begin{array}{l}\log K \\
250^{\circ} \mathrm{C}\end{array}$ & $\begin{array}{l}\log K \\
300^{\circ} \mathrm{C}\end{array}$ \\
\hline $\mathrm{NiF}_{2}$ & $\mathrm{NiF}_{2}(\mathrm{~s})=\mathrm{Ni}^{++}+2 \mathrm{~F}^{-}$ & 0.7826 & -0.2087 & -1.5390 & -2.9364 & -4.5527 & -6.1140 & -7.7328 & -9.5842 \\
\hline Trevorite & $\mathrm{NiFe}_{2} \mathrm{O}_{4}+8 \mathrm{H}^{+}=\mathrm{Ni}^{++}+2 \mathrm{Fe}^{+++}+4 \mathrm{H}_{2} \mathrm{O}$ & 13.1975 & 9.7959 & 5.8444 & 2.2106 & -1.4395 & -4.4690 & -7.1591 & -9.7170 \\
\hline $\mathrm{NiSO}_{4}$ & $\mathrm{NiSO}_{4}=\mathrm{Ni}^{++}+\mathrm{SO}_{4}^{--}$ & 6.7405 & 5.3469 & 3.4997 & 1.5773 & -0.6099 & -2.6624 & -4.7049 & -6.9235 \\
\hline $\mathrm{NiTiO}_{3}$ & $\mathrm{NiTiO}_{3}+2 \mathrm{H}^{+}+\mathrm{H}_{2} \mathrm{O}=\mathrm{Ti}(\mathrm{OH})_{4}+\mathrm{Ni}^{++}$ & 3.5707 & 2.2603 & 0.6583 & -0.8359 & -2.3208 & -3.5179 & -4.5440 & -5.5036 \\
\hline $\mathrm{NiWO}_{4}$ & $\mathrm{NiWO}_{4}=\mathrm{Ni}^{++}+\mathrm{WO}_{4}^{--}$ & -11.3005 & -11.1792 & -11.2395 & -11.4931 & -12.0046 & -12.7110 & -13.6490 & -14.9474 \\
\hline $\mathrm{Np}$ & $\mathrm{Np}+3 \mathrm{H}^{+}+0.75 \mathrm{O}_{2}(\mathrm{~g})=\mathrm{Np}^{+++}+1.5 \mathrm{H}_{2} \mathrm{O}$ & 167.5198 & 152.1799 & 134.5685 & 118.5020 & 102.6895 & 90.1833 & 79.9918 & 71.4644 \\
\hline $\mathrm{Np}_{2} \mathrm{C}_{3}$ & $\begin{array}{l}\mathrm{Np}_{2} \mathrm{C}_{3}+3 \mathrm{H}^{+}+4.5 \mathrm{O}_{2}(\mathrm{~g})=2 \mathrm{~Np}^{+++}+ \\
3 \mathrm{HCO}_{3}^{-}\end{array}$ & - & 454.4742 & - & - & - & - & - & - \\
\hline $\mathrm{Np}_{2} \mathrm{O}_{5}$ & $\mathrm{~Np}_{2} \mathrm{O}_{5}+2 \mathrm{H}^{+}=2 \mathrm{NpO}_{2}^{+}+\mathrm{H}_{2} \mathrm{O}$ & 4.9273 & 3.7031 & 2.1851 & 0.7083 & -0.8437 & -2.1654 & -3.3362 & -4.4215 \\
\hline $\mathrm{NpBr}_{3}$ & $\mathrm{NpBr}_{3}=\mathrm{Np}^{+++}+3 \mathrm{Br}^{-}$ & 23.3944 & 20.9379 & 17.8033 & 14.6332 & 11.1113 & 7.8740 & 4.7046 & 1.3143 \\
\hline $\mathrm{NpBr}_{4}$ & $\mathrm{NpBr}_{4}=\mathrm{Np}^{++++}+4 \mathrm{Br}^{-}$ & 34.0066 & 29.8101 & 24.6456 & 19.5826 & 14.1296 & 9.2708 & 4.6508 & -0.1567 \\
\hline $\mathrm{NpC}_{0.91}{ }^{\mathrm{C}}$ & $\begin{array}{l}\mathrm{NpC}_{0.91}+2.09 \mathrm{H}^{+}+1.66 \mathrm{O}_{2}(\mathrm{~g})=\mathrm{Np}^{+++}+ \\
0.91 \mathrm{HCO}_{3}{ }^{-}+0.59 \mathrm{H}_{2} \mathrm{O}\end{array}$ & 214.6543 & 194.6217 & 171.5153 & 150.3170 & 129.3115 & 112.5628 & 98.7826 & 87.0847 \\
\hline $\mathrm{NpCl}_{3}$ & $\mathrm{NpCl}_{3}=\mathrm{Np}^{+++}+3 \mathrm{Cl}^{-}$ & 15.4616 & 13.4766 & 10.8967 & 8.2378 & 5.2187 & 2.3732 & -0.4864 & -3.6310 \\
\hline $\mathrm{NpCl}_{4}$ & $\mathrm{NpCl}_{4}=\mathrm{Np}^{++++}+4 \mathrm{Cl}^{-}$ & 24.9789 & 21.2634 & 16.6639 & 12.1176 & 7.1657 & 2.6901 & -1.6343 & -6.2149 \\
\hline $\mathrm{NpF}_{3}$ & $\mathrm{NpF}_{3}=\mathrm{Np}^{+++}+3 \mathrm{~F}^{-}$ & -17.9938 & -17.9369 & -18.1661 & -18.6598 & -19.5272 & -20.6659 & -22.1483 & -24.1670 \\
\hline $\mathrm{NpF}_{4}$ & $\mathrm{NpF}_{4}=\mathrm{Np}^{++++}+4 \mathrm{~F}^{-}$ & -28.6696 & -28.9106 & -29.5061 & -30.3649 & -31.6518 & -33.2169 & -35.1861 & -37.8324 \\
\hline $\mathrm{NpF}_{5}$ & $\mathrm{NpF}_{5}+2 \mathrm{H}_{2} \mathrm{O}=\mathrm{NpO}_{2}^{+}+5 \mathrm{~F}^{-}+4 \mathrm{H}^{+}$ & 3.4168 & 1.3534 & -1.5326 & -4.6702 & -8.3916 & -12.0297 & -15.7970 & -20.0725 \\
\hline $\mathrm{NpF}_{6}$ & $\mathrm{NpF}_{6}+2 \mathrm{H}_{2} \mathrm{O}=\mathrm{NpO}_{2}^{++}+4 \mathrm{H}^{+}+6 \mathrm{~F}^{-}$ & 34.9278 & 29.8193 & 23.4792 & 17.2248 & 10.4509 & 4.3751 & -1.4543 & -7.6196 \\
\hline $\mathrm{Npl}_{3}$ & $\mathrm{Npl}_{3}=\mathrm{Np}^{+++}+31^{-}$ & 30.2029 & 27.3544 & 23.7833 & 20.2153 & 16.2960 & 12.7396 & 9.3101 & 5.7084 \\
\hline $\mathrm{NpN}$ & $\mathrm{NpN}+3 \mathrm{H}^{+}=\mathrm{Np}^{+++}+\mathrm{NH}_{3}(\mathrm{aq})$ & 52.2385 & 47.2199 & 41.4250 & 36.1113 & 30.8387 & 26.6081 & 23.0814 & 20.0350 \\
\hline $\mathrm{NpO}_{2}$ & $\mathrm{NpO}_{2}+4 \mathrm{H}^{+}=\mathrm{Np}^{++++}+2 \mathrm{H}_{2} \mathrm{O}$ & -8.8615 & -9.7398 & -10.7021 & -11.5341 & -12.3305 & -12.9874 & -13.6028 & -14.2445 \\
\hline $\mathrm{NpO}_{2}$ (hyd, aged) & $\mathrm{NpO}_{2}+4 \mathrm{H}^{+}=\mathrm{Np}^{++++}+2 \mathrm{H}_{2} \mathrm{O}$ & - & 1.5445 & - & - & - & - & - & - \\
\hline $\mathrm{NpO}_{2}\left(\mathrm{NO}_{3}\right)_{2} \cdot 6 \mathrm{H}_{2} \mathrm{O}$ & $\begin{array}{l}\mathrm{NpO}_{2}\left(\mathrm{NO}_{3}\right)_{2} \cdot 6 \mathrm{H}_{2} \mathrm{O}=\mathrm{NpO}_{2}^{++}+2 \mathrm{NO}_{3}{ }^{-}+ \\
6 \mathrm{H}_{2} \mathrm{O}\end{array}$ & - & 2.2370 & - & - & - & - & - & - \\
\hline $\mathrm{NpO}_{2} \mathrm{CO}_{3}$ & $\mathrm{NpO}_{2} \mathrm{CO}_{3}+\mathrm{H}^{+}=\mathrm{NpO}_{2}^{++}+\mathrm{HCO}_{3}^{-}$ & - & 242.0251 & - & - & - & - & - & - \\
\hline $\mathrm{NpO}_{2} \mathrm{OH}(\mathrm{am})$ & $\mathrm{NpO}_{2} \mathrm{OH}+\mathrm{H}^{+}=\mathrm{NpO}_{2}^{+}+\mathrm{H}_{2} \mathrm{O}$ & - & 4.7072 & - & - & - & - & - & - \\
\hline $\mathrm{NpO}_{2} \mathrm{OH}(\mathrm{am}$, aged $)$ & $\mathrm{NpO}_{2} \mathrm{OH}+\mathrm{H}^{+}=\mathrm{NpO}_{2}++\mathrm{H}_{2} \mathrm{O}$ & - & 5.3074 & - & - & - & - & - & - \\
\hline
\end{tabular}


Table 6-33. Log K EQ3/6 Grids for Solid Phases (Continued)

\begin{tabular}{|c|c|c|c|c|c|c|c|c|c|}
\hline $\begin{array}{l}\text { Data0.ymp.R2 } \\
\text { Species Name }^{a}\end{array}$ & \begin{tabular}{|c|} 
Reaction \\
\end{tabular} & $\begin{array}{l}\log \mathrm{K} \\
0.01^{\circ} \mathrm{C}\end{array}$ & $\begin{array}{l}\log K \\
25^{\circ} \mathrm{C}\end{array}$ & $\begin{array}{l}\log K \\
60^{\circ} \mathrm{C}\end{array}$ & $\begin{array}{l}\log K \\
100^{\circ} \mathrm{C}\end{array}$ & $\begin{array}{l}\log \mathrm{K} \\
150^{\circ} \mathrm{C}\end{array}$ & $\begin{array}{l}\log K \\
200^{\circ} \mathrm{C}\end{array}$ & $\begin{array}{l}\log K \\
250^{\circ} \mathrm{C}\end{array}$ & $\begin{array}{l}\log K \\
300^{\circ} \mathrm{C}\end{array}$ \\
\hline $\mathrm{NpO}_{3} \cdot \mathrm{H}_{2} \mathrm{O}$ & $\mathrm{NpO}_{3} \cdot \mathrm{H}_{2} \mathrm{O}+2 \mathrm{H}^{+}=\mathrm{NpO}_{2}^{++}+2 \mathrm{H}_{2} \mathrm{O}$ & - & 5.4844 & - & - & - & - & - & - \\
\hline $\mathrm{NpOBr}_{2}$ & $\mathrm{NpOBr}_{2}+2 \mathrm{H}^{+}=\mathrm{Np}^{++++}+2 \mathrm{Br}^{-}+\mathrm{H}_{2} \mathrm{O}$ & 7.3740 & 5.2794 & 2.7147 & 0.2116 & -2.4896 & -4.9259 & -7.2945 & -9.8236 \\
\hline $\mathrm{NpOCl}_{2}$ & $\mathrm{NpOCl}_{2}+2 \mathrm{H}^{+}=\mathrm{Np}^{++++}+2 \mathrm{Cl}^{-}+\mathrm{H}_{2} \mathrm{O}$ & 7.6908 & 5.4117 & 2.6464 & -0.0340 & -2.9065 & -5.4782 & -7.9587 & -10.5850 \\
\hline $\mathrm{Pu}$ & $\mathrm{Pu}+\mathrm{O}_{2}(\mathrm{~g})+4 \mathrm{H}^{+}=\mathrm{Pu}^{++++}+2 \mathrm{H}_{2} \mathrm{O}$ & 184.6832 & 166.8458 & 146.4193 & 127.8270 & 109.5673 & 95.1509 & 83.4149 & 73.5976 \\
\hline $\mathrm{Pu}\left(\mathrm{HPO}_{4}\right)_{2}(\mathrm{am}, \mathrm{hyd})$ & $\mathrm{Pu}\left(\mathrm{HPO}_{4}\right)_{2}=\mathrm{Pu}^{++++}+2 \mathrm{HPO}_{4}^{--}$ & - & -32.8499 & - & - & - & - & - & - \\
\hline $\mathrm{Pu}(\mathrm{OH})_{3}$ & $\mathrm{Pu}(\mathrm{OH})_{3}+3 \mathrm{H}^{+}=\mathrm{Pu}^{+++}+3 \mathrm{H}_{2} \mathrm{O}$ & - & 15.8218 & - & - & - & - & - & - \\
\hline $\mathrm{Pu}_{2} \mathrm{C}_{3}{ }^{\mathrm{c}}$ & $\begin{array}{l}\mathrm{Pu}_{2} \mathrm{C}_{3}+3 \mathrm{H}^{+}+4.5 \mathrm{O}_{2}(\mathrm{~g})=2 \mathrm{Pu}^{+++} \\
+3 \mathrm{HCO}_{3}^{-}\end{array}$ & 533.5333 & 483.9154 & 426.6236 & 373.9963 & 321.7747 & 280.0729 & 245.7040 & 216.4445 \\
\hline $\mathrm{Pu}_{2} \mathrm{O}_{3}$ & $\mathrm{Pu}_{2} \mathrm{O}_{3}+6 \mathrm{H}^{+}=3 \mathrm{H}_{2} \mathrm{O}+2 \mathrm{Pu}^{+++}$ & 56.7969 & 50.6550 & 43.5378 & 36.9885 & 30.4486 & 25.1389 & 20.6280 & 16.6232 \\
\hline $\mathrm{Pu}_{3} \mathrm{C}_{2}$ & $\begin{array}{l}\mathrm{Pu}_{3} \mathrm{C}_{2}+7 \mathrm{H}^{+}+4.25 \mathrm{O}_{2}(\mathrm{~g})=3 \mathrm{Pu}^{+++} \\
+2 \mathrm{HCO}_{3}^{-}+2.5 \mathrm{H}_{2} \mathrm{O}\end{array}$ & 652.3279 & 592.2086 & 522.9563 & 459.5238 & 396.7967 & 346.9117 & 306.0016 & 271.4409 \\
\hline PuAs & $\begin{array}{l}\mathrm{PuAs}+2 \mathrm{O}_{2}(\mathrm{~g})+2 \mathrm{H}^{+}=\mathrm{Pu}^{+++}+ \\
\mathrm{H}_{2} \mathrm{AsO}_{4}^{-}\end{array}$ & - & 191.0895 & - & - & - & - & - & - \\
\hline PuBi & $\begin{array}{l}\mathrm{PuBi}+6 \mathrm{H}^{+}+1.5 \mathrm{O}_{2}(\mathrm{~g})=\mathrm{Pu}^{+++}+\mathrm{Bi}^{+++}+ \\
3 \mathrm{H}_{2} \mathrm{O}\end{array}$ & - & 188.3637 & - & - & - & - & - & - \\
\hline $\mathrm{PuBi}_{2}$ & $\begin{array}{l}\mathrm{PuBi}_{2}+8 \mathrm{H}^{+}+3 \mathrm{O}_{2}(\mathrm{~g})=\mathrm{PuO}_{2}^{++}+2 \mathrm{Bi}^{+++} \\
+4 \mathrm{H}_{2} \mathrm{O}\end{array}$ & - & 244.4113 & - & - & - & - & - & - \\
\hline $\mathrm{PuBr}_{3}$ & $\mathrm{PuBr}_{3}=\mathrm{Pu}^{+++}+3 \mathrm{Br}^{-}$ & 24.2043 & 21.6939 & 18.5470 & 15.4240 & 12.0179 & 8.9338 & 5.9388 & 2.7339 \\
\hline $\mathrm{PuC}_{0.84}{ }^{\mathrm{C}}$ & $\begin{array}{l}\mathrm{PuC}_{0.84}+1.59 \mathrm{O}_{2}(\mathrm{~g})+2.16 \mathrm{H}^{+}= \\
0.84 \mathrm{HCO}_{3}^{-}+0.66 \mathrm{H}_{2} \mathrm{O}+\mathrm{Pu}^{++}=\end{array}$ & 227.5352 & 206.5054 & 182.2538 & 160.0100 & 137.9775 & 120.4229 & 105.9970 & 93.7775 \\
\hline $\mathrm{PuCl}_{3}$ & $\mathrm{PuCl}_{3}=\mathrm{Pu}^{+++}+3 \mathrm{Cl}^{-}$ & 16.2123 & 14.1989 & 11.5854 & 8.8960 & 5.8478 & 2.9809 & 0.1054 & -3.0511 \\
\hline $\mathrm{PuCl}_{3} \cdot 6 \mathrm{H}_{2} \mathrm{O}$ & $\mathrm{PuCl}_{3} \cdot 6 \mathrm{H}_{2} \mathrm{O}=\mathrm{Pu}^{+++}+3 \mathrm{Cl}^{-}+6 \mathrm{H}_{2} \mathrm{O}$ & - & 5.3599 & - & - & - & - & - & - \\
\hline $\mathrm{PuCl}_{4}$ & $\mathrm{PuCl}_{4}=\mathrm{Pu}^{++++}+4 \mathrm{Cl}^{-}$ & - & 21.6853 & - & - & - & - & - & - \\
\hline $\mathrm{PuF}_{3}$ & $\mathrm{PuF}_{3}=\mathrm{Pu}^{+++}+3 \mathrm{~F}^{-}$ & -16.2624 & -16.3164 & -16.6721 & -17.2795 & -18.2556 & -19.4767 & -21.0227 & -23.0916 \\
\hline $\mathrm{PuF}_{6}$ & $\mathrm{PuF}_{6}+2 \mathrm{H}_{2} \mathrm{O}=6 \mathrm{~F}^{-}+\mathrm{PuO}_{2}^{++}+4 \mathrm{H}^{+}$ & 49.7872 & 43.5597 & 35.9292 & 28.4915 & 20.5480 & 13.5459 & 6.9645 & 0.1760 \\
\hline $\mathrm{Pul}_{3}$ & $\mathrm{Pul}_{3}=\mathrm{Pu}^{+++}+3 \mathrm{I}^{-}$ & 30.1003 & 27.2872 & 23.7566 & 20.2269 & 16.3475 & 12.8253 & 9.4258 & 5.8508 \\
\hline PuN & $\mathrm{PuN}+3 \mathrm{H}^{+}=\mathrm{NH}_{3}(\mathrm{aq})+\mathrm{Pu}^{+++}$ & - & 58.1593 & - & - & - & - & - & - \\
\hline $\mathrm{PuO}_{1.61}$ & $\begin{array}{l}\mathrm{PuO}_{1.61}+0.195 \mathrm{O}_{2}(\mathrm{~g})+4 \mathrm{H}^{+}=\mathrm{Pu}^{++++}+ \\
2 \mathrm{H}_{2} \mathrm{O}\end{array}$ & 24.3995 & 20.5992 & 16.2792 & 12.3796 & 8.5623 & 5.5209 & 2.9735 & 0.7320 \\
\hline
\end{tabular}


Table 6-33. Log K EQ3/6 Grids for Solid Phases (Continued)

\begin{tabular}{|c|c|c|c|c|c|c|c|c|c|}
\hline $\begin{array}{l}\text { Data0.ymp.R2 } \\
\text { Species Name }^{\mathrm{a}}\end{array}$ & Reaction & $\begin{array}{l}\log \mathrm{K} \\
0.01^{\circ} \mathrm{C}\end{array}$ & $\begin{array}{l}\log K \\
25^{\circ} \mathrm{C}\end{array}$ & $\begin{array}{l}\log K \\
60^{\circ} \mathrm{C}\end{array}$ & $\begin{array}{l}\log \mathrm{K} \\
100^{\circ} \mathrm{C}\end{array}$ & $\begin{array}{l}\log \mathrm{K} \\
150^{\circ} \mathrm{C}\end{array}$ & $\begin{array}{l}\log K \\
200^{\circ} \mathrm{C}\end{array}$ & $\begin{array}{l}\log \mathrm{K} \\
250^{\circ} \mathrm{C}\end{array}$ & $\begin{array}{l}\log \mathrm{K} \\
300^{\circ} \mathrm{C}\end{array}$ \\
\hline $\mathrm{PuO}_{2}{ }^{\mathrm{C}}$ & $\mathrm{PuO}_{2}+4 \mathrm{H}^{+}=\mathrm{Pu}^{++++}+2 \mathrm{H}_{2} \mathrm{O}$ & -7.1094 & -8.0173 & -9.0228 & -9.9038 & -10.7586 & -11.4701 & -12.1362 & -12.8255 \\
\hline $\mathrm{PuO}_{2}$ (hyd, aged) & $\begin{array}{l}\mathrm{PuO}_{2}(\text { hyd, aged })+4 \mathrm{H}^{+}=\mathrm{Pu}^{++++}+ \\
2 \mathrm{H}_{2} \mathrm{O}\end{array}$ & - & -1.9803 & - & - & - & - & - & - \\
\hline $\mathrm{PuO}_{2}\left(\mathrm{NO}_{3}\right)_{2} \cdot 6 \mathrm{H}_{2} \mathrm{O}$ & $\begin{array}{l}\mathrm{PuO}_{2}\left(\mathrm{NO}_{3}\right)_{2} \cdot 6 \mathrm{H}_{2} \mathrm{O}=\mathrm{PuO}_{2}^{++}+6 \mathrm{H}_{2} \mathrm{O}+ \\
2 \mathrm{NO}_{3}^{-}\end{array}$ & - & 2.4443 & - & - & - & - & - & - \\
\hline $\mathrm{PuO}_{2}(\mathrm{OH})_{2} \cdot \mathrm{H}_{2} \mathrm{O}^{\mathrm{d}}$ & $\begin{array}{l}\mathrm{PuO}_{2}(\mathrm{OH})_{2} \cdot \mathrm{H}_{2} \mathrm{O}+2 \mathrm{H}^{+}=\mathrm{PuO}_{2}^{++}+ \\
3 \mathrm{H}_{2} \mathrm{O}\end{array}$ & - & $5.5000-$ & - & - & - & - & - & - \\
\hline $\mathrm{PuO}_{2} \mathrm{CO}_{3}$ & $\mathrm{PuO}_{2} \mathrm{CO}_{3}+\mathrm{H}^{+}=\mathrm{PuO}_{2}^{++}+\mathrm{HCO}_{3}^{-}$ & - & -3.8567 & - & - & - & - & - & - \\
\hline $\mathrm{PuO}_{2} \mathrm{OH}(\mathrm{am})$ & $\mathrm{PuO}_{2} \mathrm{OH}(\mathrm{am})+\mathrm{H}^{+}=\mathrm{PuO}_{2}{ }^{+}+\mathrm{H}_{2} \mathrm{O}$ & - & 5.0073 & - & - & - & - & - & - \\
\hline $\mathrm{PuOBr}$ & $\mathrm{PuOBr}+2 \mathrm{H}^{+}=\mathrm{Pu}^{+++}+\mathrm{Br}^{-}+\mathrm{H}_{2} \mathrm{O}$ & 16.3616 & 14.3427 & 11.9072 & 9.5748 & 7.1268 & 5.0040 & 3.0407 & 1.0763 \\
\hline $\mathrm{PuOCl}$ & $\mathrm{PuOCl}+2 \mathrm{H}^{+}=\mathrm{Pu}^{+++}+\mathrm{Cl}^{-}+\mathrm{H}_{2} \mathrm{O}$ & 13.1692 & 11.3957 & 9.2448 & 7.1717 & 4.9765 & 3.0494 & 1.2404 & -0.6016 \\
\hline $\mathrm{PuOF}^{\mathrm{c}}$ & $\mathrm{PuOF}+2 \mathrm{H}^{+}=\mathrm{Pu}^{+++}+\mathrm{F}^{-}+\mathrm{H}_{2} \mathrm{O}$ & 2.2336 & 1.1116 & -0.2857 & -1.6605 & -3.1569 & -4.5256 & -5.8808 & -7.3490 \\
\hline $\mathrm{PuOl}^{\mathrm{c}}$ & $\mathrm{PuOI}+2 \mathrm{H}^{+}=\mathrm{Pu}^{+++}+\mathrm{I}^{-}+\mathrm{H}_{2} \mathrm{O}$ & 18.1012 & 16.0237 & 13.5298 & 11.1490 & 8.6571 & 6.5028 & 4.5174 & 2.5390 \\
\hline PuP & $\mathrm{PuP}+\mathrm{H}^{+}+2 \mathrm{O}_{2}(\mathrm{~g})=\mathrm{Pu}^{+++}+\mathrm{HPO}_{4}^{--}$ & - & 237.2760 & - & - & $-\quad$ & - & - & - \\
\hline $\mathrm{PuPO}_{4}(\mathrm{~s}$, hyd $)$ & $\mathrm{PuPO}_{4}(\mathrm{~s}, \mathrm{hyd})+\mathrm{H}^{+}=\mathrm{Pu}^{+++}+\mathrm{HPO}_{4}^{--}$ & - & -13.4500 & - & - & - & - & - & - \\
\hline PuSb & $\begin{array}{l}\mathrm{PuSb}+2 \mathrm{H}^{+}+1.5 \mathrm{O}_{2}(\mathrm{~g})=\mathrm{Pu}^{+++}+\mathrm{SbO}_{2}^{-} \\
+\mathrm{H}_{2} \mathrm{O}\end{array}$ & - & 176.7466 & - & - & - & - & - & - \\
\hline $\mathrm{Ti}_{2} \mathrm{O}_{3}$ & $\mathrm{Ti}_{2} \mathrm{O}_{3}(\mathrm{~s})+4 \mathrm{H}_{2} \mathrm{O}+0.5 \mathrm{O}_{2}=2 \mathrm{Ti}(\mathrm{OH})_{4}(\mathrm{aq})$ & 51.9834 & 46.0376 & 39.0528 & 32.6332 & 26.3242 & 21.3632 & 17.3404 & 13.9500 \\
\hline $\mathrm{Ti}_{3} \mathrm{O}_{5}$ & $\mathrm{Ti}_{3} \mathrm{O}_{5}(\mathrm{~s})+6 \mathrm{H}_{2} \mathrm{O}+0.5 \mathrm{O}_{2}=3 \mathrm{Ti}(\mathrm{OH})_{4}(\mathrm{aq})$ & 45.9328 & 39.8764 & 32.6557 & 25.9696 & 19.3745 & 14.1780 & 9.9526 & 6.3600 \\
\hline $\mathrm{TiB}_{2}$ & $\begin{array}{l}\mathrm{TiB}_{2}+5 \mathrm{H}_{2} \mathrm{O}+2.5 \mathrm{O}_{2}(\mathrm{~g})=\mathrm{Ti}(\mathrm{OH})_{4}(\mathrm{aq})+ \\
2 \mathrm{~B}(\mathrm{OH})_{3}\end{array}$ & 338.0284 & 307.4013 & 272.0411 & 239.6090 & 207.5561 & 182.1678 & 161.5438 & 144.4436 \\
\hline $\mathrm{TiBr}_{3}$ & $\begin{array}{l}\mathrm{TiBr}_{3}+3.5 \mathrm{H}_{2} \mathrm{O}+0.25 \mathrm{O}_{2}(\mathrm{~g})= \\
\mathrm{Ti}(\mathrm{OH})_{4}(\mathrm{aq})+3 \mathrm{Br}^{-}+3 \mathrm{H}^{+}\end{array}$ & 54.0865 & 48.8970 & 42.5601 & 36.4515 & 30.0678 & 24.6382 & 19.7839 & 15.0958 \\
\hline $\mathrm{TiBr}_{4}$ & $\begin{array}{l}\mathrm{TiBr}_{4}+4 \mathrm{H}_{2} \mathrm{O}=\mathrm{Ti}(\mathrm{OH})_{4}(\mathrm{aq})+4 \mathrm{Br}^{-}+ \\
4 \mathrm{H}^{+}\end{array}$ & 38.6712 & 34.9543 & 30.2039 & 25.4361 & 20.2355 & 15.5928 & 11.2104 & 6.6851 \\
\hline $\mathrm{TiCl}_{2}$ & $\begin{array}{l}\mathrm{TiCl}_{2}(\mathrm{~s})+3 \mathrm{H}_{2} \mathrm{O}+0.5 \mathrm{O}_{2}=\mathrm{Ti}(\mathrm{OH})_{4}(\mathrm{aq}) \\
+2 \mathrm{Cl}^{-}+2 \mathrm{H}^{+}\end{array}$ & 79.0523 & 71.4576 & 62.4643 & 54.0315 & 45.4854 & 38.4830 & 32.5072 & 27.1059 \\
\hline $\mathrm{TiCl}_{3}$ & $\begin{array}{l}\mathrm{TiCl}_{3}(\mathrm{~s})+3.5 \mathrm{H}_{2} \mathrm{O}+0.25 \mathrm{O}_{2}= \\
\mathrm{Ti}(\mathrm{OH})_{4}(\mathrm{aq})+3 \mathrm{Cl}^{-}+3 \mathrm{H}^{+}\end{array}$ & 45.2725 & 40.6359 & 34.9411 & 29.4180 & 23.6060 & 18.6214 & 14.1207 & 9.7170 \\
\hline
\end{tabular}


Table 6-33. Log K EQ3/6 Grids for Solid Phases (Continued)

\begin{tabular}{|c|c|c|c|c|c|c|c|c|c|}
\hline $\begin{array}{l}\text { Data0.ymp.R2 } \\
\text { Species Name }^{\text {a }}\end{array}$ & Reaction & $\begin{array}{l}\log \mathrm{K} \\
0.01^{\circ} \mathrm{C} \\
\end{array}$ & $\begin{array}{l}\log K \\
25^{\circ} \mathrm{C} \\
\end{array}$ & $\begin{array}{l}\log \mathrm{K} \\
60^{\circ} \mathrm{C} \\
\end{array}$ & $\begin{array}{l}\log \mathrm{K} \\
100^{\circ} \mathrm{C}\end{array}$ & $\begin{array}{l}\log K \\
150^{\circ} \mathrm{C}\end{array}$ & $\begin{array}{l}\log K \\
200^{\circ} \mathrm{C}\end{array}$ & $\begin{array}{l}\log K \\
250^{\circ} \mathrm{C}\end{array}$ & $\begin{array}{l}\log \mathrm{K} \\
300^{\circ} \mathrm{C}\end{array}$ \\
\hline $\mathrm{TiF}_{3}$ & $\begin{array}{l}\mathrm{TiF}_{3}(\mathrm{~s})+3.5 \mathrm{H}_{2} \mathrm{O}+0.25 \mathrm{O}_{2}= \\
\mathrm{Ti}(\mathrm{OH})_{4}(\mathrm{aq})+3 \mathrm{~F}^{-}+3 \mathrm{H}^{+}\end{array}$ & -25.4440 & -24.9948 & -24.8495 & -25.0287 & -25.5696 & -26.3961 & -27.5442 & -29.1977 \\
\hline $\mathrm{TiF}_{4}(\mathrm{am})$ & $\begin{array}{l}\mathrm{TiF}_{4}(\mathrm{~s})+4 \mathrm{H}_{2} \mathrm{O}=\mathrm{Ti}(\mathrm{OH})_{4}(\mathrm{aq})+4 \mathrm{~F}^{-}+ \\
4 \mathrm{H}^{+}\end{array}$ & -9.2957 & -10.2028 & -11.6980 & -13.4568 & -15.6579 & -17.9151 & -20.3679 & -23.3138 \\
\hline $\mathrm{Til}_{4}$ & $\mathrm{Til}_{4}+4 \mathrm{H}_{2} \mathrm{O}=\mathrm{Ti}(\mathrm{OH})_{4}(\mathrm{aq})+4 \mathrm{I}^{-}+4 \mathrm{H}^{+}$ & 40.4343 & 36.9635 & 32.5191 & 28.0374 & 23.1169 & 18.6929 & 14.4885 & 10.1176 \\
\hline $\mathrm{TiO}$ & $\mathrm{TiO}(\mathrm{s})+2 \mathrm{H}_{2} \mathrm{O}+0.5 \mathrm{O}_{2}=\mathrm{Ti}(\mathrm{OH})_{4}(\mathrm{aq})$ & 65.1565 & 58.6942 & 51.1924 & 44.3201 & 37.5613 & 32.2405 & 27.9350 & 24.3501 \\
\hline Uranium & $\mathrm{U}+2 \mathrm{H}^{+}+1.5 \mathrm{O}_{2}(\mathrm{~g})=\mathrm{UO}_{2}^{++}+\mathrm{H}_{2} \mathrm{O}$ & 229.3696 & 208.4445 & 184.4377 & 162.5347 & 140.9842 & 123.9704 & 110.1644 & 98.6912 \\
\hline $\mathrm{U}\left(\mathrm{SO}_{4}\right)_{2}$ & $\mathrm{U}\left(\mathrm{SO}_{4}\right)_{2}=\mathrm{U}^{++++}+2 \mathrm{SO}_{4}^{--}$ & -10.6470 & -11.9785 & -13.8994 & -16.0361 & -18.6520 & -21.3227 & -24.2285 & -27.6849 \\
\hline $\mathrm{U}_{2} \mathrm{~S}_{3}$ & $\mathrm{U}_{2} \mathrm{~S}_{3}+3 \mathrm{H}^{+}=2 \mathrm{U}^{+++}+3 \mathrm{HS}^{-}$ & 13.0324 & 10.4341 & 7.0450 & 3.5631 & -0.3624 & -4.0266 & -7.6673 & -11.6110 \\
\hline $\mathrm{UBr}_{3}$ & $\mathrm{UBr}_{3}=\mathrm{U}^{+++}+3 \mathrm{Br}^{-}$ & 22.2645 & 19.9367 & 16.9090 & 13.7994 & 10.3020 & 7.0598 & 3.8722 & 0.4518 \\
\hline $\mathrm{UBr}_{4}$ & $\mathrm{UBr}_{4}=\mathrm{U}^{++++}+4 \mathrm{Br}^{-}$ & 35.4871 & 31.2328 & 25.9892 & 20.8389 & 15.2802 & 10.3192 & 5.5990 & 0.6917 \\
\hline $\mathrm{UCl}_{3}$ & $\mathrm{UCl}_{3}=\mathrm{U}^{+++}+3 \mathrm{Cl}^{-}$ & 14.9578 & 13.0401 & 10.4960 & 7.8326 & 4.7734 & 1.8720 & -1.0474 & -4.2567 \\
\hline $\mathrm{UCl}_{4}$ & $\mathrm{UCl}_{4}=\mathrm{U}^{++++}+4 \mathrm{Cl}^{-}$ & 25.6364 & 21.9229 & 17.3180 & 12.7569 & 7.7768 & 3.2649 & -1.1027 & -5.7335 \\
\hline $\mathrm{UCl}_{5}$ & $\mathrm{UCl}_{5}+2 \mathrm{H}_{2} \mathrm{O}=\mathrm{UO}_{2}^{+}+5 \mathrm{Cl}^{-}+4 \mathrm{H}^{+}$ & 37.2989 & 33.8207 & 29.2712 & 24.5499 & 19.1927 & 14.2091 & 9.3248 & 4.1144 \\
\hline $\mathrm{UCl}_{6}$ & $\mathrm{UCl}_{6}+2 \mathrm{H}_{2} \mathrm{O}=\mathrm{UO}_{2}^{++}+6 \mathrm{Cl}^{-}+4 \mathrm{H}^{+}$ & 58.6497 & 53.1432 & 46.2494 & 39.3547 & 31.7911 & 24.9671 & 18.4514 & 11.6658 \\
\hline $\mathrm{UF}_{3}$ & $\mathrm{UF}_{3}=\mathrm{U}^{+++}+3 \mathrm{~F}^{-}$ & -21.2939 & -20.9385 & -20.8561 & -21.0915 & -21.7266 & -22.6949 & -24.0446 & -25.9613 \\
\hline $\mathrm{UF}_{4}$ & $\mathrm{UF}_{4}=\mathrm{U}^{++++}+4 \mathrm{~F}^{-}$ & -30.3023 & -30.3553 & -30.7379 & -31.4059 & -32.5086 & -33.9313 & -35.7859 & -38.3366 \\
\hline $\mathrm{UF}_{5}$ (beta) & $\mathrm{UF}_{5}($ beta $)+2 \mathrm{H}_{2} \mathrm{O}=\mathrm{UO}_{2}^{+}+5 \mathrm{~F}^{-}+4 \mathrm{H}^{+}$ & -12.6329 & -13.1683 & -14.3055 & -15.8537 & -18.0219 & -20.4464 & -23.2437 & -26.7308 \\
\hline $\mathrm{UF}_{6}$ & $\mathrm{UF}_{6}+2 \mathrm{H}_{2} \mathrm{O}=\mathrm{UO}_{2}^{++}+6 \mathrm{~F}^{-}+4 \mathrm{H}^{+}$ & 21.5553 & 17.5678 & 12.4557 & 7.2463 & 1.3981 & -4.0509 & -9.4686 & -15.3832 \\
\hline $\mathrm{UI}_{3}$ & $\mathrm{UI}_{3}=\mathrm{U}^{+++}+3 \mathrm{I}^{-}$ & 32.9911 & 29.9408 & 26.0968 & 22.2421 & 18.0049 & 14.1734 & 10.5065 & 6.6935 \\
\hline $\mathrm{UI}_{4}$ & $U I_{4}=U^{++++}+4 I^{-}$ & 45.2686 & 40.4934 & 34.6660 & 28.9791 & 22.8794 & 17.4804 & 12.3999 & 7.1975 \\
\hline $\mathrm{UO}_{2} \mathrm{Br}_{2}$ & $\mathrm{UO}_{2} \mathrm{Br}_{2}=\mathrm{UO}_{2}^{++}+2 \mathrm{Br}^{-}$ & 18.4072 & 16.4880 & 14.0969 & 11.7192 & 9.1185 & 6.7682 & 4.5068 & 2.1241 \\
\hline $\mathrm{UO}_{2} \mathrm{Cl}_{2}$ & $\mathrm{UO}_{2} \mathrm{Cl}_{2}=\mathrm{UO}_{2}^{++}+2 \mathrm{Cl}^{-}$ & 13.7845 & 12.1037 & 9.9923 & 7.8698 & 5.5163 & 3.3543 & 1.2376 & -1.0345 \\
\hline $\mathrm{UO}_{2} \mathrm{~F}_{2}$ & $\mathrm{UO}_{2} \mathrm{~F}_{2}=\mathrm{UO}_{2}^{++}+2 \mathrm{~F}^{-}$ & -5.6669 & -6.2647 & -7.1248 & -8.0882 & -9.2818 & -10.5178 & -11.8836 & -13.5398 \\
\hline $\mathrm{UO}_{2} \mathrm{SO}_{4}$ & $\mathrm{UO}_{2} \mathrm{SO}_{4}=\mathrm{UO}_{2}^{++}+\mathrm{SO}_{4}^{--}$ & 3.6829 & 2.4282 & 0.7802 & -0.9327 & -2.8940 & -4.7579 & -6.6467 & -8.7462 \\
\hline $\mathrm{UO}_{3}$ (gamma) & $\mathrm{UO}_{3}($ gamma $)+2 \mathrm{H}^{+}=\mathrm{UO}_{2}^{++}+\mathrm{H}_{2} \mathrm{O}$ & 9.1979 & 7.8659 & 6.3470 & 4.9650 & 3.5935 & 2.4792 & 1.5215 & 0.6449 \\
\hline $\mathrm{UOBr}_{2}$ & $\mathrm{UOBr}_{2}+2 \mathrm{H}^{+}=\mathrm{U}^{++++}+2 \mathrm{Br}^{-}+\mathrm{H}_{2} \mathrm{O}$ & 10.2611 & 7.9817 & 5.2022 & 2.4995 & -0.4037 & -3.0057 & -5.5155 & -8.1697 \\
\hline $\mathrm{UOBr}_{3}$ & $\mathrm{UOBr}_{3}+\mathrm{H}_{2} \mathrm{O}=\mathrm{UO}_{2}^{+}+3 \mathrm{Br}^{-}+2 \mathrm{H}^{+}$ & 25.8237 & 23.5777 & 20.6216 & 17.5499 & 14.0696 & 10.8442 & 7.7008 & 4.3767 \\
\hline
\end{tabular}


Table 6-33. Log K EQ3/6 Grids for Solid Phases (Continued)

\begin{tabular}{|c|c|c|c|c|c|c|c|c|c|}
\hline $\begin{array}{l}\text { Data0.ymp.R2 } \\
\text { Species Name }^{\text {a }}\end{array}$ & Reaction & $\begin{array}{l}\log \mathrm{K} \\
0.01^{\circ} \mathrm{C}\end{array}$ & $\begin{array}{l}\log K \\
25^{\circ} \mathrm{C}\end{array}$ & $\begin{array}{l}\log K \\
60^{\circ} \mathrm{C}\end{array}$ & $\begin{array}{l}\log K \\
100^{\circ} \mathrm{C}\end{array}$ & $\begin{array}{l}\log K \\
150^{\circ} \mathrm{C}\end{array}$ & $\begin{array}{l}\log K \\
200^{\circ} \mathrm{C}\end{array}$ & $\begin{array}{l}\log K \\
250^{\circ} \mathrm{C}\end{array}$ & $\begin{array}{l}\log \mathrm{K} \\
300^{\circ} \mathrm{C}\end{array}$ \\
\hline $\mathrm{UOCl}$ & $\mathrm{UOCl}+2 \mathrm{H}^{+}=\mathrm{U}^{+++}+\mathrm{Cl}^{-}+\mathrm{H}_{2} \mathrm{O}$ & -9.8816 & -9.7309 & -9.7123 & -9.8415 & -10.1594 & -10.6310 & -11.2776 & -12.1751 \\
\hline $\mathrm{UOCl}_{2}$ & $\mathrm{UOCl}_{2}+2 \mathrm{H}^{+}=\mathrm{U}^{++++}+2 \mathrm{Cl}^{-}+\mathrm{H}_{2} \mathrm{O}$ & 8.1372 & 5.8869 & 3.1513 & 0.4936 & -2.3634 & -4.9300 & -7.4145 & -10.0529 \\
\hline $\mathrm{UOCl}_{3}$ & $\mathrm{UOCl}_{3}+\mathrm{H}_{2} \mathrm{O}=\mathrm{UO}_{2}^{+}+3 \mathrm{Cl}^{-}+2 \mathrm{H}^{+}$ & 9.6633 & 8.5736 & 6.9562 & 5.1092 & 2.8309 & 0.5461 & -1.8456 & -4.5610 \\
\hline $\mathrm{WCl}_{2}(\mathrm{~s})$ & $\begin{array}{l}\mathrm{WCl}_{2}(\mathrm{~s})+2 \mathrm{H}_{2} \mathrm{O}+\mathrm{O}_{2}(\mathrm{~g})=\mathrm{WO}_{4}^{--}+2 \mathrm{Cl}^{-} \\
+4 \mathrm{H}^{+}\end{array}$ & 93.6338 & 84.5211 & 73.6761 & 63.3790 & 52.7437 & 43.8115 & 35.9624 & 28.6009 \\
\hline $\mathrm{WCl}_{4}(\mathrm{~s})$ & $\begin{array}{l}\mathrm{WCl}_{4}(\mathrm{~s})+3 \mathrm{H}_{2} \mathrm{O}+0.5 \mathrm{O}_{2}=\mathrm{WO}_{4}^{--}+ \\
4 \mathrm{Cl}^{-}+6 \mathrm{H}^{+}\end{array}$ & 71.3689 & 64.5388 & 56.1177 & 47.8276 & 38.9055 & 31.0428 & 23.7400 & 16.3841 \\
\hline $\mathrm{WCl}_{5}(\mathrm{~s})$ & $\begin{array}{l}\mathrm{WCl}_{5}(\mathrm{~s})+3.5 \mathrm{H}_{2} \mathrm{O}+0.25 \mathrm{O}_{2}=\mathrm{WO}_{4}{ }^{--}+ \\
5 \mathrm{Cl}^{-}+7 \mathrm{H}^{+}\end{array}$ & 65.4016 & 59.3442 & 51.7106 & 44.0347 & 35.5828 & 27.9461 & 20.6622 & 13.0949 \\
\hline $\mathrm{WCl}_{6}(\mathrm{~s})$ & $\mathrm{WCl}_{6}(\mathrm{~s})+4 \mathrm{H}_{2} \mathrm{O}=\mathrm{WO}_{4}{ }^{--}+6 \mathrm{Cl}^{-}+8 \mathrm{H}^{+}$ & 57.2682 & 52.1561 & 45.5135 & 38.6433 & 30.8566 & 23.6054 & 16.4742 & 8.8097 \\
\hline $\mathrm{WO}_{2} \mathrm{Cl}_{2}(\mathrm{~s})$ & $\begin{array}{l}\mathrm{WO}_{2} \mathrm{Cl}_{2}(\mathrm{~s})+2 \mathrm{H}_{2} \mathrm{O}=\mathrm{WO}_{4}{ }^{--}+2 \mathrm{Cl}^{-}+ \\
4 \mathrm{H}^{+}\end{array}$ & 0.6693 & -0.0612 & -1.2805 & -2.7892 & -4.7792 & -6.8982 & -9.2424 & -12.0657 \\
\hline $\mathrm{WOCl}_{4}(\mathrm{~s})$ & $\mathrm{WOCl}_{4}(\mathrm{~s})+3 \mathrm{H}_{2} \mathrm{O}=\mathrm{WO}_{4}{ }^{--}+4 \mathrm{Cl}^{-}+6 \mathrm{H}^{+}$ & 34.4557 & 31.2806 & 27.0555 & 22.5950 & 17.4379 & 12.5397 & 7.6296 & 2.2438 \\
\hline $\mathrm{WOF}_{4}(\mathrm{~s})$ & $\mathrm{WOF}_{4}(\mathrm{~s})+3 \mathrm{H}_{2} \mathrm{O}=\mathrm{WO}_{4}^{--}+4 \mathrm{~F}^{-}+6 \mathrm{H}^{+}$ & 10.1133 & 7.7357 & 4.4528 & 0.8968 & -3.3209 & -7.4485 & -11.7279 & -16.5992 \\
\hline
\end{tabular}

DTN: MO0302SPATHDYN.000 [DIRS 161756].

a See data file data0.ymp.R2 (DTN: MO0302SPATHDYN.000 [DIRS 161756]) for spreadsheets used to calculate log K grids.

b The equation for $\mathrm{CoF}_{3}$ is corrected from the data0.ymp.R2 database (DTN: MO0302SPATHDYN.000 [DIRS 161756]), which gives an equation for CoCl 3 .

${ }^{c}$ For the species $\mathrm{NpC}_{0.91}(\mathrm{cr}), \mathrm{Pu}_{2} \mathrm{C}_{3}(\mathrm{cr}), \mathrm{PuC}_{0.84}(\mathrm{cr}), \mathrm{PuOI}(\mathrm{cr}), \mathrm{PuOF}(\mathrm{cr})$, and $\mathrm{PuO}_{2}(\mathrm{cr})$, the heat capacity coefficients given by Lemire (2001 [DIRS 159027])

were inappropriately applied as Maier-Kelly parameters (see Section 6.3.4.5).

The formula for $\mathrm{PuO}_{2}(\mathrm{OH})_{2} \cdot \mathrm{H}_{2} \mathrm{O}$ is corrected from the data0.ymp.R2 database (DTN: MO0302SPATHDYN.000 [DIRS 161756]), which gives $\mathrm{PuO}_{2}(\mathrm{OH})_{2} \cdot 2 \mathrm{H}_{2} \mathrm{O}$. The corrected form is consistent with Lemire (2001 [DIRS 159027], Section 17.2.2.1). 
Table 6-34. Corrected Log K EQ3/6 Grids for Np and Pu Solid Phases

\begin{tabular}{|c|c|c|c|c|c|c|c|c|c|}
\hline $\begin{array}{l}\text { Data0.ymp.R2 } \\
\text { Species Name }\end{array}$ & Reaction & $\begin{array}{l}\log \mathrm{K} \\
0.01^{\circ} \mathrm{C}\end{array}$ & $\begin{array}{l}\log \mathrm{K} \\
25^{\circ} \mathrm{C}\end{array}$ & $\begin{array}{l}\log \mathrm{K} \\
60^{\circ} \mathrm{C}\end{array}$ & $\begin{array}{l}\log \mathrm{K} \\
100^{\circ} \mathrm{C}\end{array}$ & $\begin{array}{l}\log \mathrm{K} \\
150^{\circ} \mathrm{C}\end{array}$ & $\begin{array}{l}\log \mathrm{K} \\
200^{\circ} \mathrm{C}\end{array}$ & $\begin{array}{l}\log \mathrm{K} \\
250^{\circ} \mathrm{C}\end{array}$ & $\begin{array}{l}\log \mathrm{K} \\
300^{\circ} \mathrm{C}\end{array}$ \\
\hline $\mathrm{Na}_{3} \mathrm{NpF}_{8}$ & $\begin{array}{l}\mathrm{Na}_{3} \mathrm{NpF}_{8}+2 \mathrm{H}_{2} \mathrm{O}=\mathrm{NpO}_{2}{ }^{+}+3 \mathrm{Na}^{+}+4 \mathrm{H}^{+} \\
+8 \mathrm{~F}^{-}\end{array}$ & -7.2110 & -8.4426 & -10.5811 & -13.2128 & -16.6747 & -20.4159 & -24.6880 & -30.0499 \\
\hline $\mathrm{Np}$ & $\mathrm{Np}+3 \mathrm{H}^{+}+0.75 \mathrm{O}_{2}(\mathrm{~g})=\mathrm{Np}^{+++}+1.5 \mathrm{H}_{2} \mathrm{O}$ & 167.5129 & 152.1799 & 134.5579 & 118.4599 & 102.5893 & 90.0115 & 79.7396 & 71.1257 \\
\hline $\mathrm{Np}_{2} \mathrm{O}_{5}$ & $\mathrm{~Np}_{2} \mathrm{O}_{5}+2 \mathrm{H}^{+}=2 \mathrm{NpO}_{2}^{+}+\mathrm{H}_{2} \mathrm{O}$ & 4.9214 & 3.7031 & 2.1757 & 0.6695 & -0.9387 & -2.3319 & -3.5852 & -4.7609 \\
\hline $\mathrm{NpBr}_{3}$ & $\mathrm{NpBr}_{3}=\mathrm{Np}^{+++}+3 \mathrm{Br}^{-}$ & 23.3940 & 20.9379 & 17.8023 & 14.6289 & 11.0996 & 7.8519 & 4.6698 & 1.2647 \\
\hline $\mathrm{NpBr}_{4}$ & $\mathrm{NpBr}_{4}=\mathrm{Np}^{++++}+4 \mathrm{Br}^{-}$ & 34.0049 & 29.8101 & 24.6427 & 19.5708 & 14.1006 & 9.2201 & 4.5750 & -0.2600 \\
\hline $\mathrm{NpC}_{0.91}{ }^{*}$ & $\begin{array}{l}\mathrm{NpC}_{0.91}+2.09 \mathrm{H}^{+}+1.66 \mathrm{O}_{2}(\mathrm{~g})=\mathrm{Np}^{+++}+ \\
0.91 \mathrm{HCO}_{3}^{-}+0.59 \mathrm{H}_{2} \mathrm{O}\end{array}$ & 214.6573 & 194.6217 & 171.5199 & 150.3350 & 129.3544 & 112.6364 & 98.8906 & 87.2297 \\
\hline $\mathrm{NpCl}_{3}$ & $\mathrm{NpCl}_{3}=\mathrm{Np}^{+++}+3 \mathrm{Cl}^{-}$ & 15.4590 & 13.4766 & 10.8928 & 8.2227 & 5.1830 & 2.3122 & -0.5754 & -3.7500 \\
\hline $\mathrm{NpCl}_{4}$ & $\mathrm{NpCl}_{4}=\mathrm{Np}^{++++}+4 \mathrm{Cl}^{-}$ & 24.9771 & 21.2634 & 16.6608 & 12.1047 & 7.1338 & 2.6337 & -1.7192 & -6.3314 \\
\hline $\mathrm{NpF}_{3}$ & $\mathrm{NpF}_{3}=\mathrm{Np}^{+++}+3 \mathrm{~F}^{-}$ & -17.9914 & -17.9369 & -18.1629 & -18.6483 & -19.5023 & -20.6271 & -22.0960 & -24.1022 \\
\hline $\mathrm{NpF}_{4}$ & $\mathrm{NpF}_{4}=\mathrm{Np}^{++++}+4 \mathrm{~F}^{-}$ & -28.6681 & -28.9106 & -29.5043 & -30.3588 & -31.6397 & -33.1997 & -35.1650 & -37.8092 \\
\hline $\mathrm{NpF}_{5}$ & $\mathrm{NpF}_{5}+2 \mathrm{H}_{2} \mathrm{O}=\mathrm{NpO}^{+}+5 \mathrm{~F}^{-}+4 \mathrm{H}^{+}$ & 3.4150 & 1.3534 & -1.5354 & -4.6820 & -8.4205 & -12.0804 & -15.8728 & -20.1758 \\
\hline $\mathrm{NpF}_{6}$ & $\mathrm{NpF}_{6}+2 \mathrm{H}_{2} \mathrm{O}=\mathrm{NpO}_{2}^{++}+4 \mathrm{H}^{+}+6 \mathrm{~F}^{-}$ & 34.9067 & 29.8193 & 23.4454 & 17.0862 & 10.1113 & 3.7797 & -2.3444 & -8.8333 \\
\hline $\mathrm{Npl}_{3}$ & $\mathrm{Npl}_{3}+\mathrm{Np}^{+++}+3 \mathrm{I}^{-}$ & 30.2017 & 27.3544 & 23.7814 & 20.2075 & 16.2767 & 12.7058 & 9.2596 & 5.6395 \\
\hline $\mathrm{NpN}$ & $\mathrm{NpN}+3 \mathrm{H}^{+}=\mathrm{Np}^{+++}+\mathrm{NH}_{3}(\mathrm{aq})$ & 52.2383 & 47.2199 & 41.4246 & 36.1091 & 30.8326 & 26.5962 & 23.0622 & 20.0070 \\
\hline
\end{tabular}


Table 6-34. Corrected Log K EQ3/6 Grids for Np and Pu Solid Phases (Continued)

\begin{tabular}{|c|c|c|c|c|c|c|c|c|c|}
\hline $\begin{array}{l}\text { Data0.ymp.R2 } \\
\text { Species Name } \\
\end{array}$ & Reaction & $\begin{array}{l}\log \mathrm{K} \\
0.01^{\circ} \mathrm{C} \\
\end{array}$ & $\begin{array}{l}\log \mathrm{K} \\
25^{\circ} \mathrm{C}\end{array}$ & $\begin{array}{l}\log \mathrm{K} \\
60^{\circ} \mathrm{C}\end{array}$ & $\begin{array}{l}\log \mathrm{K} \\
100^{\circ} \mathrm{C} \\
\end{array}$ & $\begin{array}{l}\log \mathrm{K} \\
150^{\circ} \mathrm{C} \\
\end{array}$ & $\begin{array}{l}\log \mathrm{K} \\
200^{\circ} \mathrm{C} \\
\end{array}$ & $\begin{array}{l}\log \mathrm{K} \\
250^{\circ} \mathrm{C} \\
\end{array}$ & $\begin{array}{l}\log \mathrm{K} \\
300^{\circ} \mathrm{C}\end{array}$ \\
\hline $\mathrm{NpOBr}_{2}$ & $\mathrm{NpOBr}_{2}+2 \mathrm{H}^{+}=\mathrm{Np}^{++++}+2 \mathrm{Br}^{-}+\mathrm{H}_{2} \mathrm{O}$ & 7.3768 & 5.2794 & 2.7183 & 0.2240 & -2.4643 & -4.8887 & -7.2475 & -9.7693 \\
\hline $\mathrm{NpOCl}_{2}$ & $\mathrm{NpOCl}_{2}+2 \mathrm{H}^{+}=\mathrm{Np}^{++++}+2 \mathrm{Cl}^{-}+\mathrm{H}_{2} \mathrm{O}$ & 7.6917 & 5.4117 & 2.6473 & -0.0317 & -2.9041 & -5.4784 & -7.9642 & -10.5985 \\
\hline $\mathrm{Cs}_{3} \mathrm{PuCl}_{6}$ & $\mathrm{Cs}_{3} \mathrm{PuCl}_{6}=\mathrm{Pu}^{+++}+3 \mathrm{Cs}^{+}+6 \mathrm{Cl}^{-}$ & 76.2000 & 70.6870 & 63.7152 & 56.7349 & 49.0858 & 42.1827 & 35.5667 & 28.6366 \\
\hline $\mathrm{CsPu}_{2} \mathrm{Cl}_{7}$ & $\mathrm{CsPu}_{2} \mathrm{Cl}_{7}=2 \mathrm{Pu}^{+++}+\mathrm{Cs}^{+}+7 \mathrm{Cl}^{-}$ & 31.8127 & 28.1392 & 23.1957 & 17.9614 & 11.8680 & 5.9881 & -0.0505 & -6.8394 \\
\hline $\mathrm{Pu}$ & $\mathrm{Pu}+\mathrm{O}_{2}(\mathrm{~g})+4 \mathrm{H}^{+}=\mathrm{Pu}^{++++}+2 \mathrm{H}_{2} \mathrm{O}$ & 184.6805 & 166.8458 & 146.4150 & 127.8093 & 109.5241 & 95.0752 & 83.3017 & 73.4433 \\
\hline $\mathrm{Pu}_{2} \mathrm{C}_{3}{ }^{*}$ & $\begin{array}{l}\mathrm{Pu}_{2} \mathrm{C}_{3}+3 \mathrm{H}^{+}+4.5 \mathrm{O}_{2}(\mathrm{~g})=2 \mathrm{Pu}^{+++} \\
+3 \mathrm{HCO}_{3}^{-}\end{array}$ & 533.5625 & 483.9329 & 426.6540 & 374.0675 & 321.9198 & 280.3062 & 246.0339 & 216.8757 \\
\hline $\mathrm{Pu}_{2} \mathrm{O}_{3}$ & $\mathrm{Pu}_{2} \mathrm{O}_{3}+6 \mathrm{H}^{+}=3 \mathrm{H}_{2} \mathrm{O}+2 \mathrm{Pu}^{+++}$ & 56.8079 & 50.6550 & 43.5537 & 37.0502 & 30.5909 & 25.3763 & 20.9682 & 17.0707 \\
\hline $\mathrm{Pu}_{3} \mathrm{C}_{2}$ & $\begin{array}{l}\mathrm{Pu}_{3} \mathrm{C}_{2}+7 \mathrm{H}^{+}+4.25 \mathrm{O}_{2}(\mathrm{~g})=3 \mathrm{Pu}^{+++} \\
+2 \mathrm{HCO}_{3}^{-}+2.5 \mathrm{H}_{2} \mathrm{O}\end{array}$ & 652.3246 & 592.2086 & 522.9512 & 459.5030 & 396.7466 & 346.8247 & 305.8727 & 271.2665 \\
\hline $\mathrm{PuBr}_{3}$ & $\mathrm{PuBr}_{3}=\mathrm{Pu}^{+++}+3 \mathrm{Br}^{-}$ & 24.1856 & 21.6939 & 18.5185 & 15.3107 & 11.7509 & 8.4824 & 5.2862 & 1.8718 \\
\hline $\mathrm{PuC}_{0.84^{*}}$ & $\begin{array}{l}\mathrm{PuC}_{0.84}+1.59 \mathrm{O}_{2}(\mathrm{~g})+2.16 \mathrm{H}_{+}= \\
0.84 \mathrm{HCO}_{3}^{-}+0.66 \mathrm{H}_{2} \mathrm{O}+\mathrm{Pu}^{+++}\end{array}$ & 227.5412 & 206.5054 & 182.2628 & 160.0451 & 138.0603 & 120.5633 & 106.2012 & 94.0495 \\
\hline $\mathrm{PuCl}_{3}$ & $\mathrm{PuCl}_{3}=\mathrm{Pu}^{+++}+3 \mathrm{Cl}^{-}$ & 16.2103 & 14.1989 & 11.5823 & 8.8837 & 5.8185 & 2.9307 & 0.0318 & -3.1500 \\
\hline $\mathrm{PuF}_{3}$ & $\mathrm{PuF}_{3}=\mathrm{Pu}^{+++}+3 \mathrm{~F}^{-}$ & -16.2599 & -16.3164 & -16.6688 & -17.2675 & -18.2297 & -19.4362 & -20.9682 & -23.0240 \\
\hline $\mathrm{PuF}_{6}$ & $\mathrm{PuF}_{6}+2 \mathrm{H}_{2} \mathrm{O}=6 \mathrm{~F}^{-}+\mathrm{PuO}_{2}^{++}+4 \mathrm{H}^{+}$ & 49.7680 & 43.5597 & 35.8984 & 28.3650 & 20.2382 & 13.0028 & 6.1526 & -0.9311 \\
\hline $\mathrm{Pul}_{3}$ & $\mathrm{Pul}_{3}=\mathrm{Pu}^{+++}+3 \mathrm{I}^{-}$ & 30.0992 & 27.2872 & 23.7547 & 20.2190 & 16.3282 & 12.7915 & 9.3753 & 5.7819 \\
\hline $\mathrm{PuO}_{1.61}$ & $\begin{array}{l}\mathrm{PuO}_{1.61}+0.195 \mathrm{O}_{2}(\mathrm{~g})+4 \mathrm{H}^{+}=\mathrm{Pu}^{++++}+ \\
2 \mathrm{H}_{2} \mathrm{O}\end{array}$ & 24.4008 & 20.5992 & 16.2807 & 12.3845 & 8.5714 & 5.5327 & 2.9861 & 0.7435 \\
\hline $\mathrm{PuO}_{2}{ }^{*}$ & $\mathrm{PuO}_{2}+4 \mathrm{H}^{+}=\mathrm{Pu}^{++++}+2 \mathrm{H}_{2} \mathrm{O}$ & -7.1053 & -8.0173 & -9.0177 & -9.8854 & -10.7201 & -11.4116 & -12.0598 & -12.7335 \\
\hline $\mathrm{PuOBr}$ & $\mathrm{PuOBr}+2 \mathrm{H}^{+}=\mathrm{Pu}^{+++}+\mathrm{Br}^{-}+\mathrm{H}_{2} \mathrm{O}$ & 16.3619 & 14.3427 & 11.9073 & 9.5742 & 7.1237 & 4.9960 & 3.0258 & 1.0526 \\
\hline $\mathrm{PuOCl}$ & $\mathrm{PuOCl}+2 \mathrm{H}^{+}=\mathrm{Pu}^{+++}+\mathrm{Cl}^{-}+\mathrm{H}_{2} \mathrm{O}$ & 13.1696 & 11.3957 & 9.2450 & 7.1719 & 4.9750 & 3.0439 & 1.2289 & -0.6210 \\
\hline $\mathrm{PuOF}^{*}$ & $\mathrm{PuOF}+2 \mathrm{H}^{+}=\mathrm{Pu}^{+++}+\mathrm{F}^{-}+\mathrm{H}_{2} \mathrm{O}$ & 2.2342 & 1.1116 & -0.2852 & -1.6594 & -3.1564 & -4.5278 & -5.8875 & -7.3622 \\
\hline $\mathrm{PuOl}^{*}$ & $\mathrm{PuOI}+2 \mathrm{H}^{+}=\mathrm{Pu}^{+++}+\mathrm{I}^{-}+\mathrm{H}_{2} \mathrm{O}$ & 18.0993 & 16.0237 & 13.5267 & 11.1361 & 8.6251 & 6.4461 & 4.4321 & 2.4222 \\
\hline
\end{tabular}

Output DTN: SN0410T0510404.001 (Spreadsheets Minerals_j_PVB_Pu_CFJC_fix.xIs and Minerals_j_PVB_Np_CFJC_fix.xIs).

* For the species $\mathrm{NpC}_{0.91}(\mathrm{cr}), \mathrm{Pu}_{2} \mathrm{C}_{3}(\mathrm{cr}), \mathrm{PuC}_{0.84}(\mathrm{cr}), \mathrm{PuOI}(\mathrm{cr}), \mathrm{PuOF}(\mathrm{cr})$, and $\mathrm{PuO}_{2}(\mathrm{cr})$, the heat capacity coefficients given by Lemire (2001 [DIRS 159027]) were inappropriately applied as Maier-Kelly parameters (see Section 6.3.4.5). 
Table 6-35. $\Delta$ Log K (Difference Between Incorrect and Corrected Values) for Np and Pu Solid Phases

\begin{tabular}{|c|c|c|c|c|c|c|c|c|c|}
\hline $\begin{array}{l}\text { Data0.ymp.R2 } \\
\text { Species Name }\end{array}$ & Reaction & $\begin{array}{l}\log \mathrm{K} \\
0.01^{\circ} \mathrm{C}\end{array}$ & $\begin{array}{l}\log \mathrm{K} \\
25^{\circ} \mathrm{C}\end{array}$ & $\begin{array}{l}\log \mathrm{K} \\
60^{\circ} \mathrm{C}\end{array}$ & $\begin{array}{l}\log K \\
100^{\circ} \mathrm{C}\end{array}$ & $\begin{array}{l}\log \mathrm{K} \\
150^{\circ} \mathrm{C}\end{array}$ & $\begin{array}{l}\log K \\
200^{\circ} \mathrm{C}\end{array}$ & $\begin{array}{l}\log K \\
250^{\circ} \mathrm{C}\end{array}$ & $\begin{array}{l}\log \mathrm{K} \\
300^{\circ} \mathrm{C}\end{array}$ \\
\hline $\mathrm{Na}_{3} \mathrm{NpF}_{8}$ & $\begin{array}{l}\mathrm{Na}_{3} \mathrm{NpF}_{8}+2 \mathrm{H}_{2} \mathrm{O}=\mathrm{NpO}_{2}^{+}+3 \mathrm{Na}^{+}+4 \\
\mathrm{H}^{+}+8 \mathrm{~F}^{-}\end{array}$ & -0.0002 & 0.0000 & -0.0012 & -0.0068 & -0.0212 & -0.0433 & -0.0723 & -0.1069 \\
\hline $\mathrm{Np}$ & $\mathrm{Np}+3 \mathrm{H}^{+}+0.75 \mathrm{O}_{2}(\mathrm{~g})=\mathrm{Np}^{+++}+1.5 \mathrm{H}_{2} \mathrm{O}$ & -0.0069 & 0.0000 & -0.0105 & -0.0420 & -0.1002 & -0.1718 & -0.2522 & -0.3387 \\
\hline $\mathrm{Np}_{2} \mathrm{O}_{5}$ & $\mathrm{~Np}_{2} \mathrm{O}_{5}+2 \mathrm{H}^{+}=2 \mathrm{NpO}_{2}^{+}+\mathrm{H}_{2} \mathrm{O}$ & -0.0059 & 0.0000 & -0.0095 & -0.0388 & -0.0950 & -0.1665 & -0.2489 & -0.3394 \\
\hline $\mathrm{NpBr}_{3}$ & $\mathrm{NpBr}_{3}=\mathrm{Np}^{+++}+3 \mathrm{Br}^{-}$ & -0.0004 & 0.0000 & -0.0009 & -0.0043 & -0.0117 & -0.0221 & -0.0348 & -0.0495 \\
\hline $\mathrm{NpBr}_{4}$ & $\mathrm{NpBr}_{4}=\mathrm{Np}^{++++}+4 \mathrm{Br}^{-}$ & -0.0018 & 0.0000 & -0.0029 & -0.0118 & -0.0289 & -0.0507 & -0.0757 & -0.1033 \\
\hline $\mathrm{NpC}_{0.91}$ & $\begin{array}{l}\mathrm{NpC}_{0.91}+2.09 \mathrm{H}^{+}+1.66 \mathrm{O}_{2}(\mathrm{~g})=\mathrm{Np}^{+++}+ \\
0.91 \mathrm{HCO}_{3}^{-}+0.59 \mathrm{H}_{2} \mathrm{O}\end{array}$ & 0.0030 & 0.0000 & 0.0045 & 0.0180 & 0.0429 & 0.0736 & 0.1080 & 0.1450 \\
\hline $\mathrm{NpCl}_{3}$ & $\mathrm{NpCl}_{3}=\mathrm{Np}^{+++}+3 \mathrm{Cl}^{-}$ & -0.0025 & 0.0000 & -0.0038 & -0.0151 & -0.0357 & -0.0609 & -0.0890 & -0.1190 \\
\hline $\mathrm{NpCl}_{4}$ & $\mathrm{NpCl}_{4}=\mathrm{Np}^{++++}+4 \mathrm{Cl}^{-}$ & -0.0019 & 0.0000 & -0.0031 & -0.0129 & -0.0319 & -0.0564 & -0.0849 & -0.1165 \\
\hline $\mathrm{NpF}_{3}$ & $\mathrm{NpF}_{3}=\mathrm{Np}^{+++}+3 \mathrm{~F}^{-}$ & 0.0024 & 0.0000 & 0.0032 & 0.0115 & 0.0249 & 0.0388 & 0.0523 & 0.0648 \\
\hline $\mathrm{NpF}_{4}$ & $\mathrm{NpF}_{4}=\mathrm{Np}^{++++}+4 \mathrm{~F}^{-}$ & 0.0015 & 0.0000 & 0.0018 & 0.0061 & 0.0121 & 0.0173 & 0.0210 & 0.0232 \\
\hline $\mathrm{NpF}_{5}$ & $\mathrm{NpF}_{5}+2 \mathrm{H}_{2} \mathrm{O}=\mathrm{NpO}_{2}^{+}+5 \mathrm{~F}^{-}+4 \mathrm{H}^{+}$ & -0.0018 & 0.0000 & -0.0029 & -0.0118 & -0.0289 & -0.0507 & -0.0757 & -0.1033 \\
\hline $\mathrm{NpF}_{6}$ & $\mathrm{NpF}_{6}+2 \mathrm{H}_{2} \mathrm{O}=\mathrm{NpO}_{2}^{++}+4 \mathrm{H}^{+}+6 \mathrm{~F}^{-}$ & -0.0210 & 0.0000 & -0.0338 & -0.1387 & -0.3396 & -0.5954 & -0.8901 & -1.2137 \\
\hline $\mathrm{Npl}_{3}$ & $\mathrm{Npl}_{3}+\mathrm{Np}^{+++}+3 \mathrm{I}^{-}$ & -0.0012 & 0.0000 & -0.0019 & -0.0079 & -0.0193 & -0.0338 & -0.0505 & -0.0689 \\
\hline $\mathrm{NpN}$ & $\mathrm{NpN}+3 \mathrm{H}^{+}=\mathrm{Np}^{+++}+\mathrm{NH}_{3}(\mathrm{aq})$ & -0.0002 & 0.0000 & -0.0004 & -0.0021 & -0.0061 & -0.0119 & -0.0193 & -0.0279 \\
\hline $\mathrm{NpO}_{2}$ & $\mathrm{NpO}_{2}+4 \mathrm{H}^{+}=\mathrm{Np}^{++++}+2 \mathrm{H}_{2} \mathrm{O}$ & 0.0004 & 0.0000 & 0.0001 & -0.0007 & -0.0046 & -0.0120 & -0.0226 & -0.0362 \\
\hline $\mathrm{NpOBr}_{2}$ & $\mathrm{NpOBr}_{2}+2 \mathrm{H}^{+}=\mathrm{Np}^{++++}+2 \mathrm{Br}^{-}+\mathrm{H}_{2} \mathrm{O}$ & 0.0029 & 0.0000 & 0.0035 & 0.0124 & 0.0253 & 0.0372 & 0.0469 & 0.0543 \\
\hline $\mathrm{NpOCl}_{2}$ & $\mathrm{NpOCl}_{2}+2 \mathrm{H}^{+}=\mathrm{Np}^{++++}+2 \mathrm{Cl}^{-}+\mathrm{H}_{2} \mathrm{O}$ & 0.0009 & 0.0000 & 0.0009 & 0.0023 & 0.0024 & -0.0002 & -0.0055 & -0.0135 \\
\hline $\mathrm{Cs}_{3} \mathrm{PuCl}_{6}$ & $\mathrm{Cs}_{3} \mathrm{PuCl}_{6}=\mathrm{Pu}^{+++}+3 \mathrm{Cs}^{+}+6 \mathrm{Cl}^{-}$ & -0.0002 & 0.0000 & -0.0009 & -0.0048 & -0.0144 & -0.0287 & -0.0471 & -0.0691 \\
\hline $\mathrm{CsPu}_{2} \mathrm{Cl}_{7}$ & $\mathrm{CsPu}_{2} \mathrm{Cl}_{7}=2 \mathrm{Pu}^{+++}+\mathrm{Cs}^{+}+7 \mathrm{Cl}^{-}$ & -0.0035 & 0.0000 & -0.0054 & -0.0221 & -0.0536 & -0.0932 & -0.1385 & -0.1878 \\
\hline $\mathrm{Pu}$ & $\mathrm{Pu}+\mathrm{O}_{2}(\mathrm{~g})+4 \mathrm{H}^{+}=\mathrm{Pu}^{++++}+2 \mathrm{H}_{2} \mathrm{O}$ & -0.0027 & 0.0000 & -0.0043 & -0.0176 & -0.0432 & -0.0757 & -0.1132 & -0.1543 \\
\hline $\mathrm{Pu}_{2} \mathrm{C}_{3}$ & $\begin{array}{l}\mathrm{Pu}_{2} \mathrm{C}_{3}+3 \mathrm{H}^{+}+4.5 \mathrm{O}_{2}(\mathrm{~g})=2 \mathrm{Pu}^{+++} \\
+3 \mathrm{HCO}_{3}^{-}\end{array}$ & 0.0292 & 0.0175 & 0.0304 & 0.0712 & 0.1451 & 0.2334 & 0.3299 & 0.4312 \\
\hline $\mathrm{Pu}_{2} \mathrm{O}_{3}$ & $\mathrm{Pu}_{2} \mathrm{O}_{3}+6 \mathrm{H}^{+}=3 \mathrm{H}_{2} \mathrm{O}+2 \mathrm{Pu}^{+++}$ & 0.0110 & 0.0000 & 0.0159 & 0.0617 & 0.1423 & 0.2374 & 0.3403 & 0.4475 \\
\hline $\mathrm{Pu}_{3} \mathrm{C}_{2}$ & $\begin{array}{l}\mathrm{Pu}_{3} \mathrm{C}_{2}+7 \mathrm{H}^{+}+4.25 \mathrm{O}_{2}(\mathrm{~g})=3 \mathrm{Pu}^{+++} \\
+2 \mathrm{HCO}_{3}^{-}+2.5 \mathrm{H}_{2} \mathrm{O}\end{array}$ & -0.0033 & 0.0000 & -0.0051 & -0.0207 & -0.0501 & -0.0870 & -0.1289 & -0.1745 \\
\hline $\mathrm{PuBr}_{3}$ & $\mathrm{PuBr}_{3}=\mathrm{Pu}^{+++}+3 \mathrm{Br}^{-}$ & -0.0187 & 0.0000 & -0.0285 & -0.1132 & -0.2669 & -0.4514 & -0.6526 & -0.8620 \\
\hline $\mathrm{PuC}_{0.84}$ & $\begin{array}{l}\mathrm{PuC}_{0.84}+1.59 \mathrm{O}_{2}(\mathrm{~g})+2.16 \mathrm{H}^{+}= \\
0.84 \mathrm{HCO}_{3}^{-}+0.66 \mathrm{H}_{2} \mathrm{O}+\mathrm{Pu}^{+++}\end{array}$ & 0.0060 & 0.0000 & 0.0089 & 0.0352 & 0.0828 & 0.1404 & 0.2042 & 0.2720 \\
\hline
\end{tabular}


Table 6-35. $\Delta$ Log K (Difference Between Incorrect and Corrected Values) for Np and Pu Solid Phases (Continued)

\begin{tabular}{|c|c|c|c|c|c|c|c|c|c|}
\hline $\begin{array}{l}\text { Data0.ymp.R2 } \\
\text { Species Name }\end{array}$ & Reaction & $\begin{array}{l}\log \mathrm{K} \\
0.01^{\circ} \mathrm{C}\end{array}$ & $\begin{array}{l}\log \mathrm{K} \\
25^{\circ} \mathrm{C}\end{array}$ & $\begin{array}{l}\log \mathrm{K} \\
60^{\circ} \mathrm{C}\end{array}$ & $\begin{array}{l}\log \mathrm{K} \\
100^{\circ} \mathrm{C}\end{array}$ & $\begin{array}{l}\log \mathrm{K} \\
150^{\circ} \mathrm{C}\end{array}$ & $\begin{array}{l}\log K \\
200^{\circ} \mathrm{C}\end{array}$ & $\begin{array}{l}\log K \\
250^{\circ} \mathrm{C}\end{array}$ & $\begin{array}{l}\log \mathrm{K} \\
300^{\circ} \mathrm{C}\end{array}$ \\
\hline $\mathrm{PuCl}_{3}$ & $\mathrm{PuCl}_{3}=\mathrm{Pu}^{+++}+3 \mathrm{Cl}^{-}$ & -0.0020 & 0.0000 & -0.0031 & -0.0123 & -0.0293 & -0.0502 & -0.0736 & -0.0989 \\
\hline $\mathrm{PuF}_{3}$ & $\mathrm{PuF}_{3}=\mathrm{Pu}^{+++}+3 \mathrm{~F}^{-}$ & 0.0025 & 0.0000 & 0.0033 & 0.0120 & 0.0259 & 0.0404 & 0.0545 & 0.0676 \\
\hline $\mathrm{PuF}_{6}$ & $\mathrm{PuF}_{6}+2 \mathrm{H}_{2} \mathrm{O}=6 \mathrm{~F}^{-}+\mathrm{PuO}_{2}^{++}+4 \mathrm{H}^{+}$ & -0.0192 & 0.0000 & -0.0309 & -0.1265 & -0.3098 & -0.5431 & -0.8119 & -1.1071 \\
\hline $\mathrm{Pul}_{3}$ & $\mathrm{Pul}_{3}=\mathrm{Pu}^{+++}+3 \mathrm{I}^{-}$ & -0.0012 & 0.0000 & -0.0019 & -0.0079 & -0.0193 & -0.0338 & -0.0505 & -0.0689 \\
\hline $\mathrm{PuO}_{1.61}$ & $\begin{array}{l}\mathrm{PuO}_{1.61}+0.195 \mathrm{O}_{2}(\mathrm{~g})+4 \mathrm{H}^{+}=\mathrm{Pu}^{++++}+ \\
2 \mathrm{H}_{2} \mathrm{O}\end{array}$ & 0.0013 & 0.0000 & 0.0015 & 0.0049 & 0.0091 & 0.0118 & 0.0126 & 0.0115 \\
\hline $\mathrm{PuO}_{2}$ & $\mathrm{PuO}_{2}+4 \mathrm{H}^{+}=\mathrm{Pu}^{++++}+2 \mathrm{H}_{2} \mathrm{O}$ & 0.0040 & 0.0000 & 0.0051 & 0.0184 & 0.0385 & 0.0584 & 0.0764 & 0.0919 \\
\hline $\mathrm{PuOBr}$ & $\mathrm{PuOBr}+2 \mathrm{H}^{+}=\mathrm{Pu}^{+++}+\mathrm{Br}^{-}+\mathrm{H}_{2} \mathrm{O}$ & 0.0003 & 0.0000 & 0.0000 & -0.0006 & -0.0032 & -0.0080 & -0.0149 & -0.0237 \\
\hline $\mathrm{PuOCl}$ & $\mathrm{PuOCl}+2 \mathrm{H}^{+}=\mathrm{Pu}^{+++}+\mathrm{Cl}^{-}+\mathrm{H}_{2} \mathrm{O}$ & 0.0004 & 0.0000 & 0.0002 & 0.0002 & -0.0015 & -0.0054 & -0.0115 & -0.0194 \\
\hline PuOF & $\mathrm{PuOF}+2 \mathrm{H}^{+}=\mathrm{Pu}^{+++}+\mathrm{F}^{-}+\mathrm{H}_{2} \mathrm{O}$ & 0.0006 & 0.0000 & 0.0005 & 0.0011 & 0.0005 & -0.0021 & -0.0067 & -0.0131 \\
\hline $\mathrm{PuOI}$ & $\mathrm{PuOl}+2 \mathrm{H}^{+}=\mathrm{Pu}^{+++}+\mathrm{I}^{-}+\mathrm{H}_{2} \mathrm{O}$ & -0.0019 & 0.0000 & -0.0031 & -0.0130 & -0.0321 & -0.0567 & -0.0852 & -0.1168 \\
\hline
\end{tabular}


Table 6-36. Thermodynamic Data Input for Gas Phases with the Correct Scaling of the "c" Heat Capacity Coefficient

\begin{tabular}{|c|c|c|c|c|c|c|c|}
\hline & & & & Heat $\mathrm{Ca}_{\mathrm{a}}$ & pacity Coeff & cients $^{a}$ & \\
\hline Name & $\begin{array}{c}\Delta \mathbf{G}^{\circ}{ }_{f} \\
(\mathrm{~J} / \mathrm{mol})\end{array}$ & $\begin{array}{c}\Delta \mathrm{H}_{\mathrm{f}}^{\circ} \\
(\mathrm{J} / \mathrm{mol})\end{array}$ & $\begin{array}{c}\mathrm{S}^{\circ} \\
(\mathrm{J} / \mathrm{mol}-\mathrm{K}) \\
\end{array}$ & $\begin{array}{c}\text { a } \\
(\mathrm{J} / \mathrm{mol}-\mathrm{K}) \\
\end{array}$ & $\begin{array}{c}b \times 10^{3} \\
\left(\mathrm{~J} / \mathrm{mol}^{\left.-K^{2}\right)}\right.\end{array}$ & $\begin{array}{c}c \times 10^{-6} \\
(\mathrm{~J}-\mathrm{K} / \mathrm{mol})^{b}\end{array}$ & Source \\
\hline $\begin{array}{l}\text { Portlandite } \\
\mathrm{Ca}(\mathrm{OH})_{2}\end{array}$ & $-898,470$ & $-986,100$ & 83.40 & 101.790 & 18.0000 & -1.740 & 1,2 \\
\hline $\begin{array}{l}\text { Ferrite- } \\
\text { Dicalcium } \\
\left(\mathrm{Ca}_{2} \mathrm{Fe}_{2} \mathrm{O}_{5}\right)^{\mathrm{c}}\end{array}$ & $-2,001,686$ & $-2,133,700$ & 188.70 & 248.610 & $\begin{array}{r}0.0000 \\
\text { (original } \\
\text { value was } \\
-4.8900) \\
\end{array}$ & $\begin{array}{r}-4.8900 \\
\text { (original } \\
\text { value was } \\
0.0000 \text { ) } \\
\end{array}$ & 1,2 \\
\hline Ferrite-Mg & $-1,317,429$ & $-1,440,100$ & 123.8 & 167.19 & 14.23 & -2.99 & 1,2 \\
\hline $\mathrm{Ca}_{3} \mathrm{Al}_{2} \mathrm{O}_{6}$ & $-3,411,786$ & $-3,587,800$ & 205.90 & 260.580 & 19.1600 & -5.030 & 1,2 \\
\hline $\mathrm{CaAl}_{2} \mathrm{O}_{4}$ & $-2,208,820$ & $-2,326,300$ & 114.20 & 150.620 & 24.9400 & -3.330 & 1,2 \\
\hline $\begin{array}{l}\text { Pseudo } \\
\text { wollastonite } \\
\mathrm{CaSiO}_{3} \\
\end{array}$ & $-1,544,739$ & $-1,628,400$ & 87.40 & 108.160 & 16.4800 & -2.360 & 1,2 \\
\hline Titanite $\mathrm{CaSiTiO}_{5}$ & $-2,461,780$ & $-2,603,300$ & 129.20 & 177.360 & 23.1800 & -4.030 & 1,2 \\
\hline $\begin{array}{l}\text { Perovskite } \\
\mathrm{CaTiO}_{3}\end{array}$ & $-1,575,247$ & $-1,659,000$ & 93.70 & 127.490 & 5.6900 & -2.800 & 1,2 \\
\hline $\mathrm{Co}(\mathrm{OH})_{2}$ & $-454,168$ & $-541,300$ & 93.30 & 82.840 & 47.7000 & 0.000 & 1,2 \\
\hline Spinel-Co $\mathrm{Co}_{3} \mathrm{O}_{4}$ & $-794,901$ & $-918,700$ & 109.30 & 131.650 & 66.0200 & -2.480 & 1,2 \\
\hline $\mathrm{CoCl}_{2}$ & $-269,650$ & $-312,500$ & 109.30 & 81.580 & 7.4100 & -0.470 & 1,2 \\
\hline $\mathrm{CoF}_{3}$ & $-718,899$ & $-790,400$ & 94.60 & 100.280 & 4.8800 & -0.880 & 1,2 \\
\hline $\begin{array}{l}\text { Sphaerocobaltite } \\
\mathrm{CoCO}_{3}\end{array}$ & $-636,782$ & $-713,000$ & 87.90 & 88.280 & 38.9100 & -1.800 & 1,2 \\
\hline $\mathrm{CoCr}_{2} \mathrm{O}_{4}$ & $-1,329,788$ & $-1,438,300$ & 126.80 & 167.650 & 17.7400 & -1.400 & 1,2 \\
\hline $\mathrm{CoF}_{2}$ & $-626,562$ & $-672,400$ & 82.00 & 80.910 & 6.1500 & -1.240 & 1,2 \\
\hline $\mathrm{CoFe}_{2} \mathrm{O}_{4}$ & $-980,455$ & $-1,088,700$ & 142.70 & 173.220 & 54.3900 & -3.280 & 1,2 \\
\hline $\mathrm{CoO}$ & $-214,198$ & $-237,700$ & 53.00 & 45.260 & 10.6900 & 0.600 & 1,2 \\
\hline $\mathrm{CoTiO}_{3}$ & $-1,129,498$ & $-1,207,400$ & 96.90 & 123.470 & 9.7100 & -1.650 & 1,2 \\
\hline $\mathrm{CoWO}_{4}$ & $-1,035,813$ & $-1,142,700$ & 126.40 & 115.480 & 48.4900 & 0.000 & 1,2 \\
\hline Eskolaite $\mathrm{Cr}_{2} \mathrm{O}_{3}$ & $-1,058,067$ & $-1,140,600$ & 81.20 & 109.650 & 15.4600 & 0.000 & 1,2 \\
\hline $\mathrm{CrCl}_{3}$ & $-486,316$ & $-556,500$ & 123.00 & 98.830 & 13.9800 & -1.000 & 1,2 \\
\hline $\mathrm{CrF}_{3}$ & $-1,103,441$ & $-1,173,200$ & 93.90 & 93.970 & 10.2500 & -1.620 & 1,2 \\
\hline $\mathrm{Crl}_{3}$ & $-205,530$ & $-205,000$ & 199.60 & 105.440 & 20.9200 & 0.000 & 1,2 \\
\hline $\mathrm{CrO}_{3}$ & $-512,562$ & $-587,000$ & 73.20 & 71.760 & 87.8700 & -1.670 & 1,2 \\
\hline $\begin{array}{l}\text { Ferrite-Cu } \\
\left(\mathrm{CuFe}_{2} \mathrm{O}_{4}\right)^{\mathrm{c}}\end{array}$ & $-863,240$ & $\begin{array}{r}-966,500 \\
\text { (original } \\
\text { value was } \\
-1,025,100)\end{array}$ & $\begin{array}{r}148.6 \\
\text { (original } \\
\text { value } \\
\text { was } \\
177.70 \text { ) } \\
\end{array}$ & $\begin{array}{r}138.74 \\
\text { (original } \\
\text { value was } \\
200.080 \text { ) }\end{array}$ & $\begin{array}{r}119.0000 \\
\text { (original } \\
\text { value was } \\
20.2500 \text { ) }\end{array}$ & $\begin{array}{r}-2.260 \\
\text { (original } \\
\text { value was } \\
-3.360 \text { ) }\end{array}$ & 1,2 \\
\hline Iron $\mathrm{Fe}$ & 0 & 0 & 27.30 & 14.950 & 28.0800 & 0.160 & 1,2 \\
\hline $\mathrm{Fe}(\mathrm{OH})_{2}$ & $-486,975$ & $-574,000$ & 87.90 & 116.060 & 8.6500 & -2.870 & 1,2 \\
\hline $\mathrm{Fe}(\mathrm{OH})_{3}$ & $-696,486$ & $-832,600$ & 104.60 & 127.610 & 41.6400 & -4.220 & 1,2 \\
\hline $\mathrm{Fe}_{2}\left(\mathrm{SO}_{4}\right)_{3}$ & $-2,262,753$ & $-2,583,000$ & 307.50 & 361.300 & 54.7600 & -10.640 & 1,2 \\
\hline $\begin{array}{l}\text { Hercynite } \\
\mathrm{FeAl}_{2} \mathrm{O}_{4}\end{array}$ & $-1,879,669$ & $-1,969,500$ & 106.30 & 155.310 & 26.1500 & -3.520 & 1,2 \\
\hline Lawrencite $\mathrm{FeCl}_{2}$ & $-302,343$ & $-341,600$ & 117.90 & 78.260 & 9.9500 & -0.420 & 1,2 \\
\hline Molysite $\mathrm{FeCl}_{3}$ & $-333,926$ & $-399,200$ & 147.80 & 74.590 & 78.2700 & -0.090 & 1,2 \\
\hline $\begin{array}{l}\text { Chromite } \\
\mathrm{FeCr}_{2} \mathrm{O}_{4}\end{array}$ & $-1,355,891$ & $-1,458,600$ & 146.90 & 163.010 & 22.3400 & -3.190 & 1,2 \\
\hline
\end{tabular}


Table 6-36. Thermodynamic Data Input for Gas Phases with the Correct Scaling of the "c" Heat Capacitiy Coefficient (Continued)

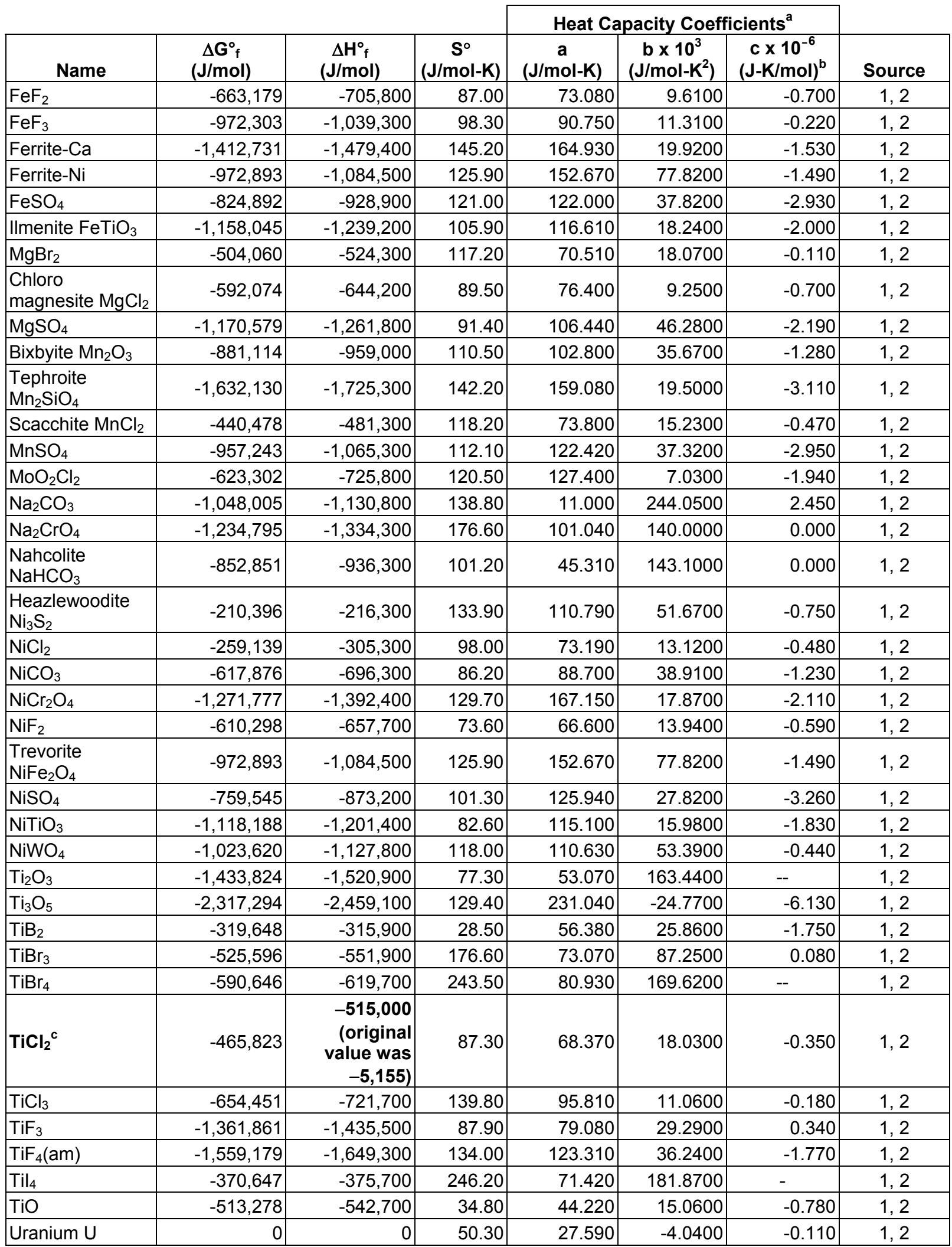


Table 6-36. Thermodynamic Data Input for Gas Phases with the Correct Scaling of the "c" Heat Capacitiy Coefficient (Continued)

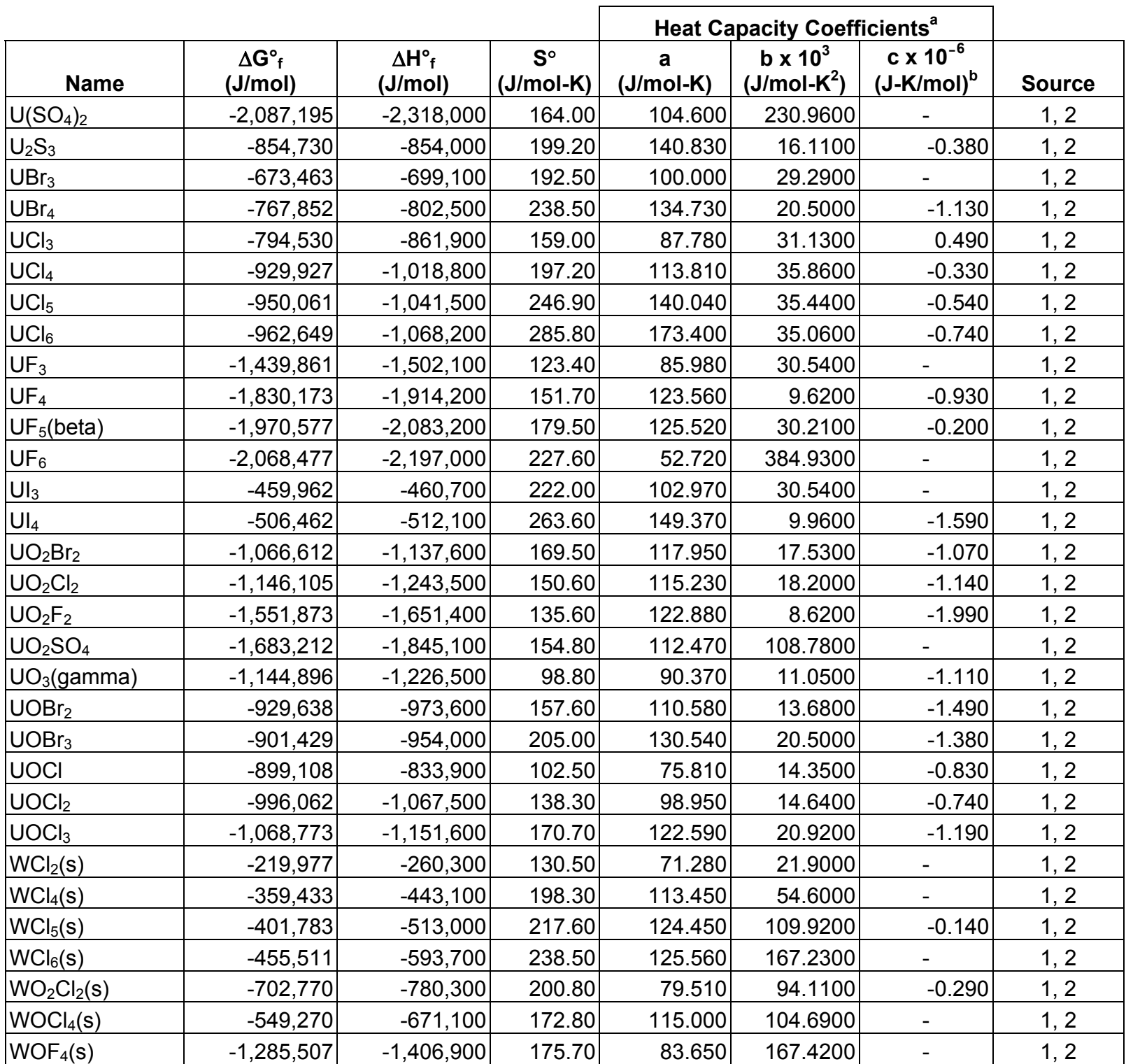

Sources: 1 All values of $\Delta \mathrm{G}_{\mathrm{f}}^{\circ}$ are from Barin and Platzki (1995 [DIRS 157865]).

2 All values of $\Delta \mathrm{H}^{\circ}$, $\mathrm{S}^{\circ}$, and heat capacity coefficients are from Binnewies and Milke (1999 [DIRS 158955]).

${ }^{a}$ Heat capacity coefficients a, b, and c defined in Eq. 4-1.

${ }^{b}$ Scaling corrected from $10^{-5}$ to $10^{-6}$ in the formula used to calculate apparent Gibbs energies within the respective species spreadsheet.

${ }^{c}$ Values in boldface are corrected in output DTN: SN0410T0510404.001, from errors identified in the original source spreadsheets (DTN: MO0302SPATHDYN.001 [DIRS 161886]). The corrected values in the output DTN are developed in the following spreadsheets:

Ferrite-Dicalcium: Spreadsheet Minerals_j_psd_8_DS_fix.xIs, Worksheet Ferrite-Dicalcium (fix).

Ferrite-Cu $\left(\mathrm{CuFe}_{2} \mathrm{O}_{4}\right)$ : Spreadsheet Minerals_j_psd_9_DS_fix.xIs, Worksheet Ferrite-Cu (fix).

$\mathrm{TiCl}_{2}$ : Spreadsheet Minerals_j_psd_1_DS_fix.Xls, Worksheet TiCl2(s) (fix). 
Table 6-37. Corrected Log K EQ3/6 Grids for Affected Solid Phases

\begin{tabular}{|c|c|c|c|c|c|c|c|c|c|}
\hline $\begin{array}{l}\text { Data0.ymp.R2 } \\
\text { Species Name }\end{array}$ & Reaction & $\begin{array}{l}\log \mathrm{K} \\
0.01^{\circ} \mathrm{C}\end{array}$ & $\begin{array}{l}\log \mathrm{K} \\
25^{\circ} \mathrm{C}\end{array}$ & $\begin{array}{l}\log \mathrm{K} \\
60^{\circ} \mathrm{C}\end{array}$ & $\begin{array}{l}\log \mathrm{K} \\
100^{\circ} \mathrm{C}\end{array}$ & $\begin{array}{l}\log \mathrm{K} \\
150^{\circ} \mathrm{C}\end{array}$ & $\begin{array}{l}\log \mathrm{K} \\
200^{\circ} \mathrm{C}\end{array}$ & $\begin{array}{l}\log \mathrm{K} \\
250^{\circ} \mathrm{C}\end{array}$ & $\begin{array}{l}\log \mathrm{K} \\
300^{\circ} \mathrm{C}\end{array}$ \\
\hline Witherite $\left(\mathrm{BaCO}_{3}\right)$ & $\mathrm{BaCO}_{3}+\mathrm{H}^{+}=\mathrm{Ba}^{++}+\mathrm{HCO}_{3}^{-}$ & 1.9041 & 1.7639 & 1.5062 & 1.1717 & 0.7100 & 0.1917 & -0.4144 & -1.1855 \\
\hline Portlandite $\left(\mathrm{Ca}(\mathrm{OH})_{2}\right)$ & $\mathrm{Ca}(\mathrm{OH})_{2}+2 \mathrm{H}^{+}=\mathrm{Ca}^{++}+2 \mathrm{H}_{2} \mathrm{O}$ & 24.6125 & 22.5444 & 20.1862 & 18.0517 & 15.9616 & 14.3045 & 12.9323 & 11.7391 \\
\hline $\begin{array}{l}\text { Ferrite Dicalcium } \\
\left(\mathrm{Ca}_{2} \mathrm{Fe}_{2} \mathrm{O}_{5}\right)\end{array}$ & $\begin{array}{l}\mathrm{Ca}_{2} \mathrm{Fe}_{2} \mathrm{O}_{5}+10 \mathrm{H}^{+}=2 \mathrm{Ca}^{++}+2 \mathrm{Fe}^{+++}+ \\
5 \mathrm{H}_{2} \mathrm{O}\end{array}$ & 64.4136 & 56.8114 & 48.0584 & 40.0564 & 32.1116 & 25.6815 & 20.2076 & 15.2897 \\
\hline Ferrite-Mg $\left(\mathrm{MgFe}_{2} \mathrm{O}_{4}\right)$ & $\begin{array}{l}\text { Ferrite-Mg }+8 \mathrm{H}^{+}=2 \mathrm{Fe}^{+++}+\mathrm{Mg}^{++}+ \\
4 \mathrm{H}_{2} \mathrm{O}\end{array}$ & 25.4526 & 20.9808 & 15.8346 & 11.1482 & 6.5052 & 2.7292 & -0.5359 & -3.5453 \\
\hline $\mathrm{Ca}_{3} \mathrm{Al}_{2} \mathrm{O}_{6}$ & $\begin{array}{l}\mathrm{Ca}_{3} \mathrm{Al}_{2} \mathrm{O}_{6}+12 \mathrm{H}^{+}=3 \mathrm{Ca}^{++}+2 \mathrm{Al}^{+++}+ \\
6 \mathrm{H}_{2} \mathrm{O}\end{array}$ & 124.6852 & 111.6139 & 96.5383 & 82.7213 & 68.9964 & 57.9377 & 48.6374 & 40.4634 \\
\hline $\mathrm{CaAl}_{2} \mathrm{O}_{4}$ & $\mathrm{CaAl}_{2} \mathrm{O}_{4}+8 \mathrm{H}^{+}=\mathrm{Ca}^{++}+2 \mathrm{Al}^{+++}+4 \mathrm{H}_{2} \mathrm{O}$ & 52.2923 & 45.5699 & 37.7870 & 30.6288 & 23.4767 & 17.6536 & 12.6792 & 8.2205 \\
\hline $\begin{array}{l}\text { Pseudo-wollastonite } \\
\left(\mathrm{CaSiO}_{3}\right)\end{array}$ & $\mathrm{CaSiO}_{3}+2 \mathrm{H}^{+}=\mathrm{Ca}^{++}+\mathrm{SiO}_{2}(\mathrm{aq})+\mathrm{H}_{2} \mathrm{O}$ & 15.4054 & 14.0344 & 12.3838 & 10.8597 & 9.3603 & 8.1663 & 7.1587 & 6.2301 \\
\hline Titanite $\left(\mathrm{CaSiTiO}_{5}\right)$ & $\begin{array}{l}\mathrm{CaSiTiO}_{5}+2 \mathrm{H}^{+}+\mathrm{H}_{2} \mathrm{O}=\mathrm{Ti}(\mathrm{OH})_{4}+ \\
\mathrm{Ca}_{2}^{+}+\mathrm{SiO}_{2}(\mathrm{aq})\end{array}$ & 2.8995 & 1.9918 & 0.7981 & -0.3263 & -1.4237 & -2.2881 & -3.0278 & -3.7622 \\
\hline Perovskite $\left(\mathrm{CaTiO}_{3}\right)$ & $\mathrm{CaTiO}_{3}+2 \mathrm{H}^{+}+\mathrm{H}_{2} \mathrm{O}=\mathrm{Ti}(\mathrm{OH})_{4}+\mathrm{Ca}^{++}$ & 12.8727 & 11.0419 & 8.8630 & 6.8551 & 4.8765 & 3.3010 & 1.9809 & 0.7905 \\
\hline $\mathrm{Co}(\mathrm{OH})_{2}$ & $\mathrm{Co}(\mathrm{OH})_{2}+2 \mathrm{H}^{+}=\mathrm{Co}^{++}+2 \mathrm{H}_{2} \mathrm{O}$ & 14.5818 & 13.0671 & 11.3386 & 9.7790 & 8.2566 & 7.0476 & 6.0355 & 5.1363 \\
\hline Spinel-Co $\left(\mathrm{CO}_{3} \mathrm{O}_{4}\right)$ & $\mathrm{Co}_{3} \mathrm{O}_{4}+8 \mathrm{H}^{+}=\mathrm{Co}^{++}+2 \mathrm{Co}^{+++}+4 \mathrm{H}_{2} \mathrm{O}$ & -8.7683 & -10.4344 & -12.3845 & -14.1795 & -16.0115 & -17.6046 & -19.1362 & -20.7431 \\
\hline $\mathrm{CoCl}_{2}$ & $\mathrm{CoCl}_{2}(\mathrm{~s})=\mathrm{Co}^{++}+2 \mathrm{Cl}^{-}$ & 9.4861 & 8.2904 & 6.7200 & 5.0870 & 3.2193 & 1.4485 & -0.3404 & -2.3262 \\
\hline $\mathrm{CoF}_{3}{ }^{*}$ & $\mathrm{CoF}_{3}=\mathrm{Co}^{+++}+3 \mathrm{~F}^{-*}$ & 0.5317 & -1.3201 & -3.7439 & -6.2444 & -9.0880 & -11.7850 & -14.5255 & -17.5790 \\
\hline $\begin{array}{l}\text { Sphaerocobaltite } \\
\left(\mathrm{CoCO}_{3}\right)\end{array}$ & $\mathrm{CoCO}_{3}(\mathrm{~s})+\mathrm{H}^{+}=\mathrm{Co}^{++}+\mathrm{HCO}_{3}^{-}$ & 1.3240 & 0.7971 & 0.1099 & -0.5992 & -1.4131 & -2.2012 & -3.0266 & -3.9840 \\
\hline $\mathrm{CoCr}_{2} \mathrm{O}_{4}$ & $\mathrm{CoCr}_{2} \mathrm{O}_{4}+8 \mathrm{H}^{+}=\mathrm{Co}^{++}+2 \mathrm{Cr}^{+++}+4 \mathrm{H}_{2} \mathrm{O}$ & 19.2812 & 15.0442 & 10.1319 & 5.6202 & 1.1016 & -2.6209 & -5.8826 & -8.9219 \\
\hline $\mathrm{CoF}_{2}$ & $\mathrm{CoF}_{2}=\mathrm{Co}^{++}+2 \mathrm{~F}^{-}$ & -0.6789 & -1.5187 & -2.6656 & -3.8880 & -5.3257 & -6.7418 & -8.2402 & -9.9907 \\
\hline $\mathrm{CoFe}_{2} \mathrm{O}_{4}$ & $\mathrm{CoFe}_{2} \mathrm{O}_{4}+8 \mathrm{H}^{+}=\mathrm{Co}^{++}+2 \mathrm{Fe}^{+++}+4 \mathrm{H}_{2} \mathrm{O}$ & 13.4446 & 10.0104 & 6.0420 & 2.4107 & -1.2228 & -4.2310 & -6.9018 & -9.4475 \\
\hline $\mathrm{CoO}$ & $\mathrm{CoO}+2 \mathrm{H}^{+}=\mathrm{Co}^{++}+\mathrm{H}_{2} \mathrm{O}$ & 15.2495 & 13.5557 & 11.6031 & 9.8196 & 8.0552 & 6.6368 & 5.4402 & 4.3753 \\
\hline $\mathrm{CoTiO}_{3}$ & $\begin{array}{l}\mathrm{CoTiO}_{3}+2 \mathrm{H}^{+}+\mathrm{H}_{2} \mathrm{O}=\mathrm{Co}^{++}+ \\
\mathrm{Ti}(\mathrm{OH})_{4}(\mathrm{aq})\end{array}$ & 18.2297 & 17.0136 & 15.5343 & 14.1645 & 12.8139 & 11.7316 & 10.8045 & 9.9308 \\
\hline $\mathrm{CoWO}_{4}$ & $\mathrm{CoWO}_{4}=\mathrm{Co}^{++}+\mathrm{WO}_{4}^{--}$ & -11.9847 & -11.7760 & -11.7291 & -11.8788 & -12.2822 & -12.8981 & -13.7588 & -14.9905 \\
\hline
\end{tabular}


Table 6-37. Corrected Log K EQ3/6 Grids for Affected Solid Phases (Continued)

\begin{tabular}{|c|c|c|c|c|c|c|c|c|c|}
\hline $\begin{array}{l}\text { Data0.ymp.R2 } \\
\text { Species Name }\end{array}$ & Reaction & $\begin{array}{l}\log \mathrm{K} \\
0.01^{\circ} \mathrm{C}\end{array}$ & $\begin{array}{l}\log \mathrm{K} \\
25^{\circ} \mathrm{C}\end{array}$ & $\begin{array}{l}\log \mathrm{K} \\
60^{\circ} \mathrm{C}\end{array}$ & $\begin{array}{l}\log K \\
100^{\circ} \mathrm{C} \\
\end{array}$ & $\begin{array}{l}\log \mathrm{K} \\
150^{\circ} \mathrm{C} \\
\end{array}$ & $\begin{array}{l}\log \mathrm{K} \\
200^{\circ} \mathrm{C} \\
\end{array}$ & $\begin{array}{l}\log K \\
250^{\circ} \mathrm{C} \\
\end{array}$ & $\begin{array}{l}\log K \\
300^{\circ} \mathrm{C}\end{array}$ \\
\hline Eskolaite $\left(\mathrm{Cr}_{2} \mathrm{O}_{3}\right)$ & $\begin{array}{l}\mathrm{Cr}_{2} \mathrm{O}_{3}+2 \mathrm{H}_{2} \mathrm{O}+1.5 \mathrm{O}_{2}(\mathrm{~g})=2 \mathrm{CrO}_{4}^{--}+ \\
4 \mathrm{H}^{+}\end{array}$ & -11.5436 & -12.2116 & -13.4372 & -15.0171 & -17.1381 & -19.4062 & -21.9006 & -24.8658 \\
\hline $\mathrm{CrCl}_{3}$ & $\mathrm{CrCl}_{3}(\mathrm{~s})=\mathrm{Cr}^{+++}+3 \mathrm{Cl}^{-}$ & 22.9508 & 19.9413 & 16.1776 & 12.4285 & 8.3270 & 4.6206 & 1.0623 & -2.6568 \\
\hline $\mathrm{CrF}_{3}$ & $\mathrm{CrF}_{3}(\mathrm{~s})=\mathrm{Cr}^{+++}+3 \mathrm{~F}^{-}$ & -7.8740 & -9.0957 & -10.7847 & -12.6037 & -14.7665 & -16.9197 & -19.2158 & -21.8988 \\
\hline $\mathrm{Crl}_{3}$ & $\mathrm{Cr}_{3}=\mathrm{Cr}^{+++}+31^{-}$ & 30.7636 & 27.4198 & 23.2699 & 19.1619 & 14.7015 & 10.7132 & 6.9359 & 3.0557 \\
\hline $\mathrm{CrO}_{3}$ & $\mathrm{CrO}_{3}+\mathrm{H}_{2} \mathrm{O}=\mathrm{CrO}_{4}^{--}+2 \mathrm{H}^{+}$ & -3.2012 & -3.2201 & -3.4714 & -3.9351 & -4.6827 & -5.5804 & -6.6462 & -7.9877 \\
\hline Ferrite- $\mathrm{Cu}\left(\mathrm{CuFe}_{2} \mathrm{O}_{4}\right)$ & $\mathrm{CuFe}_{2} \mathrm{O}_{4}+8 \mathrm{H}^{+}=\mathrm{Cu}^{++}+2 \mathrm{Fe}^{+++}+4 \mathrm{H}_{2} \mathrm{O}$ & 12.8745 & 9.5266 & 5.6722 & 2.1613 & -1.3333 & -4.2134 & -6.7633 & -9.1921 \\
\hline Iron $(\mathrm{Fe})$ & $\mathrm{Fe}+2 \mathrm{H}^{+}+0.5 \mathrm{O}_{2}(\mathrm{~g})=\mathrm{Fe}^{++}+\mathrm{H}_{2} \mathrm{O}$ & 63.6419 & 57.5836 & 50.6273 & 44.2830 & 38.0396 & 33.0967 & 29.0558 & 25.6483 \\
\hline $\mathrm{Fe}(\mathrm{OH})_{2}$ & $\mathrm{Fe}(\mathrm{OH})_{2}(\mathrm{~s})+2 \mathrm{H}^{+}=\mathrm{Fe}^{++}+2 \mathrm{H}_{2} \mathrm{O}$ & 15.3477 & 13.8214 & 12.0849 & 10.5217 & 8.9974 & 7.7876 & 6.7751 & 5.8759 \\
\hline $\mathrm{Fe}(\mathrm{OH})_{3}$ & $\mathrm{Fe}(\mathrm{OH})_{3}(\mathrm{~s})+3 \mathrm{H}^{+}=\mathrm{Fe}^{+++}+3 \mathrm{H}_{2} \mathrm{O}$ & 7.0070 & 5.6581 & 4.1380 & 2.7863 & 1.4749 & 0.4205 & -0.4958 & -1.3572 \\
\hline $\mathrm{Fe}_{2}\left(\mathrm{SO}_{4}\right)_{3}$ & $\mathrm{Fe}_{3}\left(\mathrm{SO}_{4}\right)_{3}(\mathrm{~s})=\mathrm{Fe}^{+++}+3 \mathrm{SO}_{4}^{--}$ & 4.5382 & 0.8936 & -3.9646 & -9.0528 & -14.9043 & -20.4839 & -26.1426 & -32.4119 \\
\hline Hercynite $\left(\mathrm{FeAl}_{2} \mathrm{O}_{4}\right)$ & $\mathrm{FeAl}_{2} \mathrm{O}_{4}+8 \mathrm{H}^{+}=\mathrm{Fe}^{++}+2 \mathrm{Al}^{+++}+4 \mathrm{H}_{2} \mathrm{O}$ & 27.2213 & 22.4207 & 16.8420 & 11.6987 & 6.5321 & 2.2752 & -1.4349 & -4.8537 \\
\hline Lawrencite $\left(\mathrm{FeCl}_{2}\right)$ & $\mathrm{FeCl}_{2}(\mathrm{~g})=\mathrm{Fe}^{++}+2 \mathrm{Cl}^{-}$ & 10.3385 & 9.0646 & 7.4052 & 5.6922 & 3.7458 & 1.9119 & 0.0690 & -1.9676 \\
\hline Molysite $\left(\mathrm{FeCl}_{3}\right)$ & $\mathrm{FeCl}_{3}(\mathrm{~s})=\mathrm{Fe}^{+++}+3 \mathrm{Cl}^{-}$ & 15.8516 & 13.5217 & 10.5454 & 7.5215 & 4.1378 & 0.9993 & -2.1023 & -5.4547 \\
\hline Chromite $\left(\mathrm{FeCr}_{2} \mathrm{O}_{4}\right)$ & $\mathrm{FeCr}_{2} \mathrm{O}_{4}+8 \mathrm{H}^{+}=\mathrm{Fe}^{++}+2 \mathrm{Cr}^{+++}+4 \mathrm{H}_{2} \mathrm{O}$ & 21.4534 & 16.9730 & 11.7934 & 7.0498 & 2.3169 & -1.5620 & -4.9377 & -8.0576 \\
\hline $\mathrm{FeF}_{2}$ & $\mathrm{FeF}_{2}(\mathrm{~s})=\mathrm{Fe}^{++}+2 \mathrm{~F}^{-}$ & -0.5943 & -1.4320 & -2.5761 & -3.7949 & -5.2267 & -6.6351 & -8.1241 & -9.8639 \\
\hline $\mathrm{FeF}_{3}$ & $\mathrm{FeF}_{3}(\mathrm{~s})=\mathrm{Fe}^{+++}+3 \mathrm{~F}^{-}$ & -19.1363 & -19.2386 & -19.6390 & -20.2780 & -21.2731 & -22.4970 & -24.0325 & -26.0812 \\
\hline Ferrite-Ca $\left(\mathrm{CaFe}_{2} \mathrm{O}_{4}\right)$ & $\begin{array}{l}\text { Ferrite-Ca }+8 \mathrm{H}^{+}=2 \mathrm{Fe}^{+++}+\mathrm{Ca}^{++}+ \\
4 \mathrm{H}_{2} \mathrm{O}\end{array}$ & 25.8315 & 21.5945 & 16.7047 & 12.2304 & 7.7701 & 4.1185 & 0.9419 & -2.0036 \\
\hline Ferrite-Ni $\left(\mathrm{NiFe}_{2} \mathrm{O}_{4}\right)$ & Ferrite-Ni $+8 \mathrm{H}^{+}=2 \mathrm{Fe}^{+++}+\mathrm{Ni}^{++}+4 \mathrm{H}_{2} \mathrm{O}$ & 13.2008 & 9.7959 & 5.8487 & 2.2265 & -1.4072 & -4.4224 & -7.1037 & -9.6613 \\
\hline $\mathrm{FeSO}_{4}$ & $\mathrm{FeSO}_{4}(\mathrm{~s})=\mathrm{Fe}^{++}+\mathrm{SO}_{4}^{--}$ & 3.0160 & 1.9396 & 0.4818 & -1.0620 & -2.8537 & -4.5771 & -6.3409 & -8.3212 \\
\hline IImenite $\left(\mathrm{FeTiO}_{3}\right)$ & $\mathrm{FeTiO}_{3}+2 \mathrm{H}^{+}+\mathrm{H}_{2} \mathrm{O}=\mathrm{Ti}(\mathrm{OH})_{4}+\mathrm{Fe}^{++}$ & 4.7351 & 3.3187 & 1.6136 & 0.0422 & -1.5020 & -2.7328 & -3.7765 & -4.7442 \\
\hline $\mathrm{MgBr}_{2}$ & $\mathrm{MgBr}_{2}=\mathrm{Mg}^{++}+2 \mathrm{Br}^{-}$ & 30.5646 & 27.6871 & 24.1884 & 20.8089 & 17.2448 & 14.1591 & 11.3276 & 8.5018 \\
\hline Chloromagnesite $\left(\mathrm{MgCl}_{2}\right)$ & $\mathrm{MgCl}_{2}=\mathrm{Mg}^{++}+2 \mathrm{Cl}^{-}$ & 24.2706 & 21.8099 & 18.7962 & 15.8593 & 12.7237 & 9.9647 & 7.3824 & 4.7429 \\
\hline $\mathrm{MgSO}_{4}$ & $\mathrm{MgSO}_{4}=\mathrm{Mg}^{++}+\mathrm{SO}_{4}^{--}$ & 6.2422 & 4.8818 & 3.1062 & 1.2859 & -0.7602 & -2.6686 & -4.5701 & -6.6537 \\
\hline Bixbyite $\left(\mathrm{Mn}_{2} \mathrm{O}_{3}\right)$ & $\mathrm{Mn}_{2} \mathrm{O}_{3}+6 \mathrm{H}^{+}=2 \mathrm{Mn}^{+++}+3 \mathrm{H}_{2} \mathrm{O}$ & 2.5151 & 0.0527 & -2.8252 & -5.4871 & -8.1834 & -10.4469 & -12.4826 & -14.4362 \\
\hline Tephroite $\left(\mathrm{Mn}_{2} \mathrm{SiO}_{4}\right)$ & $\begin{array}{l}\mathrm{Mn}_{2} \mathrm{SiO}_{4}+4 \mathrm{H}^{+}=2 \mathrm{Mn}^{++}+\mathrm{SiO}_{2}(\mathrm{aq}) \\
+2 \mathrm{H}_{2} \mathrm{O}\end{array}$ & 26.8198 & 24.2091 & 21.1502 & 18.3654 & 15.6422 & 13.4760 & 11.6435 & 9.9606 \\
\hline Scacchite $\left(\mathrm{MnCl}_{2}\right)$ & $\mathrm{MnCl}_{2}=\mathrm{Mn}^{++}+2 \mathrm{Cl}^{-}$ & 10.3344 & 9.2222 & 7.7590 & 6.2351 & 4.4853 & 2.8154 & 1.1121 & -0.8040 \\
\hline $\mathrm{MnSO}_{4}$ & $\mathrm{MnSO}_{4}=\mathrm{Mn}^{++}+\mathrm{SO}_{4}^{--}$ & 4.0732 & 3.1105 & 1.7919 & 0.3831 & -1.2693 & -2.8789 & -4.5504 & -6.4586 \\
\hline
\end{tabular}


Table 6-37. Corrected Log K EQ3/6 Grids for Affected Solid Phases (Continued)

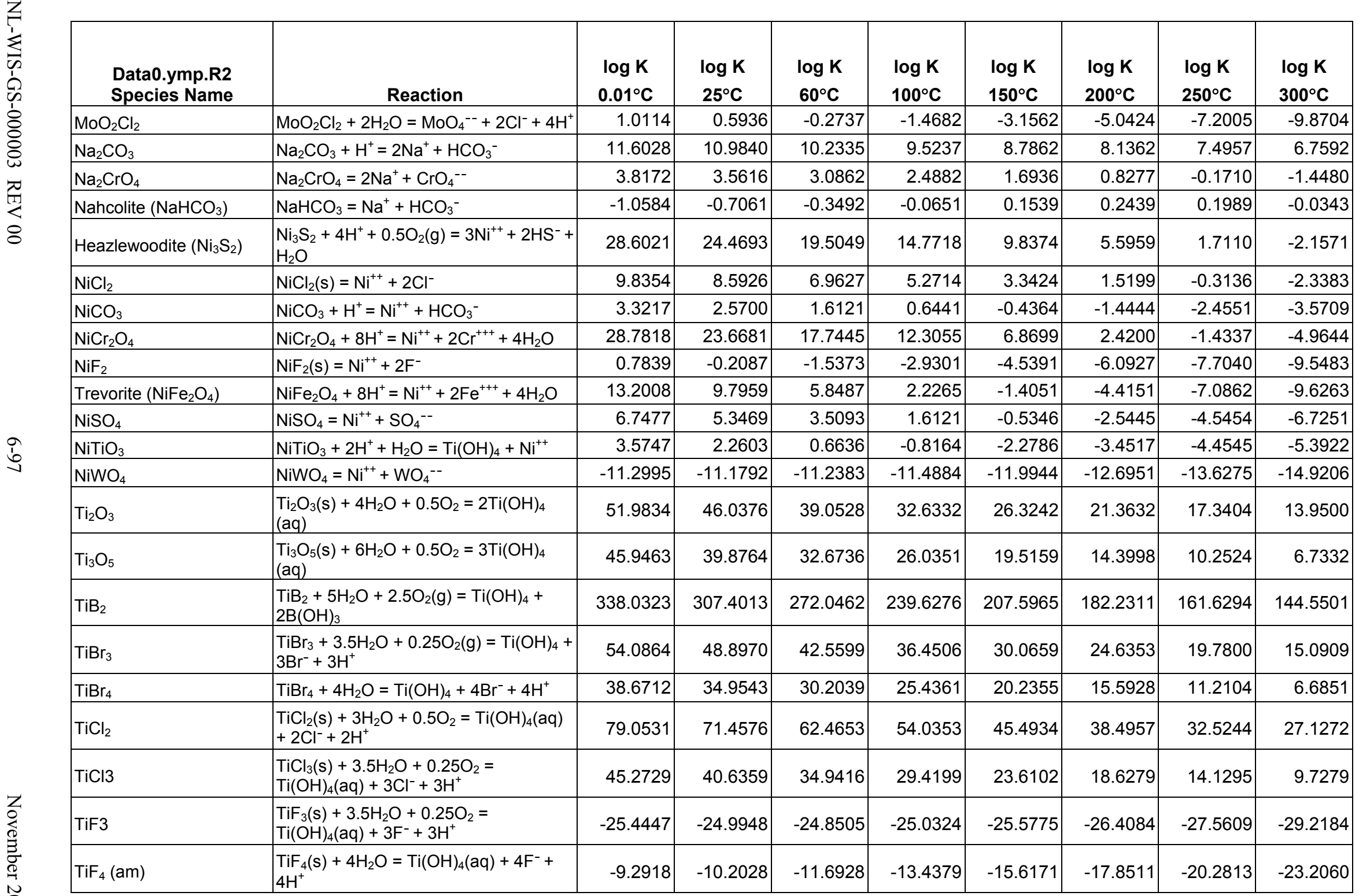


Table 6-37. Corrected Log K EQ3/6 Grids for Affected Solid Phases (Continued)

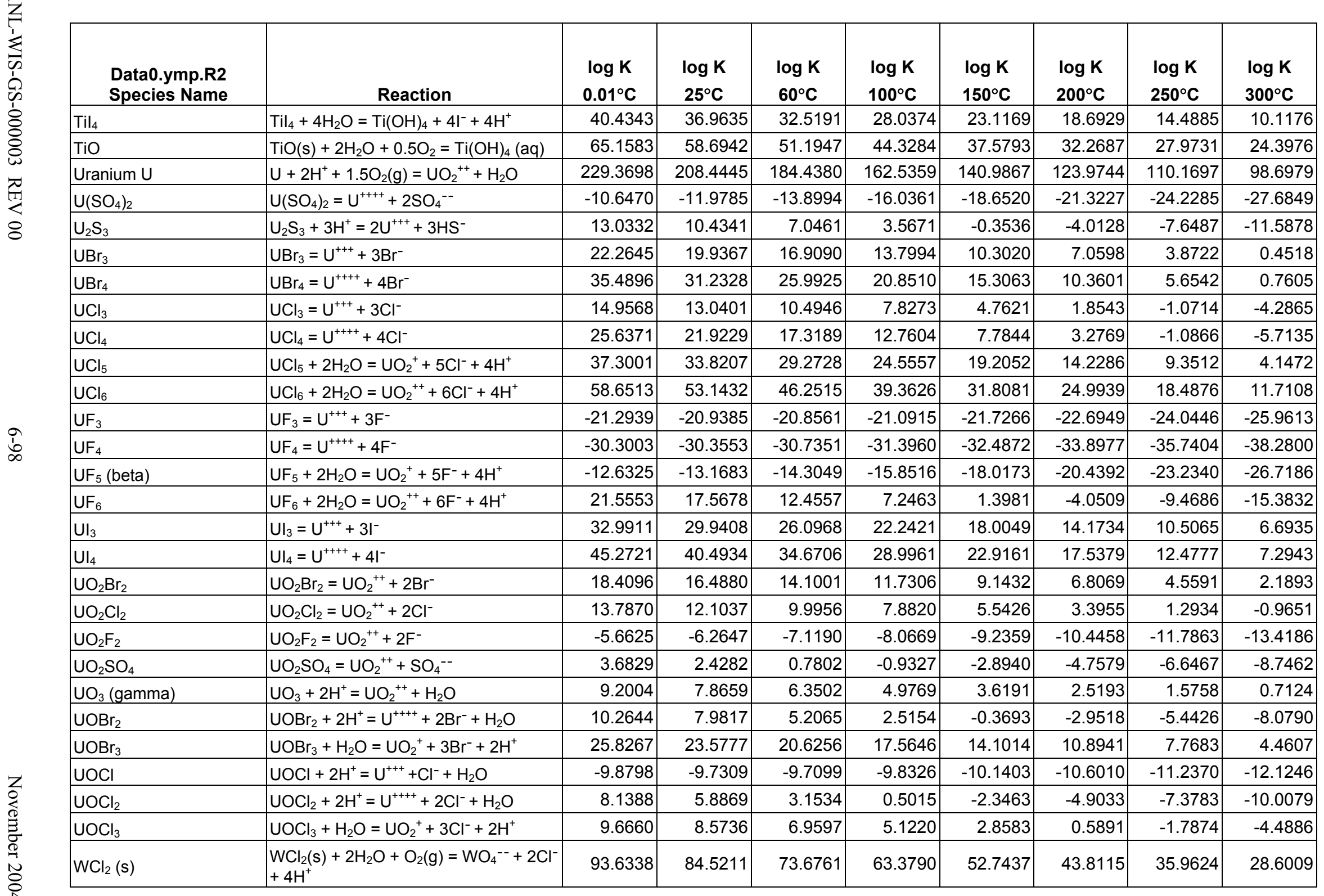


Table 6-37. Corrected Log K EQ3/6 Grids for Affected Solid Phases (Continued)

\begin{tabular}{|c|c|c|c|c|c|c|c|c|c|}
\hline $\begin{array}{l}\text { Data0.ymp.R2 } \\
\text { Species Name }\end{array}$ & Reaction & $\begin{array}{l}\log \mathrm{K} \\
0.01^{\circ} \mathrm{C}\end{array}$ & $\begin{array}{l}\log \mathrm{K} \\
25^{\circ} \mathrm{C}\end{array}$ & $\begin{array}{l}\log \mathrm{K} \\
60^{\circ} \mathrm{C}\end{array}$ & $\begin{array}{l}\log \mathrm{K} \\
100^{\circ} \mathrm{C}\end{array}$ & $\begin{array}{l}\log K \\
150^{\circ} \mathrm{C}\end{array}$ & $\begin{array}{l}\log \mathrm{K} \\
200^{\circ} \mathrm{C} \\
\end{array}$ & $\begin{array}{l}\log K \\
250^{\circ} \mathrm{C} \\
\end{array}$ & $\begin{array}{l}\log \mathrm{K} \\
300^{\circ} \mathrm{C}\end{array}$ \\
\hline $\mathrm{WCl}_{4}(\mathrm{~s})$ & $\begin{array}{l}\mathrm{WCl}_{4}(\mathrm{~s})+3 \mathrm{H}_{2} \mathrm{O}+0.5 \mathrm{O}_{2}=\mathrm{WO}_{4}{ }^{--}+ \\
4 \mathrm{Cl}^{-}+6 \mathrm{H}^{+}\end{array}$ & 71.3689 & 64.5388 & 56.1177 & 47.8276 & 38.9055 & 31.0428 & 23.7400 & 16.3841 \\
\hline $\mathrm{WCl}_{5}(\mathrm{~s})$ & $\begin{array}{l}\mathrm{WCl}_{5}(\mathrm{~s})+3.5 \mathrm{H}_{2} \mathrm{O}+0.25 \mathrm{O}_{2}= \\
\mathrm{WO}_{4}^{--}+5 \mathrm{Cl}^{-}+7 \mathrm{H}^{+}\end{array}$ & 65.4019 & 59.3442 & 51.7110 & 44.0362 & 35.5861 & 27.9512 & 20.6691 & 13.1034 \\
\hline $\mathrm{WCl}_{6}(\mathrm{~s})$ & $\mathrm{WCl}_{6}(\mathrm{~s})+4 \mathrm{H}_{2} \mathrm{O}=\mathrm{WO}_{4}{ }^{--}+6 \mathrm{Cl}^{-}+8 \mathrm{H}^{+}$ & 57.2682 & 52.1561 & 45.5135 & 38.6433 & 30.8566 & 23.6054 & 16.4742 & 8.8097 \\
\hline $\mathrm{WO}_{2} \mathrm{Cl}_{2}(\mathrm{~s})$ & $\begin{array}{l}\mathrm{WO}_{2} \mathrm{Cl}_{2}(\mathrm{~s})+2 \mathrm{H}_{2} \mathrm{O}=\mathrm{WO}_{4}^{--}+2 \mathrm{Cl}^{-}+ \\
4 \mathrm{H}^{+}\end{array}$ & 0.6699 & -0.0612 & -1.2796 & -2.7861 & -4.7725 & -6.8877 & -9.2282 & -12.0481 \\
\hline $\mathrm{WOCl}_{4}(\mathrm{~s})$ & $\mathrm{WOCl}_{4}(\mathrm{~s})+3 \mathrm{H}_{2} \mathrm{O}=\mathrm{WO}_{4}{ }^{--}+4 \mathrm{Cl}^{-}+6 \mathrm{H}^{+}$ & 34.4557 & 31.2806 & 27.0555 & 22.5950 & 17.4379 & 12.5397 & 7.6296 & 2.2438 \\
\hline $\mathrm{WOF}_{4}(\mathrm{~s})$ & $\mathrm{WOF}_{4}(\mathrm{~s})+3 \mathrm{H}_{2} \mathrm{O}=\mathrm{WO}_{4}^{--}+4 \mathrm{~F}^{-}+6 \mathrm{H}^{+}$ & 10.1133 & 7.7357 & 4.4528 & 0.8968 & -3.3209 & -7.4485 & -11.7279 & -16.5992 \\
\hline
\end{tabular}

Output DTN: SN0410T0510404.001 (Spreadsheets Minerals_j_psd_1_DS_fix.xls to Minerals_j_psd_9_DS_fix.xls and Minerals_j_psd_10_U_DS_fix.xls).

* The equation for $\mathrm{CoF}_{3}$ is corrected from the data0.ymp.R2 database (DTN: MO0302SPATHDYN.000 [DIRS 161756]), which gives an equation for CoCl 3 . Note that the corrected values in this table are not implemented in the data0.ymp.R4 database (output DTN: SN0410T0510404.002). 
Table 6-38. $\Delta$ Log K (Difference Between Incorrect and Corrected Values) for Solid Phases

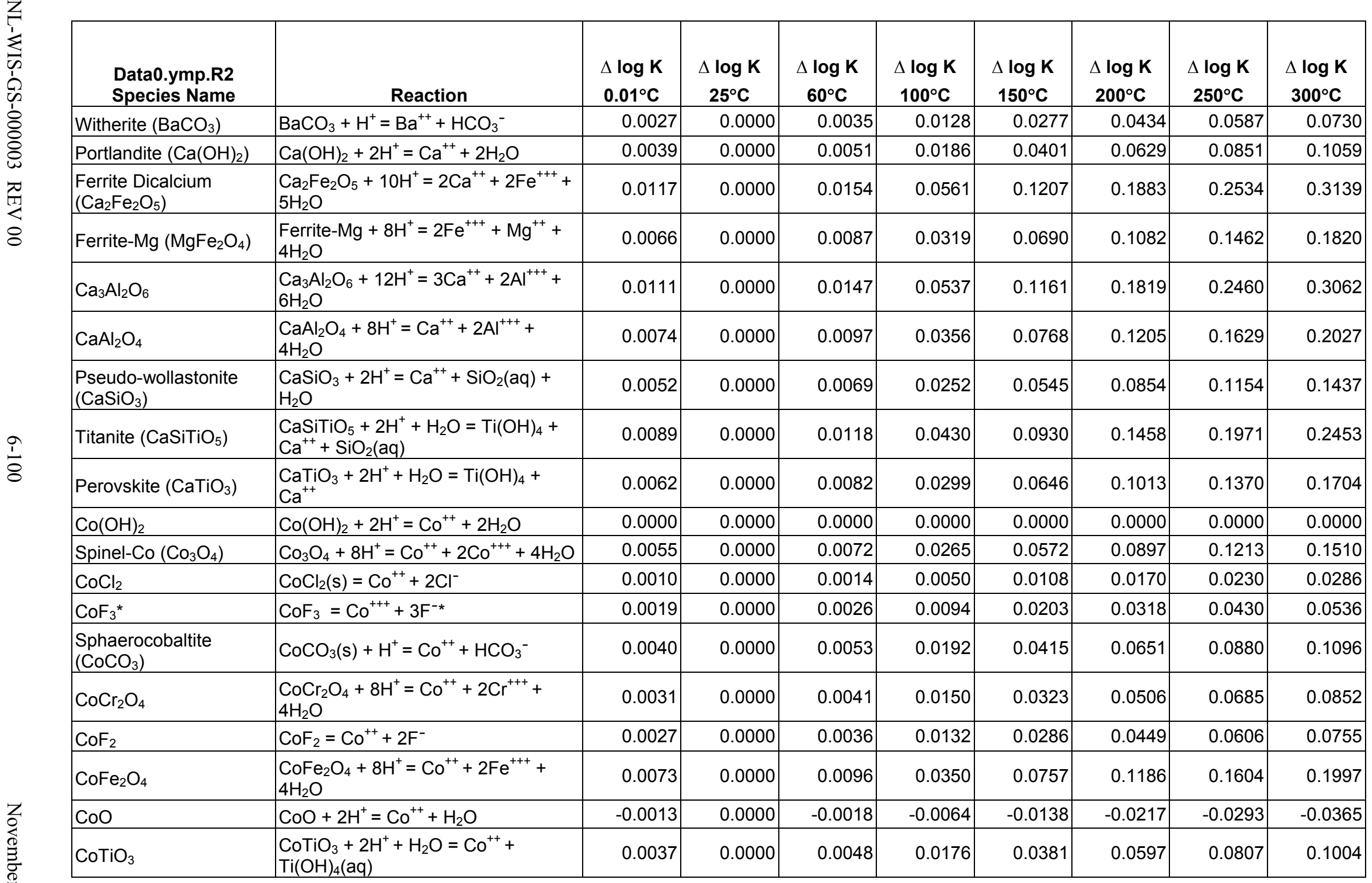


Table 6-38. $\Delta$ Log K (Difference Between Incorrect and Corrected Values) for Solid Phases (Continued)

\begin{tabular}{|c|c|c|c|c|c|c|c|c|c|}
\hline $\begin{array}{l}\text { Data0.ymp.R2 } \\
\text { Species Name }\end{array}$ & Reaction & $\begin{array}{c}\Delta \log \mathrm{K} \\
0.01^{\circ} \mathrm{C}\end{array}$ & $\begin{array}{c}\Delta \log \mathrm{K} \\
25^{\circ} \mathrm{C} \\
\end{array}$ & $\begin{array}{c}\Delta \log \mathrm{K} \\
60^{\circ} \mathrm{C}\end{array}$ & $\begin{array}{c}\Delta \log \mathrm{K} \\
100^{\circ} \mathrm{C}\end{array}$ & $\begin{array}{c}\Delta \log \mathrm{K} \\
150^{\circ} \mathrm{C}\end{array}$ & $\begin{array}{c}\Delta \log \mathrm{K} \\
200^{\circ} \mathrm{C}\end{array}$ & $\begin{array}{c}\Delta \log \mathrm{K} \\
250^{\circ} \mathrm{C}\end{array}$ & $\begin{array}{c}\Delta \log \mathrm{K} \\
300^{\circ} \mathrm{C}\end{array}$ \\
\hline $\mathrm{CoWO}_{4}$ & $\mathrm{CoWO}_{4}=\mathrm{Co}^{++}+\mathrm{WO}_{4}{ }^{--}$ & 0.0000 & 0.0000 & 0.0000 & 0.0000 & 0.0000 & 0.0000 & 0.0000 & 0.0000 \\
\hline Eskolaite $\left(\mathrm{Cr}_{2} \mathrm{O}_{3}\right)$ & $\begin{array}{l}\mathrm{Cr}_{2} \mathrm{O}_{3}+2 \mathrm{H}_{2} \mathrm{O}+1.5 \mathrm{O}_{2}(\mathrm{~g})=2 \mathrm{CrO}_{4}{ }^{--}+ \\
4 \mathrm{H}^{+}\end{array}$ & 0.0000 & 0.0000 & 0.0000 & 0.0000 & 0.0000 & 0.0000 & 0.0000 & 0.0000 \\
\hline $\mathrm{CrCl}_{3}$ & $\mathrm{CrCl}_{3}(\mathrm{~s})=\mathrm{Cr}^{+++}+3 \mathrm{Cl}^{-}$ & 0.0022 & 0.0000 & 0.0029 & 0.0107 & 0.0231 & 0.0362 & 0.0489 & 0.0609 \\
\hline $\mathrm{CrF}_{3}$ & $\mathrm{CrF}_{3}(\mathrm{~s})=\mathrm{Cr}^{+++}+3 \mathrm{~F}^{-}$ & 0.0036 & 0.0000 & 0.0047 & 0.0173 & 0.0374 & 0.0586 & 0.0792 & 0.0986 \\
\hline $\mathrm{Crl}_{3}$ & $\mathrm{Crl}_{3}=\mathrm{Cr}^{+++}+3 \mathrm{I}^{-}$ & 0.0000 & 0.0000 & 0.0000 & 0.0000 & 0.0000 & 0.0000 & 0.0000 & 0.0000 \\
\hline $\mathrm{CrO}_{3}$ & $\mathrm{CrO}_{3}+\mathrm{H}_{2} \mathrm{O}=\mathrm{CrO}_{4}^{--}+2 \mathrm{H}^{+}$ & 0.0037 & 0.0000 & 0.0049 & 0.0178 & 0.0385 & 0.0604 & 0.0817 & 0.1017 \\
\hline Ferrite-Cu $\left(\mathrm{CuFe}_{2} \mathrm{O}_{4}\right)$ & $\begin{array}{l}\mathrm{CuFe}_{2} \mathrm{O}_{4}+8 \mathrm{H}^{+}=\mathrm{Cu}^{++}+2 \mathrm{Fe}^{+++}+ \\
4 \mathrm{H}_{2} \mathrm{O}\end{array}$ & -0.1276 & 0.0000 & 0.1755 & 0.3644 & 0.5785 & 0.7672 & 0.9322 & 1.0758 \\
\hline Iron $(\mathrm{Fe})$ & $\mathrm{Fe}+2 \mathrm{H}^{+}+0.5 \mathrm{O}_{2}(\mathrm{~g})=\mathrm{Fe}^{++}+\mathrm{H}_{2} \mathrm{O}$ & -0.0004 & 0.0000 & -0.0005 & -0.0017 & -0.0037 & -0.0058 & -0.0078 & -0.0097 \\
\hline $\mathrm{Fe}(\mathrm{OH})_{2}$ & $\mathrm{Fe}(\mathrm{OH})_{2}(\mathrm{~s})+2 \mathrm{H}^{+}=\mathrm{Fe}^{++}+2 \mathrm{H}_{2} \mathrm{O}$ & 0.0064 & 0.0000 & 0.0084 & 0.0307 & 0.0662 & 0.1038 & 0.1404 & 0.1747 \\
\hline $\mathrm{Fe}(\mathrm{OH})_{3}$ & $\mathrm{Fe}(\mathrm{OH})_{3}(\mathrm{~s})+3 \mathrm{H}^{+}=\mathrm{Fe}^{+++}+3 \mathrm{H}_{2} \mathrm{O}$ & 0.0093 & 0.0000 & 0.0123 & 0.0451 & 0.0974 & 0.1526 & 0.2064 & 0.2569 \\
\hline $\mathrm{Fe}_{2}\left(\mathrm{SO}_{4}\right)_{3}$ & $\mathrm{Fe}_{3}\left(\mathrm{SO}_{4}\right)_{3}(\mathrm{~s})=\mathrm{Fe}^{+++}+3 \mathrm{SO}_{4}^{--}$ & 0.0235 & 0.0000 & 0.0311 & 0.1137 & 0.2455 & 0.3849 & 0.5204 & 0.6477 \\
\hline Hercynite $\left(\mathrm{FeAl}_{2} \mathrm{O}_{4}\right)$ & $\begin{array}{l}\mathrm{FeAl}_{2} \mathrm{O}_{4}+8 \mathrm{H}^{+}=\mathrm{Fe}^{++}+2 \mathrm{Al}^{+++}+ \\
4 \mathrm{H}_{2} \mathrm{O}\end{array}$ & 0.0078 & 0.0000 & 0.0103 & 0.0376 & 0.0812 & 0.1273 & 0.1722 & 0.2143 \\
\hline Lawrencite $\left(\mathrm{FeCl}_{2}\right)$ & $\mathrm{FeCl}_{2}(\mathrm{~g})=\mathrm{Fe}^{++}+2 \mathrm{Cl}^{-}$ & 0.0009 & 0.0000 & 0.0012 & 0.0045 & 0.0097 & 0.0152 & 0.0205 & 0.0256 \\
\hline Molysite $\left(\mathrm{FeCl}_{3}\right)$ & $\mathrm{FeCl}_{3}(\mathrm{~s})=\mathrm{Fe}^{+++}+3 \mathrm{Cl}^{-}$ & 0.0002 & 0.0000 & 0.0003 & 0.0010 & 0.0021 & 0.0033 & 0.0044 & 0.0055 \\
\hline Chromite $\left(\mathrm{FeCr}_{2} \mathrm{O}_{4}\right)$ & $\begin{array}{l}\mathrm{FeCr}_{2} \mathrm{O}_{4}+8 \mathrm{H}^{+}=\mathrm{Fe}^{++}+2 \mathrm{Cr}^{--}+ \\
4 \mathrm{H}_{2} \mathrm{O}\end{array}$ & 0.0071 & 0.0000 & 0.0093 & 0.0341 & 0.0736 & 0.1154 & 0.1560 & 0.1942 \\
\hline $\mathrm{FeF}_{2}$ & $\mathrm{FeF}_{2}(\mathrm{~s})=\mathrm{Fe}^{++}+2 \mathrm{~F}^{-}$ & 0.0015 & 0.0000 & 0.0020 & 0.0075 & 0.0162 & 0.0253 & 0.0342 & 0.0426 \\
\hline $\mathrm{FeF}_{3}$ & $\mathrm{FeF}_{3}(\mathrm{~s})=\mathrm{Fe}^{+++}+3 \mathrm{~F}^{-}$ & 0.0005 & 0.0000 & 0.0006 & 0.0024 & 0.0051 & 0.0080 & 0.0108 & 0.0134 \\
\hline Ferrite-Ca $\left(\mathrm{CaFe}_{2} \mathrm{O}_{4}\right)$ & $\begin{array}{l}\text { Ferrite-Ca }+8 \mathrm{H}^{+}=2 \mathrm{Fe}^{+++}+\mathrm{Ca}^{++}+ \\
4 \mathrm{H}_{2} \mathrm{O}\end{array}$ & 0.0034 & 0.0000 & 0.0045 & 0.0163 & 0.0353 & 0.0553 & 0.0748 & 0.0931 \\
\hline Ferrite-Ni $\left(\mathrm{NiFe}_{2} \mathrm{O}_{4}\right)$ & $\begin{array}{l}\text { Ferrite-Ni }+8 \mathrm{H}^{+}=2 \mathrm{Fe}^{+++}+\mathrm{Ni}^{++}+ \\
4 \mathrm{H}_{2} \mathrm{O}\end{array}$ & 0.0033 & 0.0000 & 0.0043 & 0.0159 & 0.0344 & 0.0539 & 0.0729 & 0.0907 \\
\hline $\mathrm{FeSO}_{4}$ & $\mathrm{FeSO}_{4}(\mathrm{~s})=\mathrm{Fe}^{++}+\mathrm{SO}_{4}{ }^{--}$ & 0.0065 & 0.0000 & 0.0086 & 0.0313 & 0.0676 & 0.1060 & 0.1433 & 0.1784 \\
\hline IImenite $\left(\mathrm{FeTiO}_{3}\right)$ & $\mathrm{FeTiO}_{3}+2 \mathrm{H}^{+}+\mathrm{H}_{2} \mathrm{O}=\mathrm{Ti}(\mathrm{OH})_{4}+\mathrm{Fe}^{++}$ & 0.0044 & 0.0000 & 0.0058 & 0.0214 & 0.0461 & 0.0723 & 0.0978 & 0.1217 \\
\hline $\mathrm{MgBr}_{2}$ & $\mathrm{MgBr}_{2}=\mathrm{Mg}^{++}+2 \mathrm{Br}^{-}$ & 0.0002 & 0.0000 & 0.0003 & 0.0012 & 0.0025 & 0.0040 & 0.0054 & 0.0067 \\
\hline
\end{tabular}


Table 6-38. $\Delta$ Log K (Difference Between Incorrect and Corrected Values) for Solid Phases (Continued)

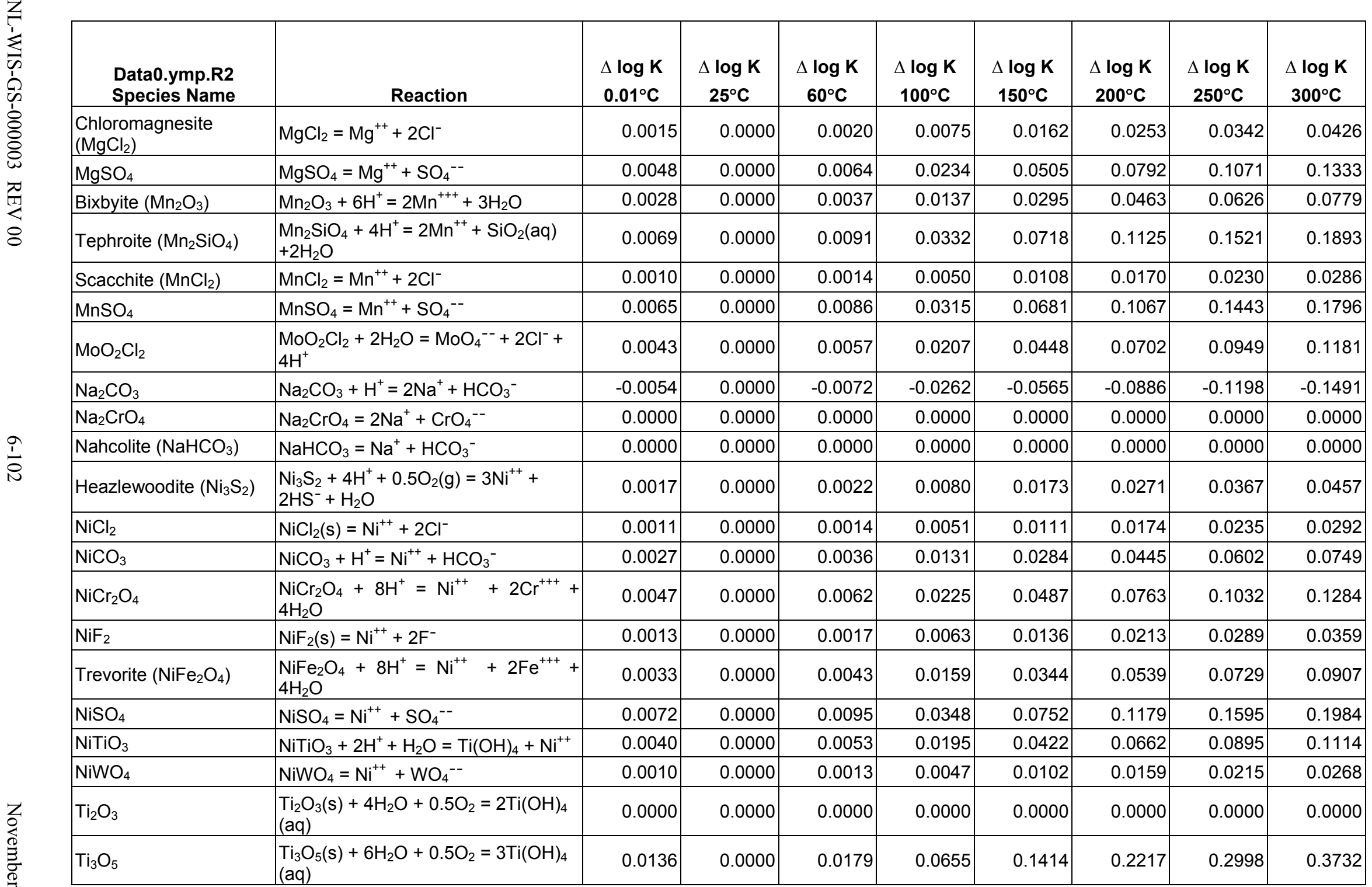


Table 6-38. $\Delta$ Log K (Difference Between Incorrect and Corrected Values) for Solid Phases (Continued)

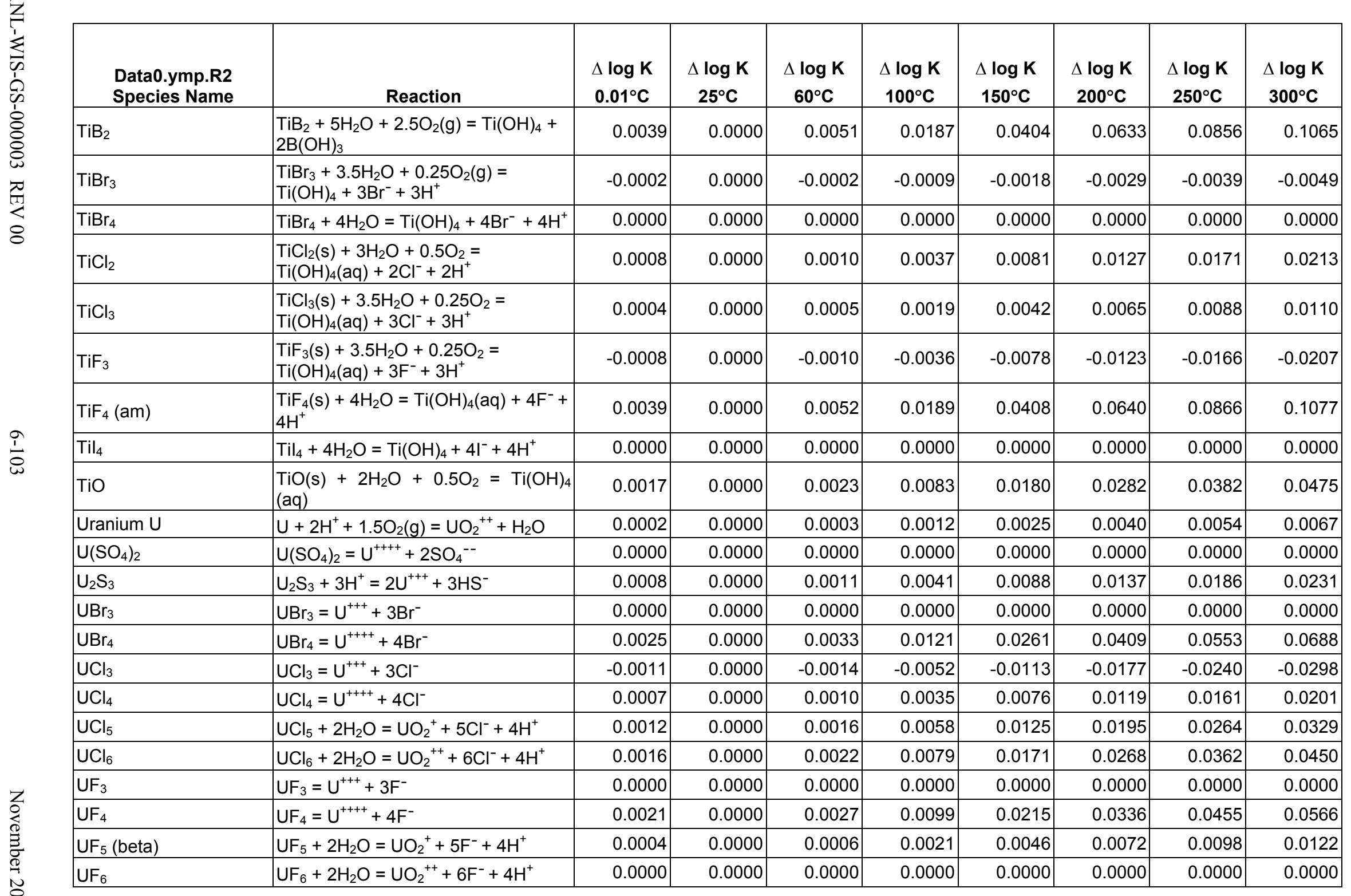


Table 6-38. $\Delta$ Log K (Difference Between Incorrect and Corrected Values) for Solid Phases (Continued)

\begin{tabular}{|c|c|c|c|c|c|c|c|c|c|}
\hline $\begin{array}{l}\text { Data0.ymp.R2 } \\
\text { Species Name }\end{array}$ & Reaction & $\begin{array}{l}\Delta \log \mathrm{K} \\
0.01^{\circ} \mathrm{C}\end{array}$ & $\begin{array}{c}\Delta \log \mathrm{K} \\
25^{\circ} \mathrm{C} \\
\end{array}$ & $\begin{array}{c}\Delta \log \mathrm{K} \\
60^{\circ} \mathrm{C} \\
\end{array}$ & $\begin{array}{c}\Delta \log \mathrm{K} \\
100^{\circ} \mathrm{C}\end{array}$ & $\begin{array}{c}\Delta \log \mathrm{K} \\
150^{\circ} \mathrm{C}\end{array}$ & $\begin{array}{c}\Delta \log \mathrm{K} \\
200^{\circ} \mathrm{C}\end{array}$ & $\begin{array}{c}\Delta \log \mathrm{K} \\
250^{\circ} \mathrm{C}\end{array}$ & $\begin{array}{c}\Delta \log \mathrm{K} \\
300^{\circ} \mathrm{C}\end{array}$ \\
\hline $\mathrm{Ul}_{3}$ & $U I_{3}=U^{+++}+3 I^{-}$ & 0.0000 & 0.0000 & 0.0000 & 0.0000 & 0.0000 & 0.0000 & 0.0000 & 0.0000 \\
\hline $\mathrm{Ul}_{4}$ & $\mathrm{UI}_{4}=\mathrm{U}^{++++}+4 \mathrm{I}^{-}$ & 0.0035 & 0.0000 & 0.0046 & 0.0170 & 0.0367 & 0.0575 & 0.0778 & 0.0968 \\
\hline $\mathrm{UO}_{2} \mathrm{Br}_{2}$ & $\mathrm{UO}_{2} \mathrm{Br}_{2}=\mathrm{UO}_{2}^{++}+2 \mathrm{Br}^{-}$ & 0.0024 & 0.0000 & 0.0031 & 0.0114 & 0.0247 & 0.0387 & 0.0523 & 0.0651 \\
\hline $\mathrm{UO}_{2} \mathrm{Cl}_{2}$ & $\mathrm{UO}_{2} \mathrm{Cl}_{2}=\mathrm{UO}_{2}^{++}+2 \mathrm{Cl}^{-}$ & 0.0025 & 0.0000 & 0.0033 & 0.0122 & 0.0263 & 0.0412 & 0.0558 & 0.0694 \\
\hline $\mathrm{UO}_{2} \mathrm{~F}_{2}$ & $\mathrm{UO}_{2} \mathrm{~F}_{2}=\mathrm{UO}_{2}^{++}+2 \mathrm{~F}^{-}$ & 0.0044 & 0.0000 & 0.0058 & 0.0213 & 0.0459 & 0.0720 & 0.0973 & 0.1211 \\
\hline $\mathrm{UO}_{2} \mathrm{SO}_{4}$ & $\mathrm{UO}_{2} \mathrm{SO}_{4}=\mathrm{UO}_{2}^{++}+\mathrm{SO}_{4}{ }^{--}$ & 0.0000 & 0.0000 & 0.0000 & 0.0000 & 0.0000 & 0.0000 & 0.0000 & 0.0000 \\
\hline $\mathrm{UO}_{3}$ (gamma) & $\mathrm{UO}_{3}+2 \mathrm{H}^{+}=\mathrm{UO}_{2}^{++}+\mathrm{H}_{2} \mathrm{O}$ & 0.0025 & 0.0000 & 0.0032 & 0.0119 & 0.0256 & 0.0402 & 0.0543 & 0.0676 \\
\hline $\mathrm{UOBr}_{2}$ & $\mathrm{UOBr}_{2}+2 \mathrm{H}^{+}=\mathrm{U}^{++++}+2 \mathrm{Br}^{-}+\mathrm{H}_{2} \mathrm{O}$ & 0.0033 & 0.0000 & 0.0043 & 0.0159 & 0.0344 & 0.0539 & 0.0729 & 0.0907 \\
\hline $\mathrm{UOBr}_{3}$ & $\mathrm{UOBr}_{3}+\mathrm{H}_{2} \mathrm{O}=\mathrm{UO}_{2}^{+}+3 \mathrm{Br}^{-}+2 \mathrm{H}^{+}$ & 0.0031 & 0.0000 & 0.0040 & 0.0147 & 0.0318 & 0.0499 & 0.0675 & 0.0840 \\
\hline UOCl & $\mathrm{UOCl}+2 \mathrm{H}^{+}=\mathrm{U}^{+++}+\mathrm{Cl}^{-}+\mathrm{H}_{2} \mathrm{O}$ & 0.0018 & 0.0000 & 0.0024 & 0.0089 & 0.0192 & 0.0300 & 0.0406 & 0.0505 \\
\hline $\mathrm{UOCl}_{2}$ & $\mathrm{UOCl}_{2}+2 \mathrm{H}^{+}=\mathrm{U}^{++++}+2 \mathrm{Cl}^{-}+\mathrm{H}_{2} \mathrm{O}$ & 0.0016 & 0.0000 & 0.0022 & 0.0079 & 0.0171 & 0.0268 & 0.0362 & 0.0450 \\
\hline $\mathrm{UOCl}_{3}$ & $\mathrm{UOCl}_{3}+\mathrm{H}_{2} \mathrm{O}=\mathrm{UO}_{2}^{+}+3 \mathrm{Cl}^{-}+2 \mathrm{H}^{+}$ & 0.0026 & 0.0000 & 0.0035 & 0.0127 & 0.0275 & 0.0430 & 0.0582 & 0.0724 \\
\hline $\mathrm{WCl}_{2}(\mathrm{~s})$ & $\begin{array}{l}\mathrm{WCl}_{2}(\mathrm{~s})+2 \mathrm{H}_{2} \mathrm{O}+\mathrm{O}_{2}(\mathrm{~g})=\mathrm{WO}_{4}^{--}+ \\
2 \mathrm{Cl}^{-}+4 \mathrm{H}^{+}\end{array}$ & 0.0000 & 0.0000 & 0.0000 & 0.0000 & 0.0000 & 0.0000 & 0.0000 & 0.0000 \\
\hline $\mathrm{WCl}_{4}(\mathrm{~s})$ & $\begin{array}{l}\mathrm{WCl}_{4}(\mathrm{~s})+3 \mathrm{H}_{2} \mathrm{O}+0.5 \mathrm{O}_{2}=\mathrm{WO}_{4}^{--}+ \\
4 \mathrm{Cl}^{-}+6 \mathrm{H}^{+}\end{array}$ & 0.0000 & 0.0000 & 0.0000 & 0.0000 & 0.0000 & 0.0000 & 0.0000 & 0.0000 \\
\hline $\mathrm{WCl}_{5}(\mathrm{~s})$ & $\begin{array}{l}\mathrm{WCl}_{5}(\mathrm{~s})+3.5 \mathrm{H}_{2} \mathrm{O}+0.25 \mathrm{O}_{2}= \\
\mathrm{WO}_{4}^{--}+5 \mathrm{Cl}^{-}+7 \mathrm{H}^{+}\end{array}$ & 0.0003 & 0.0000 & 0.0004 & 0.0015 & 0.0032 & 0.0051 & 0.0068 & 0.0085 \\
\hline $\mathrm{WCl}_{6}$ (s) & $\begin{array}{l}\mathrm{WCl}_{6}(\mathrm{~s})+4 \mathrm{H}_{2} \mathrm{O}=\mathrm{WO}_{4}^{--}+6 \mathrm{Cl}^{-}+ \\
8 \mathrm{H}^{+}\end{array}$ & 0.0000 & 0.0000 & 0.0000 & 0.0000 & 0.0000 & 0.0000 & 0.0000 & 0.0000 \\
\hline $\mathrm{WO}_{2} \mathrm{Cl}_{2}(\mathrm{~s})$ & $\begin{array}{l}\mathrm{WO}_{2} \mathrm{Cl}_{2}(\mathrm{~s})+2 \mathrm{H}_{2} \mathrm{O}=\mathrm{WO}_{4}{ }^{--}+2 \mathrm{Cl}^{-}+ \\
4 \mathrm{H}+\end{array}$ & 0.0006 & 0.0000 & 0.0008 & 0.0031 & 0.0067 & 0.0105 & 0.0142 & 0.0177 \\
\hline $\mathrm{WOCl}_{4}$ (s) & $\begin{array}{l}\mathrm{WOCl}_{4}(\mathrm{~s})+3 \mathrm{H}_{2} \mathrm{O}=\mathrm{WO}_{4}^{--}+4 \mathrm{Cl}^{-}+ \\
6 \mathrm{H}^{+}\end{array}$ & 0.0000 & 0.0000 & 0.0000 & 0.0000 & 0.0000 & 0.0000 & 0.0000 & 0.0000 \\
\hline $\mathrm{WOF}_{4}(\mathrm{~s})$ & $\begin{array}{l}\mathrm{WOF}_{4}(\mathrm{~s})+3 \mathrm{H}_{2} \mathrm{O}=\mathrm{WO}_{4}{ }^{--}+4 \mathrm{~F}^{-}+ \\
6 \mathrm{H}^{+}\end{array}$ & 0.0000 & 0.0000 & 0.0000 & 0.0000 & 0.0000 & 0.0000 & 0.0000 & 0.0000 \\
\hline
\end{tabular}

Output DTN: SN0410T0510404.001 (Spreadsheets Minerals_j_psd_1_DS_fix.xIs to Minerals_j_psd_9_DS_fix.xIs and Minerals_j_psd_10_U_DS_fix.xIs).

* The equation for $\mathrm{CoF}_{3}$ is corrected from the data0.ymp.R2 database (DTN: MO0302SPATHDYN.000 [DIRS 161756]), which gives an equation for CoCl 3 . 
Table 6-39. Comparison of $\Delta \mathrm{H}_{\mathrm{f}}^{\circ}$ and $\mathrm{S}^{\circ}$ Values for Solid Species from Binnewies and Milke, and Barin and Platzki

\begin{tabular}{|c|c|c|c|c|c|c|c|c|}
\hline Solid Species & $\begin{array}{c}\Delta \mathrm{H}_{\mathrm{f}}^{\circ} \\
(\mathrm{J} / \mathrm{mol}) \\
99 \mathrm{Bin} / \mathrm{Mil}^{1}\end{array}$ & $\begin{array}{c}\Delta \mathrm{H}_{\mathrm{f}}^{\circ} \\
(\mathrm{J} / \mathrm{mol}) \\
95 \mathrm{Bar} / \mathrm{Pla}^{2} \\
\end{array}$ & $\begin{array}{c}\text { Difference } \\
\text { in } \Delta \mathrm{H}_{\mathrm{f}}^{\circ} \\
\left(\mathrm{J} / \mathrm{mol}^{\circ}\right)\end{array}$ & $\begin{array}{c}\mathrm{S}^{\circ} \\
\left(\mathrm{J} / \mathrm{mol}^{-K}\right) \\
\text { 99Bin/Mil }^{1}\end{array}$ & $\begin{array}{c}\mathrm{S}^{\circ} \\
\left(\mathrm{J} / \mathrm{mol}^{-K}\right) \\
95 \mathrm{Bar} / \mathrm{Pla}^{2} \\
\end{array}$ & $\begin{array}{c}\text { Difference } \\
\text { in } \mathrm{S}^{\circ} \\
(\mathrm{J} / \mathrm{mol}-\mathrm{K})\end{array}$ & $\begin{array}{c}\text { Page } \\
\text { Numbers } \\
\text { 99Bin/Mil }{ }^{1}\end{array}$ & $\begin{array}{c}\text { Page } \\
\text { Numbers } \\
\text { 95Bar/Pla }\end{array}$ \\
\hline $\begin{array}{l}\text { Portlandite } \\
\mathrm{Ca}(\mathrm{OH})_{2}\end{array}$ & $-986,100$ & $-986,085$ & -15.00 & 83.4 & 83.387 & 0.013 & 281 & 455 \\
\hline $\begin{array}{l}\text { Ferrite- Dicalcium } \\
\mathrm{Ca}_{2} \mathrm{Fe}_{2} \mathrm{O}_{5}\end{array}$ & $-2,133,700$ & $-2,139,279$ & 5579.00 & 188.7 & 188.782 & -0.082 & 289 & 453 \\
\hline Ferrite-Mg & $-1,440,100$ & $-1,428,857$ & -11243.00 & 123.8 & 123.800 & 0.000 & 544 & 706 \\
\hline $\mathrm{Ca}_{3} \mathrm{Al}_{2} \mathrm{O}_{6}$ & $-3,587,800$ & $-3,587,801$ & 1.00 & 205.9 & 205.899 & 0.001 & 46 & 445 \\
\hline $\mathrm{CaAl}_{2} \mathrm{O}_{4}$ & $-2,326,300$ & $-2,326,304$ & 4.00 & 114.2 & 114.223 & -0.023 & 45 & 442 \\
\hline Wollastonite & $-1,634,900$ & -1634940 & 40.00 & $82^{*}$ & 81.919 & 0.081 & 285 & 461 \\
\hline $\begin{array}{l}\text { Pseudo } \\
\text { wollastonite } \\
\mathrm{CaSiO}_{3}\end{array}$ & $-1,628,400$ & $-1,628,400$ & 0.00 & 87.4 & 87.362 & 0.038 & 286 & 462 \\
\hline Titanite $\mathrm{CaSiTiO}_{5}$ & $-2,603,300$ & $-2,603,302$ & 2.00 & 129.2 & 129.202 & -0.002 & 287 & 473 \\
\hline $\begin{array}{l}\text { Perovskite } \\
\mathrm{CaTiO}_{3} \\
\end{array}$ & $-1,659,000$ & $-1,660,596$ & 1596.00 & 93.7 & 93.638 & 0.062 & 286 & 470 \\
\hline $\mathrm{Co}(\mathrm{OH})_{2}$ & $-541,300$ & $-539,698$ & -1602.00 & 93.3 & 78.998 & 14.302 & 408 & 545 \\
\hline Spinel-Co $\mathrm{Co}_{3} \mathrm{O}_{4}$ & $-918,700$ & $-910,020$ & -8680.00 & 109.3 & 114.307 & -5.007 & 414 & 544 \\
\hline $\mathrm{CoCl}_{2}$ & $-312,500$ & $-312,545$ & 45.00 & 109.3 & 109.286 & 0.014 & 333 & 536 \\
\hline $\mathrm{CoF}_{3}$ & $-790,400$ & $-790,358$ & -42.00 & 94.6 & 94.558 & 0.042 & 407 & 541 \\
\hline $\begin{array}{l}\text { Sphaerocobaltite } \\
\mathrm{CoCO}_{3}\end{array}$ & $-713,000$ & $-713,000$ & 0.00 & 87.9 & 87.864 & 0.036 & 227 & 535 \\
\hline $\mathrm{CoCr}_{2} \mathrm{O}_{4}$ & $-1,438,300$ & $-1,437,497$ & -803.00 & 126.8 & 126.357 & 0.443 & 406 & 544 \\
\hline $\mathrm{CoF}_{2}$ & $-672,400$ & $-671,532$ & -868.00 & $81.9^{*}$ & 82.006 & -0.106 & 406 & 540 \\
\hline $\mathrm{CoFe}_{2} \mathrm{O}_{4}$ & $-1,088,700$ & $-1,087,840$ & -860.00 & 142.7 & 134.725 & 7.975 & 408 & 545 \\
\hline $\mathrm{CoO}$ & $-237,700$ & $-237,944$ & 244.00 & 53 & 52.969 & 0.031 & 408 & 543 \\
\hline $\mathrm{CoTiO}_{3}$ & $-1,207,400$ & $-1,210,431$ & 3031.00 & 96.9 & 97.069 & -0.169 & 409 & 547 \\
\hline $\mathrm{CoWO}_{4}$ & $-1,142,700$ & $-1,136,918$ & -5782.00 & 126.4 & 133.888 & -7.488 & 410 & 554 \\
\hline Eskolaite $\mathrm{Cr}_{2} \mathrm{O}_{3}$ & $-1,140,600$ & $-1,139,701$ & -899.00 & 81.2 & 81.199 & 0.001 & 422 & 573 \\
\hline $\mathrm{CrCl}_{3}$ & $-556,500$ & $-556,472$ & -28.00 & 123 & 123.010 & -0.010 & 359 & 563 \\
\hline $\mathrm{CrF}_{3}$ & $-1,173,200$ & $-1,173,194$ & -6.00 & 93.9 & 93.881 & 0.019 & 416 & 565 \\
\hline $\mathrm{Crl}_{3}$ & $-205,000$ & $-205,016$ & 16.00 & 199.6 & 199.577 & 0.023 & 416 & 566 \\
\hline $\mathrm{CrO}_{3}$ & $-587,000$ & $-589,526$ & 2526.00 & 73.2 & 73.220 & -0.020 & 419 & 571 \\
\hline $\begin{array}{l}\text { Ferrite-Cu } \\
\mathrm{CuFe}_{2} \mathrm{O}_{4} \text { (alpha) }\end{array}$ & $-966,500$ & $-967,968$ & 1468.00 & 146.8 & 146.758 & 0.042 & 436 & 624 \\
\hline Iron $\mathrm{Fe}$ & 0 & 0 & 0.00 & 27.3 & 27.280 & 0.020 & 534 & 675 \\
\hline $\mathrm{Fe}(\mathrm{OH})_{2}$ & $-574,000$ & $-568,999$ & -5001.00 & 87.9 & 87.998 & -0.098 & 535 & 705 \\
\hline $\mathrm{Fe}(\mathrm{OH})_{3}$ & $-832,600$ & $-822,997$ & -9603.00 & 104.6 & 106.700 & -2.100 & 536 & 705 \\
\hline $\mathrm{Fe}_{2}\left(\mathrm{SO}_{4}\right)_{3}$ & $-2,583,000$ & $-2,582,992$ & -8.00 & 307.5 & 307.524 & -0.024 & 546 & 721 \\
\hline Hercynite $\mathrm{FeAl}_{2} \mathrm{O}_{4}$ & $-1,969,500$ & $-1,995,299$ & 25799.00 & 106.3 & 106.299 & 0.001 & 49 & 704 \\
\hline Lawrencite $\mathrm{FeCl}_{2}$ & $-341,600$ & $-341,833$ & 233.00 & 117.9 & 117.947 & -0.047 & 336 & 686 \\
\hline
\end{tabular}


Table 6-39. Comparison of $\Delta \mathrm{H}_{\mathrm{f}}^{\circ}$ and $\mathrm{S}^{\circ}$ Values for Solid Species from Binnewies and Milke, and Barin and Platzki (Continued)

\begin{tabular}{|c|c|c|c|c|c|c|c|c|}
\hline Solid Species & $\begin{array}{c}\Delta \mathrm{H}_{\mathrm{f}}^{\circ} \\
(\mathrm{J} / \mathrm{mol}) \\
99 \mathrm{Bin} / \mathrm{Mil}^{1}\end{array}$ & $\begin{array}{c}\Delta \mathrm{H}_{\mathrm{f}}^{\circ} \\
\left(\mathrm{J} / \mathrm{mol}^{\circ}\right) \\
95 \mathrm{Bar} / \mathrm{Pla}^{2}\end{array}$ & $\begin{array}{c}\text { Difference } \\
\text { in } \Delta \mathbf{H}_{\mathrm{f}}^{\circ} \\
(\mathrm{J} / \mathrm{mol})\end{array}$ & $\begin{array}{c}\mathrm{S}^{\circ} \\
\left(\mathrm{J} / \mathrm{mol}^{-K}\right) \\
99 \mathrm{Bin} / \mathrm{Mil}^{1}\end{array}$ & $\begin{array}{c}\mathrm{S}^{\circ} \\
\left(\mathrm{J} / \mathrm{mol}^{-K}\right) \\
95 \mathrm{Bar} \mathrm{Pla}^{2} \\
\end{array}$ & $\begin{array}{l}\text { Difference } \\
\text { in S } \\
(\mathrm{J} / \mathrm{mol}-\mathrm{K})\end{array}$ & $\begin{array}{c}\text { Page } \\
\text { Numbers } \\
\text { 99Bin/Mil }{ }^{1}\end{array}$ & $\begin{array}{c}\text { Page } \\
\text { Numbers } \\
\text { 95Bar/Pla }\end{array}$ \\
\hline Molysite $\mathrm{FeCl}_{3}$ & $-399,200$ & $-399,405$ & 205.00 & 147.8 & 142.336 & 5.464 & 362 & 687 \\
\hline $\begin{array}{l}\text { Chromite } \\
\mathrm{FeCr}_{2} \mathrm{O}_{4} \\
\end{array}$ & $-1,458,600$ & $-1,458,124$ & -476.00 & 146.9 & 141.963 & 4.937 & 421 & 575 \\
\hline $\mathrm{FeF}_{2}$ & $-705,800$ & $-705,841$ & 41.00 & 87 & 86.985 & 0.015 & 475 & 691 \\
\hline $\mathrm{FeF}_{3}$ & $-1,039,300$ & $-1,041,816$ & 2516.00 & 98.3 & 98.324 & -0.024 & 493 & 692 \\
\hline \begin{tabular}{|l|} 
Goethite \\
FeOOH \\
\end{tabular} & $-558,100$ & - & - & 60.4 & - & - & 535 & - \\
\hline $\begin{array}{l}\text { Ferrite-Ca } \\
\left(\mathrm{CaFe} \mathrm{O}_{4} \mathrm{O}_{4}\right) \\
\end{array}$ & $-1,479,400$ & $-1,520,340$ & 40940.00 & 145.2 & 145.352 & -0.152 & 279 & 453 \\
\hline $\begin{array}{l}\text { Ferrite-Ni } \\
\left(\mathrm{NiFe}_{2} \mathrm{O}_{4}\right)\end{array}$ & $-1,084,500$ & $-1,081,100$ & -3400.00 & 125.9 & 131.800 & -5.900 & 545 & 709 \\
\hline $\mathrm{FeSO}_{4}$ & $-928,900$ & $-928,848$ & -52.00 & 121 & 120.959 & 0.041 & 539 & 720 \\
\hline IImenite $\mathrm{FeTiO}_{3}$ & $-1,239,200$ & $-1,235,535$ & -3665.00 & 105.9 & 105.855 & 0.045 & 538 & 714 \\
\hline \begin{tabular}{|l|l}
$\mathrm{MgBr}_{2}$ \\
\end{tabular} & $-524,300$ & $-524,255$ & -45.00 & 117.2 & 117.152 & 0.048 & 184 & 997 \\
\hline $\begin{array}{l}\text { Chloro } \\
\text { magnesite } \\
\mathrm{MgCl}_{2}\end{array}$ & $-644,200$ & $-641,616$ & -2584.00 & 89.5 & 89.630 & -0.130 & 340 & 1003 \\
\hline $\mathrm{MgSO}_{4}$ & $-1,261,800$ & $-1,284,898$ & 23098.00 & 91.4 & 91.600 & -0.200 & 676 & 1028 \\
\hline Bixbyite $\mathrm{Mn} 2 \mathrm{O} 3$ & $-959,000$ & $-959,002$ & 2.00 & 110.5 & 110.499 & 0.001 & 689 & 1047 \\
\hline \begin{tabular}{|l|} 
Tephroite \\
$\mathrm{Mn}_{2} \mathrm{SiO}_{4}$
\end{tabular} & $-1,725,300$ & $-1,730,498$ & 5198.00 & 142.2 & 163.201 & -21.001 & 690 & 1051 \\
\hline $\begin{array}{l}\text { Scacchite } \\
\mathrm{MnCl}_{2}\end{array}$ & $-481,300$ & $-481,290$ & -10.00 & 118.2 & 118.240 & -0.040 & 341 & 1040 \\
\hline $\mathrm{MnSO}_{4}$ & $-1,065,300$ & $-1,065,251$ & -49.00 & 112.1 & 112.098 & 0.002 & 686 & 1056 \\
\hline $\mathrm{MoO}_{2} \mathrm{Cl}_{2}$ & $-725,800$ & $-717,100$ & -8700.00 & 120.5 & 142.256 & -21.756 & 342 & 1074 \\
\hline $\mathrm{Na}_{2} \mathrm{CO}_{3}$ & $-1,130,800$ & $-1,130,768$ & -32.00 & 138.8 & 138.783 & 0.017 & 243 & 1117 \\
\hline $\mathrm{Na}_{2} \mathrm{CrO}_{4}$ & $-1,334,300$ & $-1,342,198$ & 7898.00 & 176.6 & 176.611 & -0.011 & 418 & 1121 \\
\hline $\begin{array}{l}\text { Nahcolite } \\
\mathrm{NaHCO}_{3}\end{array}$ & $-936,300$ & $-950,810$ & 14510.00 & 101.2 & 101.701 & -0.501 & 232 & 1125 \\
\hline $\begin{array}{l}\text { Heazlewoodite } \\
\mathrm{Ni}_{3} \mathrm{~S}_{2}\end{array}$ & $-216,300$ & $-216,313$ & 13.00 & 133.9 & 133.888 & 0.012 & 740 & 1222 \\
\hline $\mathrm{NiCl}_{2}$ & $-305,300$ & $-305,348$ & 48.00 & 98 & 98.006 & -0.006 & 344 & 1207 \\
\hline $\mathrm{NiCO}_{3}$ & $-696,300$ & $-694,544$ & -1756.00 & 86.2 & 86.190 & 0.010 & 244 & 1205 \\
\hline $\mathrm{NiCr}_{2} \mathrm{O}_{4}$ & $-1,392,400$ & $-1,381,557$ & -10843.00 & 129.7 & 119.244 & 10.456 & 422 & 577 \\
\hline $\mathrm{NiF}_{2}$ & $-657,700$ & $-657,725$ & 25.00 & 73.6 & 73.597 & 0.003 & 483 & 1210 \\
\hline $\begin{array}{l}\text { Trevorite } \\
\mathrm{NiFe}_{2} \mathrm{O}_{4} \\
\end{array}$ & $-1,084,500$ & $-1,081,100$ & -3400.00 & 125.9 & 131.800 & -5.900 & 545 & 709 \\
\hline $\mathrm{NiSO}_{4}$ & $-873,200$ & $-872,908$ & -292.00 & 101.3 & 92.002 & 9.298 & 735 & 1223 \\
\hline $\mathrm{NiTiO}_{3}$ & $-1,201,400$ & $-1,202,440$ & 1040.00 & 82.6 & 85.772 & -3.172 & 734 & 1217 \\
\hline $\mathrm{NiWO}_{4}$ & $-1,127,800$ & $-1,127,170$ & -630.00 & 118 & 125.520 & -7.520 & 735 & 1230 \\
\hline $\mathrm{Ti}_{2} \mathrm{O}_{3}$ & $-1,520,900$ & $-1,520,884$ & -16.00 & 77.3 & 77.237 & 0.063 & 772 & 1694 \\
\hline $\mathrm{Ti}_{3} \mathrm{O}_{5}$ (alpha) & $-2,459,100$ & $-2,459,146$ & 46.00 & 129.4 & 129.369 & 0.031 & 786 & 1695 \\
\hline $\mathrm{TiB}_{2}$ & $-315,900$ & $-323,800$ & 7900.00 & 28.5 & 28.493 & 0.007 & 115 & 1669 \\
\hline $\mathrm{TiBr}_{3}$ & $-551,900$ & $-550,196$ & -1704.00 & 176.6 & 176.565 & 0.035 & 207 & 1671 \\
\hline $\mathrm{TiBr}_{4}$ & $-619,700$ & $-617,977$ & -1723.00 & 243.5 & 243.509 & -0.009 & 215 & 1672 \\
\hline $\mathrm{TiCl}_{2}$ & $-515,500$ & $-515,469$ & -310.00 & 87.3 & 87.362 & -0.062 & 355 & 1676 \\
\hline $\mathrm{TiCl}_{3}$ & $-721,700$ & $-721,740$ & 40.00 & 139.8 & 139.746 & 0.054 & 380 & 1677 \\
\hline
\end{tabular}


Table 6-39. Comparison of $\Delta \mathrm{H}_{\mathrm{f}}^{\circ}$ and $\mathrm{S}^{\circ}$ Values for Solid Species from Binnewies and Milke, and Barin and Platzki (Continued)

\begin{tabular}{|c|c|c|c|c|c|c|c|c|}
\hline Solid Species & $\begin{array}{c}\Delta \mathrm{H}_{\mathrm{f}}^{\circ} \\
(\mathrm{J} / \mathrm{mol}) \\
99 \mathrm{Bin} / \mathrm{Mil}^{1}\end{array}$ & $\begin{array}{c}\Delta \mathrm{H}_{\mathrm{f}}^{\circ} \\
\left(\mathrm{J} / \mathrm{mol}^{\prime}\right) \\
95 \mathrm{Bar} / \mathrm{Pla}^{2}\end{array}$ & $\begin{array}{c}\text { Difference } \\
\text { in } \Delta \mathbf{H}_{\mathrm{f}}^{\circ} \\
(\mathrm{J} / \mathrm{mol})\end{array}$ & $\begin{array}{c}\mathrm{S}^{\circ} \\
\left(\mathrm{J} / \mathrm{mol}^{-K}\right) \\
99 \mathrm{Bin} / \mathrm{Mil}^{1}\end{array}$ & $\begin{array}{c}\mathrm{S}^{\circ} \\
\left(\mathrm{J} / \mathrm{mol}^{-K}\right) \\
95 \mathrm{Bar} \mathrm{Pla}^{2}\end{array}$ & $\begin{array}{l}\text { Difference } \\
\text { in S } \\
(\mathrm{J} / \mathrm{mol}-\mathrm{K})\end{array}$ & $\begin{array}{c}\text { Page } \\
\text { Numbers } \\
\text { 99Bin/Mil }{ }^{1}\end{array}$ & $\begin{array}{c}\text { Page } \\
\text { Numbers } \\
\text { 95Bar/Pla }\end{array}$ \\
\hline $\mathrm{TiF}_{3}$ & $-1,435,500$ & $-1,435,530$ & 30.00 & \begin{tabular}{|l|}
87.9 \\
\end{tabular} & \begin{tabular}{|l|}
87.864 \\
\end{tabular} & 0.036 & 509 & 1681 \\
\hline $\mathrm{TiF}_{4}(\mathrm{am})$ & $-1,649,300$ & $-1,649,333$ & 33.00 & 134 & 133.972 & 0.028 & 520 & 1682 \\
\hline $\mathrm{Til}_{4}$ & $-375,700$ & $-375,723$ & 23.00 & 246.2 & 246.019 & 0.181 & 631 & 1687 \\
\hline TiO & $-542,700$ & $-542,665$ & -35.00 & 34.8 & 34.769 & 0.031 & 749 & 1690 \\
\hline Uranium U & 0 & 0 & 0.00 & 50.3 & 50.292 & 0.008 & 888 & 1725 \\
\hline $\mathrm{U}\left(\mathrm{SO}_{4}\right)_{2}$ & $-2,318,000$ & $-2,317,936$ & -64.00 & 164 & 161.084 & 2.916 & 794 & 1757 \\
\hline $\mathrm{U}_{2} \mathrm{~S}_{3}$ & $-854,000$ & $-854,000$ & 0.00 & 199.2 & 199.200 & 0.000 & 843 & 1757 \\
\hline $\mathrm{UBr}_{3}$ & $-699,100$ & $-699,146$ & 46.00 & 192.5 & 192.464 & 0.036 & 208 & 1729 \\
\hline $\mathrm{UBr}_{4}$ & $-802,500$ & $-802,500$ & 0.00 & 238.5 & 238.501 & -0.001 & 216 & 1730 \\
\hline $\mathrm{UCl}_{3}$ & $-861,900$ & $-861,904$ & 4.00 & 159 & 158.992 & 0.008 & 381 & 1734 \\
\hline $\mathrm{UCl}_{4}$ & $-1,018,800$ & $-1,019,201$ & 401.00 & 197.2 & 197.100 & 0.100 & 394 & 1735 \\
\hline $\mathrm{UCl}_{5}$ & $-1,041,500$ & $-1,059,000$ & 17500.00 & 246.9 & 242.701 & 4.199 & 400 & 1736 \\
\hline $\mathrm{UCl}_{6}$ & $-1,068,200$ & $-1,091,999$ & 23799.00 & 285.8 & 285.801 & -0.001 & 402 & 1737 \\
\hline $\mathrm{UF}_{3}$ & $-1,502,100$ & $-1,508,750$ & 6650.00 & 123.4 & 123.428 & -0.028 & 510 & 1738 \\
\hline $\mathrm{UF}_{4}$ & $-1,914,200$ & $-1,920,874$ & 6674.00 & 151.7 & 151.670 & 0.030 & 520 & 1739 \\
\hline $\mathrm{UF}_{5}$ (beta) & $-2,083,200$ & $-2,083,214$ & 14.00 & 179.5 & 179.494 & 0.006 & 527 & 1741 \\
\hline $\mathrm{UF}_{6}$ & $-2,197,000$ & $-2,197,002$ & 2.00 & 227.6 & 227.601 & -0.001 & 531 & 1742 \\
\hline $\mathrm{UI}_{3}$ & $-460,700$ & $-460,658$ & -42.00 & 222 & 222.170 & -0.170 & 625 & 1743 \\
\hline $\mathrm{UI}_{4}$ & $-512,100$ & $-512,122$ & 22.00 & 263.6 & 263.592 & 0.008 & 632 & 1744 \\
\hline $\mathrm{UO}_{2} \mathrm{Br}_{2}$ & $-1,137,600$ & $-1,137,630$ & 30.00 & 169.5 & 169.452 & 0.048 & 187 & 1749 \\
\hline $\mathrm{UO}_{2} \mathrm{Cl}_{2}$ & $-1,243,500$ & $-1,243,903$ & 403.00 & 150.6 & 150.540 & 0.060 & 346 & 1751 \\
\hline $\mathrm{UO}_{2} \mathrm{~F}_{2}$ & $-1,651,400$ & $-1,648,078$ & -3322.00 & 135.6 & 135.562 & 0.038 & 484 & 1752 \\
\hline $\mathrm{UO}_{2} \mathrm{SO}_{4}$ & $-1,845,100$ & $-1,845,102$ & 2.00 & 154.8 & 154.808 & -0.008 & 789 & 1754 \\
\hline $\mathrm{UO}_{3}$ (gamma) & $-1,226,500$ & $-1,222,983$ & -3517.00 & 98.8 & 96.107 & 2.693 & 774 & 1747 \\
\hline $\mathrm{UOBr}_{2}$ & $-973,600$ & $-973,617$ & 17.00 & 157.6 & 157.569 & 0.031 & 187 & 1748 \\
\hline $\mathrm{UOBr}_{3}$ & $-954,000$ & $-953,952$ & -48.00 & 205 & 205.016 & -0.016 & 202 & 1749 \\
\hline $\mathrm{UOCl}$ & $-833,900$ & $-947,258$ & 113358.00 & 102.5 & 102.926 & -0.426 & 328 & 1750 \\
\hline $\mathrm{UOCl}_{2}$ & $-1,067,500$ & $-1,066,920$ & -580.00 & 138.3 & 138.323 & -0.023 & 345 & 1750 \\
\hline $\mathrm{UOCl}_{3}$ & $-1,151,600$ & $-1,163,001$ & 11401.00 & 170.7 & 171.498 & -0.798 & 371 & 1751 \\
\hline $\mathrm{WCl}_{2}(\mathrm{~s})$ & $-260,300$ & $-257,316$ & -2984.00 & 130.5 & 130.541 & -0.041 & 356 & 1792 \\
\hline $\mathrm{WCl}_{4}(\mathrm{~s})$ & $-443,100$ & $-443,086$ & -14.00 & 198.3 & 198.322 & -0.022 & 395 & 1793 \\
\hline $\mathrm{WCl}_{5}(\mathrm{~s})$ & $-513,000$ & $-512,958$ & -42.00 & 217.6 & 217.568 & 0.032 & 400 & 1794 \\
\hline $\mathrm{WCl}_{6}(\mathrm{~s})$ & $-593,700$ & $-593,710$ & 10.00 & 238.5 & 238.488 & 0.012 & 402 & 1795 \\
\hline $\mathrm{WO}_{2} \mathrm{Cl}_{2}(\mathrm{~s})$ & $-780,300$ & $-780,316$ & 16.00 & 200.8 & 200.832 & -0.032 & 347 & 1812 \\
\hline $\mathrm{WOCl}_{4}(\mathrm{~s})$ & $-671,100$ & $-671,114$ & 14.00 & 172.8 & 172.799 & 0.001 & 388 & 1811 \\
\hline $\mathrm{WOF}_{4}(\mathrm{~s})$ & $-1,406,900$ & $-1,394,360$ & -12540.00 & 175.7 & 175.728 & -0.028 & 516 & 1813 \\
\hline
\end{tabular}

Sources: 1 Binnewies and Milke 1999 [DIRS 158955].

2 Barin and Platzki 1995 [DIRS 157865].

Output DTN: This table appears in output DTN: SN0410T0510404.001.

* The $\mathrm{S}^{\circ}$ values for wollastonite and $\mathrm{CoF}_{2}$ are switched in this table and in DTN: SN0410T0510404.001; the output values are equivalent, given the uncertainty of these results, and are thus qualified. 


\subsection{EVALUATION AND QUALIFICATION OF THERMODYNAMIC DATA FOR GASES AND ASSOCIATED AQUEOUS SPECIES}

Data for dissociation of HF (aq) were taken from two sources. The values selected from Ellis and Mahon (1977 [DIRS 159230], Table 8.4, p. 288) are for the $\mathrm{pK}_{\mathrm{a}}$ of HF between steam and water at various temperatures $\left(25^{\circ} \mathrm{C}-300^{\circ} \mathrm{C}\right)$. This source is an excellent compilation of data collected from geothermal wells in New Zealand. In addition to this, data found in Table 18-4 in Clark (1966 [DIRS 153163], pp. 407) are used, which corroborate many of the data points $\left(250^{\circ} \mathrm{C}-300^{\circ} \mathrm{C}\right)$ from Ellis and Mahon (1977 [DIRS 159230]). The data from Clark (1966 [DIRS 153163]) are considered handbook data. The eight log $\mathrm{K}$ grid points necessary for the EQ3/6 data blocks were extracted from a regression of this data in HF Dissasoc.xls (DTN: MO0302SPATHDYN.001 [DIRS 161886]) for the reaction:

$$
\mathrm{HF}(\mathrm{aq})=\mathrm{H}^{+}+\mathrm{F}^{-}
$$

Data for dissociation of $\mathrm{HF}_{2}^{-}$(aq) were taken from data found in Table 18-4 in Clark (1966 [DIRS 153163], p. 407). The data from Clark (1966 [DIRS 153163]) are also considered handbook data. The log $\mathrm{K}$ grid points necessary for the EQ3/6 data block were extracted from a regression of this data in HF2- Dissasoc.xls (DTN: MO0302SPATHDYN.001 [DIRS 161886]) for the reaction:

$$
\mathrm{HF}(\mathrm{aq})+\mathrm{F}^{-}=\mathrm{HF}_{2}^{-}
$$

In the current qualification effort it was found that the reaction delineated by Eq. 6-35 is wrongly implemented in data0.ymp.R2 (DTN: MO0302SPATHDYN.000 [DIRS 161756]). The reaction in the data0.ymp.R2 database (DTN: MO0302SPATHDYN.000 [DIRS 161756]) is given by:

$$
\mathrm{HF}_{2}^{-}=\mathrm{H}^{+}+2 \mathrm{~F}^{-}
$$

Moreover, the values given in the source for the reaction delineated by Eq. 6-35 are expressed as $\mathrm{K}$, not $\log \mathrm{K}$ as documented in the Spreadsheet HF2-Dissasoc.xls (DTN: MO0302SPATHDYN.001 [DIRS 161886]). Therefore, the data block needs to be corrected in accord with Eq. 6-36 using the retrieved $\log \mathrm{K}$ data from for reactions given by Eqs. 6-34 and 6-35 with the data of Clark (1966 [DIRS 153163]) and Ellis and Mahon (1977 [DIRS 159230]) as presented above. The proper linear combination of reactions given by Eqs. 6-34 and 6-35 yields the $\log \mathrm{K}$ value for Eq. 6-36 as function of temperature (see Spreadsheet HF2-_Dissoc1_CFJC_fix.xls; output DTN: SN0410T0510404.001). The data are compared to the values reported in the qualified database data0.ymp.R0 (DTN: MO0009THRMODYN.001 [DIRS 152576]) (Table 6-40). The comparison shows that the $\log \mathrm{K}$ values for $\mathrm{HF}(\mathrm{aq})$ dissociation are in strong agreement to those reported in data0.ymp.R0 (DTN: MO0009THRMODYN.001 [DIRS 152576]). Thus, these values are considered qualified for intended use on the basis of corroborative data. However, the corrected $\log \mathrm{K}$ values for the dissociation of $\mathrm{HF}_{2}^{-}$show a similar trend of decreasing $\log \mathrm{K}$ with increasing temperature when compared to data0.ymp.R0 (DTN: MO0009THRMODYN.001 [DIRS 152576]) but shifted to lower values by approximately $1.15 \log$ units. For corroborative purposes, a $\log \mathrm{K}$ value at $25^{\circ} \mathrm{C}$ for the reaction defined by Eq. 6-36 computed using handbook thermodynamic data (Wagman et al. 1982 [DIRS 159216]) is used to evaluate the difference 
between the corrected values for $\mathrm{HF}_{2}{ }^{-}$dissociation described in this section and those from data0.ymp.R0 (DTN: MO0009THRMODYN.001 [DIRS 152576]). The difference between the corrected $\log \mathrm{K}$ value using Clark (1966 [DIRS 153163]) data and that obtained from (Wagman et al. 1982 [DIRS 159216]) is relatively small (approximately $0.12 \log \mathrm{K}$ units.), therefore indicating a strong data corroboration between "established fact" sources. The difference in $\log \mathrm{K}$ at $25^{\circ} \mathrm{C}$ between data0.ymp.R0 (DTN: MO0009THRMODYN.001 [DIRS 152576]) and Wagman et al. (1982 [DIRS 159216]) is relatively large (approximately $1 \log \mathrm{K}$ unit). The erroneous $\log \mathrm{K}$ value for $\mathrm{HF}_{2}{ }^{-}$in data0.ymp.R2 (DTN: MO0302SPATHDYN.000 [DIRS 161756]) should not be used for YMP work. The corrected log K values are listed in Table 6-41 and are included in the updated database file data0.ymp.R4 (output DTN: SN0410T0510404.002).

Table 6-40. Log K EQ3/6 Grids for Hydrogen Fluoride Species

\begin{tabular}{|l|c|c|c|c|c|c|c|c|c|}
\hline \multicolumn{1}{|c|}{$\mathbf{T}\left({ }^{\circ} \mathbf{C}\right)$} & $\mathbf{0 . 0 1}$ & $\mathbf{2 5}$ & $\mathbf{6 0}$ & $\mathbf{1 0 0}$ & $\mathbf{1 5 0}$ & $\mathbf{2 0 0}$ & $\mathbf{2 5 0}$ & $\mathbf{3 0 0}$ & Source \\
\hline $\mathrm{HF}(\mathrm{aq})$ & -2.9654 & -3.1791 & -3.4948 & -3.8477 & -4.3264 & -4.9345 & -5.7479 & -6.8164 & 1,2 \\
\hline $\mathrm{HF}(\mathrm{aq})$ & -2.9848 & -3.1681 & -3.4737 & -3.8482 & - & - & - & - & 3 \\
\hline $\mathrm{HF}_{2}{ }^{-}$ & 4.2705 & 3.4048 & 4.2836 & 4.9121 & 5.2966 & 7.9085 & - & - & 4 \\
\hline $\mathrm{HF}_{2}{ }^{-\mathrm{a}}$ & -3.4639 & -3.7101 & -4.1266 & -4.5367 & -5.0532 & -5.8324 & - & - & 1,2 \\
\hline $\mathrm{HF}_{2}^{-}$ & -2.2376 & -2.5509 & -2.9600 & -3.3848 & - & - & - & - & 3 \\
\hline $\mathrm{HF}_{2}{ }^{-\mathrm{b}}$ & - & -3.5915 & - & - & - & - & - & - & 5 \\
\hline
\end{tabular}

Sources: Output DTN: $\quad$ SN0410T0510404.001 (Spreadsheet HF2__Dissoc1_CFJC_fix.xIs).

DTN: MO0302SPATHDYN.001 ([DIRS 161886], Spreadsheets HF Dissasoc.xls and HF2- Dissasoc.xIs).

$1 \quad$ Clark 1966 [DIRS 153163], p.407, Table 18-4.

$2 \quad$ Ellis and Mahon 1977 [DIRS 159230], Table 8.4, p.288.

3 data0.ymp.R0 (DTN: MO0009THRMODYN.001 [DIRS 152576]) for the reaction given by Eq. 6-36.

4 Incorrect value for the reaction delineated by Eq. 6-36 as entered in data0.ymp.R2 (DTN: MO0302SPATHDYN.000 [DIRS 161756]). The data0.ymp.R2 file contains null values (500.00) for this species at temperatures $250^{\circ} \mathrm{C}$ and $300^{\circ} \mathrm{C}$.

$5 \quad$ Wagman et al. 1982 [DIRS 159216], pp. 2-38, 2-45, and 2-46.

${ }^{\text {a }}$ Corrected log $\mathrm{K}$ value for the reaction delineated in Eq. 6-36 using data from 1 and 2 (see Spreadsheet HF2-_Dissoc1_CFJC_fix.xIs; output DTN: SN0410T0510404.001).

b Calculated using Gibbs free energy of formation data from Wagman et al. (1982 [DIRS 159216], pp. 2-38, 2-45, and 2-46) for the species $\mathrm{HF}_{2}^{-}, \mathrm{F}^{-}$, and $\mathrm{H}^{+}$.

Log $\mathrm{K}$ values for other gas species computed using thermodynamic data from Barin and Platzki (1995 [DIRS 157865]) and Binnewies and Milke (1999 [DIRS 158955]) are listed in Table 6-41. In revising the heat capacity coefficient data in Table 4-17, an error was identified corresponding to the correct scaling of the "c" coefficient for the gas species shown in Table 6-42. The scaling difference between source and adopted values in this work is by factor of 10 and the corrected values are given in Table 6-42. The corrected $\log \mathrm{K}$ values upon correction of this heat capacity term in the source spreadsheets are given in Table 6-43. The $\Delta \log \mathrm{K}$ values (difference between incorrect and corrected values) are given in Table 6-44. Notice in this table that the maximum difference is on the order of $0.2 \log \mathrm{K}$ units at $300^{\circ} \mathrm{C}$, which is considered negligible given the inherent uncertainties in the source data. 
The combined use of different sets of thermodynamic data could create discrepancies between the retrieved thermodynamic parameters generated by this study (e.g., $\Delta \mathrm{G}_{\mathrm{f}}{ }^{\circ}$ and $\log \mathrm{K}$ ). In this report, two types of thermodynamic data $\left(\Delta \mathrm{G}_{\mathrm{f}}{ }^{\circ}\right.$ and $\Delta \mathrm{H}_{\mathrm{f}}{ }^{\circ} ; \mathrm{S}^{\circ}$ and $\left.\mathrm{Cp}^{\circ}\right)$ from two different sources (Barin and Platzki 1995 [DIRS 157865] and Binnewies and Milke 1999 [DIRS 158955]), respectively, were combined in the source spreadsheets. To anyone knowledgeable in the manipulation of thermodynamic parameters, such mixing of data could translate into some level of inconsistency that could affect the resulting log $\mathrm{K}$ value adopted in this report. That is, the retrieved $\log \mathrm{K}$ value as obtained using reference-state thermodynamic data from two different sources can have some level of discrepancy due to differences in the standard-state thermodynamic data adopted by each source. In the case of the affected gas species given in Table 6-45, the $\Delta \mathrm{G}_{\mathrm{f}}{ }^{\circ}$ values were obtained from Barin and Platzki (1995 [DIRS 157865]) and the heat capacity data $\left(\mathrm{Cp}^{\circ}\right)$ used to extrapolate the apparent Gibbs free energy of formation to temperatures other than $25^{\circ} \mathrm{C}$ were obtained from Binnewies and Milke (1999 [DIRS 158955]). This combination of data can be justified if the source thermodynamic data used to derive values of $\Delta \mathrm{G}_{\mathrm{f}}^{\circ}$ (i.e., $\Delta \mathrm{H}_{\mathrm{f}}^{\circ}$ and $\mathrm{S}^{\circ}$ ) are identical or at least very close within the uncertainty reported in each source. Table 6-45 shows a comparison of $\Delta \mathrm{H}_{\mathrm{f}}^{\circ}$ and $\mathrm{S}^{\circ}$ values given by Barin and Platzki (1995 [DIRS 157865]) and Binnewies and Milke (1999 [DIRS 158955]) for the affected gas species. As can be seen in this table, the overall maximum difference in $\Delta \mathrm{H}_{\mathrm{f}}{ }^{\circ}$ and $\mathrm{S}^{\circ}$ values between the two sources do not exceed approximately $0.3 \mathrm{~kJ} / \mathrm{mol}$ and $0.3 \mathrm{~J} / \mathrm{mol}-\mathrm{K}$, respectively. These differences are deemed small, given the range of values observed for these thermodynamic parameters in multiple sources. Therefore, the combined use of these data should not generate large inconsistencies that could adversely affect the extrapolation of $\log \mathrm{K}$ values at various temperatures. 
Table 6-41. Log K EQ3/6 Grids for Gas Species

\begin{tabular}{|c|c|c|c|c|c|c|c|c|c|}
\hline $\begin{array}{c}\text { Data0 Species } \\
\text { Designation }\end{array}$ & Reaction & $\begin{array}{c}\log K \\
0.01\end{array}$ & $\begin{array}{c}\log K \\
25\end{array}$ & $\begin{array}{c}\log K \\
60\end{array}$ & $\begin{array}{c}\log K \\
100\end{array}$ & $\begin{array}{c}\log K \\
150\end{array}$ & $\begin{array}{c}\log K \\
200\end{array}$ & $\begin{array}{c}\log K \\
250\end{array}$ & $\begin{array}{c}\log K \\
300\end{array}$ \\
\hline $\mathrm{CoCl}_{2}(\mathrm{~g})$ & $\mathrm{CoCl}_{2}(\mathrm{~g})=\mathrm{Co}^{++}+2 \mathrm{Cl}^{-}$ & 41.4537 & 36.7471 & 31.1543 & 25.8597 & 20.4010 & 15.8084 & 11.7430 & 7.8795 \\
\hline $\mathrm{CoF}_{2}(\mathrm{~g})$ & $\mathrm{CoCl}_{2}(\mathrm{~g})=\mathrm{Co}^{++}+2 \mathrm{~F}^{-}$ & 49.3305 & 43.4386 & 36.4974 & 29.9939 & 23.3714 & 17.8778 & 13.0898 & 8.6294 \\
\hline $\mathrm{CoCl}_{3}(\mathrm{~g})$ & $\mathrm{CoCl}_{3}(\mathrm{~g})=\mathrm{Co}^{+++}+3 \mathrm{Cl}^{-}$ & 22.2966 & 18.4912 & 13.8127 & 9.2301 & 4.3105 & -0.0388 & -4.1179 & -8.2725 \\
\hline $\mathrm{FeCl}_{2}(\mathrm{~g})$ & $\mathrm{FeCl}_{2}(\mathrm{~g})=\mathrm{Fe}^{++}+2 \mathrm{Cl}^{-}$ & 39.2745 & 34.7781 & 29.4270 & 24.3536 & 19.1135 & 14.6946 & 10.7712 & 7.0262 \\
\hline $\mathrm{FeCl}_{3}(\mathrm{~g})$ & $\mathrm{FeCl}_{3}(\mathrm{~g})=\mathrm{Fe}^{+++}+3 \mathrm{Cl}^{-}$ & 33.2539 & 28.6029 & 22.9692 & 17.5297 & 11.7840 & 6.7987 & 2.2182 & -2.3408 \\
\hline $\mathrm{FeF}_{2}(\mathrm{~g})$ & $\mathrm{FeF}_{2}(\mathrm{~g})=\mathrm{Fe}^{++}+2 \mathrm{~F}^{-}$ & 50.5720 & 44.6657 & 37.7009 & 31.1680 & 24.5078 & 18.9773 & 14.1542 & 9.6606 \\
\hline $\mathrm{FeF}_{3}(\mathrm{~g})$ & $\mathrm{FeF}_{3}(\mathrm{~g})=\mathrm{Fe}^{+++}+3 \mathrm{~F}^{-}$ & 12.3517 & 8.7062 & 4.2443 & -0.0944 & -4.7214 & -8.8021 & -12.6442 & -16.5964 \\
\hline $\mathrm{H}_{2} \mathrm{O}(\mathrm{g})$ & $\mathrm{H}_{2} \mathrm{O}(\mathrm{g})=\mathrm{H}_{2} \mathrm{O}(\mathrm{l})$ & 2.2146 & 1.4999 & 0.7020 & -0.0003 & -0.6614 & -1.1562 & -1.5353 & -1.8314 \\
\hline $\mathrm{N}_{2} \mathrm{O}(\mathrm{g})$ & $\begin{array}{l}\mathrm{N}_{2} \mathrm{O}(\mathrm{g})+\mathrm{O}_{2}(\mathrm{~g})+\mathrm{H}_{2} \mathrm{O}=2 \mathrm{H}^{+}+ \\
2 \mathrm{NO}_{2}^{-}\end{array}$ & -12.0018 & -12.0141 & -12.2146 & -12.5775 & -13.1546 & -13.8444 & -14.6712 & -15.7404 \\
\hline $\mathrm{N}_{2} \mathrm{O}_{3}(\mathrm{~g})$ & $\mathrm{N}_{2} \mathrm{O}_{3}(\mathrm{~g})+\mathrm{H}_{2} \mathrm{O}=2 \mathrm{H}^{+}+2 \mathrm{NO}_{2}^{-}$ & -5.8017 & -5.8273 & -6.0418 & -6.4165 & -7.0044 & -7.7025 & -8.5364 & -9.6122 \\
\hline $\mathrm{N}_{2} \mathrm{O}_{4}(\mathrm{~g})$ & $\begin{array}{l}\mathrm{N}_{2} \mathrm{O}_{4}(\mathrm{~g})+\mathrm{H}_{2} \mathrm{O}=2 \mathrm{H}^{+}+\mathrm{NO}_{3}{ }^{-}+ \\
\mathrm{NO}_{2}{ }^{-}\end{array}$ & 1.1380 & 0.6532 & -0.0785 & -0.9175 & -1.9549 & -3.0014 & -4.1115 & -5.4080 \\
\hline $\mathrm{N}_{2} \mathrm{O}_{5}(\mathrm{~g})$ & $\mathrm{N}_{2} \mathrm{O}_{5}(\mathrm{~g})+\mathrm{H}_{2} \mathrm{O}=2 \mathrm{H}^{+}+2 \mathrm{NO}_{3}^{-}$ & 20.1428 & 17.9824 & 15.3326 & 12.7454 & 9.9892 & 7.5886 & 5.3857 & 3.1923 \\
\hline $\mathrm{NiCl}_{2}(\mathrm{~g})$ & $\mathrm{NiCl}_{2}(\mathrm{~g})=\mathrm{Ni}^{++}+2 \mathrm{Cl}^{-}$ & 44.3255 & 39.3145 & 33.3600 & 27.7233 & 21.9152 & 17.0361 & 12.7305 & 8.6624 \\
\hline $\mathrm{NiF}_{2}(\mathrm{~g})$ & $\mathrm{NiF}_{2}(\mathrm{~g})=\mathrm{Ni}^{++}+2 \mathrm{~F}^{-}$ & 51.9705 & 45.8142 & 38.5561 & 31.7502 & 24.8158 & 19.0640 & 14.0574 & 9.4092 \\
\hline $\mathrm{NO}(\mathrm{g})$ & $\begin{array}{l}\mathrm{NO}(\mathrm{g})+0.25 \mathrm{O}_{2}(\mathrm{~g})+0.5 \mathrm{H}_{2} \mathrm{O}=\mathrm{H}^{+} \\
+\mathrm{NO}_{2}^{-}\end{array}$ & 0.8345 & 0.0394 & -0.9685 & -1.9803 & -3.0873 & -4.0781 & -5.0142 & -5.9801 \\
\hline $\mathrm{NO}_{2}(\mathrm{~g})$ & $\begin{array}{l}\mathrm{NO}_{2}(\mathrm{~g})+0.5 \mathrm{H}_{2} \mathrm{O}=\mathrm{H}^{+}+0.5 \mathrm{NO}_{3}^{-} \\
+0.5 \mathrm{NO}_{2}^{-}\end{array}$ & 1.4420 & 0.7415 & -0.1493 & -1.0467 & -2.0338 & -2.9243 & -3.7741 & -4.6634 \\
\hline $\mathrm{NO}_{3}(\mathrm{~g})$ & $\begin{array}{l}\mathrm{NO}_{3}(\mathrm{~g})+0.5 \mathrm{H}_{2} \mathrm{O}=\mathrm{H}^{+}+\mathrm{NO}_{3^{-}}+ \\
0.25 \mathrm{O}_{2}(\mathrm{~g})\end{array}$ & 21.1117 & 18.9865 & 16.4496 & 14.0349 & 11.5358 & 9.4348 & 7.5903 & 5.8674 \\
\hline $\mathrm{TiCl}(\mathrm{g})$ & $\begin{array}{l}\mathrm{TiCl}(\mathrm{g})+2.5 \mathrm{H}_{2} \mathrm{O}+0.75 \mathrm{O}_{2}= \\
\mathrm{Ti}(\mathrm{OH})_{4}(\mathrm{aq})+\mathrm{Cl}^{-}+\mathrm{H}^{+}\end{array}$ & 190.2907 & 172.3060 & 151.4823 & 132.3524 & 113.4126 & 98.3569 & 86.0287 & 75.6078 \\
\hline $\mathrm{TiCl}_{2}(\mathrm{~g})$ & $\begin{array}{l}\mathrm{TiCl}_{2}(\mathrm{~g})+3 \mathrm{H}_{2} \mathrm{O}+0.5 \mathrm{O}_{2}= \\
\mathrm{Ti}(\mathrm{OH})_{4}(\mathrm{aq})+2 \mathrm{Cl}^{-}+2 \mathrm{H}^{+}\end{array}$ & 122.2838 & 110.2269 & 96.1165 & 83.0195 & 69.8936 & 59.2891 & 50.4081 & 42.6156 \\
\hline $\mathrm{TiCl}_{3}(\mathrm{~g})$ & $\begin{array}{l}\mathrm{TiCl}_{3}(\mathrm{~g})+3.5 \mathrm{H}_{2} \mathrm{O}+0.25 \mathrm{O}_{2}= \\
\mathrm{Ti}(\mathrm{OH})_{4}(\mathrm{aq})+3 \mathrm{Cl}^{-}+3 \mathrm{H}^{+}\end{array}$ & 70.9080 & 63.3449 & 54.2966 & 45.7197 & 36.9126 & 29.5752 & 23.1791 & 17.2172 \\
\hline
\end{tabular}


Table 6-41. Log K EQ3/6 Grids for Gas Species (Continued)

\begin{tabular}{|c|c|c|c|c|c|c|c|c|c|}
\hline $\begin{array}{l}\text { Data0 Species } \\
\text { Designation }\end{array}$ & Reaction & $\begin{array}{c}\log K \\
0.01\end{array}$ & $\begin{array}{c}\log K \\
25\end{array}$ & $\begin{array}{c}\log K \\
60\end{array}$ & $\begin{array}{c}\log K \\
100\end{array}$ & $\begin{array}{c}\log K \\
150\end{array}$ & $\begin{array}{c}\log K \\
200\end{array}$ & $\begin{array}{l}\log K \\
250\end{array}$ & $\begin{array}{c}\log K \\
300\end{array}$ \\
\hline $\mathrm{TiCl}_{4}(\mathrm{~g})$ & $\begin{array}{l}\mathrm{TiCl}_{4}(\mathrm{~g})+4 \mathrm{H}_{2} \mathrm{O}=\mathrm{Ti}(\mathrm{OH})_{4}(\mathrm{aq})+ \\
4 \mathrm{Cl}^{-}+4 \mathrm{H}^{+}\end{array}$ & 34.5154 & 30.1919 & 24.7681 & 19.4016 & 13.6279 & 8.5467 & 3.8206 & -0.9813 \\
\hline $\mathrm{TiF}(\mathrm{g})$ & $\begin{array}{l}\mathrm{TiF}(\mathrm{g})+2.5 \mathrm{H}_{2} \mathrm{O}+0.75 \mathrm{O}_{2}= \\
\mathrm{Ti}(\mathrm{OH})_{4}(\mathrm{aq})+\mathrm{F}^{-}+\mathrm{H}^{+}\end{array}$ & 177.1146 & 159.9794 & 140.1364 & 121.9117 & 103.8742 & 89.5369 & 77.7918 & 67.8510 \\
\hline $\mathrm{TiF}_{2}(\mathrm{~g})$ & $\begin{array}{l}\mathrm{TiF}_{2}(\mathrm{~g})+3 \mathrm{H}_{2} \mathrm{O}+0.5 \mathrm{O}_{2}= \\
\mathrm{Ti}(\mathrm{OH})_{4}(\mathrm{aq})+2 \mathrm{~F}^{-}+2 \mathrm{H}^{+}\end{array}$ & 94.2707 & 84.0468 & 72.0515 & 60.9053 & 49.7216 & 40.6626 & 33.0352 & 26.2751 \\
\hline $\mathrm{TiF}_{3}(\mathrm{~g})$ & $\begin{array}{l}\mathrm{TiF}_{3}(\mathrm{~g})+3.5 \mathrm{H}_{2} \mathrm{O}+0.25 \mathrm{O}_{2}= \\
\mathrm{Ti}(\mathrm{OH})_{4}(\mathrm{aq})+3 \mathrm{~F}^{-}+3 \mathrm{H}^{+}\end{array}$ & 11.1332 & 7.6257 & 3.2298 & -1.0933 & -5.7082 & -9.7432 & -13.4825 & -17.2709 \\
\hline $\mathrm{TiF}_{4}(\mathrm{~g})$ & $\begin{array}{l}\mathrm{TiF}_{4}(\mathrm{~g})+4 \mathrm{H}_{2} \mathrm{O}=\mathrm{Ti}(\mathrm{OH})_{4}(\mathrm{aq})+4 \mathrm{~F}^{-} \\
+4 \mathrm{H}^{+}\end{array}$ & -0.0196 & -2.5016 & -5.7894 & -9.1658 & -12.9354 & -16.4076 & -19.8245 & -23.5501 \\
\hline $\mathrm{TiO}(\mathrm{g})$ & $\begin{array}{l}\mathrm{TiO}(\mathrm{g})+2 \mathrm{H}_{2} \mathrm{O}+0.5 \mathrm{O}_{2}=\mathrm{Ti}(\mathrm{OH})_{4} \\
(\mathrm{aq})\end{array}$ & 168.9494 & 152.9154 & 134.4281 & 117.5315 & 100.9167 & 87.8313 & 77.2527 & 68.4955 \\
\hline $\mathrm{WCl}_{2}(\mathrm{~g})$ & $\begin{array}{l}\mathrm{WCl}_{2}(\mathrm{~g})+2 \mathrm{H}_{2} \mathrm{O}+\mathrm{O}_{2}(\mathrm{~g})=\mathrm{WO}_{4}{ }^{--}+ \\
2 \mathrm{Cl}^{-}+4 \mathrm{H}^{+}\end{array}$ & 131.0808 & 118.0426 & 102.7000 & 88.3078 & 73.6569 & 61.5713 & 51.1828 & 41.7346 \\
\hline $\mathrm{WCl}_{4}(\mathrm{~g})$ & $\begin{array}{l}\mathrm{WCl}_{4}(\mathrm{~g})+3 \mathrm{H}_{2} \mathrm{O}+0.5 \mathrm{O}_{2}=\mathrm{WO}_{4}^{--}+ \\
4 \mathrm{Cl}^{-}+6 \mathrm{H}^{+}\end{array}$ & 82.4091 & 73.8570 & 63.4710 & 53.4023 & 42.7497 & 33.5415 & 25.1672 & 16.9419 \\
\hline $\mathrm{WCl}_{6}(\mathrm{~g})$ & $\begin{array}{l}\mathrm{WCl}_{6}(\mathrm{~g})+4 \mathrm{H}_{2} \mathrm{O}=\mathrm{WO}_{4}^{--}+6 \mathrm{Cl}^{-}+ \\
8 \mathrm{H}^{+}\end{array}$ & 66.9459 & 60.2282 & 51.7525 & 43.2240 & 33.8288 & 25.3346 & 17.2232 & 8.7737 \\
\hline$W F(g)$ & $\begin{array}{l}\mathrm{WF}(\mathrm{g})+1.5 \mathrm{H}_{2} \mathrm{O}+1.25 \mathrm{O}_{2}=\mathrm{WO}_{4}^{--} \\
+\mathrm{F}^{-}+3 \mathrm{H}^{+}\end{array}$ & 446.1868 & 406.2009 & 359.7610 & 316.8493 & 273.9572 & 239.3569 & 210.4069 & 185.0598 \\
\hline $\mathrm{WF}_{6}(\mathrm{~g})$ & $\begin{array}{l}\mathrm{WF}_{6}(\mathrm{~g})+4 \mathrm{H}_{2} \mathrm{O}=\mathrm{WO}_{4}^{--}+6 \mathrm{~F}^{-}+ \\
8 \mathrm{H}^{+}\end{array}$ & 7.3753 & 4.1500 & -0.2826 & -5.0591 & -10.6927 & -16.1771 & -21.8419 & -28.2782 \\
\hline $\mathrm{WO}_{2} \mathrm{Cl}_{2}(\mathrm{~g})$ & $\begin{array}{l}\mathrm{WO}_{2} \mathrm{Cl}_{2}(\mathrm{~g})+2 \mathrm{H}_{2} \mathrm{O}=\mathrm{WO}_{4}{ }^{--}+2 \mathrm{Cl}^{-} \\
+4 \mathrm{H}^{+}\end{array}$ & 13.4668 & 10.9926 & 7.7737 & 4.4438 & 0.6700 & -2.8458 & -6.3093 & -10.0460 \\
\hline $\mathrm{WOCl}_{4}(\mathrm{~g})$ & $\begin{array}{l}\mathrm{WOCl}_{4}(\mathrm{~g})+3 \mathrm{H}_{2} \mathrm{O}=\mathrm{WO}_{4}{ }^{--}+4 \mathrm{Cl}^{-}+ \\
6 \mathrm{H}^{+}\end{array}$ & 42.5106 & 37.7624 & 31.7416 & 25.6554 & 18.9179 & 12.7936 & 6.9105 & 0.7393 \\
\hline $\mathrm{WOF}_{4}(\mathrm{~g})$ & $\begin{array}{l}\mathrm{WOF}_{4}(\mathrm{~g})+3 \mathrm{H}_{2} \mathrm{O}=\mathrm{WO}_{4}^{--}+4 \mathrm{~F}^{-}+ \\
6 \mathrm{H}^{+}\end{array}$ & 12.8522 & 9.5474 & 5.2052 & 0.6912 & -4.4534 & -9.2934 & -14.1299 & -19.4418 \\
\hline
\end{tabular}

DTN: MO0302SPATHDYN.001 ([DIRS 161886], Spreadsheets Minerals_j_psd_1.xIs, Minerals_j_psd_2.xIs, Minerals_j_psd_3.xls, Minerals_j_psd_4.xIs, Minerals___psd_5.xls, Minerals_j_psd_6.xls, and Minerals_j_psd_7.xls). 
Table 6-42. Thermodynamic Data Input for Gas Phases with the Correct Scaling of the "c" Heat Capacity Coefficient

\begin{tabular}{|c|c|c|c|c|c|c|c|}
\hline & & & & Heat C & pacity Coef & cients $^{a}$ & \\
\hline $\begin{array}{c}\text { Gas } \\
\text { Species }\end{array}$ & $\begin{array}{c}\Delta \mathbf{G}_{\mathrm{f}}^{\circ} \\
(\mathrm{J} / \mathrm{mol})\end{array}$ & $\begin{array}{c}\Delta \mathrm{H}_{\mathrm{f}}^{\circ} \\
(\mathrm{J} / \mathrm{mol})\end{array}$ & $\begin{array}{c}\mathrm{S}^{\circ} \\
(\mathrm{J} / \mathrm{mol}-\mathrm{K})\end{array}$ & $\begin{array}{c}a \\
(\mathrm{~J} / \mathrm{mol}-\mathrm{K})\end{array}$ & $\begin{array}{c}b \times 10^{3} \\
\left(\mathrm{~J} / \mathrm{mol}^{\left.-\mathrm{K}^{2}\right)}\right.\end{array}$ & $\begin{array}{c}\mathrm{c} \times 10^{-6} \\
(\mathrm{~J}-\mathrm{K} / \mathrm{mol})^{b}\end{array}$ & Source \\
\hline $\mathrm{CoCl}_{2}(\mathrm{~g})$ & $-107,220$ & $-93,700$ & 298.50 & 60.730 & 2.820 & -0.170 & 1,2 \\
\hline $\mathrm{CoF}_{2}(\mathrm{~g})$ & $-369,947$ & $-356,500$ & 278.00 & 55.410 & 2.680 & -0.440 & 1,2 \\
\hline $\mathrm{CoCl}_{3}(\mathrm{~g})$ & $-154,434$ & $-163,600$ & 334.20 & 87.610 & -2.000 & -0.960 & 1,2 \\
\hline $\mathrm{CrCl}_{4}(\mathrm{~g})$ & $-395,322$ & $-426,800$ & 364.40 & 106.43 & 1.310 & -0.950 & 1,2 \\
\hline $\mathrm{FeCl}_{2}(\mathrm{~g})$ & $-155,571$ & $-141,000$ & 299.30 & 59.950 & 2.920 & -0.290 & 1,2 \\
\hline $\mathrm{FeCl}_{3}(\mathrm{~g})$ & $-247,843$ & $-253,100$ & 344.20 & 82.880 & 0.160 & -0.460 & 1,2 \\
\hline $\mathrm{FeF}_{2}(\mathrm{~g})$ & $-400,055$ & $-389,500$ & 265.20 & 70.540 & -3.320 & -1.230 & 1,2 \\
\hline $\mathrm{FeF}_{3}(\mathrm{~g})$ & $-812,795$ & $-820,900$ & 304.20 & 78.590 & 2.800 & -1.230 & 1,2 \\
\hline $\mathrm{NiCl}_{2}(\mathrm{~g})$ & $-83,779$ & $-70,200$ & 298.20 & 68.290 & -0.970 & -0.660 & 1,2 \\
\hline $\mathrm{NiF}_{2}(\mathrm{~g})$ & $-347,601$ & $-335,600$ & 273.10 & 64.310 & 1.040 & -1.080 & 1,2 \\
\hline $\mathrm{TiCl}(\mathrm{g})$ & 122,516 & 154,400 & 249.20 & 43.940 & 0.250 & -0.610 & 1,2 \\
\hline $\mathrm{TiCl}_{2}(\mathrm{~g})$ & $-244,529$ & $-237,200$ & 278.30 & 60.120 & 2.220 & -0.280 & 1,2 \\
\hline $\mathrm{TiCl}_{3}(\mathrm{~g})$ & $-524,829$ & $-539,300$ & 316.90 & 87.260 & -0.710 & -1.290 & 1,2 \\
\hline $\mathrm{TiCl}_{4}(\mathrm{~g})$ & $-726,764$ & $-763,200$ & 354.90 & 107.170 & 0.490 & -1.050 & 1,2 \\
\hline $\mathrm{TiF}(\mathrm{g})$ & $-98,305$ & $-66,900$ & 237.30 & 43.480 & 0.340 & -0.760 & 1,2 \\
\hline $\mathrm{TiF}_{2}(\mathrm{~g})$ & $-694,886$ & $-688,300$ & 255.70 & 59.470 & 2.560 & -0.650 & 1,2 \\
\hline $\mathrm{TiF}_{3}(\mathrm{~g})$ & $-1,175,664$ & $-1,188,200$ & 291.20 & 86.280 & -0.260 & -2.070 & 1,2 \\
\hline $\mathrm{TiF}_{4}(\mathrm{~g})$ & $-1,515,221$ & $-1,551,400$ & 314.90 & 104.250 & 1.980 & -1.800 & 1,2 \\
\hline $\mathrm{TiO}(\mathrm{g})$ & 24,534 & 54,400 & 233.50 & 37.040 & 0.970 & -0.490 & 1,2 \\
\hline $\mathrm{WCl}_{2}(\mathrm{~g})$ & $-28,637$ & $-12,600$ & 309.40 & 58.170 & 4.510 & -0.100 & 1,2 \\
\hline $\mathrm{WCl}_{4}(\mathrm{~g})$ & $-306,245$ & $-336,000$ & 379.30 & 107.400 & 0.460 & -0.780 & 1,2 \\
\hline $\mathrm{WCl}_{6}(\mathrm{~g})$ & $-409,436$ & $-493,700$ & 419.20 & 157.540 & 0.190 & -1.230 & 1,2 \\
\hline$W F(g)$ & 351,397 & 386,200 & 251.10 & 37.810 & 2.900 & -0.520 & 1,2 \\
\hline $\mathrm{WF}_{6}(\mathrm{~g})$ & $-1,632,294$ & $-1,721,700$ & 341.10 & 152.650 & 2.750 & -3.140 & 1,2 \\
\hline $\mathrm{WO}_{2} \mathrm{Cl}_{2}(\mathrm{~g})$ & $-639,675$ & $-671,500$ & 353.90 & 103.580 & 2.300 & -1.570 & 1,2 \\
\hline $\mathrm{WOCl}_{4}(\mathrm{~g})$ & $-512,272$ & $-573,500$ & 377.10 & 128.840 & 1.850 & -2.230 & 1,2 \\
\hline $\mathrm{WOF}_{4}(\mathrm{~g})$ & $-1,275,166$ & $-1,336,600$ & 334.70 & 125.690 & 4.140 & -2.770 & 1,2 \\
\hline
\end{tabular}

${ }^{a}$ Heat capacity coefficients $a, b$, and $c$ defined in Eq. 4-1.

${ }^{b}$ Scaling corrected from $10^{-5}$ to $10^{-6}$ in the formula used to calculate apparent Gibbs energies within the respective species spreadsheet. 
Table 6-43. Log K EQ3/6 Grid for Corrected Gas Species in Table 6-41

\begin{tabular}{|c|c|c|c|c|c|c|c|c|c|}
\hline $\begin{array}{l}\text { Data0.ymp.R2 } \\
\text { Species Name }\end{array}$ & \begin{tabular}{|l} 
Reaction \\
\end{tabular} & $\begin{array}{l}\log \mathrm{K} \\
0.01^{\circ} \mathrm{C}\end{array}$ & $\begin{array}{l}\log \mathrm{K} \\
25^{\circ} \mathrm{C}\end{array}$ & $\begin{array}{l}\log \mathrm{K} \\
60^{\circ} \mathrm{C}\end{array}$ & $\begin{array}{l}\log \mathrm{K} \\
100^{\circ} \mathrm{C}\end{array}$ & $\begin{array}{l}\log \mathrm{K} \\
150^{\circ} \mathrm{C}\end{array}$ & $\begin{array}{l}\log \mathrm{K} \\
200^{\circ} \mathrm{C}\end{array}$ & $\begin{array}{l}\log K \\
250^{\circ} \mathrm{C}\end{array}$ & $\begin{array}{l}\log \mathrm{K} \\
300^{\circ} \mathrm{C}\end{array}$ \\
\hline $\mathrm{CoCl}_{2}(\mathrm{~g})$ & $\mathrm{CoCl}_{2}(\mathrm{~g})=\mathrm{Co}^{++}+2 \mathrm{Cl}^{-}$ & 41.4541 & 36.7471 & 31.1548 & 25.8615 & 20.4049 & 15.8145 & 11.7513 & 7.8899 \\
\hline $\mathrm{CoF}_{2}(\mathrm{~g})^{*}$ & $\mathrm{CoF}_{2}(\mathrm{~g})=\mathrm{Co}^{++}+2 \mathrm{~F}^{-*}$ & 49.3315 & 43.4386 & 36.4987 & 29.9986 & 23.3815 & 17.8937 & 13.1113 & 8.6562 \\
\hline $\mathrm{CoCl}_{3}(\mathrm{~g})$ & $\mathrm{CoCl}_{3}(\mathrm{~g})=\mathrm{Co}^{+++}+3 \mathrm{Cl}^{-}$ & 22.2987 & 18.4912 & 13.8155 & 9.2403 & 4.3327 & -0.0040 & -4.0710 & -8.2141 \\
\hline $\mathrm{CrCl}_{4}(\mathrm{~g})$ & $\begin{array}{l}\mathrm{CrCl}_{4}(\mathrm{~g})+0.5 \mathrm{H}_{2} \mathrm{O}=\mathrm{Cr}^{+++}+4 \mathrm{Cl}^{-}+ \\
0.25 \mathrm{O}_{2}(\mathrm{~g})+\mathrm{H}^{+}\end{array}$ & 43.5477 & 38.1077 & 31.4658 & 24.9997 & 18.1084 & 12.0732 & 6.4784 & 0.8564 \\
\hline $\mathrm{FeCl}_{2}(\mathrm{~g})$ & $\mathrm{FeCl}_{2}(\mathrm{~g})=\mathrm{Fe}^{++}+2 \mathrm{Cl}^{-}$ & 39.2751 & 34.7781 & 29.4278 & 24.3567 & 19.1202 & 14.7051 & 10.7854 & 7.0438 \\
\hline $\mathrm{FeCl}_{3}(\mathrm{~g})$ & $\mathrm{FeCl}_{3}(\mathrm{~g})=\mathrm{Fe}^{+++}+3 \mathrm{Cl}^{-}$ & 33.2549 & 28.6029 & 22.9706 & 17.5346 & 11.7946 & 6.8153 & 2.2407 & -2.3128 \\
\hline $\mathrm{FeF}_{2}(\mathrm{~g})$ & $\mathrm{FeF}_{2}(\mathrm{~g})=\mathrm{Fe}^{++}+2 \mathrm{~F}^{-}$ & 50.5747 & 44.6657 & 37.7045 & 31.1811 & 24.5361 & 19.0218 & 14.2144 & 9.7355 \\
\hline $\mathrm{FeF}_{3}(\mathrm{~g})$ & $\mathrm{FeF}_{3}(\mathrm{~g})=\mathrm{Fe}^{+++}+3 \mathrm{~F}^{-}$ & 12.3544 & 8.7062 & 4.2479 & -0.0813 & -4.6930 & -8.7576 & -12.5840 & -16.5215 \\
\hline $\mathrm{NiCl}_{2}(\mathrm{~g})$ & $\mathrm{NiCl}_{2}(\mathrm{~g})=\mathrm{Ni}^{++}+2 \mathrm{Cl}^{-}$ & 44.3269 & 39.3145 & 33.3619 & 27.7303 & 21.9304 & 17.0599 & 12.7627 & 8.7026 \\
\hline $\mathrm{NiF}_{2}(\mathrm{~g})$ & $\mathrm{NiF}_{2}(\mathrm{~g})=\mathrm{Ni}^{++}+2 \mathrm{~F}^{-}$ & 51.9729 & 45.8142 & 38.5592 & 31.7617 & 24.8407 & 19.1030 & 14.1102 & 9.4749 \\
\hline $\mathrm{TiCl}(\mathrm{g})$ & $\begin{array}{l}\mathrm{TiCl}(\mathrm{g})+2.5 \mathrm{H}_{2} \mathrm{O}+0.75 \mathrm{O}_{2}= \\
\mathrm{Ti}(\mathrm{OH})_{4}(\mathrm{aq})+\mathrm{Cl}^{-}+\mathrm{H}^{+}\end{array}$ & 190.2921 & 172.3060 & 151.4841 & 132.3589 & 113.4267 & 98.3790 & 86.0585 & 75.6449 \\
\hline $\mathrm{TiCl}_{2}(\mathrm{~g})$ & $\begin{array}{l}\mathrm{TiCl}_{2}(\mathrm{~g})+3 \mathrm{H}_{2} \mathrm{O}+0.5 \mathrm{O}_{2}= \\
\mathrm{Ti}(\mathrm{OH})_{4}(\mathrm{aq})+2 \mathrm{Cl}^{-}+2 \mathrm{H}^{+}\end{array}$ & 122.2844 & 110.2269 & 96.1173 & 83.0225 & 69.9000 & 59.2993 & 50.4218 & 42.6326 \\
\hline $\mathrm{TiCl}_{3}(\mathrm{~g})$ & $\begin{array}{l}\mathrm{TiCl}_{3}(\mathrm{~g})+3.5 \mathrm{H}_{2} \mathrm{O}+0.25 \mathrm{O}_{2}= \\
\mathrm{Ti}(\mathrm{OH})_{4}(\mathrm{aq})+3 \mathrm{Cl}^{-}+3 \mathrm{H}^{+}\end{array}$ & 70.9109 & 63.3449 & 54.3004 & 45.7335 & 36.9424 & 29.6218 & 23.2422 & 17.2958 \\
\hline $\mathrm{TiCl}_{4}(\mathrm{~g})$ & $\begin{array}{l}\mathrm{TiCl}_{4}(\mathrm{~g})+4 \mathrm{H}_{2} \mathrm{O}=\mathrm{Ti}(\mathrm{OH})_{4}(\mathrm{aq})+4 \mathrm{Cl}^{-} \\
+4 \mathrm{H}^{+}\end{array}$ & 34.5178 & 30.1919 & 24.7712 & 19.4128 & 13.6521 & 8.5847 & 3.8720 & -0.9174 \\
\hline $\operatorname{TiF}(\mathrm{g})$ & $\begin{array}{l}\mathrm{TiF}(\mathrm{g})+2.5 \mathrm{H}_{2} \mathrm{O}+0.75 \mathrm{O}_{2}= \\
\mathrm{Ti}(\mathrm{OH})_{4}(\mathrm{aq})+\mathrm{F}^{-}+\mathrm{H}^{+}\end{array}$ & 177.1163 & 159.9794 & 140.1386 & 121.9198 & 103.8917 & 89.5644 & 77.8289 & 67.8972 \\
\hline $\mathrm{TiF}_{2}(\mathrm{~g})$ & $\begin{array}{l}\mathrm{TiF}_{2}(\mathrm{~g})+3 \mathrm{H}_{2} \mathrm{O}+0.5 \mathrm{O}_{2}= \\
\mathrm{Ti}(\mathrm{OH})_{4}(\mathrm{aq})+2 \mathrm{~F}^{-}+2 \mathrm{H}^{+}\end{array}$ & 94.2722 & 84.0468 & 72.0534 & 60.9123 & 49.7366 & 40.6861 & 33.0670 & 26.3146 \\
\hline $\mathrm{TiF}_{3}(\mathrm{~g})$ & $\begin{array}{l}\mathrm{TiF}_{3}(\mathrm{~g})+3.5 \mathrm{H}_{2} \mathrm{O}+0.25 \mathrm{O}_{2}= \\
\mathrm{Ti}(\mathrm{OH})_{4}(\mathrm{aq})+3 \mathrm{~F}^{-}+3 \mathrm{H}^{+}\end{array}$ & 11.1378 & 7.6257 & 3.2358 & -1.0712 & -5.6604 & -9.6683 & -13.3812 & -17.1449 \\
\hline $\mathrm{TiF}_{4}(\mathrm{~g})$ & $\begin{array}{l}\mathrm{TiF}_{4}(\mathrm{~g})+4 \mathrm{H}_{2} \mathrm{O}=\mathrm{Ti}(\mathrm{OH})_{4}(\mathrm{aq})+4 \mathrm{~F}^{-} \\
+4 \mathrm{H}^{+}\end{array}$ & -0.0156 & -2.5016 & -5.7841 & -9.1466 & -12.8939 & -16.3425 & -19.7364 & -23.4406 \\
\hline $\mathrm{TiO}(\mathrm{g})$ & $\begin{array}{l}\mathrm{TiO}(\mathrm{g})+2 \mathrm{H}_{2} \mathrm{O}+0.5 \mathrm{O}_{2}=\mathrm{Ti}(\mathrm{OH})_{4} \\
(\mathrm{aq})\end{array}$ & 168.9505 & 152.9154 & 134.4295 & 117.5368 & 100.9280 & 87.8490 & 77.2766 & 68.5253 \\
\hline
\end{tabular}


Table 6-43. Log K EQ3/6 Grid for Corrected Gas Species in Table 6-41 (Continued)

\begin{tabular}{|c|c|c|c|c|c|c|c|c|c|}
\hline $\begin{array}{l}\text { Data0.ymp.R2 } \\
\text { Species Name }\end{array}$ & Reaction & $\begin{array}{l}\log \mathrm{K} \\
0.01^{\circ} \mathrm{C}\end{array}$ & $\begin{array}{l}\log \mathrm{K} \\
25^{\circ} \mathrm{C}\end{array}$ & $\begin{array}{l}\log \mathrm{K} \\
60^{\circ} \mathrm{C}\end{array}$ & $\begin{array}{l}\log \mathrm{K} \\
100^{\circ} \mathrm{C} \\
\end{array}$ & $\begin{array}{l}\log \mathrm{K} \\
150^{\circ} \mathrm{C}\end{array}$ & $\begin{array}{l}\log \mathrm{K} \\
200^{\circ} \mathrm{C}\end{array}$ & $\begin{array}{l}\log \mathrm{K} \\
250^{\circ} \mathrm{C}\end{array}$ & $\begin{array}{l}\log \mathrm{K} \\
300^{\circ} \mathrm{C}\end{array}$ \\
\hline $\mathrm{WCl}_{2}(\mathrm{~g})$ & $\begin{array}{l}\mathrm{WCl}_{2}(\mathrm{~g})+2 \mathrm{H}_{2} \mathrm{O}+\mathrm{O}_{2}(\mathrm{~g})=\mathrm{WO}_{4}^{--}+ \\
2 \mathrm{Cl}^{-}+4 \mathrm{H}^{+}\end{array}$ & 131.0810 & 118.0426 & 102.7003 & 88.3089 & 73.6592 & 61.5749 & 51.1877 & 41.7407 \\
\hline $\mathrm{WCl}_{4}(\mathrm{~g})$ & $\begin{array}{l}\mathrm{WCl}_{4}(\mathrm{~g})+3 \mathrm{H}_{2} \mathrm{O}+0.5 \mathrm{O}_{2}=\mathrm{WO}_{4}{ }^{--}+ \\
4 \mathrm{Cl}^{-}+6 \mathrm{H}^{+}\end{array}$ & 82.4109 & 73.8570 & 63.4733 & 53.4106 & 42.7677 & 33.5697 & 25.2054 & 16.9894 \\
\hline $\mathrm{WCl}_{6}(\mathrm{~g})$ & $\begin{array}{l}\mathrm{WCl}_{6}(\mathrm{~g})+4 \mathrm{H}_{2} \mathrm{O}=\mathrm{WO}_{4}{ }^{--}+6 \mathrm{Cl}^{-}+ \\
8 \mathrm{H}^{+}\end{array}$ & 66.9486 & 60.2282 & 51.7561 & 43.2371 & 33.8571 & 25.3791 & 17.2833 & 8.8486 \\
\hline$W F(g)$ & $\begin{array}{l}\mathrm{WF}(\mathrm{g})+1.5 \mathrm{H}_{2} \mathrm{O}+1.25 \mathrm{O}_{2}=\mathrm{WO}_{4}^{--}+ \\
\mathrm{F}^{-}+3 \mathrm{H}^{+}\end{array}$ & 446.1880 & 406.2009 & 359.7625 & 316.8549 & 273.9692 & 239.3758 & 210.4323 & 185.0915 \\
\hline $\mathrm{WF}_{6}(\mathrm{~g})$ & $\mathrm{WF}_{6}(\mathrm{~g})+4 \mathrm{H}_{2} \mathrm{O}=\mathrm{WO}_{4}^{--}+6 \mathrm{~F}^{-}+8 \mathrm{H}^{+}$ & 7.3823 & 4.1500 & -0.2735 & -5.0256 & -10.6202 & -16.0635 & -21.6883 & -28.0870 \\
\hline $\mathrm{WO}_{2} \mathrm{Cl}_{2}(\mathrm{~g})$ & $\begin{array}{l}\mathrm{WO}_{2} \mathrm{Cl}_{2}(\mathrm{~g})+2 \mathrm{H}_{2} \mathrm{O}=\mathrm{WO}_{4}^{--}+2 \mathrm{Cl}^{-}+ \\
4 \mathrm{H}^{+}\end{array}$ & 13.4703 & 10.9926 & 7.7783 & 4.4606 & 0.7062 & -2.7890 & -6.2325 & -9.9504 \\
\hline $\mathrm{WOCl}_{4}(\mathrm{~g})$ & $\begin{array}{l}\mathrm{WOCl}_{4}(\mathrm{~g})+3 \mathrm{H}_{2} \mathrm{O}=\mathrm{WO}_{4}^{--}+4 \mathrm{Cl}^{-}+ \\
6 \mathrm{H}^{+}\end{array}$ & 42.5155 & 37.7624 & 31.7481 & 25.6792 & 18.9694 & 12.8742 & 7.0196 & 0.8751 \\
\hline $\mathrm{WOF}_{4}(\mathrm{~g})$ & $\begin{array}{l}\mathrm{WOF}_{4}(\mathrm{~g})+3 \mathrm{H}_{2} \mathrm{O}=\mathrm{WO}_{4}^{--}+4 \mathrm{~F}^{-}+ \\
6 \mathrm{H}^{+}\end{array}$ & 12.8584 & 9.5474 & 5.2133 & 0.7208 & -4.3895 & -9.1932 & -13.9944 & -19.2731 \\
\hline
\end{tabular}

Output DTN: $\quad$ SN0410T0510404.001 (Spreadsheets Minerals_j_psd_1_DS_fix.xIs to Minerals_j_psd_9_DS_fix.XIs and Minerals_j_psd_10_U_DS_fix.xls).

* The equation for $\mathrm{CoF}_{2}$ is corrected from the data0.ymp.R2 file (DTN: MO0302SPATHDYN.000 [DIRS 161756]), which gives an equation for CoCl 2 . 
Table 6-44. $\Delta$ Log K (Difference Between Incorrect and Corrected Values) for Gas Species

\begin{tabular}{|c|c|c|c|c|c|c|c|c|c|}
\hline $\begin{array}{l}\text { Data0.ymp.R2 } \\
\text { Species Name }\end{array}$ & Reaction & $\begin{array}{l}\Delta \log \mathrm{K} \\
0.01^{\circ} \mathrm{C}\end{array}$ & $\begin{array}{l}\Delta \log \mathrm{K} \\
25^{\circ} \mathrm{C}\end{array}$ & $\begin{array}{l}\Delta \log K \\
60^{\circ} \mathrm{C}\end{array}$ & $\begin{array}{l}\Delta \log \mathrm{K} \\
100^{\circ} \mathrm{C}\end{array}$ & $\begin{array}{l}\Delta \log \mathrm{K} \\
150^{\circ} \mathrm{C}\end{array}$ & $\begin{array}{l}\Delta \log \mathrm{K} \\
200^{\circ} \mathrm{C}\end{array}$ & $\begin{array}{c}\Delta \log \mathrm{K} \\
250^{\circ} \mathrm{C}\end{array}$ & $\begin{array}{l}\Delta \log \mathrm{K} \\
300^{\circ} \mathrm{C}\end{array}$ \\
\hline $\mathrm{CoCl}_{2}(\mathrm{~g})$ & $\mathrm{CoCl}_{2}(\mathrm{~g})=\mathrm{Co}^{++}+2 \mathrm{Cl}^{-}$ & 0.0004 & 0.0000 & 0.0005 & 0.0018 & 0.0039 & 0.0061 & 0.0083 & 0.0103 \\
\hline $\mathrm{CoF}_{2}(\mathrm{~g})^{*}$ & $\mathrm{CoF}_{2}(\mathrm{~g})=\mathrm{Co}^{++}+2 \mathrm{~F}^{-*}$ & 0.0010 & 0.0000 & 0.0013 & 0.0047 & 0.0102 & 0.0159 & 0.0215 & 0.0268 \\
\hline $\mathrm{CoCl}_{3}(\mathrm{~g})$ & $\mathrm{CoCl}_{3}(\mathrm{~g})=\mathrm{Co}^{+++}+3 \mathrm{Cl}^{-}$ & 0.0021 & 0.0000 & 0.0028 & 0.0103 & 0.0222 & 0.0347 & 0.0470 & 0.0584 \\
\hline $\mathrm{CrCl}_{4}(\mathrm{~g})$ & $\begin{array}{l}\mathrm{CrCl}_{4}(\mathrm{~g})+0.5 \mathrm{H}_{2} \mathrm{O}=\mathrm{Cr}^{+++}+4 \mathrm{Cl}^{-} \\
+0.25 \mathrm{O}_{2}(\mathrm{~g})+\mathrm{H}^{+}\end{array}$ & 0.0021 & 0.0000 & 0.0028 & 0.0101 & 0.0219 & 0.0344 & 0.0465 & 0.0578 \\
\hline $\mathrm{FeCl}_{2}(\mathrm{~g})$ & $\mathrm{FeCl}_{2}(\mathrm{~g})=\mathrm{Fe}^{++}+2 \mathrm{Cl}^{-}$ & 0.0006 & 0.0000 & 0.0008 & 0.0031 & 0.0067 & 0.0105 & 0.0142 & 0.0177 \\
\hline $\mathrm{FeCl}_{3}(\mathrm{~g})$ & $\mathrm{FeCl}_{3}(\mathrm{~g})=\mathrm{Fe}^{+++}+3 \mathrm{Cl}^{-}$ & 0.0010 & 0.0000 & 0.0013 & 0.0049 & 0.0106 & 0.0166 & 0.0225 & 0.0280 \\
\hline $\mathrm{FeF}_{2}(\mathrm{~g})$ & $\mathrm{FeF}_{2}(\mathrm{~g})=\mathrm{Fe}^{++}+2 \mathrm{~F}^{-}$ & 0.0027 & 0.0000 & 0.0036 & 0.0131 & 0.0284 & 0.0445 & 0.0602 & 0.0749 \\
\hline $\mathrm{FeF}_{3}(\mathrm{~g})$ & $\mathrm{FeF}_{3}(\mathrm{~g})=\mathrm{Fe}^{+++}+3 \mathrm{~F}^{-}$ & 0.0027 & 0.0000 & 0.0036 & 0.0131 & 0.0284 & 0.0445 & 0.0602 & 0.0749 \\
\hline $\mathrm{NiCl}_{2}(\mathrm{~g})$ & $\mathrm{NiCl}_{2}(\mathrm{~g})=\mathrm{Ni}^{++}+2 \mathrm{Cl}^{-}$ & 0.0015 & 0.0000 & 0.0019 & 0.0071 & 0.0152 & 0.0239 & 0.0323 & 0.0402 \\
\hline $\mathrm{NiF}_{2}(\mathrm{~g})$ & $\mathrm{NiF}_{2}(\mathrm{~g})=\mathrm{Ni}^{++}+2 \mathrm{~F}^{-}$ & 0.0024 & 0.0000 & 0.0032 & 0.0115 & 0.0249 & 0.0391 & 0.0528 & 0.0657 \\
\hline $\mathrm{TiCl}(\mathrm{g})$ & $\begin{array}{l}\mathrm{TiCl}(\mathrm{g})+2.5 \mathrm{H}_{2} \mathrm{O}+0.75 \mathrm{O}_{2}= \\
\mathrm{Ti}(\mathrm{OH})_{4}(\mathrm{aq})+\mathrm{Cl}^{+}+\mathrm{H}^{+}\end{array}$ & 0.0013 & 0.0000 & 0.0018 & 0.0065 & 0.0141 & 0.0221 & 0.0298 & 0.0371 \\
\hline $\mathrm{TiCl}_{2}(\mathrm{~g})$ & $\begin{array}{l}\mathrm{TiCl}_{2}(\mathrm{~g})+3 \mathrm{H}_{2} \mathrm{O}+0.5 \mathrm{O}_{2}= \\
\mathrm{Ti}(\mathrm{OH})_{4}(\mathrm{aq})+2 \mathrm{Cl}^{-}+2 \mathrm{H}^{+}\end{array}$ & 0.0006 & 0.0000 & 0.0008 & 0.0030 & 0.0065 & 0.0101 & 0.0137 & 0.0170 \\
\hline $\mathrm{TiCl}_{3}(\mathrm{~g})$ & $\begin{array}{l}\mathrm{TiCl}_{3}(\mathrm{~g})+3.5 \mathrm{H}_{2} \mathrm{O}+0.25 \mathrm{O}_{2}= \\
\mathrm{Ti}(\mathrm{OH})_{4}(\mathrm{aq})+3 \mathrm{Cl}^{-}+3 \mathrm{H}^{+}\end{array}$ & 0.0029 & 0.0000 & 0.0038 & 0.0138 & 0.0298 & 0.0467 & 0.0631 & 0.0785 \\
\hline $\mathrm{TiCl}_{4}(\mathrm{~g})$ & $\begin{array}{l}\mathrm{TiCl}_{4}(\mathrm{~g})+4 \mathrm{H}_{2} \mathrm{O}=\mathrm{Ti}(\mathrm{OH})_{4}(\mathrm{aq})+ \\
4 \mathrm{Cl}^{-}+4 \mathrm{H}^{+}\end{array}$ & 0.0023 & 0.0000 & 0.0031 & 0.0112 & 0.0242 & 0.0380 & 0.0514 & 0.0639 \\
\hline $\operatorname{TiF}(\mathrm{g})$ & $\begin{array}{l}\mathrm{TiF}(\mathrm{g})+2.5 \mathrm{H}_{2} \mathrm{O}+0.75 \mathrm{O}_{2}= \\
\mathrm{Ti}(\mathrm{OH})_{4}(\mathrm{aq})+\mathrm{F}^{-}+\mathrm{H}^{+}\end{array}$ & 0.0017 & 0.0000 & 0.0022 & 0.0081 & 0.0175 & 0.0275 & 0.0372 & 0.0463 \\
\hline $\mathrm{TiF}_{2}(\mathrm{~g})$ & $\begin{array}{l}\mathrm{TiF}_{2}(\mathrm{~g})+3 \mathrm{H}_{2} \mathrm{O}+0.5 \mathrm{O}_{2}= \\
\mathrm{Ti}(\mathrm{OH})_{4}(\mathrm{aq})+2 \mathrm{~F}^{-}+2 \mathrm{H}^{+}\end{array}$ & 0.0014 & 0.0000 & 0.0019 & 0.0069 & 0.0150 & 0.0235 & 0.0318 & 0.0396 \\
\hline $\mathrm{TiF}_{3}(\mathrm{~g})$ & $\begin{array}{l}\mathrm{TiF}_{3}(\mathrm{~g})+3.5 \mathrm{H}_{2} \mathrm{O}+0.25 \mathrm{O}_{2}= \\
\mathrm{Ti}(\mathrm{OH})_{4}(\mathrm{aq})+3 \mathrm{~F}^{-}+3 \mathrm{H}^{+}\end{array}$ & 0.0046 & 0.0000 & 0.0060 & 0.0221 & 0.0478 & 0.0749 & 0.1012 & 0.1260 \\
\hline $\mathrm{TiF}_{4}(\mathrm{~g})$ & $\begin{array}{l}\mathrm{TiF}_{4}(\mathrm{~g})+4 \mathrm{H}_{2} \mathrm{O}=\mathrm{Ti}(\mathrm{OH})_{4}(\mathrm{aq})+ \\
4 \mathrm{~F}^{-}+4 \mathrm{H}^{+}\end{array}$ & 0.0040 & 0.0000 & 0.0053 & 0.0192 & 0.0415 & 0.0651 & 0.0880 & 0.1096 \\
\hline $\mathrm{TiO}(\mathrm{g})$ & $\begin{array}{l}\mathrm{TiO}(\mathrm{g})+2 \mathrm{H}_{2} \mathrm{O}+0.5 \mathrm{O}_{2}=\mathrm{Ti}(\mathrm{OH})_{4} \\
(\mathrm{aq})\end{array}$ & 0.0011 & 0.0000 & 0.0014 & 0.0052 & 0.0113 & 0.0177 & 0.0240 & 0.0298 \\
\hline
\end{tabular}


Table 6-44. $\Delta$ Log K (Difference Between Incorrect and Corrected Values) for Gas Species (Continued)

\begin{tabular}{|c|c|c|c|c|c|c|c|c|c|}
\hline $\begin{array}{l}\text { Data0.ymp.R2 } \\
\text { Species Name }\end{array}$ & Reaction & $\begin{array}{l}\Delta \log \mathrm{K} \\
0.01^{\circ} \mathrm{C}\end{array}$ & $\begin{array}{l}\Delta \log K \\
25^{\circ} \mathrm{C}\end{array}$ & $\begin{array}{c}\Delta \log \mathrm{K} \\
60^{\circ} \mathrm{C}\end{array}$ & $\begin{array}{c}\Delta \log \mathrm{K} \\
100^{\circ} \mathrm{C}\end{array}$ & $\begin{array}{c}\Delta \log \mathrm{K} \\
150^{\circ} \mathrm{C}\end{array}$ & $\begin{array}{l}\Delta \log \mathrm{K} \\
200^{\circ} \mathrm{C}\end{array}$ & $\begin{array}{l}\Delta \log \mathrm{K} \\
250^{\circ} \mathrm{C}\end{array}$ & $\begin{array}{c}\Delta \log \mathrm{K} \\
300^{\circ} \mathrm{C}\end{array}$ \\
\hline $\mathrm{WCl}_{2}(\mathrm{~g})$ & $\begin{array}{l}\mathrm{WCl}_{2}(\mathrm{~g})+2 \mathrm{H}_{2} \mathrm{O}+\mathrm{O}_{2}(\mathrm{~g})= \\
\mathrm{WO}_{4}^{--}+2 \mathrm{Cl}^{-}+4 \mathrm{H}^{+}\end{array}$ & 0.0002 & 0.0000 & 0.0003 & 0.0011 & 0.0023 & 0.0036 & 0.0049 & 0.0061 \\
\hline $\mathrm{WCl}_{4}(\mathrm{~g})$ & $\begin{array}{l}\mathrm{WCl}_{4}(\mathrm{~g})+3 \mathrm{H}_{2} \mathrm{O}+0.5 \mathrm{O}_{2}= \\
\mathrm{WO}_{4}^{--}+4 \mathrm{Cl}^{-}+6 \mathrm{H}^{+}\end{array}$ & 0.0017 & 0.0000 & 0.0023 & 0.0083 & 0.0180 & 0.0282 & 0.0382 & 0.0475 \\
\hline $\mathrm{WCl}_{6}(\mathrm{~g})$ & $\begin{array}{l}\mathrm{WCl}_{6}(\mathrm{~g})+4 \mathrm{H}_{2} \mathrm{O}=\mathrm{WO}_{4}{ }^{--}+ \\
6 \mathrm{Cl}^{-}+8 \mathrm{H}^{+}\end{array}$ & 0.0027 & 0.0000 & 0.0036 & 0.0131 & 0.0284 & 0.0445 & 0.0602 & 0.0749 \\
\hline WF(g) & $\begin{array}{l}\mathrm{WF}(\mathrm{g})+1.5 \mathrm{H}_{2} \mathrm{O}+1.25 \mathrm{O}_{2}= \\
\mathrm{WO}_{4}^{---}+\mathrm{F}^{-}+3 \mathrm{H}^{+}\end{array}$ & 0.0012 & 0.0000 & 0.0015 & 0.0056 & 0.0120 & 0.0188 & 0.0254 & 0.0317 \\
\hline $\mathrm{WF}_{6}(\mathrm{~g})$ & $\begin{array}{l}\mathrm{WF}_{6}(\mathrm{~g})+4 \mathrm{H}_{2} \mathrm{O}=\mathrm{WO}_{4}{ }^{--}+6 \mathrm{~F}^{-} \\
+8 \mathrm{H}^{+}\end{array}$ & 0.0069 & 0.0000 & 0.0092 & 0.0335 & 0.0725 & 0.1136 & 0.1536 & 0.1911 \\
\hline $\mathrm{WO}_{2} \mathrm{Cl}_{2}(\mathrm{~g})$ & $\begin{array}{l}\mathrm{WO}_{2} \mathrm{Cl}_{2}(\mathrm{~g})+2 \mathrm{H}_{2} \mathrm{O}=\mathrm{WO}_{4}{ }^{--}+ \\
2 \mathrm{Cl}^{-}+4 \mathrm{H}^{+}\end{array}$ & 0.0035 & 0.0000 & 0.0046 & 0.0168 & 0.0362 & 0.0568 & 0.0768 & 0.0956 \\
\hline $\mathrm{WOCl}_{4}(\mathrm{~g})$ & $\begin{array}{l}\mathrm{WOCl}_{4}(\mathrm{~g})+3 \mathrm{H}_{2} \mathrm{O}=\mathrm{WO}_{4}^{--}+ \\
4 \mathrm{Cl}^{-}+6 \mathrm{H}^{+}\end{array}$ & 0.0049 & 0.0000 & 0.0065 & 0.0238 & 0.0515 & 0.0807 & 0.1091 & 0.1357 \\
\hline $\mathrm{WOF}_{4}(\mathrm{~g})$ & $\begin{array}{l}\mathrm{WOF}_{4}(\mathrm{~g})+3 \mathrm{H}_{2} \mathrm{O}=\mathrm{WO}_{4}^{--}+ \\
4 \mathrm{~F}^{-}+6 \mathrm{H}^{+}\end{array}$ & 0.0061 & 0.0000 & 0.0081 & 0.0296 & 0.0639 & 0.1002 & 0.1355 & 0.1686 \\
\hline
\end{tabular}

Output DTN: SN0410T0510404.001 (Spreadsheets Minerals_j_psd_1_DS_fix.xls to Minerals_j_psd_9_DS_fix.xls and Minerals_j_psd_10_U_DS_fix.XIs).

* The equation for $\mathrm{CoF}_{2}$ is corrected from the data0.ymp.R2 file (DTN: MO0302SPATHDYN.000 [DIRS 161756]), which gives an equation for CoCl 2 . 
Table 6-45. Comparison of $\Delta \mathrm{H}_{\mathrm{f}}^{\circ}$ and $\mathrm{S}^{\circ}$ Values from Binnewies and Milke, and Barin and Platzki

\begin{tabular}{|c|c|c|c|c|c|c|c|c|}
\hline $\begin{array}{c}\text { Gas } \\
\text { Species }\end{array}$ & $\begin{array}{c}\Delta \mathrm{H}_{\mathrm{f}}^{\circ} \\
(\mathrm{J} / \mathrm{mol}) \\
99 \mathrm{Bin} / \mathrm{Mil}^{1}\end{array}$ & $\begin{array}{c}\Delta \mathrm{H}_{\mathrm{f}}^{\circ} \\
(\mathrm{J} / \mathrm{mol}) \\
95 \mathrm{Bar} / \mathrm{Pla}^{2}\end{array}$ & $\begin{array}{c}\text { Difference } \\
\text { in } \Delta \mathrm{H}_{\mathrm{f}}^{\circ} \\
(\mathrm{J} / \mathrm{mol})\end{array}$ & $\begin{array}{c}\mathrm{S}^{\circ} \\
(\mathrm{J} / \mathrm{mol}-\mathrm{K}) \\
\text { 99Bin/Mil }\end{array}$ & $\begin{array}{c}\mathrm{S}^{\circ} \\
\text { (J/mol-K) } \\
\text { 95Bar/Pla }\end{array}$ & $\begin{array}{c}\text { Difference } \\
\text { in } \mathrm{S}^{\circ} \\
(\mathrm{J} / \mathrm{mol}-\mathrm{K})\end{array}$ & $\begin{array}{c}\text { Page } \\
\text { Numbers } \\
\text { 99Bin/Mil }^{1}\end{array}$ & $\begin{array}{c}\text { Page } \\
\text { Numbers } \\
\text { 95Bar/Pla }\end{array}$ \\
\hline $\mathrm{CoCl}_{2}(\mathrm{~g})$ & $-93,700$ & $-93,722$ & 22 & 298.5 & 298.429 & 0.071 & 334 & 536 \\
\hline $\mathrm{CoF}_{2}(\mathrm{~g})$ & $-356,500$ & $-356,477$ & -23 & 278 & 278.015 & -0.015 & 407 & 541 \\
\hline $\mathrm{CoCl}_{3}(\mathrm{~g})$ & $-163,600$ & $-163,594$ & -6 & 334.2 & 333.993 & 0.207 & 358 & 538 \\
\hline $\mathrm{CrCl}_{4}(\mathrm{~g})$ & $-426,800$ & $-426,768$ & -32 & 364.4 & 364.402 & -0.002 & 385 & 564 \\
\hline $\mathrm{FeCl}_{2}(\mathrm{~g})$ & $-141,000$ & $-141,001$ & 1 & 299.3 & 299.265 & 0.035 & 337 & 687 \\
\hline $\mathrm{FeCl}_{3}(\mathrm{~g})$ & $-253,100$ & $-253,132$ & 32 & 344.2 & 344.214 & -0.014 & 363 & 688 \\
\hline $\mathrm{FeF}_{2}(\mathrm{~g})$ & $-389,500$ & $-389,530$ & 30 & 265.2 & 265.375 & -0.175 & 475 & 692 \\
\hline $\mathrm{FeF}_{3}(\mathrm{~g})$ & $-820,900$ & $-820,901$ & 1 & 304.2 & 304.286 & -0.086 & 493 & 693 \\
\hline $\mathrm{NiCl}_{2}(\mathrm{~g})$ & $-70,200$ & $-70,291$ & 91 & 298.2 & 298.228 & -0.028 & 344 & 1208 \\
\hline $\mathrm{NiF}_{2}(\mathrm{~g})$ & $-335,600$ & $-335,557$ & -43 & 273.1 & 273.065 & 0.035 & 483 & 1211 \\
\hline $\mathrm{TiCl}(\mathrm{g})$ & 154,400 & 154,390 & 10 & 249.2 & 249.225 & -0.025 & 331 & 1675 \\
\hline $\mathrm{TiCl}_{2}(\mathrm{~g})$ & $-237,200$ & $-237,233$ & 33 & 278.3 & 278.345 & -0.045 & 355 & 1677 \\
\hline $\mathrm{TiCl}_{3}(\mathrm{~g})$ & $-539,300$ & $-539,318$ & 18 & 316.9 & 316.838 & 0.062 & 380 & 1678 \\
\hline $\mathrm{TiCl}_{4}(\mathrm{~g})$ & $-763,200$ & $-763,162$ & -38 & 354.9 & 354.913 & -0.013 & 394 & 1679 \\
\hline $\mathrm{TiF}(\mathrm{g})$ & $-66,900$ & $-66,944$ & 44 & 237.3 & 237.342 & -0.042 & 472 & 1680 \\
\hline $\mathrm{TiF}_{2}(\mathrm{~g})$ & $-688,300$ & $-688,268$ & -32 & 255.7 & 255.752 & -0.052 & 490 & 1681 \\
\hline $\mathrm{TiF}_{3}(\mathrm{~g})$ & $-1,188,200$ & $-1,188,674$ & 474 & 291.2 & 291.316 & -0.116 & 509 & 1682 \\
\hline $\mathrm{TiF}_{4}(\mathrm{~g})$ & $-1,551,400$ & $-1,551,427$ & 27 & 314.9 & 314.914 & -0.014 & 520 & 1683 \\
\hline $\mathrm{TiO}(\mathrm{g})$ & 54,400 & 54,392 & 8 & 233.5 & 233.476 & 0.024 & 750 & 1691 \\
\hline $\mathrm{WCl}_{2}(\mathrm{~g})$ & $-12,600$ & $-12,552$ & -48 & 309.4 & 309.725 & -0.325 & 356 & 1792 \\
\hline $\mathrm{WCl}_{4}(\mathrm{~g})$ & $-336,000$ & $-335,975$ & -25 & 379.3 & 379.180 & 0.120 & 395 & 1793 \\
\hline $\mathrm{WCl}_{6}(\mathrm{~g})$ & $-493,700$ & $-493,712$ & 12 & 419.2 & 419.346 & -0.146 & 404 & 1796 \\
\hline $\mathrm{WF}(\mathrm{g})$ & 386,200 & 386,183 & 17 & 251.1 & 250.731 & 0.369 & 474 & 1798 \\
\hline $\mathrm{WF}_{6}(\mathrm{~g})$ & $-1,721,700$ & $-1,721,716$ & 16 & 341.1 & 341.122 & -0.022 & 532 & 1799 \\
\hline $\mathrm{WO}_{2} \mathrm{Cl}_{2}(\mathrm{~g})$ & $-671,500$ & $-671,532$ & 32 & 353.9 & 354.076 & -0.176 & 347 & 1813 \\
\hline $\mathrm{WOCl}_{4}(\mathrm{~g})$ & $-573,500$ & $-573,208$ & -292 & 377.1 & 377.088 & 0.012 & 388 & 1812 \\
\hline $\mathrm{WOF}_{4}(\mathrm{~g})$ & $-1,336,600$ & $-1,336,621$ & 21 & 334.7 & 334.704 & -0.004 & 516 & 1814 \\
\hline
\end{tabular}

Sources: 1 Binnewies and Milke 1999 [DIRS 158955].

2 Barin and Platzki 1995 [DIRS 157865]. 


\section{5 “AZERO” ION SIZE PARAMETERS}

The "azero" parameters appear in the B-dot equation (Helgeson 1969 [DIRS 137246]), which is used to calculate activity coefficients of aqueous species in dilute solution. The equation is given by:

$$
\log \gamma_{i}=-\frac{A_{\gamma, 10} z_{i}^{2} \sqrt{I}}{1+B_{\gamma} \stackrel{a}{i}_{i} \sqrt{I}}+\dot{B} I
$$

where $\gamma_{i}$ is the activity coefficient of the $\mathrm{i}$-th solute species, $A_{\gamma, 10}$ and $B_{\gamma}$ are the relevant Debye-Hückel parameters, $\dot{B}$ is the B-dot parameter, I is the ionic strength, $Z_{i}$ is the electrical charge number of the species, and $\mathrm{a}_{i}$ is the corresponding ionic diameter or "azero" parameter. The "azero" parameter is more properly described as the hard core diameter. It is also known as the "ion size" parameter. The above equation, less the second term on the right-hand side, is known as the extended Debye-Hückel equation. That is to distinguish it from the Debye-Hückel limiting law, which is obtained by further setting the denominator in the right-hand-side term to unity.

The B-dot equation is an EQ3/6 option (Wolery 1992 [DIRS 100836], pp. 39-41) for determining aqueous activity coefficients. Values for the "azero" parameters are contained in a non-Pitzer EQ3/6 data file (data0.ymp.R2; DTN: MO0302SPATHDYN.000 [DIRS 161756]) and data0.ymp.R4 (output DTN: SN0410T0510404.002) in a block that is headed by the somewhat misleading label of "bdot parameters." This block contains lines, each of which includes a species name and a corresponding "azero" parameter value. If the data file contains a normal species block for a species that is not represented by an entry in the "azero" section, the software assigns a default "azero" value of 4.0 angstroms.

In the data0.ymp.R2 database (DTN: MO0302SPATHDYN.000 [DIRS 161756]), little effort was made to provide "azero" values for species added to the file. This is by design (the intent is to use the default value assigned by EQ3/6).

The B-dot equation is only an approximate relationship whose nominal validity extends to an ionic strength of about one molal (Wolery 1992 [DIRS 100836], p. 38). However, that is intended only as a suggested practical limit for calculations that do not require high accuracy. If accuracy matching that of physical measurements is required, the ionic strength limit is much less, the more so for higher magnitudes of the electrical charge number. In the case of monovalent ions, this limit is closer to 0.3-0.4 molal. For divalent ions, it is more like 0.1-0.2 molal. For more highly charged ions, the high accuracy limit is generally even smaller. What is the exact high accuracy limit depends on both the ions in question and the measurement accuracies associated with the physical measurement techniques. Nevertheless, these numbers are illustrative. 
The approximate nature of the B-dot equation is highlighted by the fact that it does not satisfy a key thermodynamic consistency equation (e.g., Wolery 1990 [DIRS 159223], p. 313-315):

$$
\frac{\partial \log \gamma_{i}}{\partial n_{j}}=\frac{\partial \log \gamma_{j}}{\partial n_{i}}
$$

There is a violation in the B-dot (second) term, unless $I$ there is replaced by $\Sigma m$, the sum of solute molalities. There is another in the first term, which can only be resolved if all ions have the same value for the "azero" parameter.

Historically, the B-dot equation was developed in Helgeson (1969 [DIRS 137246], pp. 742-752) by fitting the B-dot parameter itself to mean activity coefficient data for aqueous sodium chloride. The effective ion size parameter for the electrolyte (both ions) was estimated in Helgeson (1969 [DIRS 137246], pp. 748-749) using an entirely different theory. The resulting parameter varied with temperature (Helgeson 1969 [DIRS 137246], p. 746, Table 2) but was 3.89 angstroms at $25^{\circ} \mathrm{C}$ and ranged from 3.22 to 4.4 angstroms over the temperature range of $25^{\circ} \mathrm{C}$ to $300^{\circ} \mathrm{C}$. For comparison, Kielland (1937 [DIRS 151237], p. 1677, Table 2) gives a value of 4.0-4.5 angstroms for $\mathrm{Na}^{+}$and 3.0 for $\mathrm{Cl}^{-}$. In the subsequent application of the B-dot equation, fixed ion sizes have generally been employed, roughly following the values recommended by Kielland. Such data have never been fitted or optimized for use with the B-dot equation itself.

Kielland's table of ion sizes (Kielland 1937 [DIRS 151237], p. 1676, Table 1, and p. 1677, Table 2) is limited to only a few dozen species. That table has been reproduced in many physical chemistry, geochemistry, chemical engineering, and metallurgy texts, commonly with both omissions and undocumented additions (e.g., Table 7-4 in Nordstrom and Munoz 1986 [DIRS 153965], pp. 200-201). The extended Debye-Hückel model represented by the first term in the B-dot equation has also been incorporated into other activity coefficient models. Even in that context, there have been very few attempts to fit or to optimize any of the ion size parameters to one or another set of physical data. Other theories that treat the ion size as an important fitting parameter do exist (e.g., Triolo et al. 1976 [DIRS 159210]); however, the values obtained must be viewed as specific to those theories.

Even in the earlier EQ3/6 database development, the number of aqueous species far exceeded those in Kielland (1937 [DIRS 151237], Table 2). The data in Kielland's table roughly correlate with electrical charge numbers. The correlation in Table 4-4 was used at one time to estimate "azero" values for species not in Kielland's table that were added to the EQ3/6 database. However, this was only intended as a guideline and many exceptions may be found in the set of values in, for example, data0.ymp.R0 (DTN: MO0009THRMODYN.001 [DIRS 152576]).

Because the intrinsically approximate nature of the B-dot equation, any attempt to optimize the ion size parameters beyond the scope of Kielland (1937 [DIRS 151237], Table 1) is considered unwarranted. Instead, it is preferable to use the EQ3/6 default value of 4.0 angstroms. In fact, one of the few species for which such a value would definitely not be appropriate is $\mathrm{H}^{+}$, which is in Kielland's table with an ion size of 9.0 angstroms. The large size is associated with water of hydration. 
The Spreadsheet Azero_sensitivity_TJW.xls (DTN: MO0302SPATHDYN.001 [DIRS 161886]) contains calculations of sensitivity of calculated activity coefficients to the "azero" parameter. In general, assuming "azero" values in the range of 3.0-5.0 angstroms (likely the case in the vast majority of instances), there is not much sensitivity to the exact value in the limited ionic strength ranges in which the B-dot equation is truly accurate. High sensitivity is seen at higher ionic strengths. However, B-dot equation results there can not be made generally accurate by any meaningful optimization of "azero" parameters.

The "azero" parameter can be avoided by using either of two other options for aqueous activity coefficients in EQ3/6. The Davies equation (Wolery 1992 [DIRS 100836], pp. 38-39) is valid for use in the same concentration range as the B-dot equation. Pitzer's equations (Wolery 1992 [DIRS 100836], pp. 44-64) can be used in both dilute and concentrated solutions. Neither of these options uses the "azero" parameter.

\subsection{EVALUATION OF MINERAL MOLAR VOLUME DATA}

This section documents the qualification of molar volume data given in Section 4.1, that were added when the data0.ymp.R2 database (DTN: MO0302SPATHDYN.000 [DIRS 161756]) was developed. Previously qualified molar volume data in the data0.ymp.R0 database (DTN: MO0009THRMODYN.001 [DIRS 152576]), which are included in the data0.ymp.R2 database (DTN: MO0302SPATHDYN.000 [DIRS 161756]), are not considered for qualification here with the exception of schoepite as discussed below.

Qualification of molar volume data for clays is discussed in Section 6.3.1. The mineral volume sources are mainly the Encyclopedia of Minerals (Roberts et al. 1990 [DIRS 107105]), Gaines et al. (1997 [DIRS 172360]), and the internet resource website www.webmineral.com. The latter is an extensive compilation of mineral data that includes crystallographic (cell) parameters from recognized resources such as peer-reviewed mineralogical journals.

Table 6-46 lists the molar volume estimates or ranges, developed in this qualification report for comparison to values from the data0.ymp.R2 database (DTN: MO0302SPATHDYN.000 [DIRS 161756]). Molar volume estimates based on information from alternate sources are used to qualify the data0.ymp.R2 values (DTN: MO0302SPATHDYN.000 [DIRS 161756]) through data corroboration. Most of the mineral species in Table 6-46 are clays and zeolites.

The qualification effort focuses on literature sources and established-fact sources for density and mineral volume data. Calculations of mineral volumes based on mineral density and volume data are given in Spreadsheet Volume_Q_DS_11-17-04.xls (output DTN: SN0410T0510404.001). Most of the mineral volumes (not to be confused with molar volume) obtained from the corroborative sources are derived from mineral crystallographic data. In many cases, the density data given in handbook sources (e.g., Gaines et al. 1997 [DIRS 172360]) appear to be based on mineral volumes. In the spreadsheet, the computed molar volume values are compared to those from the data0.ymp.R2 database (DTN: MO0302SPATHDYN.000 [DIRS 161756]). Overall, the calculated molar volumes in Table 6-46 are typically within 5 to $15 \%$ of those in the data0.ymp.R2 database (DTN: MO0302SPATHDYN.000 [DIRS 161756]), and within approximately 50\% for clays (discussed below). These differences are satisfactory considering that molar volume is not a 
parameter in the application of EQ3/6 modeling to repository simulation, because pressure changes in the repository are too small to significantly affect chemical equilibria. Volume changes associated with chemical reactions simulated using EQ3/6 must be calculated externally to the code, with attention to the applicability of molar volume data. Accordingly, the molar volume data in data0.ymp.R2 (DTN: MO0302SPATHDYN.000 [DIRS 161756]) are qualified by corroboration with data from other sources, subject to the stated uncertainties.

Corroborating molar volume estimates for many clay minerals differ from those in data0.ymp.R2 (DTN: MO0302SPATHDYN.000 [DIRS 161756]) by as much as $50 \%$ for some species (Table 6-46). Such differences between reported measurements and estimates are reasonable because the volumes occupied by clays depend on the physical state, especially moisture content. Clays experience substantial changes in unit-cell volume depending on the hydration state and the type of cation occupying exchangeable sites in the mineral structure. The amount of inter-layer water is a function of composition and the physical characteristics of the clay minerals (Deer et al. 1992 [DIRS 163286]). For example, Brindley and Brown (1980 [DIRS 105235], Chapter 3, p. 205-206, Figure 3.3-3.4) shows changes in basal spacing (d001) distance as a function of relative humidity for various clay phases, including montmorillonite and beidellite. These differences in basal spacings for beidellite range from approximately 9.8 angstroms at low relative humidities (e.g., 0 to $10 \%$ ) to 15.5 angstroms at elevated relative humidities (e.g., 70 to $100 \%$ ). Because clay mineral volumes estimated from crystallographic data are usually obtained for well-hydrated conditions or after induced swelling of the clay (e.g., using ethylene glycol), differences in reported molar volumes of 50\% should be expected. Accordingly, these ranges in molar volume (and density) for clays are realistic and acceptable, and the values developed for data0.ymp.R2 (DTN: MO0302SPATHDYN.000 [DIRS 161756]) are qualified.

For one phase $\left(\mathrm{Ni}_{3}\left(\mathrm{PO}_{4}\right)_{2}\right)$, corroborative data for molar volume were not found in the literature. These data are considered qualified because the first author (Calvo and Faggiani 1975 [DIRS 172265]) has authored a substantial number of articles related to the characterization and refinement of crystal structures for various types of chemical compounds including phosphates (Ng et al. 1978 [DIRS 172385]; Shannon and Calvo 1973 [DIRS 172386]; Krishnamachari and Calvo 1972 [DIRS 172387]). The expertise and publishing record of the authors justify confidence in the data obtained from their source.

A molar volume value of $66.080 \mathrm{~cm}^{3} / \mathrm{mol}$ is reported for schoepite in the data0.ymp.R2 database (DTN: MO0302SPATHDYN.000 [DIRS 161756]). On recalculation for this report, the correct value is found to be $66.70 \mathrm{~cm}^{3} / \mathrm{mol}$, or approximately one percent greater. This difference is well within the corroborative comparisons made for other minerals above, and the original value from data0.ymp.R2 (DTN: MO0302SPATHDYN.000 [DIRS 161756]) is therefore qualified. The original value of $66.080 \mathrm{~cm}^{3} / \mathrm{mol}$ is used in the new database data0.ymp.R4 (output DTN: SN0410T0510404.002). 


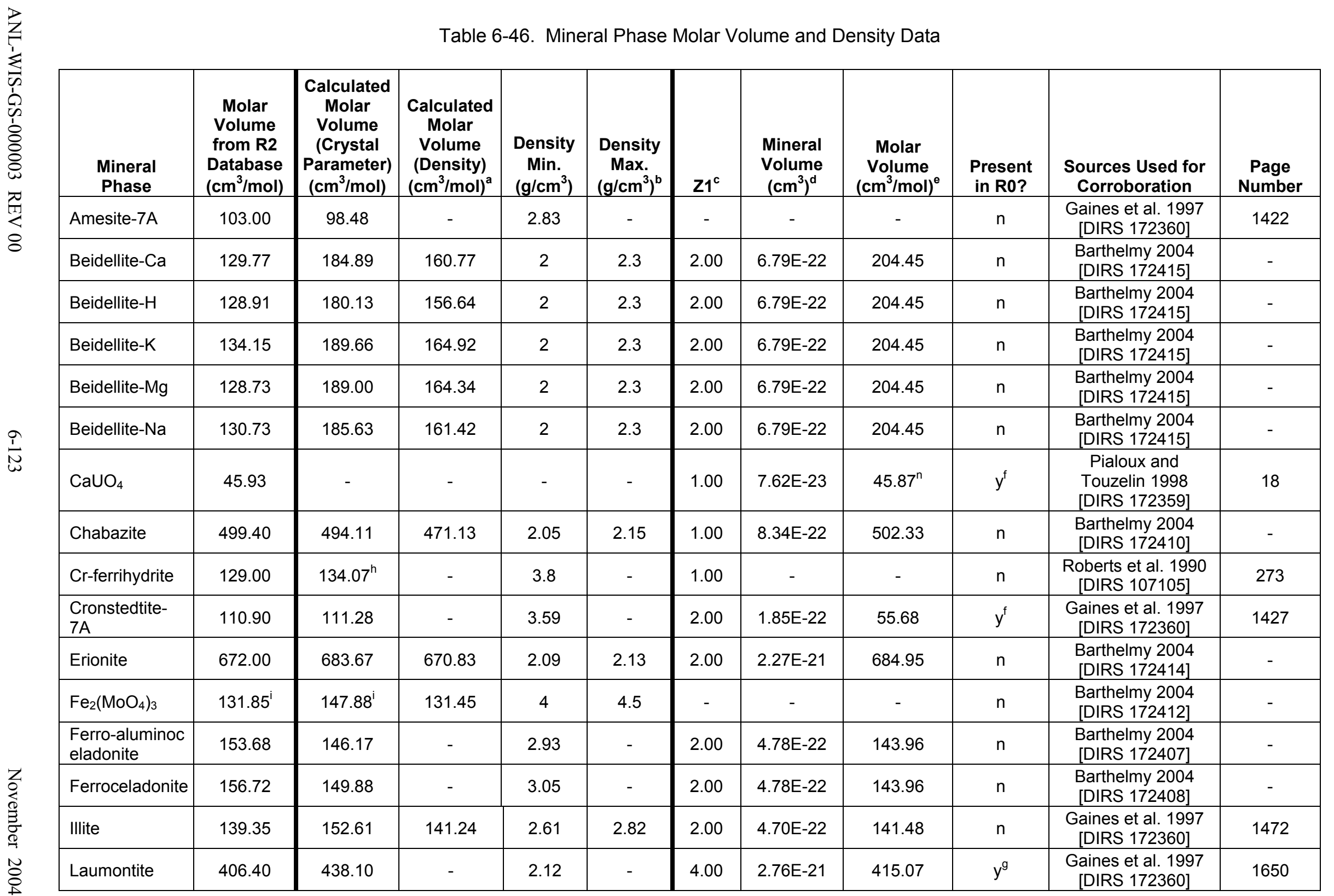




\begin{tabular}{|c|c|c|c|c|c|c|c|c|c|c|c|}
\hline $\begin{array}{l}\text { Mineral } \\
\text { Phase }\end{array}$ & $\begin{array}{c}\text { Molar } \\
\text { Volume } \\
\text { from R2 } \\
\text { Database } \\
\left(\mathrm{cm}^{3} / \mathrm{mol}\right)\end{array}$ & $\begin{array}{c}\text { Calculated } \\
\text { Molar } \\
\text { Volume } \\
\text { (Crystal } \\
\text { Parameter) } \\
\left(\mathrm{cm}^{3} / \mathrm{mol}\right)\end{array}$ & $\begin{array}{c}\text { Calculated } \\
\text { Molar } \\
\text { Volume } \\
\text { (Density) } \\
\left(\mathrm{cm}^{3} / \mathrm{mol}\right)^{\mathrm{a}}\end{array}$ & $\begin{array}{l}\text { Density } \\
\text { Min. } \\
\left(\mathrm{g} / \mathrm{cm}^{3}\right)\end{array}$ & $\begin{array}{c}\text { Density } \\
\text { Max. } \\
\left(\mathbf{g} / \mathbf{c m}^{3}\right)^{b}\end{array}$ & $\mathrm{Z1}^{\mathrm{c}}$ & $\begin{array}{l}\text { Mineral } \\
\text { Volume } \\
\left(\mathrm{cm}^{3}\right)^{d}\end{array}$ & $\begin{array}{c}\text { Molar } \\
\text { Volume } \\
\left(\mathrm{cm}^{3} / \mathrm{mol}\right)^{\mathrm{e}}\end{array}$ & $\begin{array}{c}\text { Present } \\
\text { in R0? }\end{array}$ & $\begin{array}{l}\text { Sources Used for } \\
\text { Corroboration }\end{array}$ & $\begin{array}{c}\text { Page } \\
\text { Number }\end{array}$ \\
\hline $\begin{array}{l}\text { Montmorillonite } \\
-\mathrm{Ca}\end{array}$ & 133.07 & 181.72 & 134.61 & 2 & 2.7 & 2.00 & $4.53 \mathrm{E}-22$ & 136.41 & $\mathrm{n}$ & $\begin{array}{l}\text { Barthelmy 2004 } \\
\text { [DIRS 172413] }\end{array}$ & - \\
\hline $\begin{array}{l}\text { Montmorillonite } \\
-\mathrm{H}\end{array}$ & 132.22 & 179.82 & 133.20 & 2 & 2.7 & 2.00 & $4.53 \mathrm{E}-22$ & 136.41 & $\mathrm{n}$ & $\begin{array}{l}\text { Barthelmy 2004 } \\
\text { [DIRS 172413] }\end{array}$ & - \\
\hline $\begin{array}{l}\text { Montmorillonite } \\
-K\end{array}$ & 137.46 & 183.63 & 136.02 & 2 & 2.7 & 2.00 & 4.53E-22 & 136.41 & $\mathrm{n}$ & $\begin{array}{l}\text { Barthelmy 2004 } \\
\text { [DIRS 172413] }\end{array}$ & - \\
\hline $\begin{array}{l}\text { Montmorillonite } \\
-\mathrm{Mg}\end{array}$ & 132.03 & 179.96 & 133.30 & 2 & 2.7 & 2.00 & 4.53E-22 & 136.41 & $\mathrm{n}$ & $\begin{array}{l}\text { Barthelmy 2004 } \\
\text { [DIRS 172413] }\end{array}$ & - \\
\hline $\begin{array}{l}\text { Montmorillonite } \\
\text { - Na }\end{array}$ & 134.03 & 182.01 & 134.83 & 2 & 2.7 & 2.00 & 4.53E-22 & 136.41 & $\mathrm{n}$ & $\begin{array}{l}\text { Barthelmy 2004 } \\
\text { [DIRS 172413] }\end{array}$ & - \\
\hline $\mathrm{Ni}_{3}\left(\mathrm{PO}_{4}\right)_{2}{ }^{\mathrm{j}}$ & 83.36 & - & - & - & - & - & - & - & $y^{f}$ & - & - \\
\hline $\mathrm{Na}_{4} \mathrm{UO}_{2}\left(\mathrm{CO}_{3}\right)_{3}{ }^{\mathrm{k}}$ & 149.31 & 147.69 & - & 3.67 & - & 4.00 & $9.65 \mathrm{E}-22$ & 145.30 & $y^{f}$ & $\begin{array}{c}\text { Ralph n.d. } \\
\text { [DIRS 172416] } \\
\end{array}$ & - \\
\hline Nontronite-Ca & 135.85 & 185.28 & 179.78 & 2.29 & 2.36 & 2.00 & 7.23E-22 & 217.58 & $\mathrm{n}$ & $\begin{array}{l}\text { Gaines et al. } 1997 \\
\text { [DIRS 172360] }\end{array}$ & 1485 \\
\hline Nontronite-K & 140.24 & 188.03 & 182.45 & 2.29 & 2.36 & 2.00 & $7.23 \mathrm{E}-22$ & 217.58 & $\mathrm{n}$ & $\begin{array}{l}\text { Gaines et al. 1997 } \\
\text { [DIRS 172360] }\end{array}$ & 1485 \\
\hline Nontronite-Mg & 134.81 & 184.14 & 178.68 & 2.29 & 2.36 & 2.00 & $7.23 \mathrm{E}-22$ & 217.58 & $\mathrm{n}$ & $\begin{array}{c}\text { Gaines et al. 1997 } \\
\text { [DIRS 172360] }\end{array}$ & 1485 \\
\hline Nontronite-Na & 136.81 & 185.70 & 180.20 & 2.29 & 2.36 & 2.00 & 7.23E-22 & 217.58 & $\mathrm{n}$ & $\begin{array}{l}\text { Gaines et al. } 1997 \\
\text { [DIRS 172360] }\end{array}$ & 1485 \\
\hline Phillipsite & 609.20 & 581.15 & - & 2.17 & - & 1.00 & $9.93 \mathrm{E}-22$ & 598.15 & $\mathrm{n}$ & $\begin{array}{c}\text { Gaines et al. } 1997 \\
\text { [DIRS 172360] }\end{array}$ & 1665 \\
\hline Ripidolite-14A & 209.63 & $225.02^{\mathrm{m}}$ & $192.99^{m}$ & 2.47 & 2.88 & 2.00 & 7.00E-22 & 210.65 & $\mathrm{n}$ & $\begin{array}{c}\text { Gaines et al. 1997 } \\
\text { [DIRS 172360] }\end{array}$ & 1501 \\
\hline Ripidolite-7A & 215.38 & $225.02^{\mathrm{m}}$ & $192.99^{\mathrm{m}}$ & 2.47 & 2.88 & 2.00 & 7.00E-22 & 210.65 & $\mathrm{n}$ & $\begin{array}{l}\text { Gaines et al. } 1997 \\
\text { [DIRS 172360] }\end{array}$ & 1501 \\
\hline Saponite-Ca & 134.36 & 183.58 & 169.83 & 2.1 & 2.27 & 2.00 & 7.00E-22 & 210.65 & $\mathrm{n}$ & \multirow{5}{*}{$\begin{array}{c}\text { Gaines et al. 1997 } \\
\text { [DIRS 172360] } \\
\text { Roberts et al. 1990 } \\
\text { [DIRS 107105] }\end{array}$} & \multirow{5}{*}{$\begin{array}{c}1489 \\
\text { (Gaines) } \\
756 \\
\text { (Roberts) }\end{array}$} \\
\hline Saponite-H & 133.51 & 180.59 & 167.06 & 2.1 & 2.27 & 2.00 & $7.00 \mathrm{E}-22$ & 210.65 & $\mathrm{n}$ & & \\
\hline Saponite-K & 138.75 & 186.57 & 172.60 & 2.1 & 2.27 & 2.00 & $7.00 \mathrm{E}-22$ & 210.65 & $\mathrm{n}$ & & \\
\hline Saponite-Mg & 132.60 & 182.34 & 168.68 & 2.1 & 2.27 & 2.00 & $7.00 \mathrm{E}-22$ & 210.65 & $\mathrm{n}$ & & \\
\hline Saponite-Na & 135.32 & 184.04 & 170.26 & 2.1 & 2.27 & 2.00 & $7.00 \mathrm{E}-22$ & 210.65 & $n$ & & \\
\hline
\end{tabular}


Table 6-46. Mineral Phase Molar Volume and Density Data (Continued)

\begin{tabular}{|c|c|c|c|c|c|c|c|c|c|c|c|}
\hline $\begin{array}{c}\text { Mineral } \\
\text { Phase }\end{array}$ & $\begin{array}{c}\text { Molar } \\
\text { Volume } \\
\text { from R2 } \\
\text { Database } \\
\left(\mathrm{cm}^{3} / \mathrm{mol}\right) \\
\end{array}$ & $\begin{array}{c}\text { Calculated } \\
\text { Molar } \\
\text { Volume } \\
\text { (Crystal } \\
\text { Parameter) } \\
\left(\mathrm{cm}^{3} / \mathrm{mol}\right)\end{array}$ & $\begin{array}{c}\text { Calculated } \\
\text { Molar } \\
\text { Volume } \\
\text { (Density) } \\
\left(\mathrm{cm}^{3} / \mathrm{mol}\right)^{a}\end{array}$ & $\begin{array}{c}\text { Density } \\
\text { Min. } \\
\left(\mathrm{g} / \mathrm{cm}^{3}\right)\end{array}$ & $\begin{array}{l}\text { Density } \\
\text { Max. } \\
\left(\mathrm{g} / \mathrm{cm}^{3}\right)^{\mathrm{b}}\end{array}$ & $\mathrm{Z1}^{\mathrm{c}}$ & $\begin{array}{c}\text { Mineral } \\
\text { Volume } \\
\left(\mathrm{cm}^{3}\right)^{\mathrm{d}}\end{array}$ & $\begin{array}{c}\text { Molar } \\
\text { Volume } \\
\left(\mathrm{cm}^{3} / \mathrm{mol}\right)^{\mathrm{e}}\end{array}$ & $\begin{array}{l}\text { Present } \\
\text { in R0? }\end{array}$ & $\begin{array}{c}\text { Sources Used for } \\
\text { Corroboration }\end{array}$ & $\begin{array}{c}\text { Page } \\
\text { Number }\end{array}$ \\
\hline $\begin{array}{l}\text { Smectite- } \\
\text { Reykjanes }\end{array}$ & 142.85 & - & - & 2 & 2.7 & 2.00 & 4.53E-22 & 136.41 & $\mathrm{n}$ & $\begin{array}{l}\text { Barthelmy 2004 } \\
\text { [DIRS 172413] }\end{array}$ & - \\
\hline $\begin{array}{l}\text { Smectite } \\
\text { high-Fe-Mg' }\end{array}$ & 139.51 & - & - & 2 & 2.7 & 2.00 & 4.53E-22 & 136.41 & $\mathrm{n}$ & $\begin{array}{l}\text { Barthelmy 2004 } \\
\text { [DIRS 172413] }\end{array}$ & - \\
\hline $\begin{array}{l}\text { Smectite } \\
\text { low-Fe-Mgl }\end{array}$ & 139.60 & - & - & 2 & 2.7 & 2.00 & 4.53E-22 & 136.41 & $\mathrm{n}$ & $\begin{array}{l}\text { Barthelmy } 2004 \\
\text { [DIRS 172413] }\end{array}$ & - \\
\hline Stellerite & 665.50 & 664.85 & - & 2.12 & - & 4.00 & $4.38 \mathrm{E}-21$ & 659.70 & $\mathrm{n}$ & $\begin{array}{c}\text { Gaines et al. 1997 } \\
\text { [DIRS 172360] }\end{array}$ & 1676 \\
\hline $\begin{array}{l}\text { Uranophane } \\
\text { (alpha) }\end{array}$ & 251.34 & 226.56 & - & 3.78 & - & 3.00 & 7.39E-22 & 148.38 & $\mathrm{n}$ & $\begin{array}{l}\text { Gaines et al. 1997 } \\
\text { [DIRS 172360] }\end{array}$ & 1111 \\
\hline Weeksite-Na & 246.04 & 270.78 & - & 3.71 & - & 16.00 & 7.26E-21 & 273.32 & $\mathrm{n}$ & $\begin{array}{l}\text { Gaines et al. 1997 } \\
\text { [DIRS 172360] }\end{array}$ & 1114 \\
\hline
\end{tabular}

Output DTN: SN0410T0510404.001 (All calculated values reported in this table are generated in Spreadsheet Volume_Q_DS_11-17-04.xIS).

a Molar volume calculated only when a range of densities (lower value and upper value; Columns 5 and 6 , respectively) given in the source.

${ }^{\mathrm{b}}$ Density Max., given only when the source gives a lower and upper value for density.

Number of formula units used in defining cell parameters.

Based on crystollographic data as given in source $\left(\mathrm{cm}^{3}\right)$.

e Based on crystollographic data as given in source $\left(\mathrm{cm}^{3} / \mathrm{mol}\right)$.

f In data0.ymp.RO (DTN: MO0009THRMODYN.001 [DIRS 152576]) but no molar volume or mineral volume data available.

9 Present in data0.ymp.R0 (DTN: MO0009THRMODYN.001 [DIRS 152576]), but there is a slight difference in chemical formula.

${ }^{\mathrm{h}}$ Molar volume calculated using density and molecular weight of ferrihydrite (not Cr-ferrihydrite), because no data available for this mineral phase.

Molar volume calculated using density value of the phase $\mathrm{Fe}_{2}\left(\mathrm{MoO}_{4}\right)_{3} \cdot 8 \mathrm{H}_{2} \mathrm{O}$, because no data for $\mathrm{Fe}_{2}\left(\mathrm{MoO}_{4}\right)_{3}$ available.

See text for qualification argument.

${ }^{k}$ Density and molecular weight for volume calculation from the mineral Cejkaite, which has the same chemical formula.

Density values are from Montmorillonite, because no data available for this smectite.

${ }^{m}$ Molar volume calculated using the formula for Ripidolite as $\mathrm{Mg}_{3}\left(\mathrm{Mg}_{2} \mathrm{Al}\right)\left(\mathrm{Si}_{3} \mathrm{AlO} \mathrm{O}_{10}\right)(\mathrm{OH})_{8}$. Volume in data0.ymp.R2 (DTN: MO0302SPATHDYN.000

[DIRS 161756]) calculated using the formula $\mathrm{Mg}_{3} \mathrm{Fe}_{2}\left(\mathrm{Al}_{2} \mathrm{Si}_{3} \mathrm{O}_{10}\right)(\mathrm{OH})_{8}$.

${ }^{n}$ The volume data from various sources given in Pialoux and Touzelin (1998 [DIRS 172359]) is for a hexagonal transformation of the true rhombohedral structure of this phase. The conversion from rhombohedral to hexagonal for the volume relation is $\mathrm{V}$.hexa $=3 \mathrm{~V} \_$rhomb. Therefore, the values tabulated by Pialoux and Touzelin (1998 [DIRS 172359]) need to be divided by 3. 


\section{INTENTIONALLY LEFT BLANK}




\section{CONCLUSIONS}

The data sets listed in Table 7-1 were qualified or generated in the course of this evaluation. These include the input data0.ymp.R2 database and supporting files (DTN: MO0302SPATHDYN.000 [DIRS 161756], qualified by this report; DTN: MO0302SPATHDYN.001 [DIRS 161886], and DTN: MO0303SPASPEQ2.000 [DIRS 162278]), and the corrected data0.ymp.R4 database and supporting files (output DTNs: SN0410T0510404.002 and SN0410T0510404.001). Similarly, the sources used to develop the data0.ymp.R2 database (DTN: MO0302SPATHDYN.000 [DIRS 161756]), as listed in Table 1-1, were evaluated, and justification provided for the appropriateness of these sources. Errors were found related to some of these sources, and substitutions for the data are included in the new data0.ymp.R4 database (output DTN: SN0410T0510404.002).

Table 7-1. Summary of Qualification Recommendations

\begin{tabular}{|l|l|l|l|}
\hline \multicolumn{1}{|c|}{ Title } & \multicolumn{1}{|c|}{ Preliminary DTN } & \multicolumn{1}{c|}{ Status* } & \multicolumn{1}{c|}{ Description } \\
\hline Data0.ymp.R2 & $\begin{array}{l}\text { MO0302SPATHDYN.000 } \\
\text { [DIRS 161756] }\end{array}$ & Qualified & Thermodynamic database (input) \\
\hline Speq02.dat & $\begin{array}{l}\text { MO0303SPASPEQ2.000 } \\
\text { [DIRS 162278] }\end{array}$ & Qualified & $\begin{array}{l}\text { Updated SUPCRT92 database file } \\
\text { used to develop data0.ymp.R2 (input) }\end{array}$ \\
\hline Supporting Files & $\begin{array}{l}\text { MO0302SPATHDYN.001 } \\
\text { [DIRS 161886] }\end{array}$ & Qualified & $\begin{array}{l}\text { Spreadsheets and SUPCRT92 files } \\
\text { used to develop data0.ymp.R2 (input) }\end{array}$ \\
\hline Data0.ymp.R4 & SN0410T0510404.002 & Qualified & $\begin{array}{l}\text { Corrected thermodynamic database } \\
\text { (output) }\end{array}$ \\
\hline Additional Supporting Files & SN0410T0510404.001 & Qualified & $\begin{array}{l}\text { Additional spreadsheets supporting } \\
\text { data0.ymp.R4 (output) }\end{array}$ \\
\hline
\end{tabular}

* Recommended as a result of this report.

In addition to the criteria discussed in Section 4.2, development of a thermodynamic database in this report includes the following considerations:

A. Are the data reasonable in terms of compatibility with other existing data (thermodynamic consistency)?

The data have been cross-checked within the database to ensure that the data are internally consistent. The change to the "Rimstidt" paradigm for quartz solubility (Section 6.1.5) required that all silicate species (with some exceptions) be checked for consistency, including the recalculation of these species that was performed for development of the data0.ymp.R2 database (DTN: MO0302SPATHDYN.000 [DIRS 161756]). Although multiple sources of input data were used in the data0.ymp.R2 database (DTN: MO0302SPATHDYN.000 [DIRS 161756]), the development process prevented any significant departure from overall internal consistency. Some discrepancies were noted during qualification, including transcription errors, and these are summarized below and explained in detail in Section 6. 
B. Are the qualifications of the personnel or organizations generating the data comparable to qualification requirements of personnel generating similar data under the approved 10 CFR 63, Subpart G [DIRS 156605] quality assurance program?

The data used to update the data0.ymp.R0 database (DTN: MO0009THRMODYN.001 [DIRS 152576]) creating the data0.ymp.R2 database (DTN: MO0302SPATHDYN.000 [DIRS 161756]), were generated in internationally recognized laboratories in North America and Europe. They were published either in internationally recognized handbooks or in peer-reviewed international journals and national laboratory reports. The data selected for the data0.ymp.R2 database (DTN: MO0302SPATHDYN.000 [DIRS 161756]) are selected from sources that are widely accepted by the geochemical modeling community. Most of the chemical data for transuranic elements were generated in national laboratories or their international equivalents.

C. Does analysis of comparable qualified and unqualified data indicate a reasonable level of accuracy for the fundamental thermodynamic data?

The data used to implement changes to the data0.ymp.R0 database (DTN: MO0009THRMODYN.001 [DIRS 152576]), creating the data0.ymp.R2 database (DTN: MO0302SPATHDYN.000 [DIRS 161756]), are compatible with the previous data0.ymp.R0 database (DTN: MO0009THRMODYN.001 [DIRS 152576]) that has been in use for several years and is qualified for use by the YMP. The additional data and the methodology used for the update are comparable in accuracy to the original basis for the data0.ymp.R0 database (DTN: MO0009THRMODYN.001 [DIRS 152576]). In some cases, newer data were available and replaced previous values reflecting the evolving nature of thermodynamic data. These changes used to create the data0.ymp.R2 database (DTN: MO0302SPATHDYN.000 [DIRS 161756]), and the justification for those changes, are documented in this report.

As a result of the data evaluation described in Section 6, various errors and discrepancies were identified in this qualification effort. The errors are mostly from errors in transcription of data from original sources to the spreadsheets used to adjust and calculate $\log \mathrm{K}$ values for data0.ymp.R2 (DTN: MO0302SPATHDYN.000 [DIRS 161756]). Other errors are related to implementation of $\log \mathrm{K}$ values in the database and representation of chemical reactions relative to the reactions given in the sources. The errors found in qualification of data0.ymp.R2 (DTN: MO0302SPATHDYN.000 [DIRS 161756]) are summarized as follows:

- Log K Values for Certain Zeolites (Section 6.3.2) - Transcription errors, mainly in heat capacity data for zeolite species which were added in creation of the data0.ymp.R2 database (DTN: MO0302SPATHDYN.000 [DIRS 161756]), caused potentially significant differences in the $\log \mathrm{K}$ values after the correction in the data0.ymp.R4 database (output DTN: SN0410T0510404.002). These differences are larger at higher temperatures. The problem was remedied for the data0.ymp.R4 database (output DTN: SN0410T0510404.002) by correcting the scaling for heat capacity coefficients and recalculating the $\log \mathrm{K}$ values. Section 6.3.2 provides further details including tabulation of corrected $\log \mathrm{K}$ 
values and listing of the differences $(\Delta \log \mathrm{K})$ between corrected and uncorrected $\log \mathrm{K}$ values. The significance of these changes increases with temperature: at $25^{\circ} \mathrm{C}$ there is no effect, at $100^{\circ} \mathrm{C}$ the maximum difference for any affected zeolite is $1.7 \log \mathrm{K}$ units (analcime, erionite, and stellerite in Table 6-22), and at $300^{\circ} \mathrm{C}$ the maximum difference is $15 \log \mathrm{K}$ units (analcime, erionite, phillipsite, and stellerite in Table 6-22). Accordingly, data for the affected zeolites in the data0.ymp.R2 database (DTN: MO0302SPATHDYN.000 [DIRS 161756]) should not be used above $100^{\circ} \mathrm{C}$. The corrected data are included in data0.ymp.R4 (output DTN: SN0410T0510404.002), which should be used instead.

- Discrepancies in Thermodynamic Data for Cement Minerals Na- and Ca-Gismondine, Syngenite, and "Friedl Salt" (Sections 6.3.3.3 and 6.3.3.9)

- Corroborating thermodynamic data for Ca-gismondine (but not Na-gismondine) are available in the literature. Technical assessment (this report) of the data used in data0.ymp.R2 (DTN: MO0302SPATHDYN.000 [DIRS 161756]) is based on data comparison with respect to this phase. The $\Delta \mathrm{G}_{f}^{\circ}$ value estimated in technical assessment generates a $\log \mathrm{K}$ value (see Table 6-28) that is significantly different from the data0.ymp.R2 (DTN: MO0302SPATHDYN.000 [DIRS 161756]) value computed using data from Atkins et al. (1993 [DIRS 131758]. Also, comparison of $\Delta \mathrm{H}_{f}^{\circ}$ for Ca-gismondine reported in another literature source (Section 6.3.3.3) also indicates a discrepancy. These results show that the data adopted for Ca-gismondine in data0.ymp.R2 (DTN: MO0302SPATHDYN.000 [DIRS 161756]) are incorrect. No corroborating data are available for Na-gismondine, but the same conclusion is drawn by analogy to Ca-gismondine. The data block for the cement phase "Friedl salt" (Section 6.3.3.4) is inactive in the data0.ymp.R2 database (DTN: MO0302SPATHDYN.000 [DIRS 161756]); the data for this phase in data0.ymp.R2 were also found to be incorrect. No corrections to the Na- and Ca-gismondine species or the inactive "Friedl salt" species were made to the data0.ymp.R4 database (output DTN: SN0410T0510404.002); these species appear in the data0.ymp.R4 database the same as in data0.ymp.R2 (DTN: MO0302SPATHDYN.000 [DIRS 161756]). The log K value for syngenite at $25^{\circ} \mathrm{C}$ present in data0.ymp.R2 cannot be duplicated using the available data given in Harvie et al. (1984 [DIRS 118163]) and no documentation on how it was estimated is available. As explained in Section 6.3.3.9, an alternative $\log \mathrm{K}$ value from the qualified Pitzer thermodynamic database, data0.ypf (DTN: SN0302T0510102.002 [DIRS 162572]) was identified. The difference between the value in data0.ymp.R2 and this alternative value ( $0.15 \log$ units) is insignificant.

- Correction of Stoichiometry for the Pu Phase $\mathrm{PuO}_{2}(\mathrm{OH})_{2} \cdot \mathrm{H}_{2} \mathrm{O}$ - A modification of the $\mathrm{Pu}$ solid $\mathrm{PuO}_{2}(\mathrm{OH})_{2}: \mathrm{H}_{2} \mathrm{O}$ was made to correct an error found in data0.ymp.R2 (DTN: MO0302SPATHDYN.000 [DIRS 161756]) related to the stoichiometry of this species (the incorrect $\mathrm{PuO}_{2}(\mathrm{OH})_{2}: 2 \mathrm{H}_{2} \mathrm{O}$ was 
corrected to $\left.\mathrm{PuO}_{2}(\mathrm{OH})_{2}: \mathrm{H}_{2} \mathrm{O}\right)$. This correction is consistent with the usage in Lemire (2001 [DIRS 159027], Section 17.2.2.1) and was made originally in data0.ymp.R3 (DTN: MO0312SPATDMIF.000 [DIRS 167800]). This correction is carried into the new data0.ymp.R4 database (output DTN: SN0410T0510404.002).

- Correction to Log K Values for $\mathbf{H F}_{2}{ }^{-}$Dissociation (Section 6.4) - Two errors were identified for this species: 1) incorrect transcription of solubility constants from the source related to scaling of log values, and 2) incorrect representation of the chemical reaction as entered in the data0.ymp.R2 database (DTN: MO0302SPATHDYN.000 [DIRS 161756]) with respect to the one given in the source. The protonated form of hydrofluoric acid (HF) is related to the formation of $\mathrm{HF}_{2}^{-}$(Eq. 6-36). Aqueous dissociation of hydroflouric acid (HF) occurs at approximately $\mathrm{pH} 3.85$ at $100^{\circ} \mathrm{C}$, and at higher $\mathrm{pH}$ values with increasing temperature (Ellis and Mahon 1977 [DIRS 159230], Table 8.4). The error is present for calculations at all $\mathrm{pH}$ levels, but can produce a quantitatively significant result only for acidic conditions (e.g., $\mathrm{pH}<3.85$ at $100^{\circ} \mathrm{C}$ ) with abundant fluoride. The correction is included in the updated database data0.ymp.R4 (output DTN: SN0410T0510404.002).

- Log K Values for Np and Pu Solids (Section 6.3.4.5) - Similar transcription errors were identified for these actinides. The errors are: 1) a factor of 1000 on the "b" parameter for the Maier-Kelley equation, 2) the "c" parameter was ignored in many cases for this same equation, and 3) for certain species $\left(\mathrm{NpC}_{0.91}(\mathrm{cr}), \quad \mathrm{Pu}_{2} \mathrm{C}_{3}(\mathrm{cr}), \quad \mathrm{PuC}_{0.84}(\mathrm{cr}), \mathrm{PuOI}(\mathrm{cr}), \mathrm{PuOF}(\mathrm{cr})\right.$, and $\mathrm{PuO}_{2}(\mathrm{cr}) ;$ Tables 6-33 and 6-34), the adopted coefficients were inappropriately applied as Maier-Kelly parameters. For listed items 1) and 2) the problem was remedied by correcting the scaling for heat capacity coefficients and recalculating the $\log \mathrm{K}$ values, for the data0.ymp.R4 corrected database (output DTN: SN0410T0510404.002). Overall, the differences are not significant and the maximum difference was restricted to the upper temperature limit of $300^{\circ} \mathrm{C}$. For the two species in listed item 3) above, the errors were not corrected in the data0.ymp.R4 database (output DTN: SN0410T0510404.002), and the $\log \mathrm{K}$ values for temperatures other than $25^{\circ} \mathrm{C}$ should not be used. Section 6.3.4.5 details the errors and associated corrections plus tabulation of corrected $\log \mathrm{K}$ values, including a listing of the differences (or $\Delta \log \mathrm{K}$ ) between the corrected and uncorrected $\log \mathrm{K}$ values.

- Log K Values for Metal Gas Species and Solids (Section 6.3.4.5) - Similar transcription errors were identified for metal-bearing gas and solid species. Transcription errors related to scaling of the "c" Maier-Kelly heat capacity coefficient for several solids and gas species from the source Binnewies and Milke (1999 [DIRS 158955]) were found in the spreadsheets supporting the data0.ymp.R2 database development (DTN: MO0302SPATHDYN.001 [DIRS 161886]). For the gas and solid species, the "c" heat capacity coefficient is off by a factor of 10 . As with the other transcription errors, the problem was 
remedied by correcting the scaling for the heat capacity coefficients and recalculating the $\log \mathrm{K}$ values. Overall, the differences are not significant (within the uncertainty of the available thermodynamic data) and the maximum differences are restricted to the upper temperature limit of $300^{\circ} \mathrm{C}$. The corrected values are reported in Section 6.3.4.5, along with the differences $(\Delta \log K)$, but the corrected values are not included in the updated database data0.ymp.R4 (output DTN: SN0410T0510404.002).

For users of the data0.ymp.R2 database (DTN: MO0302SPATHDYN.000 [DIRS 161756]), given these discrepancies, uncertainties, and transcription errors, this report provides a corrected data0.ymp.R4 database (output DTN: SN0410T0510404.002) plus tabulation of the log K differences for all affected species not included in the data0.ymp.R4 database (output DTN: SN0410T0510404.002). As explained above, the most substantial errors for active data blocks in data0.ymp.R2 (DTN: MO0302SPATHDYN.000 [DIRS 161756]) pertain to the zeolites, the gismondine cement species $(\mathrm{Na}$ and $\mathrm{Ca}$ ), and the corrected stoichiometry of the $\mathrm{Pu}$ phase $\mathrm{PuO}_{2}(\mathrm{OH})_{2} \cdot \mathrm{H}_{2} \mathrm{O}$. The error associated with $\mathrm{HF}_{2}{ }^{-}$is potentially significant depending on the $\mathrm{pH}$ range and fluoride activity.

Molar volume data for many phases were included in the data0.ymp.R2 database (DTN: MO0302SPATHDYN.000 [DIRS 161756]) but no details on qualification were given in the original data qualification report (Steinborn et al. 2003 [DIRS 161956]). These data were assessed in this report (Section 6.6). For all phases for which molar volume data were not available in the original data0.ymp.R0 database (DTN: MO0009THRMODYN.001 [DIRS 152576]), and for which molar volume data were added to the data0.ymp.R2 database (DTN: MO0302SPATHDYN.000 [DIRS 161756]), the values are corroborated (within 5 to $15 \%$ ) by alternate sources or comparison with analogous species. For certain clays there is substantial uncertainty $(50 \%)$ in molar volume estimates from different sources (Section 6.3.1). As explained in Section 6.6, such difference are expected because of the variable hydration condition of measured clay mineral samples, which affects the unit-cell structure data.

\subsection{EVALUATION OF UNCERTAINTY AND RECOMMENDED USE OF THE DATABASE}

The chemical thermodynamic data needed for geochemical modeling of processes of importance to the YMP have been compiled, developed, and evaluated. The data sets qualified or created during the evaluation process are listed in Table 7-1. The following text provides additional discussion on the evaluated uncertainties and recommended use of the data.

Extrapolation of $\log \mathrm{K}$ data for clays up to $300^{\circ} \mathrm{C}$ should be treated with caution since equilibrium between solution and clay minerals at elevated temperatures has been experimentally observed for only a few species. At temperatures above $250^{\circ} \mathrm{C}$, mica-like phases may be more stable. The argument needed to establish which clay or mica phase is more or less stable as a function of pressure and temperature goes beyond the scope of this report. Therefore, it is up to the user of the data0.ymp.R2 database (DTN: MO0302SPATHDYN.000 [DIRS 161756]) (and the updated data0.ymp.R4 database; output DTN: SN0410T0510404.002) to determine the 
appropriate assemblage of clay minerals (e.g., minerals to include or suppress) for the system of interest. The same statement applies to every solid species tabulated in these databases and is an important principle of geochemical modeling.

In addition to the qualification findings summarized in the previous section, a number of other assumptions and approximations were identified in the data0.ymp.R2 development (DTN: MO0302SPATHDYN.000 [DIRS 161756]), which may affect use of the database:

- Thermodynamic data for steam (Section 6.1.2) should not be retrieved from the SUPCRT92 database files, which are calibrated for ranges of temperature and pressure outside the range of interest to YMP. Rather, handbook values should be used.

- Reevaluation of SUPCRT92 properties was not performed for aqueous silica reactions (Section 6.1.5) because these reactions are generally unimportant for $\mathrm{pH}$ less than 9 to 10 . However, for more alkaline $\mathrm{pH}$ these reactions should be reexamined and the thermodynamic properties reevaluated as appropriate.

- About 100 silicate minerals were not corrected to the Rimstidt paradigm (Section 6.1.5). The difference in $\log \mathrm{K}$ units is generally less than 1 unit, and typically less than $0.5 \log$ units. For close comparison of equilibria involving different silicate minerals, this aspect should be taken into account.

- The thermodynamic data for clays have some additional uncertainties (Section 6.3.1) because: clay species in the data0.ymp.R2 database (DTN: MO0302SPATHDYN.000 [DIRS 161756]) have idealized formulae, and the mineralogical compositions of clays can be uncertain, especially in nature; and the temperature dependence of Gibbs free energies for exchangeable components are approximate.

- Extrapolation of thermodynamic parameters for zeolites beyond the experimental range of temperature for heat capacity data from Viani and Bruton (1992 [DIRS 101407]) is not recommended (Section 6.3.2). The temperature ranges of these experiments varied, for example clinoptilolite was measured up to $500 \mathrm{~K}$ (except for $\mathrm{NH}_{4}$-clinoptilolite, which was measured only at $25^{\circ} \mathrm{C}$ ).

- Transcription errors were discovered in the development of $\log \mathrm{K}$ values for uranium silicates soddyite, uranophane, Na-weeksite, and Na-boltwoodite (Section 6.3.4). These errors were found to be insignificant and the $\log \mathrm{K}$ values for these minerals in the data0.ymp.R2 database (DTN: MO0302SPATHDYN.000 [DIRS 161756]) are qualified.

Additional detailed information on uncertainty associated with thermodynamic properties of clay minerals is provided in Section 6.3.1.

\subsubsection{Uncertainty in Thermodynamic Data}

Uncertainties in thermodynamics are challenging to describe quantitatively because they do not propagate linearly. Uncertainties in thermodynamic parameters are often correlated so that simplistic representations of propagation overestimate the uncertainty. The problem is 
compounded by the fact that thermodynamic calculations have variable inputs (e.g., $\mathrm{pH}$, solubilities, and Gibbs free energies) and these same parameters can also be outputs. The mathematical structure of thermodynamics is a contributing factor because it allows different kinds of physical measurements to be used to solve the same problem (e.g., "second law" vs. "third law" approaches). It is an example of both the predictive power of thermodynamics and the difficulty in describing uncertainty, that one can, for example calculate the solubility of a solid in water when the relevant solubility equilibrium has never been measured or even observed. The $\log \mathrm{K}$ data for crystalline $\mathrm{PuO}_{2}$ and $\mathrm{NpO}_{2}$ in the current $\mathrm{EQ} 3 / 6$ database are examples of this.

Reflecting this situation, a common dictum in dealing with thermodynamic data is that "consistency is more important than accuracy." This means that the treatment of thermodynamic data (e.g., reduction into a standard, relatively compact form for inclusion in a database) must be such that the constraining measurements can be faithfully recovered. All standard thermodynamic relations must be satisfied, both in data reduction and in subsequent usage. These include basic relations such as $\mathrm{G}=\mathrm{H}-\mathrm{TS},-\mathrm{S}=\delta \mathrm{G} / \delta \mathrm{T}$, and $\mathrm{V}=\delta \mathrm{G} / \delta \mathrm{P}$, where $\mathrm{G}$ is Gibbs free energy, $\mathrm{H}$ is enthalpy, $\mathrm{T}$ is absolute temperature, $\mathrm{S}$ is entropy, $\mathrm{V}$ is volume, and $\mathrm{P}$ is pressure. They also include "solution" consistency relations such as $\delta^{2} \mathrm{G} / \delta \mathrm{n}_{\mathrm{i}} \delta \mathrm{n}_{\mathrm{j}}=\delta^{2} \mathrm{G} / \delta \mathrm{n}_{\mathrm{j}} \delta \mathrm{n}_{\mathrm{i}}$, where $\mathrm{n}$ is the number of moles of a component.

In reducing thermodynamic data, especially from a tabulated database, it is important that the starting data often are not original measurements but are values calculated from measurements. The ability to create a compact database from data in standardized form and then use this for a wide range of applications is one of the great powers of thermodynamics. Typically, there is some variation in the types of tabulated data, but standard Gibbs free energies of formation, standard enthalpies of formation, entropies, and heat capacities are most common. There are also data tabulations specific to $\log \mathrm{K}$ values for reactions and to solubilities in simple chemical systems. Although tabulated solubilities are generally actual measurements, standard Gibbs free energies of formation, for example, are calculated.

Unfortunately, the uncertainties that go with the data can not generally be treated like the data. The uncertainty assigned to a tabulated value that is not a measurement reflects both the uncertainty in the original measured parameter and the uncertainties in any other parameters used to obtain the tabulated value. It may also reflect additional uncertainties in the use of thermodynamic models for solution behavior (e.g., ionic strength corrections). Not only do such models introduce additional parameters with their own uncertainties, the approximate nature of such models may add additional uncertainty. Also, failing to recognize how uncertainties are correlated, a much larger uncertainty than the one actually associated with the measurement could be calculated.

Many tabulations of thermodynamic data, particularly Gibbs free energies, do not include associated uncertainties. Furthermore, estimates of uncertainties in thermodynamic data often do not take a standard form such as the standard deviation. Even when replicates are used, it can be difficult to calculate a standard deviation with any statistical rigor. Apparent bounds or an informally defined scale of measurement are the approaches most likely to be encountered. 
As a consequence, the exact uncertainties associated with a thermodynamic database depend on the history of the data. If uncertainties are small to begin with, there may be no significant consequences from the use of simplistic propagation calculations that tend to overstate the uncertainty. However, it is important to know the larger uncertainties associated with factors like sluggish kinetics, poorly crystallized or poorly defined phases (e.g., colloids), precise composition of the solid phase, radiation effects, low solubilities, and chemical systems that are difficult to control in the laboratory (e.g., plutonium). Uncertainties may also result from lack of published information (e.g., $\mathrm{Cr}(\mathrm{VI})$ solids).

A common approach to characterizing uncertainty in thermodynamic data is to estimate uncertainty for classes of thermodynamic data that share commonality in type and method of origin. This approach is used whenever uncertainty is estimated using analogies. The best tabulated $\log \mathrm{K}$ values for complexation reactions, for example, tend to have an uncertainty of about $0.02 \log$ unit or less, and many such values have an uncertainty within $0.1 \log$ unit. The best calorimetrically determined standard Gibbs free energies of formation at $298.15 \mathrm{~K}$ of clay minerals have uncertainties of about 4 to $6 \mathrm{~kJ} / \mathrm{mol}$. Reported solubilities of soluble salt minerals are probably uncertain to within about 1 percent, or higher for less soluble minerals.

For a detailed discussion of the treatment of uncertainties in thermodynamic data, refer to the NEA guidelines on the subject (Wanner and Osthols 1999 [DIRS 159222]). The NEA-sponsored volumes on the thermodynamics of radionuclide elements (e.g., Grenthe et al. 1992 [DIRS 101671], on uranium; Silva et al. 1995 [DIRS 102087], on americium; Lemire 2001 [DIRS 159027], on neptunium and plutonium) are excellent examples of expert treatment of thermodynamic data and uncertainties.

The remainder of this section addresses uncertainties associated with the use of the isocoulombic/isoelectric method for extrapolating thermodynamic data to higher temperature. This method is the only "new" temperature extrapolation method introduced in the development of the data0.ymp.R2 database (DTN: MO0302SPATHDYN.000 [DIRS 161756]) and is therefore of special interest. With regard to other methods, which have been used previously, refer to sources cited elsewhere in the present and previous reports, particularly the NEA guidelines on temperature extrapolations (Puigdomenech et al. 1997 [DIRS 159204], 1999 [DIRS 159205]). The latter source recommends use of the isocoulombic/isoelectric method to about $275^{\circ} \mathrm{C}$.

The isocoulombic/isoelectric method requires as inputs Gibbs free energies (or log K values) and entropies, normally for $298.15 \mathrm{~K}$. The method utilizes an isocoulombic/isoelectric reference reaction together with the assumption that the corresponding heat capacity of reaction is zero. Rarely, the heat capacity of reaction is assumed to be a non-zero constant. Here the focus is on uncertainty in the method itself by examining the use of different reference reactions and how the results vary. One case is examined below, involving extrapolation of the apparent Gibbs free energy of formation for $\mathrm{Am}^{+++}$, which is a basis species for this element in the data0.ymp.R2 database (DTN: MO0302SPATHDYN.000 [DIRS 161756]). While the example is limited, the comparison is instructive.

Calculation of the apparent Gibbs free energy of formation using the isocoulombic/isoelectric method is addressed, given a choice of different reference reactions. The $\mathrm{Am}^{+++}$ion is not in the 
SUPCRT92 database, so the Gibbs free energy grid was calculated for the normal library worksheets. The basic $25^{\circ} \mathrm{C}$ data (Gibbs free energy of formation and entropy) for the $\mathrm{Am}^{+++}$ were taken from Silva et al. (1995 [DIRS 102087], p. 37). All other data were taken from the SUPCRT92 database. Calculations were done in the Spreadsheet BasisSpecies_j_TJW_1.xls (DTN: MO0302SPATHDYN.001 ([DIRS 161886]). The following reference reactions were considered:

$$
\begin{aligned}
2 \mathrm{Am}^{+++}+\mathrm{Cr}_{2} \mathrm{O}_{3} & =2 \mathrm{Cr}^{+++}+\mathrm{Am}_{2} \mathrm{O}_{3} \\
2 \mathrm{Am}^{+++}+\mathrm{Fe}_{2} \mathrm{O}_{3} & =2 \mathrm{Fe}^{+++}+\mathrm{Am}_{2} \mathrm{O}_{3} \\
2 \mathrm{Am}^{+++}+\mathrm{Ce}_{2} \mathrm{O}_{3} & =2 \mathrm{Ce}^{+++}+\mathrm{Am}_{2} \mathrm{O}_{3} \\
2 \mathrm{Am}^{+++}+\mathrm{Gd}_{2} \mathrm{O}_{3} & =2 \mathrm{Gd}^{+++}+\mathrm{Am}_{2} \mathrm{O}_{3} \\
2 \mathrm{Am}^{+++}+\mathrm{Lu}_{2} \mathrm{O}_{3} & =2 \mathrm{Lu}^{+++}+\mathrm{Am}_{2} \mathrm{O}_{3} \\
2 \mathrm{Am}^{+++}+\mathrm{UO}_{2} & =2 \mathrm{U}^{+++}+\mathrm{AmO}_{2}
\end{aligned}
$$

The results are shown in Table 7-2. They suggest an uncertainty at $200^{\circ} \mathrm{C}$ of about 1 to $2 \mathrm{~kJ} / \mathrm{mol}$. The cerium data here led to the greatest deviations from the mean. For the database, it was decided to use the chromium extrapolation, on the basis that the reference data are more likely to be accurate than the other analogs considered here. The properties of $\mathrm{Fe}^{+++}, \mathrm{U}^{+++}$and the trivalent rare earths are difficult to obtain because ferric iron is rather insoluble; those of $\mathrm{U}^{+++}$because this represents a difficult species to maintain, and those of the trivalent rare earths due to potential problems with sample purity.

This discussion shows the range of Gibbs free energy values that can be obtained, using the isocoulombic/isoelectric method with different reference reactions. The results shown can be considered typical for those species in the data0.ymp.R2 database (DTN: MO0302SPATHDYN.000 [DIRS 161756]) for which this method is relied upon. Smaller uncertainties pertain for reactions that have extensive laboratory measurement basis, and larger uncertainties may pertain for species with a paucity of reference data.

Table 7-2. Isocoulombic Extrapolation of the Calculated Apparent Gibbs Free Energy Grids of Am ${ }^{+++}$, Comparing Extrapolations Using Various Reference Reactions

\begin{tabular}{|r|c|c|c|c|c|c|c|}
\hline $\mathbf{T}\left({ }^{\circ} \mathbf{C}\right)$ & $\begin{array}{c}\mathbf{C r}^{+++} \\
\text {Analog }\end{array}$ & $\begin{array}{c}\mathbf{F e}^{+++} \\
\text {Analog }\end{array}$ & $\begin{array}{c}\mathbf{C e}^{+++} \\
\text {Analog }\end{array}$ & $\begin{array}{c}\mathbf{G d}^{+++} \\
\text {Analog }\end{array}$ & $\begin{array}{c}\mathbf{L u}^{+++} \\
\text {Analog }\end{array}$ & $\begin{array}{c}\mathbf{U}^{+++} \\
\text {Analog }\end{array}$ & Mean \\
\hline 0 & -603601.4 & -603624.0 & -603467.9 & -603534.6 & -603552.8 & -603527.4 & -603551.4 \\
\hline 25 & -598698.0 & -598698.0 & -598698.0 & -598698.0 & -598698.0 & -598698.0 & -598698.0 \\
\hline 60 & -591510.4 & -591542.7 & -591314.3 & -591414.2 & -591440.8 & -591405.2 & -591437.9 \\
\hline 100 & -582964.5 & -583097.4 & -582164.8 & -582580.4 & -582685.5 & -582548.1 & -582673.5 \\
\hline 150 & -571700.5 & -572043.7 & -569734.4 & -570785.7 & -571035.2 & -570727.5 & -571004.5 \\
\hline 200 & -559550.7 & -560195.0 & -556082.7 & -557995.7 & -558418.7 & -557931.8 & -558362.4 \\
\hline 250 & -546146.8 & -547186.9 & -540934.0 & -543904.0 & -544512.6 & -543875.0 & -544426.6 \\
\hline 300 & -531053.9 & -532560.9 & -523855.0 & -528053.1 & -528867.2 & -528115.7 & -528751.0 \\
\hline
\end{tabular}

DTN: MO0302SPATHDYN.001 ([DIRS 161886], Spreadsheet BasisSpecies_j_TJW_1.XIs).

NOTE: Characterized by analogues; see text for details. Units are Joules/mole. 
Table 7-3. Isocoulombic Extrapolation of the Calculated Apparent Gibbs Free Energy Deviations from Mean of $\mathrm{Am}^{+++}$

\begin{tabular}{|c|c|c|c|c|c|c|}
\hline $\mathbf{T}\left({ }^{\circ} \mathbf{C}\right)$ & $\begin{array}{c}\mathrm{Cr}^{+++} \\
\text {Analog }\end{array}$ & $\begin{array}{c}\mathrm{Fe}^{+++} \\
\text {Analog }\end{array}$ & $\begin{array}{c}\mathrm{Ce}^{+++} \\
\text {Analog }\end{array}$ & $\begin{array}{c}\mathbf{G d}^{+++} \\
\text {Analog }\end{array}$ & $\begin{array}{c}\mathbf{L u}^{+++} \\
\text {Analog }\end{array}$ & $\begin{array}{c}\mathbf{U}^{+++} \\
\text {Analog }\end{array}$ \\
\hline 0 & -50.1 & -72.7 & 83.4 & 16.8 & -1.4 & 23.9 \\
\hline 25 & 0.0 & 0.0 & 0.0 & 0.0 & 0.0 & 0.0 \\
\hline 60 & -72.4 & -104.7 & 123.7 & 23.7 & -2.9 & 32.7 \\
\hline 100 & -291.0 & -424.0 & 508.6 & 93.0 & -12.0 & 125.4 \\
\hline 150 & -696.0 & -1039.2 & 1270.2 & 218.8 & -30.7 & 277.0 \\
\hline 200 & -1188.3 & -1832.6 & 2279.7 & 366.7 & -56.3 & 430.6 \\
\hline 300 & -1720.2 & -2760.4 & 3492.5 & 522.6 & -86.0 & 551.5 \\
\hline
\end{tabular}

DTN: MO0302SPATHDYN.001 ([DIRS 161886], Spreadsheet BasisSpecies_j_TJW_1.xIs).

NOTE: Characterized by analogues; see text for details. Units are Joules/mole.

\subsubsection{Use of Cement Data}

Many of the cement mineral phases (e.g., portlandite, tobermorite, and gyrolite) included in the final data0.ymp.R2 database (DTN: MO0302SPATHDYN.000 [DIRS 161756]) and the data0.ymp.R4 database (output DTN: SN0410T0510404.002) are naturally occurring minerals and could be formed if thermodynamically or kinetically possible. However, other cement phases in the data0.ymp.R2 database (DTN: MO0302SPATHDYN.000 [DIRS 161756]) are not likely to form in nature, and a modeler should use only those minerals that could be expected to form in the environment being modeled.

Cement phase minerals form from the alteration of cement used in the repository, and minerals such as gyrolite and tobermorite can also form as alteration products on nuclear waste glass (Gong et al. 1998 [DIRS 158976]) and from the alteration of host rock if conditions are sufficiently alkaline. Cement minerals that are not naturally occurring (not observed in rocks outside of cements and grouts) should not be considered in a non-cement model or set of calculations. Often when included in a calculation, the use of the data will cause the model run to precipitate cement mineral phases like hydrogarnet and Friedl salt. These phases are only relevant to calculations directly associated with cements and grouts. Finally, the reader is reminded that the CSH:1.7, Friedl salt, and hydrogarnet phases in the data0.ymp.R2 database (DTN: MO0302SPATHDYN.000 [DIRS 161756]) are inactive (i.e., they are "commented out" and not accessible to the EQ3/6 software) and the associated thermodynamic data in the file are not considered qualified. 


\section{INPUTS AND REFERENCES}

The following is a list of the references cited in this document. Column 2 represents the unique six-digit numerical identifiers (the DIRS numbers), which are placed in the text following the reference callout (e.g., Atkins et al. 1992 [DIRS 100700]). The purpose of these numbers is to assist in locating a specific reference. Multiple sources by the same author (e.g., BSC 2004) are sorted alphabetically by title.

\subsection{DOCUMENTS CITED}

Atkins, M.; Bennett, D.; Dawes, A.; Glasser, F.; Kindness, A.; and Read, D. 1992.

100700 A Thermodynamic Model for Blended Cements. DoE/HMIP/RR/92/005. London, England: Department of the Environment. TIC: 233334.

Atkins, M.; Glasser, F.P.; Kindness, A.; and Macphee, D.E. 1991. Solubility Data for Cement Hydrate Phases $\left(25^{\circ} \mathrm{C}\right)$. Experimental Data Generated at Aberdeen University During 1987-1990. DOE/HMIP/RR/91/032. London, England: Department of the Environment, Her Majesty's Inspectorate of Pollution. TIC: 241636.

Atkins, M.; Glasser, F.P.; Moroni, L.P.; and Jack, J.J. 1993. Thermodynamic Modelling of Blended Cements at Elevated Temperatures $\left(50-90^{\circ} \mathrm{C}\right)$.

DoE/HMIP/RR/94/011. Aberdeen, United Kingdom: Aberdeen University. TIC: 235985.

Babushkin, V.I.; Matveyev, G.M.; and Mchedlov-Petrossyan, O.P. 1985. Thermodynamics of Silicates. Mchedlov-Petrossyan, O.P., ed. Berlin, Germany: Springer-Verlag. TIC: 244843.

Baes, C.F., Jr. and Mesmer, R.E. 1976. The Hydrolysis of Cations. Pages 1, 6, 7, 157860 176, 177, 180, 181, 184-191. New York, New York: John Wiley \& Sons.

TIC: 217440 .

Barin, I. and Knacke, O. 1973. Thermochemical Properties of Inorganic 160926 Substances. New York, New York: Springer-Verlag. TIC: 248490.

Barin, I. and Platzki, G. 1995. Thermochemical Data of Pure Substances. 3rd 157865 Edition. Two volumes. New York, New York: VCH Publishers. TIC: 251934.

Barthelmy, D. 2004. "Beidellite" Beidellite Mineral Data. Accessed 172415 October 26, 2004. URL: http:/www.webmineral.com/data/Beidellite.shtml

Barthelmy, D. 2004. "Chabazite" Chabazite Mineral Data. Accessed

October 26, 2004. URL: http:/www.webmineral.com/data/Chabazite.shtml

Barthelmy, D. 2004. "Erionite Mineral Data.” Accessed October 26, 2004. URL: http://www.webmineral.com/data/Erionite.shtml 
Barthelmy, D. 2004. "Ferrimolybdite Mineral Data." Accessed October 26, 2004. 172412 URL: http://www.webmineral.com/data/Ferrimolybdite.shtml

Barthelmy, D. 2004. "Ferro-Aluminoceladonite Mineral Data." Accessed

172407 October 26, 2004. URL: http://webmineral.com/data/Ferroaluminoceladonite.shtml

Barthelmy, D. 2004. "Ferroceladonite Mineral Data." Accessed October 26, 2004. URL: http://www.webmineral.com/data/Ferroceladonite.shtml

Barthelmy, D. 2004. "Montmorillonite Mineral Data." Accessed October 26, 172413 2004. URL: http://www.webmineral.com/data/Montmorillonite.shtml

Batchelor, B. and Wu, K. 1993. "Effects of Equilibrium Chemistry on Leaching of Contaminants from Stabilized/Solidified Wastes." Chapter 9 of Chemistry and Microstructure of Solidified Waste Forms. Spence, R.D., ed. Boca Raton, Florida: Lewis Publishers. TIC: 250621.

Bennett, D.G.; Read, D.; Atkins, M.; and Glasser, F.P. 1992. “A Thermodynamic Model for Blended Cements. II: Cement Hydrate Phases; Thermodynamic Values and Modelling Studies." Journal of Nuclear Materials, 190, 315-325.

Amsterdam, The Netherlands: Elsevier. TIC: 246493.

Berner, U. 1990. A Thermodynamic Description of the Evolution of Pore Water Chemistry and Uranium Speciation During the Degradation of Cement.

PSI-Bericht 62. Wurenlingen und Villigen, Switzerland: Paul Scherrer Institut. TIC: 238928.

Berner, U.R. 1987. "Modeling Porewater Chemistry in Hydrated Portland Cement." Scientific Basis for Nuclear Waste Management X, Symposium held December 1-4, 1986, Boston, Massachusetts. Bates, J.K. and Seefeldt, W.B., eds. 84, 319-330. Pittsburgh, Pennsylvania: Materials Research Society.

TIC: 203663.

Binnewies, M. and Milke, E. 1999. Thermochemical Data of Elements and 158955 Compounds. New York, New York: Wiley-VCH. TIC: 251818.

Brindley, G.W. and Brown, G. 1980. Crystal Structures of Clay Minerals and Their X-Ray Identification. Mineralogical Society Monograph No. 5. London, England: Mineralogical Society. TIC: 243417.

Bruton, C.J.; Meike, A.; Viani, B.E.; Martin, S.; and Phillips, B.L. 1993. 100710 "Thermodynamic and Structural Characteristics of Cement Minerals at Elevated Temperature." Proceedings of the Topical Meeting on Site Characterization and Model Validation, FOCUS '93, September 26-29, 1993, Las Vegas, Nevada. Pages 150-156. La Grange Park, Illinois: American Nuclear Society. TIC: 102245. 
BSC (Bechtel SAIC Company) 2004. Data Qualification for Thermodynamic 170268 Data Used to Support THC Calculations. ANL-NBS-HS-000043 REV 00. Las Vegas, Nevada: Bechtel SAIC Company. ACC: DOC.20041118.0004.

BSC 2004. Engineered Barrier System: Physical and Chemical Environment. 169860 ANL-EBS-MD-000033, Rev. 03. Las Vegas, Nevada: Bechtel SAIC Company.

BSC 2004. Mineralogic Model (MM3.0) Report. MDL-NBS-GS-000003

REV 01. Las Vegas, Nevada: Bechtel SAIC Company.

ACC: DOC.20040908.0006.

BSC 2004. Multiscale Thermohydrologic Model. ANL-EBS-MD-000049

169565

REV 02. Las Vegas, Nevada: Bechtel SAIC Company.

ACC: DOC.20041014.0008.

BSC 2004. Q-List. 000-30R-MGR0-00500-000-000 REV 00. Las Vegas, Nevada: Bechtel SAIC Company. ACC: ENG.20040721.0007.

BSC 2004. Technical Work Plan for: Near-Field Environment and Transport In-Drift Geochemistry Analyses. TWP-MGR-PA-000013 REV 02. Las Vegas, Nevada: Bechtel SAIC Company. ACC: DOC.20041101.0001.

Burns, P.C. 1998. "The Structure of Boltwoodite and Implications of Solid Solution Toward Sodium Boltwoodite." The Canadian Mineralogist, 36, 1069-1075. Ottawa, Ontario, Canada: Mineralogical Association of Canada. TIC: 246038.

Calvo, C. and Faggiani, R. 1975. "Structure of Nickel Orthophosphate." 172265 Canadian Journal of Chemistry, 53, (10), 1516-1520. Ottawa, Canada: National Research Council of Canada. TIC: 252224.

Carlos, B.A.; Chipera, S.J.; Bish, D.L.; and Raymond, R. 1995. "Distribution and 105213 Chemistry of Fracture-Lining Zeolites at Yucca Mountain, Nevada." Natural Zeolites '93: Occurrence, Properties, Use, Proceedings of the 4th International Conference on the Occurrence, Properties, and Utilization of Natural Zeolites, June 20-28, 1993, Boise, Idaho. Ming, D.W. and Mumpton, F.A., eds. Pages 547-563. Brockport, New York: International Committee on Natural Zeolites. TIC: 243086.

Casas, I.; Bruno, J.; Cera, E.; Finch, R.J.; and Ewing, R.C. 1994. Kinetic and Thermodynamic Studies of Uranium Minerals - Assessment of the Long-Term Evolution of Spent Nuclear Fuel. SKB TR-94-16. Stockholm, Sweden: Svensk Kärnbränsleförsörjning A.B. TIC: 213723.

Casas, I.; Perez, I.; Torrero, E.; Bruno, J.; Cera, E.; and Duro, E. 1997. 168361 172402 127210 Dissolution Studies of Synthetic Soddyite and Uranophane. SKB TR-97-15. Stockholm, Sweden: Svensk Kärnbränsleförsörjning A.B. TIC: 237591. 
Chase, M.W., Jr. 1998. NIST-JANAF Thermochemical Tables. 4th Edition.

157874

Monograph No. 9. Woodbury, New York: American Chemical Society.

TIC: 249978.

Chen, F.; Ewing R.C.; and Clark S.B. 1999. "The Gibbs Free Energies and

106346

Enthalpies of Formation of U6+ Phases: An Empirical Method of Prediction."

American Mineralogist, 84, (4), 650-664. Washington, D.C.: American

Mineralogist. TIC: 245800.

Chen, F.; Ewing, R.C.; and Clark, S.B. 1999. "Errata--The Gibbs Free Energies

123270 and Enthalpies of Formation of Uranium(VI) Phases: An Empirical Method of Prediction." American Mineralogist, 84, (7-8), 1208. Washington, D.C.: Mineralogical Society of America. TIC: 246579.

Chipera S.J. and Apps, J.A. 2001. "Geochemical Stability of Natural Zeolites." In Natural Zeolites: Occurrence, Properties, Applications, Bish, D.L. and Ming, D.W.; eds, Chapter 13 of Reviews in Mineralogy and Geochemistry. Volume 45. Washington, D.C.: Mineralogical Society of America. TIC: 256369.

Chipera, S.J.; Bish, D.L.; and Carlos, B.A. 1995. "Equilibrium Modeling of the Formation of Zeolites in Fractures at Yucca Mountain, Nevada." Natural Zeolites '93: Occurrence, Properties, Use, Proceedings of the 4th International Conference on the Occurrence, Properties, and Utilization of Natural Zeolites, June 20-28, 1993, Boise, Idaho. Ming, D.W. and Mumpton, F.A., eds. Pages 565-577. Brockport, New York: International Committee on Natural Zeolites. TIC: 243086.

Clark, S.P., Jr., ed. 1966. Handbook of Physical Constants. Memoir 97. New York, New York: Geological Society of America. TIC: 244868.

CRWMS (Civilian Radioactive Waste Management System) M\&O (Management and Operating Contractor) 2000. Data Qualification Report for Thermodynamic Data File, Data0.ympR0 for Geochemical Code, EQ3/6. TDR-EBS-MD-000012 REV 00. Las Vegas, Nevada: CRWMS M\&O. ACC: MOL.20001016.0004.

Damidot, D.; Stronach, S.; Kindness, A.; Atkins, M.; and Glasser, F.P. 1994. "Thermodynamic Investigation of the CaO-A12O3-CaCO3-H2O Closed System at $25^{\circ} \mathrm{C}$ and Influence of Na2O." Cement and Concrete Research, 24, (3), 563-572. New York, New York: Elsevier. TIC: 248189.

de Ligny, D. and Navrotsky, A. 1999. "Energetics of Kaolin Polymorphs." 158973 American Mineralogist, 84, (4), 506-516. Washington, D.C.: Mineralogical Society of America. TIC: 252470.

Deer, W.A.; Howie, R.A.; and Zussman, J. 1992. An Introduction to the 171017 100025 153163 152575 Rock-Forming Minerals. 2nd Edition. New York, New York: Prentice Hall. TIC: 221918. 
Douglass, R.M. 1956. "Tetrasodium Uranyl Tricarbonate, $\mathrm{Na}_{4} \mathrm{UO}_{2}\left(\mathrm{CO}_{3}\right)_{3}$." 172266 Analytical Chemistry, 28, (10), 1635. Washington, D.C.: American Chemical Society. TIC: 252227.

Ellis, A.J. and Mahon, W.A.J., eds. 1977. "Table 8.4. Distribution of HF Between 159230 Steam and Water at Various Temperatures." Chemistry and Geothermal Systems. New York, New York: Academic Press. TIC: 252725.

Fernandez-Prini, R.J.; Corti, H.R.; and Japas, M.L. 1992. High-Temperature 161651 Aqueous Solutions: Thermodynamic Properties. Pages 124-127. Boca Raton, Florida: CRC Press. TIC: 253048.

Fialips, C.-I.; Navrotsky, A.; and Petit, S. 2001. "Crystal Properties and 158975 Energetics of Synthetic Kaolinite." American Mineralogist, 86, (3), 304-311. Washington, D.C.: Mineralogical Society of America. TIC: 252471.

Finch, R.J. 1997. "Thermodynamic Stabilities of U(VI) Minerals: Estimated and 106347 Observed Relationships." Scientific Basis for Nuclear Waste Management XX, Symposium held December 2-6, 1996, Boston, Massachusetts. Gray, W.J. and Triay, I.R., eds. 465, 1185-1192. Pittsburgh, Pennsylvania: Materials Research Society. TIC: 238884.

Fournier, R.O. and Potter, R.W., II. 1982. "An Equation Correlating the Solubility of Quartz in Water from $25^{\circ}$ to $900^{\circ}$ at Pressures up to 10,000 Bars." Geochimica et Cosmochimica Acta, 46, 1969-1973. New York, New York: Pergamon. TIC: 223170.

Fridriksson, T.; Neuhoff, P.S.; Arnórsson, S.; and Bird, D.K. 2001. "Geological Constraints on the Thermodynamic Properties of the Stilbite-Stellerite Solid Solution in Low-Grade Metabasalts." Geochimica et Cosmochimica Acta, 65, (21), 3993-4008. New York, New York: Elsevier. TIC: 253460.

Fujii, K. and Kondo, W. 1981. "Heterogeneous Equilibrium of Calcium Silicate 158026 Hydrate in Water at $30^{\circ} \mathrm{C}$." Journal of the Chemical Society, Dalton Transactions, A, (2), 645-651. London, England: Chemical Society. TIC: 251812.

Fujii, K. and Kondo, W. 1983. "Estimation of Thermochemical Data for Calcium 144876 Silicate Hydrate (C-S-H)." Journal of the American Ceramic Society, 66, (12), C220-C221. Columbus, Ohio: American Ceramic Society. TIC: 240838.

Gaines, R.V.; Skinner, H.C.W.; Foord, E.E.; Mason, B.; and Rosenzweig, A. 1997. Dana's New Mineralogy, The System of Mineralogy of James Dwight Dana and Edward Salisbury Dana. 8th Edition. New York, New York: John Wiley \& Sons. TIC: 256455. 
Garrels, R.M. and Christ, C.L. 1990. Solutions, Minerals, and Equilibria. Boston, 144877 Massachusetts: Jones and Bartlett Publishers. TIC: 223483.

Gartner, E.M. and Jennings, H.M. 1987. "Thermodynamics of Calcium Silicate 144879 Hydrates and Their Solutions." Journal of the American Ceramic Society, 70, (10), 743-749. Westerville, Ohio: American Ceramic Society. TIC: 248682.

Glasser, F. P.; E. E. Lachowski; and D. E. MacPhee 1987. “Compositional Model 118111 for Calcium Silicate Hydrate (C-S-H) Gels, Their Solubilities, and Free Energies of Formation." Journal of the American Ceramic Society, 70, (7), 481-485. Westerville, Ohio: American Ceramic Society. TIC: 246777.

Gong, W.L.; Wang, L.M.; Ewing, R.C.; Vernaz, E.; Bates, J.K.; and Ebert, W.L. 1998. "Analytical Electron Microscopy Study of Surface Layers Formed on the French SON68 Nuclear Waste Glass During Vapor Hydration at $200^{\circ}$ C." Journal of Nuclear Materials, 254, (2-3), 249-265. New York, New York: Elsevier. TIC: 252351.

Greenberg, J.P. and Moller, N. 1989. "The Prediction of Mineral Solubilities in Natural Waters: A Chemical Equilibrium Model for the Na-K-Ca-Cl-SO4-H2O System to High Concentration from 0 to $250^{\circ} \mathrm{C}$." Geochimica et Cosmochimica Acta, 53, 2503-2518. New York, New York: Pergamon Press. TIC: 249020.

Greenberg, S.A. and Chang, T.N. 1965. "Investigation of the Colloidal Hydrated 144989 Calcium Silicates. II. Solubility Relationships in the Calcium Oxide-Silica-Water System at 25․" Journal of Physical Chemistry, 69, (1), 182-188. Easton, Pennsylvania: American Chemical Society. TIC: 248686.

Grenthe, I.; Fuger, J.; Konings, R.J.M.; Lemire, R.J.; Muller, A.B.; Nguyen-Trung, C.; and Wanner, H. 1992. Chemical Thermodynamics of Uranium. Volume 1 of Chemical Thermodynamics. Wanner, H. and Forest, I., eds. Amsterdam, The Netherlands: North-Holland Publishing Company. TIC: 224074.

Gunnarsson, I. and Arnórsson, S. 2000. "Amorphous Silica Solubility and the Thermodynamic Properties of $\mathrm{H}_{4} \mathrm{SiO}_{4}^{\circ}$ in the Range of $0^{\circ}$ to $350^{\circ} \mathrm{C}$ at $\mathrm{P}_{\text {sat." }}$ Geochimica et Cosmochimica Acta, 64, (13), 2295-2307. New York, New York: Elsevier. TIC: 250506.

Haas, J.L., Jr. and Fisher, J.R. 1976. "Simultaneous Evaluation and Correlation of 158983 Thermodynamic Data." American Journal of Science, 276, 525-545. New Haven, Connecticut: Yale University, Kline Geology Laboratory. TIC: 239706.

Hardin, E.L. 1998. Near-Field/Altered-Zone Models Report. UCRL-ID-129179 DR. Livermore, California: Lawrence Livermore National Laboratory. ACC: MOL.19980504.0577. 
Harvie, C.E.; Moller, N.; and Weare, J.H. 1984. "The Prediction of Mineral

118163

Solubilities in Natural Waters: The Na-K-Mg-Ca-H-Cl-SO $\mathrm{S}_{4}-\mathrm{OH}-\mathrm{HCO}_{3}-\mathrm{CO}_{3}-$ $\mathrm{CO}_{2}-\mathrm{H}_{2} \mathrm{O}$ System to High Ionic Strengths at $25^{\circ} \mathrm{C}$." Geochimica et Cosmochimica Acta, 48, (4), 723-751. New York, New York: Pergamon Press. TIC: 239849.

Helgeson, H.C. 1969. "Thermodynamics of Hydrothermal Systems at Elevated 137246 Temperatures and Pressures." American Journal of Science, 267, (6), 729-804. New Haven, Connecticut: Scholarly Publications. TIC: 241817.

Helgeson, H.C.; Delany, J.M.; Nesbitt, H.W.; and Bird, D.K. 1978. "Summary and Critique of the Thermodynamic Properties of Rock Forming Minerals." American Journal of Science, 278-A. New Haven, Connecticut: Yale University, Kline Geology Laboratory. TIC: 220013.

Hemingway, B.S. 1982. Thermodynamic Properties of Selected Uranium Compounds and Aqueous Species at 298.15 K and 1 Bar and at Higher Temperatures--Preliminary Models for the Origin of Coffinite Deposits. Open-File Report 82-619. Denver, Colorado: U.S. Geological Survey. TIC: 211709.

Johnson, J.W.; Oelkers, E.H.; and Helgeson, H.C. 1992. "SUPCRT92: A 101632 Software Package for Calculating the Standard Molal Thermodynamic Properties of Minerals, Gases, Aqueous Species, and Reactions from 1 to 5000 Bar and 0 to $1000^{\circ}$ C.” Computers \& Geosciences, 18, (7), 899-947. New York, New York: Pergamon Press. TIC: 234273.

Kashik, S.A.; Karpov, I.K.; and Kozlova, G.V. 1979. “An Empirical Method of Calculating Free Energies for Layer Silicates." Geochemistry International, 15, (2), 70-74. Washington, D.C.: Scripta Publishing. TIC: 252608.

Kielland, J. 1937. "Individual Activity Coefficients of Ions in Aqueous

101596 Solutions." Journal of the American Chemical Society, 59, (9), 1675-1678. Easton, Pennsylvania: The American Chemical Society. TIC: 248309.

Kiseleva, I.A.; Navrotsky, A.; Belitskii, I.A.; Fursenko, B.A. 2001. "Thermodynamic Properties of the Calcium Zeolites Stilbite and Stellerite." Geochemistry International, 39, 170-176. Moscow, Russia: Nauka/Interperiodica.

Knauss, K.G.; Dibley, M.J.; Bourcier, W.L.; and Shaw, H.F. 2001. “Ti(IV) 158998 Hydrolysis Constants Derived from Rutile Solubility Measurements Made from 100 to $300^{\circ}$ C." Applied Geochemistry, 16, (9-10), 1115-1128. New York, New York: Elsevier. TIC: 252032.

Krishnamachari, N.; Calvo, C. 1972. "The Crystal Structure of Cobalt Diphosphate." Acta Crystallographica, Section B (Structural Crystallography and Crystal Chemistry), vol. B28, (pt. 9), 2883-2885. Copenhagen, Denmark:

Munksgaard International Publishers. 
Krishnamurty, K.V. and Harris, G.M. 1961. "The Chemistry of the Metal Oxalato 159026 Complexes.” Chemical Reviews, 61, (1), 213-246. Washington, D.C.: American Chemical Society. TIC: 252321.

Lemire, R.J. 2001. Chemical Thermodynamics of Neptunium and Plutonium. 159027 Volume 4 of Chemical Thermodynamics. New York, New York: Elsevier. TIC: 209037.

Li, G.; Peacor, D.R.; Coombs, D.S.; and Kawachi, Y. 1997. "Solid Solution in the Celadonite Family: The New Minerals Ferroceladonite, $\mathrm{K}_{2} \mathrm{Fe}^{2}{ }_{2}+\mathrm{Fe}^{3}{ }_{2}+$ $\mathrm{Si}_{8} \mathrm{O}_{20}(\mathrm{OH})_{4}$, and Ferroaluminoceladonite, $\mathrm{K}_{2} \mathrm{Fe}_{2}{ }_{2}+\mathrm{Al}_{2} \mathrm{Si}_{8} \mathrm{O}_{20}(\mathrm{OH})_{4}$." American Mineralogist, 82, (5-6), 503-511. Washington, D.C.: Mineralogical Society of America. TIC: 252472.

Lindsay, W.T., Jr. 1980. "Estimation of Concentration Quotients for Ionic Equilibria in High Temperature Water: The Model Substance Approach." Official Proceedings, The International Water Conference, 41st Annual Meeting, October 20, 21, \& 22, 1980, Pittsburgh, Pennsylvania. Pages 284-294. Pittsburgh, Pennsylvania: Engineers' Society of Western Pennsylvania. TIC: 252705.

Loopstra, B.O. and Rietveld, H.M. 1969. "The Structure of Some Alkaline-Earth Metal Uranates." Acta Crystallographica, B25, (4), 787-791. Copenhagen, Denmark: Munksgaard. TIC: 252223.

MacPhee, D.E.; Luke, K.; Glasser, F.P.; and Lachowski, E.E. 1989. "'Solubility 145004 and Aging of Calcium Silicate Hydrates in Alkaline Solutions at $25^{\circ} \mathrm{C}$." Journal of the American Ceramic Society, 72, (4), 646-654. Westerville, Ohio: American Ceramic Society. TIC: 248232.

Maier, C.G. and Kelley, K.K. 1932. "An Equation For The Representation Of 101691 High Temperature Heat Content Data." Journal of the American Chemical Society, 54, 3243-3246. Washington, D.C.: American Chemical Society. TIC: 239023.

Martell, A.E. and Smith, R.M. 1982. First Supplement. Volume 5 of Critical Stability Constants. New York, New York: Plenum Press. TIC: 248488.

Mattigod S.V. and McGrail, B.P. 1999. "Estimating The Standard Free Energy Of 172343 Formation Of Zeolites Using The Polymer Model." Microporous and Mesoporous Materials, 27, (1), 41-47. Amsterdam, The Netherlands: Elsevier.

Mattigod, S.V. and Sposito, G. 1978. "Improved Method for Estimating the Standard Free Energies of Formation $\left(\Delta \mathrm{G}_{\mathrm{f}, 298.15}\right.$ ) of Smectites." Geochimica et Cosmochimica Acta, 42, (12), 1753-1762. New York, New York: Pergamon. TIC: 252609. 
McKenzie, W.F.; Richard, L.; and Salah, S. 2001. "Gibbs Free Energies of 172346 Formation of Uranyl Silicates at 298.15 K." Proceedings of the Tenth International Symposium on Water-Rock Interaction/ WRI-10/ Villasimius/ Italy/ 10-15 July 2001. Cidu, R., ed. 1, 299-303. Exton, Pennsylvania: A.A. Balkema. TIC: 256709.

Moll, H.; Geipel, G.; Matz, W.; Bernhard, G.; and Nitsche, H. 1996. "Solubility 106349 and Speciation of $\left(\mathrm{UO}_{2}\right)_{2} \mathrm{SiO}_{4} \cdot 2 \mathrm{H}_{2} \mathrm{O}$ in Aqueous Systems." Radiochimica Acta, 74, 3-7. Munich, Germany: R. Oldenbourg Verlag. TIC: 236975.

Morel, F.M.M. and Hering, J.G. 1993. Principles and Applications of Aquatic Chemistry. New York, New York: John Wiley \& Sons. TIC: 248465.

Morey, G.W.; Fournier, R.O.; and Rowe, J.J. 1962. "The Solubility of Quartz in 159198 Water in the Temperature Interval from $25^{\circ}$ to $300^{\circ} \mathrm{C}$." Geochimica et Cosmochimica Acta, 26, 1029-1043. New York, New York: Pergamon Press. TIC: 250706.

Murphy, W.M. and Pabalan, R.T. 1995. Review of Empirical Thermodynamic 144449 Data for Uranyl Silicate Minerals and Experimental Plan. CNWRA 95-014. San Antonio, Texas: Center for Nuclear Waste Regulatory Analyses. TIC: 233385.

Murray, R.C., Jr. and Cobble, J.W. 1980. "Chemical Equilibria in Aqueous 159200 Systems at High Temperatures." The International Water Conference, 41st Annual Meeting, October 20, 21, \& 22, 1980, Pittsburgh, Pennsylvania. Pages 295-310. Pittsburgh, Pennsylvania: Engineers' Society of Western Pennsylvania. TIC: 252705.

Neall, F.B. 1994. Modelling of the Near-Field Chemistry of the SMA Repository at the Wellenberg Site. PSI Bericht 94-18. Wurenlingen und Villigen, Switzerland: Paul Scherrer Institute. TIC: 238927.

Neall, F.B. 1996. "Modelling the Long-Term Chemical Evolution of Cement-Groundwater Systems." Scientific Basis for Nuclear Waste Management XIX, Symposium held November 27-December 1, 1995, Boston, Massachusetts. Murphy, W.M. and Knecht, D.A., eds. 412, 483-490. Pittsburgh, Pennsylvania: Materials Research Society. TIC: 233877.

Neuhoff, P.S.; Hovis, G.L.; Balassone, G.; Stebbins, J.F. 2004. "Thermodynamic Properties of Analcime Solid Solutions." American Journal of Science, 304, 21-66. New Haven, Connecticut: Yale University, Kline Geology Laboratory.

Ng, HN; Calvo, C.; Faggiani, R. 1978. "A New Investigation of the Structure of Silver Orthophosphate." Acta Crystallographica, Section B (Structural Crystallography and Crystal Chemistry), B34, (pt. 3), 898 - 899. Chester, England: International Union of Crystallography. 
Nguyen, S.N.; Silva, R.J.; Weed, H.C.; and Andrews, J.E., Jr. 1992. "Standard 100809 Gibbs Free Energies of Formation at the Temperature 303.15 K of Four Uranyl Silicates: Soddyite, Uranophane, Sodium Boltwoodite, and Sodium Weeksite." Journal of Chemical Thermodynamics, 24, (1-6), 359-376. New York, New York: Academic Press. TIC: 238507.

Nordstrom, D.K. and Munoz, J.L. 1986. Geochemical Thermodynamics. Palo Alto, California: Blackwell Scientific Publications. TIC: 208228.

Ogorodova, L.P.; Kiseleva, I.A.; Mel'chakova, L.V.; Belitskii, I.A. 2003.

"Thermodynamic Properties of Calcium and Potassium Chabazites."

Geochemistry International, 40, (5), 466-471. Moscow, Russia: MAIK Nauka/Interperiodica.

Ogorodova, L.P.; Mel'chakova, L.V.; Kiseleva, I.A.; and Belitskii, I.A. 2003. "Thermodynamic Properties of Natural Zeolites of the Gismondine-Harronite Group." Russian Journal of Physical Chemistry, 77, (9), 1543-1545. Moscow, Russia: MAIK Nauka/Interperiodica. TIC: 256674.

Pérez, I.; Casas, I.; Martín, M.; and Bruno, J. 2000. "The Thermodynamics and 157910 Kinetics of Uranophane Dissolution in Bicarbonate Test Solutions." Geochimica et Cosmochimica Acta, 64, (4), 603-608. New York, New York: Elsevier.

TIC: 250919.

Perkins, R.B. and Palmer, C.D. 1999. "Solubility of Ettringite $\left(\mathrm{Ca}_{6}\left[\mathrm{Al} .(\mathrm{OH})_{6}\right]_{2}\left(\mathrm{SO}_{4}\right)_{3} \times 26 \mathrm{H}_{2} \mathrm{O}\right)$ at $5-75^{\circ} \mathrm{C}$." Geochimica et Cosmochimica Acta, 63, (13/14), 1969-1980. New York, New York: Pergamon Press. TIC: 248983.

Perkins, R.B. and Palmer, C.D. 2000. "Solubility of $\mathrm{Ca}_{6}\left[\mathrm{Al} .(\mathrm{OH})_{6}\right]_{2}\left(\mathrm{CrO}_{4}\right)_{3}$. $26 \mathrm{H}_{2} \mathrm{O}$, the Chromate Analog of Ettringite; 5-75 ${ }^{\circ} \mathrm{C}$." Applied Geochemistry, 15 , 1203-1218. New York, New York: Pergamon Press. TIC: 248980.

Pialoux, A. and Touzelin, B. 1998. "Etude du Système U-Ca-O par 153965 172353 Diffractométrie de Rayons X à Haute Température." Journal of Nuclear Materials, 255, 14-25. New York, New York: Elsevier. TIC: 256724.

Plummer, L.N. and Busenberg, E. 1982. "The Solubilities of Calcite, Aragonite 151737 and Vaterite in $\mathrm{CO} 2-\mathrm{H} 20$ Solutions Between 0 and $90^{\circ} \mathrm{C}$, and an Evaluation of the Aqueous Model for the System CaCO3-CO2-H2O." Geochimica et Cosmochimica Acta, 46, (6), 1011-1040. Elmsford, New York: Pergamon Press. TIC: 248743.

Puigdomenech I.; Rard, J.A.; Plyasunov, A.V.; and Grenthe, I. 1997. "Temperature Corrections to Thermodynamic Data and Enthalpy Calculations." Chapter X of Modelling in Aquatic Chemistry. Grenthe, I. and Puigdomenech, I., eds. Paris, France: Organisation for Economic Co-Operation and Development, Nuclear Energy Agency. TIC: 250748. 
Puigdomènech, I.; Rard, J.A.; Plyasunov, A.V.; and Grenthe, I. 1999. 159205

Temperature Corrections to Thermodynamic Data and Enthalpy Calculations. TDB-4. Issy-les-Moulineaux, France: Organization for Economic Co-Operation and Development, Nuclear Energy Agency. TIC: 252917.

Ralph, J. n.d. "Cejkaite" Cejkaite Mineral Data. Croydon, Surrey, England: Mindat.org. Accessed October 26, 2004. TIC: 256690.

URL: http://www.mindat.org/min-7105.html

Ransom, B. and Helgeson, H.C. 1994. "Estimation of the Standard Molal Heat Capacities, Entropies, and Volumes of 2:1 Clay Minerals." Geochimica et Cosmochimica Acta, 58, (21), 4537-4547. New York, New York: Elsevier. TIC: 252610.

Reardon, E.J. 1990. "An Ion Interaction Model for the Determination of Chemical 100821 Equilibria in Cement Water Systems." Cement and Concrete Research, 20, 175-192. Elmsford, New York: Pergamon Press. TIC: 239801.

Reardon, E.J. 1992. "Problems and Approaches to the Prediction of the Chemical Composition in Cement/Water Systems." Waste Management, 12, 221-239. New York, New York: Pergamon Press. TIC: 236730.

Rimstidt, J.D. 1997. "Quartz Solubility at Low Temperatures." Geochimica et 101709 Cosmochimica Acta, 61, (13), 2553-2558. New York, New York: Pergamon Press. TIC: 239020.

Roberts, W.L.; Campbell, T.J.; and Rapp, G.R., Jr. 1990. Encyclopedia of Minerals. 2nd Edition. New York, New York: Van Nostrand Reinhold. TIC: 242976.

Robie, R.A. and Hemingway, B.S. 1995. Thermodynamic Properties of Minerals and Related Substances at $298.15 \mathrm{~K}$ and 1 Bar (10 $0^{5}$ Pascals) Pressure and at Higher Temperatures. Bulletin 2131. Reston, Virginia: U.S. Geological Survey. TIC: 249441.

Robie, R.A.; Hemingway, B.S.; and Fisher, J.R. 1979. Thermodynamic Properties of Minerals and Related Substances at $298.15 \mathrm{~K}$ and 1 Bar (10 ${ }^{5}$ Pascals) Pressure and at Higher Temperatures. U.S. Geological Survey Bulletin 1452. Washington, D.C.: U.S. Government Printing Office. TIC: 230505.

Sarkar, A.K.; Barnes, M.W.; and Roy, D.M. 1982. Longevity of Borehole and Shaft Sealing Materials: Thermodynamic Properties of Cements and Related Phases Applied to Repository Sealing. ONWI-201. Columbus, Ohio: Battelle Memorial Institute, Office of Nuclear Waste Isolation. TIC: 248672. 
Shannon, R.D.; Calvo, C. 1973. "Crystal structure of $\mathrm{Cu}_{5} \mathrm{~V}_{2} \mathrm{O}_{10}$." Acta 172386 Crystallographica, Section B (Structural Crystallography and Crystal Chemistry), vol. B29, (pt. 6), 1338-1345. Copenhagen, Denmark: Munksgaard International Publishers.

Shaw, S.; Henderson, C.M.B.; and Komanschek, B.U. 2000. "Dehydration/ 158028 Recrystallization Mechanisms, Energetics, and Kinetics of Hydrated Calcium Silicate Minerals: An in Situ TGA/DSC and Synchrotron Radiation SAXS/WAXS Study." Chemical Geology, 167, (1-2), 141-159. New York, New York: Elsevier. TIC: 251588.

Shock, E.L. and Helgeson, H.C. 1988. "Calculation of the Thermodynamic and 144817 Transport Properties of Aqueous Species at High Pressures and Temperatures: Correlation Algorithms for Ionic Species and Equation of State Predictions to $5 \mathrm{~kb}$ and $1000^{\circ}$ C." Geochimica Cosmochimica Acta, 52, (8), 2009-2016. New York, New York: Pergamon Press. TIC: 247203.

Shock, E.L.; Sassani, D.C.; Willis, M.; and Sverjensky, D.A. 1997. "Inorganic Species in Geologic Fluids: Correlations Among Standard Molal Thermodynamic Properties of Aqueous Ions and Hydroxide Complexes." Geochimica et Cosmochimica Acta, 61, (5), 907-950. New York, New York: Pergamon Press. TIC: 246451.

Silva, R.J.; Bidoglio, G.; Rand, M.H.; Robouch, P.B.; Wanner, H.; and 102087 Puigdomenech, I. 1995. Chemical Thermodynamics of Americium. Volume 2 of Chemical Thermodynamics. Amsterdam, The Netherlands: Elsevier. TIC: 237106.

Stefánsson, A. 2001. "Dissolution of Primary Minerals of Basalt in Natural Waters I. Calculation of Mineral Solubilities from $0^{\circ} \mathrm{C}$ to $350^{\circ} \mathrm{C}$." Chemical Geology, 172, (3-4), 225-250. New York, New York: Elsevier. TIC: 250507.

Steinborn, T.L.; Wolery, T.J.; Alcorn, S.R.; Arthur, S.E.; Bernot, P.A.; Brady, P.V.; Chen, Y.; Domski, P.S.; Jolley, D.M.; Metcalf, R.C.; and Thomas, E. 2003. Data Qualification: Update and Revision of the Geochemical Thermodynamic Database, Data0.ymp. TDR-EBS-MD-000022 REV 00. Las Vegas, Nevada: Bechtel SAIC Company. ACC: DOC.20030331.0003.

Stumm, W. and Morgan, J.J. 1981. Aquatic Chemistry, An Introduction Emphasizing Chemical Equilibria in Natural Waters. 2nd Edition. New York, New York: John Wiley \& Sons. TIC: 208448.

Tardy, Y. and Garrels, R.M. 1974. "A Method of Estimating the Gibbs Energies of Formation of Layer Silicates." Geochimica et Cosmochimica Acta, 38, (7), 1101-1116. New York, New York: Pergamon Press. TIC: 252611. 
Taylor, H.F.W. 1990. Cement Chemistry. San Diego, California: Academic Press 120495 Limited. TIC: 243267.

Towe, K.M. and Bradley, W.F. 1967. "Mineralogical Constitution of Colloidal 'Hydrous Ferric Oxides'." Journal of Colloid and Interface Science, 24, 384-392. New York, New York: Academic Press. TIC: 250230.

Triolo, R.; Grigera, J.R.; and Blum, L. 1976. "Simple Electrolytes in the Mean 159210 Spherical Approximation.” Journal of Physical Chemistry, 80, (17), 1858-1861. Washington, D.C.: American Chemical Society. TIC: 253397.

Vaniman D.T. and Bish, D.L. 1995. "The Importance of Zeolites in the Potential High-Level Radioactive Waste Repository at Yucca Mountain, Nevada." Natural Zeolites 93: Occurrence, Properties, Use, Proceedings of the 4th International Conference on the Occurrence, Properties, and Utilization of Natural Zeolites, June 20-28, 1993, Boise, Idaho. Ming, D.W. and Mumpton, F.A., eds. Pages 533-546. Brockport, New York: International Committee on Natural Zeolites. TIC: 243086.

Vasil'ev, V.P.; Vorobe.ev, P.N.; and Khodakovskii, I.L. 1974. "Standard Free Energies of Formation of Titanium Hydroxo-Complexes and of the Ti4+ Ion in Aqueous Solution." Translated from: Russian Journal of Inorganic Chemistry, 19, (10), 1481-1483. London, England: Royal Society of Chemistry.

TIC: 248330.

Viani, B.E. and Bruton, C.J. 1992. Modeling Fluid-Rock Interaction at Yucca Mountain, Nevada: A Progress Report. UCRL-ID-109921. Livermore, California: Lawrence Livermore National Laboratory.

ACC: NNA.19920805.0002.

Vieillard, p. 1994. "Prediction of Enthalpy of Formation Based on Refined Crystal Structures of Multisite Compounds: Part 1. Theories and Examples." Geochimica et Cosmochimica Acta, 58, (19), 4049-4063. New York, New York: Elsevier. TIC: 252614.

Vieillard, p. 1994. "Prediction of Enthalpy of Formation Based on Refined Crystal Structures of Multisite Compounds: Part 2. Application to Minerals Belonging to the System $\mathrm{Li}_{2} \mathrm{O}-\mathrm{Na}_{2} \mathrm{O}-\mathrm{K}_{2} \mathrm{O}-\mathrm{BeO}-\mathrm{MgO}-\mathrm{CaO}-\mathrm{MnO}-\mathrm{FeO}-\mathrm{Fe}_{2} \mathrm{O}_{3}-\mathrm{Al}_{2} \mathrm{O}_{3}-\mathrm{SiO}_{2}-\mathrm{H}_{2} \mathrm{O}$. Results and Discussion." Geochimica et Cosmochimica Acta, 58, (19), 4065-4107. New York, New York: Elsevier. TIC: 252615.

Vieillard, p. 1995. "Estimation of Enthalpy of Formation of Some Zeolites from their Refined Crystal Structures." Zeolites, 15, 202-212. New York, New York: Elsevier. TIC: 256712. 
Vieillard, p. 2000. "A New Method for the Prediction of Gibbs Free Energies of 171586 Formation of Hydrated Clay Minerals Based on the Electronegativity Scale." Clay and Clay Minerals, 48, (4), 459-473. Aurora, Colorado: Clays Mineral Society. TIC: 256527.

Vieillard, p. and Rassineux, F. 1992. "Thermodynamic and Geochemical 120508 Modelling of the Alteration of Two Cement Matrices." Applied Geochemistry, Geochemistry of Radioactive Waste Disposal: A French Contribution, Supplemental Issue No. 1, 125-136. New York, New York: Pergamon Press. TIC: 246918.

Wagman, D.D.; Evans, W.H.; Parker, V.B.; Schumm, R.H.; Halow, I.; Bailey, 159216 S.M.; Churney, K.L.; and Nuttall, R.L. 1982. "The NBS Tables of Chemical Thermodynamic Properties, Selected Values for Inorganic and $\mathrm{C}_{1}$ and $\mathrm{C}_{2}$ Organic Substances in SI Units." Journal of Physical and Chemical Reference Data, 11, (Supplement No. 2), Pages 2-276 and 2-282. Washington, D.C.: American Chemical Society. TIC: 239715.

Walther, J.V. and Helgeson, H.C. 1977. "Calculation of the Thermodynamic Properties of Aqueous Silica and the Solubility of Quartz and Its Polymorphs at High Pressures and Temperatures." American Journal of Science, 277, 1315-1351. New Haven, Connecticut: Yale University, Kline Geology Laboratory. TIC: 223171.

Wanner, H. and Osthols, E. 1999. Guidelines for the Assignment of Uncertainties. 159222 TDB-3. Issy-les-Moulineaux, France: Organization for Economic Co-operation and Development, Nuclear Energy Agency. TIC: 253366.

Weast, R.C. and Astle, M.J., eds. 1979. CRC Handbook of Chemistry and Physics. 60th Edition. 2nd Printing 1980. Boca Raton, Florida: CRC Press. TIC: 245312.

Wilkin, R.T.;Barnes, H.L. 1998. "Solubility and Stability of Zeolites in Aqueous Solutions: I. Analcime, Na-, and K-Clinoptilolite.” American Mineralogist, 83, 746-761. Lawrence, Kansas: Mineralogical Society of America.

Wolery, T.J. 1978. Some Chemical Aspects of Hydrothermal Processes at 151346 Mid-Oceanic Ridges - A Theoretical Study. I. Basalt-Sea Water Reaction and Chemical Cycling Between the Oceanic Crust and the Oceans. II. Calculation of Chemical Equilibrium Between Aqueous Solutions and Minerals. Ph.D. dissertation. Evanston, Illinois: Northwestern University. TIC: 219640.

Wolery, T.J. 1990. "On the Thermodynamic Framework of Solutions (with Special Reference to Aqueous Electrolyte Solutions)." American Journal of Science, 290, (3), 296-320. New Haven, Connecticut: Yale University, Kline Geology Laboratory. TIC: 252904. 
Wolery, T.J. 1992. EQ3NR, A Computer Program for Geochemical Aqueous

100836

Speciation-Solubility Calculations: Theoretical Manual, User's Guide, and

Related Documentation (Version 7.0). UCRL-MA-110662 PT III. Livermore, California: Lawrence Livermore National Laboratory.

ACC: MOL.19980717.0626.

Ziemniak, S.E.; Jones, M.E.; and Combs, K.E.S. 1993. "Solubility Behavior of

Titanium(IV) Oxide in Alkaline Media at Elevated Temperatures." Journal of Solution Chemistry, 22, (7), 601-623. New York, New York: Plenum Press.

TIC: 256710.

\subsection{CODES, STANDARDS, REGULATIONS, AND PROCEDURES}

10 CFR 63. Energy: Disposal of High-Level Radioactive Wastes in a Geologic

Repository at Yucca Mountain, Nevada. Readily available.

AP-2.22Q, Rev. 1, ICN 1. Classification Analyses and Maintenance of the Q-List. Washington, D.C.: U.S. Department of Energy, Office of Civilian Radioactive Waste Management. ACC: DOC.20040714.0002

AP-SIII.2Q, Rev. 1, ICN 2. Qualification of Unqualified Data.

Washington, D.C.: U.S. Department of Energy, Office of Civilian Radioactive

Waste Management. ACC: DOC.20040127.0008.

AP-SIII.9Q, Rev. 1, ICN 7. Scientific Analyses. Washington, D.C.:

U.S. Department of Energy, Office of Civilian Radioactive Waste Management.

ACC: DOC.20040920.0001.

AP-SV.1Q, Rev. 1, ICN 1. Control of the Electronic Management of Information. Washington, D.C.: U.S. Department of Energy, Office of Civilian Radioactive Waste Management. ACC: DOC.20040308.0001.

LP-SI.11Q-BSC, Rev. 0, ICN 1. Software Management. Washington, D.C.:

U.S. Department of Energy, Office of Civilian Radioactive Waste Management.

ACC: DOC.20041005.0008.

\subsection{SOURCE DATA, LISTED BY DATA TRACKING NUMBER}

MO0009THRMODYN.001. Input Transmittal for Thermodynamic Data Input

152576

Files for Geochemical Calculations. Submittal date: 09/20/2000.

MO0106MWDTDG01.035. Model Warehouse Data for the Development of

161791

Temperature Dependant GIBBS Free Energys for Selected Half Reactions Involved in Microbial Metabolism. Submittal date: 06/18/2001.

MO0109THRMODYN.000. Data0.cem Thermodynamic Database File for 156190 Geochemical Calculations. Submittal date: 09/19/2001. 
MO0208THDYNORG.000. Thermodynamic Data Input Files - Total Organics.

172399

Submittal date: 08/05/2002.

MO0302SPATHDYN.000. Thermodynamic Data Input Files - Data0.YMP.R2. 161756

Submittal date: 02/05/2003.

MO0302SPATHDYN.001. Thermodynamic Data Supporting Spreadsheet Files - 161886

Data0.YMP.R2. Submittal date: 02/05/2003.

MO0303SPASPEQ2.000. Thermodynamic Datafile SPEQ02.DAT. Submittal 162278 date: $03 / 17 / 2003$.

MO0312SPATDMIF.000. Thermodynamic Data Input Files - Data0.YMP.R3. 167800

Submittal date: $12 / 22 / 2003$.

SN0302T0510102.002. Pitzer Thermodynamic Database (data0.ypf, Revision 1). 162572 Submittal date: 02/06/2003.

\subsection{OUTPUT DATA, LISTED BY DATA TRACKING NUMBER}

SN0410T0510404.001. Corrections to Erros in the Data0.ymp.R2 Thermodynamic Database. Submittal date: 11/01/2004.

SN0410T0510404.002. Thermodynamic Database Input File for EQ3/6 -

Data0.ymp.R4. Submittal date: 11/01/2004.

\subsection{SOFTWARE CODES}

BSC 2002. Software Code: EQ6. 7.2bLV. PC. 10075-7.2bLV-02.

Windows NT, 2000.

BSC 2002. Software Code: PHREEQC_Post. V1.1. PC. 10723-1.1-00. 157839

BSC 2003. Software Code: EQ3/6. V8.0. PC w/ Windows 95/98/2000/NT 4.0. 162228 10813-8.0-00.

LBNL (Lawrence Berkeley National Laboratory) 1999. Software Code:

153218

SUPCRT92. V1.0. PC w/Windows OS and MAC w/MAC OS. 10058-1.0-00.

LBNL 2002. Software Code: TOUGHREACT. V3.0. DEC ALPHA/OSF1 V5.1, 161256 DEC ALPHA/OSF1 V5.0, Sun UltraSparc/Sun OS 5.5.1, PC/Linux Redhat 7.2. 10396-3.0-00. 